Manuela Catafesta

\title{
ALBERT KAHN: UMA FÁBRICA NO BRASIL
}

Versão original

Tese apresentada à Faculdade de Arquitetura e Urbanismo da Universidade de São Paulo para obtenção do título de Doutora em Arquitetura e Urbanismo.

Orientador: Prof. Dr. Paulo Júlio Valentino Bruna 
Autorizo a reprodução e divulgação total ou parcial deste trabalho, por qualquer meio convencional ou eletrônico, para fins de estudo e pesquisa, desde que citada a fonte.

Catafesta, Manuela

Albert Kahn: uma fábrica no Brasil / Manuela Catafesta; orientador Paulo Júlio Valentino Bruna. - São Paulo, 2019. $332 \mathrm{p}$.

Tese (Doutorado) - Faculdade de Arquitetura e Urbanismo da Universidade de São Paulo. Área de concentração: História e Fundamentos da Arquitetura e do Urbanismo.

1. Arquitetura. 2. Edifícios Industriais. 3. Indústrias (arquitetura). 4. Kahn, Albert, 1869-1942. I. Bruna, Paulo Júlio Valentino, orient. II. Título. 
CATAFESTA, Manuela. Albert Kahn: uma fábrica no Brasil. 2019. 332 p. Tese (Doutorado em Atquitetura e Urbanismo) - Faculdade de Arquitetura e Urbanismo, Universidade de São Paulo, São Paulo, 2019.

Aprovado em:

\section{Banca Examinadora}

Prof. Dr.

Julgamento

Prof. Dr.

Julgamento

Prof. Dr.

Julgamento

Prof. Dr.

Julgamento

Prof. Dr.

Julgamento
Instituição

Assinatura

Instituição

Assinatura

Instituição

Assinatura

Instituição

Assinatura

Instituiç̧ão

Assinatura 



\section{AGRADECIMENTOS}

Ao orientador, Paulo Júlio Valentino Bruna, pelos ensinamentos, pela credibilidade em mim depositada e por me apresentar o arquiteto Albert Kahn. Por fim, pelo empréstimo dos valiosos livros da sua invejável biblioteca.

À professora Claire Zimmerman, pela generosidade de me receber em Ann Arbor. Ao Juliano Medina, com amor, admiração e gratidão por sua compreensão, auxílio e incansável apoio ao longo do período de elaboração deste trabalho.

À arquiteta e doutora Silvia Raquel Chiarelli, agradeço a amizade e a generosa hospitalidade de sua casa em São Paulo.

Ao meu irmão Lucas Catafesta, pelo apoio e pela parceria na viagem de estudo a Michigan.

Ao Gustavo Czekster, pela revisão cuidadosa e pelo incentivo no momento final da pesquisa.

Aos amigos e colegas professores das faculdades de Arquitetura e Urbanismo do Uniritter e do Ipa - sem citar nomes pois são muitos -, pelo apoio durante a realização desse trabalho.

Aos funcionários da Biblioteca Histórica Bentley, pela gentileza durante a pesquisa nos acervos.

À minha família e aos meus amigos pela compreensão, especialmente nos momentos de ausência. 



\section{RESUM0}

Este trabalho tem como tema central a apresentação e análise da fábrica da Ford Motor Company, localizada no bairro Bom Retiro, em São Paulo. Construída em 1921, foi a primeira fábrica de automóveis no Brasil a utilizar o concreto armado e grandes planos de vidro, exibindo uma linguagem plástica moderna. Quase centenária, a fábrica, mesmo tendo utilizado tecnologias construtivas inovadoras e formas mais puras e econômicas, constitui um assunto ainda inédito no cenário da arquitetura nacional. $\mathrm{O}$ estudo desse caso se oferece também como oportunidade para a compreensão mais ampla da obra de Albert Kahn que, em parceria com o empresário Henry Ford, a partir da primeira década do século XX, foi responsável pela nova concepção do edifício industrial - um espaço capaz de proporcionar a flexibilidade e segurança necessárias para a nova organização científica da produção, livre de qualquer linguagem arquitetônica historicista. A coleta, análise e divulgação desse material inédito, composto por desenhos arquitetônicos do projeto, disponíveis no acervo do escritório Albert Kahn Associates, além de permitir que a autoria do projeto fosse confirmada como sendo do arquiteto americano, configura uma contribuição para a história da arquitetura brasileira, algo que poderá determinar a mudança de paradigmas a respeito da arquitetura industrial e sua importância como parte indissociável do movimento moderno. Com isso, se espera colaborar para o surgimento de novos estudos que apresentem, discutam e qualifiquem as fábricas como produção arquitetônica, dando-lhes a devida importância na qualidade de programas tanto técnicos quanto formalmente inovadores. Além disso, o estudo da fábrica da Ford no Brasil representa um importante instrumento para o seu melhor conhecimento e valorização cultural, podendo auxiliar a tomada de decisão acerca do papel que esta instalação industrial irá desempenhar no futuro.

Palavras-chave: Fábrica de automóvel. Albert Kahn. Ford Motor Co. Henry Ford. Arquitetura moderna. 



\section{ABSTRACT}

This research has as subject the presentation and analysis of the Ford Motor Company plant, located in Bom Retiro, a São Paulo's district. Built in 1921, it was the first automobile factory in Brazil to use reinforced concrete and large glass panels, showing a modern aesthetic. Almost 100 years old, the assembly plant, even using innovative technologies and more pure and economic forms, is a subject still unpublished in the national architecture's scenario. The study of this case also offers an opportunity for a wide understanding of the work of Albert Kahn, who in partnership with the businessman Henry Ford, from the first decade of the twentieth century, was responsible for the new layout of the industrial building - a space capable of providing the necessary flexibility and safety for the new mass production, independent from any historical architecture aesthetics. The search, analysis and disclosure of the unpublished material, composed of architectural drawings of the assembly plant, available in the Albert Kahn Associates records, besides confirming the authorship of the project, it is a contribution to the history of Brazilian architecture, something that may determine the paradigm regarding industrial architecture and its importance as an inseparable part of the Modern Movement. This research hopes to contribute to the emergence of new studies that present, discuss and qualify the factories as architectural production, giving them the importance of technical and formal innovative programs. In addition, the study of the Ford assembly plant in Brazil represents an important instrument for its better knowledge and cultural appreciation, and can help the decision about the role that this industrial architectural will play in the future.

Keywords: Automobile factory. Albert Kahn. Ford Motor Co. Henry Ford. Modern Architecture. 



\section{SUMÁRIO}

INTRODUÇÃO — 15

$\begin{array}{lr}\text { 1.PERSONAGENS } & 27\end{array}$

1.10 fabricante 30

1.1.1 Henry Ford, o visionário _ـ 37

1.1.2 Ford Motor Company e a sua expansão pelo mundo ___ 14

1.20 arquiteto 48

1.2.1 Albert Kahn, 0 arquiteto das fábricas __ 48

1.2.2 A revolução no escritório: a fábrica de projetar fábricas __ 66

2.TÉCNICA 77

2.10 concreto armado e a fábrica moderna __ 79

2.2 A eletricidade e o edifício funcionalista __ 84

2.3 As primeiras fábricas americanas de automóveis _ 87

2.4 A fábrica como máquina _ـ 97

2.4.1 Highland Park Old Shop: os primeiros experimentos ___ 98

2.4.2 Highland Park New Shop: a máquina automática __ 109

2.4.3 Ford River Rouge: a maior fábrica do mundo __ 121

3.GENEALOGIA 133

3.1 As estruturas de concreto de Albert Kahn __ 138

3.1.1 Fábrica de automóveis - Building n¹0 (1905) __ 140

Packard Motor Car Company/Detroit, Michigan

3.1.2 Fábrica de automóveis - Highland Park Old Shop (1909) ___ 144

Ford Motor Company / Detroit, Michigan

3.1.3 Fábrica de automóveis - Highland Park New Shop (1914) 149

Ford Motor Company / Detroit, Michigan 
3.2 As estruturas metálicas de Albert Kahn __ 155

3.2.1 Forge Shop (1911) _ 158

Packard Motor Car Company / Detroit, Michigan

3.2.2 Fábrica de vidros - River Rouge (1922) __ 165

Ford Motor Company / Dearborn, Michigan

3.2.3 Fábrica de tratores (1930)

Amtorg Trading Corporation / Stalingrado, União Soviética

3.2.4 Fábrica de caminhões (1937)

Chrysler Corporation - Dodge division / Warren, Michigan

3.2.5 Fábrica de aviões (1937)

Glenn L. Martin Company / Baltimore. Maryland

3.2.6 Fábrica de aviões - Willow Run Bomber (1941)

Ford Motor Company / Ypsilanti, Michigan

4.FÁBRICA 201

4.1 Antecedentes 203

4.2 os primeiros passos 209

4.30 desejo de ser moderno 216

4.4 A Ford Motor Company no Brasil 222

4.5 Anteprojeto e construção 233

5.LEGADO 257

5.1 Influência simbólica 259

5.2 Influência técnica 269

5.3 Influência formativa 290 


INTRODUÇÃO 
Os edifícios industriais sempre configuraram espaços pragmáticos. Seja em virtude das atividades que abrigavam, as quais não possuíam pretensões de visibilidade social, seja porque careciam de referenciais históricos, eles se desenvolveram como locais propícios à valorização da experimentação. Neste contexto, o edifício industrial pertence a uma nova tipologia em que o programa é tomado como motivação do projeto, tendo como principais parâmetros a funcionalidade e a racionalidade.

No entanto, nem sempre as construções destinadas a acomodar processos produtivos e industriais tiveram relevância arquitetônica. Até o século XX, poucos arquitetos projetavam fábricas, sendo essa uma tarefa normalmente destinada a construtores e, às vezes, engenheiros. $\mathrm{O}$ mesmo acontecia em relação aos críticos e historiadores de arquitetura, que pareciam considerar pouco relevantes os edifícios destinados à indústria, desinteresse este manifestado pelas escassas publicações técnicas a respeito do assunto.

Foi no início do século XX que ocorreu uma mudança significativa - inicialmente nos Estados Unidos e depois na Europa - em busca de uma racionalidade absoluta do processo produtivo e de uma nova compreensão do edifício industrial enquanto parte desse processo. $O$ edifício deixou de ser considerado como um elemento irrelevante e assumiu tanta importância quanto o arranjo produtivo. Tornou-se, assim, objeto da mesma atenção analítica destinada a qualquer máquina, em um esforço de controlar todos os parâmetros que poderiam interferir no processo produtivo. Tomando consciência disto, alguns arquitetos famosos expressaram o seu encantamento com a cada vez mais intensa era tecnológica e, sendo a fábrica um dos seus símbolos, começaram a projetá-las.

Não é à toa que, diante desta mudança de paradigma, a visão do edifício industrial como um espaço capaz de proporcionar a flexibilidade e segurança necessárias para a organização científica da produção tornou-se algo muito presente - para não dizer decisivo - nos edifícios da indústria automobilística americana surgidos da colaboração entre Henry Ford e Albert Kahn, ocorrida a partir da primeira década do século XX.

Henry Ford (1863-1947) fundou a Ford Motor Company em Detroit, em 1903, com a proposta de tornar os automóveis acessíveis para as pessoas. Para 
realizar este intuito, Ford introduziu métodos revolucionários de produção em massa, os quais foram materializados através do desenvolvimento da primeira linha de montagem móvel para carros. Foi principalmente em razão do lançamento do carro Modelo T, o qual se tornaria um enorme sucesso de vendas, que Ford experimentou um novo projeto e organização da fábrica para atender a grande demanda do veículo. O êxito das vendas fez com que a Ford Motor Company se tornasse a maior fabricante de automóveis do mundo.

No entanto, nada disto seria possível se não existisse, de forma concomitante, o desenvolvimento do edifício industrial em que acontecia a fabricação e montagem dos veículos. A necessidade de dinamizar o processo produtivo dos carros e atender a demanda comercial cada vez mais intensa fez com que, em 1908, Ford se aproximasse do arquiteto americano Albert Kahn (1869-1942). Após a exitosa construção de uma fábrica de automóveis em Highland Park, subúrbio de Detroit, iniciou-se uma parceria de longa duração entre dois gênios: Henry Ford, que previu as futuras vantagens da produção através da linha de montagem, e Albert Kahn, que "found aesthetic values in the forms engendered by new techniques and functional considerations." 1

Kahn se destacou como o principal arquiteto industrial do início do século XX, fazendo grandes contribuições para o projeto das fábricas nos Estados Unidos. Com o objetivo de apresentar soluções arquitetônicas viáveis para os princípios defendidos por Henry Ford, o arquiteto inicialmente refinou e popularizou a fábrica de concreto armado entre 1905 e o final da década de 1910, sendo que, a partir das décadas de 1920 e 1930, passou a desenvolver projetos inovadores de fábricas com estrutura metálica. A mudança progressiva da técnica devia-se à capacidade quase camaleônica de ajuste às necessidades dos clientes. Kahn tinha uma visão diferente do papel do arquiteto: a fim de concentrar-se no cumprimento das necessidades operacionais, econômicas e práticas, características do edifício fabril, o arquiteto necessitava deixar de lado preocupações estéticas tradicionais.

Conhecido geralmente por suas realizações quantitativas (somente para a Ford Motor Company, o arquiteto desenvolveu mais de 1000 projetos, sem contar os trabalhos realizados para outras centenas de empresas, inclusive aquelas ligadas aos

1 Tradução da autora: "encontrou valores estéticos nas formas engendradas por novas técnicas e considerações funcionais". In: FERRY, H. Legacy of Albert Kahn. Detroit: The Detroit Institute of Arts, 1970, p.11. 
setores aeronáutico e à maioria dos concorrentes americanos do setor automotivo), Kahn também foi o chefe de um dos maiores escritórios de arquitetura do mundo, localizado em Detroit, tendo sido responsável por grande parte da produção da arquitetura industrial americana. Não bastando, através de um contrato sem precedentes na área da arquitetura, projetou fábricas para a União Soviética durante o primeiro Plano Quinquenal (1929-1932). Contudo, o trabalho de Albert Kahn não se limitou às fábricas. De seu escritório saíram também projetos de edifícios comerciais, residenciais e institucionais, esses últimos especialmente para a Universidade de Michigan, na cidade de Ann Arbor.

Uma das grandes inovações de Kahn também ocorreu na parte operacional da sua empresa. Ao assumir um grande volume de projetos, ele revolucionou a operação de seu escritório de arquitetura. Através da integração do trabalho de especialistas em arquitetura e engenharia, também utilizou uma abordagem multidisciplinar de equipe para o projeto e racionalizou as operações do escritório. Influenciado pelo fordismo, o escritório tornou-se algo que podemos considerar como uma linha de montagem arquitetônica, uma "fábrica de projetos" para a produção em massa de edifícios.

A aliança entre Henry Ford e Albert Kahn permitiu conceber edifícios assentes no respeito aos requisitos funcionais, usando os novos materiais da indústria - concreto armado, aço e vidro -, garantindo o bem estar do ambiente de trabalho e proporcionando espaços interiores inovadores. Por meio deste movimento de redução de suas formas ao estritamente necessário, o edifício industrial passou, ele próprio, a servir de referência para a Arquitetura Moderna europeia. Tornaramse, assim, fundamentais para as concepções arquitetônicas modernas, chegando ao ponto de máquinas e equipamentos industriais inspirarem arquitetos como Walter Gropius e Le Corbusier, que enalteceram, em pleno século XX, os edifícios fabris norte-americanos ao demonstrarem o seu entusiasmo pela era da máquina.

Graças ao sucesso de vendas do Modelo T, e diante do interesse manifestado por Henry Ford de expandir o mercado da América Latina, a Ford Motor Company acabou construindo em 1919 e 1921 as suas primeiras fábricas de automóveis, respectivamente, na Argentina e no Brasil. Tal decisão de Ford não foi guiada 
somente pelo desejo de expandir o mercado da sua empresa, mas, especialmente, pelos impactos gerados pela Primeira Guerra Mundial (1914-1918) na economia latino-americana, que resultaram no aumento das importações norte-americanas.

A implantação da indústria automobilística no Brasil foi um marco no processo de industrialização e modernização do país. São Paulo, cidade com maior infraestrutura, passou a ser o local escolhido pela maioria das indústrias. Os automóveis ofereceram a possibilidade de transformar o Brasil não apenas econômica e espacialmente, mas também culturalmente. Nesse cenário de início da expansão da indústria brasileira é que foi construída a fábrica da Ford Motor Company, localizada no bairro Bom Retiro, em São Paulo. Tornou-se a primeira fábrica de automóveis no Brasil a utilizar o concreto armado e grandes planos de vidro.

Quase centenária, a fábrica de volume prismático, que utilizou tecnologias construtivas inovadoras e formas puras e econômicas é, surpreendentemente, uma pesquisa ainda inédita, inclusive no cenário brasileiro. $\mathrm{Na}$ busca de esclarecimento a respeito da construção desse edifício, sugere-se a hipótese de que a primeira fábrica da Ford em São Paulo tenha sido projetada também por Albert Kahn, arquiteto responsável por grande parte dos projetos da Ford Motor Company. Essa suposição também é alimentada pelo fato da fábrica possuir características formais e construtivas muitos semelhantes às fábricas americanas da Ford.

Desta forma, o trabalho divide-se em dois objetivos, um geral e outro mais específico. $\mathrm{O}$ objetivo geral seria criar ferramentas para o avanço do estudo histórico da arquitetura brasileira, a partir da divulgação de documentos inéditos a respeito do projeto para a primeira fábrica da Ford no Brasil. Por sua vez, o objetivo específico seria compreender de forma mais ampla a obra de Albert Kahn, com a intenção de encontrar as possíveis relações entre o projeto da fábrica em São Paulo e as suas demais obras industriais. Para isso, será necessário abordar a relação de mútuas trocas e aprendizados entre Henry Ford e Albert Kahn e o quanto isto se refletiu nas fábricas construídas ao redor do mundo, especialmente aquela localizada no Brasil; apontar a contribuição do concreto armado e da energia elétrica para a mudança no projeto das fábricas; revelar a mudança que a linha de montagem 
fordista trouxe para o projeto da fábrica, dando origem a um novo edifício fabril, e, finalmente, demonstrar a evolução do projeto industrial dentro da obra de Albert Kahn, desde as estruturas de concreto até o uso de estruturas metálicas e como o fordismo revolucionou o seu próprio escritório de arquitetura.

Portanto, essa tese se justifica através da publicação e análise do projeto da fábrica da Ford no Brasil, atuando como forma de contribuir para a história da arquitetura brasileira devido à ausência de publicações a respeito e a dificuldade de acesso ao material gráfico e fotográfico.

A arquitetura industrial nunca teve a devida atenção por parte da historiografia da arquitetura, talvez por se tratar de uma arquitetura eminentemente funcional. Dessa maneira, não causa espanto que, entre as obras canônicas da historiografia da arquitetura moderna, existam raras referências aos edifícios industriais. Tanto nas páginas de livros estrangeiros consagrados quanto nas obras nacionais citamse invariavelmente os mesmos poucos exemplares com dados repetidos, sempre registrados em escassas linhas, as quais são desproporcionais diante da relevância concedida aos demais programas do período. Tal constatação parece indicar uma visível desvalorização dos edifícios industriais como programa arquitetônico na modernidade.

O tema permanece em aberto quando se trata da arquitetura da modernidade em virtude da ausência de estudos amplos e sistemáticos que apresentem, discutam e qualifiquem as fábricas como produção arquitetônica. Tal lacuna de desconhecimento não só estabelece uma história parcial e incompleta como ainda descontinua a própria história da arquitetura industrial enquanto construção e representação, permitindo imprecisões e equívocos para os que pretendem fazer afirmações a respeito.

Para realizar essa tarefa, é imprescindível a adoção de uma bibliografia consistente. No entanto, um dos obstáculos com que essa tese se deparou foi a falta de fortuna crítica a respeito do arquiteto Albert Kahn, determinando uma profunda revisão de sua figura dentro dos escopos das críticas da arquitetura do século XX. As publicações existentes sobre Kahn são escassas e, além disso, em geral são tratadas de forma biográfica ou meramente descritiva, com pouca contribuição crítica em 
relação ao desenvolvimento do projeto em todo o seu extenso trabalho. Seus poucos textos teóricos também estão dispersos em publicações atualmente não disponíveis no mercado, sendo que a maioria delas não foi sequer objeto de revisão crítica.

Em relação à pesquisa acadêmica, podemos dizer que a exiguidade de informações técnicas e críticas sobre o trabalho de Kahn se repete. Existem poucas teses dedicadas exclusivamente a Albert Kahn ou a aspectos parciais do seu trabalho. As teses de doutorado em que o arquiteto é abordado de forma tangencial também possuem um caráter de crítica descritiva e um aspecto marcante de pesquisa histórica, concedendo pouca atenção ao seu método de projeto.

Mesmo tendo sido um dos mais importantes e prolíficos arquitetos americanos do século XX, e embora seu trabalho tenha revolucionado a arquitetura industrial, Albert Kahn não recebeu o reconhecimento adequado de suas contribuições por parte dos críticos e historiadores. Portanto, para realizar essa tese, praticamente se buscou acessar todo o material existente sobre Kahn, a começar pela primeira publicação conhecida a respeito do seu trabalho, uma monografia ilustrada que recebeu o título de "Industrial Architecture of Albert Kahn Inc.", de George Nelson, publicada em 1939. Através de uma apresentação cronológica dos projetos de Kahn dentro de determinadas categorias arquitetônicas, com abundantes fotografias e ilustrações em preto e branco, W. Hawkins Ferry publica, em 1970, o livro "The Legacy of Albert Kahn", que trata, originalmente, do catálogo de uma exposição retrospectiva sobre o arquiteto americano no Detroit Institute of Arts, ocorrida no mesmo ano. Uma das análises mais abrangentes das obras industriais de Albert Kahn está presente no livro "Designing for industry”, de Grant Hildebrand, publicado em 1974.

Na obra “A Concrete Atlantis”, publicada em 1986, Reyner Banham chamou a atenção para os projetos das fábricas de Kahn que exerceram uma forte influência entre os modernistas europeus, incluindo Gropius e Le Corbusier. Federico Bucci contribuiu para a bibliografia sobre Kahn em 1993, através do livro intitulado "Albert Kahn: arquiteto de Ford". Até certo ponto, Bucci repetiu observações encontradas em outros estudos, especialmente as feitas por Terry Smith em "Making the Modern: Industry, Art, and Design in America", publicado 
também em 1993. No entanto, o estudo de Bucci, retirado em parte dos arquivos do escritório de Kahn, fornece um relato narrativo mais detalhado. Além disso, Bucci também analisa de forma superficial o trabalho do projeto industrial de Kahn para o governo soviético entre 1929 e 1932, bem como a montagem - em alta velocidade - de fábricas de aviões e armamentos durante a Segunda Guerra Mundial.

Outros historiadores iluminaram recentemente a complexa produção de Kahn. Claire Zimmerman, professora da Faculdade de Arquitetura da Universidade de Michigan, lidera, atualmente, um projeto de pesquisa intitulado "Albert Kahn Building the Capitalist World: Albert Kahn Associates Detroit, 1900-1961", tendo publicado diversos artigos sobre o assunto. A tese de doutorado de Luis Pancorbo Crespo, defendida em 2016 na Universidade Politécnica de Madri, apresenta documentos e análises inéditos dos projetos industriais, especialmente da fábrica Ford Willow Run (1941), projeto este mantido como segredo de Estado até 2006. Porém, nenhum desses autores trata dos projetos de Kahn na América Latina.

No Brasil, a situação é ainda pior. Não existe nenhuma publicação ou estudo acadêmico sobre o arquiteto Albert Kahn e muito menos sobre o projeto da fábrica brasileira. As únicas publicações encontradas são norte-americanas e tratam superficialmente do assunto. O livro "American Business Abroad: Ford on Six Continents", de Mira Wilkins e Frank Hill, publicado em 1964, traça a ascensão e expansão da Ford Motor Company pelo mundo, adotando um viés mais históricoeconômico. Já no livro "Autos and Progress: The Brazilian Search for Modernity", publicado em 2010, o autor Joel Wolfe vê o Brasil do século XX através do prisma do automóvel.

Para reverter essa situação, foi necessário consultar os arquivos do escritório de Kahn, que foram doados em 2004 à Biblioteca Histórica Bentley, localizada na Universidade de Michigan, e o Centro de Pesquisas Benson Ford, localizado dentro do Museu Henry Ford, na cidade de Dearborn. O arquivo histórico de São Paulo, consultado na ocasião da pesquisa, não possui material sobre o projeto arquitetônico. Apesar do edifício onde se situava a fábrica ainda estar sendo utilizado atualmente, há uma dificuldade de acesso ao interior dela devido à negativa de seus atuais locatários. 
Importante destacar que, desde as primeiras décadas do século XX, o relacionamento entre Brasil e Estados Unidos foi decisivo para o processo de divulgação e fortalecimento do modernismo brasileiro. É inegável a importância do american way of life, bem como das experiências e contatos com os arquitetos e com o campo arquitetônico norte-americano, fato que se refletiu no desenvolvimento de nossa produção local.

No entanto, esta linha de pensamento é relativamente recente, na medida em que a historiografia arquitetônica canônica se funda em estudar a contribuição de Le Corbusier e das vertentes europeias de vanguarda, negligenciando outras fontes. A historiografia da arquitetura moderna introduzida no Brasil a partir do final da década de 1920 é um fenômeno que está sendo estudado há pouco tempo. Como comenta Abilio Guerra: "Durante décadas imperou a visão presente nos mitológicos Brazil Builds (Philip Goodwin, 1943) e Modern Architecture in Brazil (Henrique Mindlin, prefácio de Sigfried Giedion, 1956), que foi repetida de forma tão sistemática que se transformou em quase axioma." ${ }^{2}$

Como apontam Cavalcanti e Lago, a história da arquitetura modernista brasileira "não pode mais ser escrita somente em termos da influência europeia nas Américas." ${ }^{3}$ É imprescindível, assim, a realização de uma abordagem considerando um diálogo mais amplo, o que deverá expandir e lançar nova luz na compreensão a respeito da gênese da arquitetura moderna do Brasil. Seguindo esta linha de pensamento, desmistificar a história de certa forma "oficial", como nos foi contada e recontada acerca dos primeiros passos da arquitetura moderna brasileira, é um processo que se faz necessário, procurando conhecer suas entrelinhas, as quais ainda estão escondidas, tal como a relevância da arquitetura industrial como programa na modernidade.

Em termos estruturais, optou-se por organizar o trabalho em cinco capítulos, alimentados por fontes de naturezas distintas: revisão bibliográfica, arquivos históricos onde estão arquivados material gráfico sobre as obras e, por fim, as obras originais, sobretudo aquelas que ainda podem ser visitadas. O primeiro capítulo, Personagens, traz dados biográficos a respeito de

2 GUERRA, A. A Construção de um Campo Historiográfico In: GUERRA, A. (org.). Textos fundamentais sobre história da arquitetura moderna brasileira. São Paulo: Romano Guerra Editora, 2010, Parte 1, p. 11.

3 CAVALCANTI, L. e LAGO, A. C. Ainda moderno? Arquitetura brasileira contemporânea. In: Arquitextos, São Paulo, ano 06, n. 066.00, Vitruvius, nov. 2005. Disponível em <http://www.vitruvius.com.br/revistas/read/arquitextos/06.066/404>. Acesso em 09 nov 2018. 
Henry Ford e Albert Kahn, essenciais para entender a conjuntura da época. O capítulo também abordará a expansão da Ford Motor Company pelo mundo e a forma com que o fordismo revolucionou não só a obra do arquiteto como o seu próprio escritório de arquitetura que, não bastando ser um dos maiores de Detroit no período, era capaz de produzir muitas obras ao mesmo tempo.

O segundo capítulo, Técnica, tratará da contribuição do concreto armado e da energia elétrica para a mudança no projeto das fábricas, dando origem à mecanização total da produção e a um novo edifício fabril. Ao tratar das primeiras fábricas de automóveis americanas, o capítulo demonstrará a mudança que a linha de montagem fordista trouxe para o projeto da fábrica, o qual passou a ser visto como parte de uma grande máquina e detalha a contribuição das inovadoras fábricas da Ford Motor Company.

O terceiro capítulo, Genealogia, demonstrará a evolução do projeto industrial dentro da obra de Albert Kahn, desde as estruturas de concreto até o uso de estruturas metálicas. A solução para as necessidades práticas e materiais dos clientes e a exigência de uma construção estritamente econômica e racional levaram Kahn a projetar estruturas baseadas em diferentes níveis de complexidade, associação, relação com o meio, flexibilidade e possibilidade de crescimento, o que será explicitado nesta parte da tese.

O quarto capítulo, Fábrica, tratará do projeto da primeira fábrica de automóveis do Brasil, construída para a Ford Motor Company. Por meio de uma descrição analítica e teórica e através da confecção de diagramas, pretende-se examinar o sítio e pormenorizar o programa, as técnicas e as estratégias adotadas, contextualizada num período de busca de modernidade no país.

O quinto e último capítulo, Legado, apresenta como o trabalho industrial de Albert Kahn influenciou, involuntariamente, os arquitetos do Movimento Moderno europeu, através da produção e a disseminação dos componentes de edifícios, além da circulação de imagens fotográficas dos projetos de Kahn e a formação de arquitetos e engenheiros pelo seu escritório. Também aborda como essa influência foi negligenciada pela maioria dos críticos arquitetônicos. 
Estudar a primeira fábrica construída em concreto armado no Brasil poderá ser fundamental para a mudança de paradigmas na arquitetura nacional e iluminar uma parte muito importante da própria história da arquitetura, lançando as sementes para estudos e reflexões posteriores. 

CAP.1 PERSONAGENS 
Qualquer área do conhecimento humano está indissoluvelmente ligada à ideia de inovação, aqui considerada como a capacidade que algumas pessoas possuem de sentirem as demandas do seu tempo e da sociedade, trabalhando no sentido de compatibilizá-las e torná-las não só existentes, mas acessíveis a todos. Geralmente consideradas como "precursores" ou "pioneiros", essas pessoas se diferenciam das outras pelo simples aspecto de verem com clareza aquilo que estava o tempo inteiro ao alcance, mas ainda não tinha se transformado em realidade.

Neste sentido, como pioneiro na produção em massa de automóveis, podemos elencar Henry Ford, o fabricante de veículos do século XX que praticamente redefiniu essa indústria e cujas ideias ainda se propagam nos tempos atuais. Por outro lado, considerado um precursor tanto no projeto quanto na construção de edifícios em massa, não se pode esquecer de Albert Kahn, o arquiteto americano responsável por projetos que redefiniram o cenário da arquitetura industrial e acabaram por lançar as bases de uma maneira racional de construir edifícios, algo que aliava a beleza sóbria das estruturas com a sua absoluta funcionalidade.

Com a missão de tornar os automóveis acessíveis para as pessoas dos mais diferentes estratos sociais, Henry Ford (1863-1947) fundou a Ford Motor Company em Detroit. Para realizar o seu objetivo principal, racionalizando ao máximo o custo e a produção de um automóvel (que até então, além de caro, era fabricado de forma quase artesanal), Ford introduziu métodos revolucionários de produção em massa, bem como foi o responsável pela criação da primeira linha de montagem móvel para carros. Em decorrência dessa nova forma de enxergar a produção de automóveis, Ford experimentou também um inovador projeto de fábrica. $\mathrm{O}$ êxito comercial e o crescimento do interesse dos consumidores pelo carro Modelo T fez com que a Ford Motor Company abrisse fábricas em todo o mundo, do Velho Continente, passando pela União Soviética e Japão, até chegar à fábrica aberta no Brasil, objetivo maior da pesquisa realizada no âmbito deste estudo.

Por outro lado, o trabalho realizado por Albert Kahn (1869-1942) foi decisivo para o sucesso da indústria automotiva dos Estados Unidos no início do século XX, principalmente por causa das fábricas inovadoras que projetou para Ford Motor Company e para outros fabricantes de automóveis de Detroit. Não bastando 
refinar e popularizar a fábrica de concreto armado entre 1905 e o final da década de 1910, mostrando enorme versatilidade e capacidade de ajuste às demandas dos seus clientes, o arquiteto também desenvolveu uma quantidade significativa de projetos inovadores de fábrica com estrutura metálica nas décadas de 1920 e 1930. Suas inovações não pararam no campo da arquitetura, mas se expandiram para a própria metodologia e técnica do trabalho que realizava: ao assumir um grande volume de projetos de fábrica, consciente de que precisava dinamizar o tempo para viabilizálos, Kahn revolucionou a operação de seu escritório de arquitetura, subdividindo tarefas e criando assim uma linha de montagem arquitetônica - uma fábrica de projetos que lhe permitia a produção em massa de fábricas.

$\mathrm{O}$ encontro dessas personagens tão emblemáticas levaria ao projeto da primeira fábrica da Ford no Brasil. Por tal motivo, é de suma importância realizar um breve retrospecto do percurso feito por Henry Ford e Albert Kahn, a fim de destacar que as suas ideias foram o resultado de uma série de reflexões que conjugaram técnica, poder de observação e o desejo de construir algo que satisfizesse as necessidades dos seus clientes, com muita inventividade e dedicação. 


\subsection{FABRICANTE}

\subsubsection{Henry Ford, o visionário}

Henry Ford (1863-1947) não inventou o automóvel e também não foi o responsável pela criação da linha de montagem. No entanto, o seu nome está indelevelmente ligado tanto à história do automóvel quanto ao seu modo de produção. Isso ocorre pelo fato de que Ford foi responsável por transformar o carro na inovação que moldou profundamente o século XX e continua a afetar as nossas vidas até hoje.

Henry Ford nasceu na fazenda de seu pai, naquela que hoje é a cidade de Dearborn, Michigan, em 30 de julho de 1863. Quando tinha 16 anos, contrariando o seu pai, que preferia que ele se tornasse agricultor, o rapaz deixou a fazenda para se tornar um aprendiz na Michigan Car Company, fabricante de vagões ferroviários em Detroit. Desde o começo, Ford era fascinado por máquinas e acabou se revelando um mecânico talentoso.

Antes de sua carreira realmente decolar, Ford teve vários empregos, e todos 
acabaram sendo decisivos para o futuro que imaginava para si. Além de trabalhar como mecânico, consertando máquinas a vapor e máquinas agrícolas, um dos seus empregos mais significativos foi como engenheiro na Edison Illuminating Company, empresa de distribuição de energia fundada por Thomas Edison, a qual teve a lâmpada incandescente entre uma das suas mais importantes patentes e inventos. ${ }^{4}$ Contudo, os interesses de Ford eram outros, e ter esse tipo de experiência profissional ajudou a consolidar o desejo de se firmar como empresário no ramo automobilístico.

Para tanto, em um momento inicial, com o objetivo de construir um meio de transporte que não exigisse o uso de tração animal, Ford passou a realizar projetos pessoais em um pequeno galpão em Detroit, sempre empregando métodos empíricos. Seus experimentos culminaram, em 1896, com a conclusão daquele que seria o seu primeiro veículo autopropulsado, o Quadriciclo. O veículo possuía quatro rodas, parecidas com rodas de bicicleta, apresentando apenas duas velocidades.

Dois anos depois, Ford finalizou o seu segundo protótipo de automóvel e, ao procurar investidores para o empreendimento, decidiu fundar, em 1899, a Detroit Automobile Company. Pouco tempo depois, contudo, a fábrica viria a fechar por conta de desentendimentos surgidos entre os sócios. Alguns destes, no entanto, permaneceram confiantes em Ford e, em novembro de 1901, outra empresa foi fundada - a Henry Ford Company. No entanto, Henry Ford não soube administrar o negócio e a nova empresa acabou sendo dissolvida, assim como ocorrera com a primeira. Nessa segunda experiência, Ford assumiu alguns riscos, construindo e até dirigindo carros de corrida. $\mathrm{O}$ sucesso desses carros atraiu outros financiadores e, em 16 de junho de 1903, Henry iniciou o seu terceiro empreendimento automotivo e aquele que tornaria o seu nome mundialmente conhecido: a Ford Motor Company. ${ }^{5}$

A história inicial da Ford Motor Company ilustra uma das características mais importantes de Henry Ford: a capacidade de identificar e atrair pessoas talentosas. Prova disso foi o fato dele contratar um núcleo de funcionários, todos jovens, que acreditaram em sua visão e transformaram a Ford Motor Company em uma das

4 LOWRY, R. “The People’s Tycoon”: Driven. New York Times, New York, 4 set. 2005. Disponível em: < https://www. nytimes.com/2005/09/04/books/review/the-peoples-tycoon-driven.html >. Acesso em: 27 jun. 2018.

5 Situando as conquistas e controvérsias de Henry Ford dentro do contexto americano do início do século XX, Watts escreveu uma biografia abrangente sobre o empresário. Ver: WATTS, S. The People's Tycoon: Henry Ford and the American Century. Nova York: Vintage Books, 2006., p. 70. 
grandes empresas industriais do mundo. O primeiro carro da Ford, chamado Modelo A,foi seguido por uma variedade de modelos que eram progressivamente aprimorados, demonstrando a grande insatisfação do seu inventor, sempre em busca do melhor. Em 1907, poucos anos depois do início da Ford Motor Company, o Modelo N, de quatro cilindros, se tornou o carro mais vendido no país. Entretanto, a essa altura, o inquieto Henry Ford já tinha um objetivo maior: um carro melhor e que fosse acessível para a população. Foi assim que, no primeiro dia do mês de outubro de 1908, ele lançaria o Modelo T, o automóvel que se tornou - no ponto de vista tecnológico, econômico e cultural - o mais significativo da história automobilística americana.

Desde o início, as vendas do Modelo T superaram todos os concorrentes e o carro tornou-se o mais popular já produzido nos Estados Unidos. Os veículos, antes restritos a poucos, tornaram-se baratos e, portanto, mais acessíveis à parte considerável da população que antes se via excluída da propriedade desses automóveis, fazendo com que eles se tornassem objeto de desejo da classe média norte-americana.

O Modelo $\mathrm{T}$ foi produzido em apenas uma cor (preta) e somente em um modelo. Assim, ao invés de desenvolver carros para utilização nos finais de semanacarros de luxo, como os produzidos pelos seus concorrentes -, o Modelo T da Ford foi feito para o uso diário. Desta forma, era forte, durável, simples de dirigir e de fácil manutenção. Por causa da conjugação desses fatores, o seu sucesso foi tão grande que, por dezoito anos, acabou sendo o único carro fabricado pela Ford. A respeito do veículo, Henry Ford disse:

"I will build a car for the great multitude. It will be large enough for the family, but small enough for the individual to run and care for. It will be constructed of the best materials, by the best men to be hired, after the simplest designs that modern engineering can devise. But it will be so low in price that no man making a good salary will be unable to own one."

Como a produção de automóveis estava crescendo em decorrência do aumento da demanda, a fábrica da Ford Motor Company tornou-se restrita pela falta

6 Tradução da autora: "Eu vou construir um carro para a grande multidão. Será grande o suficiente para a família, mas pequeno o suficiente para o indivíduo correr e cuidar. Ele será construído com os melhores materiais, pelos melhores homens a serem contratados, após os projetos mais simples que a engenharia moderna pode conceber. Contudo, será tão barato que nenhum homem que tenha um bom salário será incapaz de possuir um.” Ver: FORD, Henry. My life and work. New York: Doubleday, Page \& Company, 1922. 
de espaço físico para ampliar a produção. Para produzir mais, era necessário possuir uma fábrica maior e mais eficiente, e foi assim que, em 1908, Henry Ford aproximouse do arquiteto Albert Kahn, contratando-o para construir uma nova fábrica de automóveis em um terreno localizado em Highland Park, no subúrbio de Detroit. Nesse período, em uma atitude que se tornaria a sua principal marca e um fator que a distinguiria entre as demais fábricas de automóveis do mundo, a Ford Motor Company começou uma campanha incansável para aumentar a produção e reduzir os custos. Pegando emprestados conceitos de fabricantes de relógios, fabricantes de armas, fabricantes de bicicletas e frigoríficos, Henry e sua equipe misturaram essas noções com as suas próprias ideias e, no final de 1913, desenvolveram aquela que seria a primeira linha de montagem móvel para automóveis. ${ }^{7}$ A fábrica Ford Highland Park representou o início de uma nova era no projeto de fábricas de automóveis, uma época em que novos pressupostos sobre a produção ditaram mudanças importantes no projeto das fábricas. Ela também foi o início de uma proveitosa parceria entre os dois, fabricante e arquiteto, que se estenderia por trinta e quatro anos, com mais de mil projetos realizados para a Ford Motor Company em vários países e, dentre eles, inclusive uma fábrica no Brasil. Em 1919, Henry decidiu comprar todas as ações da Ford Motor Company, tornando-se o único proprietário daquela que, na época, era a maior empresa automobilística do mundo. Ford nomeou seu filho Edsel, de 26 anos, como presidente. No entanto, era Henry quem realmente administrava os negócios. As vendas do Modelo $\mathrm{T}$ aumentavam de forma constante à medida que o preço se tornava cada vez mais acessível e atrativo. Assim, com o crescimento gradativo da produção, não espanta que, em 1922, metade dos carros americanos fossem Modelos T. ${ }^{8}$

Porém, o mesmo modelo responsável pelo grande sucesso de vendas acabou se transformando no responsável pelo seu declínio. O Modelo $\mathrm{T}$ passou a perder popularidade para carros mais caros, porém mais elegantes e confortáveis, como os fabricados pela General Motors Company. Em contraste com a estratégia da Ford, caracterizada pela oferta de um modelo único de automóvel - algo altamente funcional, mas sem opções para o cliente, nem mesmo quanto a cor -, a General Motors produzia uma ampla variedade de modelos, com diferentes cores e estilos,

7 BIGGS, L. B. Industry's master machine: factory planning and design in the age of mass production, 1900 to 1930 . Tese (Ph.D in Urban Studies and Planning). Massachusetts Institute of Technology: Cambridge, 1987.

8 História de Henry Ford disponível no site do Museu The Henry Ford. < https://www.thehenryford.org/explore/stories-ofinnovation/visionaries/henry-ford/> Acesso: 5 dez. 2018. 

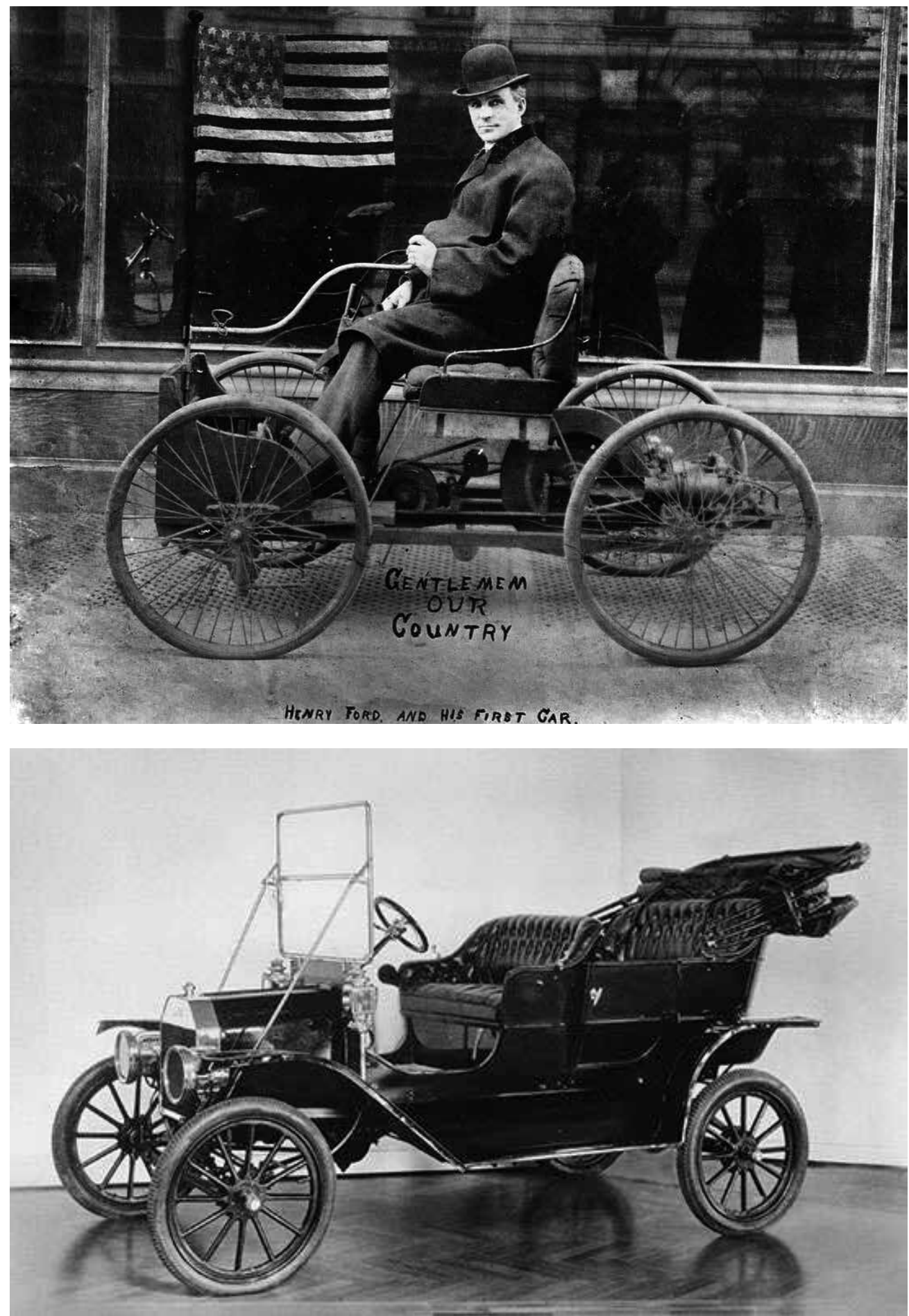

Fig. 1 Henry Ford em seu primeiro carro, o Ford Quadricycle (1896). Fonte: <http://historyloversclub.com/history-of-ford-motor-company-in-photos/> Acesso 07 mai 2018. Fig. 2 Ford Modelo T (1909).

Fonte: <https://www.britannica.com/technology/Model-T> Acesso 07 mai 2018. 


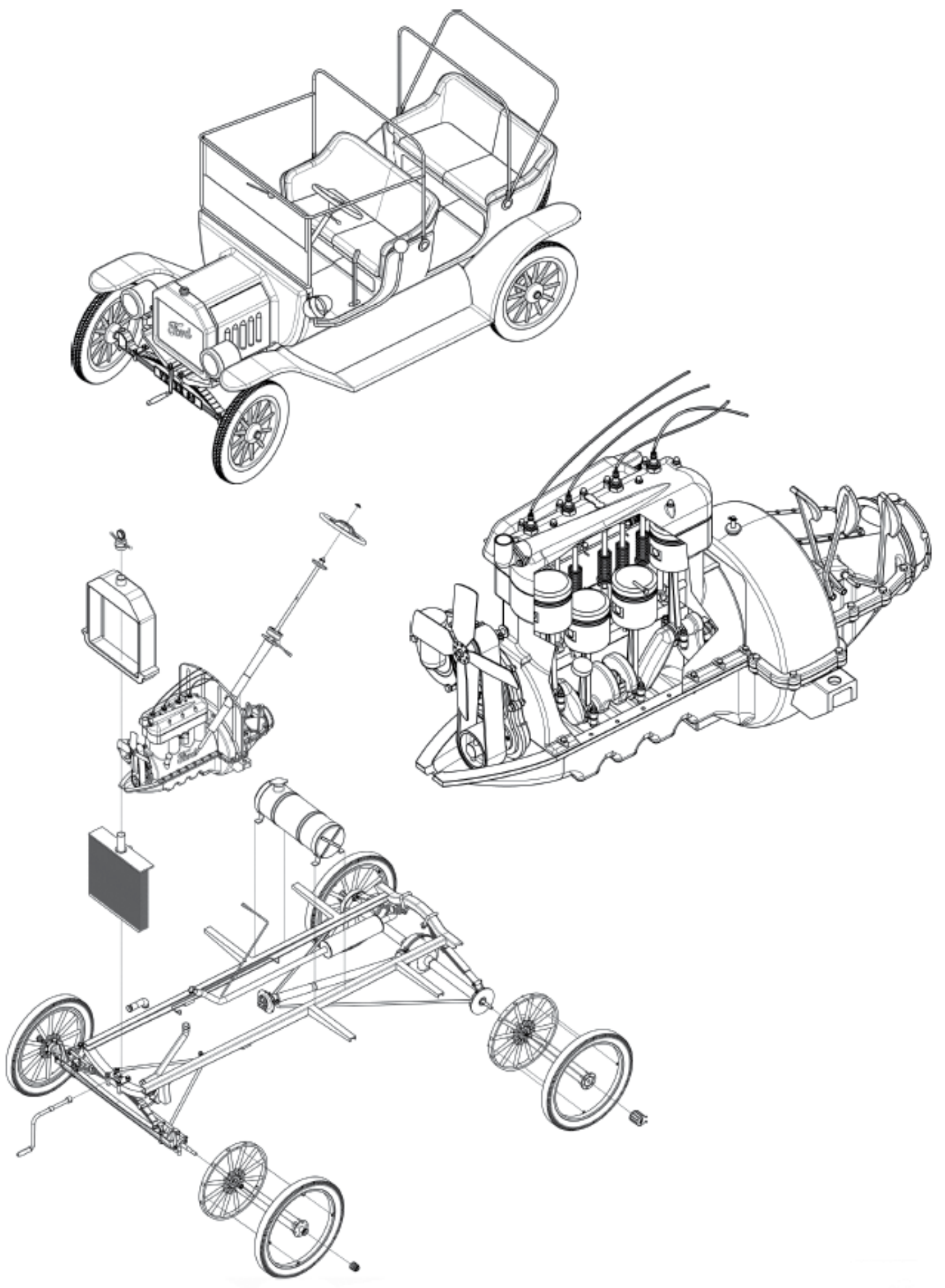

Fig. 3 Ford Modelo T, modelo tridimensional. Fonte: Rasner (2013). 
os quais era atualizados todos os anos. Esta estratégia deu origem ao conceito de "modelo do ano", criando uma nova demanda entre os compradores.

De 1926 a 1950, a quantidade total de carros vendidos nos Estados Unidos saltou de dois milhões para sete milhões por ano, e a General Motors aumentou sua participação no mercado total de $20 \%$ para $50 \%$, enquanto a da Ford caía de 50\% para 20\%. ${ }^{9}$ Diante dessa situação, em 1927, Henry Ford relutantemente desligou as linhas de montagem do Modelo T e começou a projetar um carro novo. Em dezembro de 1927, apareceu com um modelo tão diferente do Modelo T que a empresa voltou ao início do alfabeto para nomeá-lo - eles o chamaram de Modelo A.

O novo carro, contudo, não seria produzido em Highland Park. Em 1917, a Ford iniciou a construção de uma fábrica ainda maior em River Rouge, na cidade de Dearborn, Michigan. Em 1927, todas as etapas do processo de fabricação, desde o refinamento de matérias-primas até a montagem final do automóvel, ocorriam na gigantesca fábrica do Rouge. Com o tempo, ela se tornaria a maior fábrica do mundo, produzindo não apenas carros, mas também aço, vidro, pneus e outros componentes dos veículos.

O Modelo A foi competitivo por apenas quatro anos, antes de ser substituído por um novo design. Em 1932, aos 69 anos, Henry Ford apresentou sua novidade automotiva, o Modelo B, um carro leve e econômico, dotado de motor V8. Mesmo assim, não foi suficiente para deter o declínio de sua empresa. Em 1936, a Ford Motor Company havia caído para o terceiro lugar no mercado dos Estados Unidos, atrás da General Motors e da Chrysler Corporation. ${ }^{10}$ Além disso, durante a Grande Depressão, Ford foi forçado a baixar os salários e demitir trabalhadores.

Quando a Segunda Guerra Mundial começou em 1939, Henry Ford, que sempre odiou a guerra, fez de tudo para impedir que os Estados Unidos tomassem partido. Contudo, depois do ataque japonês a Pearl Harbor, não havia mais como evitar o conflito e, dessa forma, a Ford Motor Company tornou-se uma das maiores empresas militares dos Estados Unidos, fornecendo aviões, motores, jipes e tanques para o Exército.

9 KIM, C. e MAUBORGNE, R. A estratégia do oceano azul: como criar novos mercados e tornar a concorrência irrelevante. Rio de Janeiro: Campus-Elsevier, 2005 p. 191-195.

10 História de Henry Ford, disponível no site do Museu The Henry Ford. < https://www.thehenryford.org/explore/storiesof-innovation/visionaries/henry-ford/> Acesso: 5 dez. 2018. 
Henry Ford morreu de hemorragia cerebral aos 83 anos, em 1947, perto de Dearborn, Michigan. Quatro anos antes, Edsel Ford, seu filho, havia falecido, fato que levou Henry, em 1945, a entregar oficialmente o controle da empresa para Henry Ford II, seu neto e filho de Edsel. A fama do Modelo T tornou Henry Ford um dos homens mais bem sucedidos dos Estados Unidos, tendo influenciado a indústria automotiva tanto americana quanto mundial.

O legado de Henry Ford, também conhecido como fordismo, consistia na produção em massa, redução de custos e organização administrativa da empresa para incentivar o consumo, o qual também ocorria de forma massificada. A técnica desenvolvida pelo fabricante de automóveis foi descrita em seu livro, "Minha Philosofia da Industria"11, tendo contribuído para a otimização do processo de produção e para o aumento da produtividade não somente na área automobilística, mas em diversos outros aspectos.

Foi para atender às demandas de produção do Ford Modelo $\mathrm{T}$ que o fordismo acabou não só surgindo como também sendo aperfeiçoado. A sua relação com o espaço físico da fábrica e com a forma de pensar a produção fizeram com que as peculiaridades da fabricação do veículo extrapolassem as questões meramente comerciais e ingressassem nas necessidades espaciais atendidas por Albert Kahn, podendo, assim, ser replicadas em outras fábricas ao redor do mundo.

\subsubsection{Ford Motor Company e a sua expansão pelo mundo}

O intenso empenho de Henry Ford no sentido de baixar os custos de produção - para dar vazão às necessidades de consumo cada vez maiores da classe média americana - resultou em muitas inovações técnicas e de gerenciamento da Ford Motor Company. Ao utilizar os princípios do seu criador, a empresa acabou se expandindo e levando essas ideias para serem aplicadas em outros países, modificando a mentalidade produtiva por onde passava. Essa expansão incluiu um sistema de franquias que instalou uma filial em quase todas as cidades da América do Norte e nas maiores cidades do mundo. Assim, a história global da empresa acompanha de perto a herança construída no seu país de origem desde 1904, ano em que ocorreu a abertura da primeira fábrica no exterior e a 
exportação dos primeiros carros da Ford, até a sua expansão pelos seis continentes. ${ }^{12}$

Os automóveis da Ford não foram apenas vendidos em todos os continentes - exceto na Antártica -, mas também foram fabricados neles. Depois de se tornar um sucesso de vendas nos Estados Unidos, o Modelo T transformou-se no primeiro carro construído por vários países simultaneamente. Desde o início, a Ford Motor Company contava com uma rede de revendedores que vendiam os carros Modelo $\mathrm{T}$ e peças de estoque, além de prestarem serviços mecânicos.

Inicialmente, a Ford fabricava os carros em Detroit e depois os enviava aos revendedores em todo o país e no exterior. Para melhor atender à rede de concessionárias, em 1906, a Ford inaugurou filiais em Boston, Buffalo, Cleveland, Chicago, St. Louis e Kansas City. Tão logo a Ford Motor Company iniciou a venda de carros nos Estados Unidos, começou também a criar relações com empresas estrangeiras para montar e vender a sua produção automobilística no exterior. Em 1914, a Ford Motor Company já possuía 29 filiais ao redor do mundo, as quais representavam $80 \%$ das vendas da empresa. À medida que as vendas nos Estados Unidos e no mundo começaram a aumentar, a Ford passou a construir suas próprias fábricas, cujos edifícios eram, geralmente, projetados pelo arquiteto Albert Kahn.

$\mathrm{O}$ primeiro contrato da Ford com um fabricante estrangeiro foi firmado com Gordon McGregor, um fabricante de vagões de Ontário que se tornaria o fundador da Ford Canadá. McGregor assinou um contrato com a Ford Motor Company, passando a deter direitos exclusivos para fabricar e vender carros Ford em todo o Canadá e nas outras colônias britânicas, exceto Grã-Bretanha e Irlanda. A Ford Motor Company transferiu os direitos de patente e venda a fim de evitar as taxas de tarifas para comercialização nos países do Império Britânico. Por este motivo, a Ford Canadá não era uma subsidiária ou filial da Ford Motor Company: ao contrário, constituía uma organização separada, autônoma, possuindo inclusive o seu próprio grupo de acionistas. Os acionistas fundadores da Ford Motor Company detinham diretamente $51 \%$ das ações da Ford Canadá, ao passo que Henry Ford possuía 13\% da nova empresa. O Ford Modelo C, o primeiro carro a ser produzido em Walkerville, Ontário, saiu da fábrica no final de setembro de $1904 .{ }^{13}$

Mais ou menos na mesma época, Percival Perry, de Birmingham, Inglaterra,

12 A publicação mais completa sobre o assunto é o livro American Business Abroad: Ford on Six Continents (1964), de Mira Wilkins e Frank Ernest Hill, que documenta os primeiros sessenta anos da expansão internacional da Ford Motor Company. Ver: WILKINS, M. e HILL, F. E. American Business Abroad: Ford on Six Continents. New York: Cambridge University Press, 2011.

13 ANASTAKIS, D. From independence to integration: the corporate evolution of the Ford Motor Company of Canada, 1904-2004. The Business History Review, v. 78, n. 2, p. 213-253, 2004 
iniciou negociações com a Ford Motor Company para obter os direitos exclusivos de venda e distribuição de automóveis Ford na Europa. Tendo realizado esse acordo, a filial foi aberta em Londres e ele logo começou a negociar a construção de uma fábrica na Inglaterra. A produção de carros baratos permitia que a Ford competisse com os grandes fabricantes europeus, oferecendo um produto diferenciado e econômico. Em decorrência desse fato, em 1907, a Ford já possuía distribuidores na Alemanha, Bélgica, Espanha, Holanda, Itália, Dinamarca, Suécia, Áustria, Polônia e Rússia. Mesmo assim, as vendas dos carros da Ford continuavam lentas. Com o objetivo de supervisionar as vendas europeias, uma concessionária da Ford Motor Company em Paris foi criada em 1908 pelo principal agente francês da Ford, Henri Depasse, eis que a França era sede da maior indústria automobilística da Europa.

Nos Estados Unidos, um fator decisivo para a expansão da Ford foi a adoção de kits CKD (Complete Knocked-Down), fazendo com que partes do veículo fossem fornecidas pela fábrica Ford Highland Park para serem montadas nas fábricas de montagem da Ford que se espalhariam pelo território americano. Em 1910, a Ford abriu a primeira fábrica de montagem fora de Detroit, localizada em Kansas City. Mais tarde ainda neste mesmo ano, a segunda fábrica foi aberta em Fargo, Dakota do Norte. Uma das mais significativas vantagens de finalizar a montagem dos automóveis em outras fábricas era a redução nas taxas de envio. Enquanto um vagão ferroviário padrão da época só comportava três ou quatro carros Modelo $\mathrm{T}$, no sistema $\mathrm{CKD}$, o mesmo vagão podia acomodar as peças e subconjuntos desmontados de doze carros. Isso não apenas possibilitou a diminuição do valor gasto com as taxas de frete como também reduziu o congestionamento ferroviário na fábrica de Highland Park. ${ }^{14}$

De forma gradual, as filiais da Ford no exterior também fizeram a transição para a montagem. A primeira fábrica de montagem da Ford fora do território norteamericano foi aberta por Percival Perry em Trafford Park, Manchester, Inglaterra, em 1911, sendo a primeira fábrica na Europa a instalar uma linha de produção móvel. ${ }^{15}$ A Inglaterra foi escolhida porque vinha apresentando um significativo crescimento de vendas, em especial após o lançamento a preços competitivos do Modelo N, o que ocorreu em 1906. O lugar era uma antiga fábrica de bondes,

14 Disponível em: <http://fordmotorhistory.com/factories/branch_system.php> Acesso: 9 jul. 2018. 15 Ibidem. 

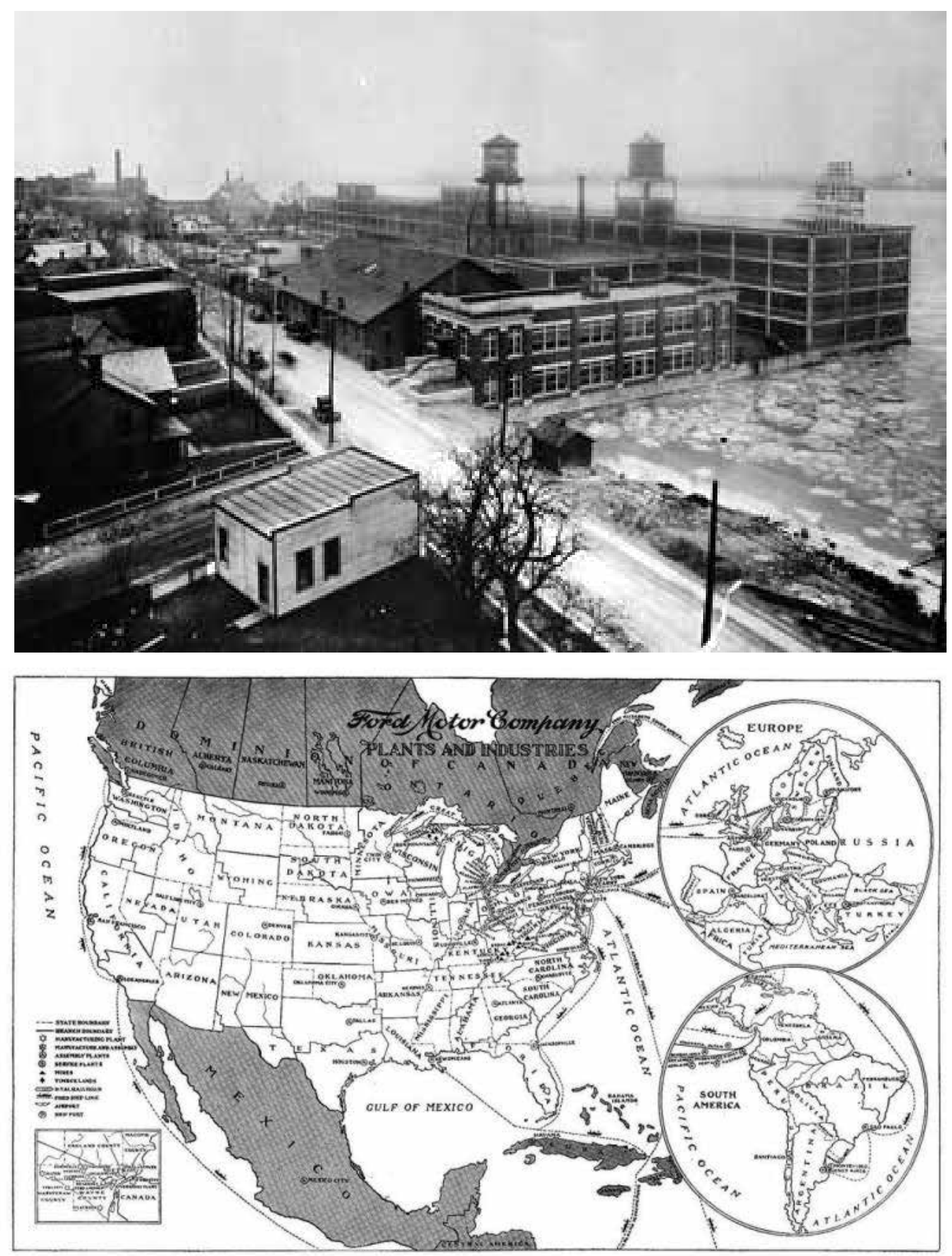

Fig. 4 Ford Motor Company do Canada (1904).

Fonte: <http://13876539.weebly.com/growth-and-expansion.html>Acesso 20 jul 2018.

Fig. 5 Mapa da expansão da Ford pelo mundo.

Fonte: <http://www.mtfca.com/discus/messages/257047/310623.html>Acesso 20 jul 2018. 

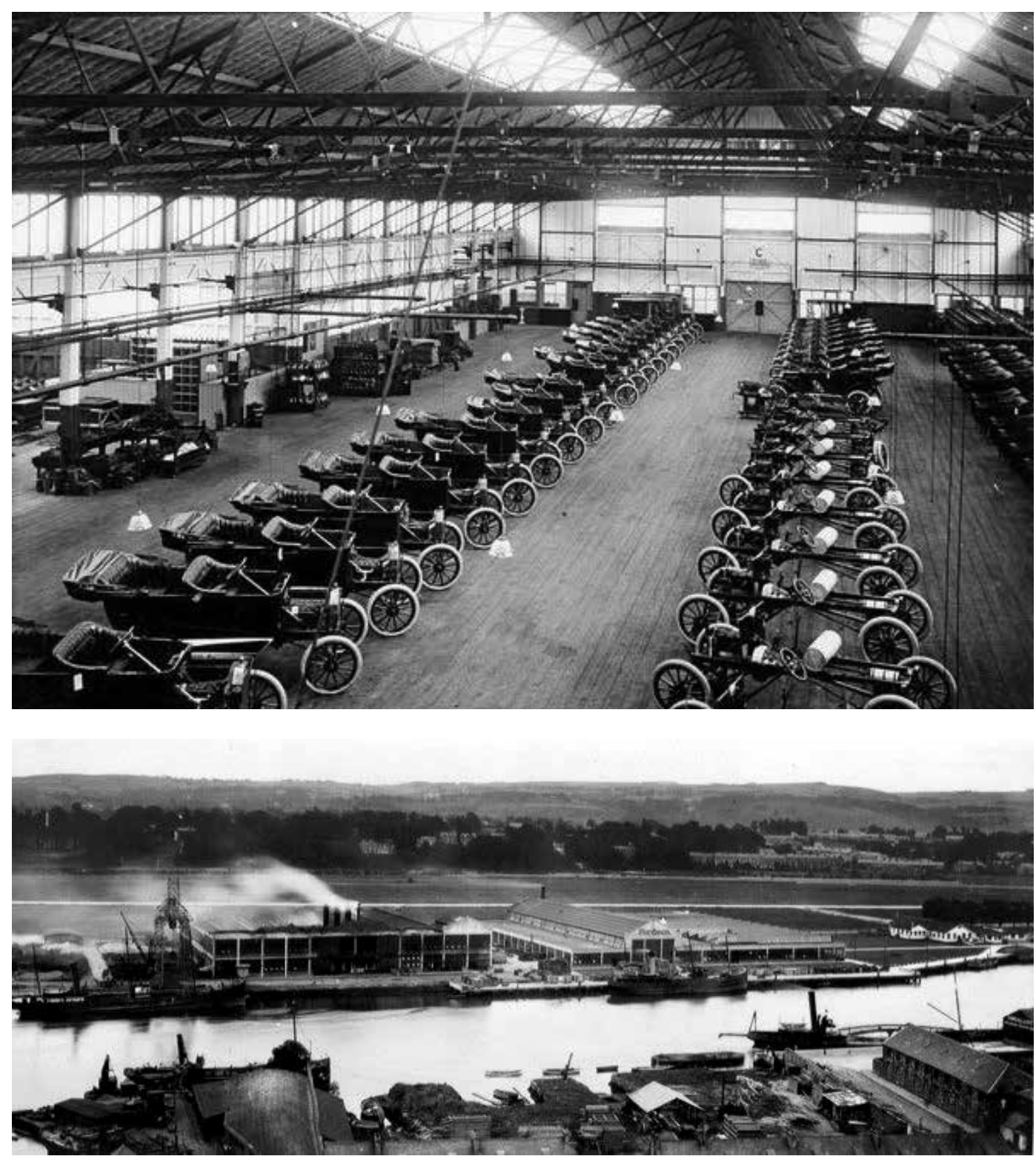

Fig. 6 Interior da fábrica da Ford Motor Company em Manchester, Inglaterra (1911). Projeto de Albert Kahn. Fonte: <http://historyloversclub.com/history-of-ford-motor-company-in-photos/> Acesso 20 jul 2018.

Fig. 7 Fábrica da Ford Motor Company em Cork, Irlanda (1917). Projeto de Albert Kahn.

Fonte: $<$ https://avondhupress.ie/monday-april-17th-centenary-day-ford-ireland/120417ford-ire_13-ford-100-centenary-ford-plant-marinacork-1919> Acesso 20 jul 2018. 


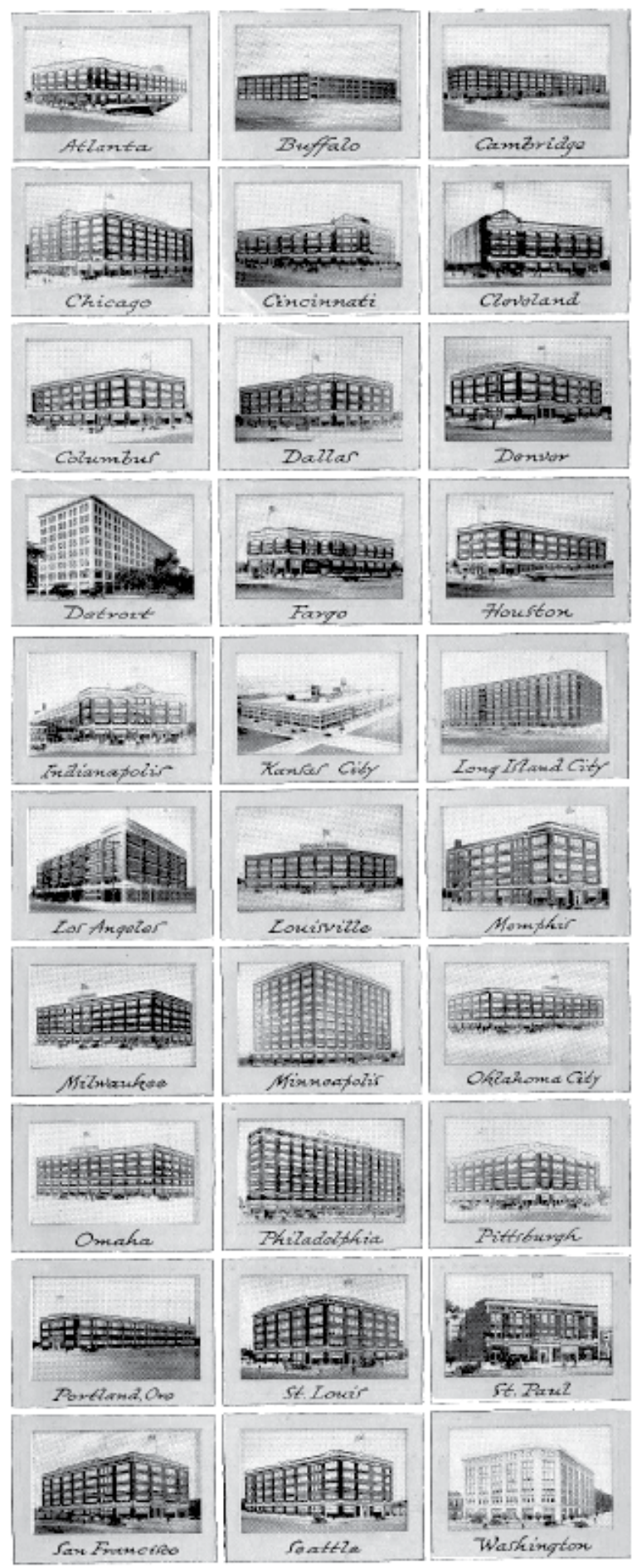

Fig. 8 Fábricas filiais da Ford Motor Company em 1915. Projetos de Albert Kahn. Fonte: Pancorbo (2014) 

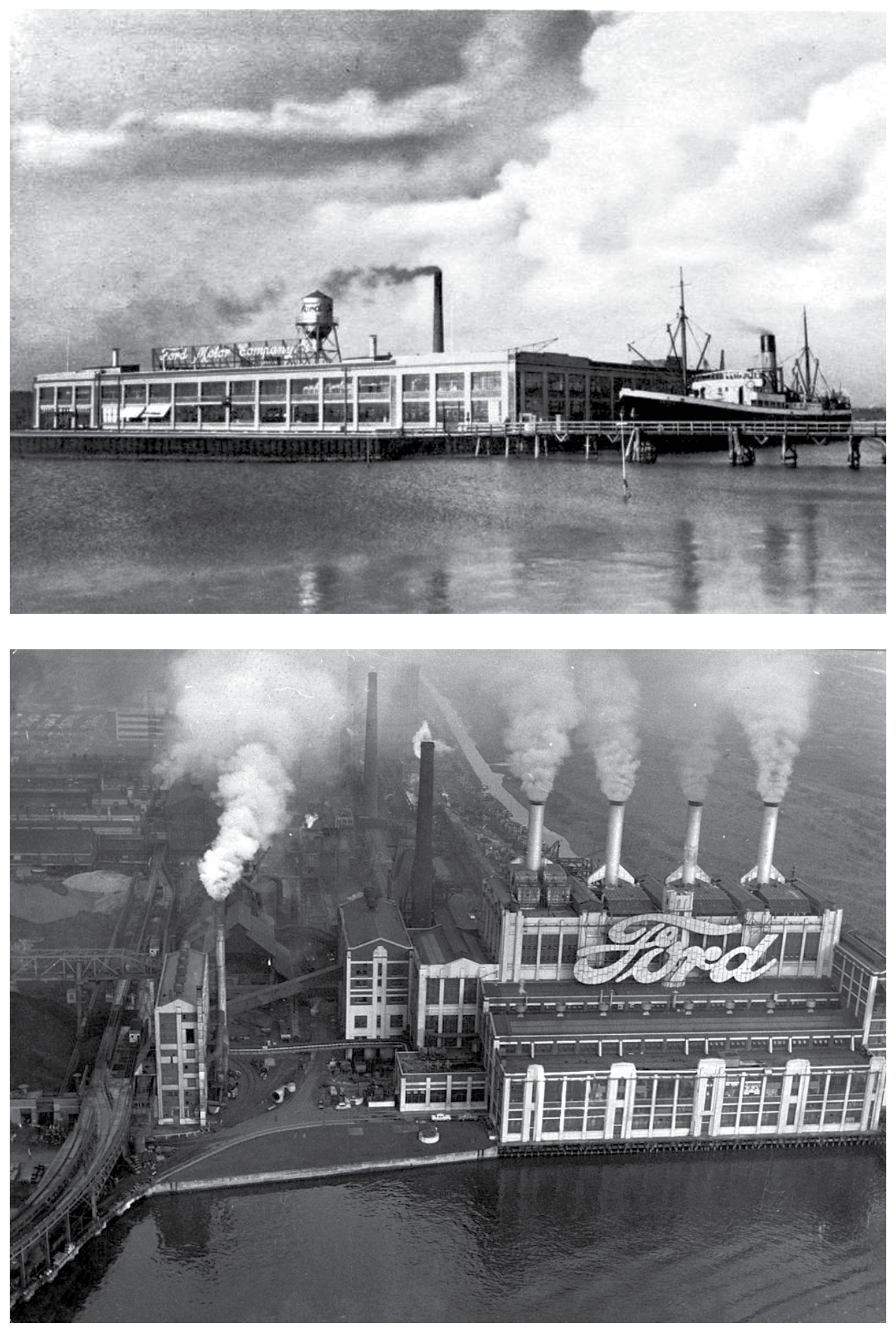

Fig. 9 Fábrica da Ford Motor Company em Copenhagen, Dinamarca (1919). Projeto de Albert Kahn. Fonte: Christensen (2014)

Fig. 10 Fábrica da Ford em Dagenham, Inglaterra (1931). Projeto de Albert Kahn. Fonte: <www. gettyimages.co.uk> Acesso 20 jul 2018. 
localizada em um parque industrial próximo ao Manchester Canal e a uma curta distância da cidade de Manchester. A fábrica montava os veículos usando peças fabricadas em Detroit.

Devido ao crescimento dos negócios no sul do continente americano, em 1914, a Ford Motor Company decidiu instalar uma fábrica de montagem em Buenos Aires, na Argentina, além de investir também em novas revendas em outros países latino-americanos. O volume de vendas estava aumentando, apesar das condições econômicas adversas desses países e da concorrência dos carros europeus. Além disso, com a eclosão da Primeira Guerra Mundial, a maioria das exportações automotivas da Europa para a América Latina tinha cessado, o que começava a impactar os negócios. A fábrica de montagem argentina da Ford Motor Company foi a primeira filial estabelecida em território latino-americano e significou assim como ocorreu na Inglaterra - taxas de importação e vendas mais baratas.

Em 1914, quinze das vinte e nove filiais da Ford eram fábricas de montagem, com uma organização baseada na fábrica Highland Park: o showroom localizava-se no primeiro andar, ao passo que o armazenamento de peças de estoque, bem como uma linha de montagem de automóveis, estavam dispostos nos andares superiores. As quinze fábricas de montagem tornaram-se responsáveis por cerca de um quarto da produção total da empresa. O sistema Ford de fábricas de montagem foi tão bem sucedido que os concorrentes da empresa logo adotaram a prática. ${ }^{16}$

Durante a Primeira Guerra Mundial, Perry persuadiu Henry Ford a construir uma fábrica de tratores - a primeira da Ford na Europa feita com este propósito não muito longe da cidade em que o pai de Ford nascera, ou seja, Cork, Irlanda. Assim, o projeto da fábrica, localizada na marina de Cork, foi realizado por Albert Kahn, sendo ela construída entre 1917 e 1919. Embora tenha sido projetada para a fabricação dos tratores Fordson, a produção de automóveis - o famoso Modelo T - começaria em 1921. A fábrica desempenhou um papel importante na vida industrial, econômica e social da cidade até o seu fechamento, ocorrido em 1984. ${ }^{17}$

Durante a Primeira Guerra Mundial, os Fords canadenses serviram como ambulâncias para as tropas canadenses e os Fords britânicos carregavam munição, ao passo que os Ford feitos nos Estados Unidos realizavam diversas funções

16 A General Motors, por exemplo, estabeleceu quatro fábricas de montagem entre os anos de 1915-1916, todas em locais estratégicos nos Estados Unidos.Disponível em: <http://fordmotorhistory.com/factories/branch_system.php> Acesso: 9 jul. 2018.

17 ENGLISH, E. Iconic Ford plant to become protected structure. Irish Examiner, Dublin, 22 jun. 2009. Disponível em: < https://www.irishexaminer.com/ireland/iconic-ford-plant-to-become-protected-structure-94633.html>. Acesso em: 9 jul. 2018. 
militares para os americanos. Foi para atender ao crescente mercado do pós-guerra que a empresa abriu duas novas fábricas de montagem, uma em Copenhague, na Dinamarca, e outra em Cadiz, na Espanha.

A primeira fábrica de montagem na Europa do período pós-guerra foi construída em Copenhague, onde a Ford Dinamarca tinha sido fundada em 1919. Foi também a segunda fábrica projetada por Albert Kahn ${ }^{18}$ para a Ford na Europa, sendo construída na área portuária da cidade. A isenção de impostos oferecida pelo governo dinamarquês e o fato de Copenhague servir como porta de entrada da Ford para a União Soviética e para os demais países bálticos foram fatores determinantes para a decisão de estabelecer uma fábrica na Dinamarca. $\mathrm{Na}$ sua parte externa, o edifício se assemelhava muito à Ford Highland Park e, internamente, continha as tecnologias do método de produção fordista.

Tendo ingressado no mercado europeu, o objetivo seguinte da Ford Motor Company era se espalhar pelos países e levar os seus veículos para novos interessados. Aos poucos, a empresa começou a se estabelecer em outros lugares, construindo fábricas de montagem e estabelecendo a sua marca como sinônimo não somente de carros, mas de um modo americano de ver o mundo e o mercado de consumo. Ansiosa em servir o sul da Europa, a Ford propôs a abertura de uma nova fábrica em uma antiga bodega localizada na zona franca de Cádiz, na Espanha, em 1920. Na Itália, em 1922, uma das mais notáveis fábricas da Ford foi estabelecida em um depósito desativado da cidade de Trieste. Surpreendentemente, a Alemanha, país em que o primeiro automóvel fora inventado na década de $1880^{19}$, chegou atrasada no esquema europeu das filiais da Ford Motor Company. A primeira filial alemã da Ford foi estabelecida somente em 1926, começando a montagem em um armazém alugado em Berlim.

Outras fábricas de montagem pós-guerra estavam localizadas na Bélgica (1922), na Holanda (1924), na Turquia (1928), na Romênia (1931) e na Hungria (1938). Filiais que não possuíam fábrica de montagem foram abertas na Suécia (1924), no Egito (1926), na Finlândia (1926), em Portugal (1932) e na Grécia (1932). ${ }^{20}$ Em 1921, A Ford Motor Company respondia por quase 57\% da produção mundial de automóveis.

18 A fábrica foi construída pela Monberg \& Thorsen, uma grande empresa de construção dinamarquesa. Ver: CHRISTENSEN, L. K. Between Denmark and Detroit: unionized labour at Ford Motor Company, Copenhagen, 19191939. Labor History, v. 55, n. 3, 2014, p. 5.

19 O primeiro carro a combustão foi o Benz Patent-Motorwagen, um veículo alemão equipado com o tipo de motor que usamos até hoje. Foi inventado por Karl Benz e a sua patente foi reconhecida pelo Império Alemão em 1886. Disponível em: <https://super.abril.com.br/mundo-estranho/qual-foi-o-primeiro-carro-a-combustao/> Acesso em: 18 jul. 2018.

20 Disponível em: <http://www.seriouswheels.com/art-Ford-Europe.htm> Acesso em: 18 jul. 2018. 
Enquanto isso, a Ford Canadá acompanhou o crescimento da matriz nos Estados Unidos e se expandiu pelo país, abrindo filiais em Montreal, Toronto, Winnipeg, Regina, Calgary e Vancouver. Não bastando a expansão na América do Norte, a Ford também entrou no mercado asiático em 1922, construindo uma fábrica de montagem em Yokohama, no Japão.

No final da década de 1930, a Ford possuía um extenso número de fábricas de automóveis espalhadas por toda a Europa. Nesse momento, Henry Ford sentiu a necessidade de centralizar as atividades europeias da empresa em um único local, e escolheu a Inglaterra. Parte desse plano consistia na construção de uma nova fábrica em Dagenham, Essex, no Reino Unido, em 1929, a qual seria o centro de fabricação dos carros na Europa, abastecendo as fábricas de montagem em Manchester, Cork, Paris, Berlim, Copenhague, Trieste, entre outras. Assim, a nova fábrica em Dagenham, projeto também de Albert Kahn, começou a ser construída em 1929, tornando-se a segunda maior fábrica de automóveis no mundo depois da Ford River Rouge, na qual foi inspirada. Em 1931, a fábrica da Ford Dagenham foi inaugurada em um grande terreno próximo ao Rio Tâmisa, contando com unidades fabris para a fabricação de peças e com um edifício de montagem. ${ }^{21}$

$\mathrm{O}$ esquema da Ford para expandir suas fábricas de montagem incluía um novo e essencial componente: o transporte através da água. Com a inauguração da fábrica de Rouge, em 1917, a empresa começou a constituir uma frota de embarcações para o transporte de peças para as fábricas de montagem estrangeiras. Agindo dessa forma, a Ford planejava transportar peças fabricadas na fábrica de River Rouge através dos Grandes Lagos, até chegar aos portos ao longo da costa do Atlântico, ou através do Canal do Panamá até a costa do Pacífico. ${ }^{22}$

Para aproveitar o boom da expansão do pós-guerra e como parte do plano de ampliar as operações da empresa no mercado latino-americano, a Ford Motor Company estabeleceu filiais de vendas e fábricas de montagem em outras partes da América Latina, além da Argentina. Com essa perspectiva de aumento no volume de vendas e na demanda do produto, a Ford passou a considerar viável a abertura de filiais, o que aconteceu no Brasil em 1919, no Uruguai em 1920 e no México em 1925. ${ }^{23}$ Posteriormente, novas fábricas de montagem da Ford Motor Company seriam construídas nesses quatro países, todas projetos capitaneados pelo escritório

21 WILKINS, M. e HILL, F. E. American Business Abroad: Ford on Six Continents. New York: Cambridge University Press, 2011.

22 Disponível em: <.http://fordmotorhistory.com/factories/branch_system.php> Acesso em: 18 jul.

23 WILKINS, M. e HILL, F. E. American Business Abroad: Ford on Six Continents. New York: Cambridge University Press, 2011. 
de Albert Kahn.

Iniciada graças ao espírito visionário de Henry Ford, a Ford Motor Company logo criou personalidade própria e expandiu sua rede comercial pelo mundo inteiro, tornando-se algo que não era mais só um modelo de veículo, mas um ideal de fabricação e de produção que suplantava os limites de outras empresas do ramo automobilístico. No entanto, nada seria possível se os ideais de Henry Ford não tivessem encontrado eco em outra pessoa cujo nome se tornaria sinônimo de qualidade e de eficácia na área da arquitetura, e é sob essa ótica que a importância de Albert Kahn deve ser analisada. 


\subsection{ARQUITETO}

\subsubsection{Albert Kahn, o arquiteto das fábricas}

Um dos mais influentes arquitetos industriais dos Estados Unidos do início do século XX, Albert Kahn revolucionou o projeto das fábricas, tendo trabalhando em estreita colaboração com Henry Ford para implementar a sua visão da linha de montagem nas fábricas de automóveis de Highland Park e River Rouge, as quais, posteriormente, se espalharam pelo resto do mundo. Ao mesmo tempo em que Henry Ford era o precursor no desenvolvimento da técnica de produção de veículos, Kahn foi pioneiro no uso do concreto armado, das estruturas de aço aparentes, da ventilação natural através dos grandes planos de vidro, tudo com o intuito de responder às mudanças das necessidades funcionais da fábrica americana. O seu pragmatismo, aliado à capacidade de ouvir as necessidades do cliente e à experimentação com tecnologias de construção inovadoras, resultou em uma nova arquitetura industrial, inspirando o desenvolvimento do modernismo europeu, algo que ocorreria com arquitetos como Walter Gropius, Mies van der Rohe e Le Corbusier. 
Bastante versátil em suas capacidades projetuais, Kahn também produziu muitos ícones comerciais e institucionais em Detroit e na Universidade de Michigan, incluindo o Fisher Building, Detroit Athletic Club, General Motors Building, Hill Auditorium, Angell Hall, William L. Clements Library e Burton Memorial Carillon Tower, para citar alguns dos seus projetos mais conhecidos. $\mathrm{O}$ prolífico arquiteto americano esteve envolvido na construção de milhares de projetos no mundo inteiro, sendo que, entre os anos de 1929 e 1932, desenvolveu mais de quinhentas fábricas na Rússia. ${ }^{24}$ No ano em que morreu, em 1942, Albert Kahn havia assinado contratos de defesa milionários para a construção da fábrica Willow Run e bases navais em Honolulu, Midway Island, Porto Rico e Kodiak, Alasca, entre outras instalações de guerra.

Nascido em 21 de março de 1869 em Rhaunen, na Alemanha, Kahn passou grande parte da infância em Echternach, Luxemburgo. Seu pai Joseph, um professor itinerante e rabino, imigrou para os Estados Unidos em 1879. Os filhos e a esposa de Joseph, Rosalie, juntaram-se a ele em 1880, passando a morar em Baltimore, Maryland, por um curto período de tempo antes de se estabelecerem em Detroit. Albert era o mais velho dos oito filhos da família Kahn e mostrou grande interesse pelas artes, especialmente pela música. Devido às dificuldades econômicas da família, Rosalie aconselhou-o a adotar uma linha de trabalho mais rentável que as artes, embora tenha providenciado que ele tivesse lições de desenho com o escultor alemão Julius Melchers, em Detroit. O contato de Albert Kahn com a arquitetura começou em 1882, aos 13 anos de idade, quando ocupou o cargo de office boy no escritório de arquitetura John Scott \& Company, de Detroit. Como Kahn se lembraria mais tarde:

"I had always had a bent for drawing, and despite the fact that at school I got the worst marks in that of anything, my father encouraged me by buying me drawing boards and various materials for sketching. My mother must have thought something of my drawing, for she asked for a job for me in the office of a Detroit architect." ${ }^{25}$

Em 1885, percebendo as habilidades de Kahn com o desenho, Melchers recomendou-o para o importante escritório de arquitetura de Detroit, Mason \&

24 BUCCI, F. Albert Kahn: Architect of Ford. New York: Princeton Architectural Press, 1993, p. 91.

25 Tradução da autora: "Eu sempre tive facilidade para desenhar e, apesar do fato de ter recebido as piores notas em qualquer 
Rice. Kahn começou a trabalhar como office boy sem pagamento, mas logo George Mason reconheceu seu talento e o promoveu ao cargo de desenhista. Durante os dez anos que permaneceu no escritório, Kahn trabalhou em numerosos projetos.

Enquanto trabalhava para Mason \& Rice, em 1891, aos 22 anos, Kahn ganhou uma bolsa de estudos, concedida pelas revistas American Architect e Building News, para estudar na Europa por um ano. Em Florença, ele conheceu Henry Bacon, e viajou por quatro meses pela Itália, França, Bélgica e Alemanha ao lado deste jovem arquiteto, que mais tarde projetaria o Lincoln Memorial em Washington, DC. Anos depois, Kahn disse sobre Bacon: "to me he proved not only a splendid teacher but a real friend whose kindness and stimulating influence I have treasured ever since". ${ }^{26}$ Foi durante este período de viagens de estudo que Kahn desenvolveu sua admiração por Palladio e por uma ampla gama de estilos arquitetônicos, os quais serviriam de inspiração para muitos dos seus projetos residenciais, comerciais e institucionais posteriores. Assim, quando retornou da Europa, Kahn foi promovido por Mason ao cargo de chefe de projetos. Em 1892, recusou uma oferta de emprego no importante escritório de arquitetura de Chicago, Adler \& Sullivan, para preencher a vaga do arquiteto Frank Lloyd Wright ${ }^{27}$, pois Kahn estava receoso que não pudesse dar conta e sua família dependia financeiramente dos seus ganhos.

Kahn deixou Mason \& Rice em 1895 para fundar o escritório Nettleton, Kahn \& Trowbridge ao lado de dois colegas do antigo trabalho. O novo escritório ficou conhecido pelo projeto do Children's Hospital em St. Antoine Street, o qual foi financiado por Hiram Walker em 1896. ${ }^{28}$ Quando Alexander B. Trowbridge deixou Detroit para dirigir o Departamento de Arquitetura da Universidade de Cornell em 1877, a empresa foi renomeada para Nettleton \& Kahn até o falecimento de George W. Nettleton, ocorrido em 1900.

Kahn então se juntou a George Mason por um breve período, projetando o edifício residencial Palms Apartments (1902), na Avenida Jefferson, e o projeto para o Templo Beth El (1903) na Avenida Woodward, ambos em Detroit. O projeto

coisa na escola, meu pai me encorajou comprando pranchetas e vários materiais para desenhar. A mãe deve ter achado interessante o meu desenho, pois pediu emprego para mim no escritório de um arquiteto de Detroit."Ver: HILDEBRAND, G. Designing for Industry: The Architecture of Albert Kahn. Cambridge, Massachusetts: MIT Press, 1974, p. 7.

26 Tradução da autora: "para mim, ele provou ser não só um professor esplêndido, mas um amigo real, cuja bondade e estimulante influência eu valorizo desde então”. Discurso de Albert Kahn proferido para a Boston Society of Architects, "Arquitetura industrial - seus problemas e obrigações", 11/12/40, In: ALBERT Kahn Collection. Bentley Historical Library, University of Michigan (arquivos), caixa 1.

27 NELSON, G. Industrial architecture of Albert Kahn, Inc. New York: Architectural Book Pub., 1939, p.16.

28 FERRY, H. Legacy of Albert Kahn. Detroit: The Detroit Institute of Arts,1970, p.9. 
do edifício Palms Apartments representou a primeira experiência de Kahn com estruturas de concreto armado, as quais em breve revolucionariam os seus projetos para as fábricas americanas. $\mathrm{O}$ templo foi inspirado no panteão romano, uma foto que ficava emoldurada sobre a mesa do escritório de Kahn e, nesse projeto, o arquiteto usou treliças metálicas para sustentar a cúpula. ${ }^{29}$

Em 1903, Kahn associou-se a um novo arquiteto para formar o escritório Albert Kahn, Arquiteto \& Ernest Wilby, Associado. ${ }^{30}$ Wilby fez parceria com Kahn até 1918, tendo realizado grandes contribuições para os projetos inovadores da Ford Motor Company e da Universidade de Michigan, entre outros. Ainda em 1903, o irmão de Kahn, Julius, tornou-se engenheiro-chefe da empresa e começou, assim, a sua importante colaboração com Albert para o uso de concreto armado no projeto industrial, que teria impacto global. Albert ajudou a educar Julius, que se graduou em engenharia pela Universidade de Michigan, trazendo conhecimentos técnicos de projeto estrutural para a empresa. ${ }^{31}$ Foi assim que começou a prática revolucionária de Albert Kahn, no momento em que ele uniu as disciplinas de arquitetura e engenharia sob um único campo profissional.

A primeira fábrica que Albert Kahn construiu em concreto armado foi o Edifício Número 10 da Packard Motor Company (1905), localizado em Detroit. Em 1903, Henry Joy contratou Kahn para projetar uma fábrica de automóveis na East Grand Boulevard. Os primeiros nove prédios que o arquiteto construiu no local utilizavam uma estrutura de madeira convencional do século XIX, o que fazia com que as fábricas fossem mais propensas a incêndios, além de dificultarem a produção devido à necessidade de numerosos pilares estruturais. Depois de experimentar e aperfeiçoar seu sistema de concreto armado, o "Kahn system" ${ }^{32}$, no Edifício de Engenharia da Universidade de Michigan (1903), Julius colaborou com Albert no projeto estrutural do décimo edifício para a Packard, um prédio de dois andares, utilizando essa tecnologia inovadora.

O sistema Kahn logo revolucionaria o projeto das fábricas em todo o país por uma série de motivos: os edifícios de concreto armado eram mais resistentes ao fogo; a vibração de grandes máquinas era minimizada; as áreas de trabalho podiam ser maiores e mais flexíveis com o uso de menor quantidade de pilares e,

29 FERRY, H. Legacy of Albert Kahn. Detroit: The Detroit Institute of Arts.1970, p.10.

30 HILDEBRAND, G. Designing for Industry: The Architecture of Albert Kahn. Cambridge, Massachusetts: MIT Press, 1974, p.25.

31 Entre os anos de 1896 e 1900, Julius trabalhou como engenheiro para a Marinha e Exército dos Estados Unidos. Em 1900, teve uma experiência de trabalho no Japão, retornando para Detroit somente no ano de 1903. Ver: FERRY, H. Legacy of Albert Kahn. Detroit: The Detroit Institute of Arts.1970, p.10.

32 Em 1903, Julius Kahn patenteou o sistema Kahn Trussed Bar, abrindo a empresa Trussed Concrete Steel Company para fabricar barras de reforço para o concreto armado. Como a maioria dos empreiteiros não estava disposta a se arriscar utilizando o novo sistema, Julius organizou sua própria empresa, a Concrete Steel and Tile Construction Company. Ver: FERRY, H. Legacy of Albert Kahn. Detroit: The Detroit Institute of Arts.1970, p.11. 

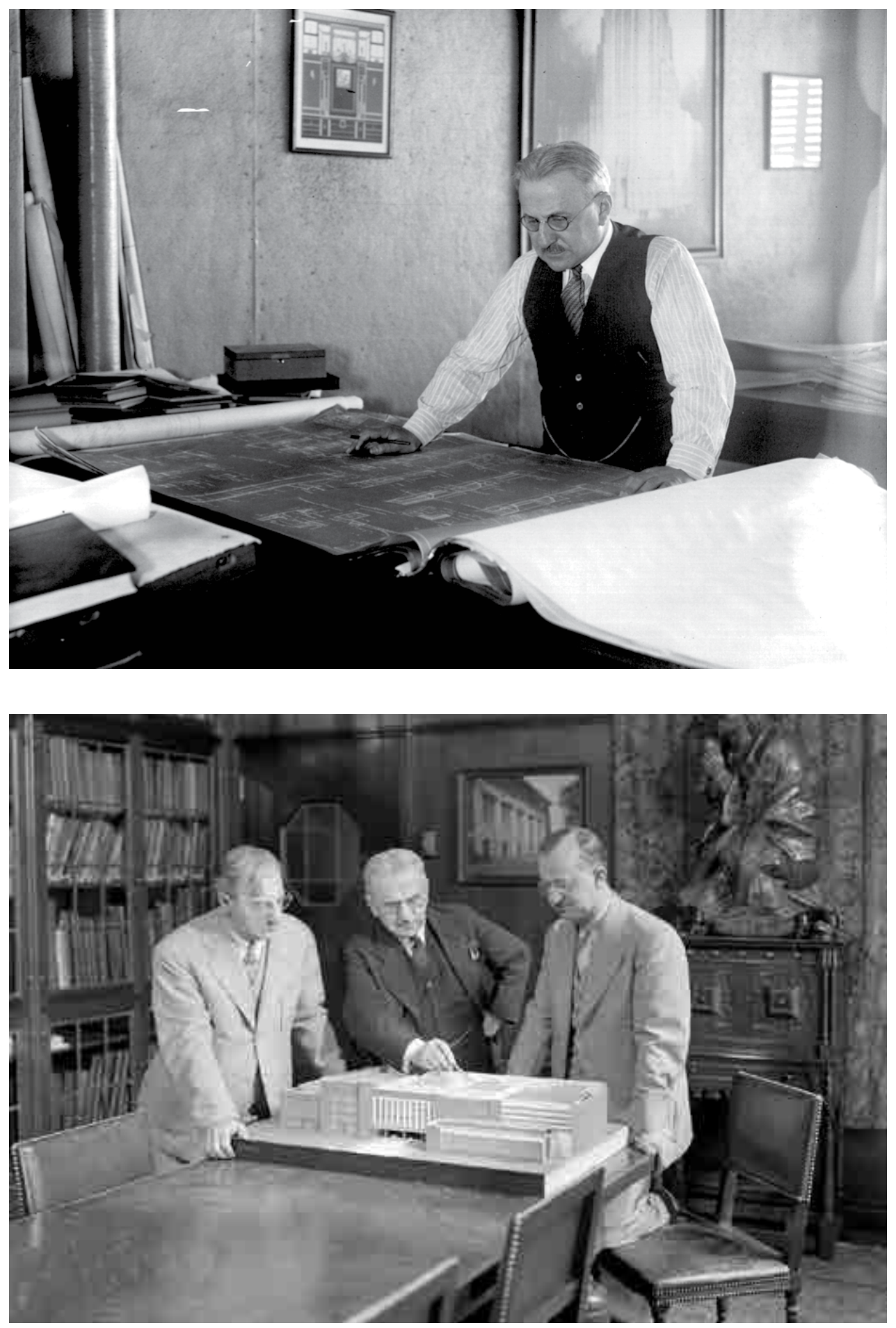

Fig. 11 Albert Kahn em seu escritório em Detroit.

Fonte: <https://www.slideshare.net/walkerpub/albert-kahn-the-20th-centurys-greatest-architect> Acesso 17 mai 18.

Fig. 12 Albert Kahn em seu escritório em Detroit, com os irmãos Julius e Moritz Kahn,

com a maquete do edifício Press Shop da Ford Motor Co., em RIver Rouge.

Fonte: <www.alamy.com $>$ Acesso 17 mai 18. 


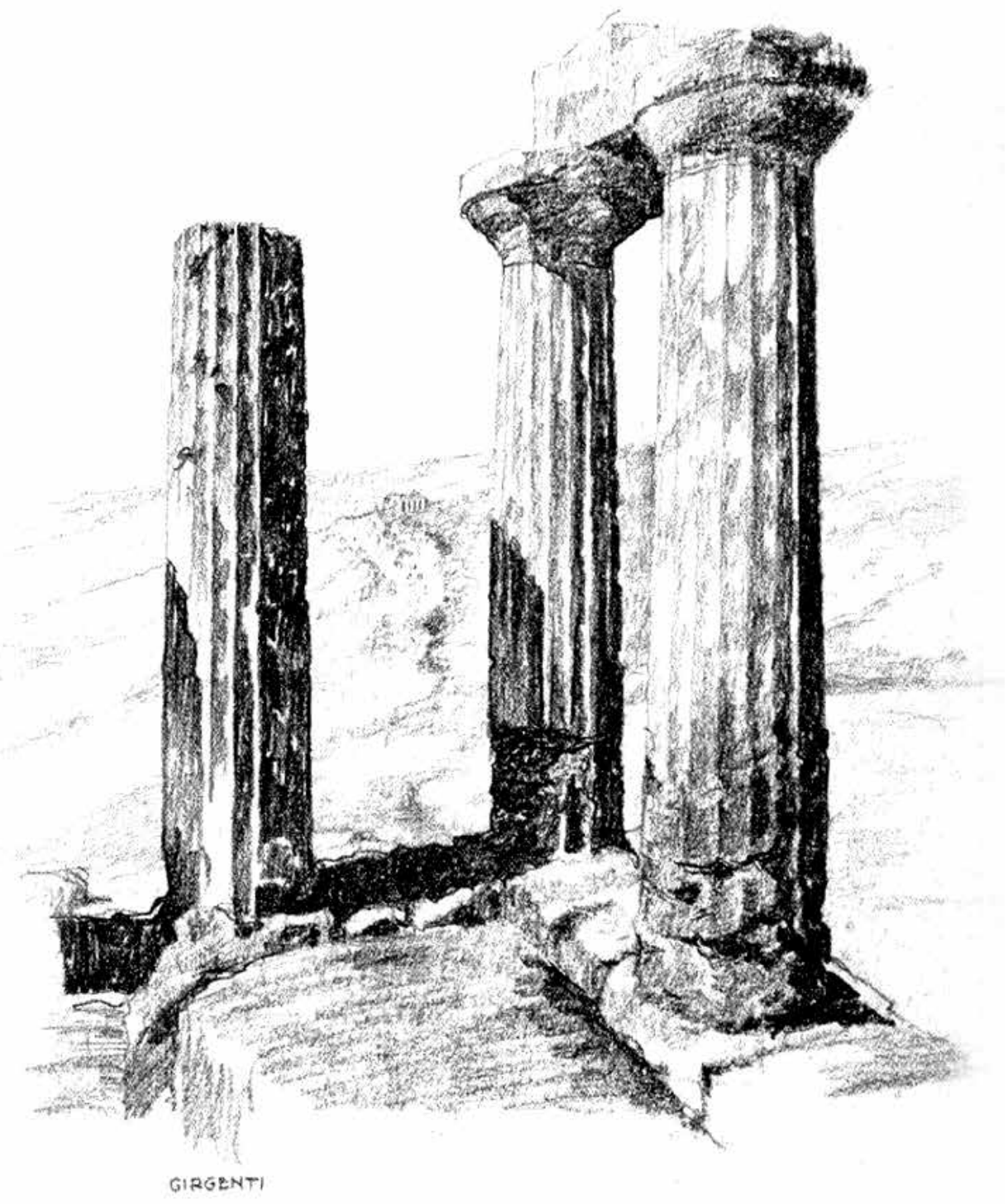

Fig. 13 Desenhos de Albert Kahn feitos durante sua viagem à Europa.

Fonte: <https://exchange.umma.umich.edu/resources/24727> Acesso $18 \mathrm{fev} 19$. 
por fim, as aberturas maiores das janelas permitiam mais luz natural e ventilação para os trabalhadores. O Edifício Número 10 da Packard era tão tecnologicamente avançado que atraiu a atenção de muitas pessoas, em especial Henry Ford. Federico Bucci refere-se a este edifício como o primeiro que conseguiu combinar o interior à pele exterior:

\begin{abstract}
"The Packard Building n. 10 thus introduced a new definition of factory space. Architectural design was no long merely the study of a shell to dress the underlying structure or the production function, but was the creation of a building which expressed the complete harmony of these two elements". ${ }^{33}$
\end{abstract}

Ford se aproximou de Kahn em 1908, com o objetivo de contratá-lo para construir uma fábrica de automóveis para a produção de seus automóveis Modelo T em um novo terreno em Highland Park, quando as suas duas primeiras fábricas estavam se tornando obsoletas. Assim começou uma parceria de longo prazo entre dois gênios: Ford, que previu as vantagens futuristas da produção através da linha de montagem, e Kahn, que "found aesthetic values in the forms engendered by new techniques and functional considerations." ${ }^{34}$ Ao implementar a visão de Henry Ford nos 34 anos seguintes da sua colaboração mútua, Kahn projetou mais de mil prédios para a Ford Motor Company, sendo a fábrica de Highland Park talvez o mais famoso deles.

O edifício de montagem de Highland Park (1910), responsável por introduzir a primeira linha de montagem mecanizada na fabricação de automóveis, era uma estrutura de concreto de quatro andares com 256 metros de comprimento. Através da utilização de grandes planos de vidro, Kahn melhorou ainda mais as condições de saúde e segurança da fábrica americana. No auge de sua impressionante simplicidade, encontrava-se o uso inovador de concreto e vidro bem como a adoção de um inovador princípio estético em que "a forma segue a função" 35 , motivos pelos quais a fábrica de Highland Park inspirou o trabalho de Walter Gropius

33 Tradução da autora: "O edifício Packard n. 10 introduziu assim uma nova definição de espaço da fábrica. O projeto arquitetônico não era apenas o estudo de uma casca para cobrir a estrutura ou a função de produção, mas constituía na criaçãode um edifício que expressasse a completa harmonia entre esses dois elementos”. Ver BUCCI, F. Albert Kahn: Architect of Ford. New York: Princeton Architectural Press, 1993, p.33.

34 Tradução da autora: "encontrou valores estéticos nas formas engendradas por novas técnicas e considerações funcionais". FERRY, H. Legacy of Albert Kahn. Detroit: The Detroit Institute of Arts.1970, p.11.

35 A forma segue a função, ou "form follows function", é um princípio do design funcionalista associado à arquitetura e design moderno do século XX. É também uma célebre frase proferida pelo arquiteto Louis Sullivan, cuja influência na arquitetura moderna foi considerável. Disponível em: <https://www.britannica.com/biography/Louis-Sullivan> Acesso: 8 fev. 2019. 
na construção da fábrica alemã de sapatos Faguswerk, em $1914^{36}$, e influenciou o desenvolvimento da Arquitetura Moderna na Europa.

Quando a operação automobilística de Highland Park excedeu sua capacidade, Henry Ford comprou um enorme terreno próximo ao Rio Rouge, contratando Albert Kahn para projetar e construir aquele que se tornaria o maior complexo industrial do mundo. O projeto da fábrica de River Rouge consolidou o nome de Kahn como pai da arquitetura industrial americana. Embora Kahn tenha projetado vários edifícios dentro do complexo da fábrica da Ford Rouge River no início da década de 1920, o projeto da Fábrica de Vidros de 1922 foi a construção de maior significado, tanto em termos da carreira de Kahn quanto na história da arquitetura industrial. ${ }^{37} \mathrm{~A}$ estrutura metálica, o uso de claraboias na cobertura e as fachadas de vidro, extremamente minimalistas, proporcionaram um amplo espaço e flexibilidade para acomodar os processos de fabricação no interior. Este ícone arquitetônico, dentro da indústria mais famosa do mundo, mudou a forma e a função da arquitetura industrial americana nos Estados Unidos e no exterior, inspirando o trabalho de outros arquitetos, engenheiros e artistas.

Kahn certamente reconheceu os valores estéticos em suas "beautiful factories" 38 , como ele as chamava, embora não tivesse o distanciamento histórico para compreender o impacto de seus projetos no emergente Movimento Moderno. Dentro do seu modo de pensar caracteristicamente orientado para a solução, ele expressou seus pontos de vista sobre a arquitetura industrial em uma palestra para a Sociedade de Arquitetos de Nova York, em 1940:

\footnotetext{
"The simpler the exterior the better it is, as a rule, for are we not quite agreed that a straight forward and direct expression of the function of the structure is an important element in all architecture, even the purely monumental; that proper proportions, effective grouping and good outline may be produced at no increase in cost; that these are infinitely more desirable than elaborate ornamentation, no matter how well executed." ${ }^{39}$
}

36 HILDEBRAND, G. Beautiful factories. In: Albert Kahn: inspiration for the modern. Ann Arbor: University of Michigan Museum of Art, 2001, p. 20.

37 Biografia do arquiteto no site da Bentley Library, da Universidade de Michigan. Disponível em: <https://quod.lib.umich. edu/b/bhlead/umich-bhl-0420?byte=202857978; focusrgn=bioghist;subview=standard;view=reslist $>$ Acesso em 07/05/18.

38 HILDEBRAND, G. Beautiful Factories. In: Albert Kahn: Inspiration for the modern. Ann Arbor: University of Michigan Museum of Art, 2001, p.17.

39 Tradução da autora: "Quanto mais simples o exterior, em geral melhor será. Não estamos de acordo que uma expressão direta da função da estrutura seja um elemento importante em toda a arquitetura, mesmo que seja puramente monumental; que proporções adequadas, agrupamento efetivo e bom esboço possam ser produzidos sem aumento de custo; que estes são infinitamente mais desejáveis que a ornamentação elaborada, não importa quão bem executada." Discurso de Albert Kahn à Sociedade de Arquitetos de Nova York, em 27 set. 1940, "Industrial Architecture - An Opportunity and Challenge," Disponível em: ALBERT Kahn Collection. Bentley Historical Library, University of Michigan (arquivos), Box 1. 
Como resultado de seu trabalho industrial inovador para a Ford Motor Company, Kahn recebeu comissões para projetar mais de uma centena de grandes edifícios para a General Motors Corporation e outros tantos para a Chrysler. Sua reputação de construir fábricas eficientes dentro do prazo e abaixo do orçamento fez com que seu escritório construísse 19\% de todas as instalações industriais projetadas por arquitetos nos Estados Unidos ${ }^{40}$, sendo a fábrica de caminhões Chrysler Dodge Half-Ton (1937) em Warren, Michigan, uma das mais conhecidas. Outro projeto que teve bastante repercussão foi o edifício de montagem de aeronaves da Glenn L. Martin Company (1937), com seu vão livre de quase 100 metros - maior vão utilizado em um edifício naquele momento -, servindo de inspiração para a obra americana do arquiteto Mies van der Rohe, igualmente baseada em estruturas de grandes vãos.

Em 1929, a famosa colaboração de Henry Ford e Albert Kahn na fábrica de River Rouge chamou a atenção dos russos, em especial pela eficiente adaptação do projeto industrial aos princípios da produção em massa. Com o intuito de industrializar a sua nação, representantes da Amtorg Trading Corporation foram a Detroit propor que Kahn se tornasse o arquiteto consultor da União Soviética no Primeiro Plano Quinquenal de Stalin. Entre 1929 e 1932, com o irmão de Kahn, Moritz, no comando do escritório de arquitetura-engenharia de Moscou, a empresa construiu 521 fábricas de tratores, aço, automóveis, aviões e produtos químicos, o maior contrato arquitetônico da história do escritório ${ }^{41}$. As fábricas de tratores em Stalingrado e Cheliabinsk foram duas das maiores fábricas construídas sob a supervisão de Kahn. A fábrica de Stalingrado, projetada com uma área de montagem com quase 400 metros de comprimento para produzir 40.000 tratores por ano, foi construída em um tempo recorde de seis meses.

O capítulo final da carreira da arquitetura industrial de Kahn se concentra em suas contribuições para o "Arsenal of Democracy"42 dos Estados Unidos durante a Segunda Guerra Mundial. Entre 1914 e 1917, Kahn já havia construído a maioria das bases navais e aeródromos do exército americano da Primeira Guerra Mundial. Nos últimos três anos de sua vida, o escritório assumiu a maior parte dos contratos do Departamento de Defesa dos Estados Unidos para a Segunda Guerra Mundial.

40 RASNER, D. Albert Kahn: Evolution of the factory. 2003. Disponível em: <https://issuu.com/a1579/docs/albert_kahn_ factory> Acesso em 07 mai 18.

41 SENKEVICH, A. J.. Albert Kahn's Great Soviet Venture as Architect of the First Five-Year Plan, 1929-1932. In: Dimensions 10, 1996, p. 34-49. Disponível em: https://issuu.com/taubmancollege/docs/dimensions10 Acesso em: 05 mar 2018, p. 45.

42 FERRY, H. Legacy of Albert Kahn. Detroit: The Detroit Institute of Arts,1970, p. 25. 
Estes contratos incluíram bases navais no Alasca, Havaí, Midway Island, Porto Rico e Jacksonville, Flórida. ${ }^{43}$ Kahn também construiu várias fábricas de aviões; a maior delas foi a fábrica Willow Run Bomber da Ford Motor Company (1941) em Ypsilanti, Michigan. Willow Run foi o último projeto industrial da Kahn para a Ford Motor Company e veio a se tornar a maior instalação industrial do mundo, produzindo um bombardeiro a cada 24 horas.

Albert Kahn ficou conhecido na história da arquitetura pela realização do projeto de edifícios industriais tecnologicamente inovadores de "utmost simplicity, rational construction, functional efficiency and a striking expressive aspect" ${ }^{\text {". Além }}$ disso, também ficou famoso por modificar a cara de Detroit com seus inúmeros edifícios institucionais, comerciais e residenciais. Atualmente, cinquenta de seus edifícios na cidade de Detroit e nos arredores figuram na lista do National Register of Historic Places ${ }^{45}$, honrando a amplitude excepcional do repertório de projetos de Kahn.

Foi por meio do seu trabalho não-industrial que Kahn se mostrou um grande estudioso da arquitetura histórica, com a qual tinha travado contato durante suas viagens pela Europa. Muitas de suas residências, sinagogas, bancos e edifícios de escritórios são provenientes de fontes clássicas. Kahn demonstrou versatilidade e inovação ao projetar uma arquitetura mais funcional e simplificada nas estruturas de aço e concreto armado das fábricas, bem como por buscar uma estética mais clássica e ornamentada no restante dos seus projetos. Esse foi, inclusive, um dos motivos pelo qual a sua arquitetura recebeu tantas críticas.

O trabalho residencial de Kahn atestou a sua capacidade de combinar inovação estrutural com elementos arquitetônicos históricos. Em sua própria casa na Avenida Mack (1907) e em outros projetos residenciais para os chefes da indústria, Kahn mostrou uma forte propensão para os estilos clássicos, como visto na Cranbrook House, de George Booth (1907). A mansão de Edsel e Eleanor Ford, em Grosse Pointe Shores (1929), é considerada um de seus melhores projetos residenciais. Nela, Kahn utilizou concreto armado nas lajes e treliças metálicas na cobertura, mas revestiu a casa com arenito tradicional.

Os projetos de Kahn, com uma ampla variedade de estilos históricos,

43 FERRY, H. Legacy of Albert Kahn. Detroit: The Detroit Institute of Arts,1970, p. 26.

44 Tradução da autora: "máxima simplicidade, construção racional, eficiência funcional e um aspecto expressivo marcante". SENKEVICH, A. J.. Albert Kahn's Great Soviet Venture as Architect of the First Five-Year Plan, 1929-1932. In: Dimensions 10, 1996, p. 34-49. Disponível em: https://issuu.com/taubmancollege/docs/dimensions10 Acesso em: 05 mar 2018, p. 35.

45 Biografia do arquiteto no site da Bentley Library, da Universidade de Michigan. Disponível em: <https:/quod.lib.umich. edu/b/bhlead/umich-bhl-0420?byte=202857978;focusrgn=bioghist;subview=standard;view=reslist $>$ Acesso em 07/05/18 

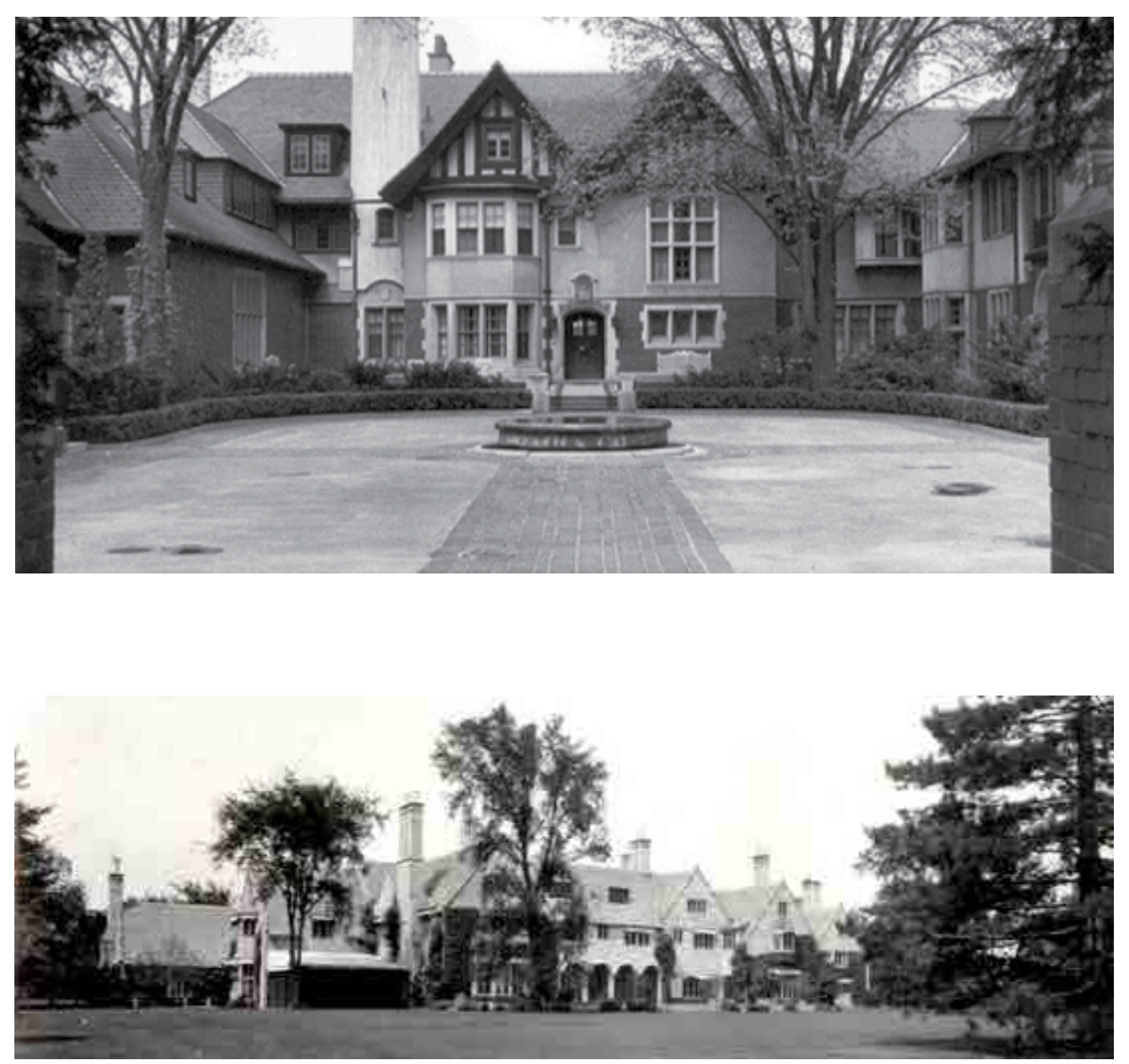

Fig. 14 Cranbrook House (residência de George Booth), em Bloomfield Hills, Michigan (1907). Fonte: <www.slideshare.net/walkerpub/albert-kahn-the-20th-centurys-greatest-architect> Acesso 17 mai 18.

Fig. 15 Residência de Edsel e Eleanor Ford ,em Grosse Pointe Shores, Michigan (1926). Fonte: Ferry (1970) 
influenciaram o projeto de muitos ícones comerciais e institucionais de Detroit, constituindo elementos que contribuem para formar o caráter da cidade até hoje. Seu famoso Detroit Athletic Club (1915) foi inspirado pelo trabalho de McKim, Meadand White, de Nova York, e pelo Palácio Farnese, de Roma, que Kahn visitou e desenhou na sua viagem em 1912. O estilo renascentista italiano foi selecionado para dar a elegância e a dignidade necessárias para este importante ponto de encontro dos líderes da indústria automobilística.

Entre 1911 e 1926, Kahn completou numerosos edifícios corporativos que combinavam estrutura industrial com elementos estilísticos tradicionais: Detroit Trust Company (1915), Detroit News Building (1916), First National Bank (1922) e o famoso edifício da General Motors (1922) estão entre alguns deles. O Edifício GM era o maior edifício de escritórios do mundo na época, com 15 andares e capacidade para 1.800 escritórios. Considerado por muitos como a obra-prima de Albert Kahn na arquitetura comercial46, o edifício foi renovado em 2000 pela Albert Kahn Associates, sendo atualmente chamado de Cadillac Place como uma homenagem ao fundador de Detroit, Antoine Laumet de la Mothe Cadillac. Nos tempos atuais, o prédio abriga escritórios para o estado de Michigan. ${ }^{47}$

Como o estilo Art Déco se tornou o preferido em meados da década de 1920, Kahn também se mostrou um mestre nele, utilizando essa linguagem no Detroit Free Press Building (1925) e Maccabees Building (1927). No entanto, foram os 28 andares do Fisher Building (1927) que atraíram a atenção nacional quando foi reconhecido como o edifício comercial mais bonito do ano, em 1928. O Instituto Americano de Arquitetos foi além e, em 2000, nomeou este edifício histórico como "Building of the Century" 48.

Assim como Kahn empregou muitos princípios estruturais das fábricas em seus projetos comerciais, também não hesitou em utilizá-los nos edifícios para a Universidade de Michigan. Seus projetos para os edifícios institucionais tinham como principal inovação o compromisso de fornecer iluminação e ventilação natural. Entre 1903 e 1938, o arquiteto projetou quatorze edifícios, mudando significativamente a cara da universidade em um momento de enorme crescimento institucional. ${ }^{49}$ Dentre os projetos, destacam-se o Edifício de Engenharia (1903),

46 HILL, E. e GALlAGHER, J. AIA Detroit: The AIA Guide to Detroit Architecture. Detroit: Wayne State University Press, 2003, p. 176.

47 Informações disponíveis em: <https://detroithistorical.org/learn/encyclopedia-of-detroit/general-motorsbuildingcadillac-place> Acesso: 09 jan. 2019.

48 ALBERT Kahn Associates. The AIA 2003 Gold Medal Submission: Albert Kahn, FAIA, 1969-1942.

49 ZIMMERMAN, C. The Labor of Albert Kahn. Aggregate Architectural History Collaborative. V. 2, p. 5-6, 2014. Disponível em: http://www.weaggregate.org/piece/the-labor-of-albert-kahn Acesso em 10 mai 2018. 

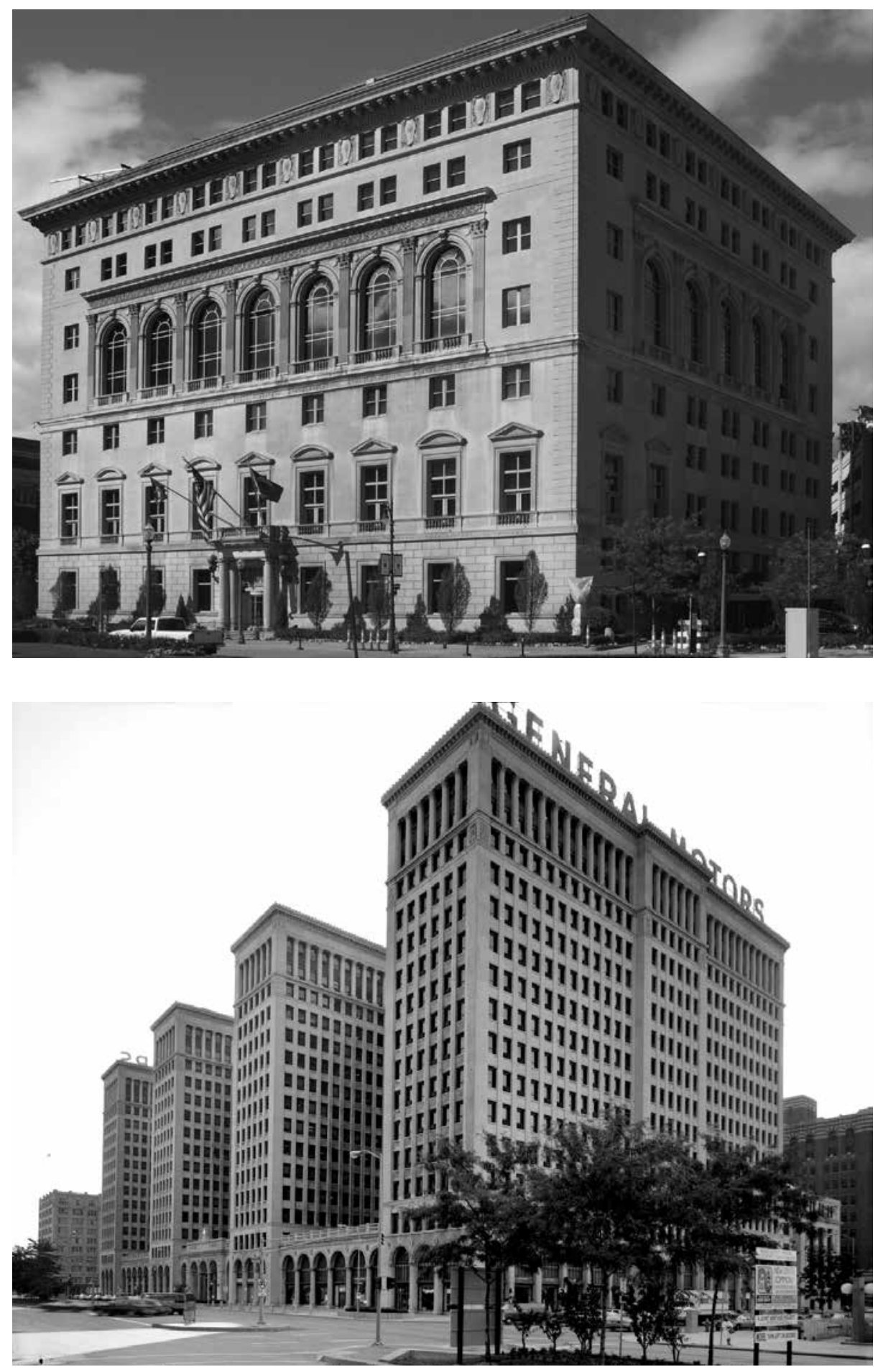

Fig. 16 Detroit Athletic Club, em Detroit, Michigan (1915).

Fonte: $<$ http://jsah.ucpress.edu/content/72/1/78.figures-only $>$ Acesso 17 mai 18.

Fig. 17 General Motors Building (atual Cadillac Place) em Detroit, Michigan (1917-21).

Fonte: Esta imagem está disponível na Divisão de Impressos e Fotografias da Biblioteca do Congresso dos Estados Unidos sob o número de identificação digital hhh mi0172.photos.089833. Acesso 17 mai 18. 

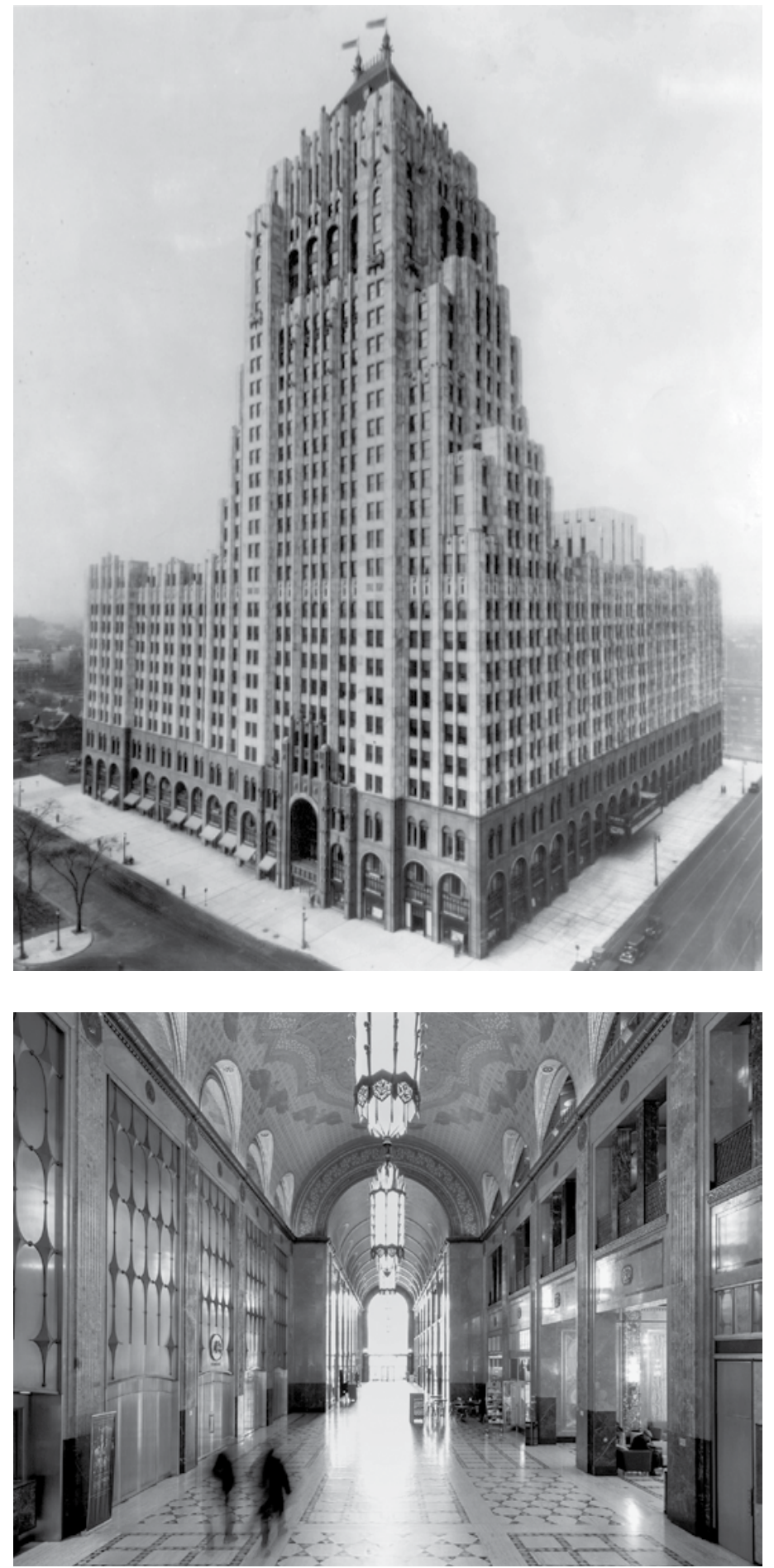

Fig. 18 Fisher Building, em Detroit, Michigan (1927)

Fonte: $<$ https://www.slideshare.net/walkerpub/albert-kahn-the-20th-centurys-greatest-architect $>$ Acesso 17 mai 18

Fig. 19 Interior do Fisher Building.

Fonte: <https://www.nytimes.com/2018/03/26/travel/architecture-detroit-albert-kahn.html> Acesso 15 jan 19. 
com a sua estrutura pioneira de concreto armado, o Auditório Hill (1913), o Edifício de Ciências Naturais (1917) e a Biblioteca Geral (1919). Com suas guarnições de alvenaria de tijolos, pedras e azulejos, Kahn se divorciou do academicismo gótico da arquitetura universitária tradicional. Seu prolífico trabalho no campus nas duas primeiras décadas também incluiu as residências Helen Newberry e Betsy Barbour (1915 e 1918) e as casas de estudante Sigma Phi e Delta Upsilon (1898 e 1903), entre outras.

Durante o boom do pós-guerra no início da década de 1920, Kahn projetou a Biblioteca William L. Clements com o objetivo de servir de abrigo para uma rara coleção de exemplares da cultura americana. No edifício, ele usou um monumental pórtico dórico para tirar a atenção da longa estrutura horizontal atrás dele, a qual remetia aos seus edifícios industriais. Outras obras importantes do campus foram o Hospital da Universidade de Michigan (1920), o Angell Hall (1922), o Simpson Memorial Institute for Medical Research (1924), o Edifício dos Museus (1927) e a Burton Memorial Carillon Tower (1936).

Durante muitas vezes na sua carreira, Albert Kahn foi homenageado por suas conquistas na moderna arquitetura industrial. Ele recebeu prêmios da Universidade de Michigan em 1933 e da Universidade de Syracuse em 1942. Em 1937, foi premiado com o “Chevalier Legion D’Honneur” pela República da França e ganhou uma medalha de ouro na Exposição Internacional de Artes e Ciências de Paris. Além do prêmio especial dado a ele pelo Instituto Americano de Arquitetos por seu serviço em tempo de guerra em 1942, Kahn também recebeu a medalha Frank P. Brown postumamente, concedida pelo Instituto Franklin do Estado da Pensilvânia em 1943. ${ }^{50}$

Sua carreira teve um término abrupto. Em meio a intensas pressões da produção inicial da Segunda Guerra, aos setenta e três anos, Albert Kahn morreu em Detroit, em 8 de dezembro de 1942. A sua arquitetura industrial baseava-se em uma mente pragmática, orientada para a solução racional, interesse pela inovação tecnológica, capacidade de ouvir as necessidades de seus clientes, energia infatigável e ética no trabalho. A citação famosa de Kahn resume, de forma sucinta, a sua opinião sobre arquitetura industrial: "Industrial architecture is 90 percent business and 10 percent art or science." ${ }^{51}$

50 FERRY, H. Legacy of Albert Kahn. Detroit: The Detroit Institute of Arts,1970, p. 26.

51 Tradução da autora: "A arquitetura industrial é composta de 90\% de trabalho e 10\% de arte ou ciência". Ver: FERRY, H. Legacy of Albert Kahn. Detroit: The Detroit Institute of Arts,1970, p.27. 

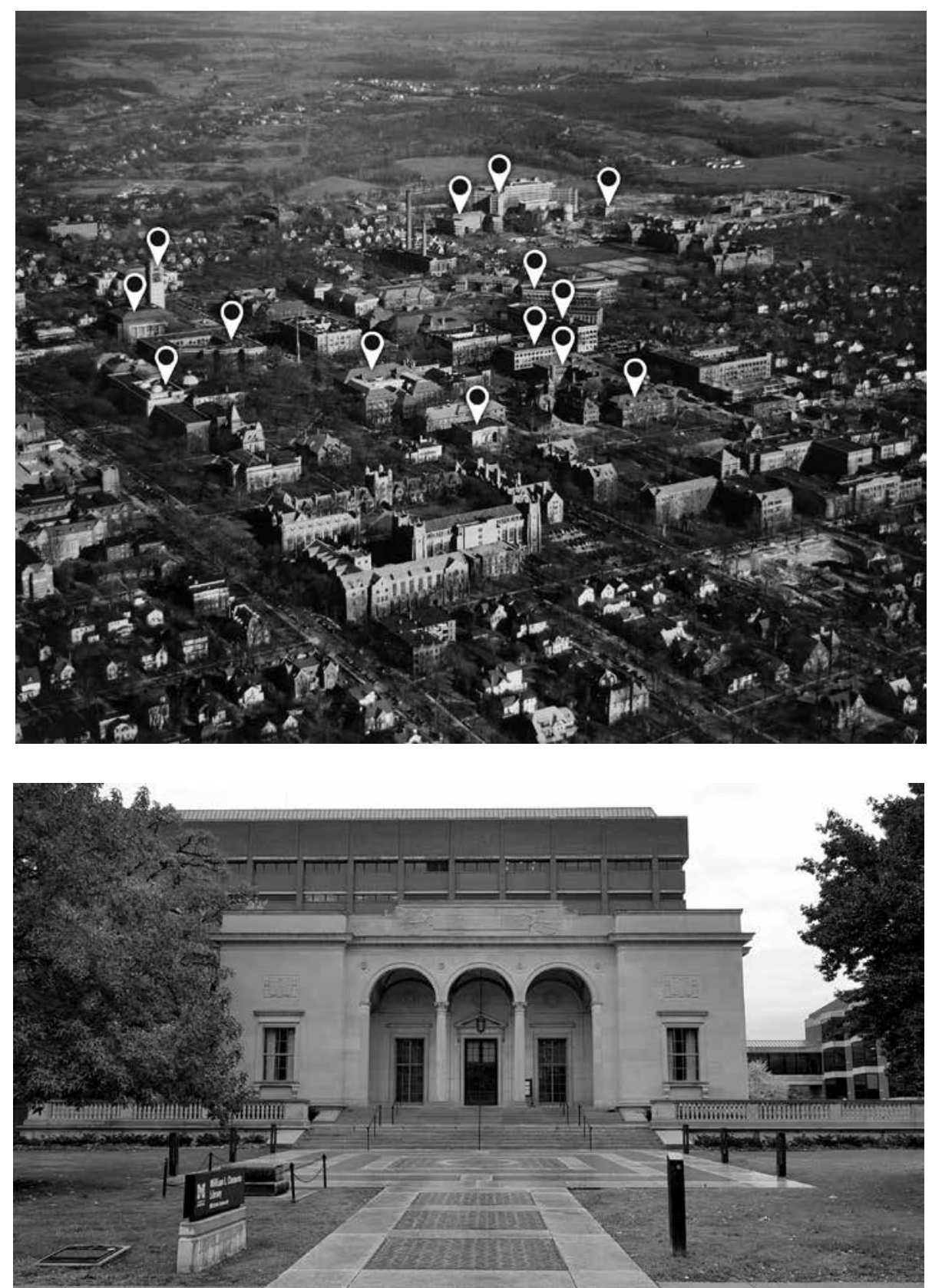

Fig. 20 Vista aérea do campus da Universidade de Michigan, em Ann Arbor, com edifícios projetados por Albert Kahn antes de 1942. Fonte: Elaborada a partir da foto original disponível em Zimmerman (2015)

Fig. 21 Biblioteca William L. Clements Library, University of Michigan (1922).

Fonte: Arquivo pessoal da autora, 2018. 

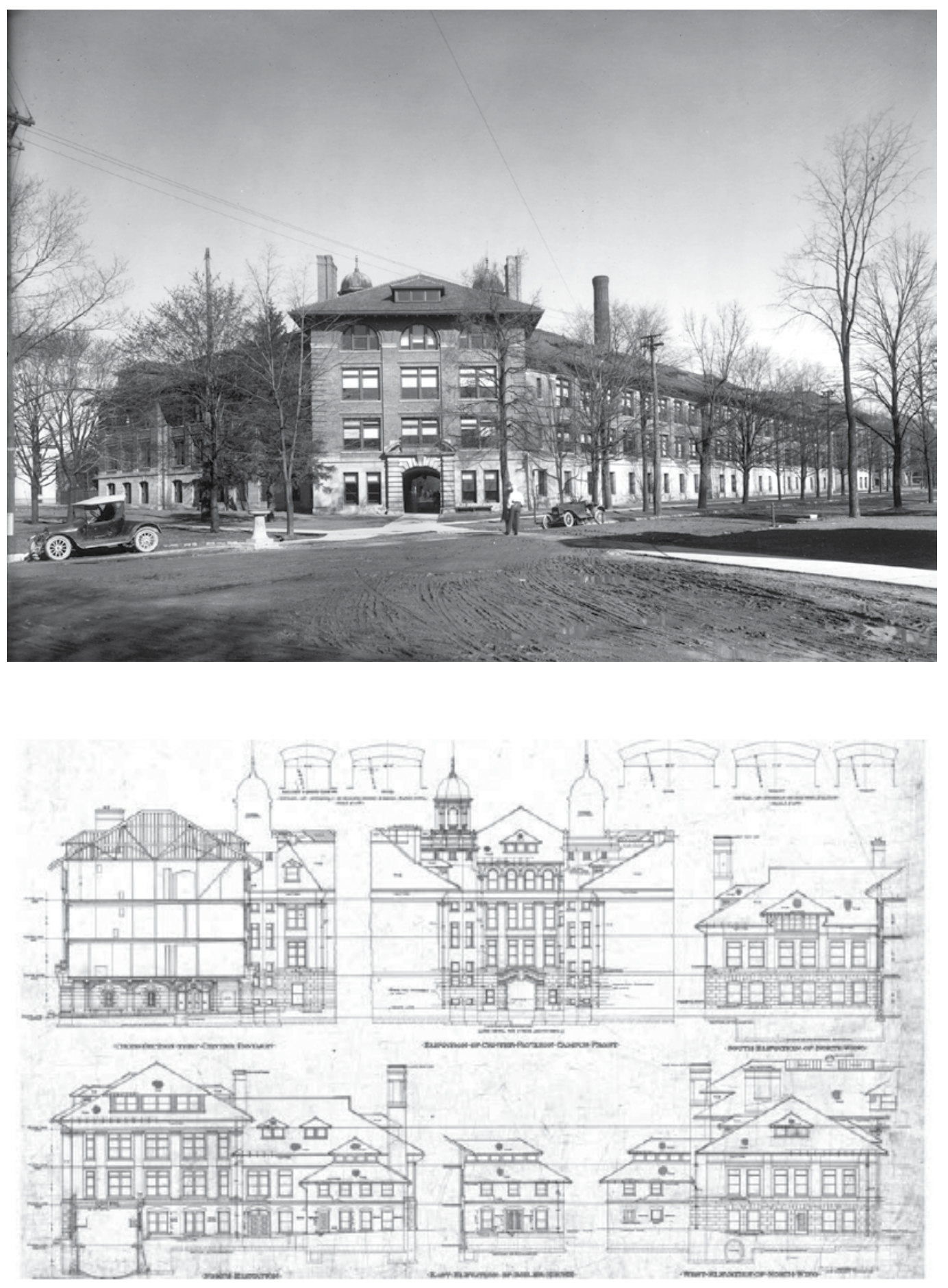

Fig. 22 Edifício de Engenharia, Universidade de Michigan (1903). Fonte: <www.umich.edu $>$ Acesso 17 mai 18.

Fig. 23 Desenhos do Edifício de Engenharia, Universidade de Michigan (1903). Fonte: <www.umalumni.com > Acesso 17mai 18. 

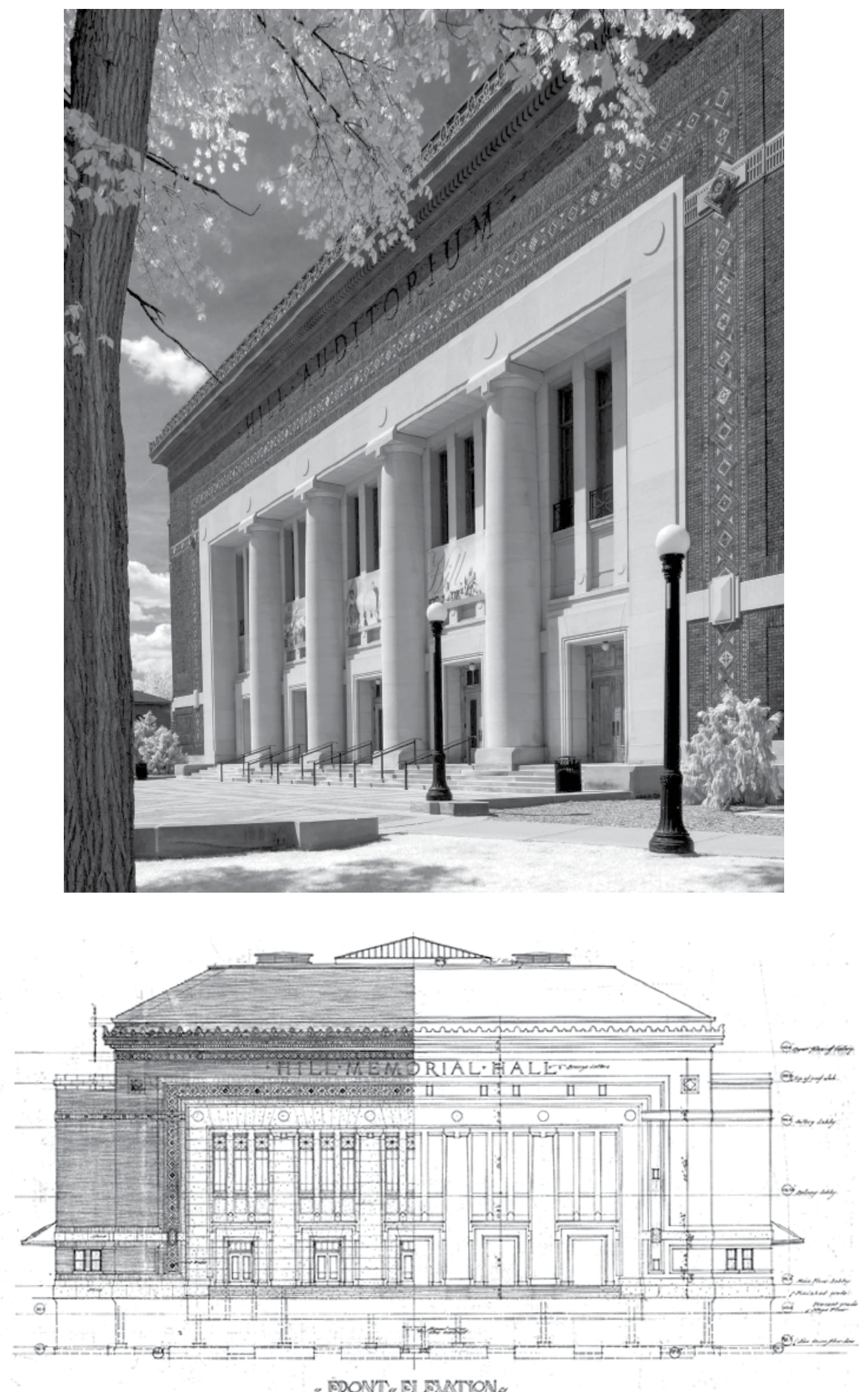

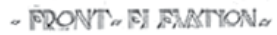

Fig. 24 Hill Auditorium, Universidade de Michigan (1913). Fonte: <www.umalumni.com> Acesso 17mai 18

Fig. 25 Fachada frontal, Hill Auditorium, Universidade de Michigan (1913).

Fonte: <www.slideshare.net/walkerpub/albert-kahn-the-20th-centurys-greatest-architect> Acesso em 17 mai 18. 
Mesmo após a morte do seu fundador, o escritório de arquitetura Albert Kahn Associates, Inc. continuou ativo, projetando e construindo inúmeras fábricas e edifícios nos Estados Unidos. Em 1998, Albert Kahn Associates, Inc. abriu um segundo escritório em São Paulo, Brasil, tendo sido determinante para essa decisão o fato da empresa ter visto oportunidades de crescimento e desenvolvimento nos mercados industrial, de saúde e corporativo do Brasil.

Assim como ocorreu com Henry Ford, que transferiu as suas ideias para a empresa na qual foi fundador, Albert Kahn também se tornou renomado não só por projetar fábricas para Ford, mas aplicar tais projetos na sua própria forma de trabalhar. Foi por meio da criação de uma organização prática e funcional que Kahn conseguiu obter índices invejáveis de produtividade, realizando vários projetos simultâneos ao redor do mundo sem prejuízo algum de qualidade. Por meio da racionalização do trabalho do próprio escritório, Albert Kahn disseminou os seus projetos por inúmeros países, firmando o seu nome no cenário da arquitetura mundial, circunstância que merece uma análise mais detalhada justamente para demonstrar como a combinação dos princípios de Ford e Kahn acabaram gerando um impacto que se espalhou entre arquitetos e engenheiros, chegando inclusive no Brasil.

\subsubsection{A revolução no escritório: a fábrica de projetar fábricas}

Uma das razões para a reputação mundial de Albert Kahn em arquitetura industrial foi o estabelecimento de um escritório não-tradicional e multidisciplinar, composto por diferentes profissionais. Através da colaboração harmônica de arquitetos, engenheiros e administradores, Kahn podia fornecer internamente todos os tipos de projetos e gerenciar a construção de um edifício, algo que tornava a construção mais eficiente e barata para os clientes.

O trabalho de Kahn tornou-se um componente importante para o desenvolvimento industrial dos Estados Unidos no início do século XX, especialmente no que se refere às fábricas de automóveis. Ao criar novos projetos de fábrica e gerenciar as suas construções, Kahn também revolucionou a própria prática da arquitetura. Para completar rapidamente um grande volume de projetos, o 
arquiteto subdividiu a produção de seu escritório em tarefas simples, desenvolvendo uma estrutura de gerenciamento que lhe permitia supervisionar e coordenar o fluxo de trabalho. Desta maneira, os especialistas de várias disciplinas trabalhavam juntos em uma estrutura de equipe, gerenciada pessoalmente por Kahn.

O contato privilegiado de Albert Kahn com a experiência fordista, realizado através dos projetos para as fábricas da Ford Motor Company, foi determinante para a gestão do próprio escritório e também para os seus projetos. Nesse intercâmbio, Kahn desenvolveu ideias para elaboração e gerenciamento de projetos específicos e autônomos, os quais proporcionaram a base para uma progressiva "Fordization" 52 do escritório. Como Henry-Russell Hitchcock escreveu:

\begin{abstract}
"Albert Kahn took the lead around 1905, in developing a type of subdivision and flow of work in his office in Detroit comparable to the new methods of mass-production that his motor-car factories were specifically designed to facilitate." 53
\end{abstract}

A capacidade de Albert Kahn de projetar e gerenciar a construção de enormes fábricas concedeu-lhe uma grande vantagem competitiva. Em conferência realizada na Cleveland Engineering Society, em 1930, intitulada "Putting Architecture on a Business Basis" ${ }^{54}$, Albert Kahn falou a respeito da necessidade de organizar o trabalho do escritório de arquitetura de acordo com os princípios da gestão científica. Nessa conferência, Kahn definiu as tarefas dos diferentes profissionais envolvidos na construção de um edifício, demonstrando que os problemas de construção industrial em massa poderiam ser adequadamente resolvidos apenas recorrendo ao trabalho em equipe e à gestão científica. A respeito de sua visão sobre o novo papel do arquiteto, ele disse:

\footnotetext{
'The architect qualified to handle the problems of today must be a combination of many parts, and, as I recently read, must, like the conductor of a well organized orchestra, assume leadership in directing groups of men to produce concerted and harmonious results. Even thirty
}

52 BUCCI, F. Albert Kahn: Architect of Ford. New York: Princeton Architectural Press, 1993, p.125.

53 Tradução da autora: "Albert Kahn assumiu a liderança por volta de 1905, desenvolvendo um tipo de subdivisão e fluxo de trabalho em seu escritório em Detroit comparável aos novos métodos de produção em massa que suas fábricas de automóveis foram especificamente projetadas para facilitar." Ver HITCHCOOK, H. R.. Architecture: nineteenth and twentieth centuries. Harmondsworth: Penguin Books, 1987, p. 403.

54 Trechos do artigo estão publicados em: BUCCI, F. Albert Kahn: Architect of Ford. New York: Princeton Architectural Press, 1993, p.125. Originalmente, o artigo foi publicado em duas partes em Michigan Society of Architects Bulletin, em 6 e 13 de janeiro de 1931. 
years ago, there were comparatively few firms employing more than fifty assistants. Today, we have numerous firms with hundreds of employees. Their practice must necessarily be managed with proper system and on a business basis... There is no place here for the temperamental artist, the clear-headed business man must have charge. Don't misunderstand me - this clear-headed businessman-architect must not be devoid of artistic training or ability, for this must ever be the corner stone of the profession." ${ }^{55}$

A proposta de Kahn se baseava em um arquiteto que fosse capaz de coordenar um grupo de colaboradores. É inquestionável que, nesse contexto, a colaboração mais significativa fosse estabelecida com o engenheiro. Desde cedo, por influência do seu irmão e engenheiro Julius, Albert Kahn integrava a área de engenharia nos seus serviços de projeto. De maneira ainda tímida, essa parceria nasceu no projeto do Edifício da Engenharia para a Universidade de Michigan (1903), fortalecendose dois anos depois, por ocasião do projeto completo do edifício número $10 \mathrm{da}$ fábrica da Packard. Segundo Kahn, em uma organização que contasse com diversos colaboradores, um trabalho em equipe realmente efetivo só poderia ser obtido por meio de uma estrutura que incluísse arquitetos, engenheiros e gestores. Tal concepção significou uma transformação radical dos relacionamentos internos nos grandes escritórios de arquitetura.

Até 1918, o escritório de Albert Kahn estava localizado no andar superior do edifício de escritórios da Trussed Concrete Steel Company, projeto que realizou em colaboração com o seu irmão Julius. Com o crescimento da demanda de projetos industriais e a duplicação do número de colaboradores, Kahn viu-se obrigado a transferir o escritório para um local mais espaçoso, localizado no Marquette Building, no centro da cidade de Detroit. ${ }^{56} \mathrm{~A}$ respeito do aumento do número de funcionários do escritório, Claire Zimmerman descreveu: "Kahn employed 40 people in 1910; by 1918, that number had grown to 80. In 1929, more than 400 staff worked at the firm. At the beginning of World War II, the number swelled

55 Tradução da autora: "Para lidar com os problemas de hoje, o arquiteto qualificado deve ser uma combinação de muitas partes e, como li recentemente, deve, como o maestro de uma orquestra bem organizada, assumir a liderança na direção de grupos de homens para produzir resultados combinados e harmoniosos. Até trinta anos atrás, existiam relativamente poucas empresas empregando mais de cinquenta assistentes. Hoje, temos inúmeras empresas com centenas de funcionários. Sua prática deve, necessariamente, ser gerenciada com o sistema adequado e em uma base de negócios... Não há lugar aqui para o artista temperamental, o empresário perspicaz deve comandar. Não me entenda mal - este empresário-arquiteto perspicaz não necessita ser desprovido de treinamento ou habilidade artística, pois isso sempre deve ser o pilar da profissão." Ver em BUCCI, F. Albert Kahn: Architect of Ford. New York: Princeton Architectural Press, 1993, p.125.

56 RAVARA, P. B. A consolidação de uma prática: do edifício fabril em betão armado nos EUA aos modelos europeus de modernidade. Tese (Doutorado em Arquitetura). Faculdade de Arquitectura da Universidade Técnica de Lisboa. Lisboa: UTL, 2008, p.176. 
to $600 . " 57$ George Nelson, em 1939, apresentou as funções desempenhadas pelos funcionários:

\author{
"In normal times the firm of Albert Kahn, Inc. employs about 400 \\ men and women; among them some 40 secretaries, stenographers, \\ typists and file clerks; about 15 accountants; 80-90 mechanical \\ and electrical engineers; 40-50 field superintendents; some 30 \\ specification writers, estimators, expeditors, etc.; 175 architectural \\ designers and draftsmen." 58
}

O espaço físico do escritório, localizado no último andar do Marquette Building, organizava-se por departamentos de atividades. O aumento do número de assistentes no escritório e o método de Kahn para controlar todo o processo de criação, construção e implementação dos edifícios industriais são claras indicações de sua afinidade com os princípios do fordismo. Uma descrição ilustrada apareceu nas colunas do The Architectural Forum, em 1918. O texto escrito por George Baldwin abordou os diferentes espaços de trabalho:

\begin{abstract}
'In addition to executive and administrative offices, an atrium, corridors, underground passageways, facilities, sample rooms, dressing rooms, meeting rooms and a library, there are two large design rooms. There are also separate rooms for the mechanical and structural engineers, one area for design, two areas for specific technicians [...] The offices for the executives and the meeting room are arranged along one side of the building, the design rooms along the other.The mechanical engineering and the structural engineering departments are situated in opposite corners $[\ldots]$ The superintendents offices are arranged in two groups on both sides of the meeting room. [...] The designers rooms are separated by clear glass divisions." ${ }^{59}$
\end{abstract}

57 Tradução da autora: “Kahn empregou 40 pessoas em 1910; em 1918, esse número havia crescido para 80. Em 1929, mais de 400 funcionários trabalhavam na empresa. No início da Segunda Guerra Mundial, o número aumentou para 600." Ver: ZIMMERMAN, C. The Labor of Albert Kahn. Aggregate Architectural History Collaborative. V. 2, p. 6-7, 2014. Disponível em: http://www.weaggregate.org/piece/the-labor-of-albert-kahn Acesso em 10 mai 2018.

58 Tradução da autora: "Em tempos normais o escritório de Albert Kahn emprega cerca de 400 homens e mulheres; entre eles, em torno de 40 secretários, estenógrafos, digitadores e arquivistas; aproximadamente 15 contadores; 80-90 engenheiros mecânicos e elétricos; 40-50 superintendentes de obra; cerca de 30 escritores de especificações, estimadores, expedidores, etc ; 175 projetistas de arquitetura e desenhistas.” Ver: NELSON, G. Industrial architecture of Albert Kahn, Inc. New York: Architectural Book Pub., 1939, p.19.

59 Tradução da autora: "Além de escritórios executivos e administrativos, um átrio, corredores, passagens subterrâneas, instalações, salas de amostra, vestiários, salas de reuniões e uma biblioteca, existem duas grandes salas de projeto. Há também salas separadas para os engenheiros mecânicos e estruturais, uma área para o projeto, duas áreas para técnicos específicos [...] Os escritórios para os executivos e a sala de reunião estão dispostos ao longo de um lado do prédio, as salas de projeto ao longo do outro. Os departamentos de engenharia mecânica e engenharia estrutural estão situados em cantos opostos [... ] Os escritórios dos superintendentes estão dispostos em dois grupos em ambos os lados da sala de reunião. [...] As salas de projeto são separadas por divisões de vidro transparente.” BALDWIN, G. C. The offices of Albert Kahn, Architect, Detroit, Michigan. In: The Architectural Forum, v. 29, n. 5, p.125-126, Novembro 1918. 

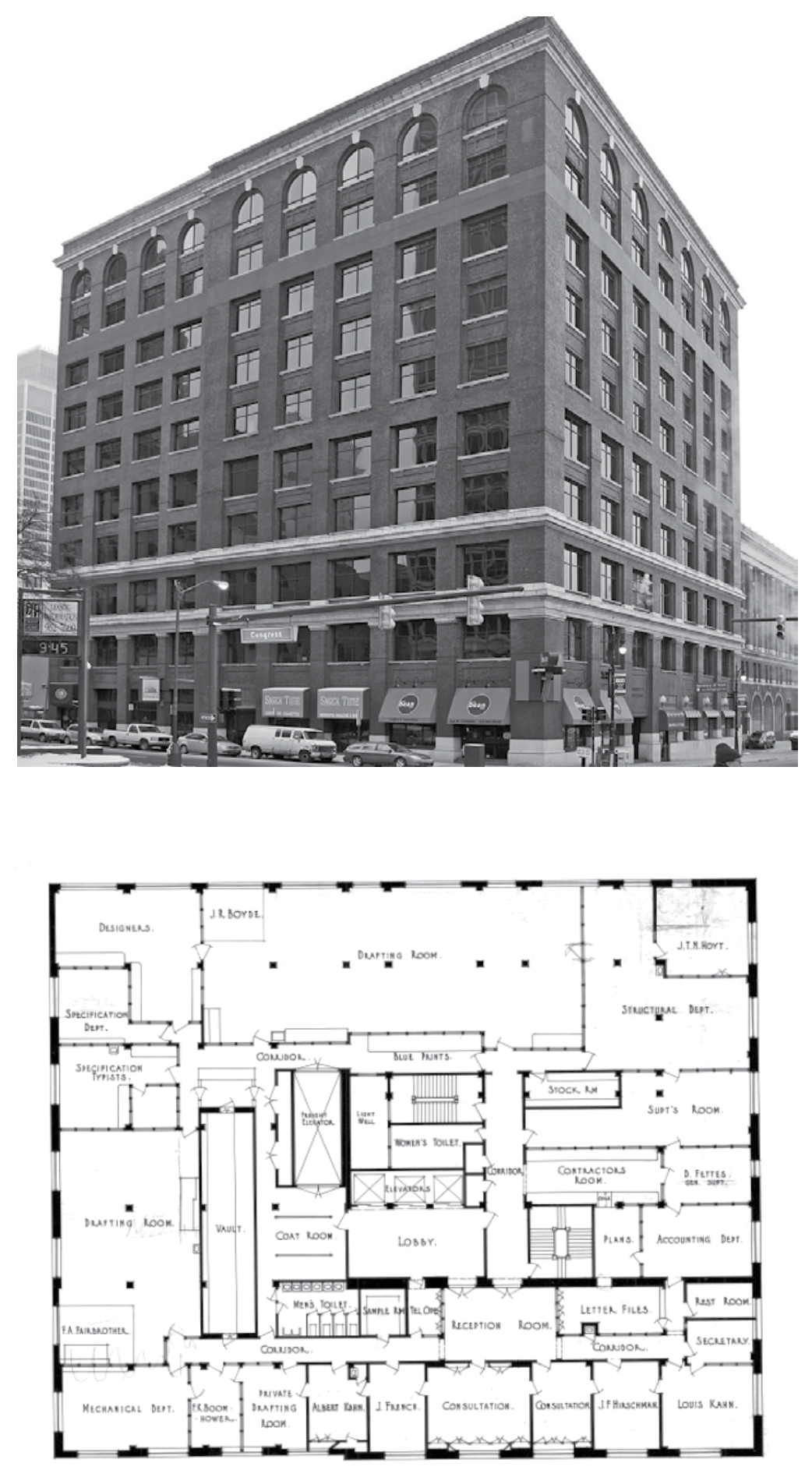

FLOOR: PLAN

Fig. 26 Marquette Building, Detroit, Michigan (1905)

Fonte: <https://detroit.curbed.com/2016/11/30/13794354/adient-hq-marquette-building-renovate>Acesso em 15 jan 19.

Fig. 27 Planta baixa do escritório de Albert Kahn, no Marquette Building. Fonte: Baldwin (1918) 

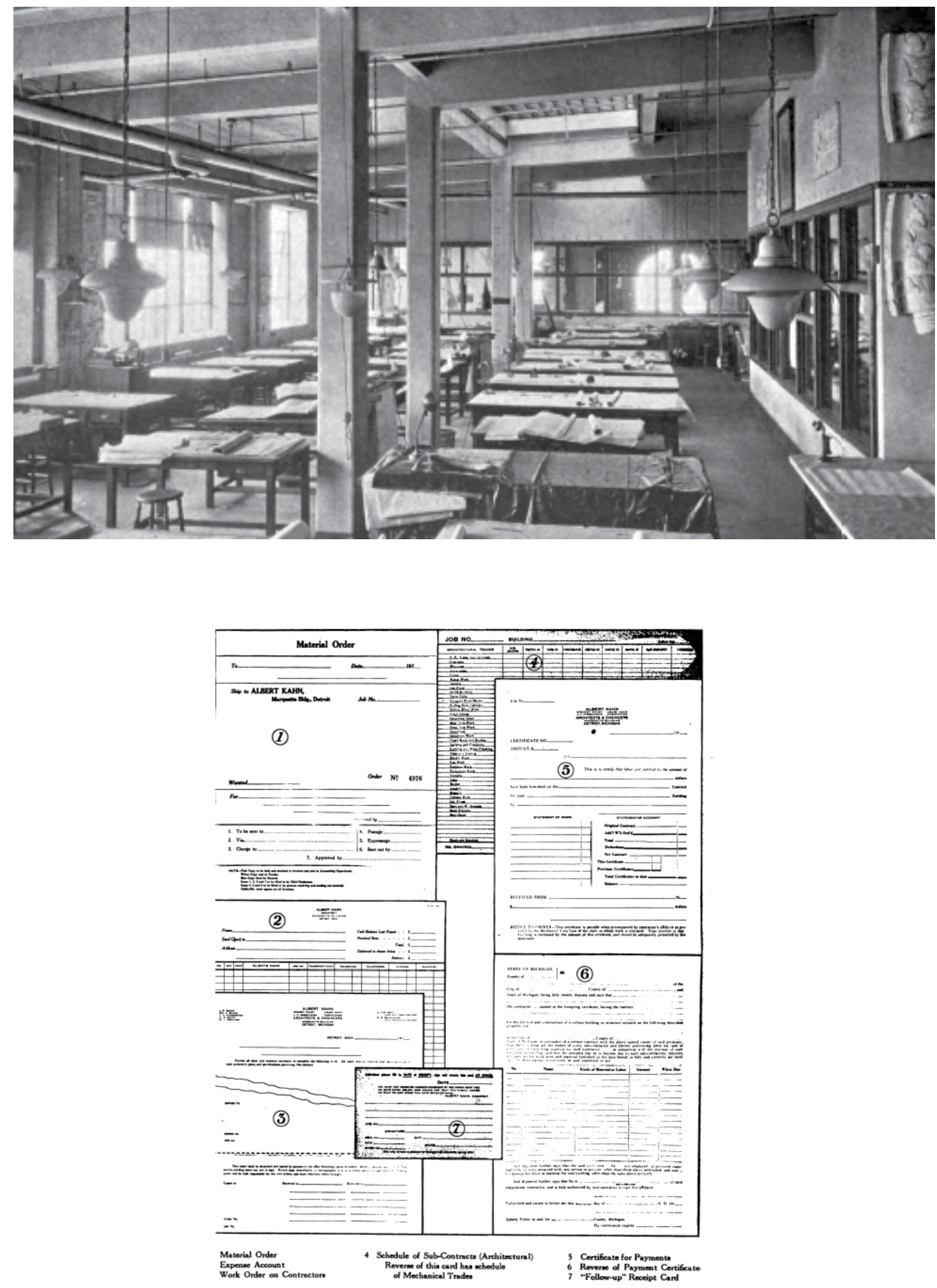

Fig. 28 Vista da sala de projeto do escritório de Albert Kahn, no Marquette Building. Fonte: Baldwin (1918)

Fig. 29 Reprodução dos formulários utilizados no escritório de Albert Kahn. Fonte: Baldwin (1918) 

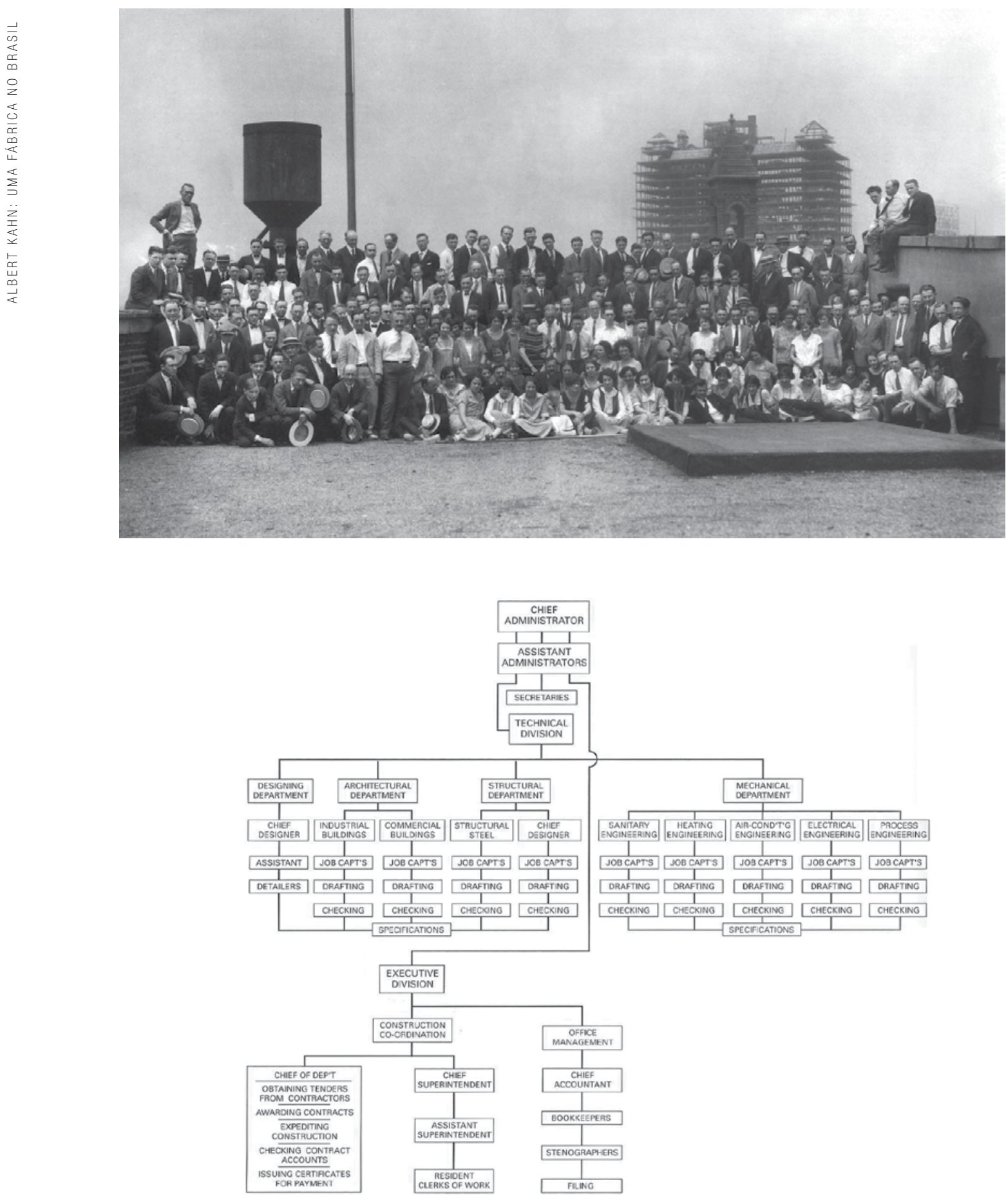

Fig. 30 Albert Kahn e os funcionários do seu escritório na cobertura Marquette Building , 1924. Fonte: Zimmerman (2017)

Fig. 31 Diagrama da organização do escritório de Albert Kahn

Fonte: Nelson (1939) 
Semelhante às fábricas, o espaço usado para o trabalho intelectual foi projetado para se obter uma produtividade máxima. Acreditava-se que esses princípios, dos quais dependia a organização do escritório, criavam as condições ambientais imprescindíveis para a maximização de energias e habilidades dos funcionários. Todas as fases do projeto eram executadas em salas específicas, convenientemente dispostas e equipadas. As salas correspondiam, nos seus grandes grupos, a departamentos e áreas de projeto.

O nível mais alto de racionalização do trabalho no escritório manifestouse nas comunicações internas. Solicitações de materiais, pagamentos, relatórios diários entre os chefes de departamento e cronogramas para os desenhistas eram feitos por intermédio de formulários. Existiam diferentes modelos de formulários, dependendo do tipo de informação ou do tipo de atividade que era executada em um projeto. Estes formulários de registro e controle do trabalho, bem como os de comunicação interna, baseavam-se nos formulários utilizados nas fábricas da Ford Motor Company para comunicação e registro de controle dos trabalhos em curso. ${ }^{60}$

Todas as etapas da concepção e produção do projeto foram ordenadas por um diagrama organizacional do escritório, o qual foi reproduzido por George Nelson. Percebe-se, assim, que o trabalho, organizado em um complexo procedimento interdisciplinar, articulava-se em torno das habilidades específicas de dois setores que constituíam o eixo da empresa: a Divisão Técnica e a Divisão Executiva. ${ }^{61}$

A Divisão Técnica, distribuída em quatro departamentos, era responsável pelo projeto dos edifícios. O departamento de desenho encarregava-se dos projetos executivos, o departamento arquitetônico fornecia a definição estilística dos edifícios, o departamento estrutural realizava o cálculo das estruturas e, finalmente, o departamento mecânico, dividido em cinco seções, era responsável pelo projeto dos aspectos mecânicos, tais como instalações de saneamento, aquecimento, ar condicionado, sistemas elétricos e diagramas de operações. Essa estrutura permitia que o trabalho em todos os departamentos começasse ao mesmo tempo, resultando na aceleração do processo de preparação dos desenhos e das especificações de todos os projetos. De acordo com Nelson, "with this procedure, the drawings for a large factory can be completed in a week or ten days'time if necessary" ${ }^{62}$. Este modelo de

60 BALDWIN, G. C. The offices of Albert Kahn, Architect, Detroit, Michigan. In: The Architectural Forum, v. 29, n. 5, p.130, Novembro 1918.

61 NELSON, G. Industrial architecture of Albert Kahn, Inc. New York: Architectural Book Pub., 1939, p.21.

62 Tradução da autora : "Através deste procedimento, os projetos para uma grande fábrica poderiam ser feitos em uma semana ou dez dias, se fosse necessário". NELSON, G. Industrial architecture of Albert Kahn, Inc. New York: Architectural Book Pub., 1939, p.19. 
produção foi bastante semelhante ao adotado pela Ford Motor Company no final da década de 1910.

Cada um dos departamentos era organizado de acordo com um plano hierárquico, composto por um chefe de equipe, técnicos especializados pela elaboração dos desenhos e funcionários designados para funções de controle. $\mathrm{O}$ trabalho era controlado por dois grupos: o primeiro coletava o trabalho dos três primeiros departamentos e o segundo dedicava-se exclusivamente às diferentes seções do departamento de mecânica.

A Divisão Executiva também ocupava uma posição importante dentro do escritório de Kahn, dividindo-se em duas partes. A gerência do escritório lidava com contabilidade e administração. A coordenação da construção, que possuía um superintendente, anunciava a licitação e escolhia (com o cliente) as melhores ofertas. Além disso, coordenava as fases de construção, verificava os cronogramas, informava periodicamente o cliente acerca do andamento dos trabalhos e atuava como um elo de ligação entre as diversas empresas. Finalmente, o superintendente garantia que o pagamento fosse realizado em dia.

Pelo fato das operações do escritório incluírem um território tão extenso e porque os tipos de trabalho projetados eram extremamente variados, era essencial que os chefes de departamento fossem especializados em suas respectivas atividades. Além disso, seus esforços deveriam ser sistemáticos, na medida em que vários edifícios poderiam estar sendo projetados simultaneamente. É duvidoso que tenha existido, naquela época, outro escritório de arquitetura que pudesse abrir um mapa e identificar seus projetos nos cinco continentes. ${ }^{63}$ Durante a sua carreira, o escritório de Albert Kahn construiu pouco menos de dois mil edifícios. ${ }^{64}$ Os edifícios industriais de Kahn, não incluindo o seu trabalho geral, estavam localizados em 134 cidades americanas. Além disso, importante listar as mais de quinhentas fábricas projetadas na União Soviética no curto período de 1929 a 1932. Mesmo tendo construído muitas fábricas de automóveis, os projetos do escritório de Kahn eram tão variados quanto a própria indústria. A extensa lista demonstra a extraordinária capacidade do arquiteto e de seus colaboradores de se ajustarem às demandas e necessidades da indústria.

63 Nelson apresenta um mapa mundial, localizando as diversas cidades onde havia algum edifício projetado pelo escritório de Albert Kahn. Ver: NELSON, G. Industrial architecture of Albert Kahn, Inc. New York: Architectural Book Pub., 1939, p.20-21.

64 ZIMMERMAN, C. The Labor of Albert Kahn. Aggregate Architectural History Collaborative. V. 2, p. 5-6, 2014. Disponível em: http://www.weaggregate.org/piece/the-labor-of-albert-kahn Acesso em 10 mai 2018. 
O criador desse modelo organizacional foi o outro irmão de Albert, Louis Kahn. Louis nasceu em 1885, quando a família já estava nos Estados Unidos há quatro anos. Formou-se em arquitetura pela Universidade de Michigan e começou a trabalhar no escritório de Albert Kahn em 1908. Desde os primeiros anos de carreira, ele se especializou em aspectos administrativos e na organização dos projetos. Louis começou como administrador e, depois da morte de Albert, em 1942, tornou-se o presidente da empresa. ${ }^{65}$

Logo no início, ele percebeu a necessidade de levar aos seus funcionários não apenas os métodos da indústria de massa, mas também um sistema avançado de participação direta nos lucros da empresa. Além dos métodos tradicionais de incentivo, Louis tomara a decisão de tornar os seus colegas participantes das vicissitudes econômicas da empresa, garantindo-lhes uma porcentagem dos lucros proporcional às suas responsabilidades, bem como bônus personalizados de acordo com os méritos adquiridos em cada trabalho específico. Em 1940, vinte e cinco de seus funcionários mais antigos se tornaram associados da empresa, criando assim a Albert Kahn Associates, Inc. ${ }^{66}$

O temperamento de Albert Kahn e a sua postura foram muito importantes para que tivesse sucesso como arquiteto industrial. Kahn elevou o projeto da fábrica a um nível legítimo de prática arquitetônica, motivo pelo qual, anos mais tarde, assim se lembraria:

\footnotetext{
"When I began, the real architects would design only museums, cathedrals, capitols, monuments. The office boy was considered good enough to do factory buildings. I'm still that office boy designing factories. I have no dignity to be impaired. " 67
}

Ao contrário de muitos arquitetos, Kahn era especialmente sensível às necessidades de seus clientes industriais, e mais sensível ainda às suas capacidades econômicas. Ao explicar as suas realizações, Kahn observou:

65 BUCCI, F. Albert Kahn: Architect of Ford. New York: Princeton Architectural Press, 1993, p.131.

66 Ibid, p.126-127.

67 Tradução da autora: "Quando comecei, os verdadeiros arquitetos projetavam apenas museus, catedrais, capitólios e monumentos. O office boy foi considerado bom o suficiente para projetar fábricas. Eu ainda sou o office boy que projeta fábricas. Eu não tenho dignidade a perder." Ver: KREGER, J. Albert Kahn and the Design of Angell Hall. LSA Magazine, primavera 1998, p. 5 . 


\begin{abstract}
"Nine-tenths of my success has come because I listened to what people said they wanted and gave it to them... In our offices there are no jealousies; sometimes six or ten of us work on a design together. We listen to our clientes and learn from them; their ideas become ours also." ${ }^{68}$
\end{abstract}

O exemplo organizacional da empresa de Albert Kahn estimulou a reflexão sobre as possibilidades de gestão científica em escritórios de arquitetura. É certo que o tamanho do escritório de Kahn não constituía novidade nos Estados Unidos. Mas, através do contato com a Ford Motor Company, Kahn soube aplicar as mais avançadas teorias de gestão científica, algo que exigiu, por parte do arquiteto, uma completa derrubada dos métodos tradicionais do exercício da profissão. $\mathrm{O}$ que caracterizava seu escritório não era uma especialidade específica dentro da arquitetura (embora também a tivesse), mas sim a capacidade de projetar qualquer tipo de construção dentro do prazo e do orçamento, mantendo sempre um alto grau de qualidade em termos de construção.

Nesse contexto, o escritório de Albert Kahn teve muita importância pela sua capacidade de unir arte e ciência em uma organização gerencial comparável aos modelos mais avançados adotados na produção em massa. O escritório de Kahn não só levou a arquitetura para a indústria como também trouxe a indústria para a arquitetura, transformando-se em uma "fábrica de projetos" que seria, então, capaz de produzir fábricas em massa.

Por meio do aperfeiçoamento constante das técnicas de trabalho do seu escritório, adaptadas dos próprios termos do fordismo, Albert Kahn conseguia realizar projetos de forma rápida e racional. Isso facilitou o desenvolvimento de técnicas que revolucionaram não só as fábricas de automóveis até então existentes como a história da arquitetura mundial. Contudo, essas inovações foram o resultado de muito trabalho e de muita reflexão, em um processo de evolução e melhoria que - no caso de Albert Kahn - será estudada com maior atenção no próximo capítulo.

68 Tradução da autora: "Nove décimos do meu sucesso vieram porque escutei o que as pessoas diziam que queriam e eu dava isso a elas ... No nossos escritório não existe inveja; às vezes seis ou dez de nós trabalham em um projeto juntos. Ouvimos nossos clientes e aprendemos com eles; suas ideias também se tornam nossas ideias." Ver: HYDE, C. K. Assembly-Line Architecture: Albert Kahn and the evolution of the U.S. Auto Factory, 1905-1940. In: IA - The Journal of the Society for Industrial Archeology, v. 22, n. 2, 1996, p. 7. 
CAP.2 TÉCNICA 
O desejo de Henry Ford e de Albert Kahn de modificarem a estrutura da produção de automóveis até então realizada e a forma com que os edifícios industriais eram construídos não seria possível sem a evolução das técnicas existentes. A contribuição do concreto armado e da energia elétrica foram fundamentais para a mudança no projeto das fábricas, dando origem a um novo edifício fabril e à mecanização total da produção.

Representante de uma nova sociedade americana na qual a estandardização do trabalho e dos seus métodos ganhavam força, a fábrica em concreto armado oferecia as vantagens da rapidez de construção, maior quantidade de iluminação natural, melhor resistência a incêndio e uma manutenção econômica, além de características como a flexibilidade, crescimento e adaptabilidade. Não bastando o concreto armado, outro fator responsável pela mudança nas fábricas foi a eletricidade, permitindo que as máquinas pudessem operar de maneira individual, usando motores. A flexibilidade trazida pelo advento da energia elétrica fez com que novos arranjos produtivos fossem experimentados, significando maior produtividade e outras formas de organização da fábrica.

Henry Ford desejava que as fábricas da Ford Motor Company racionalizassem a produção de carros, com a intenção de fabricar mais em menos tempo, e, assim, coube a Albert Kahn utilizar as novas técnicas construtivas para cumprir o pedido do seu cliente. Ao projetar as inovadoras fábricas da Ford Motor Company, Kahn deu origem à fábrica racional que, através do uso da linha de montagem móvel para a fabricação dos automóveis, funcionava de forma tão mecânica quanto as engrenagens de uma máquina.

Dessa forma, o projeto passou a responder aos novos métodos produtivos ao invés da organização produtiva ter que se adaptar ao edifício. A construção em concreto armado foi aperfeiçoada de forma simultânea à expansão da indústria através da mudança de tecnologia, gerenciamento e processos de produção. A fábrica moderna e funcional tornou-se, portanto, um edifício em constante mutação. Esse era o advento da era do funcionalismo da flexibilidade total, que expressava uma retórica de racionalidade, eficiência e simplicidade como uma materialização essencial da organização do próprio processo produtivo, sendo Albert Kahn o responsável por transportar os valores da engenharia para os domínios da arquitetura. 


\subsection{CONCRETO E A FÁBRICA MODERNA}

A partir do início do século XX, a expansão industrial ocorrida nos Estados Unidos assumiu grande importância não só para o desenvolvimento do país, como ainda na ocupação e colonização dos novos territórios. Em tal conjuntura, a fábrica passou a deter um lugar de destaque na ascensão dessa nova cultura norteamericana, atuando como paradigma do progresso e da modernidade.

Graças ao seu caráter mais utilitário, as fábricas acabaram se tornando representantes da estandardização do desenho e da construção. $\mathrm{O}$ projeto desses edifícios levava em consideração a flexibilidade e a possibilidade de crescimento, bem como a funcionalidade, a economia e a racionalidade da construção. Esses elementos só se tornaram possíveis por meio do uso de novas técnicas construtivas, entre as quais o concreto armado, que, a partir desse momento, encontrou terreno fértil para se disseminar por uma infinidade de construções.

Contudo, é importante ressalvar que a arte e a ciência da construção em concreto armado possuem uma longa história, datando pelo menos da antiga Roma $^{69}$. Não era, portanto, algo inédito, mas sim o aperfeiçoamento e a nova

69 Durante a recuperação das ruínas das termas de Caracalla em Roma, notou-se a existência de barras de bronze dentro da argamassa de pozolana em pontos onde o vão a vencer era maior do que o normal na época. Os romanos descobriram que, misturando uma cinza vulcânicaencontrada nas proximidades do Vesúvio chamada pozolana com cal hidratada, obtinham um aglomerante que endurecia sob a água. Ver: VASCONCELLOS, J. C. Concreto Armado, Arquitetura Moderna, Escola Carioca: levantamentos e notas. Dissertação (Mestrado em Arquitetura). Porto Alegre: UFRGS, 2004, p. 29. 
utilização de uma técnica já conhecida. Por outro lado, o desenvolvimento do concreto armado moderno, utilizado para a construção dos mais diversos tipos de estruturas, é relativamente recente, com pouco mais de cem anos de idade. A produção do concreto armado ocorreu de forma paulatina e simultânea em muitos lugares do mundo, em especial na Europa e nos Estados Unidos.

A ideia de associar barras metálicas à argamassa de concreto tinha como finalidade aumentar a resistência do novo material de construção. Uma vez que ambos os materiais possuem praticamente o mesmo coeficiente de dilatação, o concreto armado torna-se um composto homogêneo, dotado de novas propriedades. Desta maneira, possui tanto a capacidade de suportar não somente os esforços de compressão, que são realizados pelo concreto, quanto também os de tração, os quais ficam a cargo do aço. Além do mais, o concreto ajuda a preservar a armadura metálica da oxidação, transformando-se, assim, em uma pedra artificial que, por oposição à pedra natural, possui uma grande capacidade de absorver os esforços de tração.

O segredo da performance mecânica do concreto armado encontrou, por meio da combinação de fatores como dosagem, tipo de metal e configuração, a distinção dos inúmeros sistemas que acabaram sendo patenteados. ${ }^{70} \mathrm{~A}$ existência de diferentes patentes demonstrava a existência de várias opções de concreto armado, uma vez que ele era o resultado de um conjunto de determinadas ideias, experiências e aplicações, sendo definido pelos processos de controle de registro realizados por seus inventores. Em tais circunstâncias, as vicissitudes da fase inicial da exploração do concreto armado até a sua afirmação como material utilizável em um sistema construtivo completo devem ser interpretadas através deste viés de experimentações.

Engenheiros, arquitetos, construtores e o público em geral viam o concreto armado com opiniões diversas. Era frequente a ocorrência de incêndios desastrosos nas antigas estruturas de madeira, circunstância que contribuía para enaltecer ainda mais os edifícios construídos em concreto armado. Contudo, as falhas amplamente divulgadas de alguns edifícios de concreto levantavam sérias dúvidas sobre o material. Na maioria das vezes, tais falhas resultavam dos mesmos fatores: remoção

70 A mais antiga publicação sobre concreto armado foi feita pelo engenheiro francês Joseph-Louis Lambot que, em 1849, realizou a construção da primeira estrutura de concreto armado: um barco. Tendo obtido sucesso com a sua embarcação, resolveu apresentá-la na Exposição Universal de Paris de 1855 em conjunto com um pedido de patente. O barco de Lambot media em torno de $4 \mathrm{~m}$ de comprimento por $1,30 \mathrm{~m}$ de largura, possuindo paredes de aproximadamente $4 \mathrm{~cm}$ de espessura. $\mathrm{O}$ protótipo original encontra-se preservado no Museu de Brignoles, na França. 
prematura das fôrmas, colocação descuidada da armadura, deformação inadequada do material devido à mudança de temperatura, fôrmas pouco resistentes ou com vazamento, compactação inadequada e dependência excessiva de desenhos e testes de carga empíricos. Salienta-se, contudo, que grande parte da experimentação e do uso de concreto armado foi feita na base da tentativa e erro.

$\mathrm{O}$ interesse dos engenheiros, construtores e empreendedores por esta nova tecnologia induziu a uma certa competitividade em relação ao comércio das patentes. Para ganhar a aceitação pública e profissional da construção em concreto armado, tornaram-se imprescindíveis a investigação científica e a padronização. $\mathrm{O}$ desenvolvimento da indústria do concreto armado baseou-se muito no crescimento exponencial de novas patentes, as quais, sob a forma de especificações, normas ou regras construtivas, viraram ferramentas de controle construtivo e comercial do concreto armado.

O concreto armado passou a assumir, então, a condição de tecnologia construtiva, tanto do ponto de vista da sua estrutura quanto de suas capacidades espaciais, substituindo formas de construção tradicional que não se adequavam à rapidez, segurança, economia e eficiência com que as novas construções em concreto armado eram executadas e mantidas. Assim, ainda no início do século XX, os edifícios industriais foram os primeiros a adotar, de maneira mais ampla, essa técnica construtiva.

Enquanto modelo arquitetônico modular, a fábrica em concreto armado era representante de uma nova sociedade americana na qual a estandardização do trabalho e dos seus métodos ganharam força, pois possibilitava a ocupação do território virgem norte-americano ${ }^{71}$ e um crescimento ilimitado. A nova estética standard oferecia a possibilidade de divulgar as conquistas da produção em massa, que incluíam as atividades produtivas dentro das fábricas e também as técnicas da construção em concreto armado.

Diante de tais fatores, a estrutura em concreto armado acabou se tornando a mais adequada para os edifícios fabris, pois era bastante resistente, podendo suportar grandes cargas em seus diversos pavimentos. A rigidez da estrutura, composta por pilares, lajes e vigas, permitiu, também, um maior afastamento entre

71 A localização das fábricas passou a ter maior liberdade após a inovação trazida pela energia a vapor, na década de 1840 . Como o carvão poderia ser usado para alimentar fábricas e ferrovias, tornou-se desnecessário que elas estivessem localizadas próximas das fontes de energia de água, possibilitando que as fábricas passassem a ser construídas mais próximas dos centros urbanos. 
os pilares, condição que gerou edifícios mais amplos e com plantas mais livres. O concreto armado reduziu a vibração da laje, tornando viáveis as fábricas de múltiplos pavimentos. Adicione-se a isto a resistência ao fogo inerente ao próprio concreto e surge, então, a forma ideal para o armazenamento de materiais combustíveis.

Celebrando a crescente popularidade das fábricas de concreto, dois livros profusamente ilustrados foram publicados em 1907. A Atlas Portland Cement Company publicou "Reinforced Concrete in Factory Construction", ao passo que os editores da Cement Age encomendaram a Robert Lesley a compilação de uma coleção de materiais e especificações relacionadas ao concreto armado, a qual foi intitulada "Concrete Factories". Cinco anos depois, em 1912, a Association of American Portland Cement Manufacturers publicou outro livro promovendo os benefícios do concreto armado, "Factories and Warehouses of Concrete". Publicados entre 1907 e 1912, os três livros promoveram o uso de concreto armado em edifícios industriais, oferecendo um impressionante volume de evidências como suporte. As obras incluíam especificações detalhadas e informações de custo de dezenas de fábricas de concreto armado já em funcionamento, além de testemunhos de donos satisfeitos com essas fábricas, contando ainda com a validação de arquitetos e engenheiros. ${ }^{72}$

Os três livros apresentavam argumentos similares para provar a superioridade das fábricas de concreto armado em relação às fábricas de alvenaria de tijolos, com estrutura de madeira ou com estrutura metálica. Para começar, o custo inicial da construção era normalmente $25 \%$ abaixo do custo de uma estrutura metálica resistente ao fogo. A economia refletia-se em matérias-primas mais baratas e no uso de mão-de-obra não especializada. Os construtores puderam reduzir o tempo de construção porque eles podiam encontrar material no local, não precisando encomendar as estruturas metálicas de produtores distantes. Por fim, os livros também enfatizavam que o caráter não-inflamável do concreto resultava na diminuição do custo do seguro em um terço quando comparado aos edifícios construídos em alvenaria.

72 Hyde, C. K. Assembly-Line Architecture: Albert Kahn and the evolution of the U.S. Auto Factory, 1905-1940. In: IA The Journal of the Society for Industrial Archeology, v. 22, n. 2, 1996 p. 9. 
A grande força e rigidez de uma estrutura de concreto significava um aumento da proteção quanto à vibração, além de ampliar a sua durabilidade. A esse propósito, o livro publicado pela Atlas Portland Cement Company em 1907 lembrava que o único edifício sobrevivente do terremoto de 1906, em São Francisco, tinha estrutura de concreto. As obras também frisaram que o concreto armado ficava mais resistente com o passar do tempo, à medida que ia curando.

Finalmente, todos os livros destacaram a melhoria na entrada de luz natural proporcionada pelos projetos de concreto, com um aumento de 70 a $80 \%$ da área envidraçada das superfícies externas da parede. Esta tipologia arquitetônica referida por Banham como Daylight Factory ${ }^{73}$, ou "fábrica de luz do dia" - permitiu não só a iluminação e ventilação natural nos espaços de trabalho, como ainda a abertura do espaço interior para o exterior.

Graças às melhores condições de luz natural, ventilação e vista para o exterior, as novas fábricas proporcionavam maior bem-estar para os seus trabalhadores, fator fundamental para o aumento da produtividade. No entanto, o elemento decisivo para o sucesso das fábricas acabou sendo o desenvolvimento da ideia de um edifício funcionalista e, para tanto, o uso e distribuição da eletricidade, uma novidade do século XX, eram vitais.

73 A Daylight Factory é descrita no primeiro capítulo do livro A Concrete Atlantis como "multi-story American industrial buildings with exposed concrete frames, filled in only by transparent glazing", ou seja, os edifícios industriais norte-americanos de vários andares com estruturas de concreto aparentes, preenchidas apenas por grandes planos envidraçados, que permitiam não só a iluminação e ventilação natural nos espaços de trabalho, como ainda a abertura do espaço interior para o exterior. Ver: BANHAM, R. "A Concrete Atlantis". Cambridge: MIT Press, 1986. 


\subsection{A ELETRICIDADE E 0 EDIFÍCIO FUNCIONALISTA}

Apesar de o novo material permitir uma ampla variedade de tipos de edifícios fabris, essas mudanças dimensionais não ocorreram durante os primeiros anos da construção em concreto armado. Devido às restrições causadas pelas fontes de energia e distribuição, as fábricas mantiveram, por algum tempo, o tamanho e a forma das antigas construções.

Nestas antigas fábricas movidas a vapor, a distribuição de energia exigia um pesado conjunto de equipamentos para transmitir a energia da fonte central para as máquinas de produção. $\mathrm{O}$ sistema continha muitos problemas, como a perda de energia durante as transmissões, além das restrições no arranjo espacial da fábrica. Se uma máquina fosse ligada, todas deveriam também estar em funcionamento. Uma parte da fábrica não podia ser utilizada se tudo não estivesse perfeitamente ajustado.

A chegada de um novo sistema de transmissão de energia, a eletricidade, foi responsável por importantes mudanças nos edifícios fabris. Além do advento da iluminação elétrica, graças ao uso de motores, a eletricidade permitiu que as 
máquinas operassem de maneira individual. A flexibilidade trazida pelo advento da energia elétrica fez com que outros arranjos fossem experimentados pela fábrica. Essas mudanças significariam maior produtividade e novas formas de organização fabril.

A modificação no sistema de transmissão de energia foi um dos motivos principais para que os engenheiros e os arquitetos alterassem a forma como projetavam as fábricas. Assim como outras tecnologias industriais, a fábrica necessitava ser mais produtiva. A gestão cuidadosa dos operários, a utilização e deslocamento interno dos materiais e a velocidade de produção tornaram-se cruciais para a sobrevivência de uma empresa, e os projetos dos edifícios necessitavam auxiliar essa gestão. Pensar assim resultou em fábricas mais eficientes, viabilizando que a organização da produção fosse racionalizada.

Com o aumento do volume e da velocidade de produção, cresceu também a demanda por um manuseio de materiais mais eficaz. ${ }^{74} \mathrm{Tal}$ fato exigiu que as peças fossem transportadas com maior frequência ao longo da fábrica, processo este que conduziu, naturalmente, à linha de montagem em movimento. $\mathrm{O}$ projeto da fábrica atuou como uma das ferramentas utilizadas pelas indústrias em crescimento para aumentar a velocidade e o volume de produção e, o mais importante, assegurar um fluxo constante dessa mesma produção. ${ }^{75}$

$\mathrm{Na}$ condição de uma das funções mais importantes na fábrica, o manuseio de materiais também era considerado um dos mais problemáticos. A gestão de uma linha de produção em massa passava pelo controle científico de todas as atividades de fabricação envolvidas em uma operação industrializada. Nesse cenário, a otimização do manuseio dos materiais implicava não só na melhoria dos recursos humanos, mas na organização de toda a fábrica e na disposição dos seus equipamentos. Era uma questão quase matemática: quanto menos tempo fosse perdido no manuseio de matérias-primas e de equipamentos, mais tempo iria se ganhar para as operações específicas envolvidas na produção do objeto industrial.

Para resolver esses problemas, foram desenvolvidos sistemas de movimentação automática dos materiais e peças, como pontes rolantes e guindastes para elevação vertical, esteiras para movimentações verticais e horizontais, entre

$74 \mathrm{O}$ manuseio de materiais é o processamento de materiais através do uso de máquinas, possuindo o objetivo de aumentar a eficiência e a velocidade através das quais os materiais são produzidos, transportados, armazenados e manuseados dentro da fábrica.

75 CHANDLER, A. The visible hand. Cambridge, MA: Harvard University Press, 1977. 
outros, os quais passaram a fazer parte do sistema organizacional das fábricas. A nova tecnologia do manuseio de materiais não só aumentou a produção como ainda possibilitou a substituição da mão-de-obra por trabalhadores menos qualificados, uma vez que o trabalho se tornou menos complexo e mais repetitivo.

Ao observar esses fatores operacionais, a forma de projetar uma fábrica passou a considerar determinante a relação entre as partes, distâncias e proximidades, bem como a distribuição dos equipamentos e máquinas dentro do edifício ${ }^{76}$. Dessa forma, o cuidado estético com o interior da fábrica passou a ter tanto ou mais importância que a aparência exterior. As novas tecnologias disponíveis para a construção em concreto armado permitiram a abertura de vãos maiores no interior da fábrica, ao mesmo tempo em que a estrutura independente viabilizou o fechamento do edifício com esquadrias de vidro. A casca exterior adaptava-se às necessidades de operação do interior, com a finalidade de cumpri-la da maneira mais eficiente possível.

A construção em concreto armado foi aperfeiçoada de forma simultânea à expansão da indústria através da mudança de tecnologia, gerenciamento e processos de produção. A fábrica moderna e funcional tornara-se, portanto, um edifício em constante mutação. Agora, o projeto respondia aos novos métodos produtivos ao invés da organização produtiva ter que se adaptar ao edifício. Ao reconhecer que os fatores operativos sobrepunham-se normalmente aos formais, aceitava-se a efemeridade das fábricas e a sua natural obsolescência.

As novas fábricas de concreto foram muito importantes para a crescente indústria automobilística, com suas máquinas cada vez mais pesadas e com a expansão contínua do tamanho das operações. Instrumental no desenvolvimento da fábrica moderna e racional, a indústria automobilística notabilizou-se por combinar diferentes tipos de operações em uma escala maior do que qualquer outra indústria, tornando-se um caso que, pela sua relevância, merece ser abordado de forma autônoma.

76 Nesse planejamento, normalmente eram considerados: 1) o processo de fabricação, maquinaria e equipamento necessário; 2) tipo e quantidade dos materiais manuseados, em estado de matéria prima e/ou acabado; 3) número e distribuição das pessoas empregadas na fábrica; 4) e, finalmente, um estudo muito atento à lógica da circulação dos materiais de forma ao bom planejamento dos diversos departamentos ou partes da fábrica, evitando-se assim perdas de tempo em transporte e comunicações, de forma a otimizá-los. 


\subsection{AS PRIMEIRAS FÁBRICAS AMERICANAS DE AUTOMÓVEIS}

O caso específico das fábricas de automóveis representa um importante capítulo no estudo da indústria americana e mundial. De fato, com a emergência das comunicações e a evolução dos meios de locomoção no princípio do século XX, o automóvel assumiu uma importância crescente no quotidiano dos norteamericanos. A modernidade representada pelos automóveis acompanhava a inovação e a modernidade dos edifícios fabris que os produziam. Durante os primeiros vinte anos do século XX, a fábrica em concreto armado para a indústria de automóveis nos Estados Unidos foi o perfeito retrato de uma revolução arquitetônica, algo ocorrido graças à internacionalização de sua imagem, divulgada pelos arquitetos europeus através de fotografias e publicações. Mais do que um exemplo de uso de concreto armado, as fábricas de automóveis americanas passaram a ser admiradas como símbolo cultural e econômico do país, o que justificava a eficiência e a beleza racional das construções.

Contudo, é importante entender a história inicial da indústria automobilística antes de passar para uma discussão sobre as revolucionárias fábricas de automóveis. 
Até o início do século XX, a produção de carros nos Estados Unidos não era expressiva. Apenas alguns carros eram fabricados por dia e as fábricas funcionavam como montadoras, construindo os veículos a partir de peças ou componentes que eram produzidos por outras fábricas. A jovem indústria automobilística, com poucos requisitos, começou suas operações em pequenas oficinas mecânicas.

No final do século XIX, a incipiente indústria de automóveis estava concentrada em torno de Detroit, responsável pela atração de muitos inventores e empreendedores, que criaram pequenas empresas automobilísticas. Os primeiros fabricantes de automóveis foram a Olds Motor Company, Packard Motors Car Company, Buick Motor Company e, alguns anos mais tarde, a Ford Motor Company, que, a partir da segunda década do século XX, viria a se transformar na maior fabricante de automóveis do mundo.

Ransom Olds, o responsável pelas primeiras fábricas automobilísticas de sucesso nos Estados Unidos, começou a produzir o automóvel Oldsmobile em 1897. Olds foi o pioneiro na produção de automóveis em grande escala e também na construção de um local específico para tal objetivo. O empresário construiu duas fábricas entre 1899 e 1903, as quais tinham como objetivo aumentar o volume de produção. Edificada em 1899, a primeira fábrica da empresa possuía onze mil metros quadrados e uma capacidade de produção de dezoito carros por dia. Em 1901, Olds construiu uma segunda fábrica, em Detroit, aumentando a capacidade de produção para cinquenta carros por dia. ${ }^{77}$

A Buick Motor Company surgiu em 1903 como uma fabricante independente de automóveis, criada pelo escocês naturalizado americano David Dunbar Buick. Com a morte de Buick e a venda da empresa, a gestão ficou a cargo de William C. Durant, que se tornaria o fundador da General Motors. ${ }^{78}$ Tanto a fábrica da Olds Motor Company quanto a da Buick Motor Company consistiam em tradicionais edifícios fabris de múltiplos pavimentos, com estrutura de madeira e alvenaria de tijolos portante na fachada. As pequenas aberturas nas fachadas eram proporcionais ao tamanho permitido pela parede de sustentação de tijolos.

A maioria das primeiras fábricas de automóveis apenas projetavam e montavam os carros, adquirindo os componentes de pequenos fabricantes. $O$ trabalho

77 BIGGS, L. B. Industry's master machine: factory planning and design in the age of mass production, 1900 to 1930 . Tese (Ph.D in Urban Studies and Planning). Massachusetts Institute of Technology: Cambridge, 1987, p.96-100.

78 Disponível em: <www.hemmings.com/magazine/hcc/2015/06/David-Dunbar-Buick/> Acesso: 7 mai. 2018. 
de montar um carro exigia a habilidade de uma mão de obra experiente. Além disso, cada peça tinha que ser ajustada de maneira individual, pois a indústria ainda não havia alcançado a produção de peças padronizadas e intercambiáveis. $\mathrm{O}$ trabalho era feito por pequenos grupos de operários habilidosos, trabalhando juntos e construindo apenas um carro por vez. A construção de um automóvel dependia, portanto, da habilidade humana e não de uma máquina, embora algumas máquinas especializadas já fossem usadas em outras indústrias na época. A gestão era mínima: na maioria das empresas, tanto o proprietário como os operários desempenhavam as mesmas funções, sem uma relação hierárquica. ${ }^{79}$

Durante seus anos iniciais, a Ford Motor Company não se destacava na comunidade industrial de Michigan, sendo apenas mais uma das várias empresas automobilísticas na área de Detroit. A primeira fábrica da Ford era um pequeno edifício de um pavimento, com cerca de 76 metros de comprimento por 15 metros de largura. Localizada na Mack Avenue, em Detroit, possuía estrutura de madeira, estando equipada com as máquinas necessárias para montar as peças do carro. ${ }^{80}$

A Ford mudou-se para a fábrica em 1903 e começou a montar carros com apenas uma dúzia de trabalhadores. Os componentes eram comprados de fornecedores externos: a Dodge Brothers fornecia o chassi, motor, transmissão e eixo de transmissão, ao passo que outras três empresas forneciam os pneus, as rodas e a carroceria. Nesse momento, a Ford Motor Company não podia ser considerada uma fabricante de carros, mas sim apenas uma montadora. ${ }^{81}$

O projeto das fábricas de automóveis mudou pouco durante os primeiros anos do século XX, época em que o processo de produção permaneceu estável e fez poucas exigências à construção da fábrica. Mas, à medida que a demanda por automóveis crescia, aumentava a pressão por maior velocidade e volume de produção, o que ocasionou uma necessidade de conscientização sobre a importância de um projeto adequado para uma fábrica de automóveis.

A construção da fábrica da Packard Motors Car Company iniciaria em 1903, quando seu presidente, Henry Joy, estabeleceu um novo rumo para a construção das fábricas de automóveis. O projeto ficou a cargo de Albert Kahn, um jovem arquiteto que se tornaria famoso por seus edifícios industriais. De 1903 a 1905, Kahn

79 BIGGS, L. B. The rational factory. Baltimore: The John Hopkins University Press, 1996, p. 89

80 Disponível em <www.fordmotorhistory.com> Acesso em 16 jan. 2018.

81 Enquanto outros fabricantes de automóveis também compravam muitos componentes de fornecedores externos, a Cadillac Motor Car Company foi a pioneira ao fabricar os seus próprios motores e transmissões. Disponível em <www. fordmotorhistory.com> Acesso em 16 jan. 2018. 

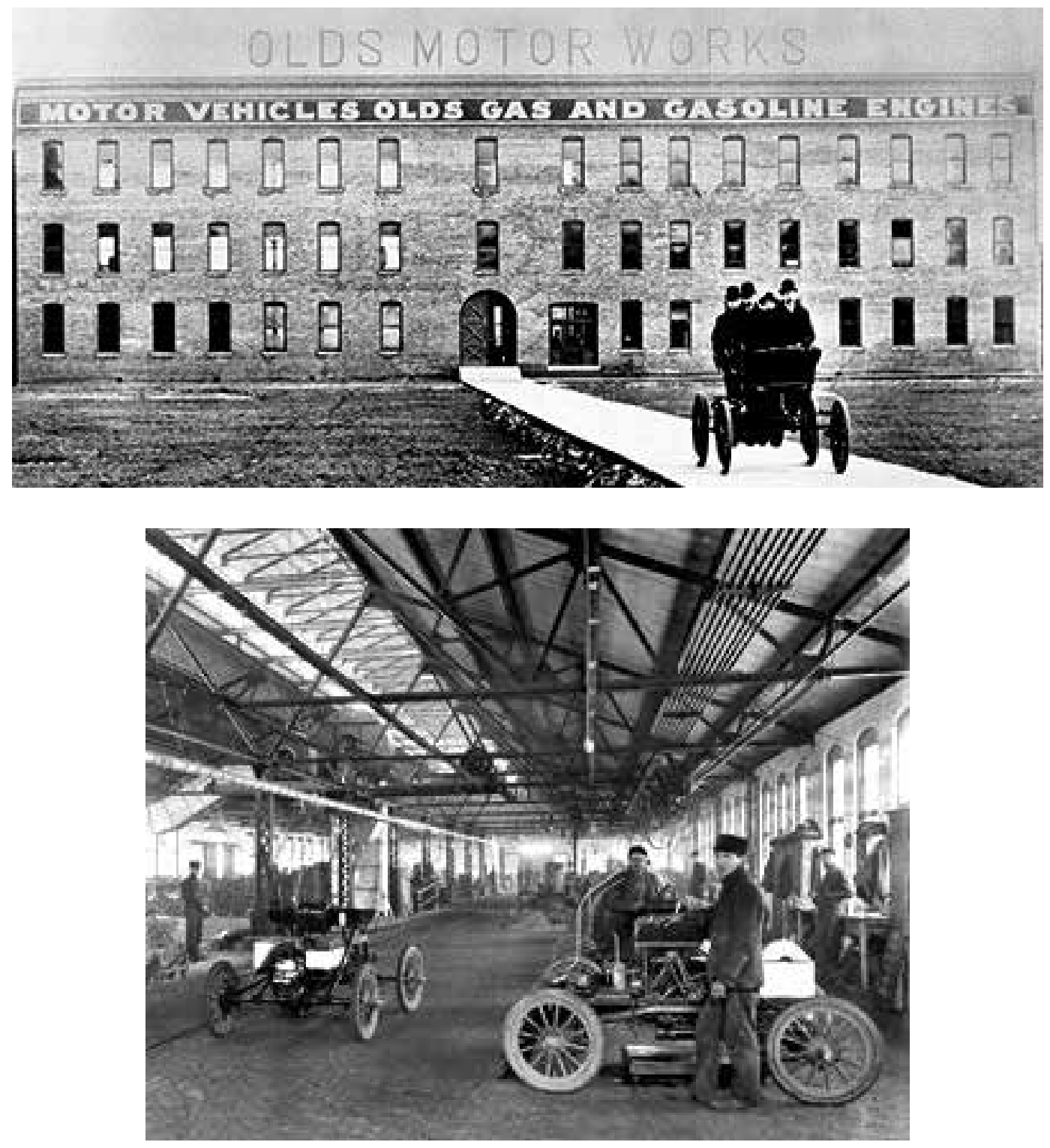

Fig. 32 Fábrica de automóveis da Oldsmobile, em Detroit, Michigan (1901). Fonte: <www.history.gmheritagecenter.com $>$ Acesso em 07 mai 18

Fig. 33 Interior da Fábrica da Oldsmobile, em Detroit, Michigan (1901).

Fonte: <www. michiganhistory.leadr.msu.edu/lansing-oldsmobile-early-history/> Acesso em 07 mai 18. 

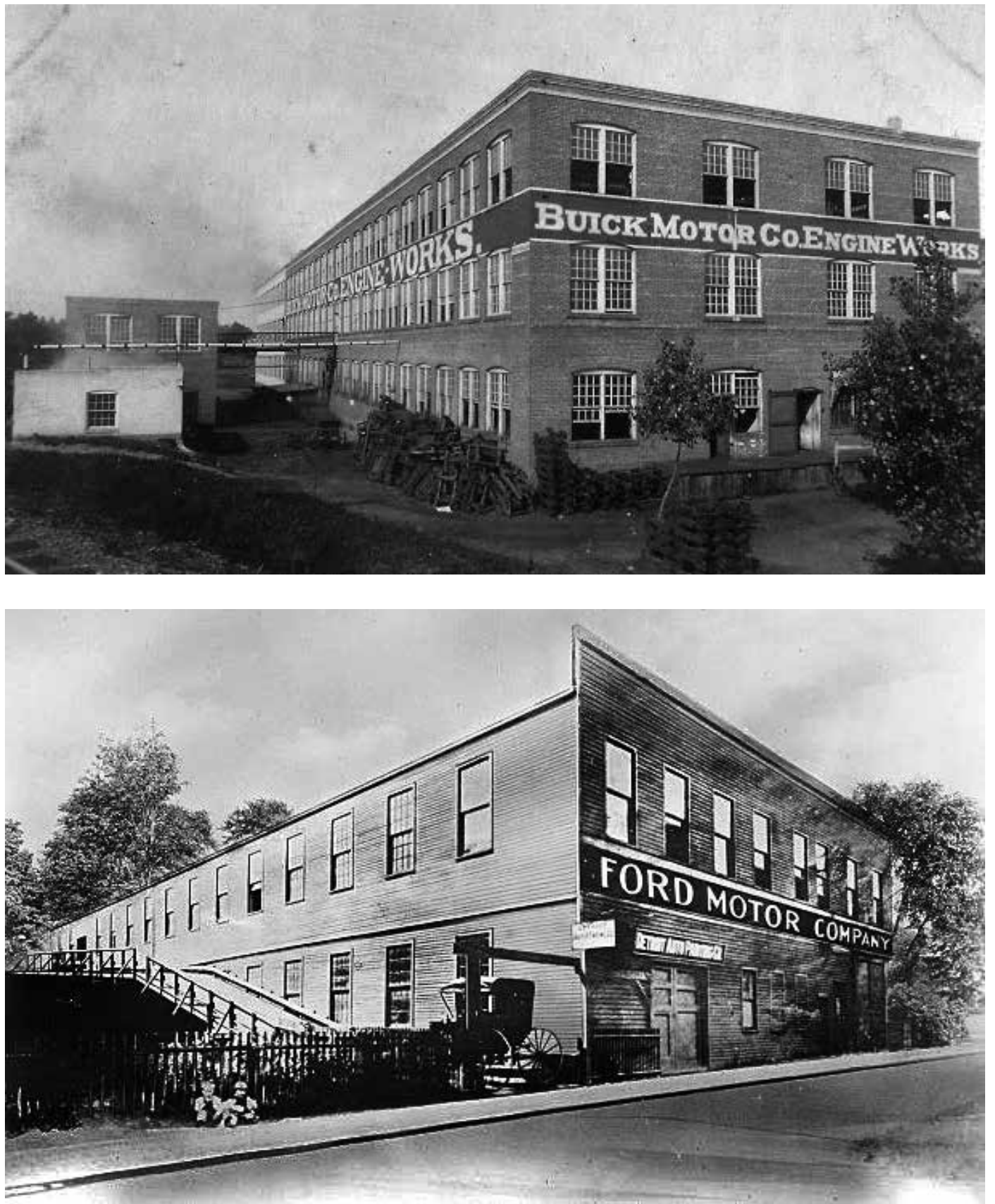

Fig. 34 Primeira fábrica de automóveis da Buick Motor Company, em Flint, Michigan Fonte: <www.buickcity.blogspot.com.br $>$ Acesso em 07 mai 18 .

Fig. 35 Fábrica da Ford Motor Company na Mack Avenue, em Detroit, Michigan (1903).

Fonte: <www.gettyimages.pt $>$ Acesso em 07 mai 18 . 

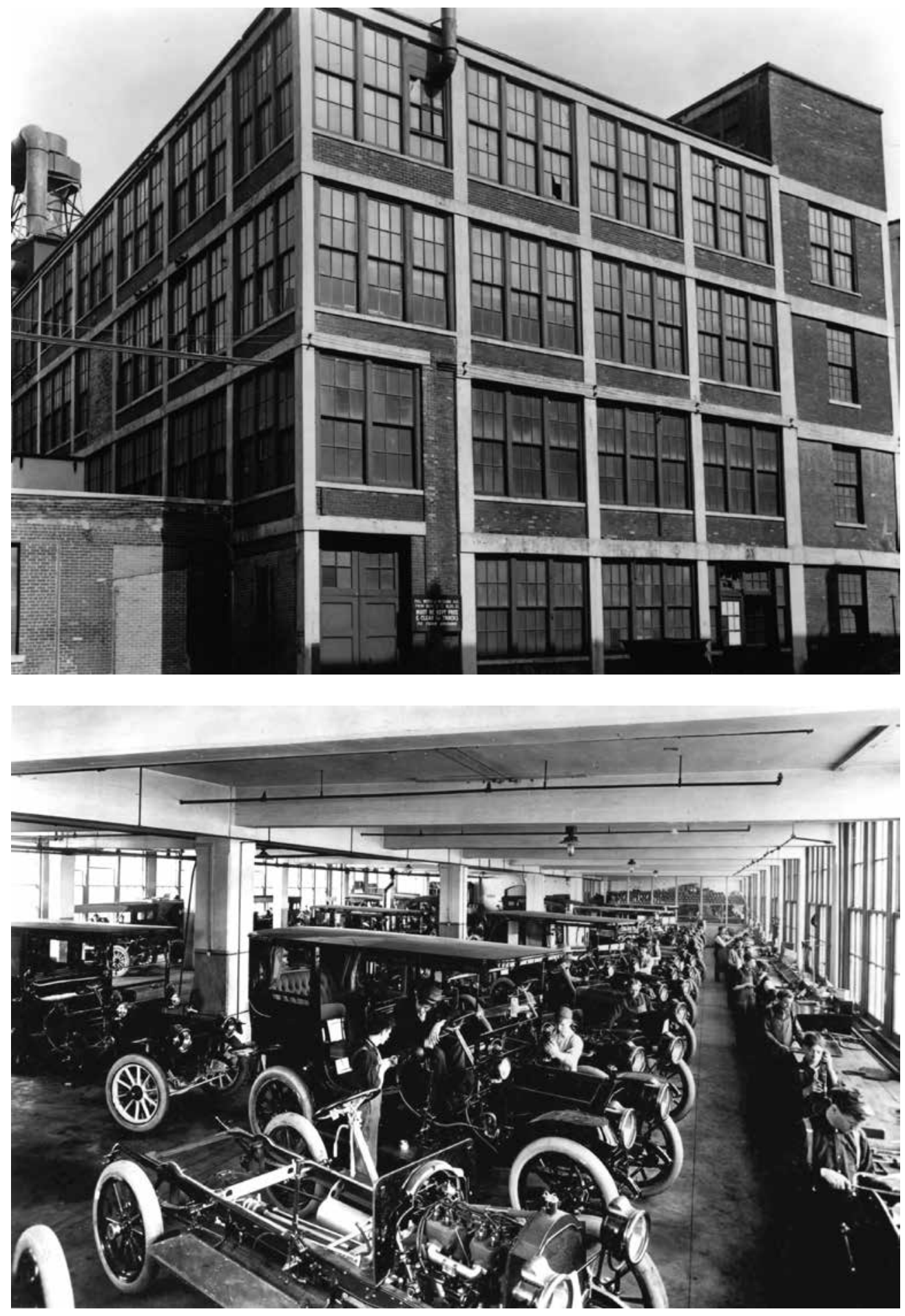

Fig. 36 Edifício 10 da Packard Motor Car Company, Detroit, Michigan (1905). Projeto de Albert Kahn. Fonte: Albert Kahn Associates Records, Bentley Library, University of Michigan.

Fig. 37 Interior do Edifício No 10 da Packard Motor Car Company, Detroit, Michigan (1905). Fonte: Albert Kahn Associates Records, Bentley Library, University of Michigan. 
projetou e supervisionou a construção de nove edifícios fabris para a empresa, todos organizados de forma semelhante a outros complexos fabris já existentes. Com o projeto do décimo edifício para o complexo fabril da Packard, em 1905, Albert e seu irmão, Julius Kahn, começaram a realizar experiências com a construção em concreto armado em edifícios fabris. ${ }^{82}$

O edifício Packard Número 10 atraiu considerável atenção da comunidade industrial de Detroit, pois representava um avanço significativo no uso de concreto armado para a construção de fábricas. A utilização desta técnica reduzia consideravelmente a vibração do piso decorrente das novas máquinas, maiores e mais pesadas. Por exigir menos pilares internos do que as antigas construções fabris, permitia a ampliação do espaço livre disponível para a produção. Por fim, a resistência estrutural do concreto armado significava que grande parte da parede exterior poderia ser preenchida com esquadrias de vidro, abrindo o interior dos edifícios de vários andares para a entrada de uma abundante quantidade de luz natural, algo que pela primeira vez se tornava possível.

Ao utilizar concreto armado nas novas fábricas, Kahn desempenhou um papel importante na revolução da construção industrial. O trabalho de Kahn foi um componente relevante do sucesso da indústria automotiva dos Estados Unidos no início do século $\mathrm{XX}$, principalmente por ter contribuído para solucionar as deficiências do tradicional edifício fabril.

O sucesso de Ford com seus modelos de carros fez com que o industrial pensasse em construir uma segunda fábrica, com o objetivo de ampliar a produção. Em janeiro de 1904, a empresa comprou um terreno em um setor pouco desenvolvido de Detroit, que era delimitado pela Piquette Avenue, ao sul, e por uma linha ferroviária, a Michigan Central Railroad, ao norte. O projeto e as especificações da nova fábrica ficaram a cargo dos construtores de Detroit, Hinchman \& Smith $^{83}$. As obras começaram em maio de 1904, com uma efetiva participação de Henry Ford na construção da fábrica. Sua colaboração ocorreu desde a concepção do projeto até a supervisão de todos os detalhes de gerenciamento e de produção, eis que a fábrica deveria ser diferente da existente na Mack Avenue.

A fábrica de três andares media 122,50 metros por 18,80 metros, estando

82 HILDEBRAND, G. Designing for Industry: The Architecture of Albert Kahn. Cambridge, Massachusetts: MIT Press, 1974, p. 26-31.

83 Além da fábrica Ford Piquette Avenue, Hinchman \& Smith projetaram fábricas para a Daisy Manufacturing Company (1903); vários edifícios para Olds Motor Works e Olds Gasoline Engine Works (1903-1905) em Lansing, Michigan; instalações para Walker \& Sons (1904-1905) em Walkerville, Ontário, Canadá, e fábricas para Dodge Brothers (1904-1905) em Detroit.Disponível em <www.fordmotorhistory.com> Acesso em 16/01/18. 
disposta em um terreno quatro vezes maior do que o edifício. Embora a fábrica recém-construída da Ford tenha possibilitado uma melhor organização e mais espaço para o crescimento da produção, não ofereceu um novo modelo para produção ou projeto de fábrica. A dimensão tradicional ainda era considerada o melhor formato para a captação da luz do dia $^{84}$ e para a distribuição de energia. Além disso, o processo através do qual os automóveis eram feitos divergia pouco da produção de outros bens pesados - carruagens, vagões ou maquinário. Eles eram produzidos da única maneira que se sabia fazer carros na época: um de cada vez, com operários trabalhando em pequenos grupos, ajustando e montando as peças. $\mathrm{O}$ projeto do edifício satisfazia, portanto, as exigências produtivas.

Embora a fábrica da Piquette Avenue se assemelhasse à primeira fábrica da empresa em suas operações de produção, ela continha mais do que apenas oficinas. O primeiro andar abrigava os escritórios gerais, bem como áreas de armazenamento e oficina de máquinas, equipadas com aquelas mais pesadas. $\mathrm{O}$ primeiro pavimento não era tão iluminado por causa das janelas um pouco menores que as dos dois andares superiores e da pilha de materiais que ficavam dispostas ao redor do perímetro da fábrica. $\mathrm{O}$ segundo andar, contudo, era diferente do primeiro: maior e mais iluminado, abrigava uma variedade de operações, desde estações de montagem e oficinas até escritórios, entre eles o escritório particular de Henry Ford. O terceiro andar parecia muito com o segundo, pois continha espaços para armazenamento e a área de montagem final. ${ }^{85}$ As imagens existentes da fábrica fornecem um olhar interessante sobre a organização da produção inicial de automóveis, que poderia ser alterada com facilidade se os modelos ou os métodos de produção mudassem, pois nada nesta fábrica era absurdamente pesado ou imóvel.

No final de 1905, Ford decidiu iniciar a fabricação própria de alguns componentes do carro. Para isso, ele montou a Ford Manufacturing Company na Bellevue Avenue, localizada a aproximadamente 6,5 quilômetros da fábrica de montagem da Piquette Avenue, para fabricar motores e eixos traseiros. Assim, a empresa começaria a fabricação de peças intercambiáveis, iniciativa fundamental para o novo processo de fabricação dos carros.

Foi assim que Henry Ford passou a repensar a organização do processo

84 Nenhuma indústria, naquela época, podia confiar unicamente na iluminação elétrica. Ver: BIGGS, L. B. The rational factory. Baltimore: The John Hopkins University Press, 1996, p.90.

85 BIGGS, L. B. The rational factory. Baltimore: The John Hopkins University Press, 1996, p.91. 

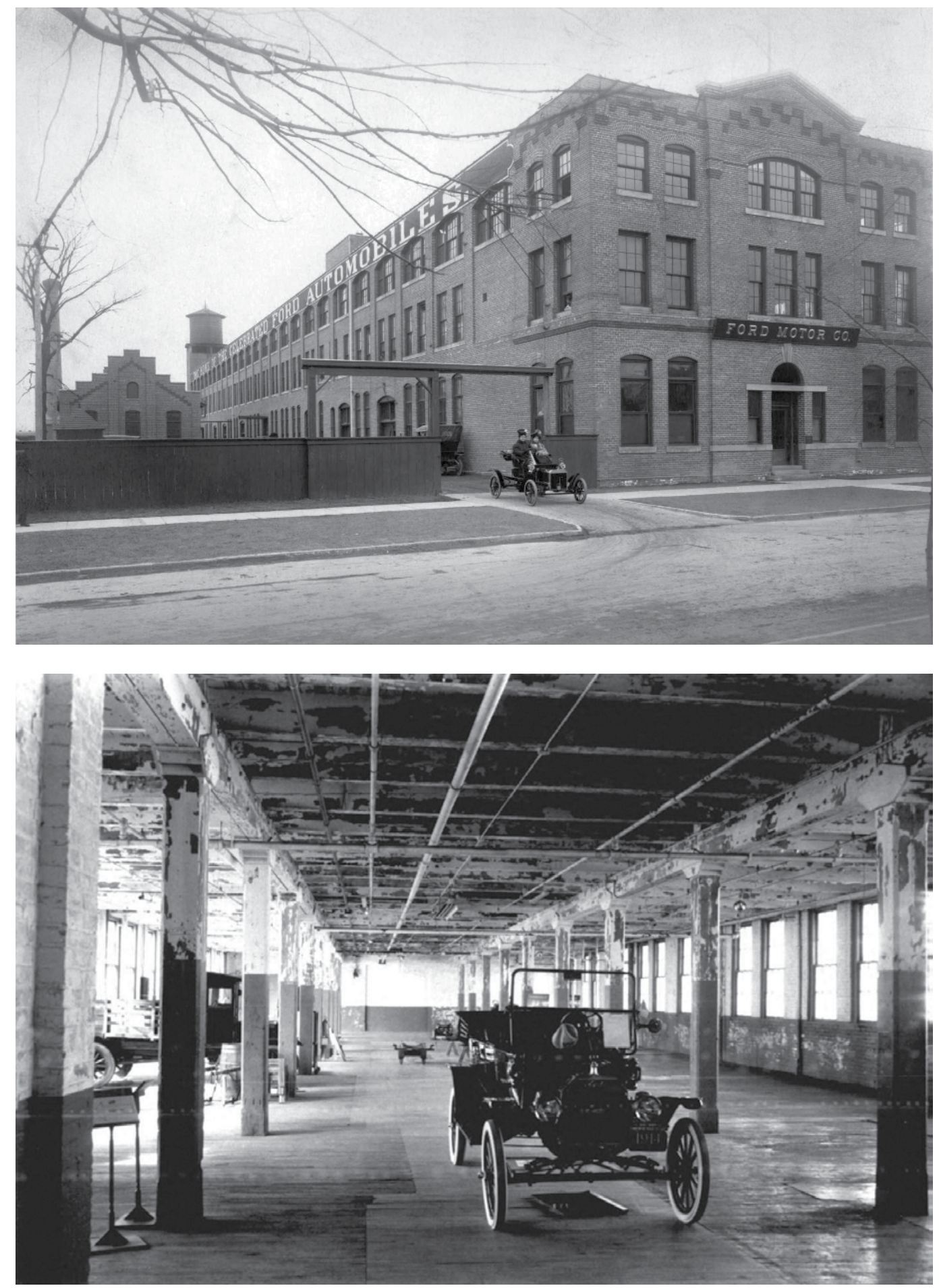

Fig. 38 Fábrica da Ford Motor Company na Piquette Avenue em Detroit, Michigan (1904). Fonte: <www.thehenryford.org $>$ Acesso em 07 mai 18.

Fig. 39 Interior do setor de montagem da Fábrica Ford Piquette Avenue.

Fonte: <www.thehenryford.org> Acesso em 07 mai 18. 
de fabricação, aliando o senso de observação das necessidades das suas fábricas às inovações técnicas disponíveis no momento. Para acelerar a produção, as máquinas foram dispostas sequencialmente, em vez de agrupar as máquinas por similaridade - algo comum na organização tradicional das fábricas. $O$ novo arranjo posicionava as máquinas na ordem em que elas seriam utilizadas, reduzindo o tempo e os custos de mão de obra para transportar peças e componentes entre elas. Outra mudança importante foi em relação aos operários, os quais não trabalhariam mais em pequenos grupos, montando um carro por vez. Ao contrário, eles caminhariam ao longo de uma fileira de carros estacionados, cada um realizando a mesma operação de um carro para outro. ${ }^{86}$ Esse experimento daria origem à futura linha de montagem.

Quando o transporte por carroça entre a fábrica na Bellevue Avenue e a fábrica de montagem na Piquette Avenue provou ser muito lento, a empresa adquiriu novos edifícios próximos à fábrica da Piquette Avenue e, em 1907, mudou a produção de motores para um local mais perto das operações de montagem. Mesmo com a expansão, mais uma vez a fábrica Ford Piquette Avenue ficou restrita pela falta de espaço para ampliar a produção. ${ }^{87}$ Essa restrição, combinada com um aumento surpreendente na demanda por seus carros, levou Henry Ford e seus engenheiros aos inovadores experimentos em relação a um novo projeto da fábrica, algo que ajudaria a alterar, para sempre, a fábrica americana.

86 BIGGS, L. B. The rational factory. Baltimore: The John Hopkins University Press, 1996, p.91-94. 87 Em 1909, a Ford Motor Company produziu 10 mil carros, o dobro da produção de 1908. Ver: BIGGS, L. B. Industry's master machine: factory planning and design in the age of mass production, 1900 to 1930. Tese (Ph.D in Urban Studies and Planning). Massachusetts Institute of Technology: Cambridge, 1987 p.100. 


\subsection{A FÁBRICA COMO MÁQUINA}

O deslocamento da Ford Motor Company para uma outra fábrica, localizada no subúrbio da cidade de Detroit, em Highland Park, sinalizou um passo significativo no desenvolvimento da fábrica racional - uma máquina criada para ser previsível e obediente. Em uma época na qual a alteração dos pressupostos sobre a produção ditaram mudanças importantes no projeto das fábricas, a Ford Highland Park representou o início de uma nova era no projeto de fábricas de automóveis.

Tendo conhecimento da inovação construtiva realizada por Albert Kahn no projeto do Edifício Número 10 da Packard Motor Car Company, Henry Ford aproximou-se do arquiteto em 1908 para construir sua nova fábrica de automóveis em Highland Park. Este foi o começo de uma parceria entre os dois que se estenderia por mais de trinta anos, com mais de mil projetos realizados para a Ford Motor Company. Essa parceria ajudou a revolucionar a fabricação de automóveis e a arquitetura industrial.

A demanda por uma fábrica bem projetada foi além das exigências anteriores de uma estrutura resistente o bastante para abrigar as máquinas pesadas 
e com amplas janelas para fornecer a iluminação adequada. A nova indústria exigia um edifício capaz de abrigar as máquinas que pareciam crescer mais a cada ano, além do manuseio eficiente de materiais e o gerenciamento dos operários, tendo em vista o aumento da velocidade e do volume de produção. O projeto adequado da fábrica, assim como outras tecnologias industriais, tornou-se um elemento essencial para o incremento da produtividade, assegurando um fluxo constante de produção.

A Ford Motor Company experimentou novos projetos e arranjos de fábrica de forma mais explícita do que a maioria das empresas. Ao contrário de muitos industriais que se encontravam acomodados com as fábricas existentes na época, Henry Ford parecia disposto a abandonar o antigo edifício e construir um novo assim que o volume de produção superasse a estrutura original ou quando o pensamento dos engenheiros sobre a escala produtiva avançasse. Ao olhar para os edifícios da Ford, podemos discernir os estágios no desenvolvimento da produção em massa, assim como as mudanças revolucionárias no projeto e organização das fábricas durante os primeiros anos do século XX.

\subsubsection{Highland Park Old Shop: os primeiros experimentos}

Em 1908, a Ford Motor Company apresentou ao mercado o Modelo T, que se tornaria o carro mais popular já produzido nos Estados Unidos. A história do Modelo T é a mais espetacular da indústria automobilística. Como o automóvel ainda era um fenômeno relativamente recente e grande parte da população estava cética em relação à sua utilidade, o Modelo $\mathrm{T}$ ajudou a persuadir as pessoas de que o automóvel era uma boa ideia. Ele era forte, durável, fácil de dirigir e de fácil manutenção. ${ }^{88}$ Por causa desses fatores, o seu sucesso foi tão grande que, por dezoito anos, foi o único carro fabricado pela Ford. Durante esse tempo, transformou-se em objeto de muita afeição no país, com canções e histórias escritas a seu respeito. A fama do Modelo $\mathrm{T}$ tornou Henry Ford um dos homens mais bem sucedidos dos Estados Unidos e do mundo.

Em 1909, o sucesso comercial do Modelo T levou Henry Ford a considerar

88 BIGGS, L. B. The rational factory. Baltimore: The John Hopkins University Press, 1996, p.101. 
a construção de uma terceira fábrica. A mudança da empresa para Highland Park significou muito mais do que ampliar o espaço de produção: foi também o início de grandes modificações na tecnologia, nos processos de fabricação, nas estratégias de gestão e até mesmo nas relações de trabalho. Tentando combinar todas as inovações disponíveis, Henry Ford e seus engenheiros decidiram por um arranjo interno de fábrica bem diferente daquele da Piquette Avenue, algo que facilitasse a expansão e abrigasse o novo processo de produção, que estava apenas começando a tomar forma. A nova fábrica era, portanto, uma estrutura industrial mais moderna, possuindo modificações importantes na tecnologia da construção e no arranjo do espaço de trabalho.

Para projetar a fábrica, Henry Ford, que já conhecia o trabalho realizado para a Packard, escolheu Albert Kahn. Os dois se encontraram várias vezes e Kahn desenvolveu um projeto que satisfazia os requisitos do empresário. Os depoimentos de Albert Kahn sugerem fortemente que Ford tenha iniciado os conceitos gerais do projeto da fábrica e o arquiteto, depois de várias tentativas fracassadas, enfim teve sucesso ao transformar as ideias de Henry Ford em um projeto viável e exequível. Vinte anos depois desse momento inicial, Albert Kahn lembrou as suas primeiras reuniões com Ford:

"When Henry Ford took me to the old race course where the Highland Park plant stands and told me what he wanted, I thought he was crazy. No buildings such as he talked of had been know to me. But I designed them according to his ideas. Ford's big contribution to industrial building is the covering of many activities with one roof and thus saving expense in building, heating and upkeep" 89

A atenção pessoal de Henry Ford na construção da fábrica revela a extensão de seu envolvimento com a empresa. Nos primeiros anos, Ford participou da concepção e supervisão de todos os detalhes de gerenciamento e produção. $\mathrm{O}$ empresário imaginou um novo tipo de fábrica, diferente das usuais, e explicou as suas necessidades para Albert Kahn: "I want the whole thing under one roof. If

89 Tradução da autora: "Quando Henry Ford me levou à antiga pista de corrida onde a fábrica Highland Park está construída e me disse o que queria, pensei que estivesse louco. Eu não conhecia edifícios como ele disse que desejava, mas eu os projetei de acordo com as suas ideias. A grande contribuição da Ford para a construção industrial é abrigar muitas atividades sob a mesma cobertura, economizando custos na construção, aquecimento e manutenção”. Em: HILDEBRAND, G. Designing for Industry: The Architecture of Albert Kahn. Cambridge, Massachusetts: MIT Press, 1974, p.51. 
you can design it the way I want it, say so and do it". ${ }^{90}$

A fábrica, construída fora dos limites da cidade de Detroit, estava localizada em uma importante avenida, a Woodward Avenue ${ }^{91}$. O novo complexo da Ford Motor Company consistia em nove edifícios, formando um conjunto compacto, conforme expressamente solicitado por Henry Ford. A ausência de espaços livres entre os edifícios permitia uma melhor conexão entre as partes e o transporte mais eficiente de materiais.

A maioria dos edifícios de Highland Park era construída com estrutura de concreto e fechamento em tijolos e vidro. Com fachada para a Woodward Avenue, o edifício de produção principal do conjunto tinha quatro andares, possuindo extensão de 860 pés $(262,10 \mathrm{~m})$ de comprimento por 75 pés $(22,80 \mathrm{~m})$ de largura. Ele abrigava operações de montagem, espaços de armazenamento, salas de ferramentas, cabines de pintura e outras operações leves. As proporções desse edifício e dos outros edifícios de quatro pavimentos do complexo eram similares aos das fábricas tradicionais - exceto pelas grandes janelas -, mas a semelhança parava por aí. $\mathrm{O}$ espaço interno era equivalente ao de uma moderna fábrica de concreto armado, com ampla superfície livre. Para liberar o máximo de área possível no interior da fábrica, quatro torres de serviços, contendo os elevadores, escadas e banheiros, foram erguidas do lado de fora do edifício.

A estrutura de Highland Park, feita com a nova patente de concreto armado do irmão de Albert Kahn, libertou a fachada de sua condição portante, tornandose uma pele de vidro contínua, com caixilharia de aço. A estrutura reticulada de concreto da fábrica ficava aparente na fachada, sendo os vãos totalmente preenchidos com esquadrias de vidro. $\mathrm{O}$ uso de grandes superfícies de vidro do edifício fez com que ele passasse a ser conhecido como "The Crystal Palace". ${ }^{92}$

Essa estrutura, apesar de ser mais segura contra incêndios, não era resistente o bastante para suportar o peso e a vibração de máquinas para a fabricação de motores, dedicando-se, portanto, à carroceria. No edifício principal, eram realizadas operações de montagem e de pintura, bem como outras tarefas leves. De acordo com uma avaliação do setor de engenharia, anos depois:

90 Tradução da autora: "Eu quero tudo sob o mesmo teto. Se você puder projetar como eu quero, diga e faça “ LEWIS, D. L. Ford and Kahn. In: Michigan History, n. 64, set/out, 1980, p. 17.

91 A Woodward Avenue é uma das cinco principais avenidas de Detroit, juntamente com as avenidas Michigan, Grand River, Gratiot e Jefferson. Chamada de Detroit's Main Street (rua principal de Detroit), liga a cidade de Detroit à região metropolitana. Disponível em: <https://en.wikipedia.org/wiki/M-1_(Michigan_highway)> Acesso: 25 jun. 2018.

92 A fábrica ficou conhecida como The Crystal Palace em referência ao famoso salão de vidro de Londres, construído por Joseph Paxton para a Grande Exposição ocorrida em 1851. Ver: BIGGS, L. B. Industry's master machine: factory planning and design in the age of mass production, 1900 to 1930. Tese (Ph.D in Urban Studies and Planning). Massachusetts Institute of Technology: Cambridge, 1987, p. 102. 

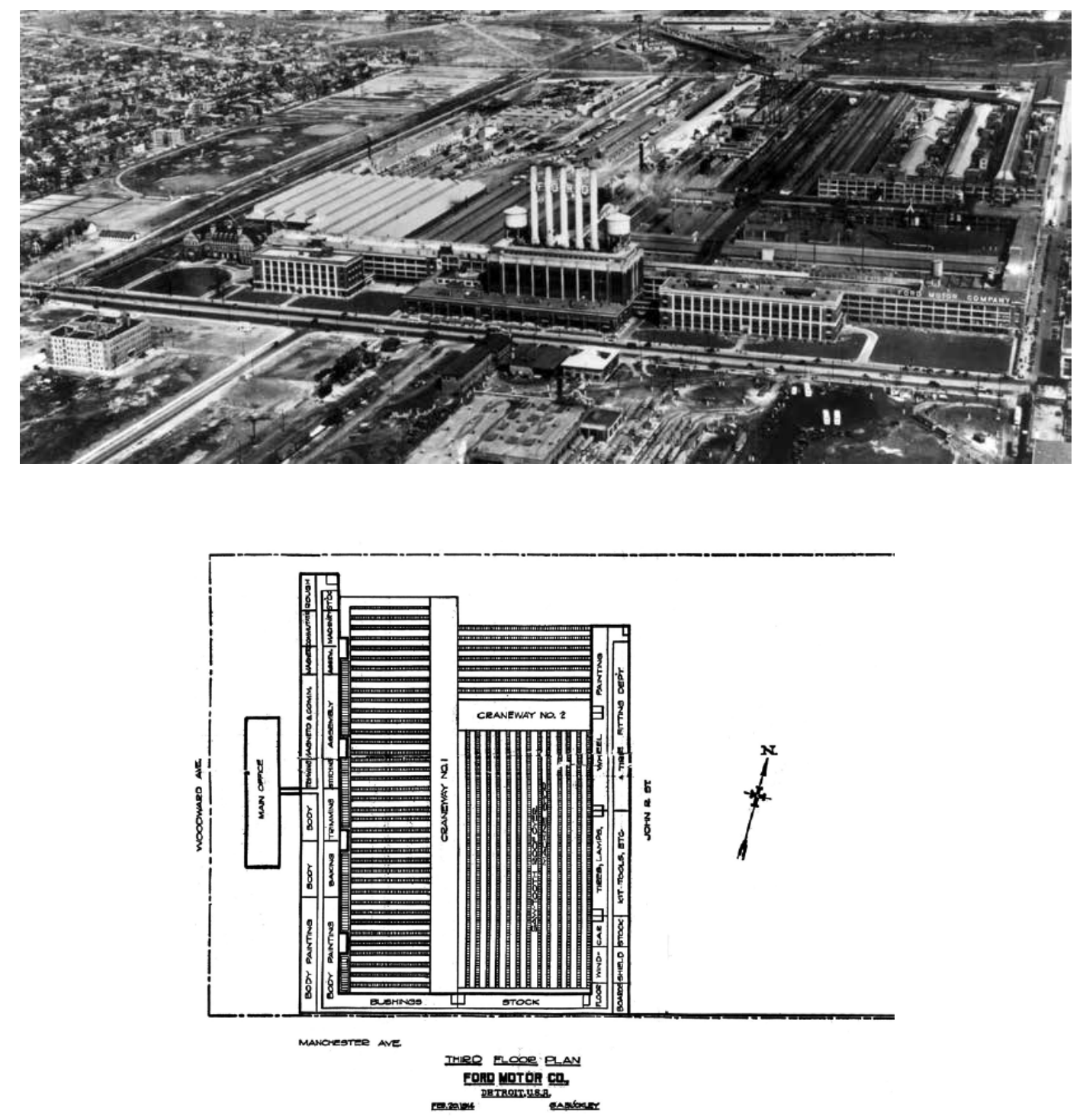

Fig. 40 Vista aérea da fábrica Ford Highland Park, Detroit, Michigan. Fonte: Albert Kahn Associates Records, Bentley Library, University of Michigan.

Fig. 41 Planta baixa esquemática da fábrica Ford Highland Park Old Shop. Fonte: Pancorbo (2014) 


\begin{abstract}
"The construction of the main factory building was inadequate for heavy manufacturing because of capacity of only about fifty pounds per square foot, a load limit suitable only for assembly and storage. After 1910, Model T production expanded so rapidly that, according to two of the plant's engineers, the company added new buildings as fast as it could." ${ }^{93}$
\end{abstract}

Para ampliar a área de operações de montagem, dois edifícios de quatro andares cada foram adicionados ao edifício principal, formando um espaço central quadrado. Situada nesse espaço central, uma grande oficina de máquinas funcionava como o coração da fábrica, responsável por fabricar os motores. A oficina de máquinas era iluminada, zenitalmente, por uma cobertura de vidro em formato de dentes de serra ${ }^{94}$, possibilitando, assim, a entrada de luz distribuída de maneira uniforme, sem sombras ou contrastes. Essa luz difusa era a mais adequada para o trabalho preciso dos operários.

No entanto, a imponente imagem do complexo da Ford Highland Park no âmbito da avenida principal, a Woodward Avenue, acabava sendo assegurada pelo edifício administrativo e o edifício dos geradores, os quais se destacavam do resto dos edifícios integrantes do complexo. A situação desses dois prédios em frente à fachada principal fala claramente acerca da intenção de Henry Ford de relacionar o complexo fabril com o ambiente suburbano existente, ambiente este que logo alcançaria a categoria de urbano.

Banham se refere à fachada de Highland Park sobre a Woodward Avenue como uma rendição ao estilo tradicional de Detroit. ${ }^{95}$ Os dois edifícios se sobrepunham à estrutura reticulada da linguagem do concreto armado presente no edifício de fabricação, que estava logo atrás. No edifício administrativo, localizavamse os escritórios, entre os quais o do próprio Henry Ford, que optou por separar as áreas administrativas das áreas produtivas. A separação física estabelecida entre a administração e a produção marcou o início de uma nova era na gestão da Ford Motor Company.

\footnotetext{
93 Tradução da autora: "A construção do edifício principal da fábrica era inadequada para a fabricação pesada por causa da capacidade de apenas cerca de cinquenta libras por pé quadrado, um limite de carga adequado apenas para montagem e armazenamento. Depois de 1910, a produção do Modelo T expandiu-se tão rapidamente que, de acordo com dois dos engenheiros da fábrica, a empresa acrescentou novos edifícios o mais rápido que conseguiu.” Disponível em: BIGGS, L. B. Industry's master machine: factory planning and design in the age of mass production, 1900 to 1930. Tese (Ph.D in Urban Studies and Planning). Massachusetts Institute of Technology: Cambridge, 1987, p.109.

94 Uma invenção inglesa, a cobertura dente da serra recebeu esse nome por causa do seu perfil irregular, que se assemelhava ao perfil de uma serra. Ver: BIGGS, L. B. The rational factory. Baltimore: The John Hopkins University Press, 1996, p. $102-103$. 95 BANHAM, R. A Concrete Atlantis. Cambridge: MIT Press, 1986, p. 85.
} 
O edifício dos geradores tornou-se a face pública da companhia, pois abrigava o nome da Ford. Suas cinco enormes chaminés mostravam a logomarca com o nome da empresa, sendo três delas desnecessárias, exceto para esse fim. ${ }^{96}$ Os grandes geradores mostravam-se para o exterior, uma vez que o edifício que os abrigava também era envidraçado. Ford tinha muito orgulho da central de energia, queria que fosse visível e insistia em mantê-la impecável. Como afirma Biggs, "he [Ford] believed that the public was as fascinated with the huge generators as he was, and he had the building walled in plate glass" ${ }^{\prime 97}$ Ford acreditava que o edifício servia como uma grande propaganda sobre o poder e sobre a modernidade da empresa. O papel da central de energia como atração turística da empresa também era facilitado pela proximidade do edifício em relação à calçada - o prédio era acessível aos pedestres, os quais podiam admirar os geradores quando passavam pelo local.

Highland Park Old Shop é, portanto, um conjunto de edifícios concebidos como um fim em si mesmo, atento às escalas do lugar físico em que está localizado e às suas relações com o espaço público e com o espectador externo, possuindo ainda objetivos inegáveis de natureza propagandística voltados para o seu entorno. Além disso, cumpria os requisitos funcionais básicos para a sua finalidade, tais como uma melhor iluminação e ventilação dos espaços de trabalho, maior resistência a cargas e maior segurança contra incêndios.

Apesar disso, a importância da fábrica Highland Park vai além do uso de concreto armado e grandes quantidades de vidro. Dentro do projeto de complexos industriais, a Old Shop constituiu-se como a primeira demonstração da supremacia do transporte de materiais sobre as próprias atividades produtivas. Este movimento na fábrica se realizava de forma descendente: partindo do armazenamento de materiais nos pavimentos superiores, as peças eram transportadas, verticalmente, aos pavimentos inferiores até chegarem ao térreo, onde a carroceria, já pronta, era montada no chassi. ${ }^{98}$ Com o corpo do automóvel finalizado, o próximo passo era a colocação do motor, cuja fabricação acontecia, de forma horizontal, na oficina de máquinas.

$\mathrm{Na}$ fábrica Ford Highland Park, as máquinas não tinham motores independentes. Elas se organizavam linearmente, conectadas a uma única fonte

96 BIGGS, L. B. Industry's master machine: factory planning and design in the age of mass production, 1900 to 1930 . Tese (Ph.D in Urban Studies and Planning). Massachusetts Institute of Technology: Cambridge, 1987, p. 103.

97 Tradução da autora: "Ele acreditava que o público estava tão fascinado com os enormes geradores quanto ele, e mantinha o prédio emparedado em vidro laminado.” Ver: BIGGS, L. B. The rational factory. Baltimore: The John Hopkins University Press, 1996, p.103.

98 Este uso da gravidade tem um importante precedente nos moinhos de grãos automáticos do americano Oliver Evans que, no final do século XVIII, conseguiu eliminar o trabalho humano e substituí-lo por máquinas totalmente automatizadas desde o momento do despejo de grãos até a coleta da farinha. A modernidade de Evans, tal como a de Ford e de Kahn, não se baseia na invenção de qualquer inovação técnica, mas no uso das técnicas existentes combinadas de uma nova maneira. Ver: BANHAM, R. A Concrete Atlantis. Cambridge: MIT Press, 1986, p. 227. 

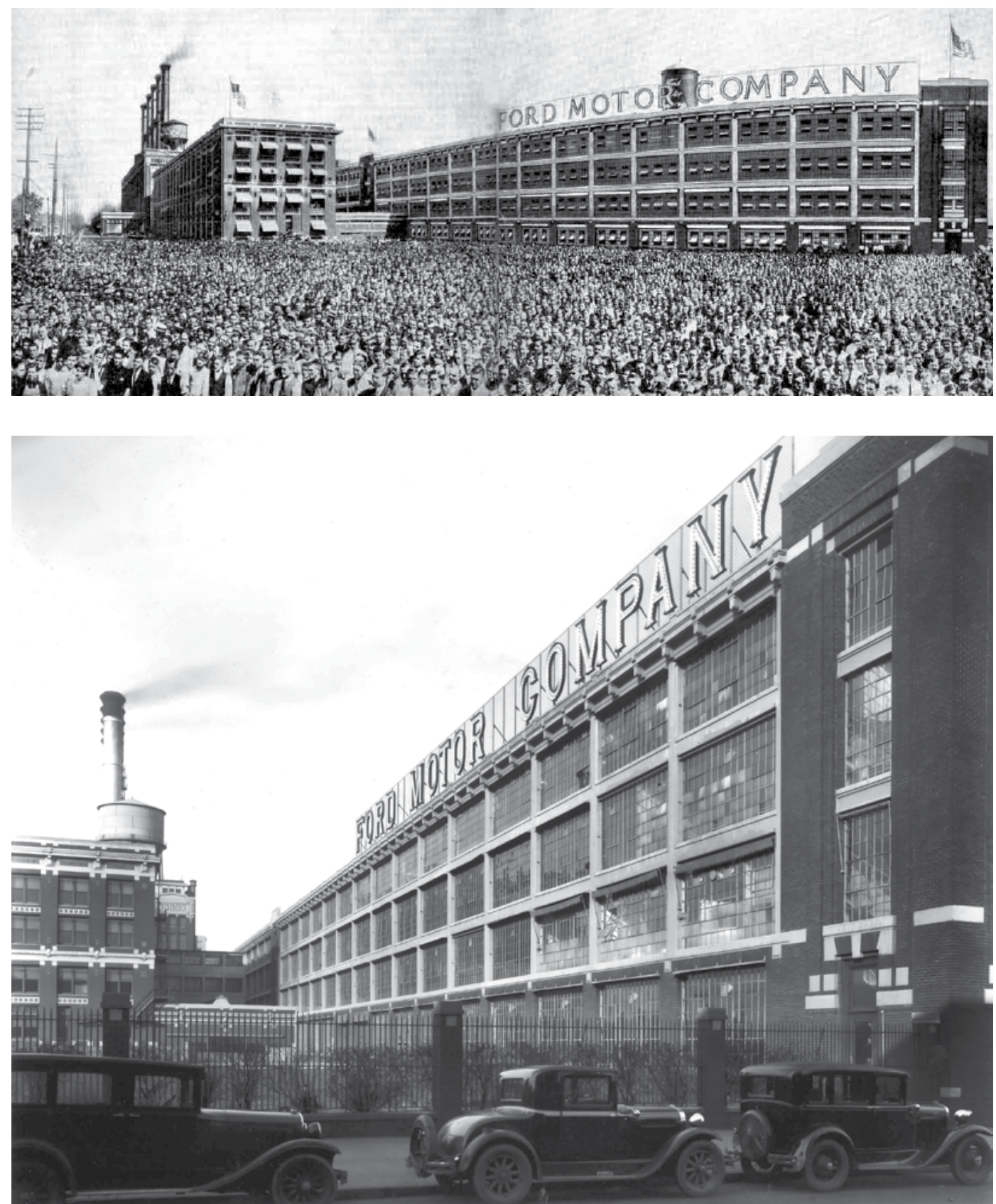

Fig. 42 Vista geral da fábrica Ford Highland Park Old Shop. Fonte: Pancorbo (2014)

Fig. 43 Exterior do edifício de montagem da fábrica Ford Highland Park Old Shop.

Fonte: Pancorbo (2016) 

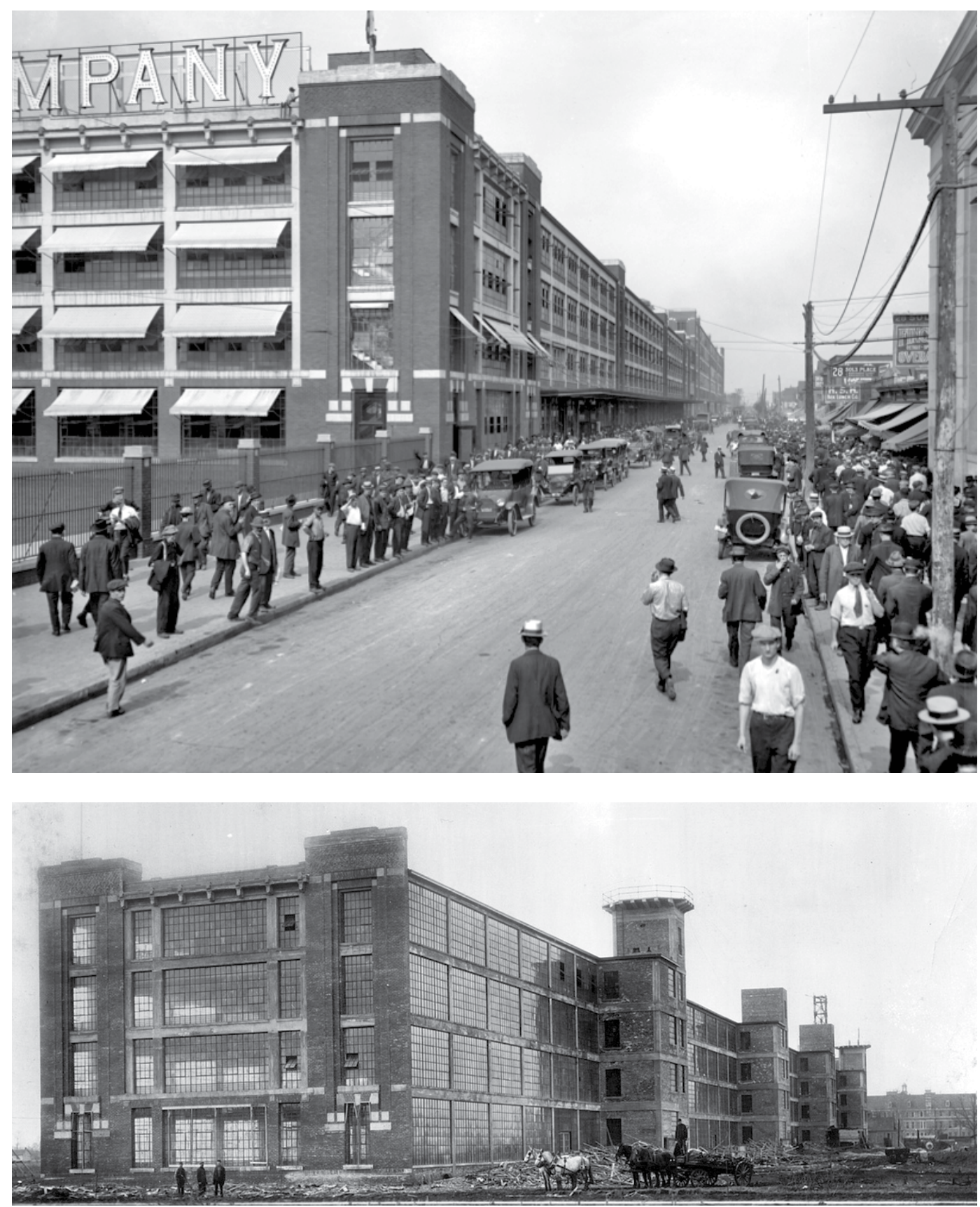

Fig. 44 Vista da fábrica Ford Highland Park desde a Manchester Street.

Fonte: <www.slideshare.net/walkerpub/albert-kahn-the-20th-centurys-greatest-architect> Acesso 28 mai 2018

Fig. 45 Vista da fachada dos fundos do edifício de montagem da fábrica Ford Highland Park Old Shop, ainda em construção. Fonte: <https://modeltfordfix.com/fords-highland-park-manufacturing-plant/> Acesso 28 mai 2018. 

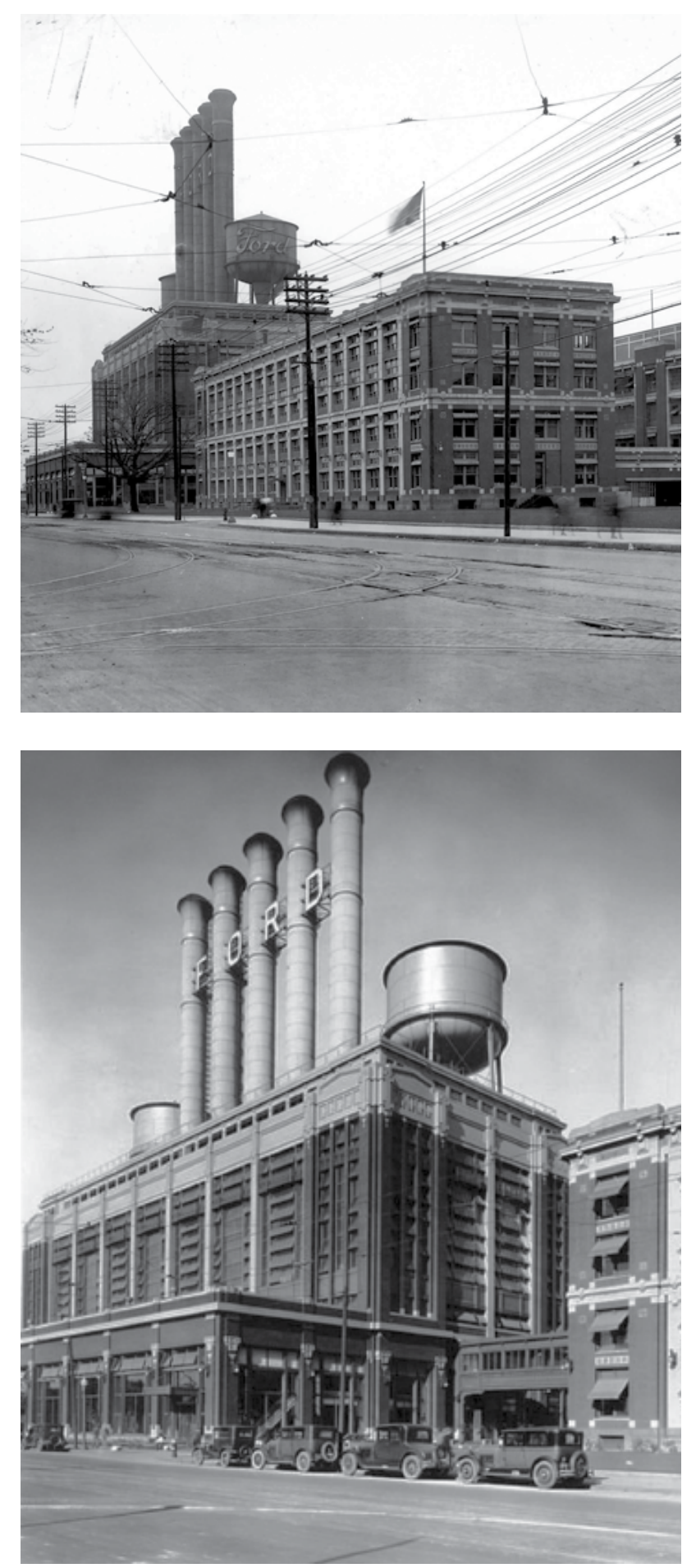

Fig. 46 Vista do edifício da administração e dos edifícios de geradores da fábrica Ford Highland Park Old Shop, a partir da Woodward Avenue.

Fonte: Albert Kahn Associates Records, Bentley Library, University of Michigan.

Fig. 47 Edifício de geradores da fábrica Ford Highland Park Old Shop. Fonte: Pancorbo (2014) 
de energia. Um eixo giratório, suspenso no teto, era responsável por acioná-las através de correias de tração. A ideia de usar a gravidade no processo foi uma situação complexa, obrigando a realização de inúmeros furos na laje de concreto a fim de transportar peças semi-montadas de um pavimento para o outro. As esteiras transportadoras só eram capazes de atender pequenas distâncias e deslocar elementos de tamanho médio. As peças pequenas eram movidas de maneira manual ou por meio de plataformas inclinadas e funis. Para resolver o movimento das grandes peças, existiam duas pontes rolantes localizadas na oficina de máquinas e, no pavimento térreo, um monotrilho suspenso atravessava vários edifícios da fábrica.

O espaço entre as máquinas foi reduzido ao mínimo necessário para que o operador pudesse realizar somente os movimentos mecânicos imprescindíveis. A parte superior do espaço estava completamente ocupada pelos elementos de transporte de materiais e pelo amontoado de correias que uniam cada máquina ao eixo central.

Nas plantas baixas do projeto, pode-se notar a distribuição do programa em detalhes, permitindo ver o sentido dos processos abrigados e a sua correspondência com cada espaço do edifício. Esta complexidade operativa conduzia a uma intrincada gestão do espaço de trabalho dos pavimentos e da respectiva relação entre eles, gerando uma enorme densidade de atividades e de equipamentos por metro quadrado de área útil. De fato, quanto maior a densidade, maior a produção da fábrica e, consequentemente, maior o número de trabalhadores e tarefas a cada andar de produção. Entre outros fatores, essa densidade tornou-se possível especialmente graças às boas condições de iluminação e de ventilação dos espaços.

A diferença mais significativa entre a Highland Park Old Shop e outras fábricas foi a organização das edificações, refletindo ideias então arrojadas sobre a produção. Com exceção daquele pertencente à administração, o prédio dos geradores e mais duas instalações de processamento (tratamento térmico e fundição), os edifícios da fábrica compartilhavam paredes comuns, transformando a nova estrutura em um grande conjunto integrado. Esta continuidade significou que, à medida que o modelo $\mathrm{T}$ era construído, partes e subconjuntos moviam-se a 

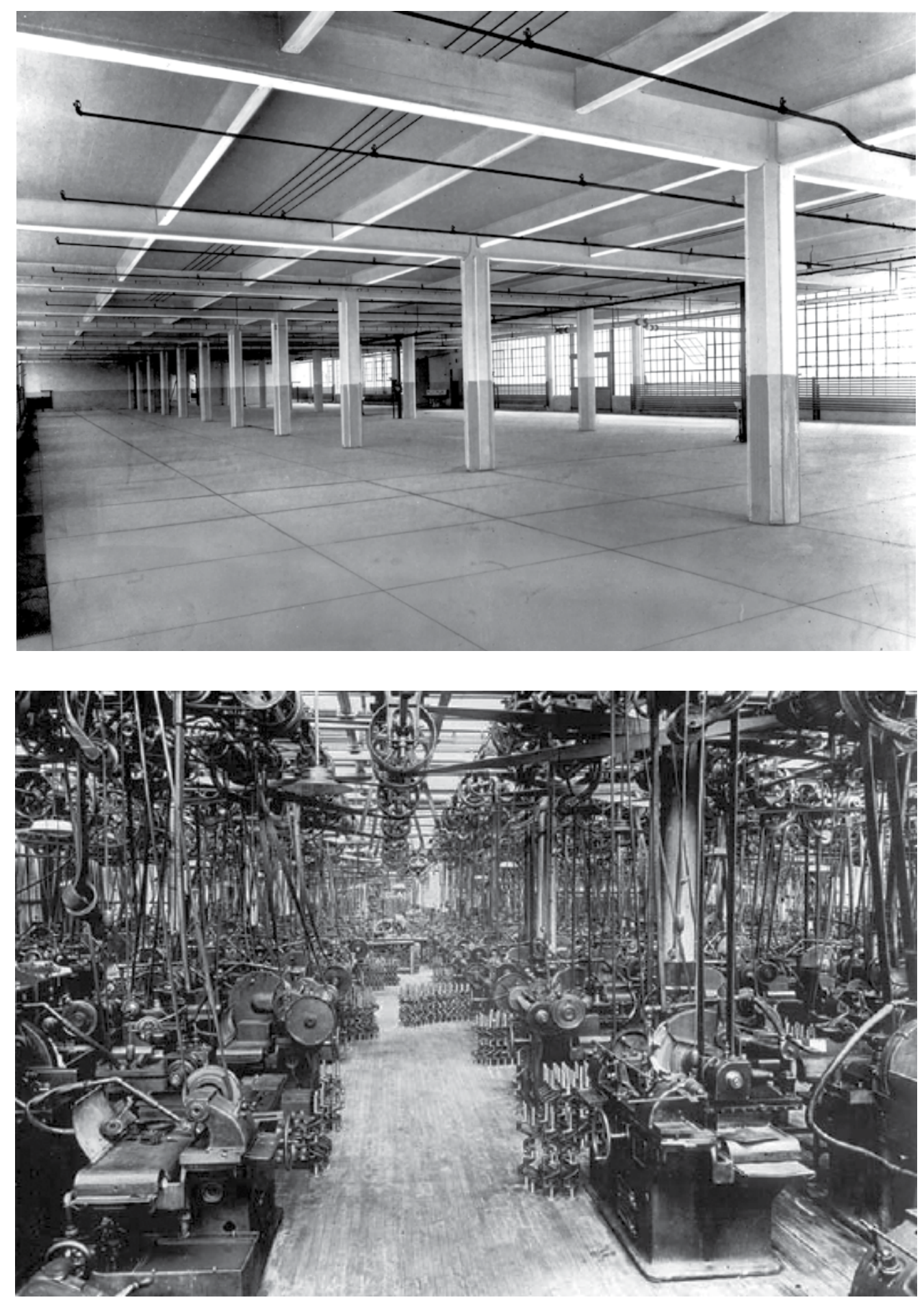

Fig. 48 Interior do edifício de montagem da fábrica Ford Highland Park Old Shop. Fonte: Albert Kahn Associates Records, Bentley Library, University of Michigan.

Fig. 49 Vista da linha de montagem do interior da fábrica Ford Highland Park Old Shop. Fonte: Pancorbo (2014) 
distâncias mais curtas, acarretando um fluxo de materiais mais rápido e economias consideráveis de tempo e de mão de obra. Poucas fábricas, antes ou depois de Highland Park, foram construídas em uma formação tão compacta. ${ }^{99}$

Tanto em seu projeto quanto na arquitetura resultante, a fábrica estava ainda muito longe das características de uma fábrica racional moderna. Mesmo com todas as inovações revolucionárias que ocorreram no seu interior, a Old Shop permaneceu, fundamentalmente, uma fábrica tradicional. ${ }^{100} \mathrm{Na}$ parte técnica, superava a continuidade tipológica de uma tradição industrial, mas não a substituía. Era a culminação da evolução da daylight factory e do vernáculo industrial americano e, por esse motivo, foi considerada - pelas publicações europeias da época - como uma arquitetura coletiva, sem autor.

Após 1910, a produção do Modelo T expandiu-se tão rapidamente que a Ford Motor Company necessitou pensar na ampliação do complexo. Sua estrutura repetitiva permitia a expansão em qualquer direção, mas o sistema produtivo só podia replicar seus próprios módulos. A obsolescência do edifício foi resultado justamente do caráter de projeto baseado na tipologia, que impediu sua adaptação à constante evolução dos processos que precisava abrigar.

\subsubsection{Highland Park New Shop: a máquina automática}

Para resolver a obsolescência da Old Shop, em 1913, Albert Kahn e os engenheiros da Ford planejaram a construção de uma nova instalação. Kahn teve a oportunidade de repensar e construir o edifício na propriedade adjacente à antiga fábrica. A Old Shop tinha sido projetada para atender a requisitos genéricos para melhor aproveitamento do espaço, sem descuidar da geração e distribuição de energia para as máquinas. Alcançados esses objetivos, a fábrica pretendida deveria se preocupar com o movimento contínuo da produção, fundamental para o avanço do recém-introduzido sistema de linha de montagem móvel da Ford Motor Company. Para distinguir entre os edifícios novos e antigos do complexo fabril da Ford Highland Park, os funcionários da Ford passaram a chamá-los de Old Shop,

99 A maioria das grandes fábricas anteriores à década de 1920 foi construída com pátios quadrados ou em configurações H, L ou E. Essas formas permitiam que a luz natural penetrasse nos vários andares da fábrica. Ao invés de deixar o espaço habitual entre os edifícios, a Ford Motor Company cobriu esses espaços com vidro, utilizando-os como espaço de trabalho. Ver: BIGGS, L. B. The rational factory. Baltimore: The John Hopkins University Press, 1996, p.109.

${ }^{100}$ PANCORBO, L; MARTÍN ROBLES, I. Anestética de la desaparición. La sección como definidora del proyecto en la arquitectura de Albert Kahn. In: ZARCH n. 2. Rethinking/Remaking. Journal of interdisciplinary studies in Architecture and Urbanism, p. 121. 
referindo-se à antiga fábrica do terreno, e New Shop, quando mencionavam a fábrica recém-construída.

O edifício fabril, a partir desse momento, não seria mais um envoltório dos processos produtivos, máquinas e operários, mas, junto com eles, formaria uma grande máquina. A configuração dessa nova fábrica deixaria de ser imposta somente pelo aspecto exterior, mas corresponderia ao funcionamento global das suas partes internas. Considerada uma das primeiras fábricas racionais, a New Shop operou sob a restrição do uso de máquinas que funcionavam em grupo devido à ausência de maquinário com fornecimento independente de energia elétrica. Além disso, como um remanescente dos projetos anteriores de fábrica, o fluxo produtivo permaneceu linear.

Esta linearidade do fluxo de produção foi transmitida aos edifícios recémconstruídos, que eram compridos e estreitos - cada um tinha 62 pés $(18,90 \mathrm{~m})$ de largura e 842 pés $(256,64 \mathrm{~m})$ de comprimento. Finalizados em 1914, os novos edifícios se mimetizavam externamente com a fábrica anterior, já que foram construídos também com estrutura em concreto armado e fechamento em tijolos e vidro. Embora ambos mantivessem as proporções das fábricas tradicionais, as inovações tecnológicas e gerenciais internas contrapunham-se a esse formato convencional.

As deficiências estruturais encontradas na Old Shop foram corrigidas. A estrutura de concreto armado permitiu melhorias significativas, tais como o uso de lajes planas de concreto armado apoiada em pilares com capitéis de reforço em forma de cogumelo, garantindo assim maior resistência estrutural.

A organização da fábrica também foi modificada em relação à Old Shop, conseguindo-se um processo produtivo totalmente acionado pela gravidade. A oficina de máquinas passou a se localizar no último andar, que era o pavimento mais iluminado. Isto somente foi possível devido a maior resistência à sobrecarga e vibração da estrutura de concreto, e também porque os guindastes suportavam mais cargas, sendo capazes de elevar com facilidade os materiais pesados até o sexto e último andar.

Construídos paralelamente um ao lado do outro, os edifícios eram unidos 
por uma ponte rolante de seis andares que percorria todo o seu comprimento de 842 pés $(256,64 \mathrm{~m})$. Esse pátio coberto era o espaço mais importante da fábrica, pois possibilitava a movimentação dos materiais necessários ao correto funcionamento do conjunto. Coberto por vidro, nele se localizava os trilhos do trem onde ocorria a carga e descarga de materiais. Por causa dos trens, o pavimento térreo tinha pédireito maior. A ponte rolante movia tudo na fábrica, literalmente, convertendo o espaço vazio de seis pavimentos de altura em um espaço-movimento, no qual cada coordenada espacial era possível de ser ocupada em algum instante por um material transportado.

As fachadas internas, localizadas neste espaço central, possibilitavam uma continuidade visual e funcional entre os pavimentos da fábrica. Elas refletiam uma ordem de estrutura mais essencial, possuindo quase duzentas plataformas em balanço, utilizadas para coletar os materiais. Dois guindastes de cinco toneladas movimentavam-se ao longo das pontes rolantes, elevando os materiais do andar térreo e colocando-os nas plataformas em balanço, distribuídas nos seis andares. ${ }^{101}$ Ferry compara as varandas com as da residência estudantil da Bauhaus de Dessau, projeto de $1926 .{ }^{102}$ Pela existência de tantas plataformas, nenhuma estação de trabalho ficava muito distante das matérias-primas recebidas. Essa proximidade reduziu significativamente a movimentação em torno da fábrica. Embora restringida pelo fornecimento de energia, a nova organização da fábrica conseguiu melhorar a movimentação de materiais no seu interior. Assim como já havia acontecido na Old Shop, as máquinas foram posicionadas o mais próximo possível, reduzindo ao máximo o transporte de material entre elas. No entanto, as demandas para a redução de tempo da linha de montagem exigiram mais do que somente uma boa organização. $\mathrm{O}$ manuseio mecanizado de materiais - considerado a principal inovação tecnológica na nova fábrica - representou uma enorme contribuição para o desenvolvimento da fábrica racional. Ele acabou se tornando a chave para garantir que a produção em massa funcionasse, antecipando o futuro da indústria automotiva.

Uma grande parte do manuseio de materiais na Old Shop era manual, ou seja, eram os trabalhadores quem moviam partes, peças e matérias-primas pela

101 BIGGS, L. B. The rational factory. Baltimore: The John Hopkins University Press, 1996, p.123. 102 FERRY, H. Legacy of Albert Kahn. Detroit: The Detroit Institute of Arts,1970, p. 12-13. 


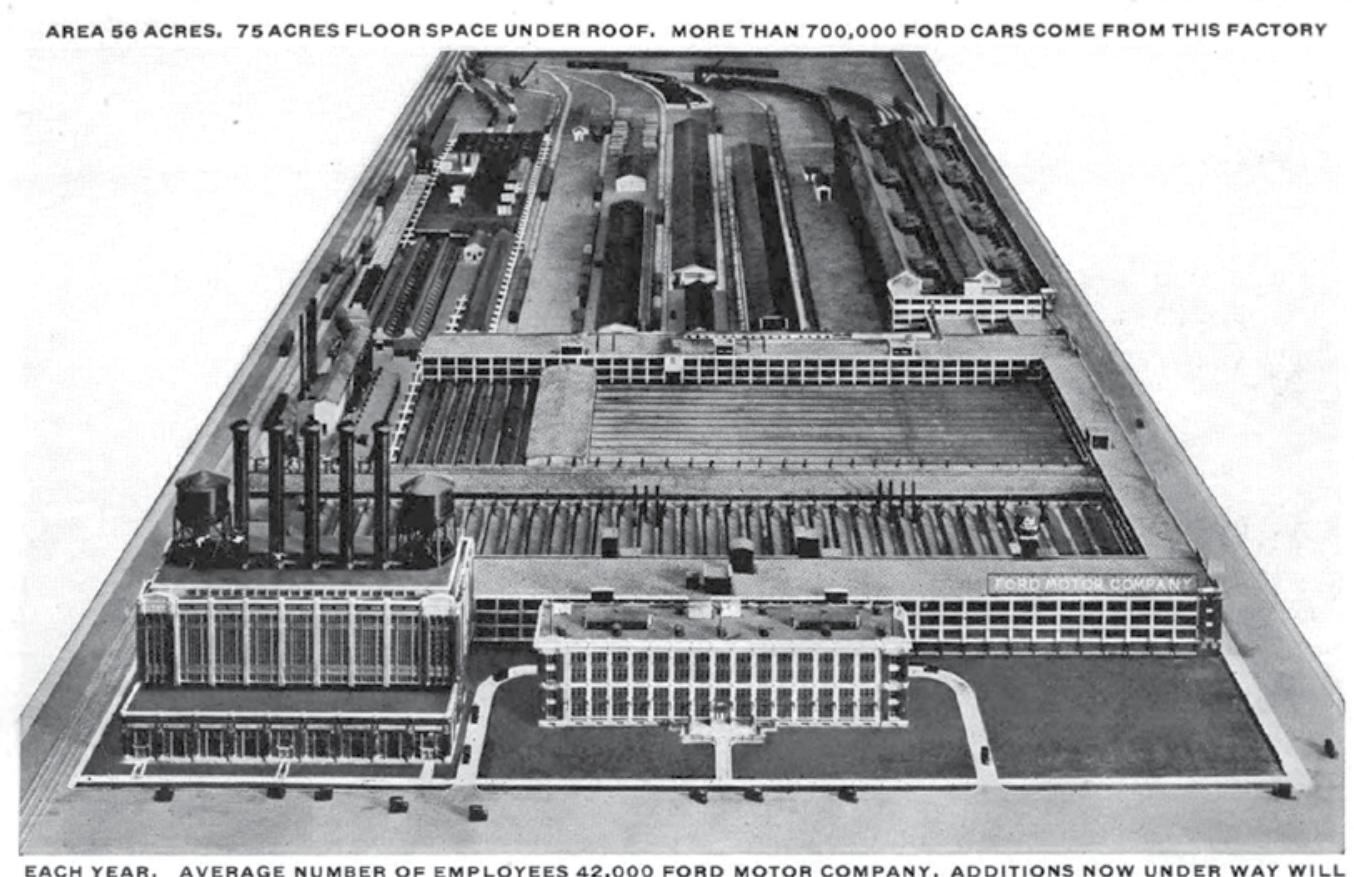

EACH YEAR. AVERAGE NUMBER OF EMPLOYEES 42,000 FORD MOTOR COMPANY. ADDITIONS NOW UNDER WAY WILL DOUBLE THE CAPACITY OF THE PLANT.

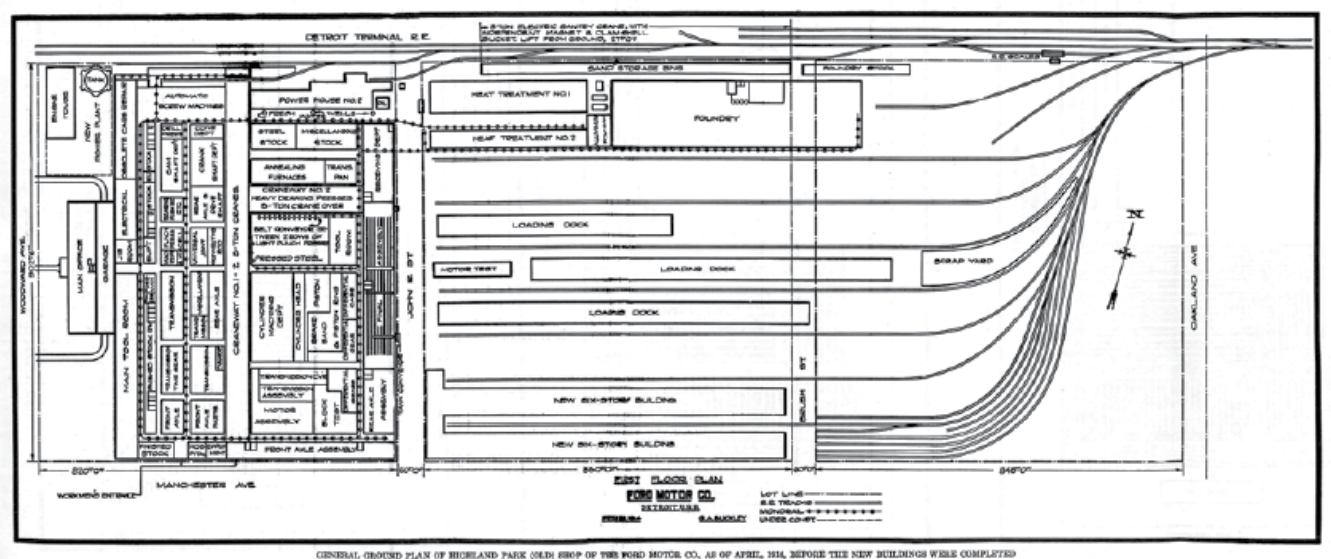

Fig. 50 Vista aérea da Fábrica Ford Highland Park.

Fonte:<https://interactive.wttw.com/sites/default/files/styles/tenbuildings_hero/public/tenbuildings/TB503ss.jpg> Acesso 28 mai 2018.

Fig. 51 Planta de implantação da Fábrica Ford de Highland Park.

Fonte: Pancorbo (2014) 

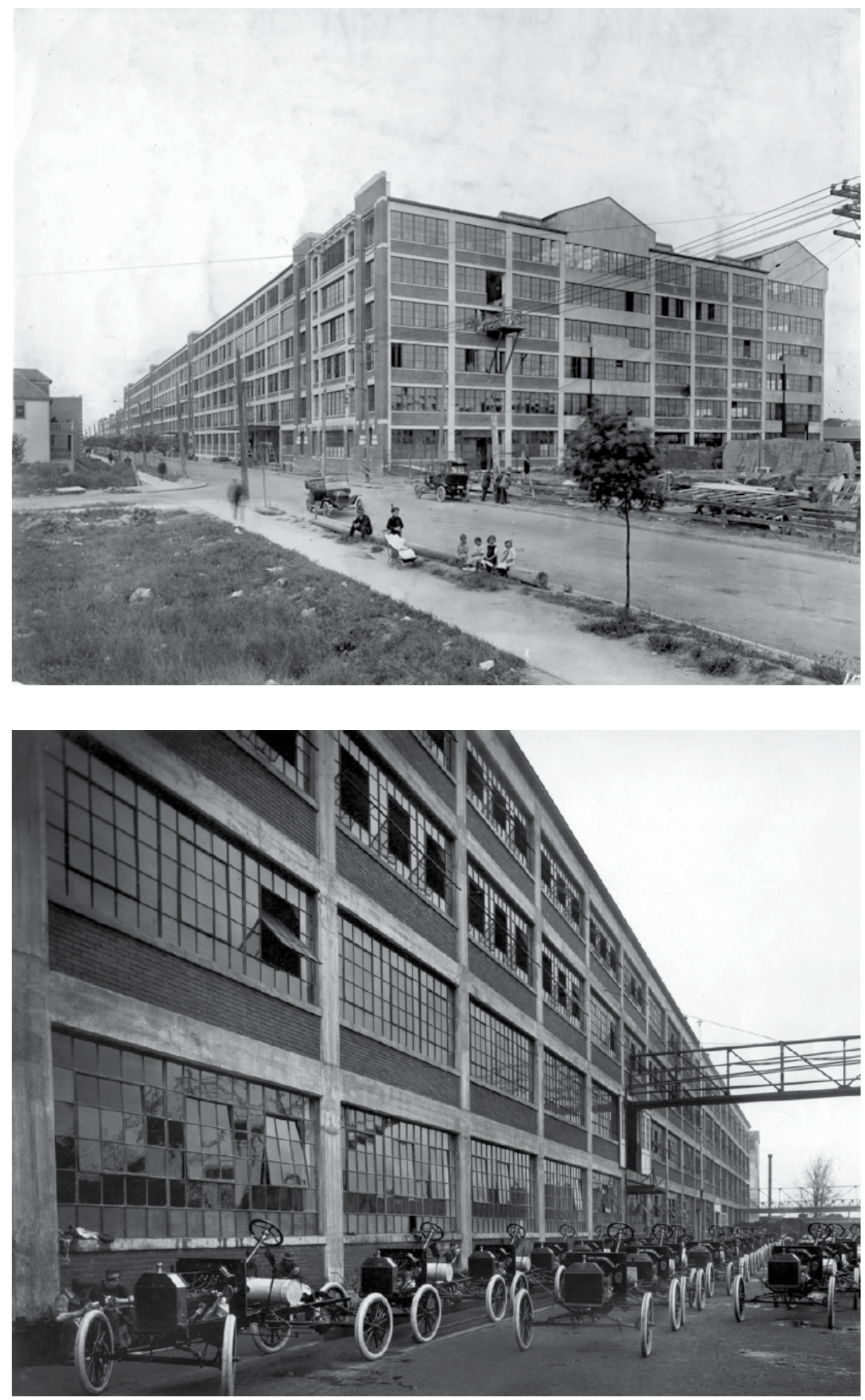

Fig. 52 Edifício de montagem da fábrica Ford Highland Park New Shop. Fonte: Albert Kahn Associates Records, Bentley Library, University of Michigan.

Fig. 53 Vista externa do edifício de montagem da fábrica Ford Highland Park New Shop (1924). Fonte: Rasner (2013) 


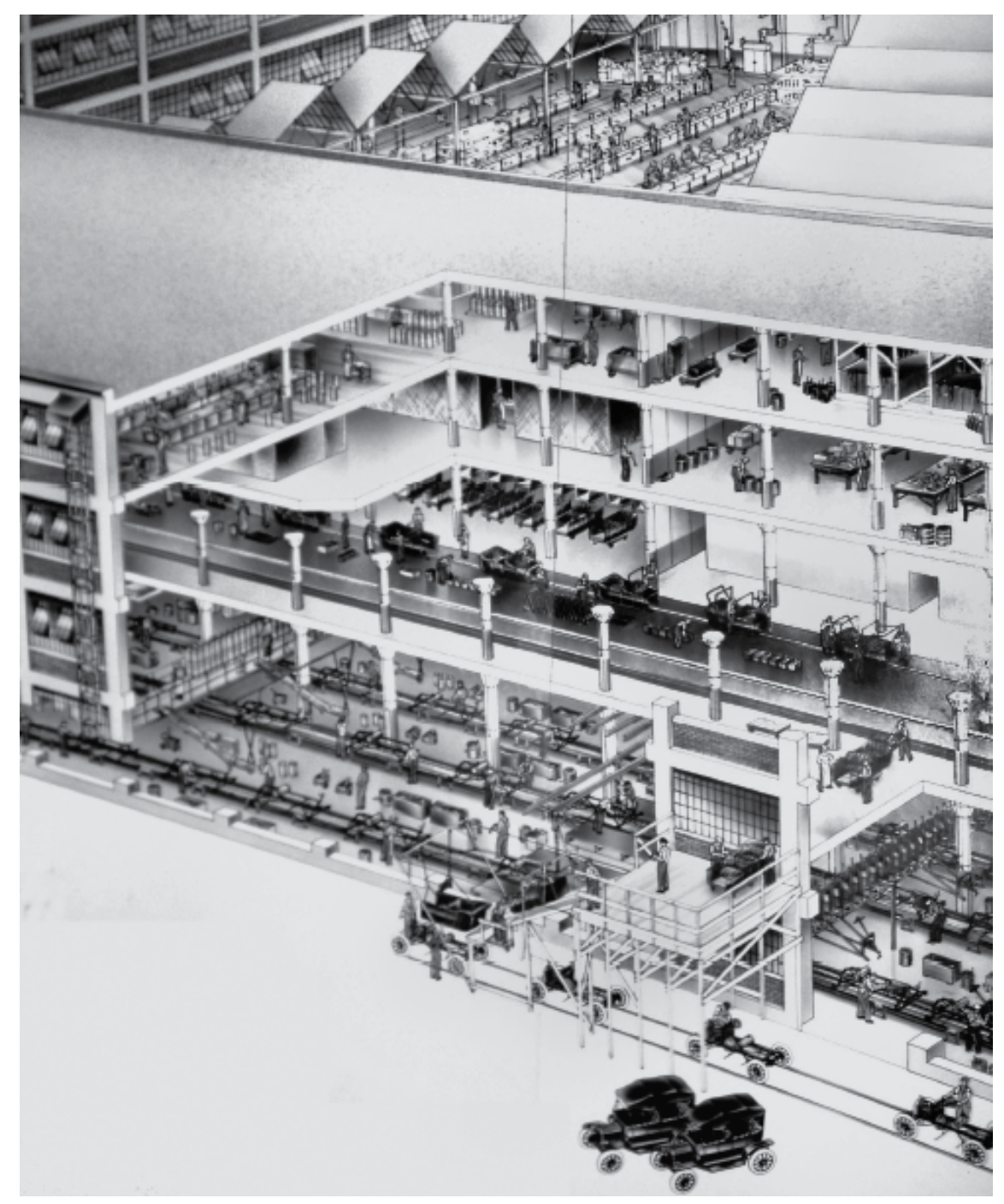

Fig. 54 Esquema tridimensional da linha de montagem da fábrica Ford Highland Park New Shop Fonte: Ravara (2008) 

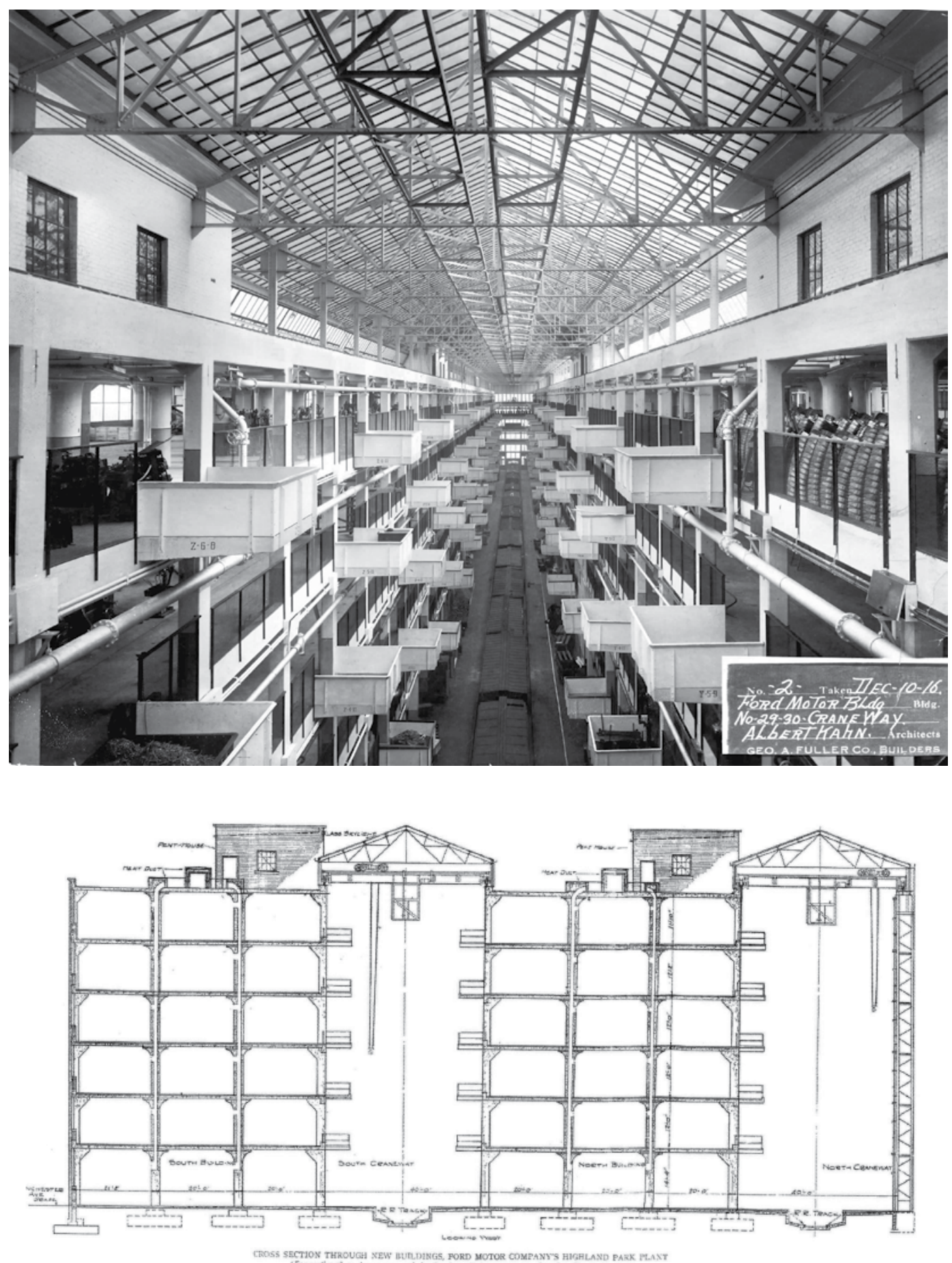

Fig. 55 Vista do pátio da fábrica Ford Highland Park New Shop. Fonte: Albert Kahn Associates Records, Bentley Library, University of Michigan.

Fig. 56 Corte transversal da fábrica Ford de Highland Park New Shop. Fonte: Pancorbo (2014) 

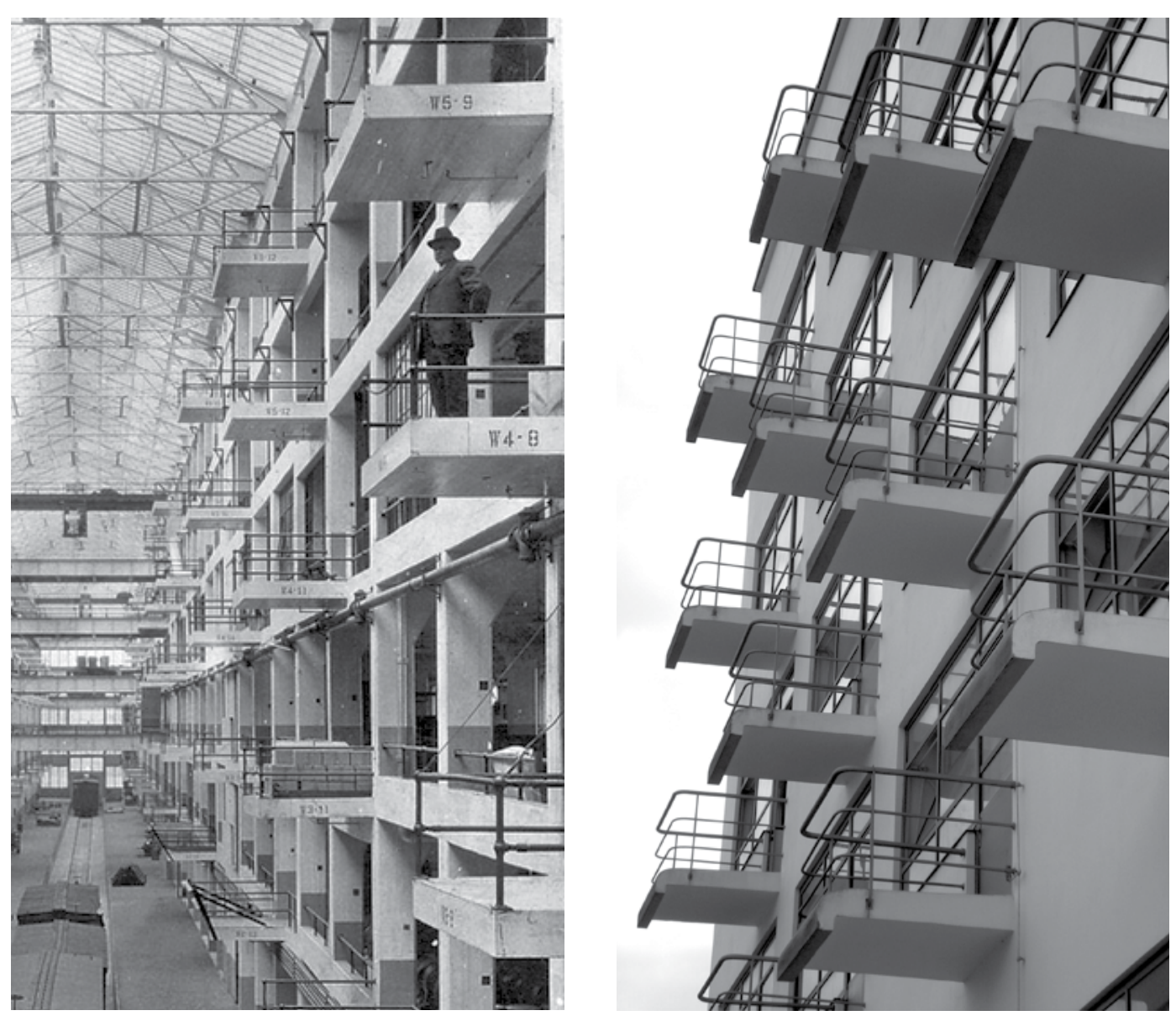

Fig. 57 Vista do pátio da fábrica Ford Highland Park New Shop. Fonte: Pancorbo (2014)

Fig. 58 Sacada do alojamento estudantil do edifício da Bauhaus, em Dessau. Projeto de Walter Gropius (1926)

Fonte: <www.flickr.com/photos/angeladk/5006407304> Acesso 15 jan 2019. 
fábrica. Isto criava vários problemas para a produção em larga escala, pois o manuseio manual era lento e imprevisível. Por depender dos operários ao invés das máquinas, o movimento não era tão fácil de controlar. No sistema então desenvolvido na New Shop, a movimentação de materiais em torno da fábrica não precisava mais ser realizada pelos operários, pois o manuseio mecânico poderia fazer o trabalho de forma mais rápida e com maior previsibilidade.

A linha de montagem móvel foi um passo decisivo para o fordismo, e a inovação tornou-se a base do complexo sistema de manuseio de materiais, algo que melhorou enormemente a velocidade e a confiabilidade da produção. Embora alguns manuseios manuais tivessem permanecido na New Shop, a maioria das movimentações passou a ser mecanizada. $\mathrm{O}$ arranjo produtivo, uma preocupação constante para a empresa, continuou importante para o seu crescimento. Os engenheiros da Ford sabiam que o alto custo de fabricação se devia à maneira aleatória com que as máquinas e materiais estavam distribuídos pela fábrica, e o desafio de como resolver esse dilema levou tais engenheiros a inventarem novos métodos de transporte interno. ${ }^{103}$

O projeto da fábrica teve grande importância para a eficácia do manuseio de materiais na New Shop, pois a organização do edifício e a adição de guindastes reduziram drasticamente as necessidades de manuseio manual de materiais. Sem o projeto do edifício, é possível que o sistema de produção então desenvolvido tivesse sucesso apenas parcial. Em seu livro, Ford declarou a importância de um projeto adequado da fábrica para tornar a produção mais rápida e eficiente:

\footnotetext{
"One point that is absolutely essential to high capacity, as well as to humane production, is a clean, well-lighted and well-ventilated factory. Our machines are placed very close together - every foot of floor space in the factory carries, of course, the same overhead charge. [...] We measure on each job the exact amount of room that a man needs; he must not be cramped - that would be waste. But if he and his machine occupy more space than is required, that also is waste. This brings our machines closer together than in probably any other factory in the world." ${ }^{104}$
}

103 BIGGS, L. B. Industry's master machine: factory planning and design in the age of mass production, 1900 to 1930. Tese (Ph.D in Urban Studies and Planning). Massachusetts Institute of Technology: Cambridge, 1987, p.119.

104 Tradução da autora: "Um ponto que é absolutamente essencial para a alta capacidade, bem como para a produção humana, é uma fábrica limpa, bem iluminada e bem ventilada. Nossas máquinas são posicionadas muito próximas - cada metro do espaço da fábrica influencia, é claro, o mesmo custo geral... Medimos em cada trabalho a quantidade exata de espaço que um homem precisa, ele não deve ser apertado - isso seria um desperdício. Mas, se ele e sua máquina ocuparem mais espaço do que o necessário, também é um desperdício. Isso faz com que as nossas máquinas estejam mais próximas do que provavelmente qualquer outra fábrica do mundo." Ver: FORD, Henry. My life and work. New York: Doubleday, Page \& Company, 1922, p.78. 
A produção na New Shop começou tão logo terminou a construção dos novos edifícios em concreto armado. Em comparação com a estrutura da Old Shop, o arranjo adotado era muito mais moderno e eficiente. Prova disso é a integração da linha de trem - meio de transporte cada vez mais essencial para a indústria norteamericana da época - no interior dos edifícios da New Shop. Os trilhos de trem adentravam a fábrica, abaixo das pontes rolantes, permitindo que a descarga de materiais acontecesse mecanicamente, direto dos vagões, algo que contribuiu muito para resolver os problemas de movimentação de materiais.

A nova fábrica não era mais um objeto acabado como a antiga, em que os desenhos do projeto mostravam elevações e plantas baixas definidas, cujos usos e programas contidos eram claramente estabelecidos e imutáveis. Optou-se por um edifício projetado em estado intermediário, com potencial para expansão linear e crescimento através do acréscimo de novos módulos. A limitação, nesse caso, era dada pelo tamanho do terreno em que a fábrica se encontrava. Enquanto a Old Shop tinha uma preocupação com a ocupação do quarteirão e com as fachadas dos edifícios, especialmente aqueles voltados para a avenida principal, a New Shop apresentava uma organização mais indiferente ao tecido urbano. Os edifícios concentravam-se somente em um quadrante do novo quarteirão do terreno, o qual era cortado pela John Street.

Aparentemente, o projeto da New Shop não foi de exclusiva responsabilidade do escritório de Albert Kahn. Ele projetou os edifícios da New Shop em estreita colaboração com Edward Gray, engenheiro-chefe da Ford Motor Company. ${ }^{105}$ Sem dúvida, existia uma estreita relação de trabalho entre os engenheiros de produção da Ford Motor Company e Albert Kahn no que diz respeito ao projeto dos edifícios da fábrica. Em certo sentido, Kahn estava projetando o envoltório para abrigar a fábrica que seu cliente desejava.

Embora a inauguração da New Shop tivesse menos repercussão do que a da Old Shop, sua conclusão significou muito para a Ford e para a indústria automobilística. Apesar dos edifícios manterem as proporções tradicionais das antigas fábricas ${ }^{106}$, as inovações tecnológicas e gerenciais no interior dos novos

105 De acordo com Charles Sorensen, braço direito de Henry Ford, Gray forneceu a Albert Kahn as dimensões gerais dos edifícios e as plantas baixas, enquanto o arquiteto seria o responsável pelo projeto e detalhes. Gray teria desenhado grande parte do novo complexo baseado nos princípios arquitetônicos da Old Shop. Ver: SORENSEN, C. E. My Forty Years with Ford. W. W. New York: Norton \& Company, 1956, p.125-126.

106 Mesmo sabendo, nesse momento, que edifícios de um único pavimento tinham menor custo de construção e maior eficiência de produção, os engenheiros da Ford optaram, na New Shop, por edifícios de seis pavimentos. Lindy Biggs sustenta que a fábrica de seis pavimentos faria sentido face às esteiras transportadoras que, por estarem nos estágios iniciais de inovação, tinham um potencial ainda incerto. Além do mais, se a fábrica Ford Highland Park estivesse espalhada em um único andar, o edifício seria extremamente extenso. As primeiras esteiras transportadoras não tinham capacidade para atingir tais distâncias. Ao mesmo tempo, os guindastes e pontes rolantes, projetados para movimento vertical, eram rápidos, eficientes e confiáveis. Ver: BIGGS, L. B. Industry's master machine: factory planning and design in the age of mass production, 1900 to 1930. Tese (Ph.D in Urban Studies and Planning). Massachusetts Institute of Technology: Cambridge, 1987, p. $174-175$. 

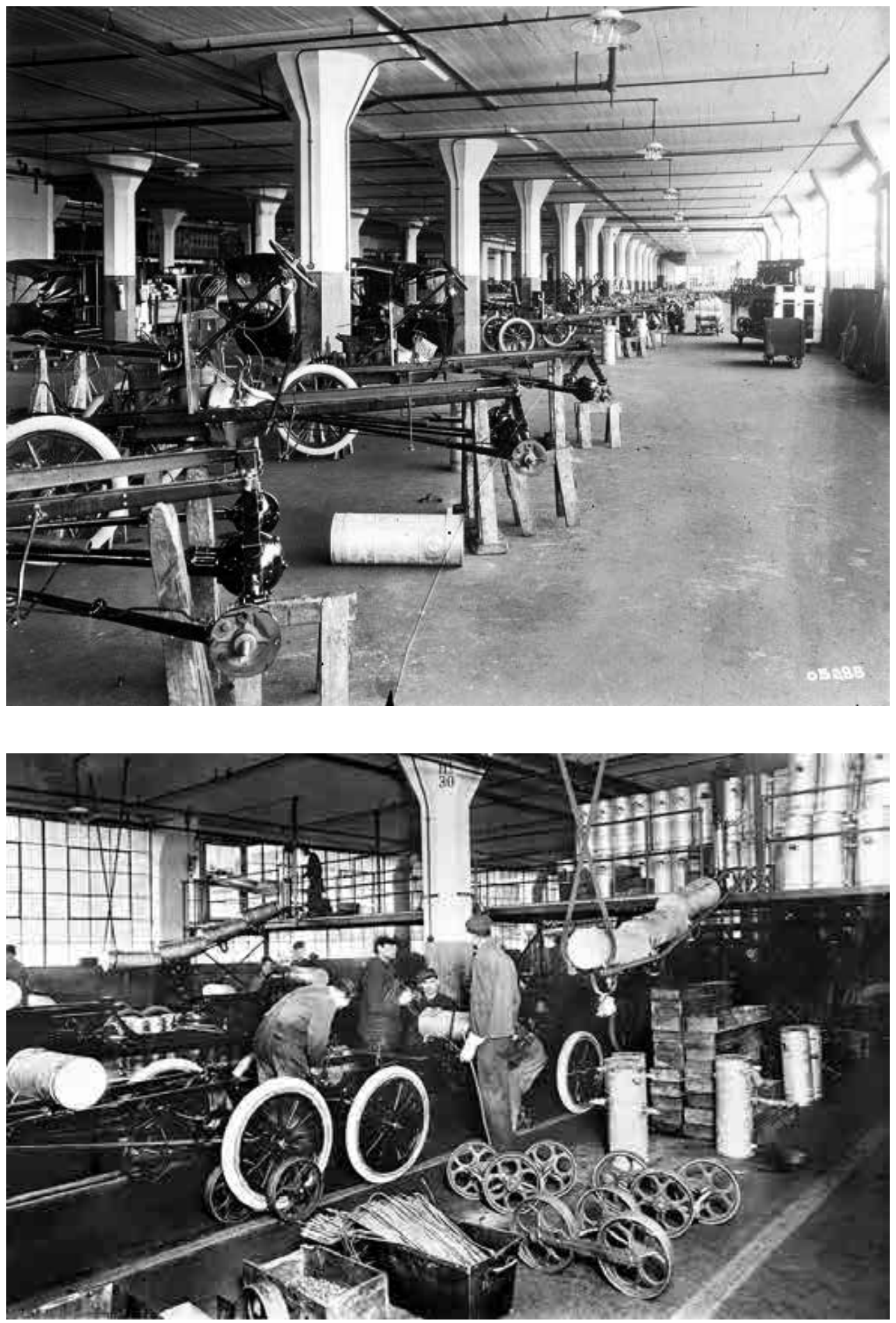

Fig. 59 Interior do edifício de montagem da fábrica Ford Highland Park Old Shop Fonte: <https://modeltfordfix.com/fords-highland-park-manufacturing-plant/> Acesso 28 mai 2018

Fig. 60 Interior do edifício de montagem da fábrica Ford Highland Park Old Shop. Fonte: <https://modeltfordfix.com/fords-highland-park-manufacturing-plant/> Acesso 28 mai 2018. 
edifícios fabris superavam a aparência mais tradicional. Com a New Shop, iniciarse-ia um vigoroso processo de transformação das fábricas, as quais passaram a ser planejadas como se fossem máquinas. A fábrica racional foi pensada para coordenar todas as atividades do edifício, de modo que cada uma fosse interligada com a próxima, atuando como as engrenagens de uma grande máquina.

A Ford Highland Park exerceu muita influência sobre os arquitetos europeus. Um caso emblemático é a fábrica da FIAT de Lingotto, em Turim, de 1916-23, considerada por Reyner Banham como “o edifício mais futurista que jamais foi construído" ${ }^{107}$. Seu projeto, estrutura e até os detalhes remetem a Ford Highland Park, mas invertendo o processo produtivo, que se tornou ascendente. O carro finalizado emergia na cobertura, onde era testado em uma pista, descendo até o térreo por rampas adicionadas posteriormente pelo próprio engenheiroarquiteto, Giacomo Mattè-Trucco. Esta pista de teste superior é uma ostentação que seria repulsiva para a ideia de modernidade preconizada por Henry Ford e por Albert Kahn. Seria rejeitada por causa do maior custo, comparado a uma cobertura convencional, além do fato de impossibilitar a expansão da fábrica. Uma simples revisão dos números da produção dá uma ideia do custo dessa decisão: na década de 1920, a Fiat Lingotto produzia duzentos carros por dia, em comparação com os três mil do seu modelo de Detroit. ${ }^{108}$ A fábrica Fiat Lingotto celebrava o carro em si, tratando-o como um produto para os acelerados tempos da era da máquina. Por sua vez, a fábrica Ford Highland Park comemorava menos o produto e mais o processo, ou seja, menos o carro e mais a própria produção em massa, enxergando esta como a chave para a modernidade.

A fábrica Ford Highland Park, hoje parcialmente demolida, foi agente da evolução e alteração substancial dos processos de fabricação e gestão do trabalho. Embora a Ford Highland Park não tenha produzido mais automóveis depois de 1927, a Ford Motor Company não abandonou o local. As instalações passaram a ser utilizadas para fabricar caminhões e tratores da Ford. Os edifícios construídos posteriormente, entre 1919 e 1926, transformaram-se em escritórios administrativos da empresa, além de pontos de vendas de automóveis, oficinas mecânicas, etc. ${ }^{109}$

Desde a década de 1960, as instalações de Highland Park estão em

107 BANHAM, R. Teoria e projeto na primeira era da máquina. São Paulo: Perspectiva, 2006., p.303. 108 PANCORBO, L.; MARTÍN ROBLES, I. Anestética de la desaparición. La sección como definidora del proyecto en la arquitectura de Albert Kahn. In: ZARCH n. 2. Rethinking/Remaking. Journal of interdisciplinary studies in Architecture and Urbanism,.p 125-126.

109 TYLER, I. R. Highland Park Ford Plant: Documentation and Redevelopment. In: APT Bulletin, v. 46, n. 2/3, 2015, p. 38 . 
declínio, e vários dos edifícios históricos remanescentes foram demolidos. Alguns edifícios do complexo fabril ainda permanecem hoje no terreno, abandonados e vandalizados. Ao mesmo tempo, o reconhecimento do significado histórico da fábrica está em contínuo crescimento. Em 1956, a fábrica foi listada no Registro de Locais Históricos do Estado de Michigan; em 1973, passou a constar no Registro Nacional de Lugares Históricos e, em 1978, foi reconhecida como Marco Histórico Nacional. ${ }^{110}$

A obsolescência de Highland Park estabeleceu um moderno parâmetro para o funcional: os edifícios não deveriam apenas acomodar as mudanças, mas antecipá-las. Esse era o novo funcionalismo da flexibilidade total, que expressava uma retórica de racionalidade, eficiência e simplicidade como uma materialização essencial da organização do próprio processo produtivo. Terry Smith propõe que, nesse momento em que um tipo diferente de modernidade nasceu, Albert Kahn transportou os valores da engenharia para os domínios da arquitetura. ${ }^{111}$

Em busca da melhoria da produção em Highland Park, Henry Ford percebeu que as fábricas de vários pavimentos eram ineficientes em razão dos enormes custos necessários para mover verticalmente os materiais pelo edifício. Por este motivo, quando Ford e Kahn começaram a desenvolver um complexo de fabricação de automóveis, o Ford River Rouge, eles introduziram outro projeto arquitetônico de fábrica - o edifício com pé-direito alto, pavimento único e estrutura metálica.

\subsubsection{Ford River Rouge: a maior fábrica do mundo}

A passagem de Highland Park para River Rouge acarretou em uma completa mudança da estrutura produtiva, além de uma significativa reorganização funcional da fábrica. $\mathrm{O}$ fluxo de materiais continuou a ser a chave do sistema de produção da Ford, mas em outra escala: passou dos limites da fábrica para se referir a toda a superfície do complexo e até mesmo, em um caráter global, à produção de matérias-primas pela própria empresa. Ford e seus engenheiros acreditavam que conseguiriam superar as limitações da Ford Highland Park, particularmente os

110 TYLER, I. R. Highland Park Ford Plant: Documentation and Redevelopment. In: APT Bulletin, v. 46, n. 2/3, 2015, p. 38.

111 SMITH, T. Making the modern. Industry, art and design in America. Chicago: The University of Chicago Press, 1993. 
inconvenientes de transporte e a falta de espaço para a expansão.

A fábrica que a Ford Motor Company construiu no Rio Rouge era um tipo inédito de instalação industrial. Era inovadora não só pelo tamanho e localização suburbana, mas também por seus edifícios, organização das fábricas e pelo fato de produzir e processar quase todos os componentes do carro fabricado pela Ford. Desde o início da década de 1920, Henry Ford acreditava que seu negócio prosperaria se não precisasse mais depender de fornecedores externos. No Rouge, o objetivo era que todo o complexo fabril se tornasse uma grande máquina integrada.

A fábrica da Ford foi construída em uma área de 2000 acres na pequena cidade de Dearborn, às margens do Rio Rouge. Mesmo ampliando a fábrica Highland Park em 1914, Henry Ford começou a comprar vários hectares de terra nas margens do Rio Rouge entre 1910 e 1920. O rio conectava-se com o Rio Detroit, que corria entre o Lago St. Clair e o Lago Erie. Ford sabia que ali não era um local perfeito, pois o rio era muito estreito e raso para os navios de carga que trariam materiais para a fábrica ${ }^{112}$, mas o valor baixo das terras compensava. Por outro lado, o terreno era grande o suficiente para a expansão contínua, ao passo que o rio forneceria a água necessária para as fábricas de processamento propostas.

Além da fábrica, a empresa construiu instalações adicionais, tais como o Instituto Edison e o Hospital Henry Ford. A empresa também fez planos para a construção de habitações para os trabalhadores, mas os planos nunca foram concretizados. ${ }^{113}$ Dearborn passou a ser, indubitavelmente, a cidade da Ford Motor Company.

As obras começaram em 1917. O primeiro edifício a ser concluído no complexo Ford River Rouge foi o Edifício B (Boat Building). Henry Ford convenceu o governo de que também poderia produzir em grande escala navios de guerra, os chamados Eagle Boat, aplicando os mesmos princípios anteriormente usados para fabricar o carro Modelo T. ${ }^{114}$ No início de 1918, o governo americano concordou em financiar a construção do edifício. Foi um dos maiores edifícios industriais da época, com estrutura metálica de um pavimento, dotado de mais de 500 metros de comprimento e com 30 metros de altura.

A construção do Edifício B sinalizou a quebra do projeto de múltiplos

112 BIGGS, L. B. The rational factory. Baltimore: The John Hopkins University Press, 1996, p.138.

113 BIGGS, L. B. Industry's master machine: factory planning and design in the age of mass production, 1900 to 1930. Tese (Ph.D in Urban Studies and Planning). Massachusetts Institute of Technology: Cambridge, 1987, p.193.

114 Após a guerra, o edifício foi usado para a montagem de carros Modelo A e tratores Fordson. A produção neste edifício continuou até 2004, e ele foi demolido em 2008. História do edifício disponível em: <http://www.fordmotorhistory.com/ factories/river_rouge/building_b.php >. Acesso em: 26/05/18. 

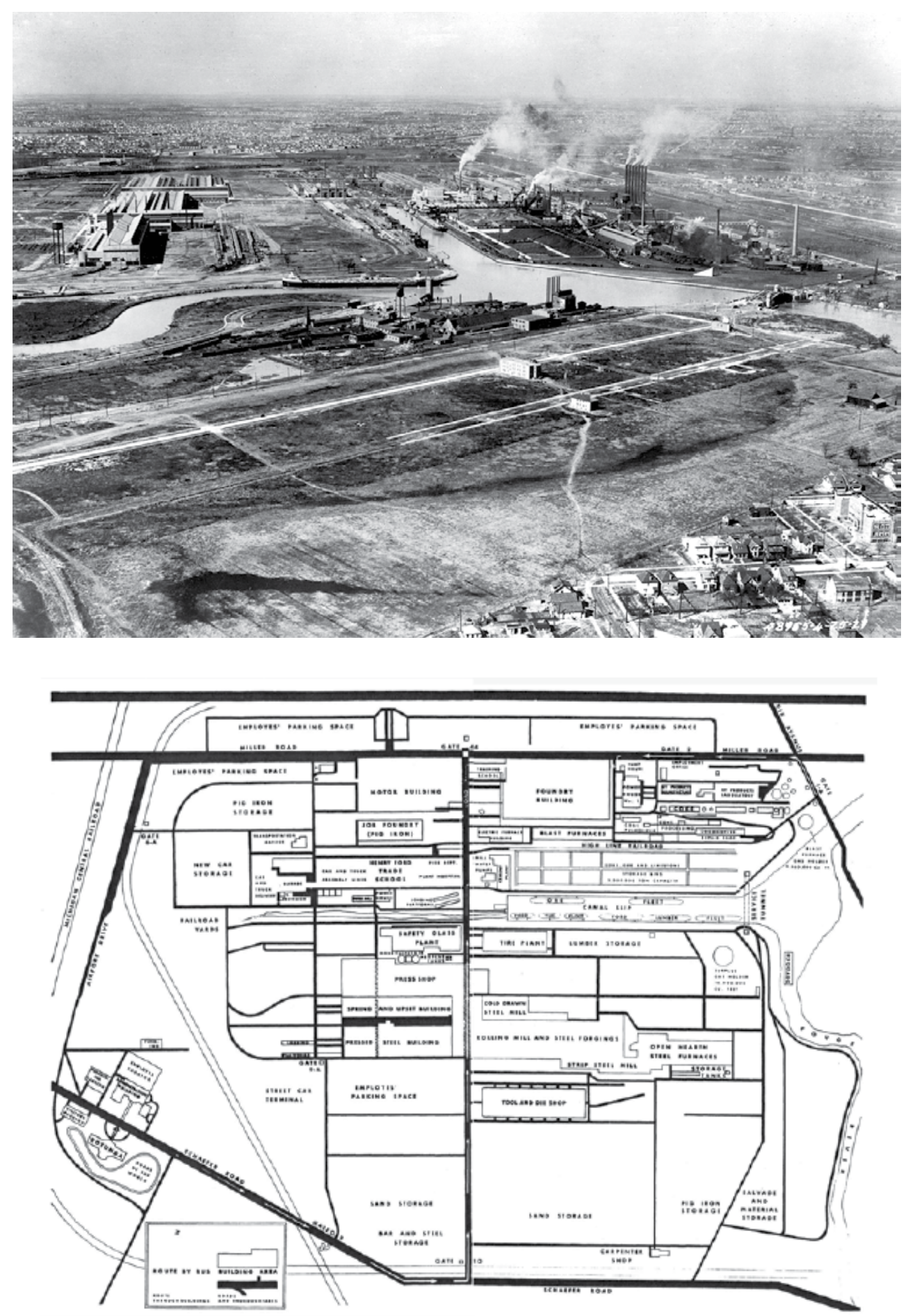

Fig. 61 Vista aérea do complexo da Ford River Rouge em 1927. Fonte: Rasner (2013)

Fig. 62 Planta geral da Fábrica Ford River Rouge. Fonte: Pancorbo (2014) 

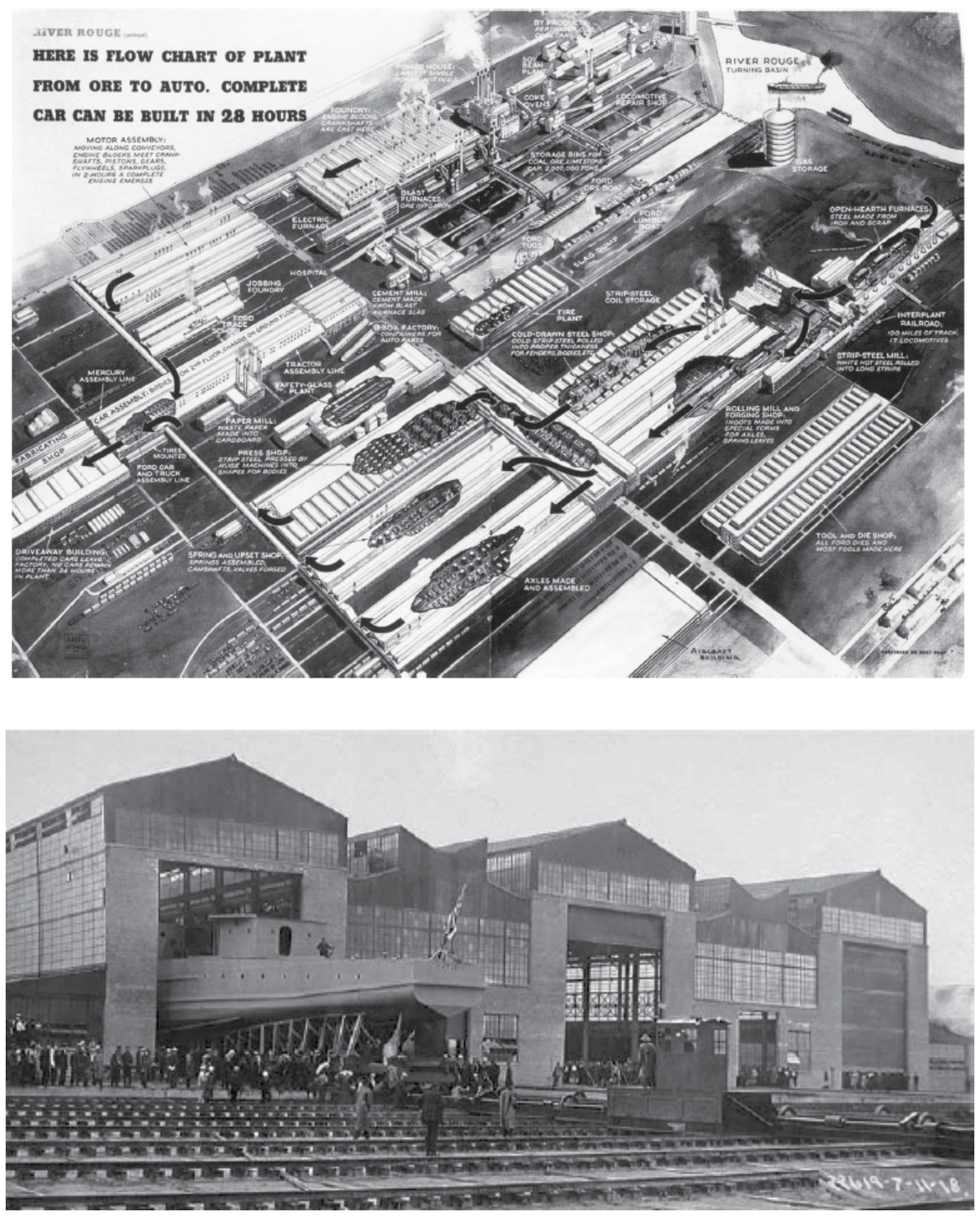

Fig. 63 Esquema tridimensional de funcionamento da Ford River Rouge. Fonte: Pancorbo (2014)

Fig. 64 Boat Building. Fábrica Ford River Rouge.

Fonte: Pancorbo (2014) 
pavimentos para a Ford Motor Company. A constante melhoria das tecnologias de construção permitiu que edifícios cada vez maiores fossem projetados. Novas habilidades de gerenciamento, juntamente com os rápidos avanços no manuseio de materiais, tornavam possíveis operações eficientes em edifícios tão grandes.

Em 1919, várias operações começaram no Rouge: além da produção da carroceria do Modelo A, os fornos de coque foram iniciados e as serrarias cortaram sua primeira madeira. Inicialmente, a empresa planejava produzir as peças fundidas em ferro, usadas na produção do motor no Modelo A. Os altosfornos foram uma das razões para a decisão da mudança da empresa para outro local, pois esse processo demandava uma enorme quantidade de água. O primeiro alto-forno começou a produzir ferro em 1920, e não demorou muito para a Ford Motor Company perceber que uma usina siderúrgica seria uma adição importante aos trabalhos da empresa. Foi uma decisão acertada: a capacidade de produzir aço tornou-se ainda mais importante após a guerra, quando o material tornou-se escasso e as montadoras competiam pelo estoque disponível.

Os altos-fornos e a usina siderúrgica representavam apenas os primórdios das vastas instalações de processamento de River Rouge. Nos cinco anos seguintes, de 1917 a 1922, a empresa construiu várias outras fábricas de processamento, tais como fábricas de vidro, borracha e têxtil. Em um passo radical, a Ford decidiu adquirir minas de carvão, minas de ferro, florestas e, no Brasil, plantações de seringueiras ${ }^{115}$, o que deixou a empresa completamente livre das variações praticadas pelo mercado sobre os preços das matérias-primas.

Por trás da decisão de investir no processamento de materiais, encontravase a frustração e a desconfiança de Henry Ford em relação aos fornecedores. Ford acreditava que era possível processar materiais mais baratos do que poderia comprálos. Além disso, por meio do controle das fontes, materiais importantes nunca seriam retidos devido à escassez, assim como seus preços jamais sofreriam as oscilações do mercado. $\mathrm{O}$ controle das matérias-primas agregou uma nova dimensão à empresa. Construindo instalações de processamento e adquirindo as fontes dos materiais,

$115 \mathrm{Na}$ época, a borracha ainda era derivada das seringueiras do Sudeste Asiático. Para manter a eficiência de sua produção sem depender dos asiáticos, Ford decidiu ter a sua própria produção de látex e, para tanto, construiu uma cidade tipicamente americana em plena Amazônia, batizada de Fordlândia. O Brasil era rico em Hevea brasiliensis, a cobiçada seringueira, e a Bacia Amazônica estava em franca expansão de 1879 a 1912 graças à necessidade das indústrias norte-americana e europeia da matéria-prima. A história de Fordlândia começou em 1927, quando Henry Ford adquiriu um terreno de quase $15.000 \mathrm{~km}^{2}$ às margens do Rio Tapajós, no Pará. No ano seguinte, ele enviou suprimentos e funcionários para criar uma típica cidade americana no local. Em pouco tempo, a cidade ficou pronta, com escolas, eletricidade, saneamento, clube e um hospital. Desprezando a palavra dos especialistas que poderiam ter fornecido conselhos valiosos sobre a agricultura tropical, os funcionários de Ford plantaram sementes de qualidade questionável e não fizeram controle de pragas, o que devastou as plantações. Ao final da Segunda Guerra Mundial, já estava claro que o cultivo das seringueiras em Fordlândia não seria rentável por causa das pragas e da competição da borracha sintética e das plantações asiáticas, livres da dominação japonesa. No mesmo ano, Ford entregou a cidade ao governo brasileiro. A partir de então, a cidade entrou em um estado de declínio constante. Ver em: ROMERO, S. Em plena Amazônia, Fordlândia: o sonho falido de Henry Ford. Estadão, São Paulo, 10 mar. 2017. Disponível em: <https://sustentabilidade.estadao.com.br/noticias/geral,em-plena-amazonia-fordlandia-o-sonhofalido-de-henry-ford,70001693319>. Acesso em: 26 mai. 2018 
a Ford Motor Company entrou em sua fase de - segundo David Lewis definiu - império industrial ${ }^{116}$. Com esse império, Henry Ford cumpriu o seu sonho de uma fábrica totalmente autossuficiente, mantendo controle sobre todas as matériasprimas e sobre o seu processamento.

Em 1927, com a transferência da montagem final para River Rouge, a fábrica tornou-se o centro absoluto da produção da Ford Motor Company. Antes de 1927, no período em que estava sendo construída, River Rouge era considerada somente uma fábrica alimentadora para Highland Park. Uma publicação da empresa de 1924 descreveu o Rouge como a fábrica que "deals primarily in raw materials." 117 Quando a construção da fábrica finalmente acabou, já na década de 1940, a Ford River Rouge continha quase cem edifícios, sendo que a maioria deles era projeto de Albert Kahn.

As enormes instalações de processamento ampliaram a necessidade de um projeto de fábrica diferente das que até então existiam. Ao contrário de Highland Park, uma fábrica integrada à cidade, a Ford River Rouge era uma fortaleza praticamente impenetrável, protegida por trilhos de trem, por muros e pelo rio. Nas fábricas anteriores, incluindo a Ford Highland Park, os edifícios de vários andares foram dispostos de forma adjacente ou agrupados em torno de um pátio central. Essa organização tinha como objetivo economizar tempo e dinheiro no manuseio de materiais, uma estratégia que, na época, se mostrou bem sucedida para acelerar o transporte. Porém, esse tipo de organização criou outro problema não facilmente resolvido pela inovação tecnológica: a expansão. Com edifícios tão bem organizados, cada departamento tinha que ser cuidadosamente planejado: assim, se mais máquinas ou operações fossem adicionadas, muitos departamentos precisavam ser alterados. Isso tornava a operação cara e demorada.

O complexo fabril no Rouge não se parecia com nenhum desses modelos. Tratava-se de um novo tipo de fábrica, inovadora não só no seu tamanho e situação suburbana, mas também devido à organização geral - era menos centralizada do que outras fábricas. Ao planejar o Rouge, os engenheiros encarregados do arranjo produtivo consideraram a facilidade de expansão como sua principal preocupação. Quando dividiram a fábrica em edifícios distintos, asseguraram a economia e o

116 LEWIS, D. The Public Image of Henry Ford. Detroit: Wayne State University Press, 1976.

117 Tradução da autora: "lida principalmente com matérias-primas". Ver: BIGGS, L. B. Industry's master machine: factory planning and design in the age of mass production, 1900 to 1930. Tese (Ph.D in Urban Studies and Planning). Massachusetts Institute of Technology: Cambridge, 1987, p. 205. 
potencial de crescimento futuro. $O$ gigantesco terreno do Rouge reflete a extensão e a velocidade do crescimento da empresa, bem como a expectativa dos engenheiros em relação a uma expansão virtualmente ilimitada. Contudo, de longe, parecia um arranjo quase aleatório de enormes prédios.

Outra grande mudança se refere ao edifício administrativo. Apesar de existir um escritório de supervisão dentro do complexo Ford River Rouge, a empresa era administrada a partir de um edifício que ficava a alguns quilômetros da fábrica. Assim, a separação do edifício administrativo representou várias modificações na forma de pensar a Ford Motor Company: para começar, Henry Ford delegou cada vez mais a administração da empresa a seu filho, Edsel Ford, e ao seu braço direito, Charles Sorensen. Em seguida, o mais importante, a expansão contínua da empresa exigia uma equipe administrativa maior, para a qual a proximidade física da fábrica era algo desnecessário. Lindy Biggs acredita que a separação existente entre a administração e a produção foi uma decorrência do aumento dos conflitos trabalhistas em 1926, ano em que começou a construção do prédio da administração. Nessa conjuntura, Ford provavelmente achou melhor ter os escritórios a uma distância segura da fábrica. ${ }^{118}$

A diferença entre as duas fábricas também é evidente nas comparações dos geradores de energia - um símbolo de progresso e força. $\mathrm{O}$ edifício de geradores de Highland Park foi construído como uma atração turística: não só as chaminés sustentavam a logomarca da Ford, mas a localização do prédio próximo à calçada de uma rua movimentada convidava os transeuntes a admirar os grandes geradores. Por sua vez, os geradores de energia da Ford River Rouge, com uma capacidade muito maior que a sua antecessora, era apenas mais um dos edifícios da fábrica. As oito chaminés, que simbolizavam a importância da fábrica para os visitantes, não continham o nome da empresa. Na verdade, a Ford River Rouge era identificada pelos visitantes apenas por um sinal no portão que impedia a livre entrada de pessoas no terreno. ${ }^{119}$ Talvez Ford presumisse que todos saberiam a identidade da enorme fábrica ao longo do rio Rouge ou talvez ele já não se importasse mais tanto com a publicidade.

A construção de fábricas de um único pavimento tornou-se a principal

118 BIGGS, L. B. Industry's master machine: factory planning and design in the age of mass production, 1900 to 1930. Tese (Ph.D in Urban Studies and Planning). Massachusetts Institute of Technology: Cambridge, 1987, p. 210. 119 Ibid, p. 192-193. 

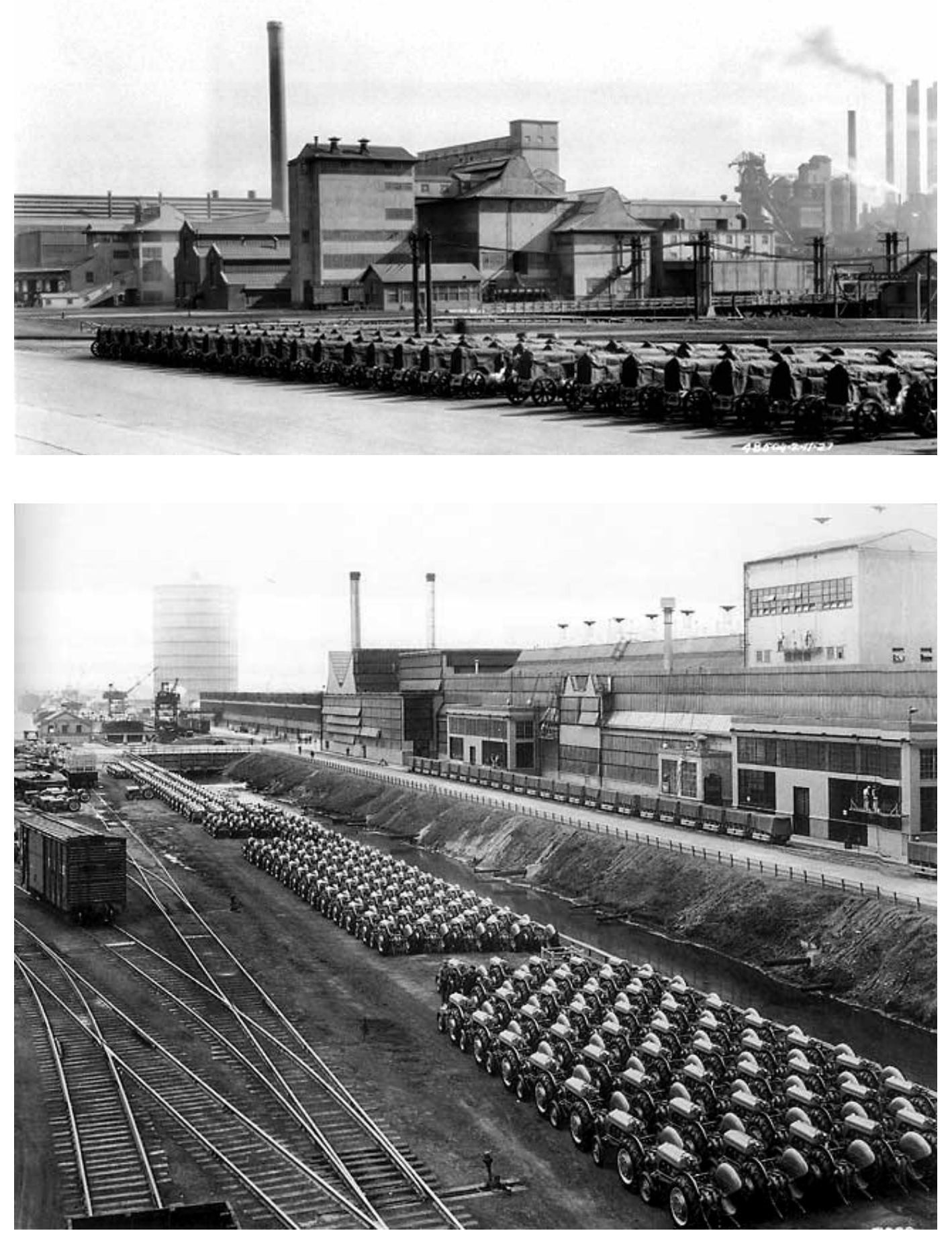

Fig. 65 Vista geral do complexo da Ford River Rouge.

Fonte: <https://modeltfordfix.com/fords-highland-park-manufacturing-plant/> Acesso 28 mai 2018.

Fig. 66 Vista geral do complexo da Ford River Rouge.

Fonte: <https://modeltfordfix.com/fords-highland-park-manufacturing-plant/> Acesso 28 mai 2018. 
política da empresa, em virtude da sua maior eficiência e a possibilidade de eliminação do transporte vertical de materiais. Essa política de uso de um único pavimento estava baseada nos enormes avanços nos meios de transporte horizontais, que se tornaram mais eficientes e econômicos do que os verticais usados em Highland Park. Em resposta a um questionário sobre o projeto da fábrica, E. G. Liebold, secretária de Henry Ford, escreveu: "we find that a one-story building for factory purposes with saw-tooth construction is about the most efficient and obviates elevator service and transferring materials up and down”. ${ }^{120}$

A Ford River Rouge não foi a primeira fábrica a construir edifícios de um só andar. Durante anos, muitos engenheiros defenderam a eficiência e a economia das fábricas de apenas um pavimento. Eles argumentavam que, além de custar menos para construir, tais fábricas forneciam espaço de fabricação mais flexível. $\mathrm{O}$ problema, no entanto, sempre foi a dificuldade em encontrar métodos eficientes para mover materiais, algo que acabou sendo desenvolvido e utilizado, pela primeira vez, pela Ford Motor Company.

A fábrica mais espalhada pelo terreno somente foi possível devido a esta melhoria do transporte horizontal. Cada departamento tinha o seu próprio sistema, conectado a uma rede geral de monotrilhos e esteiras transportadoras capazes de percorrer todo o conjunto. O que Henry Ford e seus engenheiros fizeram em River Rouge foi definir um masterplan, no qual se estabeleceu regras e um sistema de ordem geral. Dentro dessa nova política, até mesmo a natureza foi transformada para poder funcionar. Financiado pelo governo americano ${ }^{121}$, Ford alargou e tornou mais profundo o braço do rio onde se situava a fábrica, permitindo, assim, a passagem de navios de maior porte. Isso reduziria significativamente os altos custos de transporte, tornando a entrega de matérias-primas mais eficiente.

Quando terminou a construção da Ford River Rouge, o complexo se assemelhava a uma cidade industrial, não a uma fábrica. Nesse sentido, River Rouge é uma atuação mais infraestrutural do que arquitetônica, ou aquilo que alguns autores, entre os quais Lindy Biggs, chamam de máquina fordista total. ${ }^{122}$ Ao mesmo tempo em que virou a maior fábrica do mundo, tornou-se também uma das experiências industriais mais caras de todos os tempos. As decisões de localização e

120 Carta da secretária para D. Boyer, em 1922, nos arquivos da Ford Motor Company. Tradução da autora: "descobrimos que um edifício de um andar para fins de fábrica com construção de dente de serra é o mais eficiente, evitando o serviço de elevador e a transferência de materiais para cima e para baixo". Ver em: BIGGS, L. B. Industry's master machine: factory planning and design in the age of mass production, 1900 to 1930. Tese (Ph.D in Urban Studies and Planning). Massachusetts Institute of Technology: Cambridge, 1987, p. 212.

$121 \mathrm{O}$ governo dos Estados Unidos financiou a obra que tornaria navegável o rio Rouge em troca da fabricação de navios no edifício B durante a Primeira Guerra Mundial. Ver: PANCORBO, L.; MARTÍN ROBLES, I. Anestética de la desaparición. La sección como definidora del proyecto en la arquitectura de Albert Kahn. In: ZARCH n. 2. Rethinking/ Remaking. Journal of interdisciplinary studies in Architecture and Urbanism, p 127.

122 BIGGS, L. B. The rational factory. Baltimore: The John Hopkins University Press, 1996. 
projeto foram claramente motivadas por preocupações tecnológicas e econômicas, ao passo que o tamanho da fábrica revelava a decisão administrativa de aumentar os esforços de centralização da produção.

O complexo ocupava uma área tão grande que, na década de 1950, continha quase $50 \mathrm{~km}$ de estradas e vias férreas somente para transportar materiais entre os próprios edifícios, realçando a imagem de uma cidade industrial. ${ }^{123}$ A nova distribuição dos diferentes processos por entre os vários edifícios, dentro da organização geral, permitia à Ford Motor Company o crescimento virtualmente ilimitado tão sonhado. A distribuição entre os edifícios ocorria através de uma rede elevada de transporte de material chamada de Highline.

A Highline era uma estrutura de concreto de cerca de 12 metros de altura, parecida com um viaduto, e larga o suficiente para abrigar cinco trilhos, motivo pelo qual John Van Deventer chamou-a de "espinha dorsal da fábrica"124. Semelhante às pontes rolantes da fábrica de Highland Park, a Highline fornecia a entrega semiautomática de peças e materiais para vários edifícios, manuseando os materiais pesados e transportando matérias-primas. Além da Highline e do sistema interno de estradas, a ferrovia Detroit, Toledo \& Ironton ${ }^{125}$ movimentava os materiais pesados. Como no arranjo de Highland Park, os vagões de trem podiam ser levados diretamente para o interior de muitos dos edifícios, facilitando assim a carga e descarga.

A busca de Henry Ford pela fábrica racional levou-o a construir a maior e mais impressionante fábrica do mundo. A instalação industrial de River Rouge liderou o mundo da manufatura em tecnologia inovadora e projeto de fábrica. A Ford Motor Company, no entanto, não previra a desvantagem significativa que acompanharia a bem-sucedida fábrica racional - a falta de flexibilidade. A demanda por maior adaptabilidade possível para acomodar mercados menores e em constante mudança prejudicou a empresa a partir da década de 1930, devido à sua ausência de adaptabilidade.

No final, o complexo de River Rouge mostrou ao mundo até onde a racionalização poderia ir, mas também demonstrou as desvantagens que acompanhariam a racionalização total. Foi tanto o auge de uma forma de pensar

123 PANCORBO, L.; MARTÍN ROBLES, I. Anestética de la desaparición. La sección como definidora del proyecto en la arquitectura de Albert Kahn. In: ZARCH n. 2. Rethinking/Remaking. Journal of interdisciplinary studies in Architecture and Urbanism,.p 128.

124 VAN DEVENTER, J. Links in a Complete Industrial Chain. In: Industrial Management, n. 64, setembro 1922, p. 131-132.

125 A Ferrovia Detroit, Toledo \&Ironton operou de 1905 a 1983 entre as cidades homônimas de Detroit, Michigan, e Ironton, Ohio, via Toledo. Disponível em: <https://www.american-rails.com/detroit-toledo-and-ironton-railroad.html> Acesso: 27 jun. 2018. 
a fábrica quanto um indicativo do seu declínio. No entanto, a evolução técnica propiciada pelo desenvolvimento das fábricas da Ford foi acompanhada por uma progressiva evolução dos projetos feitos por Albert Kahn, os quais merecem ser estudados separadamente. 

CAP.3 GENEALOGIA 
A investigação desenvolvida na Ford Motor Company para melhorar constantemente os processos de produção do carro Modelo T, enquanto modelo único da empresa, concedeu a Henry Ford a rara possibilidade de refazer o edifício industrial várias vezes. Em virtude do processo evolutivo da arquitetura industrial e da cada vez mais imprescindível parceria entre arquiteto e empresa, Albert Kahn acabou se tornando fundamental para o desenvolvimento da fábrica em direção ao objeto técnico. ${ }^{126}$

Do ponto de vista do projeto de arquitetura, isso conduziu a um desaparecimento progressivo dos usuais desenhos técnicos, tais como plantas baixas e fachadas, que se tornaram documentos secundários na concepção do projeto. A fachada transformou-se em uma pele contínua, envoltório da máquina, cobrindo de modo uniforme toda a superfície de contato com o exterior. Por outro lado, a planta baixa, em busca da flexibilidade total, virou um mero documento de referência para a localização dos cortes, formada por uma série de eixos numerados.

Assim, o desenho definidor do projeto passou a ser o corte, em um processo redutor que se afastava da composição arquitetônica, carecendo de intencionalidade estética. A arquitetura se aproximava da evolução dos objetos técnicos, tais como aviões, navios e automóveis, elogiados por Le Corbusier por fazerem parte da "estética do engenheiro" 127 e por serem os portadores da essência daquilo que os arquitetos modernos acreditavam que deveria predominar na própria arquitetura.

Nesta época de mudanças de paradigmas para os edifícios industriais, surge Albert Kahn, um arquiteto americano que conseguiu conjugar a capacidade de realizar um vasto número de projetos em espaço reduzido de tempo com o máximo de eficiência e economia. Responsável pelos projetos de milhares de edifícios tanto para a Ford Motor Company quanto para outras empresas ao redor do mundo, o trabalho de Kahn adquiriu destaque em especial nos ramos aeronáutico e automotivo, marcando seu nome como o arquiteto dos maiores complexos industriais do seu tempo, além de ser o criador dos espaços cobertos fabris com o maior vão livre.

Para conseguir tamanha produtividade e eficiência, Albert Kahn empregava métodos e ferramentas da engenharia de maneira totalmente racional. A tradição

\footnotetext{
126 Pancorbo, em sua tese de doutorado, investiga como a adoção do paradigma mecanicista impulsiona a revolução tecnológica e industrial, dando origem à era da máquina e a uma nova categoria - os objetos técnicos. Nessa concepção, o trabalho industrial de Albert Kahn teve um papel proeminente no momento em que transporta para a arquitetura o tipo de projeto usado pelos engenheiros para a criação de objetos técnicos. Ver: PANCORBO, L. Arquitectura industrial de Albert Kahn Inc. 1900-42. La arquitectura como objeto técnico. Tese (Doutorado em Proyectos Arquitectónicos). Escuela Técnica Superior de Arquitectura - Universidad Politécnica de Madrid. Madrid: ETS - Arquitectura, 2016. 127 LE CORBUSIER. Por uma arquitetura. São Paulo: Perspectiva, 2011.
} 
industrial, em especial aquela oriunda das instalações ferroviárias, foi utilizada como referência, sendo adaptada para a construção dos edifícios industriais. São obras que, como se verá a seguir, entraram em um processo sinérgico com a linha de montagem, tornando-se a parte espacial e material de uma estrutura global composta por máquinas, trabalhadores e arquitetura.

Um olhar superficial em qualquer conjunto fabril projetado por Kahn consegue observar uma característica comum: todos os edifícios industriais estão conectados, de uma forma ou de outra, a uma ferrovia. O processo fordista de linha de montagem necessitava de uma continuidade no fluxo e no ritmo de chegada das matérias-primas, assim como na posterior distribuição dos produtos acabados, de modo que a conexão ferroviária tornava-se algo essencial. ${ }^{128} \mathrm{~A}$ conexão da arquitetura de Kahn com tipos provenientes da engenharia ferroviária americana ${ }^{129}$ permitiu ao arquiteto alcançar soluções realmente inovadoras, as quais constituíram uma influência decisiva para a evolução da arquitetura industrial do século XX.

Através da análise gráfica e da crítica descritiva de algumas fábricas projetadas por Kahn ao longo de sua vida, é possível perceber a evolução do seu método projetual e das estruturas que construiu. Assim, o presente capítulo se dedica a abordar algumas das obras mais paradigmáticas e relevantes da vasta produção de Kahn.

Os critérios para a seleção dos casos de estudo foram a importância que cada fábrica possui dentro da produção global de Kahn e a viabilidade de obtenção da documentação das mesmas. ${ }^{130}$ Determinou-se a relevância das fábricas de acordo com o caráter assumido por cada edifício selecionado, seja como precursor, como exemplo paradigmático ou como elemento mais notável e refinado do grupo tipológico dentro da arquitetura industrial projetada pelo escritório do arquiteto. Também se buscou escolher edifícios nos quais estão ilustrados conceitos-chave do método de projeto de Kahn e a sua importância histórica no campo arquitetônico, técnico ou cultural. Dessa forma, os casos de estudo selecionados foram:

128 A relação entre a linha de montagem e a ferrovia foi estudada de forma explícita e detalhada por Sigfried Giedion. Este autor situa a origem da linha de montagem nas experiências pioneiras dos moinhos mecânicos de Oliver Evans, conectando-a diretamente com a tecnologia ferroviária através do uso de trilhos suspensos e carros que deslizam neles, conforme o que era utilizado nos matadouros de Cincinnati. Ver: GIEDION, S. Mechanization Takes Command: A Contribution to Anonymous History. New York: Oxford University Press, 1970.

129 Outro dado importante é o fato de Julius Kahn, depois de se formar na faculdade de engenharia da Universidade de Michigan, ter iniciado a sua carreira profissional como funcionário de uma empresa dedicada à construção de pontes ferroviárias, a Union Bridge Company de Nova York, cujas obras incluem a Niagara Bridge (1883). Essa ponte é um importante precedente para as estruturas em balanço posteriores feitas pelo escritório de Albert Kahn. Ver: PANCORBO, L. Arquitectura industrial de Albert Kahn Inc. 1900-42. La arquitectura como objeto técnico. Tese (Doutorado em Proyectos Arquitectónicos). Escuela Técnica Superior de Arquitectura - Universidad Politécnica de Madrid. Madrid: ETS Arquitectura, 2016, p.43.

130 A documentação gráfica dessas fábricas foram publicadas nos livros de: Nelson (1939), Ferry (1970), Hildebrand (1974), Bucci (1993), e nas publicações acadêmicas de Ravara (2008) e Pancorbo (2016). A tese de doutorado de Luis Pancorbo oferece material inédito de todas as fábricas, adquiridas nos arquivos de Albert Kahn e doados à Biblioteca Histórica Bentley, da Universidade de Michigan, em Ann Arbor. 
1. Fábrica de automóveis da Packard Motor Car Company - Building no10 (1905)/Detroit, Michigan.

2. Fábrica de montagem da Ford Motor Company - Highland Park Old Shop (1909) / Detroit, Michigan.

3. Fábrica de montagem da Ford Motor Company - Highland Park New Shop (1914) / Detroit, Michigan.

4. Forge Shop da Packard Motor Car Company - Forge Shop (1911) / Detroit, Michigan.

5. Fábrica de vidros da Ford Motor Company - Complexo River Rouge (1922) /Dearborn, Michigan.

6. Fábrica de tratores da Amtorg Trading Corporation (1930) / Stalingrado, União Soviética.

7. Fábrica de caminhões da Chrysler Corporation/Dodge division Half-ton truck plant (1937) / Warren, Michigan.

8. Fábrica de montagem de aviões da Glenn L. Martin Company (1937) / Baltimore, Maryland.

9. Fábrica de montagem de aviões da Ford Motor Company - Willow Run Bomber Plant (1941) / Ypsilanti, Michigan.

Uma vez que os critérios de seleção foram explicados, uma análise crítica será realizada de forma individualizada para cada estudo de caso, abordando a escala do projeto, a estrutura, os vãos alcançados e os elementos empregados para o fechamento dos edifícios. Estes aspectos serão utilizados para produzir a descrição e o modelo tridimensional esquemático das fábricas.

Todas as dimensões, considerando-se que são obras americanas, encontramse fornecidas em milhas, pés e polegadas. A equivalência com o sistema métrico é a seguinte:

1 milha $=1,609344$ quilômetros

1 pé $=0,3048$ metros

1 polegada $=2,54$ centímetros 
Os casos de estudo estão separados em dois grupos - as estruturas de concreto e estruturas metálicas -, levando-se em consideração a evolução técnica do trabalho de Albert Kahn. O primeiro grupo a ser abordado serão as estruturas de concreto. 


\subsection{AS ESTRUTURAS DE CONCRETO DE ALBERT KAHN}

A construção de edifícios industriais de múltiplos pavimentos, dotados de estrutura de madeira e de sistemas de iluminação a gás, aumentavam muito o risco de incêndios nas fábricas. Por essa razão, no início do século XX, e paralelamente à incorporação de elementos metálicos na construção, surgiu um grande número de patentes ligadas à estrutura de concreto armado. Albert Kahn e seu irmão, Julius, começaram a trabalhar nessa direção, patenteando também um sistema de reforço para o concreto. As antigas estruturas das fábricas, que utilizavam madeira nos pilares, vigas e lajes, foram aos poucos substituídas pelo concreto armado, resultando no uso de vãos internos maiores e no surgimento de edifícios com melhor iluminação e ventilação natural, já que a liberação da fachada como parede portante permitiu o seu preenchimento por uma superfície completamente envidraçada.

O Edifício № 10, construído em 1905 para a Packard Motor Company em Detroit, Michigan, foi selecionado por ser o primeiro construído desta série de edifícios com estrutura de concreto, sendo do tipo daylight factory. $\mathrm{O}$ segundo exemplo desse grupo é a fábrica de montagem da Ford Highland Park (Old Shop) 
de 1909, primeiro projeto da parceria formada entre Albert Kahn e Henry Ford. O terceiro exemplo representa o início da influência da engenharia ferroviária no projeto de Kahn, cujo representante mais característico é a ampliação da fábrica da Ford em Highland Park (New Shop), construída em 1914. 


\section{FÁBRICA DE AUTOMÓVEIS PACKARD MOTOR CAR}

\section{1}

COBERTURA

laje de concreto

02

FECHAMENTO LATERAL concreto, vidro e tijolos

03

ESTRUTURA

concreto (pilar, laje e viga) maior vão $9,83 \mathrm{~m}$
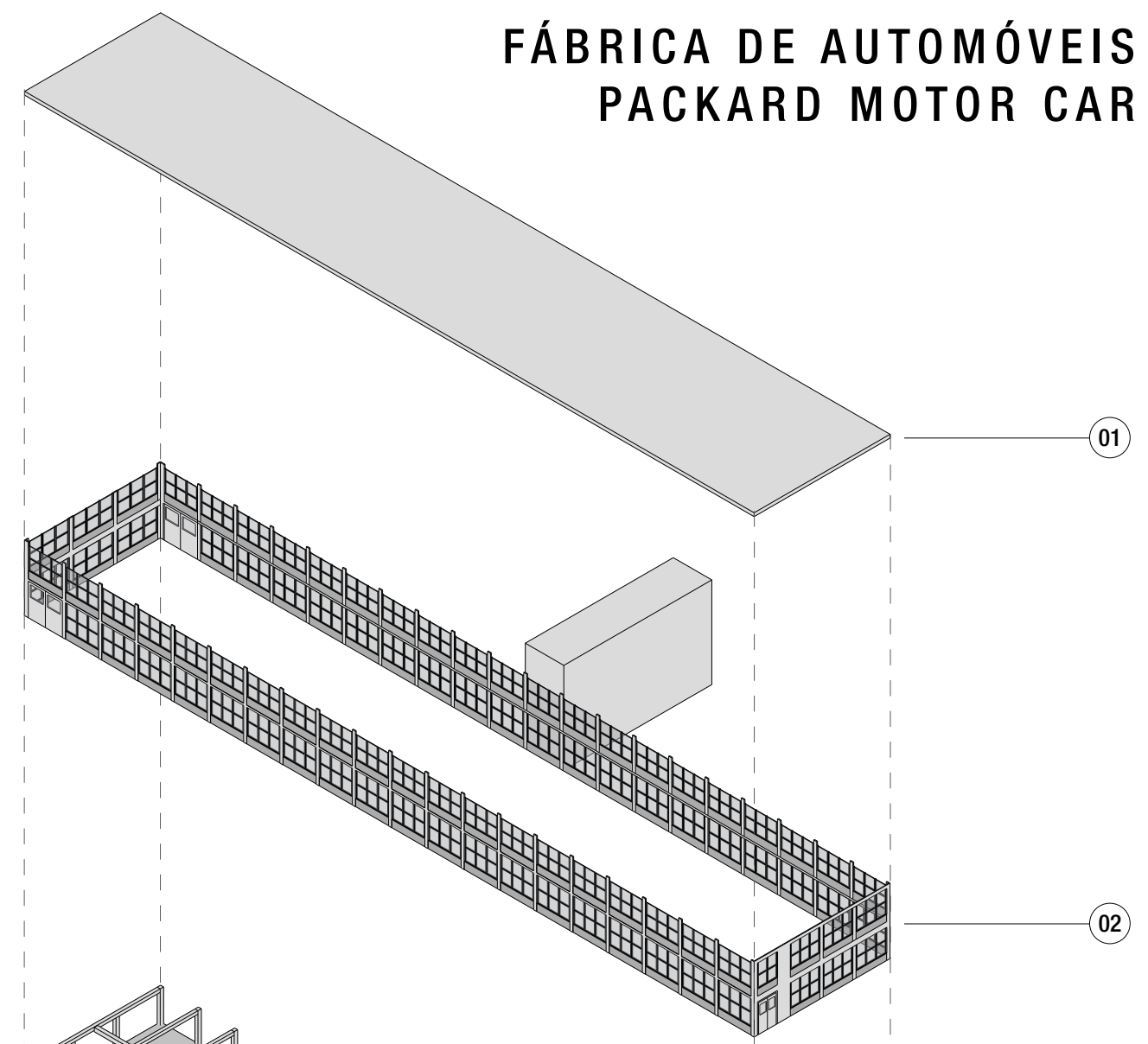

02

03 


\subsubsection{Fábrica de automóveis - Building no 10 (1905) Packard Motor Car Company/Detroit, Michigan.}

No início do século XX, o complexo fabril da Packard Motor Car Company, na cidade de Detroit, introduziria Albert Kahn e a indústria automobilística na construção de fábricas em concreto armado. Projetados pelo arquiteto, os primeiros nove edifícios fabris do complexo da Packard foram construídos com uma estrutura convencional, sem muita diferenciação entre eles. Em 1905, Albert e Julius Kahn projetaram o Edifício $\mathrm{N}^{\circ} 10$, o qual se tornaria a primeira fábrica de automóveis com estrutura de concreto armado dos Estados Unidos. ${ }^{131}$

As vantagens do Edifício $\mathrm{N}^{\circ} 10 \mathrm{em}$ relação aos anteriores foram significativas. $\mathrm{O}$ espaçamento interno dos pilares de concreto era um pouco maior do que o usual, dando maior amplitude ao espaço. A nova estrutura permitiu que as aberturas da fachada fossem maiores, tornando a fábrica melhor iluminada e ventilada. Além disso, a estrutura toda de concreto apresentava maior durabilidade que as estruturas anteriores projetadas para o complexo fabril da Packard, pois tinha a vantagem de ser mais resistente ao fogo e às vibrações.

O Edifício $\mathrm{N}^{\circ} 10$ consistia em uma estrutura de 2 pavimentos, medindo 60 pés $(18,28 \mathrm{~m})$ no sentido norte-sul por 322 pés $(98,14 \mathrm{~m})$ no sentido leste-oeste. Para a estrutura da fábrica, Kahn posicionou os pilares em intervalos de 32 pés e 3 polegadas $(9,83 \mathrm{~m})$ ao longo da linha central do edifício. Os pilares apoiavam uma viga principal e central, sobre a qual as vigas secundárias descansavam em intervalos de 16 pés e $1 / 2$ polegada $(4,89 \mathrm{~m})$. As extremidades dessas vigas encontravam-se apoiadas diretamente em pilares espaçados em intervalos de 16 pés e $1 / 2$ polegada $(4,89 \mathrm{~m})$ ao longo da parede externa. Assim, nenhuma viga era necessária nas paredes externas longitudinais, de modo que o vidro poderia se estender até a laje.

A estrutura foi totalmente exposta na fachada e Kahn pôde usar maiores extensões de janelas para melhorar a iluminação e ventilação naturais. A parte inferior do vão estrutural estava preenchida por um painel baixo de tijolos que continha um peitoril de concreto. O Edifício $\mathrm{N}^{\circ} 10$ da Packard foi construído para possuir uma arquitetura utilitária, funcional e com poucos detalhes decorativos. Contudo, apesar do uso do concreto como material estrutural, o projeto não é particularmente inovador, valendo mais pelo aspecto inovador de ser o primeiro do seu tipo construído para a indústria automobilística.

131 Apesar de não ser a primeira fábrica construída em concreto armado, sua importância deve-se ao fato de ser a primeira fábrica em concreto para a indústria automobilística. Ver: FERRY, H. Legacy of Albert Kahn. Detroit: The Detroit Institute of Arts,1970, p.11. 

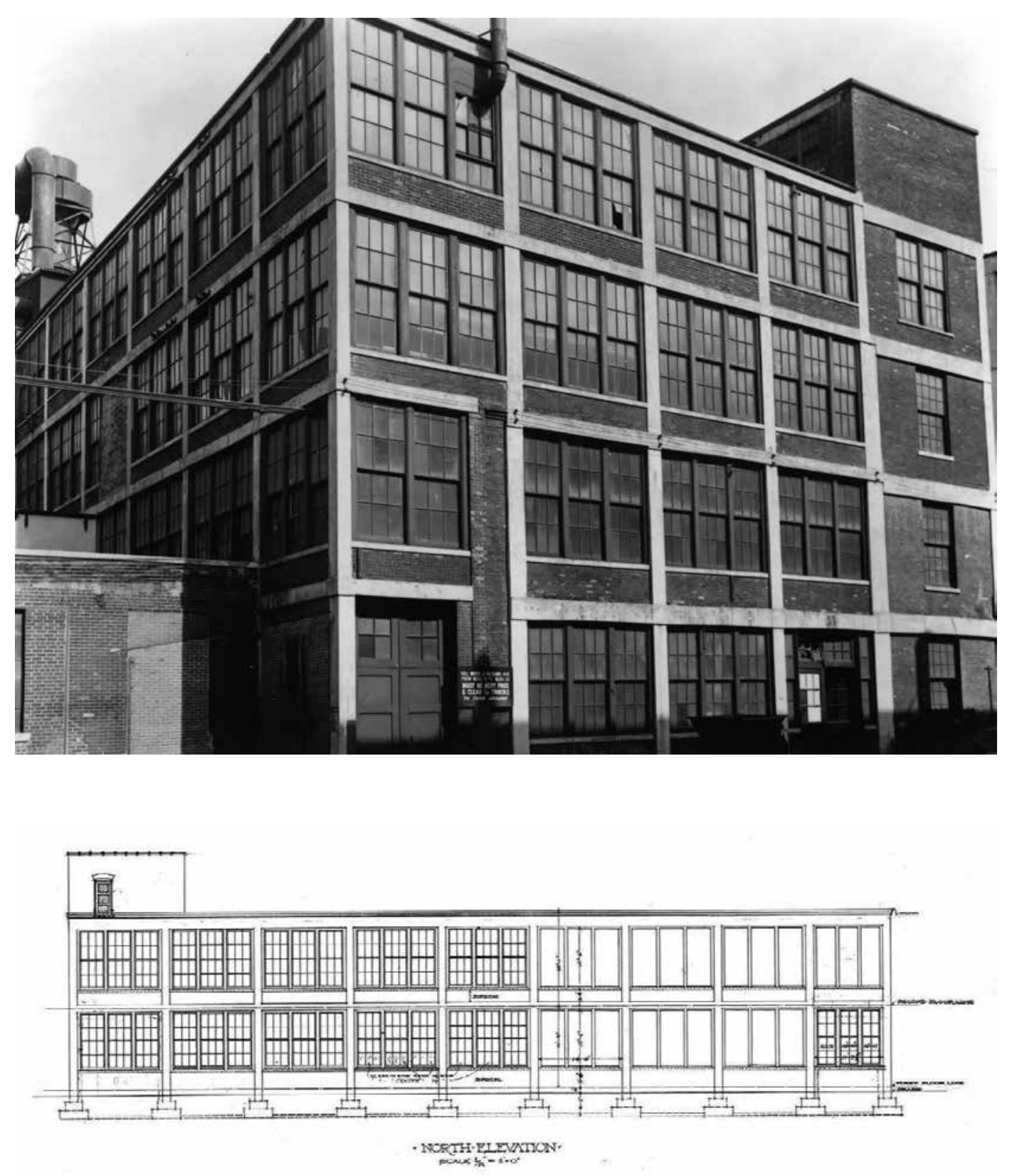

Fig. 68 Edifício $\mathrm{N}^{\circ} 10$ da Packard Motor Car Company, em Detroit, Michigan (1905).

Fonte: Albert Kahn Associates Records, Bentley Library, University of Michigan.

Fig. 69 Trecho da fachada norte do Edifício Nº 10 da Packard Motor Car Company, em Detroit, Michigan (1905).

Fonte: Ferry (1970) 


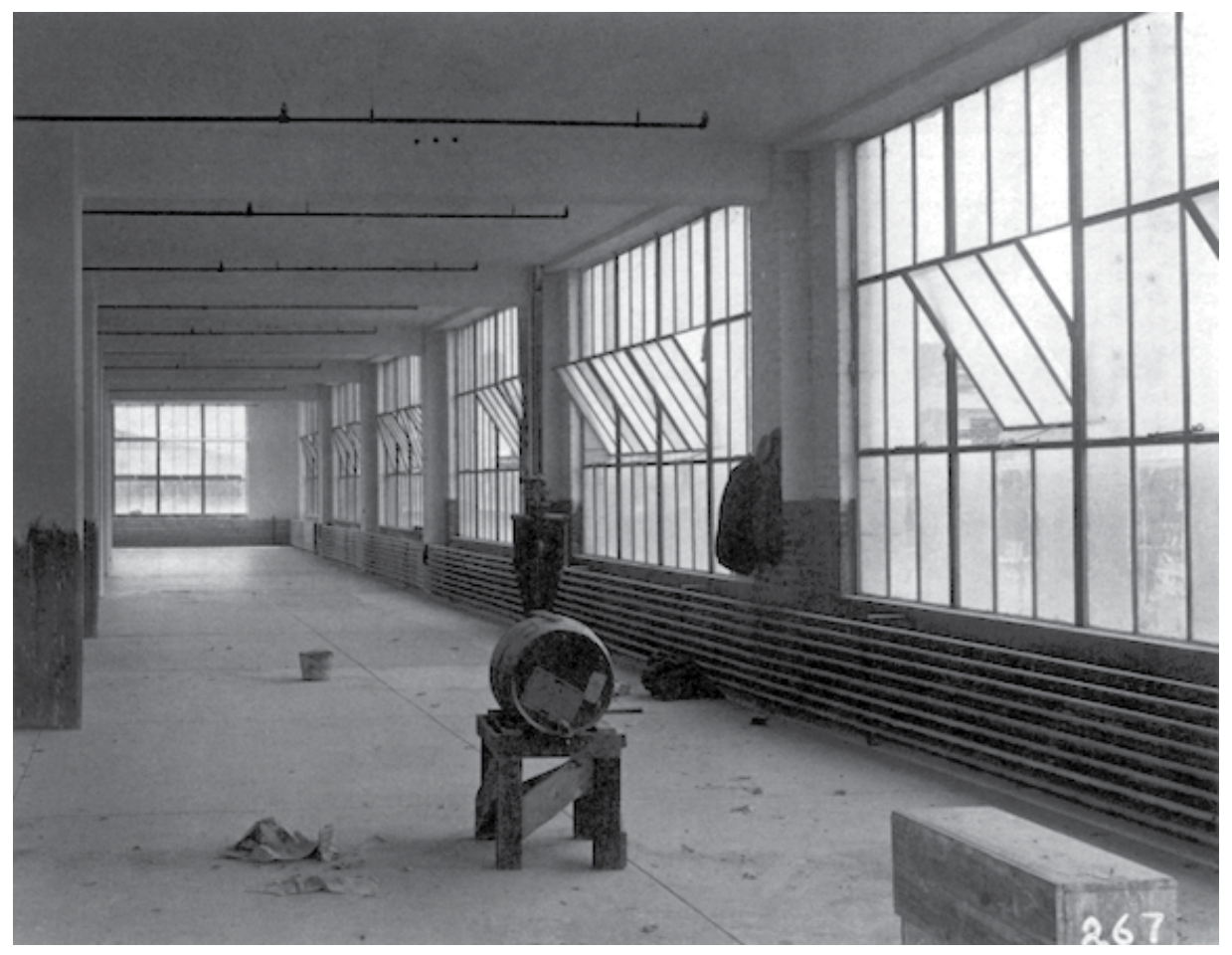

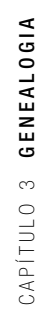

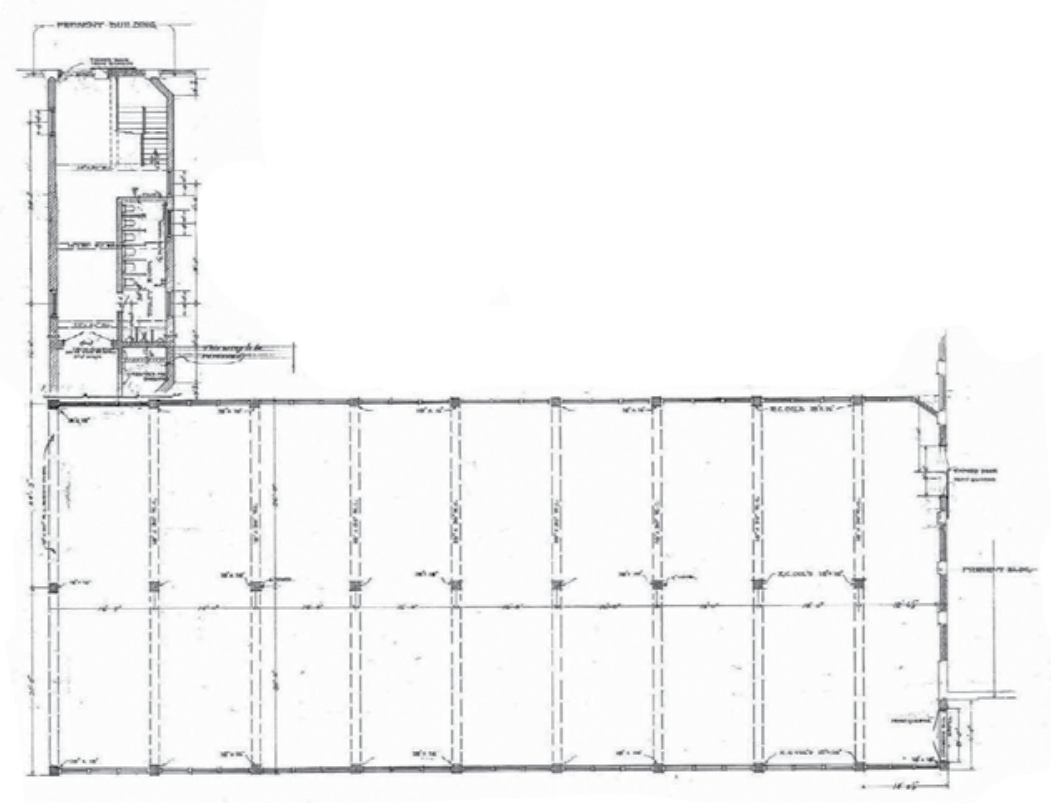

Fig. 70 Interior da Packard Motor Car Company Building, em Detroit, 1919. Fonte: Zimmerman (2017)

Fig. 71 Planta baixa parcial do Edifício $\mathrm{N}^{\circ} 10$ da Packard Motor Car Company, em Detroit, Michigan (1905). Fonte: Pancorbo (2016) 


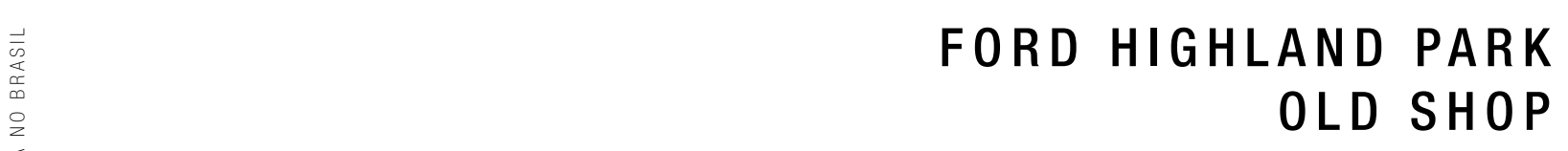

\section{1}

COBERTURA

laje de concreto

\section{2}

FECHAMENTO LATERAL

concreto, vidro e tijolos

\section{3}

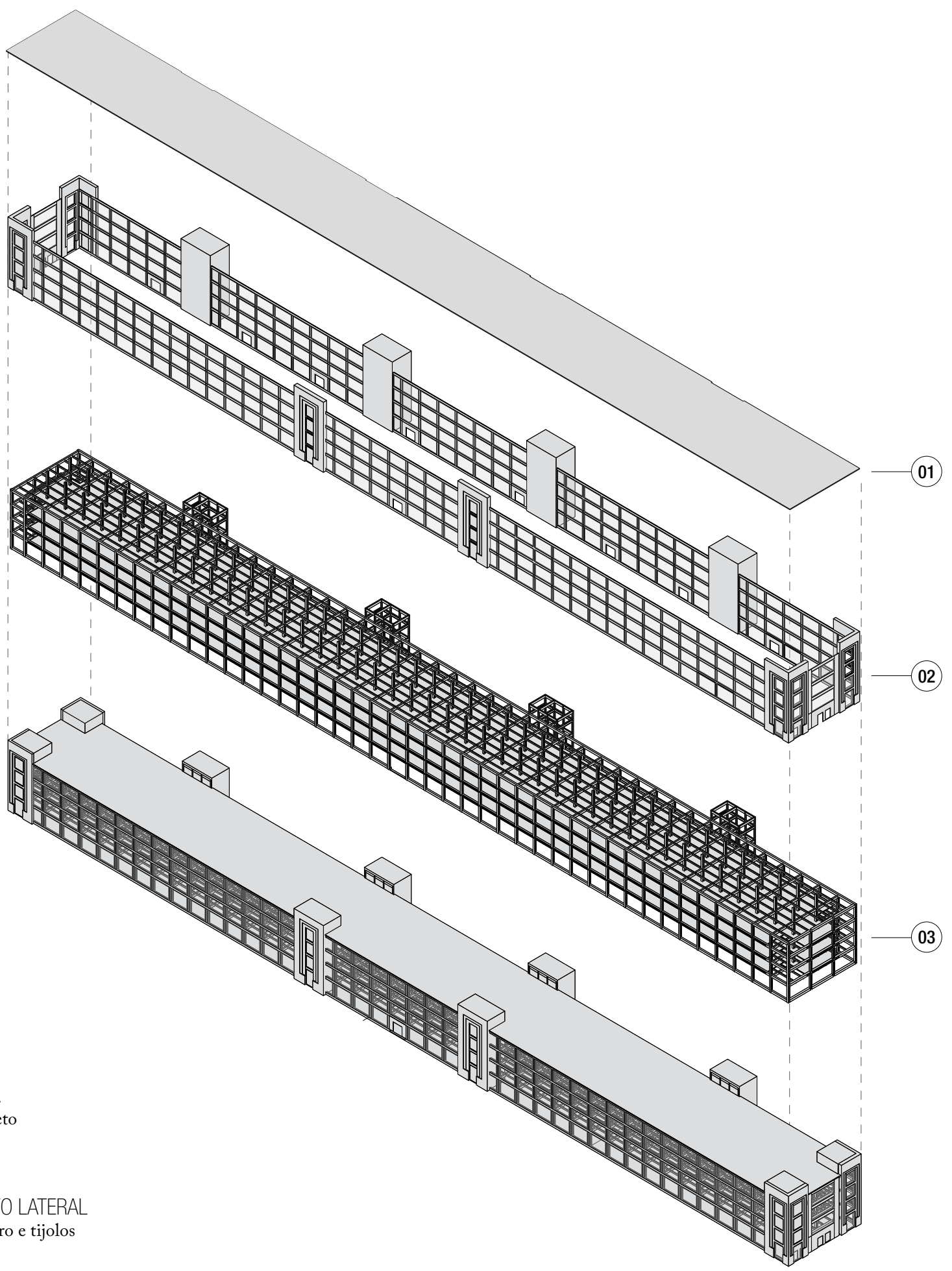

ESTRUTURA

concreto (pilar, laje e viga) maior vão $7,62 \mathrm{~m}$

Fig. 72 Diagrama Ford Highland Park Old Shop. Fonte: Arquivo pessoal da autora, 2019. 


\subsubsection{Fábrica de automóveis - Highland Park Old Shop (1909) Ford Motor Company/ Detroit, Michigan.}

O trabalho de Albert Kahn para a Packard levou Henry Ford, o maior fabricante de automóveis do momento, em meados de 1908, a escolher o arquiteto para projetar a nova fábrica responsável pela construção do Modelo T. Para a fábrica de Highland Park, Henry Ford desejava que o edifício comportasse todas as etapas da produção do automóvel sob a mesma cobertura, além de concentrar as principais operações em um único andar. Contudo, no final de 1908, Ford previu que, caso a fábrica tivesse vários andares, os números da produção da antiga fábrica da Piquette Avenue seriam multiplicados por cinco. Para colocar esse projeto em prática, Ford desenvolveu um processo de trabalho sistematizado e organizado, utilizando a gravidade para o transporte de matérias-primas, peças e subconjuntos. ${ }^{132}$

O edifício de montagem da Old Shop de Highland Park constituiu-se na primeira demonstração da supremacia do transporte de materiais sobre a própria atividade produtiva. $\mathrm{O}$ edifício foi concebido como uma estrutura tridimensional cujas relações de planejamento tinham de ser estudadas não apenas dentro de cada andar, mas também de um andar para o outro. $\mathrm{O}$ movimento na fábrica se realizava de forma descendente: partindo do armazenamento de materiais nos pavimentos superiores, as peças eram transportadas, verticalmente, aos pavimentos inferiores, chegando, então, ao térreo, onde a carroceria, já pronta, era montada no chassi.

No seu formato básico, a Old Shop era semelhante ao Edifício $\mathrm{N}^{\circ} 10$ da Packard, conservando, assim, as proporções da daylight factory. $\mathrm{O}$ edifício de quatro andares possuía 860 pés $(262,12 \mathrm{~m})$ de comprimento e 75 pés $(22,86 \mathrm{~m})$ de largura. Apesar de apresentar maiores dimensões, utilizava vãos ligeiramente menores. Os pilares estavam espaçados em intervalos de 20 pés $(6,09 \mathrm{~m})$ ao longo do comprimento e 25 pés $(7,62 \mathrm{~m})$ na largura. Vigas contínuas ocupavam esses vãos de 25 pés, suportando as vigas secundárias de 20 pés espaçadas em intervalos de 8 pés e 4 polegadas $(2,54 \mathrm{~m})$. As vigas de borda da fachada eram invertidas, possibilitando que as esquadrias se alinhassem pela altura da laje de concreto, algo que, formalmente, deixava o edifício muito semelhante ao Edifício $\mathrm{N}^{\circ} 10$ da Packard.

132 HILDEBRAND, G. Designing for Industry: The Architecture of Albert Kahn. Cambridge, Massachusetts: MIT Press, 1974, p.45. 

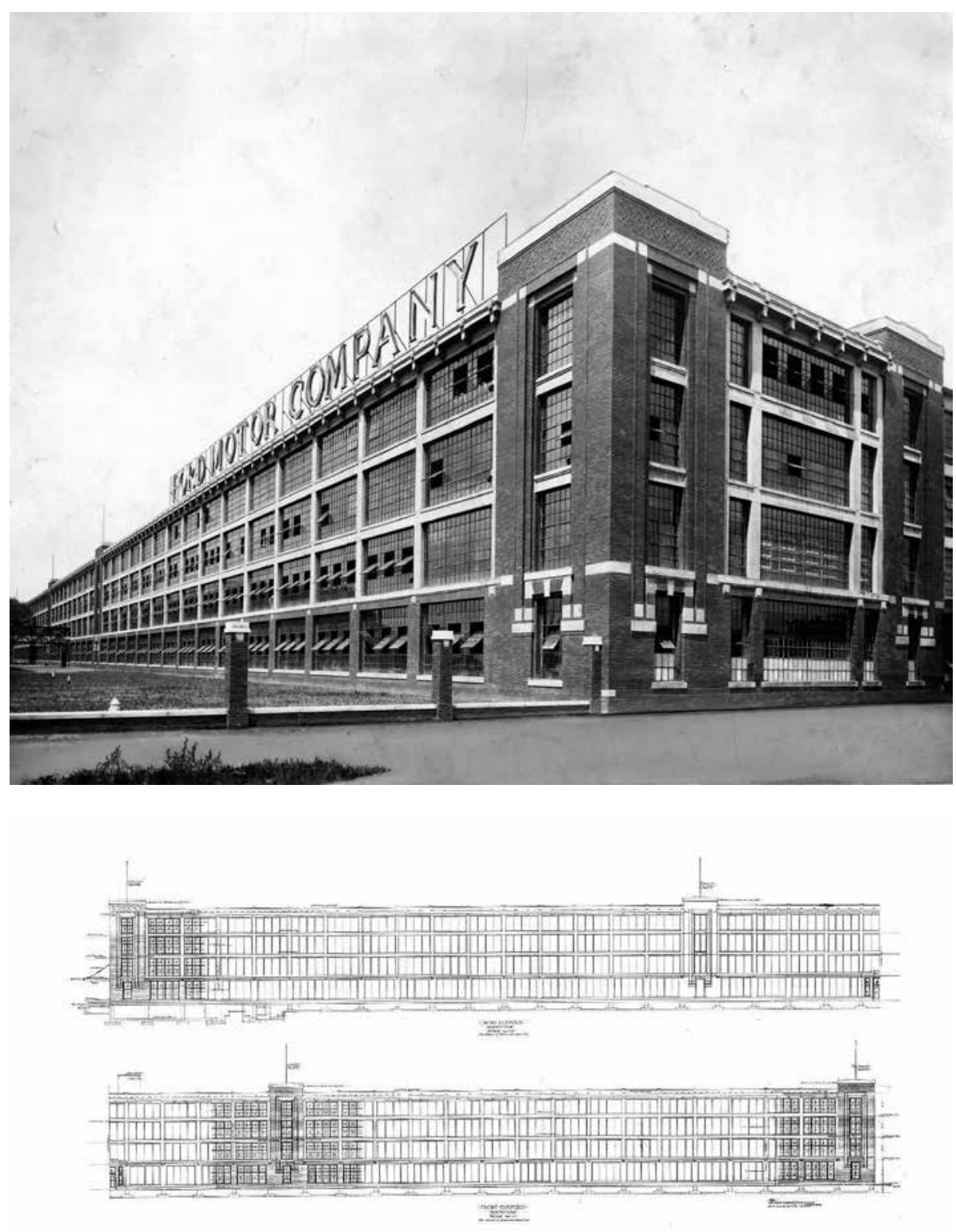

Fig. 73 Edifício de montagem da fábrica Ford Highland Park Old Shop. Fonte: Albert Kahn Associates Records, Bentley Library, University of Michigan.

Fig. 74 Fachada frontal da fábrica Ford Highland Park Old Shop. Fonte: Pancorbo (2016) 

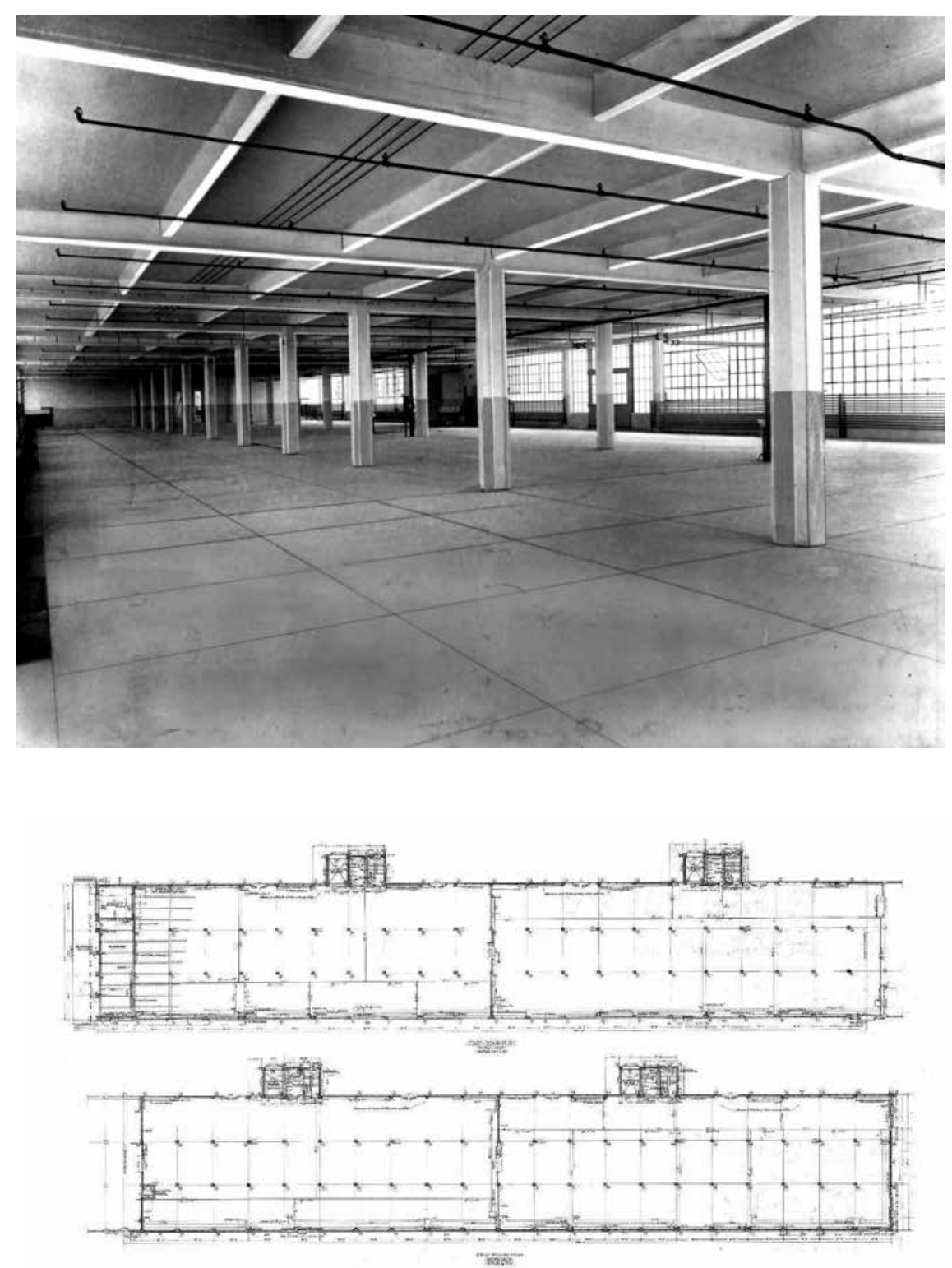

Fig. 75 Interior do edifício de montagem da fábrica Ford Highland Park Old Shop Fonte: Albert Kahn Associates Records, Bentley Library, University of Michigan.

Fig. 76 Planta baixa da fábrica Ford Highland Park Old Shop. Fonte: Pancorbo (2016) 
A estrutura reticulada de concreto da fábrica ficava aparente, sendo os vãos totalmente preenchidos com esquadrias de vidro. A estrutura era tratada com grande clareza e precisão, uma vez que a dimensão dos elementos estruturais verticais (pilares) e horizontais (vigas) era a mesma. O parapeito inferior em tijolo foi retirado, tornando a fachada mais abstrata do que aquela presente no Edifício No 10 da Packard.

Importados da Inglaterra ${ }^{133}$, os caixilhos metálicos das esquadrias preenchiam totalmente os vãos da fachada, de forma a permitir a entrada do máximo de luz natural. Diferentemente da Packard, os caixilhos utilizados eram muito mais esbeltos. As esquadrias possuíam a possibilidade de abertura através de janelas basculantes, a 2/3 da altura do vão, fazendo com que, além da iluminação, existisse uma boa ventilação para a fábrica.

Com o propósito de liberar o espaço interno para a fabricação, quatro volumes externos conectavam-se à fachada leste, contendo elevadores, escadas e banheiros. No exterior, os cantos e o coroamento do edifício recebiam uma espécie de ornamentação, em contraste com a austeridade do Edifício No 10 da Packard.

A Old Shop foi um exemplo interessante na evolução da arquitetura industrial. Contudo, não pode ser considerada como um protótipo dos trabalhos futuros mais significativos do arquiteto mas, sem sombra de dúvida, representa um passo muito importante na sua carreira e na sua visão sobre a arquitetura industrial.

133 BUCCI, F. Albert Kahn: Architect of Ford. New York: Princeton Architectural Press, 1993, p. 42. 


\section{FORD HIGHLAND PARK NEW SHOP}

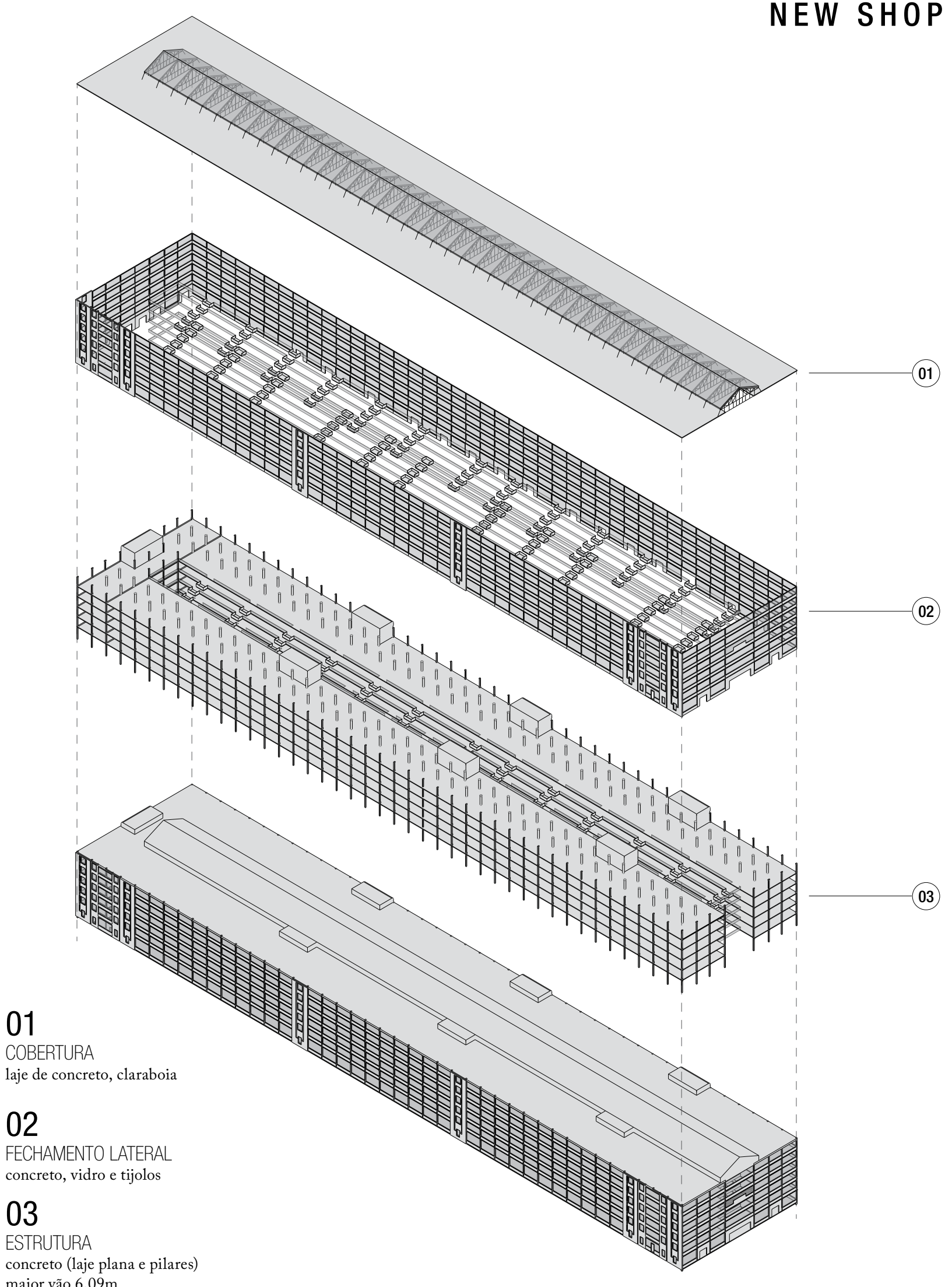

Fig. 77 Diagrama Ford Highland Park New Shop Fonte: Arquivo pessoal da autora, 2019. 


\subsubsection{Fábrica de automóveis - Highland Park New Shop (1914) Ford Motor Company/ Detroit, Michigan}

A produção do Modelo $\mathrm{T}$ dobrava a cada ano e, consequentemente, a fábrica Highland Park estava em estado contínuo de crescimento. Cinco anos após a abertura da Highland Park Old Shop, a Ford começaria a construção de um novo edifício de montagem no mesmo terreno.

Com a New Shop, inicia-se um processo de transformação das fábricas, as quais passaram a ser planejadas como se fossem máquinas. Esta máquina global era composta, além da arquitetura envolvida no edifício, pelo próprio maquinário automático e pelos operários, sendo concebida como uma estrutura capaz de atuar sinergicamente com o sistema de produção da linha de montagem fordista acionada pela gravidade.

Em comparação com a Old Shop, o arranjo adotado era muito mais moderno e eficiente. Prova disso é a absoluta integração da linha de trem - meio de transporte cada vez mais essencial para a indústria norte-americana da época - ao interior do edifício da New Shop. Os trilhos de trem adentravam a fábrica, abaixo das pontes rolantes, permitindo que a descarga de materiais acontecesse de maneira mecânica, direto dos vagões. Isso contribuiu muito para resolver os problemas de movimentação de materiais.

A organização da nova fábrica foi modificada em relação à Old Shop. A oficina de máquinas passou a se localizar no último andar, que era o pavimento mais iluminado. Tal circunstância somente foi possível em decorrência da maior resistência à sobrecarga e à vibração da estrutura de concreto, e também porque os guindastes suportavam mais cargas, sendo capazes de elevar com facilidade os materiais pesados até o sexto e último andar. Desta maneira, conseguiu-se um processo produtivo totalmente acionado pela gravidade.

O edifício em concreto armado de seis andares possuía 840 pés $(256,03 \mathrm{~m})$ de comprimento e 160 pés (48,76m) de largura. A estrutura de concreto armado permitiu várias melhorias, inclusive o uso de pilares ocos para acomodar os dutos. Os pilares com seção circular, espaçados em intervalos de 20 pés $(6,09 \mathrm{~m})$, tinham 
capitéis de reforço no encontro com a laje plana de concreto, garantindo, assim, maior resistência estrutural. As vigas foram utilizadas apenas nas extremidades, onde os pilares possuíam seção quadrada. Os núcleos de circulação vertical e banheiros acabaram sendo internalizados, possibilitando a repetição modular do edifício.

A fábrica era parecida externamente com a Old Shop, uma vez que foi construída também com estrutura em concreto armado e fechamento em tijolos e vidro. A dimensão da área envidraçada na fachada foi revista do ponto de vista do custo da fabricação de cada módulo e, na New Shop, retomou-se o uso de um parapeito em tijolo abaixo da janela, a uma altura de cerca de 90 centímetros. Esse recurso também fora utilizado por Albert Kahn no Edifício № 10 da Packard.

Um híbrido entre o tipo de construção industrial daylight factory e a engenharia ferroviária ocorreu no projeto da New Shop. As tipologias da engenharia férrea, tais como as estações de passageiros, com edificações alinhadas em ambos os lados das plataformas, acabaram servindo de referência para o projeto de Kahn na New Shop. ${ }^{134}$ É como se Kahn empilhasse várias estações de passageiros, originando, dessa forma, um espaço vertical central em que a carga e a descarga do trem ocorreriam tanto de forma mecânica quanto vertical.

O pátio interno central, com 800 pés $(243,84 \mathrm{~m})$ de comprimento e 40 pés $(12,19 \mathrm{~m})$ de largura, constituía no espaço mais importante da fábrica, pois possibilitava a movimentação vertical dos materiais necessários ao seu correto funcionamento. $\mathrm{O}$ pátio era coberto por uma estrutura de aço e vidro, abrigando os trilhos do trem, que eram responsáveis pela carga e descarga de materiais. Atravessando esse pátio, havia uma ponte rolante que movia literalmente tudo na fábrica, convertendo o espaço vazio de seis pavimentos de altura em um espaçomovimento, no qual cada coordenada espacial podia ser ocupada a qualquer instante por um material transportado. Dois guindastes de cinco toneladas movimentavam-se ao longo da ponte rolante, elevando os materiais do andar térreo e colocando-os nas plataformas em balanço, dispostas em ambos os lados, nos cinco pavimentos acima do térreo. As fachadas internas, localizadas neste espaço central, possibilitavam continuidade visual e funcional entre os pavimentos da fábrica. 

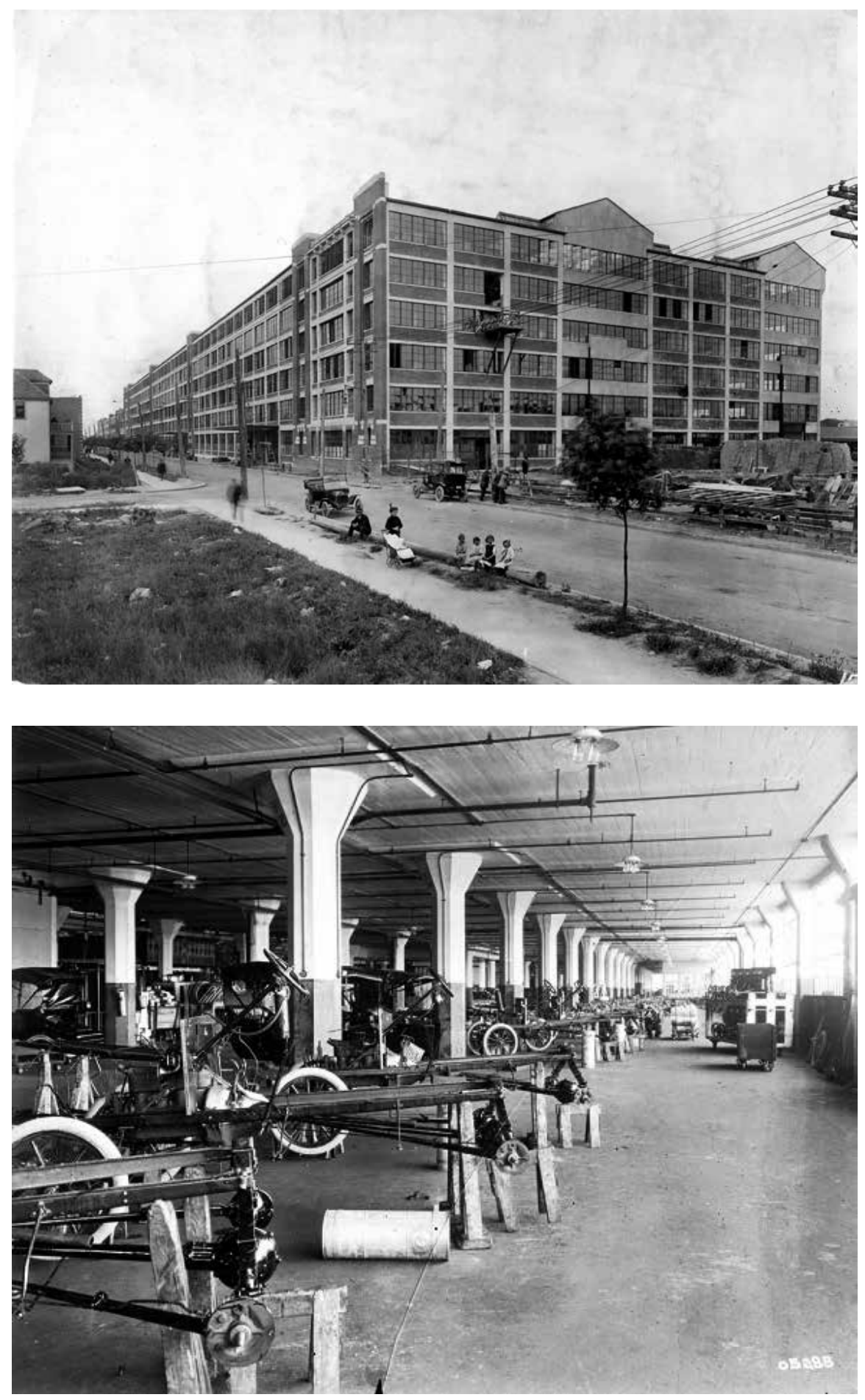

Fig. 78 Edifício de montagem da fábrica Ford Highland Park New Shop. Fonte: Albert Kahn Associates Records, Bentley Library, University of Michigan.

Fig. 79 Interior do edifício de montagem da fábrica Ford Highland Park Old Shop. Fonte: $<$ https://modeltfordfix.com/fords-highland-park-manufacturing-plant/> Acesso 28 mai 2018. 

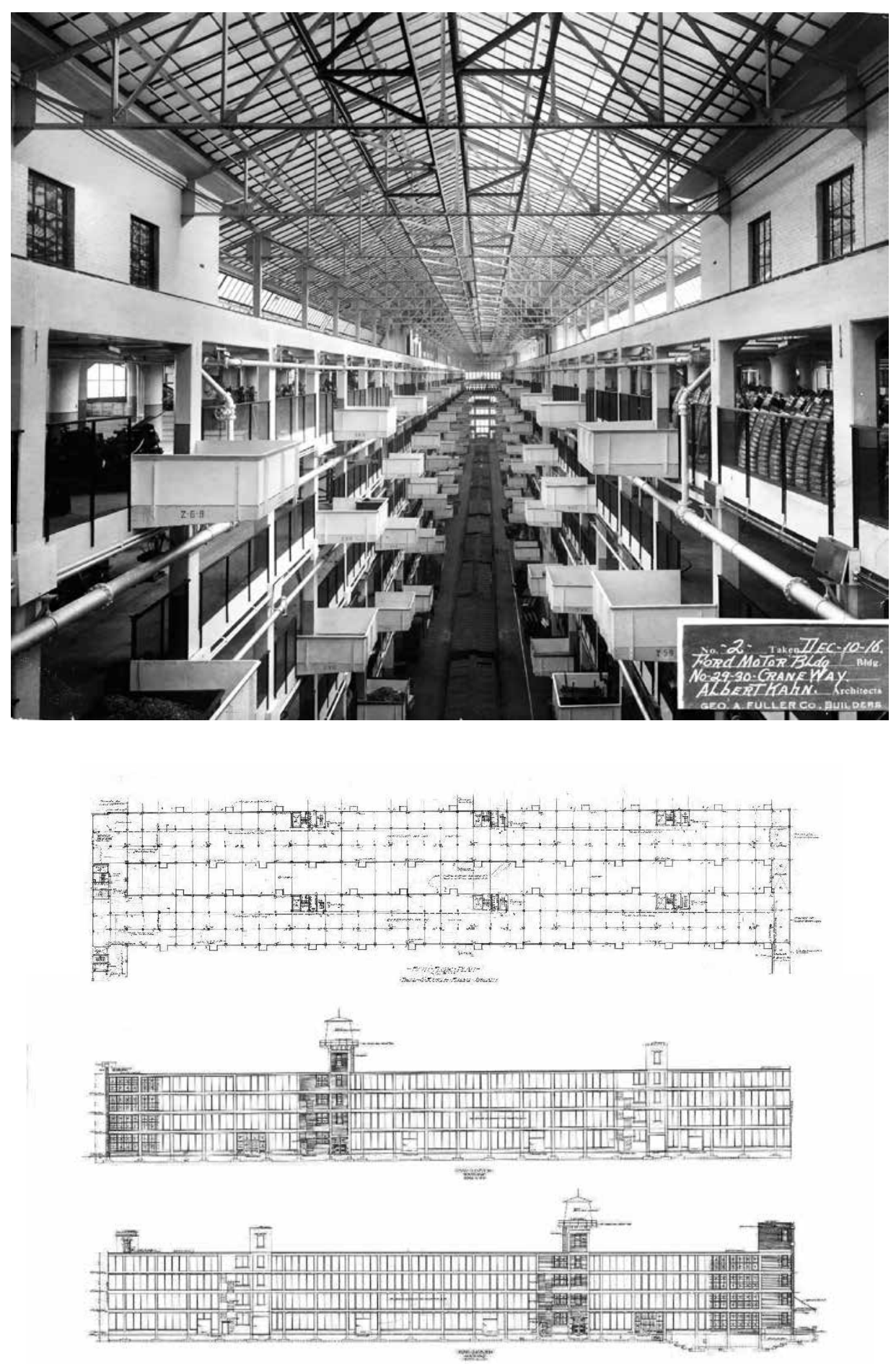

Fig. 80 Vista do pátio da fábrica Ford Highland Park New Shop. Fonte: Albert Kahn Associates Records, Bentley Library, University of Michigan.

Fig. 81 Planta baixa da fábrica Ford Highland Park New Shop. Fonte: Pancorbo (2016)

Fig. 82 Fachada frontal da fábrica Ford Highland Park New Shop. Fonte: Pancorbo (2016) 
Embora a inauguração da New Shop tivesse menos repercussão do que a da Old Shop, sua conclusão significou muito para a Ford Motor Company e para a indústria automobilística em geral. Apesar dos edifícios manterem as proporções tradicionais da daylight factory, ou seja, serem alongados e de múltiplos pavimentos, as inovações tecnológicas e gerenciais instauradas no interior da New Shop superaram a aparência mais tradicional.

A adaptação progressiva do projeto arquitetônico de Kahn a uma série de funções muito específicas, todas derivadas das necessidades da produção da linha de montagem que estava sendo implementada simultaneamente em seu interior, atingiu o ponto culminante na New Shop de Highland Park. Essa fábrica seria o último edifício vertical projetado por Kahn seguindo os critérios da racionalidade. A New Shop foi superada pelo maior complexo fabril construído pela Ford Motor Company, o River Rouge. 


\subsection{AS ESTRUTURAS METÁLICAS DE ALBERT KAHN}

Todas as questões práticas que envolveram a implementação da linha de montagem e o crescimento futuro de um edifício fabril forçaram uma mudança no projeto da estrutura. Comparado com o concreto armado, a construção em aço permitia estruturas mais leves capazes de vencerem vãos maiores. Além do mais, a construção rápida possibilitada pela estrutura metálica - pois o aço não exigia fôrma ou tempo de secagem - significava que a fábrica poderia entrar em operação mais cedo, algo que, do ponto de vista econômico, era uma vantagem considerável para a indústria. Portanto, a partir do projeto do complexo da Ford River Rouge, Kahn abandonou definitivamente a estrutura vertical de concreto armado para passar a construir fábricas com estruturas metálicas de um único pavimento.

As vantagens da construção em concreto armado, entre as quais a proteção contra incêndio, a capacidade de reduzir a vibração e a resistência à corrosão, eram importantes em edifícios verticais. Nas fábricas de apenas um pavimento, contudo, essas vantagens perderam relevância. A vibração das máquinas não era significativa, uma vez que elas estavam localizadas em uma superfície diretamente apoiada sobre 
o solo. Além disso, a distribuição de máquinas e sistemas de transporte interno era mais flexível quanto maiores fossem as dimensões dos vãos. Embora os vãos de concreto pudessem ter grandes dimensões, o peso da estrutura tornava-se desproporcional para grandes vãos.

Em se tratando das fábricas com estrutura metálica projetadas por Kahn, o primeiro exemplo selecionado foi a Forge Shop da Packard Motor Car Company, em Detroit, construída em 1911. Além de ser o primeiro edifício em que Kahn utilizou uma estrutura metálica, é também interessante do ponto de vista estrutural, porque possui, além de todas as características comuns à linha genealógica a que pertence, uma relação mais sutil entre o fechamento e a estrutura. Outro exemplo paradigmático e seminal é o complexo fabril da Ford River Rouge. Dentro deste conjunto, a Fábrica de Vidros, construída em 1922, foi escolhida pela sua importância, especialmente no que se refere ao desaparecimento das plantas baixas nos projetos do escritório do arquiteto, além de constituir em um exemplo mais refinado na relação entre a estrutura e o fechamento.

A fábrica soviética de tratores da Amtorg Trading Corporation, em Stalingrado, União Soviética, construída em 1930, foi selecionada por sua importância histórica. Não só serve para ilustrar a aventura soviética de Albert Kahn, mas também lembra que uma das causas, e provavelmente a principal, da famosa Batalha de Stalingrado ${ }^{135}$, foi a presença da fábrica de tratores projetada por Kahn, a qual, na época, tinha sido transformada em fábrica de tanques para a Segunda Guerra Mundial.

Nestes edifícios com estrutura metálica, as ferramentas de projeto e os métodos de construção da engenharia ferroviária americanas do século XIX foram traduzidos e importados para a arquitetura. As ferramentas iam desde o uso de balanço ou viga contínua até os métodos de utilização de soluções de juntas e articulações. Dentro deste conjunto de obras, a ampliação da fábrica de montagem de aviões bombardeiros da Companhia Glenn L. Martin, em Baltimore, Maryland, construída em 1937, foi selecionada. Esta família também inclui a fábrica de caminhões da Chrysler, em Warren, Michigan, de 1937, a qual é considerada o exemplo mais refinado do uso do balanço estrutural.

135 A Batalha de Stalingrado durou pouco mais de seis meses, do fim de julho de 1942 até 2 de fevereiro de 1943, e foi talvez a batalha mais sangrenta da Segunda Guerra Mundial, deixando aproximadamente 1,5 milhões de mortos. Além disso, constituiu um ponto decisivo para o término da Segunda Guerra Mundial. Ver: WERTH, A. Stalingrado: 1942, o início do fim da Alemanha nazista. São Paulo: Contexto, 2015. 
Finalmente, para representar as fábricas com estrutura metálica de enorme extensão horizontal, o exemplo escolhido foi a fábrica de aviões bombardeiros para a Ford Motor Company de Willow Run, em Ypsilanti, Michigan, construída em 1941, que representa a apoteose do gênero e foi um dos últimos projetos realizados por Kahn antes de sua morte, ocorrida no ano de 1942. 


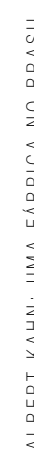

\section{FORGE SHOP PACKARD MOTOR CAR}

\section{1}

COBERTURA

treliça metálica

02

FECHAMENTO LATERAL

concreto e vidro

03

ESTRUTURA

metálica

maior vão $21,94 \mathrm{~m}$

Fig. 83 Diagrama da Packard Forge Shop 
3.2.1 Forge Shop (1911)

Packard Motor Car Company / Detroit, Michigan

Construído em 1911, o edifício Forge Shop da Packard significou para Albert Kahn o início de uma pesquisa sobre sistemas integrais que resolvessem simultaneamente estrutura, iluminação e ventilação, busca esta que se tornaria seu principal interesse a partir de então. A aplicação direta da solução encontrada, considerando critérios utilitários, econômicos e funcionais, direcionou-se para um novo tipo arquitetônico, buscando outras formas completamente desprovidas de qualquer apelo estético além de sua própria lógica construtiva. ${ }^{136}$

A Forge Shop expressou o resultado da natureza muito dinâmica da indústria. $\mathrm{O}$ interesse do projeto se concentrou em aspectos práticos, como o futuro crescimento e extensão da fábrica, além da melhoria das instalações e as possibilidades de iluminação e ventilação naturais. A grande investigação arquitetônica relacionava-se com os elementos constituintes de um módulo, que podiam ser repetidos em uma extensão indeterminada. Do contrário, se isso não fosse levado em consideração, as fábricas logo estariam desatualizadas e obsoletas, uma vez que a indústria estava em crescimento constante.

O novo edifício da Forge Shop rompeu drasticamente com o formato típico dos edifícios do restante do complexo da Packard. Ao contrário dos prédios vizinhos, possuía apenas um pavimento e foi construído com a estrutura metálica, que já estava disponível em uma ampla variedade de formas e a um custo competitivo. O projeto linear do edifício, com 372 pés $(113,38 \mathrm{~m})$ de comprimento por 72 pés $(21,94 \mathrm{~m})$ de largura, facilitava o crescimento da fábrica, simplificava os detalhes e evitava o projeto de peças especiais.

A construção de uma nave única, em que a cobertura era leve e transparente, assim como grande parte das paredes longitudinais, favorecia, em termos de rapidez, custos e material, a construção apoiada em pórticos metálicos transversais. As treliças estavam posicionadas transversalmente, em intervalos de 16 pés $(4,87 \mathrm{~m}) \mathrm{e}$ apoiadas nos pilares das fachadas. Os pórticos, por sua vez, eram travados entre eles por tirantes no sentido longitudinal, que davam estabilidade lateral contra cargas decorrentes do vento.

136 HILDEBRAND, G. Designing for Industry: The Architecture of Albert Kahn. Cambridge, Massachusetts: MIT Press, 1974, p. 52. 
O interior da Forge Shop era moldado e estruturado a partir do movimento da ponte rolante, que se deslocava por toda a extensão da fábrica. A ponte rolante permitia o deslocamento de qualquer objeto de grandes dimensões e peso entre quaisquer dois pontos da área coberta do edifício. $\mathrm{O}$ vão livre entre as paredes periféricas longitudinais era de 72 pés $(21,94 \mathrm{~m})$, permitindo que, no centro deste espaço, apoiado no sistema de balanço da cobertura, corresse a ponte rolante, com 38 pés $(11,58 \mathrm{~m})$ de largura e cerca de dez toneladas de peso. ${ }^{137} \mathrm{O}$ ponto crucial do problema era estruturar a ponte rolante de 38 pés de largura ao longo do centro do espaço com vão livre de 72 pés de largura e, portanto, sem pilares. A solução adotada foi a suspensão da ponte rolante no pórtico, resultando em um espaço livre de apoios na zona de produção. Como Hildebrand afirmou, "his work was more analogous to the actual turbine, racing car, or shoelast machinery than to the Europeans'consciously symbolic interpretation of any of these" ${ }^{\text {"138. }}$.

A família tipológica do edifício Forge Shop era proveniente da combinação e mutação dos edifícios da arquitetura ferroviária. ${ }^{139}$ A título de características gerais, esses edifícios tinham uma cobertura escalonada com estruturas sobrepostas, além da presença de claraboias centrais e laterais. Portanto, devido à configuração escalonada da cobertura da Forge Shop, a altura total de 45 pés $(13,71 \mathrm{~m})$ oferecida para iluminação e ventilação era bastante generosa. Este tipo de cobertura permitia a difusão homogênea da luz sobre os ambientes de trabalho, algo fundamental para as atividades muito meticulosas que ali eram exercidas. Proporcionalmente, $70 \%$ da superfície vertical da fábrica era envidraçada e 50\% poderia ser aberta para ventilação. ${ }^{140} \mathrm{~A}$ possibilidade de se abrirem esquadrias de vidro garantia ventilações cruzadas entre as aberturas das fachadas e das laterais da claraboia. Dessa maneira, uma constante ventilação natural era garantida, especialmente nas zonas de trabalho mais expostas a altas temperaturas devido aos maçaricos e fornos em atividade constante.

Igualmente interessantes são as linhas projetadas para indicar os caminhos da iluminação e ventilação naturais no corte apresentado pelo escritório de Albert Kahn. Eles não parecem ser inteiramente científicos ou precisos, eis que as linhas responsáveis por indicar a luz natural foram aparentemente desenhadas para

137 HYDE, C. K. Assembly-Line Architecture: Albert Kahn and the evolution of the U.S. Auto Factory, 1905-1940. In: IA - The Journal of the Society for Industrial Archeology, v. 22, n. 2, 1996, p. 14.

138 Tradução da autora: "o trabalho de Albert Kahn era mais análogo à turbina ou ao carro de corrida do que à interpretação simbólica das fábricas que construíram os arquitetos europeus.” Em: HILDEBRAND, G. Designing for Industry: The Architecture of Albert Kahn. Cambridge, Massachusetts: MIT Press, 1974, p. 67.

139 Para maiores detalhes comparativos com a arquitetura ferroviária, olhar a tese de Luiz Pancorbo. Ver: PANCORBO, L. Arquitectura industrial de Albert Kahn Inc. 1900-42. La arquitectura como objeto técnico. Tese (Doutorado em Proyectos Arquitectónicos). Escuela Técnica Superior de Arquitectura - Universidad Politécnica de Madrid. Madrid: ETS Arquitectura, 2016, p. 76.

140 HILDEBRAND, G. Designing for Industry: The Architecture of Albert Kahn. Cambridge, Massachusetts: MIT Press, 1974, p. 55. 

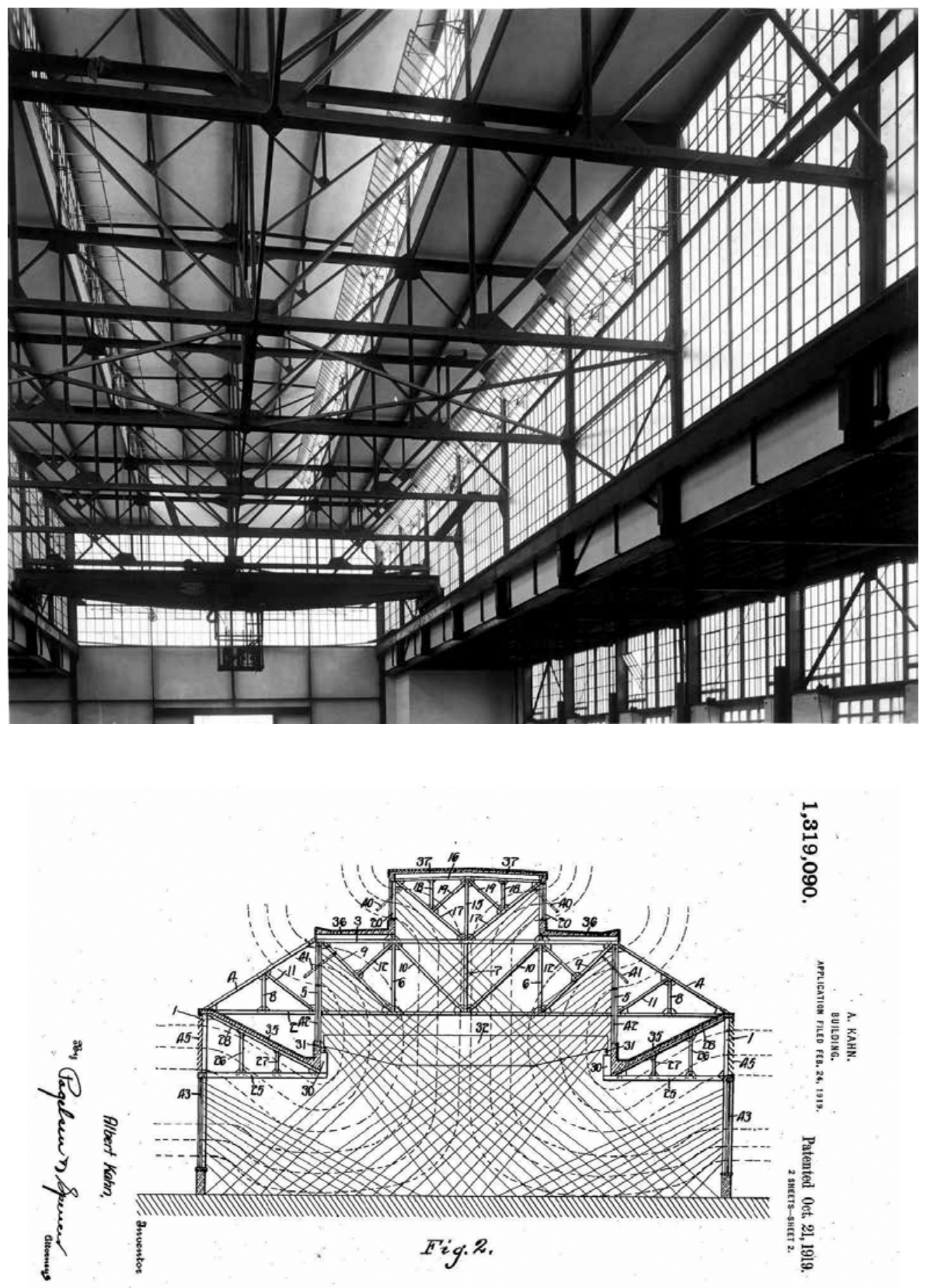

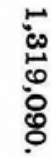

Fig. 84 Interior do edifício da Packard Forge Shop.

Fonte: Albert Kahn Associates Records, Bentley Library, University of Michigan.

Fig. 85 Corte transversal da Packard Forge Shop.

Fonte: Albert Kahn Associates Records, Bentley Library, University of Michigan. 

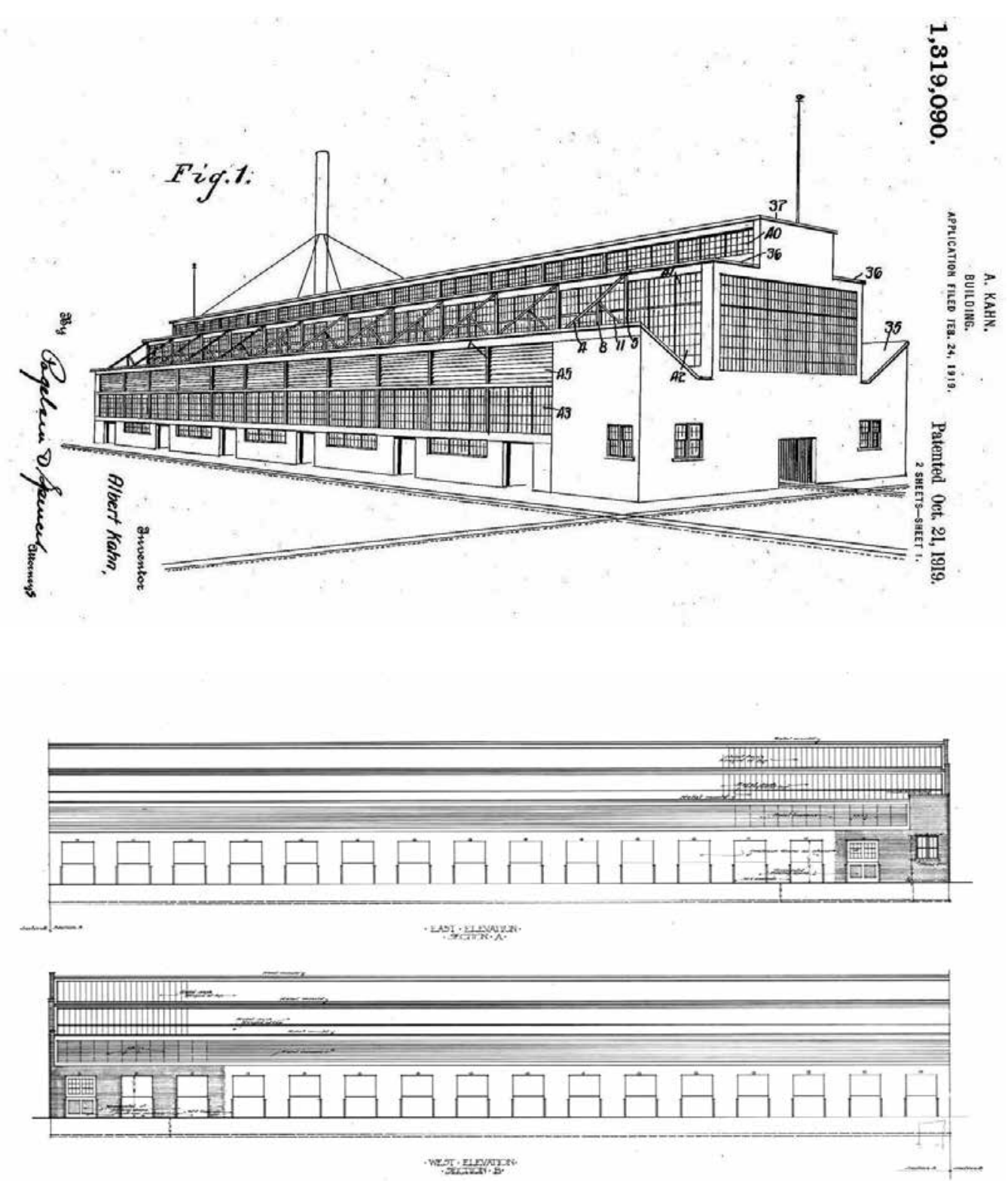

Fig. 86 Perspectiva da Packard Forge Shop. Fonte: Pancorbo (2016)

Fig. 87 Fachada da Packard Forge Shop.

Fonte: Pancorbo (2016) 


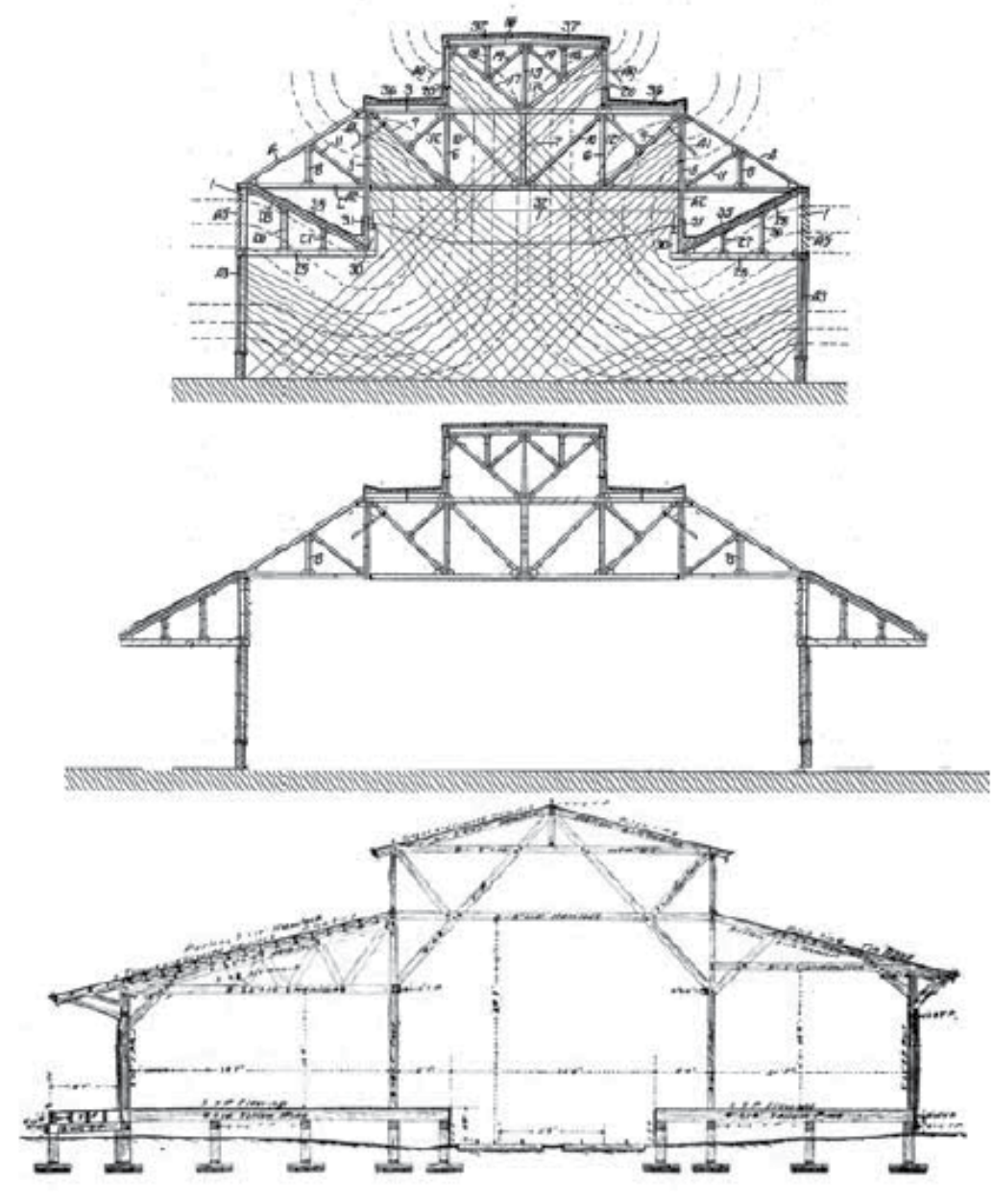

Fig. 88 Possível evolução estrutural a partir do corte transversal da Packard Forge Shop. Desenho inferior: Estação de Newark, NJ, da Leigh Valley Railroad Company (1892). Fonte: Pancorbo (2016) 
conectar as áreas de vidro com pontos equidistantes, os quais estavam espaçados de forma arbitrária no chão. Contudo, fornecem evidências indiscutíveis da preocupação consciente de Kahn com essas qualidades e, ao menos, são uma tentativa protocientífica de analisá-las. De acordo com Hildebrand, "his imagination and ability have seldom appeared more brilliantly than in this sectional drawing"141.

Analisando-se as fotografias existentes, a qualidade da luz resultante aparentava ser excelente. Todas as janelas e claraboias mostradas no corte corriam continuamente de uma extremidade à outra do prédio, pressagiando as contínuas fenestrações horizontais das fábricas posteriores de Kahn. Vale salientar que o desenho do sistema de claraboias e a sua estrutura metálica de apoio não correspondem às fotografias existentes do que foi efetivamente construído. ${ }^{142}$

A Forge Shop da Packard representa uma tipologia que viria a ser adotada por Albert Kahn e Henry Ford no complexo industrial da Ford River Rouge a partir de 1917, ocasião em que o edifício em concreto armado foi abandonado em favor da fábrica de pavimento único, de pé-direito alto e grandes vãos, permitindo, assim, o funcionamento de enormes maquinários, os quais dificilmente caberiam nos edifícios precedentes.

141 Tradução da autora: "Sua imaginação e habilidade raramente apareceram de forma mais brilhante do que neste corte." Em: Em: HILDEBRAND, G. Designing for Industry: The Architecture of Albert Kahn. Cambridge, Massachusetts: MIT Press, 1974, p. 55.

142 Ocorreram alterações na construção, sobretudo na estrutura das treliças metálicas de apoio à cobertura e à ponte rolante. Ver: PANCORBO, L. Arquitectura industrial de Albert Kahn Inc. 1900-42. La arquitectura como objeto técnico. Tese (Doutorado em Proyectos Arquitectónicos). Escuela Técnica Superior de Arquitectura - Universidad Politécnica de Madrid. Madrid: ETS - Arquitectura, 2016, p. 200-204. 
FÁBRICA DE VIDROS FORD RIVER ROUGE

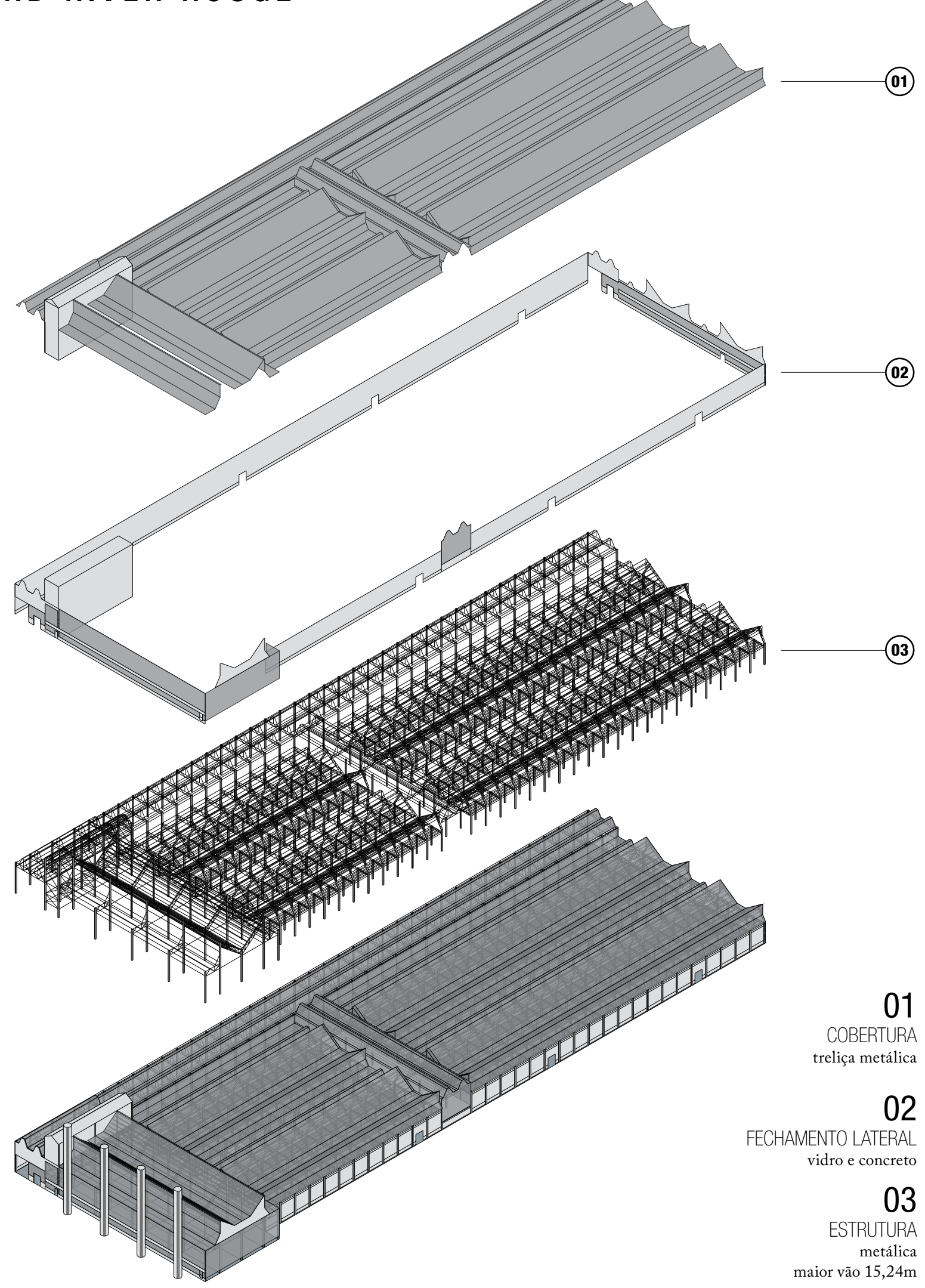




\subsubsection{Fábrica de vidros - River Rouge (1922) Ford Motor Company / Dearborn, Michigan}

Com o projeto do complexo fabril da Ford River Rouge, Albert Kahn iniciou, então, o desenvolvimento da estrutura para a padronização de soluções no edifício industrial - não de fórmulas fixas, mas da sistematização de um método e critérios de projeto. Dentro do complexo de River Rouge, a Fábrica de Vidros, projeto de 1922, tornou-se o protótipo dos edifícios da Ford na década de 1920. É um edifício de grande importância, tanto para a carreira de Kahn quanto para a história da arquitetura industrial. ${ }^{43}$

O projeto da Fábrica de Vidros foi uma resposta à intenção de integrar a estrutura e os sistemas de fechamento com a distribuição, na planta baixa, das máquinas e dos processos de fabricação, além de atender as necessidades de luz e ventilação. Esses aspectos já tinham tomado forma na Forge Shop da Packard, sendo agora melhorados.

Nesse projeto, o corte se tornou pela primeira vez o único elemento definidor do edifício e, principalmente, da estrutura. A planta baixa não condicionava mais que o mínimo no projeto, sendo reduzida a um esquema de eixos numerados e ao desenho das máquinas e dos fluxos que dependiam dela. A fachada também foi integrada ao corte, composta de uma membrana respirável, com partes móveis como brânquias, permitindo, assim, a ventilação adequada dos processos que ocorriam no interior. ${ }^{144}$

Kahn criou uma fábrica retangular, de 760 pés $(231,64 \mathrm{~m})$ no sentido nortesul por 240 pés $(73,15 \mathrm{~m})$ no sentido leste-oeste, exceto pelo fato de que existia um pequeno acréscimo na parte sul do edifício de 20 pés $(6,09 \mathrm{~m})$ por 100 pés $(30,48 \mathrm{~m})$, envolvendo a estrutura de aço inteiramente com vidro. $\mathrm{O}$ fechamento da fábrica se tornou uma pele que não permitia distinguir onde terminava ou começava a fachada e a cobertura. Era um edifício completamente tectônico e que não expressava essa condição no seu aspecto externo.

O volume da fábrica não era puro nem platônico, pois era tão complexo quanto o espaço interior determinava. A fábrica era dividida, basicamente, em três

143 HILDEBRAND, G. Designing for Industry: The Architecture of Albert Kahn. Cambridge, Massachusetts: MIT Press, 1974, p. 100-101.

144 A profusão de cortes no projeto é extraordinária, sendo o documento que claramente domina em quantidade quando comparado a plantas baixas e fachadas. Ver: PANCORBO, L. Arquitectura industrial de Albert Kahn Inc. 1900-42. $\mathrm{La}$ arquitectura como objeto técnico. Tese (Doutorado em Proyectos Arquitectónicos). Escuela Técnica Superior de Arquitectura - Universidad Politécnica de Madrid. Madrid: ETS - Arquitectura, 2016, p. 153. 
zonas: um espaço retangular de 200 pés $(60,96 \mathrm{~m})$ por 660 pés $(201,16 \mathrm{~m})$, que abrigava as linhas de processamento, dispostas na direção norte-sul; um volume mais alto de 100 pés $(30,48 \mathrm{~m})$ por 218 pés $(66,44 \mathrm{~m})$, onde ficavam os quatro grandes fornos dispostos no extremo sul; e, finalmente, uma faixa na lateral oeste, de 40 pés $(12,19 \mathrm{~m})$ por 760 pés $(231,64 \mathrm{~m})$, que abrigava a linha de trem, responsável pela carga e descarga de matérias-primas dentro da fábrica ${ }^{145}$. Acima das linhas de processamento, uma galeria suspensa de 40 pés $(12,19 \mathrm{~m})$ de largura cruzava a fábrica de forma transversal, contendo os banheiros, os vestiários e as áreas de supervisão da produção, estando suspensa a uma altura de 19 pés $(5,79 \mathrm{~m})$ em relação ao piso.

Em termos de vãos, o módulo estrutural transversal era de 20 pés $(6,09 \mathrm{~m})$. No sentido longitudinal, o módulo estrutural alternava entre 36 pés $(10,97 \mathrm{~m})$ e 14 pés $(4,26 \mathrm{~m})$. Ainda longitudinalmente, na área sobre os trilhos do trem, o vão era de 40 pés $(12,19 \mathrm{~m})$. A área que abrigava os 4 fornos possuía vãos longitudinais de 50 pés $(15,24 \mathrm{~m})$ e transversais de 20 pés $(6,09 \mathrm{~m})$ e 30 pés $(9,14 \mathrm{~m})$. A linearidade da estrutura deve-se ao processo de fabricação do vidro que foi desenvolvido pela Ford, a partir da década de 1920, para suprir a falta de continuidade na produção de vidro daquela época. ${ }^{146}$

A estrutura da cobertura sobre a área de processamento variava entre dois tipos de claraboias, uma menor sobre o vão de 36 pés (A) e outra maior, em formato borboleta, sobre o vão de 64 pés (B). As claraboias se alternavam em uma sequência A-B-A-B, totalizando 200 pés $(60,96 \mathrm{~m})$ de largura. $\mathrm{Na}$ área de processamento, o vão de 64 pés (B) era subdividido em vãos de 14, 36 e 14 pés respectivamente, que configuravam as larguras necessárias para abrigar as linhas de produção. Essas treliças longitudinais tinham a sua base a uma altura de 18 pés $(5,48 \mathrm{~m})$ do piso da fábrica.

O sistema de claraboias alternadas sobre o processamento era interrompido apenas pela galeria suspensa, cuja cobertura continha duas pequenas claraboias sobre o vão de 40 pés $(12,19 \mathrm{~m})$, ambas na direção leste-oeste. Do lado oeste, o trilho de trem, responsável pelo transporte de materiais, era coberto por um sistema similar de dupla claraboia, com pé-direito de 31 pés $(9,44 \mathrm{~m})$, que correspondia à mesma

\footnotetext{
145 Os trabalhadores não se moviam dentro da fábrica; todo o processo de fabricação linear se deslocava até os operários. Ver: PANCORBO, L. Arquitectura industrial de Albert Kahn Inc. 1900-42. La arquitectura como objeto técnico. Tese (Doutorado em Proyectos Arquitectónicos). Escuela Técnica Superior de Arquitectura - Universidad Politécnica de Madrid. Madrid: ETS - Arquitectura, 2016, p. 153.

146 Para saber mais sobre a indústria e a produção do vidro, consultar: $\leq$ http://www2.fau.usp.br/deptecnologia/docs/ bancovidros/prodvidro.htm> Acesso: 15 dez 2018.
} 

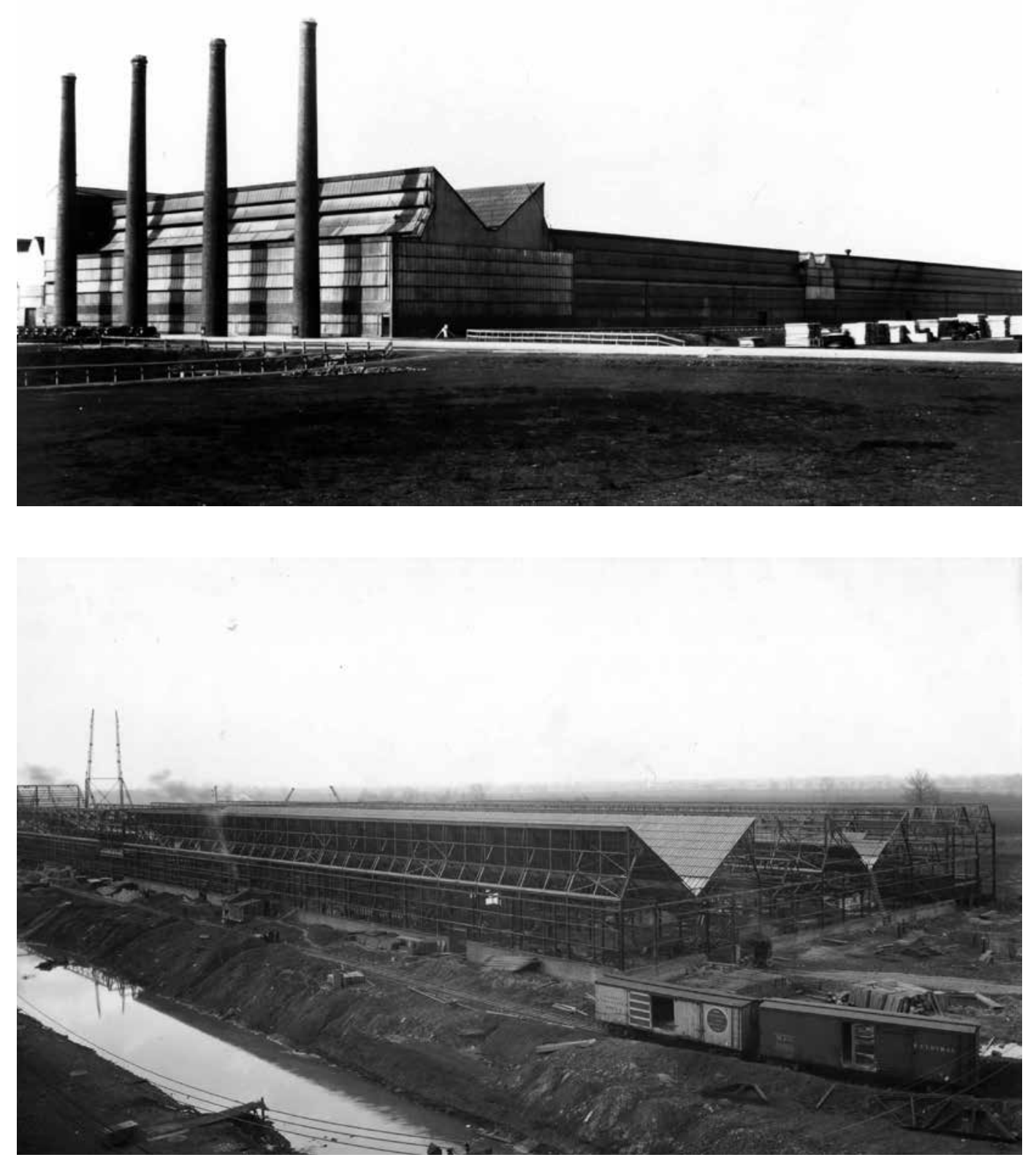

Fig. 90 Exterior da Fábrica de vidros da Ford River Rouge. Fonte: Albert Kahn Associates Records, Bentley Library, University of Michigan.

Fig. 91 Fábrica de vidros da Ford River Rouge, em construção. Fonte: Albert Kahn Associates Records, Bentley Library, University of Michigan. 

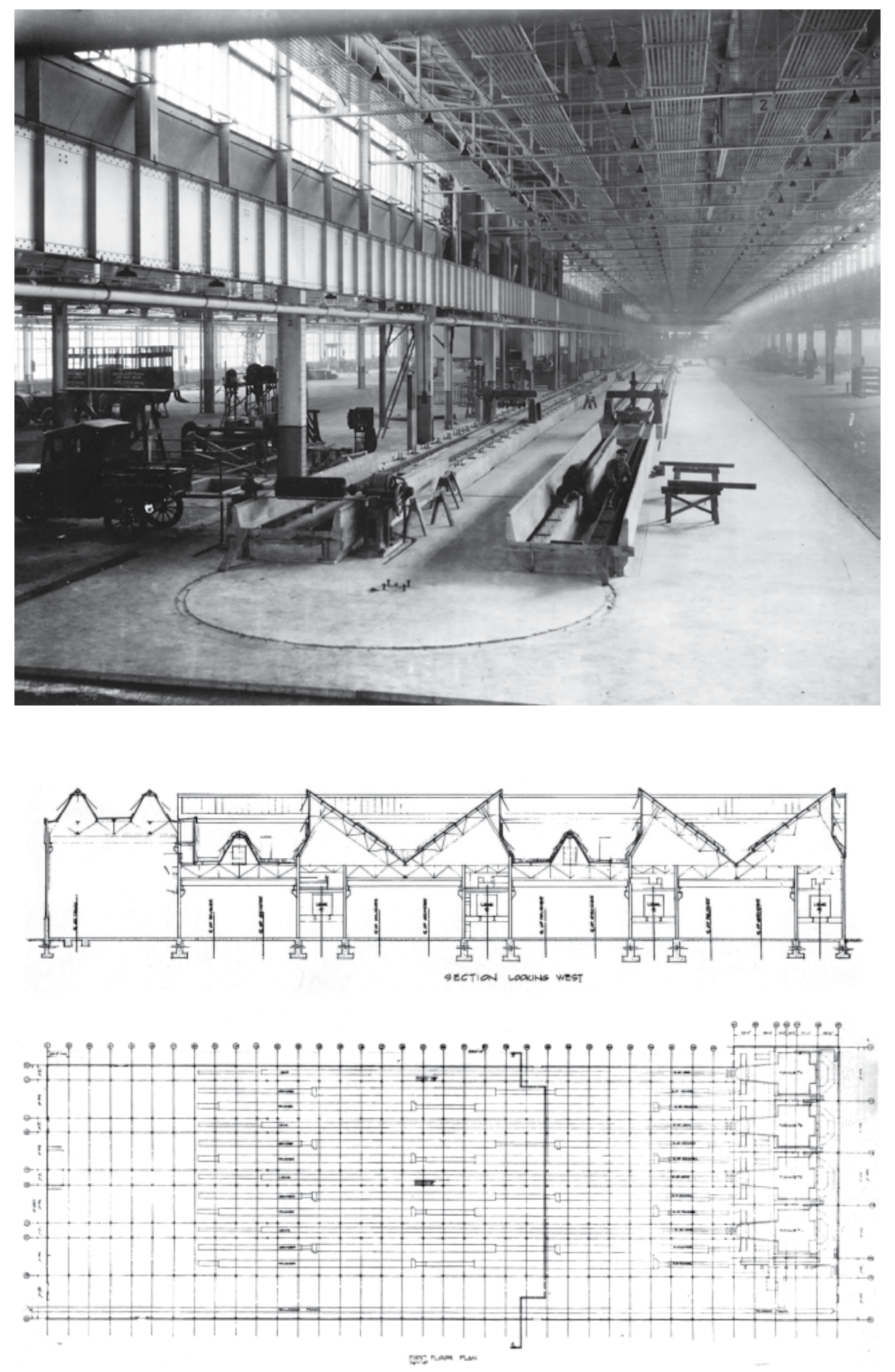

Fig. 92 Interior da Fábrica de vidros da Ford River Rouge. Fonte: Albert Kahn Associates Records, Bentley Library, University of Michigan

Fig. 93 Corte transversal da Fábrica de vidros da Ford River Rouge. Fonte: Hildebrand (1975)

Fig. 94 Planta baixa da Fábrica de vidros da Ford River Rouge. Fonte: Hildebrand (1975) 
altura da cobertura sobre a galeria suspensa. Todas as extremidades inferiores das treliças se apoiavam de maneira direta em pilares, adicionalmente enrijecidas pelo contraventamento na parte inferior das treliças.

No extremo sul, os fornos de fabricação de vidro elevavam ainda mais a altura livre para assegurar a correta dissipação de gases e calor, podendo estes escaparem através de contínuas extensões de esquadrias móveis de 25 pés (7,62m) de altura. Nesta área, a cobertura, também em formato borboleta, possuía uma linha de pilares na parte inferior do encontro entre as duas partes inclinadas, diminuindo de forma considerável o vão livre. Próximo aos fornos, externamente, na fachada sul, apareciam quatro grandes chaminés, as quais ilustravam a maioria das publicações referentes ao projeto, tais como nos livros de Ferry (1970), Hildebrand (1974) e Bucci (1993).

Toda a estrutura era metálica e a cobertura foi construída com diferentes tipos de vigas treliçadas. Em busca de funcionalidade interna e de ótimo condicionamento do espaço, Kahn utilizou claraboias na cobertura, que não só permitiam a entrada de luz como ainda ofereciam uma boa ventilação, algo imprescindível para o processo de produção. ${ }^{147}$ As atividades realizadas em temperaturas mais altas e que, portanto, precisavam de maior dissipação de calor, encontravam-se cobertas com claraboias altas. As linhas de produção em que a temperatura era mais baixa, e também os trabalhos manuais, os quais exigiam melhor iluminação, tinham uma claraboia baixa, garantindo, assim, o melhor desempenho das atividades. Para permitir uma boa ventilação, as aberturas das claraboias do telhado eram móveis no eixo horizontal superior e abriam para o exterior. Além do vidro, outro material utilizado na cobertura eram as placas de concreto, chamadas por Kahn, nos seus desenhos, de "cement tile".

Vale ressaltar que, na Fábrica de Vidros - assim como na Packard Forge Shop -, as claraboias se voltavam para as quatro direções cardeais. Isso se deve ao fato da distribuição de luz ser menos uniforme em fábricas onde somente a luz norte (em países localizados no hemisfério norte) era fornecida. Mais importante, em locais onde a parte envidraçada da claraboia estava voltada para a orientação norte, as linhas de produção deviam estar posicionadas em um certo ângulo em relação ao envidraçamento, algo que limitaria a flexibilidade de toda a fábrica. Tanto Ford quanto Kahn perceberam logo que os custos de tal limitação excediam

147 HYDE, C. K. Assembly-Line Architecture: Albert Kahn and the evolution of the U.S. Auto Factory, 1905-1940. In: IA - The Journal of the Society for Industrial Archeology, v. 22, n. 2, 1996, p. 15-17. 
os benefícios. Assim, as coberturas em formato de dente de serra desapareceram do trabalho de Kahn depois de $1920 .{ }^{148} \mathrm{O}$ arquiteto provavelmente fez isso porque não se concentrou na questão da iluminação de maneira isolada, mas reconheceu a gama de necessidades que afetavam o projeto da fábrica.

A estrutura parece complexa, como de fato é, mas o que deve ser observado é o alto grau de integração entre o processo de fabricação, os equipamentos necessários para atendê-lo, as necessidades de luz e de ventilação e a forma do edifício. Quanto mais se estuda a qualidade dessa integração, mais sofisticada e fascinante ela se torna.

O invólucro da Fábrica de Vidro consistia em grandes placas de aço e vidro. A mesma superfície se estendia ininterruptamente pela frente da estrutura para simplificar e minimizar as técnicas de união, resultando na construção de um volume simples e econômico. As fachadas existiam apenas como um fechamento das seções estruturais, demonstrando a preocupação de Kahn com o caráter extensível e potencialmente infinito da fábrica. A fachada sul, que abrigava os fornos, era a única de caráter mais permanente, devido às necessidades do processo produtivo e porque, para expandir infinitamente, apenas um lado seria necessário.

Além do aço e do vidro, utilizados em faixas horizontais de grandes extensões, havia uma base de alvenaria de tijolos. Essa base variava em altura nas fachadas, mas nunca ultrapassava a altura de 14 pés $(4,26 \mathrm{~m})$. Os revestimentos da fachada estavam afastados da linha dos pilares estruturais e, portanto, não se apoiavam neles. Para resistir às cargas originadas pelo vento, tirantes foram posicionados em vãos alternados das fachadas, situados dentro do plano da esquadria. ${ }^{149}$

A membrana externa do espaço fabril perdeu qualquer relação com a arquitetura tradicional e os seus elementos convencionais. Não existiam portas ou janelas, mas apenas um plano contínuo, que nada mais era do que uma série de escamas móveis longitudinais sobrepostas externamente à estrutura em todos os seus planos. Os elementos móveis permitiam o controle total das condições de iluminação e ventilação da fábrica. Essas decisões relativas à racionalização da construção envolveram medidas econômicas significativas, tais como a construção mais rápida e a possibilidade de futura ampliação. Na década seguinte, o estudo do envoltório nas fábricas tornar-se-ia o foco dos esforços de Albert Kahn.

148 HILDEBRAND, G. Designing for Industry: The Architecture of Albert Kahn. Cambridge, Massachusetts: MIT Press, 1974, p. 108.

149 Ibid, p. 101-109. 


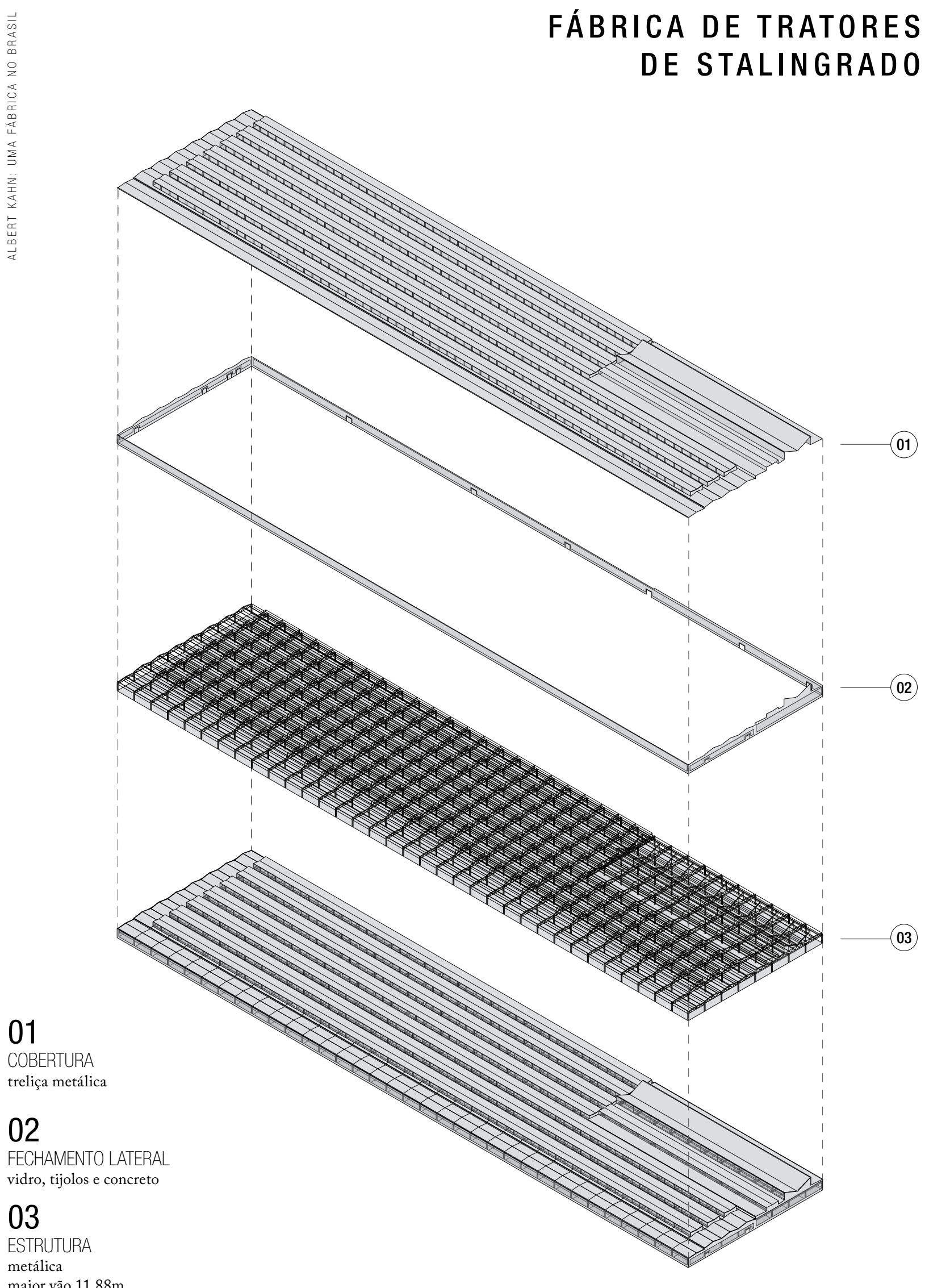

metálica

maior vão $11,88 \mathrm{~m}$

Fig. 95 Diagrama da Fábrica de tratores de Stalingrado.

Fonte: Arquivo pessoal da autora, 2019. 
3.2.3 Fábrica de tratores (1930).

Amtorg Trading Corporation / Stalingrado, União Soviética

Em meados da década de 1920, o governo soviético tomou a decisão de construir uma fábrica de tratores grande e moderna. $\mathrm{O}$ local da futura fábrica localizava-se na cidade russa de Stalingrado, a qual se estende por cerca de 80 quilômetros ao longo da margem ocidental do rio Volga. Em 1929, através do acordo assinado com a Amtorg Trading Corporation, Kahn iniciou o projeto da fábrica de tratores.

O escritório de Kahn tornou-se o responsável pelos desenhos arquitetônicos e de engenharia da fábrica, incluindo o acesso rodoviário e ferroviário. Ele também ajudaria na aquisição de materiais de construção, máquinas e equipamentos americanos. Todos os componentes da construção, entre os quais a estrutura e o fechamento externo de vidro, foram fornecidos por empresas americanas, pois ainda não existiam fabricantes nacionais. ${ }^{150}$

A fábrica de Stalingrado foi a primeira das três grandes fábricas soviéticas de tratores projetadas pelo escritório de Albert Kahn em tempo recorde. A capacidade anual da fábrica, planejada para ser de 20 mil tratores, foi em seguida aumentada para 50 mil. ${ }^{151} \mathrm{~A}$ precisão e o detalhamento eram itens extremamente importantes no projeto, com o intuito de evitar que qualquer ajuste no local fosse necessário, uma vez que a fábrica localizava-se a milhares de quilômetros de distância dos centros fornecedores de materiais.

A fábrica de tratores de Stalingrado foi concluída em seis meses ${ }^{152}$. Embora não tenha atingido a capacidade planejada até 1933, era a maior fábrica da União Soviética. O edifício de montagem consistia em um grande retângulo com 1326 pés $(404,16 \mathrm{~m})$ de comprimento no sentido nordeste-sudoeste por 312 pés $(95,09 \mathrm{~m})$ de largura no sentido noroeste-sudeste, dividindo-se em duas zonas principais: montagem e tratamento térmico.

A estrutura de aço, fabricada nos Estados Unidos e montada no local, era perfeitamente definida. As treliças venciam um vão padrão de 39 pés $(11,88 \mathrm{~m})$ em ambos os sentidos. Devido a essa regularidade, a planta baixa era composta e definida

150 MELNIKOVA-RAICH, S. The Soviet Problem with Two 'Unknowns': How an American Architect and a Soviet Negotiator Jump-Started the Industrialization of Russia, Part I: Albert Kahn. In: IA - The Journal of the Society for Industrial Archeology, v. 36, n. 2, 2010, p. 66.

151 Ibid, p. 58-59.

152 Ibid, p. 68. 

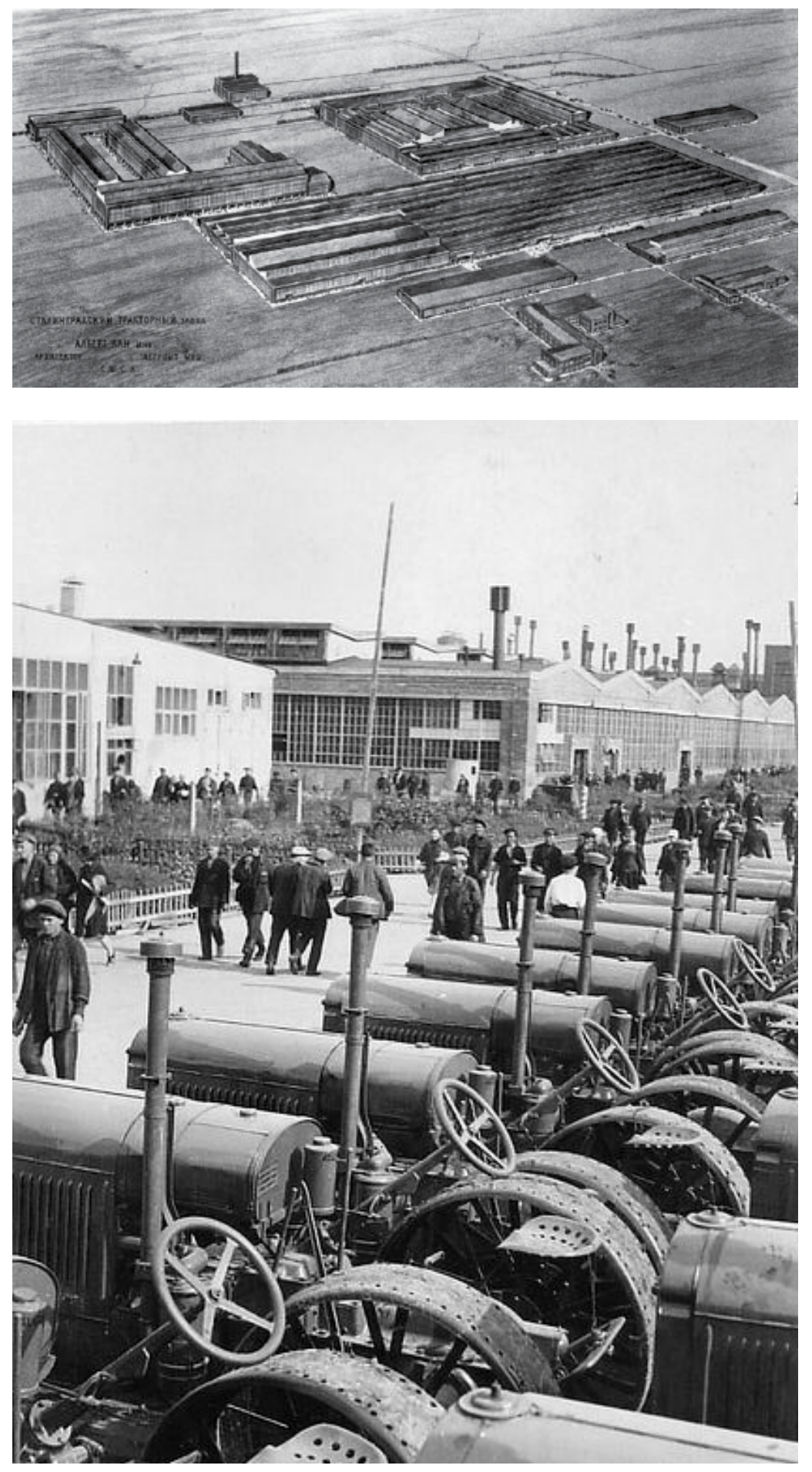

Fig. 96 Axonométrica da Fábrica de tratores de Stalingrado.

Fonte: Melnikova-Raich (2010)

Fig. 97 Exterior da Fábrica de tratores de Stalingrado.

Fonte: <https://br.pinterest.com/pin/469711436129393389/> Acesso 20 jan 19 

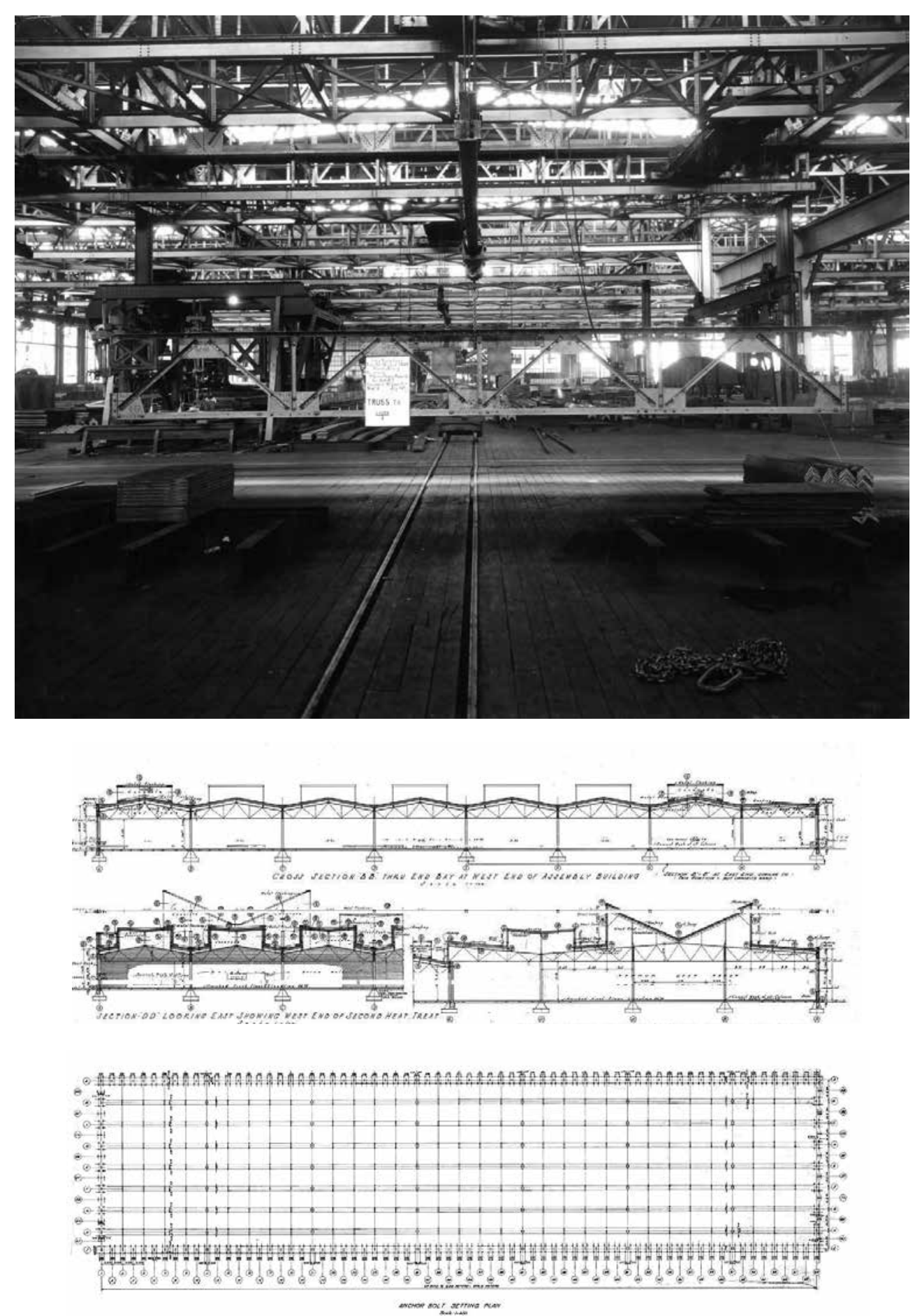

Fig. 98 Interior da Fábrica de tratores de Stalingrado.

Fonte: Albert Kahn Associates Records, Bentley Library, University of Michigan.

Fig. 99 Cortes transversais da Fábrica de tratores de Stalingrado. Fonte: Pancorbo (2016)

Fig.100 Planta baixa da Fábrica de tratores de Stalingrado Fonte: Pancorbo (2016) 
quase exclusivamente pelos eixos da estrutura e por uma linha que determinava o perímetro do limite do edifício. Por se tratar de uma solução modular e regular, a ferrovia passava externamente, cincundando todos os edifícios do complexo.

A cobertura, contudo, tinha diferentes configurações, conforme o zoneamento da fábrica. $\mathrm{Na}$ parte destinada ao tratamento térmico, na porção nordeste do edifício, a cobertura era mais alta em razão da necessidade de dissipação do calor. Em tal caso, a claraboia em formato borboleta gerava um plano vertical envidraçado, com orientação no sentido noroeste-sudeste. Nesse espaço, o vão livre até a treliça inferior era de 19 pés e 8 polegadas $(6 \mathrm{~m})$. Na área de montagem, que era a maior parte da fábrica, a cobertura possuía claraboias com a parte envidraçada também voltada para noroeste-sudeste. $\mathrm{O}$ piso era elevado em relação à área de tratamento térmico, resultando em uma altura livre de cerca de 13 pés $(4,25 \mathrm{~m})$.

As fachadas possuíam uma base regular de tijolos que, no encontro com as portas, se elevava, contornando-as como uma moldura. $\mathrm{O}$ coroamento do edifício também utilizava alvenaria de tijolos, ao mesmo tempo em que seguia o desenho da cobertura. A faixa central restante era composta por grandes esquadrias de vidro.

A fábrica de tratores de Stalingrado foi a primeira das enormes fábricas de tratores soviéticos que tinham a capacidade para produzir tanques. Ao visitarem a fábrica nos primeiros anos de funcionamento, engenheiros e especialistas americanos relataram que mudanças tinham sido realizadas para a fabricação de pequenos tanques, afirmando que a ênfase fora colocada na produção de tanques ao invés de tratores. ${ }^{153}$ No início da Segunda Guerra Mundial, a fábrica de tratores de Stalingrado já havia parcialmente mudado sua finalidade para a produção de tanques T-34/76 e, durante 1941 e 1942, tornou-se a principal fabricante de tanques T-34. A produção continuou até que as tropas alemãs invadiram a própria fábrica no final de 1942. Tornou-se um dos locais da crucial Batalha de Stalingrado onde, em janeiro de 1943, a vitória do Exército Vermelho sobre os nazistas mudou a maré da Segunda Guerra Mundial. Mesmo não tendo sido projetada com tal objetivo, de forma involuntária acabou por marcar o início dos projetos de Kahn para a indústria bélica.

153 MELNIKOVA-RAICH, S. The Soviet Problem with Two 'Unknowns': How an American Architect and a Soviet Negotiator Jump-Started the Industrialization of Russia, Part I: Albert Kahn. In: IA - The Journal of the Society for Industrial Archeology, v. 36, n. 2, p. 57-80, 2010, p. 67. 


\section{FÁBRICA DE CAMINHÕES DA CHRYSLER}

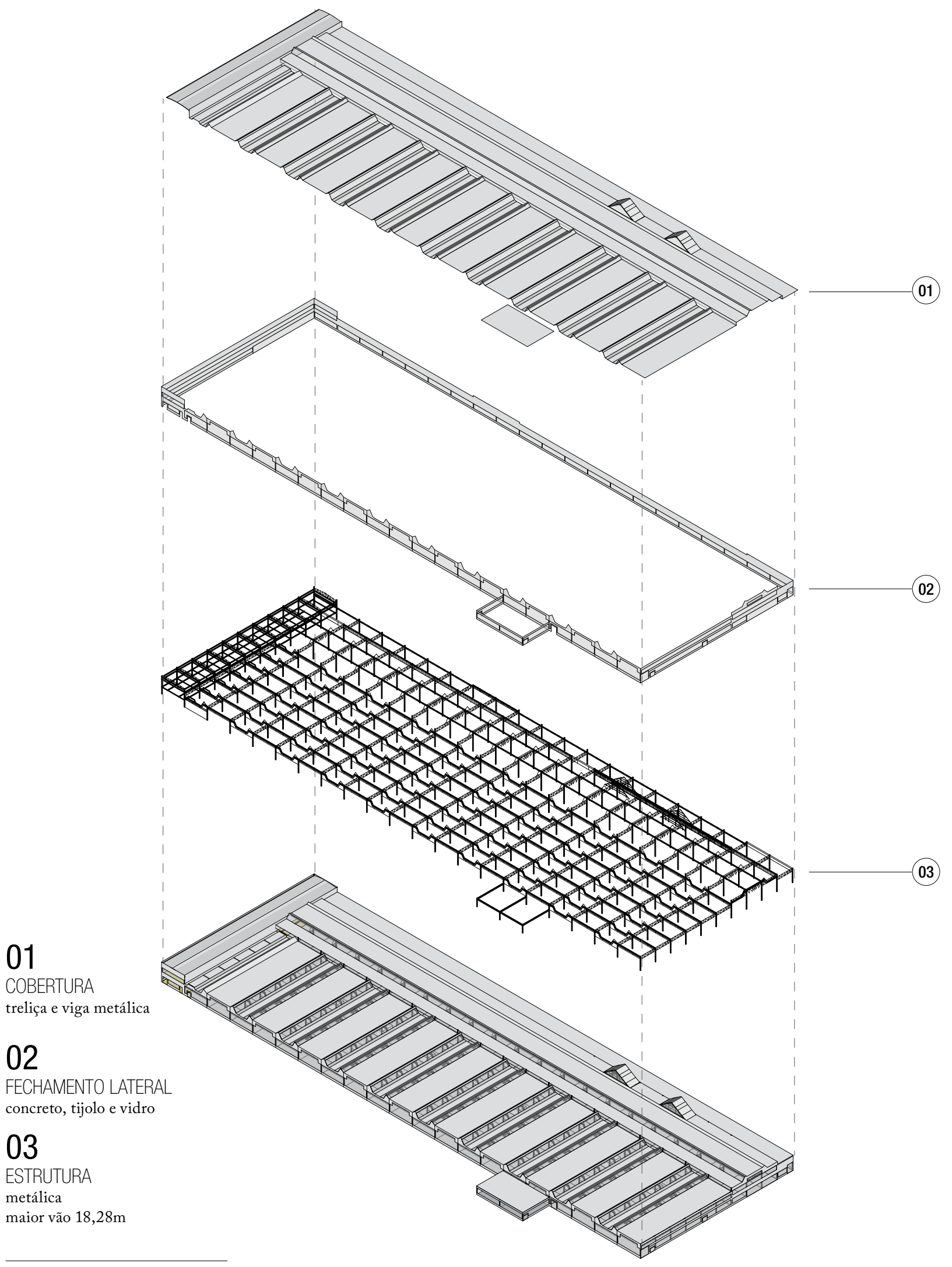

Fig. 101 Diagrama da Fábrica de caminhões da Chrysler. Fonte: Arquivo pessoal da autora, 2019. 


\subsubsection{Fábrica de caminhões (1937) Chrysler Corporation - Dodge division / Warren, Michigan}

Um projeto de 1937, a fábrica de caminhões Half-Ton Truck da Chrysler, localizada na cidade de Warren, ao norte de Detroit, é mais um exemplo do trabalho inovador de Kahn. Em geral elogiada pela expressividade de sua forma, é uma construção muito elegante e fotogênica, o que provavelmente a transforma na fábrica mais citada de todos os edifícios industriais de Kahn. As formas nítidas e a insistente planaridade fazem com que o próprio edifício pareça ter sido feito por uma máquina. No entanto, a verdadeira genialidade do projeto encontra-se em um nível mais profundo.

O edifício de montagem é um grande retângulo de 1.292 pés $(393,80 \mathrm{~m})$ no sentido norte-sul por 402 pés $(122,53 \mathrm{~m})$ no sentido oeste-leste, constituído por três volumes principais, os quais são visíveis nas fachadas. No extremo oeste, existe um volume prismático de dois andares, com fachadas de tijolo e cobertura plana que abriga o setor de escritórios. O lado norte consiste em um volume mais alto, destinado à carga e descarga e submontagens, estando coberto por claraboias. $\mathrm{O}$ terceiro volume, o corpo principal do edifício, é um espaço flexível.

O ponto alto do projeto está na estrutura da cobertura desse grande espaço versátil. Kahn introduz uma novidade no desenho da estrutura: os balanços. Um sistema que agrega eficiência estrutural ao edifício, uma vez que a posição do pilar em relação às vigas da cobertura gera dois balanços de 20 pés $(6,09 \mathrm{~m})$. Essa solução reduz a quantidade de aço para os mesmos requisitos estruturais e, por conseguinte, acaba otimizando a estrutura. ${ }^{154}$

Para a cobertura, treliças no sentido transversal foram posicionadas a cada 60 pés $(18,28 \mathrm{~m})$. Essas treliças apoiam as vigas principais, que se encontram dispostas em sentido longitudinal. Estas vigas principais, feitas de um perfil metálico de alma cheia, transferem a carga para os pilares a cada 40 pés $(12,19 \mathrm{~m})$ e balançam, nos dois lados, 20 pés $(6,09 \mathrm{~m})$, dando forma às claraboias. Dessa maneira, as tensões na viga são reduzidas para aproximadamente 40 pés $(12,19 \mathrm{~m})$, ou seja, dois terços do vão da claraboia, de modo que Kahn pôde usar uma viga mais esbelta. A parte

154 HILDEBRAND, G. Designing for Industry: The Architecture of Albert Kahn. Cambridge, Massachusetts: MIT Press, 1974, p. 173. 
mais baixa da cobertura apoia uma viga de vão menor, com cerca de 30 pés $(9,14 \mathrm{~m})$, garantindo a leveza da construção.

Uma estrutura triangular projeta-se para cima a partir da viga superior, ao passo que a face inclinada - criada por essa estrutura leve - e a parte inferior da viga são envidraçadas, servindo como a entrada de luz da claraboia. Kahn também utiliza perfis de alma cheia na parte da cobertura onde a caixilharia das claraboias se estrutura. Essas vigas foram usadas porque reduziriam o número de conexões, aumentando a velocidade da construção e, portanto, também reduzindo os custos de mão de obra.

A estrutura da cobertura utilizava uma quantidade mínima de material e o princípio do balanço, que tornava isso possível, foi explorado para permitir a entrada de luz. Entre as treliças, o espaço abaixo da cobertura mais alta era usado, ocasionalmente, como mezanino, abrigando os banheiros e as salas de transformadores.

Os vãos entre os pilares metálicos utilizados na fábrica eram extremamente regulares. Os pilares estavam posicionados de forma transversal em intervalos de 60 pés $(18,28 \mathrm{~m})$ e, longitudinalmente, com vãos de 40 pés $(12,19 \mathrm{~m})$. Além disso, tais pilares apoiavam as partes mais altas da estrutura da cobertura. Embora uma economia em seu comprimento pudesse ser feita se eles fossem posicionados sob a parte mais baixa da cobertura, isso só seria possível se o vão fosse duplicado ou se a cobertura baixa se tornasse muito mais larga do que a parte alta. A primeira alternativa seria insustentável, posto que as extensões de 120 pés $(36,57 \mathrm{~m})$ seriam antieconômicas e sem necessidades programáticas. A segunda alternativa levaria a uma zona mal iluminada sob a cobertura baixa, já que as claraboias forneceriam iluminação uniforme apenas se a parte baixa da cobertura entre elas fosse relativamente estreita. ${ }^{155}$

O fechamento da fábrica consistia em superfícies planas, precisas e elegantes. A geometria dos materiais de revestimento da fachada expressava a lógica estrutural. Na parte superior da fachada, a linha opaca do coroamento do edifício seguia o perfil da viga em balanço e de suas claraboias. A caixilharia de vidro, abaixo do coroamento, se estendia sobre uma superfície plana e contínua, com um

155 HILDEBRAND, G. Designing for Industry: The Architecture of Albert Kahn. Cambridge, Massachusetts: MIT Press, 1974, p. $173-182$. 

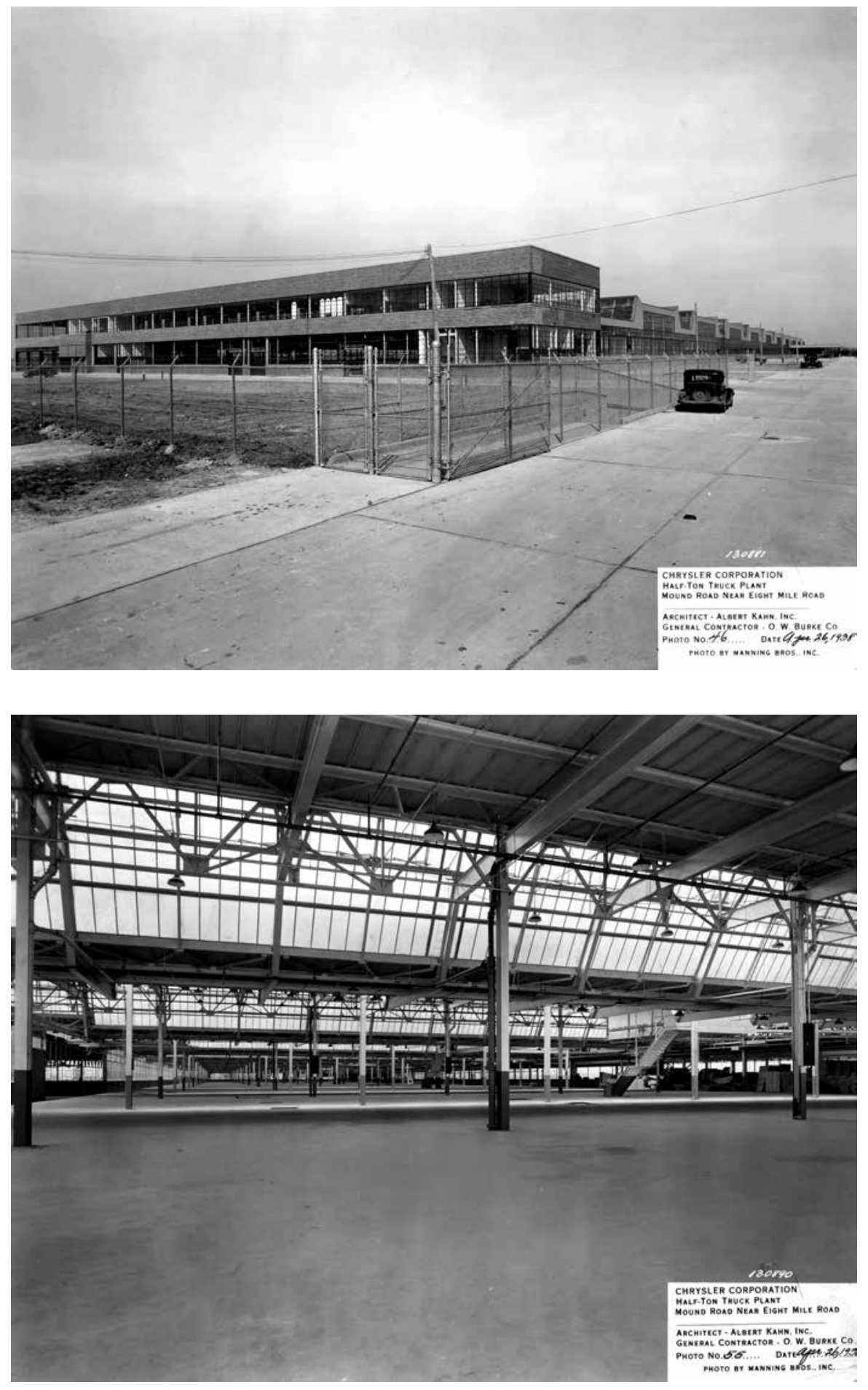

Fig. 102 Fábrica de caminhões da Chrysler, em construção. Fonte: Albert Kahn Associates Records, Bentley Library, University of Michigan.

Fig. 103 Interior da Fábrica de caminhões da Chrysler.

Fonte: Albert Kahn Associates Records, Bentley Library, University of Michigan. 

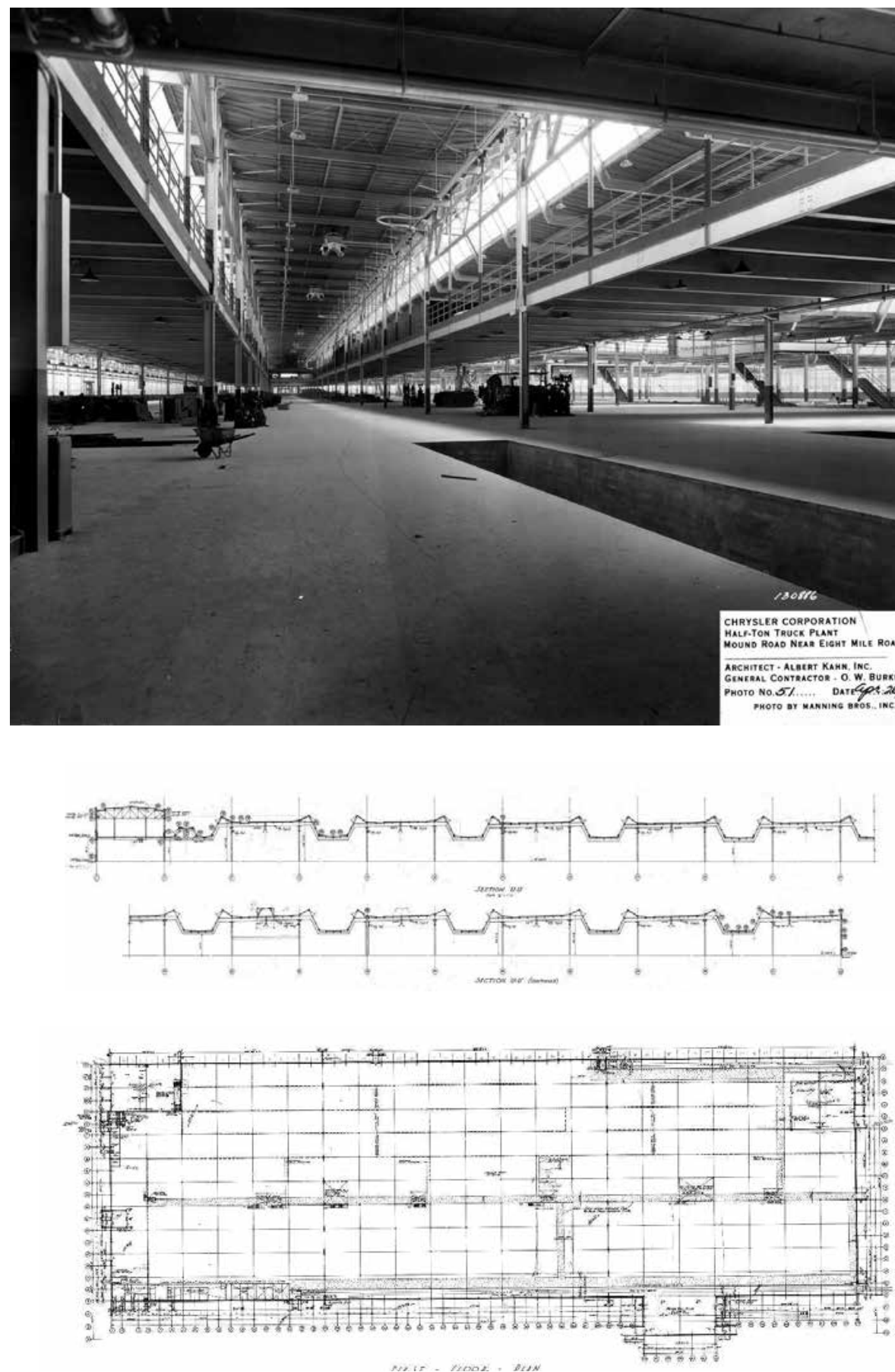

Fig. 104 Ford Interior da Fábrica de caminhões da Chrysler. Fonte: Albert Kahn Associates Records, Bentley Library, University of Michigan.

Fig. 105 Corte longitudinal da Fábrica de caminhões da Chrysler Fonte: Pancorbo (2016)

Fig. 106 Planta baixa da Fábrica de caminhões da Chrysler. Fonte: Pancorbo (2016) 

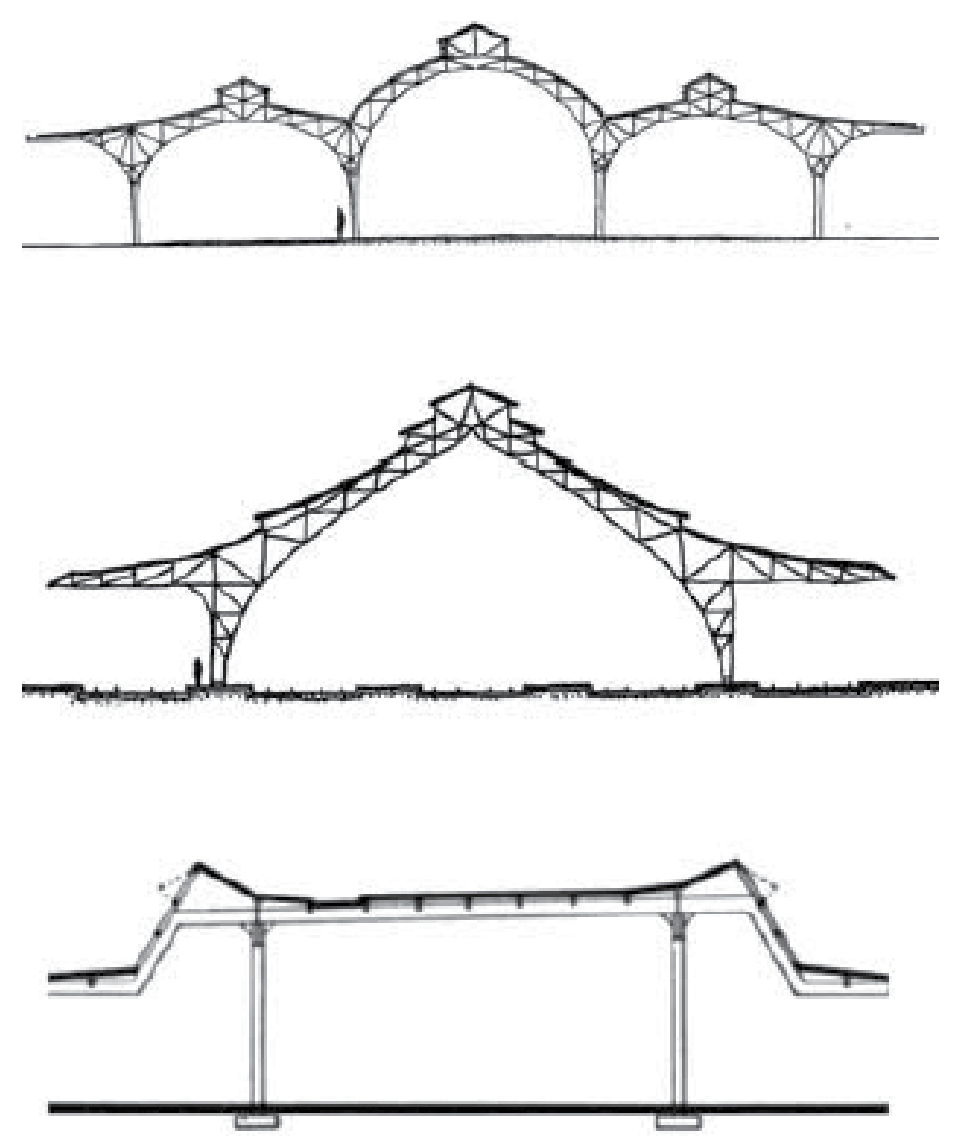

Fig. 107 De cima para baixo: Illinois Central Station de New Orleans; Illinois Central Station de Chicago; Módulo estrutural com balanços laterais da Fábrica de caminhões da Chrysler.

Fonte: Pancorbo (2016) 
formato retangular, provavelmente para simplificar os detalhes. Um embasamento de alvenaria de tijolos finalizava a composição dos planos da fachada do edifício, na altura de 4 pés e 5 polegadas $(1,34 \mathrm{~m})$. Esse grande plano envidraçado revelava externamente o fato de que o edifício era estruturado por um sistema de vigas e treliças, e não apenas por treliças.

As fachadas da fábrica parecem não ser mais do que o resultado do corte naquele comprimento específico. Todo o projeto era uma decorrência de sua vocação no sentido de buscar a extensão indeterminada da estrutura. Mais uma vez, o exterior da fábrica de caminhões refletia as tendências intuitivas de Kahn em direção a uma arquitetura modular e expansível.

A fábrica da Chrysler é considerada uma obra-prima da arquitetura industrial. De acordo com Hildebrand, "no other general manufacturing building of its date and of equal sophistication has come to light"156. A fábrica de caminhões é provavelmente a mais referenciada de todas as obras de Kahn, sendo muito elogiada pela expressividade de sua forma.

156 Tradução da autora: "nenhum outro edifício de fabricação em sua época e de igual sofisticação veio à tona". HILDEBRAND, G. Designing for Industry: The Architecture of Albert Kahn. Cambridge, Massachusetts: MIT Press, 1974, p. 182. 


\section{FÁBRICA DE AVIÕES DA GLENN MARTIN}

\section{1}

COBERTURA

treliça metálica

02

FECHAMENTO LATERAL concreto e vidro

03

ESTRUTURA

metálica

maior vão $91,44 \mathrm{~m}$

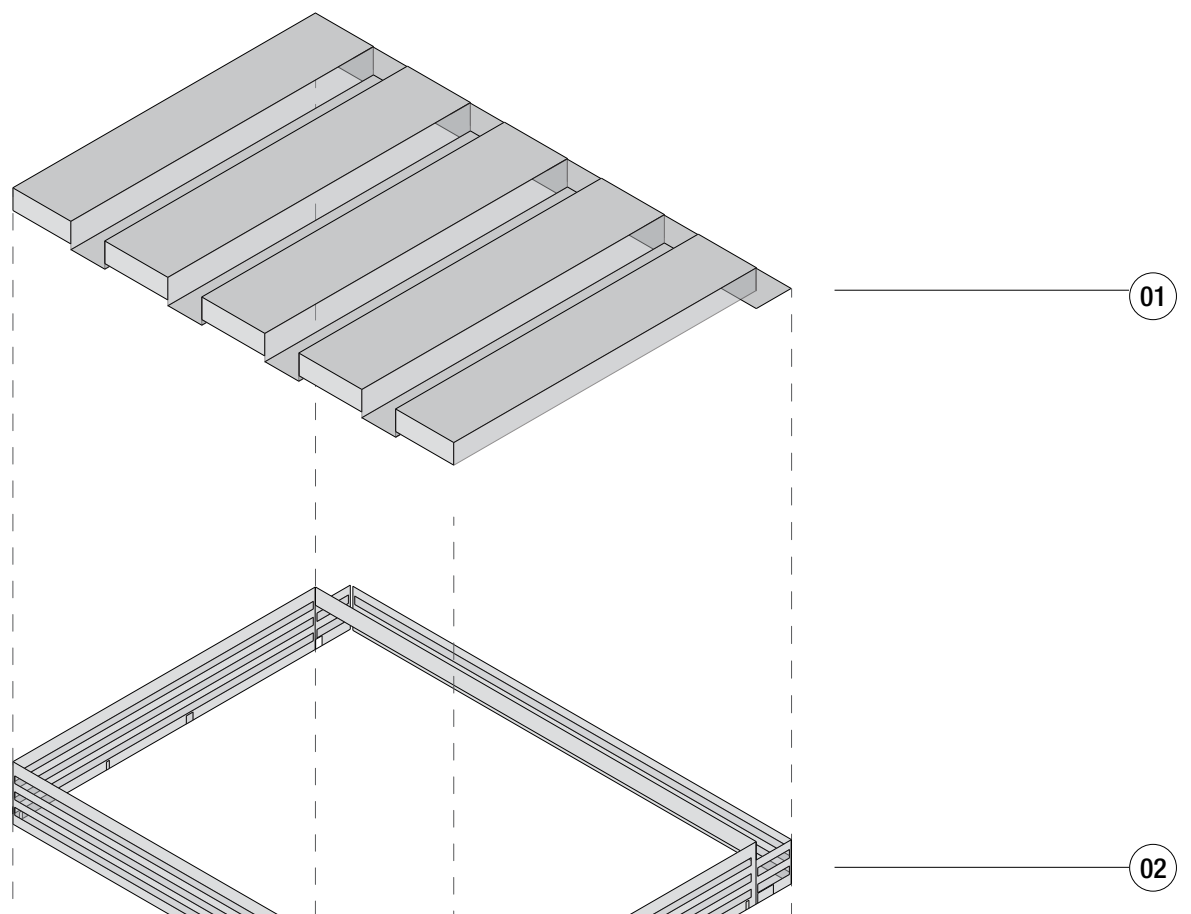

03

Fig. 108 Diagrama da Fábrica de aviões da Glenn Martin. Fonte: Arquivo pessoal da autora, 2019. 
3.2.5 Fábrica de montagem de aviões (1937)

Glenn L. Martin Company / Baltimore, Maryland

O ano de 1937 foi especial para o escritório de Kahn. Além da fábrica de caminhões da Chrysler, o escritório também projetou um notável edifício para a fábrica de aviões da Glenn L. Martin Company, localizada ao norte de Baltimore. O novo edifício seria construído de forma contígua à unidade já existente de 1929. ${ }^{157}$ Tratava-se de um espaço para fabricação de aviões, com dimensões totais de 344 pés $(104,85 \mathrm{~m})$ no sentido noroeste-sudeste por 453 pés $(138,07 \mathrm{~m})$ no sentido nordeste-sudoeste. Kahn estava convencido de que, dentro da expectativa de vida do edifício, os aviões seriam construídos com dimensões de cerca de 300 pés (91,44m), parecendo-lhe um péssimo planejamento construir uma fábrica que não pudesse ser adaptada à sua fabricação.

O desafio, portanto, seria abrigar um avião de 300 pés de largura e fazê-lo sair da fábrica após ser montado. Para resolver esse problema, uma extremidade inteira do prédio deveria ser completamente aberta por algum sistema de portas ou painéis móveis. Dessa forma, o projeto era claro já no início: um espaço único, livre de pilares, com vão livre de 300 pés $(91,44 \mathrm{~m})$, além de necessitar de uma lateral com possibilidade de ser totalmente aberta.

Uma vez estabelecido o projeto, restava decidir qual seria a estrutura capaz de vencer tamanho vão. Uma espécie de competição dentro do escritório foi realizada entre os vários setores, que propuseram alternativas diferentes. ${ }^{158} \mathrm{O}$ projeto escolhido foi o mais leve em quantidade de aço por pé quadrado. Tratavase de um esquema de vão único, livre de pilares, com treliças de 300 pés $(91,44 \mathrm{~m})$ de comprimento e 32 pés $(9,75 \mathrm{~m})$ de altura, posicionadas transversalmente em intervalos de 50 pés $(15,24 \mathrm{~m})$.

No outro sentido, as treliças eram unidas na parte superior ou inferior, alternadamente, por treliças secundárias que venciam o vão de 50 pés $(15,24 \mathrm{~m})$. Para dar maior resistência à estrutura, foi colocado um contraventamento entre as treliças. Nesta estrutura, não se fez uso de balanços, como na fábrica de caminhões da Chrysler, mas da viga biapoiada, que era típica das primeiras pontes americanas construídas em ferro.

157 Há duas expansões sucessivas da mesma fábrica de montagem da aviões Glenn L. Martin, em Baltimore nos anos de 1937 e 1939, projetadas por Albert Kahn. Trataremos aqui da primeira expansão, pois ela foi um importante desafio estrutural, já que se desejava construir um grande espaço diáfano.

158 HILDEBRAND, G. Designing for Industry: The Architecture of Albert Kahn. Cambridge, Massachusetts: MIT Press, 1974, p. 183. 

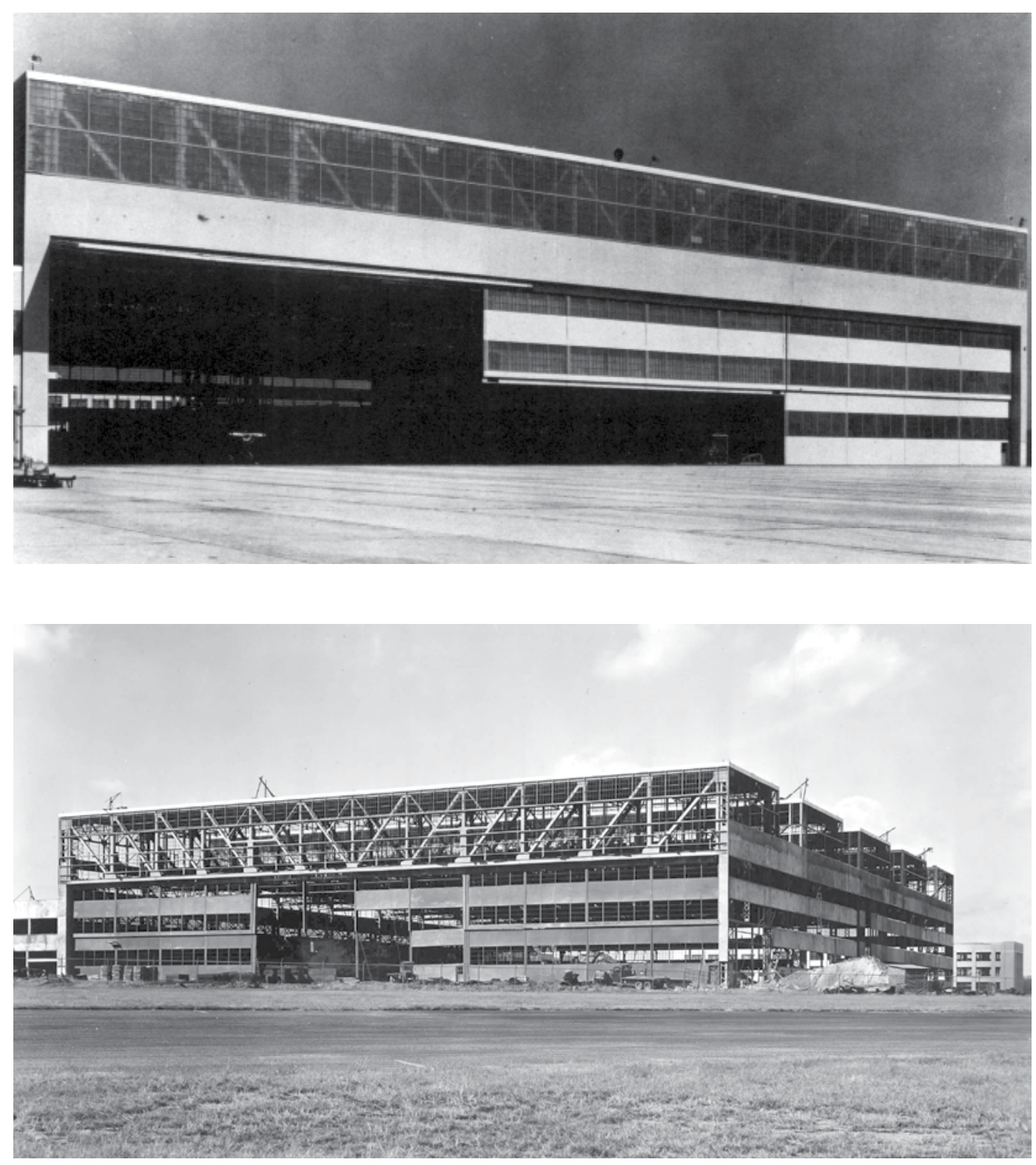

Fig. 109 Exterior da Fábrica de aviões da Glenn Martin. Fonte: Hildebrand (1975)

Fig. 110 Fábrica de aviões da Glenn Martin, em construção.

Fonte: Albert Kahn Associates Records, Bentley Library, University of Michigan. 

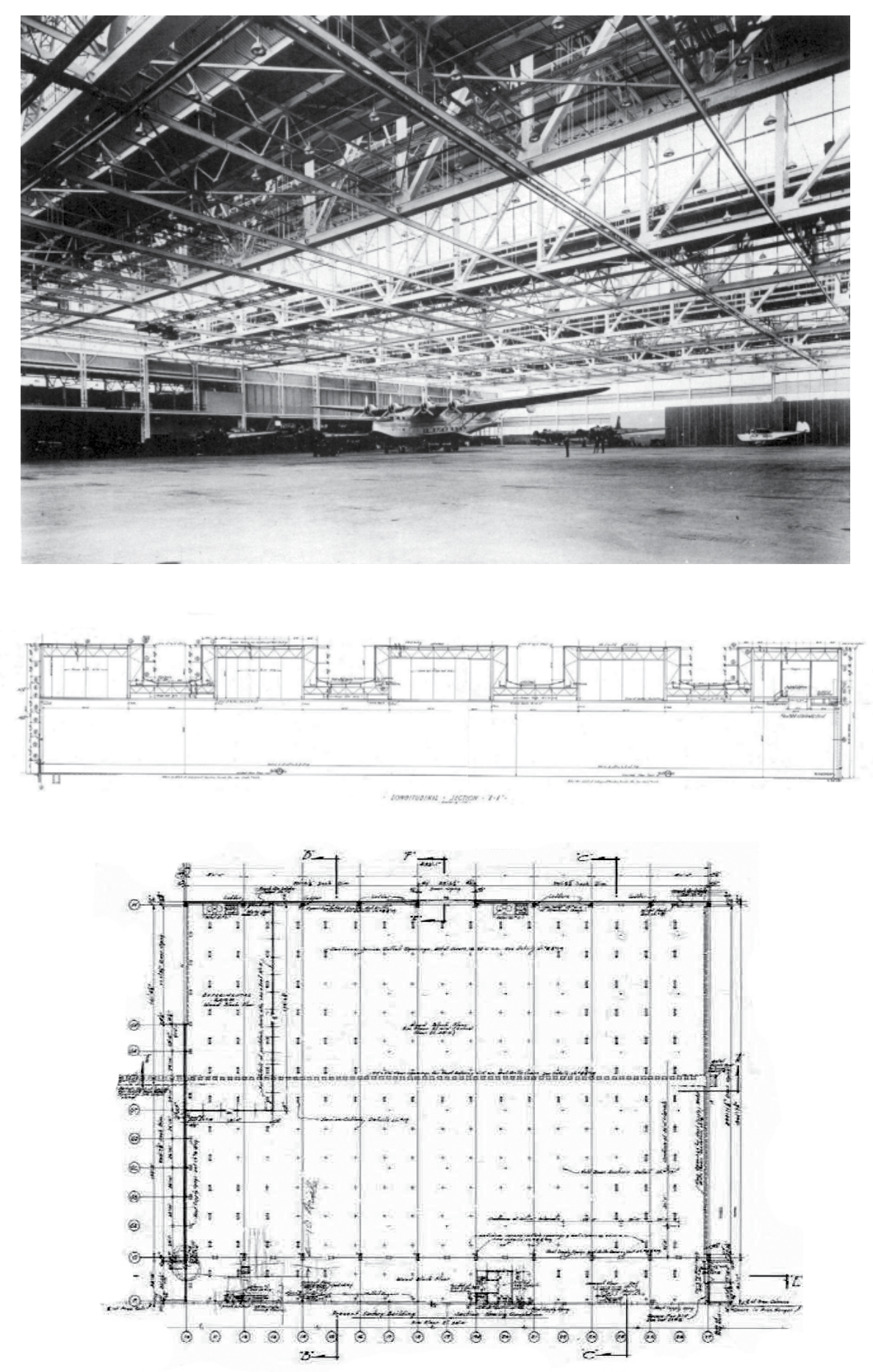

Fig. 111 Interior da Fábrica de aviões da Glenn Martin. Fonte: Hildebrand (1975)

Fig. 112 Corte da Fábrica de aviões da Glenn Martin. Fonte: Pancorbo (2016)

Fig. 113 Planta baixa da Fábrica de aviões da Glenn Martin. Fonte: Pancorbo (2016) 
A nova fábrica de montagem da Glenn L. Martin incorporava um novo desenho de claraboias que se adaptava ao projeto, facilitava a construção e dava à arquitetura uma aparência mais abstrata. $\mathrm{O}$ grande espaçamento das treliças principais permitiu o uso de claraboias paralelas entre si, admitindo a luz natural através das laterais das treliças. Assim, as treliças secundárias de 50 pés $(15,24 \mathrm{~m})$ apoiavam uma superfície opaca da cobertura que ocorria, alternadamente, na parte superior e inferior das treliças principais. A diferença de altura, um plano vertical de 19 pés $(5,79 \mathrm{~m})$, era a parte envidraçada.

A porta da fábrica ocupava toda a fachada sudeste, tendo a dimensão de 299 pés e 11 polegadas $(91,41 \mathrm{~m})$ de largura e 45 pés $(13,71 \mathrm{~m})$ de altura, estando dividida em três seções horizontais e duas na vertical, as quais eram operáveis como seções separadas ou como uma unidade. A materialidade da porta era similar ao resto do edifício, fazendo com que ela não se destacasse na volumetria. Os batentes entre as janelas, cuidadosamente pintados com uma cor mais escura, preservavam a continuidade visual das faixas horizontais que compunham a fachada.

A planta baixa era um grande espaço flexível e diáfano de 300 pés $(91,44 \mathrm{~m})$ por 450 pés $(137,16 \mathrm{~m})$. Ao contrário da indústria automotiva, a fabricação de uma aeronave não era realizada de acordo com uma linha de montagem móvel. Após os aviões serem fixados no chão da fábrica, os operários subiam em diferentes alturas para fazer o processo de montagem manualmente. Portanto, para a construção de aviões, eram necessários espaços de grande altura. ${ }^{159}$ Ambientes como banheiros e vestiários estavam localizados em um volume prismático de dois andares e 39 pés $(11,88 \mathrm{~m})$ de largura ao longo da fachada oeste, mas inserida dentro da volumetria pura da fábrica.

Até então, nenhum edifício fora construído com um vão tão grande, livre de pilares. ${ }^{160} \mathrm{O}$ projeto da fábrica baseava-se na tecnologia já utilizada em pontes, onde eram comuns vãos enormes. Este projeto iniciou uma nova etapa no trabalho do arquiteto, marcado pela mudança de escala. Como comenta Hildebrand, o impacto causado pelo enorme espaço interior era difícil de descrever ou fotografar: "The scale is magnificent $[. .$.$] the space swallows up human gestures. The exterior is a$

159 Durante a Segunda Guerra Mundial, a fábrica foi usada para montar o PBM Mariner e o PB2M Mars, os maiores aviões utilizados na guerra. Em 1943, o último tinha uma envergadura de mais de 200 pés e era, sem dúvida, o tipo de avião que a Martin tinha em mente seis anos antes. Em: HILDEBRAND, G. Designing for Industry: The Architecture of Albert Kahn. Cambridge, Massachusetts: MIT Press, 1974, p. 193.

160 Não existiam precedentes de um edifício com uma treliça de 300 pés. Hildebrand oferece, em seu livro sobre Kahn, o precedente do edifício de 240 pés da fábrica da Crucible Steel Company, de 1919, em Harrison, Nova Jersey. Comenta também que, na década de 1890, várias estações de trens foram construídas com treliças planas da ordem de 200 pés. A maior estação de trem, no entanto, era a Broad Street Station, na Filadélfia, que usava o princípio do arco para vencer o vão de 300 pés. Por outro lado, vãos muito maiores foram usados na construção de pontes por muitas décadas. A primeira ponte de aço dos Estados Unidos, por exemplo, a ponte Chicago andAltonRailroad Bridge, em Glasgow, Missouri, tinha 314 pés. Em: HILDEBRAND, G. Designing for Industry: The Architecture of Albert Kahn. Cambridge, Massachusetts: MIT Press, 1974, p. 183-184. 
handsomely concise statement of the underlying scheme, with no overstudied or fussy elements to disturb the grandness of the immense structure."161

A fábrica é um dos melhores projetos de Kahn. Embora menor que muitas outras, lida com a fabricação de máquinas em uma escala sem precedentes, mesmo no próprio trabalho do arquiteto. $\mathrm{O}$ poder da solução está na exploração desses princípios em uma escala e com uma ousadia normalmente encontrada apenas em grandes obras de engenharia, das quais, na verdade, foram extraídos os princípios por ele empregados nessa fábrica.

161 Tradução da autora: "A escala é magnífica [...]um espaço que engloba qualquer amostra humana. O exterior é uma afirmação maravilhosamente significativa do sistema subjacente, sem elementos caprichosos que perturbam a grandiosidade da imensa estrutura " Em: HILDEBRAND, G. Designing for Industry: The Architecture of Albert Kahn. Cambridge, Massachusetts: MIT Press, 1974, p. 193. 


\section{FÁBRICA DE AVIÕES WILLOW RUN BOMBER}

\section{1}

COBERTURA

treliça metálica

\section{2}

FECHAMENTO LATERAL

concreto, tijolo e vidro

03

ESTRUTURA

metálica

maior vão $24,38 \mathrm{~m}$

Fig. 114 Diagrama da Fábrica de aviões da Ford Willow Run. Fonte:Arquivo pessoal da autora, 2019. 
3.2.6 Fábrica de montagem de aviões - Willow Run Bomber (1941)

Ford Motor Company / Ypsilanti, Michigan

Embora Albert Kahn continuasse a projetar fábricas para a indústria automobilística até a sua morte, a partir de 1937, a sua prática arquitetônica focou principalmente em fábricas de defesa. Além da grande fábrica de aviões para a Glenn L. Martin Company, boa parte do trabalho de defesa, durante a Segunda Guerra Mundial, serviu para a indústria aeronáutica. ${ }^{162}$

A Ford Motor Company Willow Run Bomber, um projeto de 1941 localizado em Ypsilanti, foi o maior edifício industrial construído naquela época. A fábrica foi planejada porque os Estados Unidos precisavam de aviões bombardeiros B-24 durante a Segunda Guerra Mundial. ${ }^{163} \mathrm{O}$ edifício era uma estrutura gigantesca, com $330.000 \mathrm{~m}^{2}$ de área construída e uma linha de montagem de aeronaves com quase um quilômetro de extensão. Além disso, o complexo possuía um aeródromo próprio, com pistas de decolagem das aeronaves fabricadas em Willow Run, assim como dispunha de um hangar para armazená-las.

O edifício tinha formato em $L$ invertido, com 3.121 pés $(951,28 \mathrm{~m})$ de comprimento no sentido leste-oeste, variando em largura de 700 pés $(213,36 \mathrm{~m})$, na parte mais estreita, a 1279 pés $(389,83 \mathrm{~m})$, no sentido norte-sul. A fábrica era composta por longas naves que abrigavam as linhas de montagem da aeronave. A planta baixa apresentava as faixas de montagem separadas, divididas entre os processos de submontagem, montagem principal e montagem final. Interceptando as faixas de montagem, no sentido transversal, havia uma zona de transferência.

A zona mais próxima à fachada oeste, transversal às faixas de montagem no sentido norte-sul, abrigava a área de fabricação, ao passo que uma faixa estreita de 42 pés $(12,80 \mathrm{~m})$, junto à fachada oeste, correspondia ao setor de engenharia. A administração estava posicionada em um volume anexo, localizado em frente à fachada oeste. Também em volumes anexos e separados entre si, estavam as zonas de recebimento e distribuição de materiais, localizadas na fachada sul. $\mathrm{O}$ volume de distribuição estava conectado diretamente à zona de transferência. Abastecendo a fábrica, trilhos de trem corriam externamente, paralelos à fachada sul e conectados

162 HYDE, C. K. Assembly-Line Architecture: Albert Kahn and the evolution of the U.S. Auto Factory, 1905-1940. In: IA - The Journal of the Society for Industrial Archeology, v. 22, n. 2, 1996, p. 19-20.

163 Durante o período da guerra, a produção foi de cerca de 8.500 bombardeiros B-24, empregando 42.000 trabalhadores. Ver: BUCCI, F. Albert Kahn: Architect of Ford. New York: Princeton Architectural Press, 1993, p.111. 

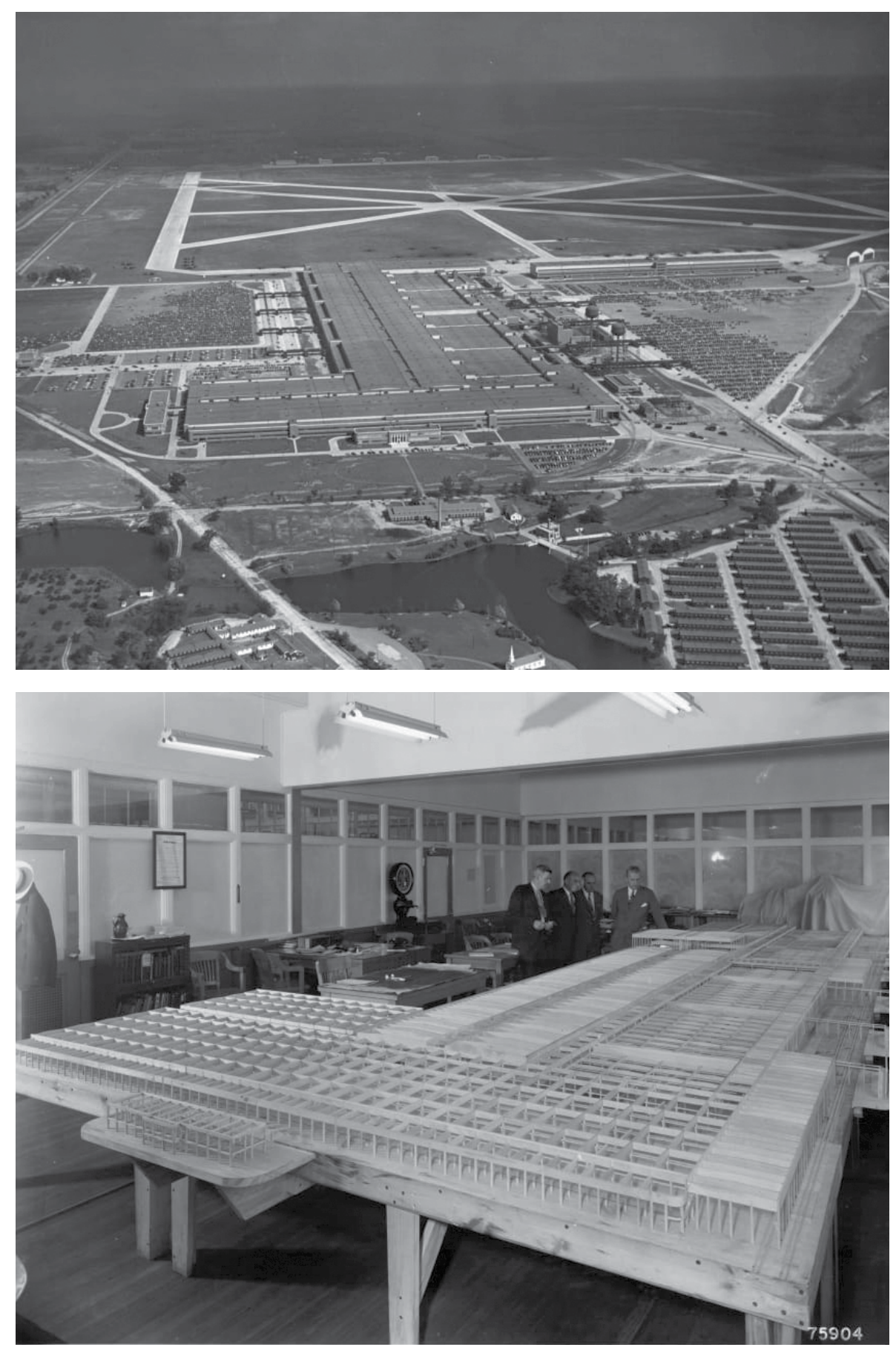

Fig. 115 Vista aérea da Fábrica de aviões da Ford Willow Run. Fonte: <www.thehenryford.org > Acesso 18 nov 18.

Fig. 116 Maquete da Fábrica de aviões da Ford Willow Run Fonte: <www.thehenryford.org> Acesso 18 nov 18. 

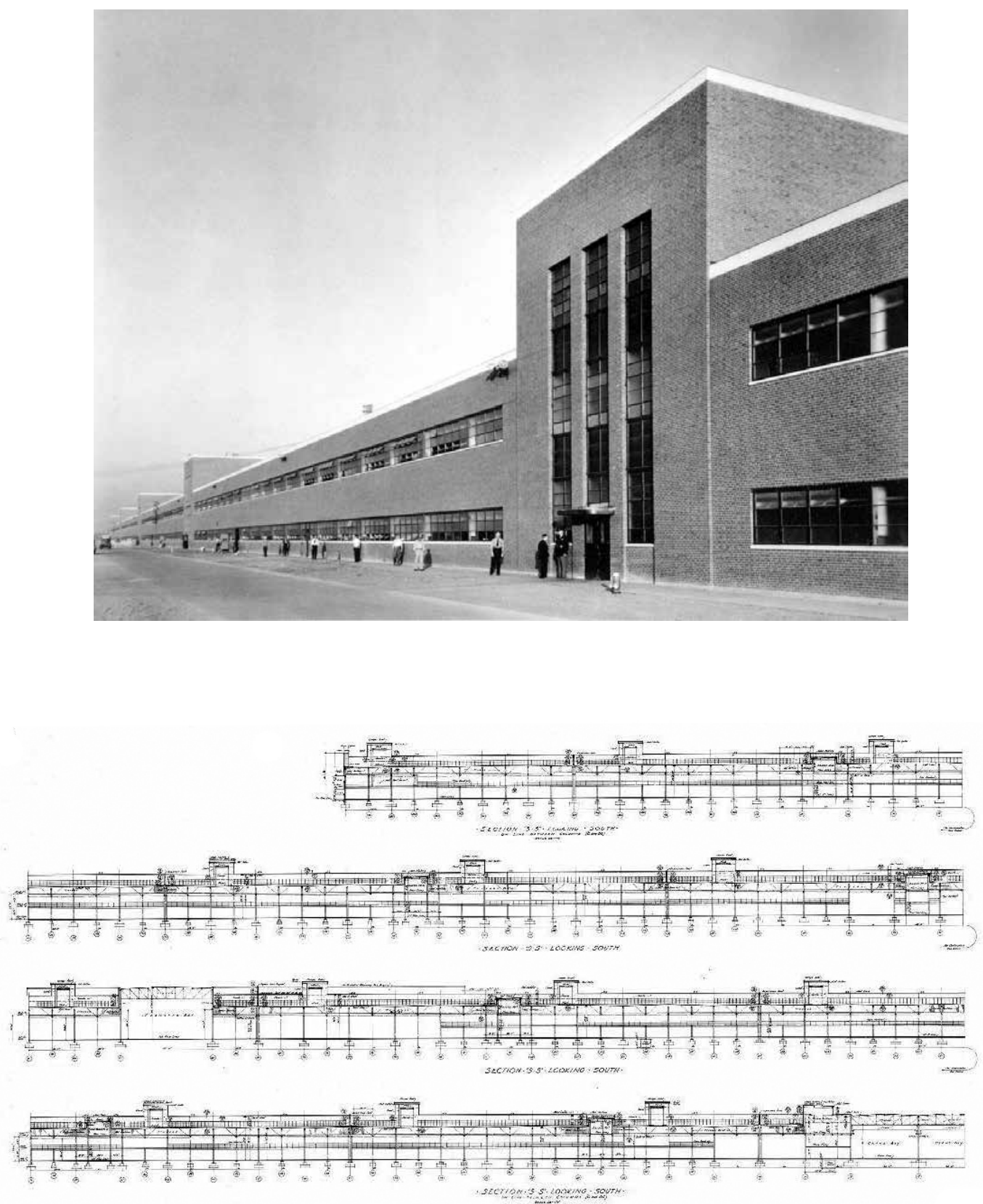

Fig. 117 Exterior da Fábrica de aviões da Ford Willow Run.

Fonte: <www.cca.qc.ca/en/search/details/collection/object/14240> Acesso 05 jan 19.

Fig. 118 Corte longitudinal da Fábrica de aviões da Ford Willow Run.

Fonte: Pancorbo (2016) 

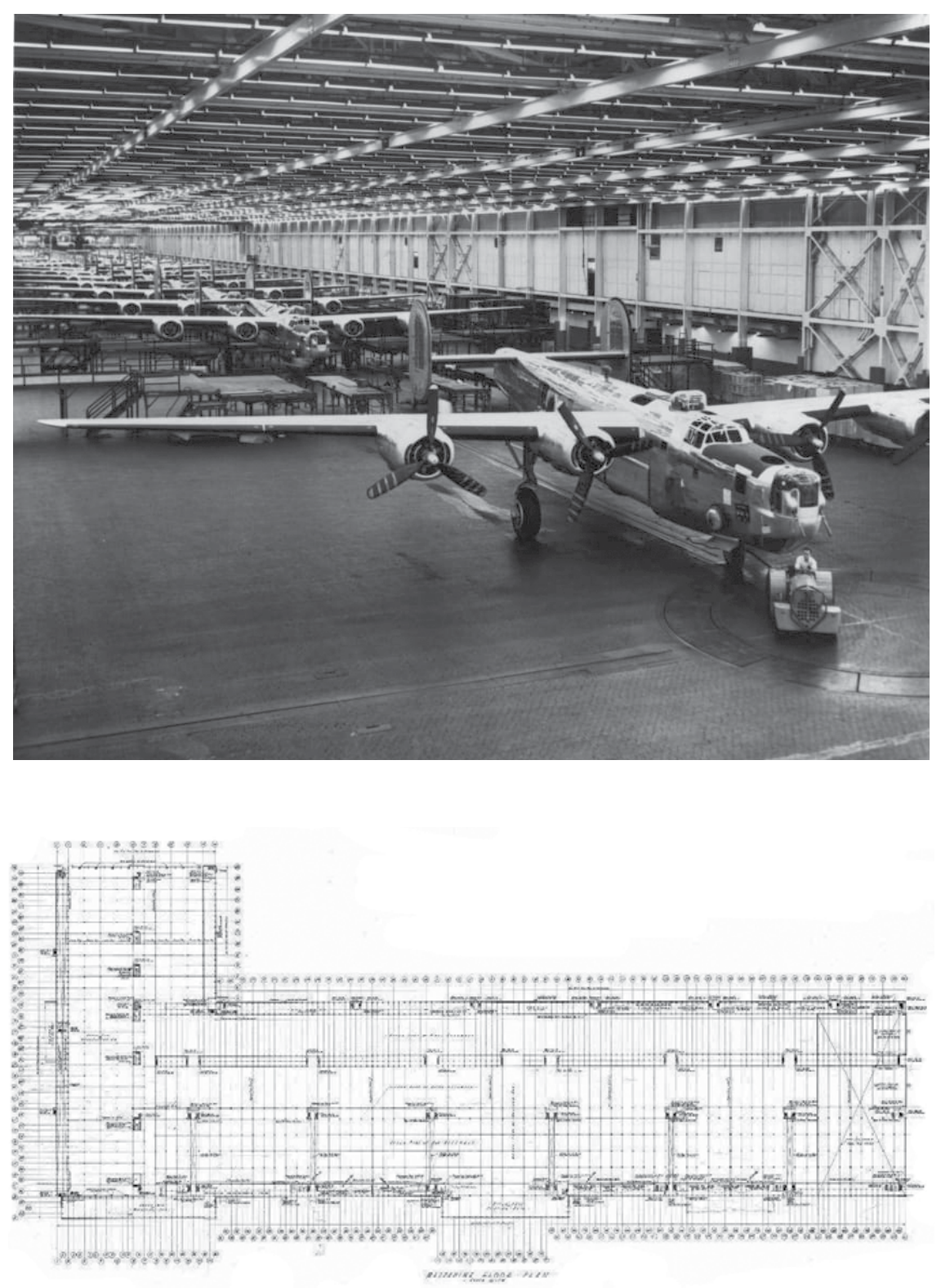

Fig. 119 Interior da Fábrica de aviões da Ford Willow Run. Fonte: <www.thehenryford.org $>$ Acesso 18 nov 18.

Fig. 120 Planta baixa da Fábrica de aviões da Ford Willow Run. Fonte: Pancorbo (2016) 


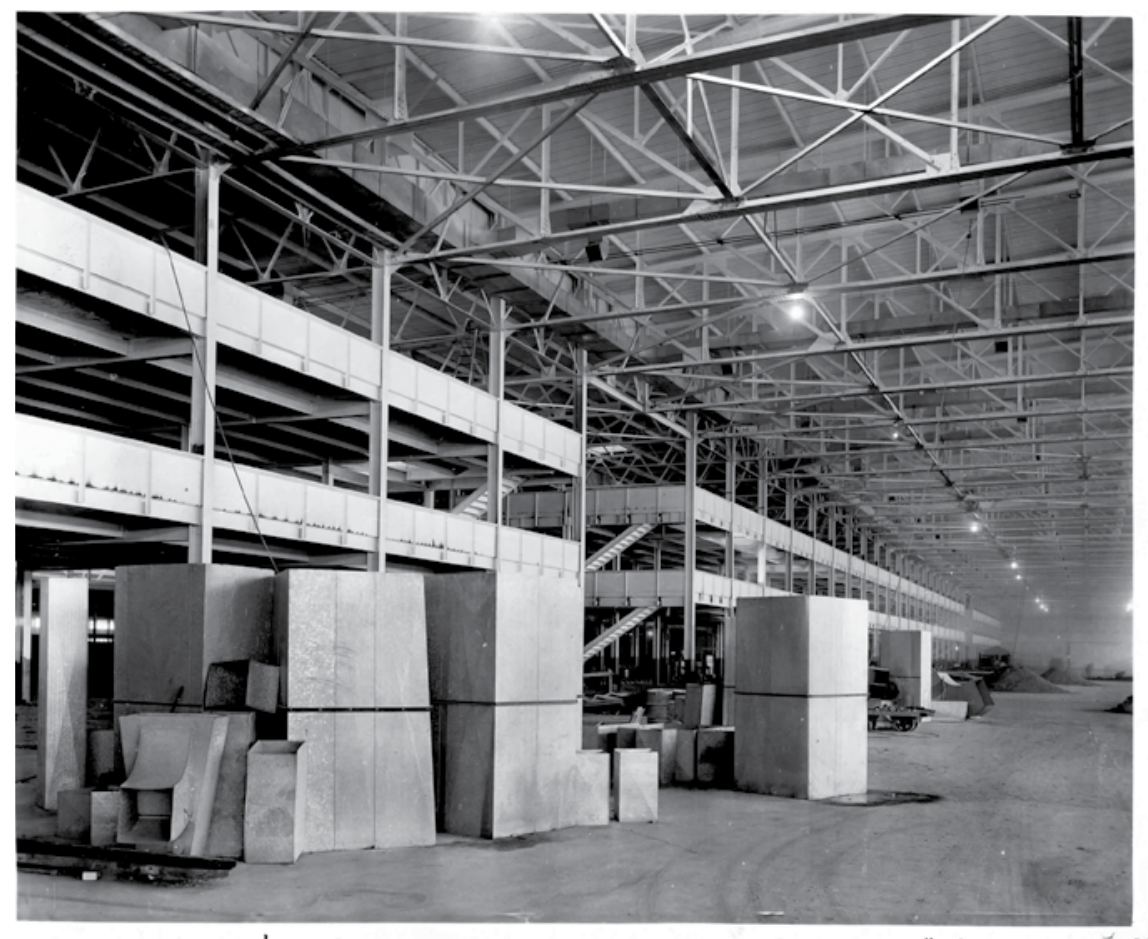

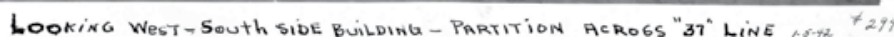

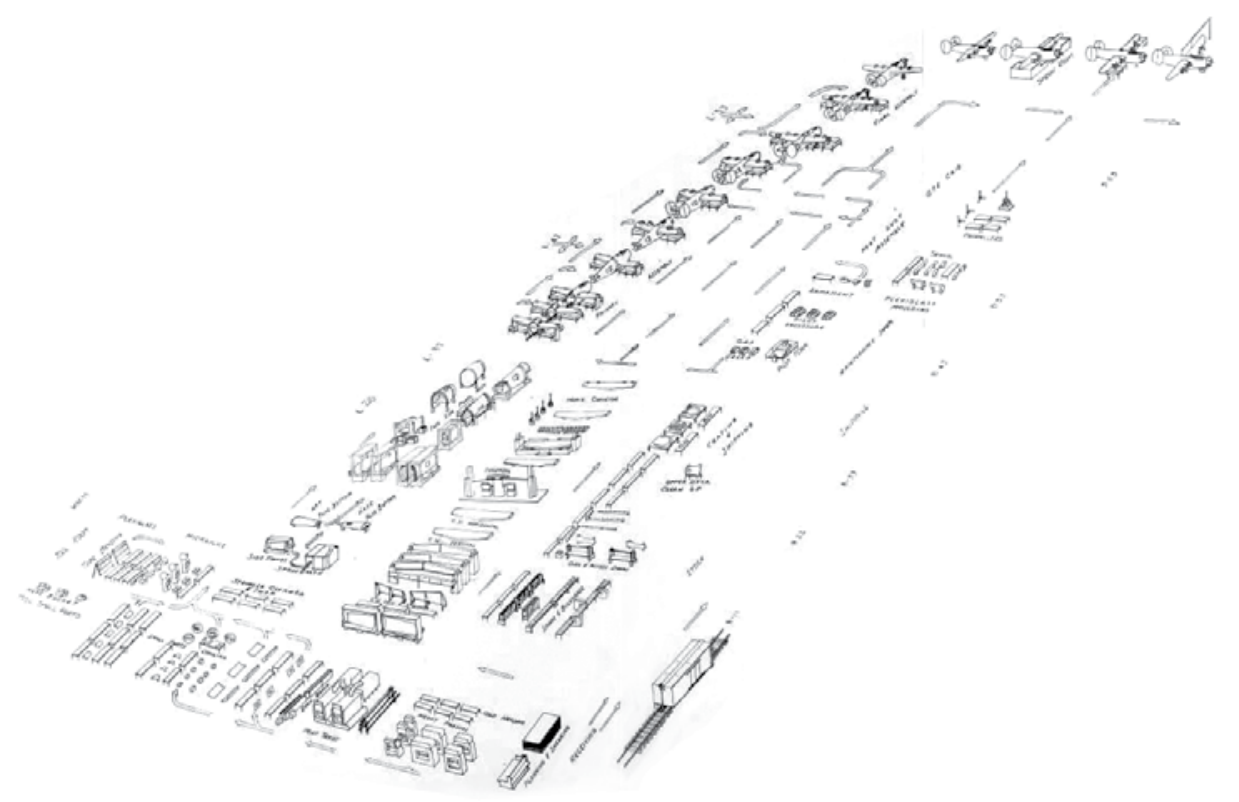

Fig. 121 Interior da Fábrica de aviões da Ford Willow Run. Fonte: Albert Kahn Associates Records, Bentley Library, University of Michigan.

Fig. 122 Fluxograma de montagem da Fábrica de aviões da Ford Willow Run Fonte: <www.thehenryford.org > Acesso 18 nov 18. 
aos volumes de recebimento e distribuição de materiais. Mesmo apresentando um complexo zoneamento das funções, a planta baixa, assim como nas fábricas anteriores de Kahn, servia como um esquema para a localização dos eixos do corte.

Pelo fato da fábrica ser uma instalação militar norte-americana ${ }^{164}$ e por causa da crescente ameaça de ataque aéreo, as áreas de produção em Willow Run não possuíam iluminação natural, invertendo assim a prática de Albert Kahn de fornecer a máxima quantidade de iluminação natural através do uso de claraboias. A cobertura, portanto, era uma superfície praticamente opaca. Por não existir razão para produzir desníveis no telhado, como, por exemplo, para suprir as necessidades de ventilação ou de iluminação, a estrutura apresentava um perfil bastante plano.

$\mathrm{Na}$ cobertura, as treliças eram semelhantes às usadas na fábrica da Glenn L. Martin, mas com duas águas. Elas venciam um vão de 150 pés $(45,72 \mathrm{~m})$ nas áreas de montagem principal e final. Alternando as faixas de montagem, encontravam-se áreas intermediárias de dois pavimentos, ambas com 40 pés $(12,19 \mathrm{~m})$ de largura. Nas zonas de submontagem, o vão diminuía para 60 pés $(18,28 \mathrm{~m})$. Na direção transversal, o vão entre as treliças era de 40 pés $(12,19 \mathrm{~m})$, em geral, e 80 pés $(24,38 \mathrm{~m})$ na zona de transferência. A altura livre era de 36 pés $(10,97 \mathrm{~m})$ nas áreas de transferência e nas áreas de montagem principal e final. $\mathrm{Na}$ área mais baixa das treliças da zonas de submontagem, a altura livre era de 26 pés $(7,92 \mathrm{~m})$.

Por motivos de segurança, a relação da fábrica Willow Run com o entorno era mínima. Por isso, no seu perímetro, posicionava os usos secundários que resultavam em uma fachada pouco permeável ao exterior, servindo ainda de filtro para as atividades do interior. ${ }^{165} \mathrm{~A}$ fachada não expressava a estrutura, e era composta por faixas horizontais de tijolo e vidro. Em relação aos projetos anteriores, a fenestração, nessa fábrica, teve significativa redução. Quebrando a horizontalidade das imensas fachadas, núcleos de circulação vertical foram posicionados a cada onze módulos estruturais, correspondendo a um volume mais alto e fornecendo um certo ritmo à fachada.

A estrutura espacial e material desta e das outras fábricas de Kahn não apenas possibilitava as funções por ela abrigadas, mas era essencial para o seu desenvolvimento. Essa conformação do espaço e, consequentemente, do volume

164 O projeto ficou classificado como segredo de Estado até 2006. Ver: PANCORBO, L. Arquitectura industrial de Albert Kahn Inc. 1900-42. La arquitectura como objeto técnico. Tese (Doutorado em Proyectos Arquitectónicos). Escuela Técnica Superior de Arquitectura - Universidad Politécnica de Madrid. Madrid: ETS - Arquitectura, 2016, p. 221.

165 PANCORBO, L. Arquitectura industrial de Albert Kahn Inc. 1900-42. La arquitectura como objeto técnico. Tese (Doutorado em Proyectos Arquitectónicos). Escuela Técnica Superior de Arquitectura - Universidad Politécnica de Madrid. Madrid: ETS - Arquitectura, 2016, p. 221. 
externo pela função que abrigava era uma característica variável dentro do trabalho de Kahn, adaptando-se à modificação do próprio conceito de função dentro do pensamento do arquiteto. A evolução deste conceito, desde o cumprimento de algumas funções genéricas, passando por um funcionalismo primário de adaptação total e sinergia com os processos produtivos, até um funcionalismo final baseado na flexibilidade, neutralidade e adaptabilidade, fizeram parte do trabalho do arquiteto.

Ao contrário do Movimento Moderno, que supôs a evolução da planta livre, os projetos de Albert Kahn evoluíram em direção ao corte, que atendiam à dimensão técnica do objeto arquitetônico. A planta baixa desapareceu como um documento que atendia às necessidades de um programa não considerado fixo, mas que podia ter múltiplos desenvolvimentos possíveis e diante dos quais a única estratégia de projeto era a flexibilidade total. Isso levava à falta de definição da planta baixa, algo que poderia ser resolvido com um simples acúmulo de cortes. Assim, o detalhamento dos cortes, tais como juntas estruturais e uniões construtivas, representavam a maior parte da documentação gráfica produzida.

No método projetivo de Kahn, a importância da relação com o lugar e o contexto foi perdendo a sua relevância. Com a chegada dos grandes complexos fabris, como o Ford River Rouge ou as fábricas para construção de aeronaves do final da década de 1930, o nível pragmático deixou de fazer parte do projeto, ou seja, desapareceu a relação com o usuário e com o programa. Esse processo levou o projeto industrial de Kahn a depender apenas da ordem estrutural e espacial e das tectônicas construtivas, as quais, por sua vez, derivavam das necessidades mais abstratas, genéricas e essenciais da produção industrial.

A importância do papel de Kahn ocorre como um veículo que transmite o fordismo para a arquitetura - responsável pela importação de métodos e ferramentas de projeto das áreas de engenharia - e seu lugar preeminente dentro da mudança de paradigma que a arquitetura sofreu nas primeiras décadas do século XX, dando origem ao Movimento Moderno. Sua influência, assim, não se estende apenas à arquitetura do Movimento Moderno europeu, mas igualmente transcende as barreiras culturais que pareciam tão distantes, como projetar fábricas na tecnicamente atrasada América Latina dos anos 1920. 


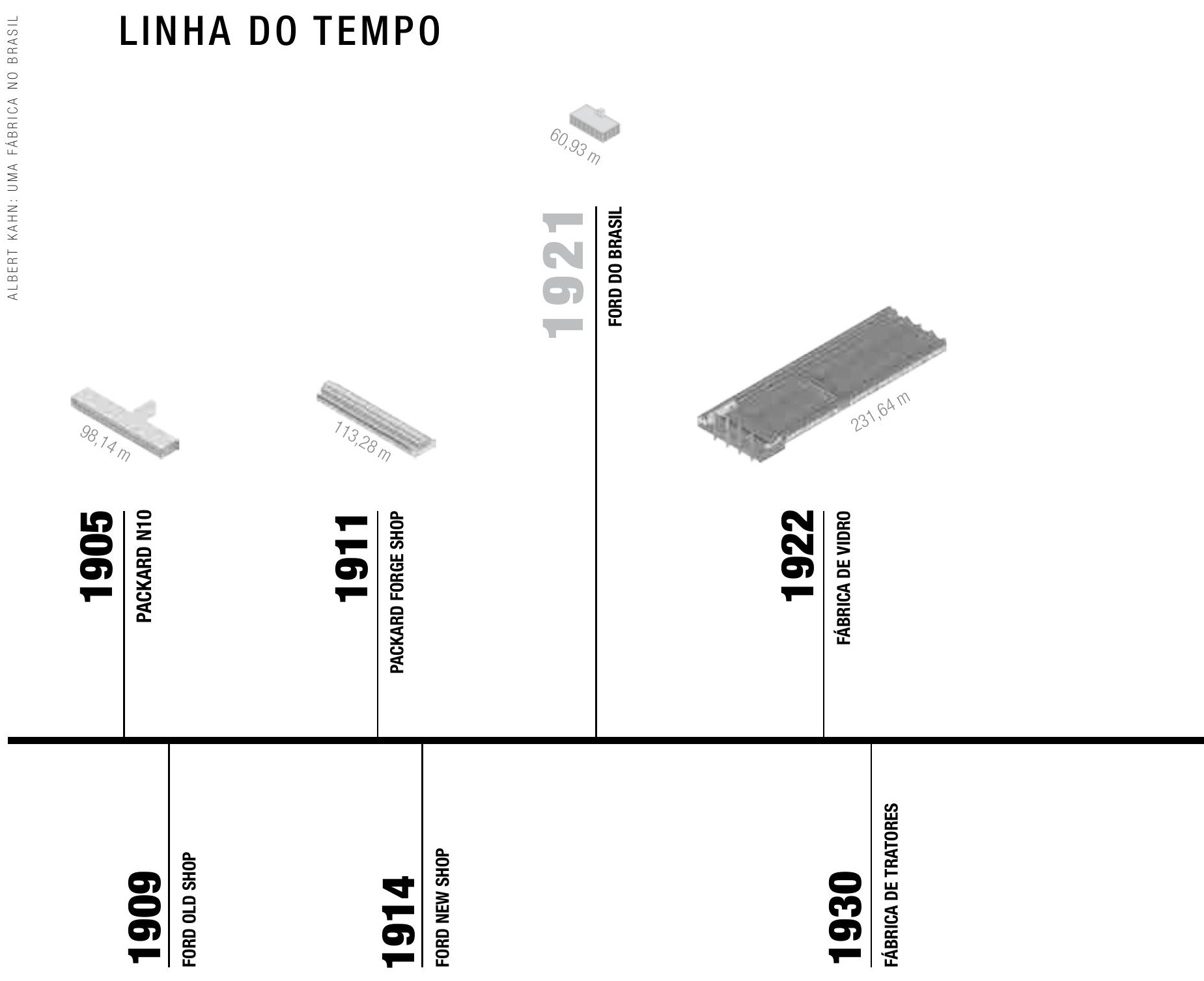



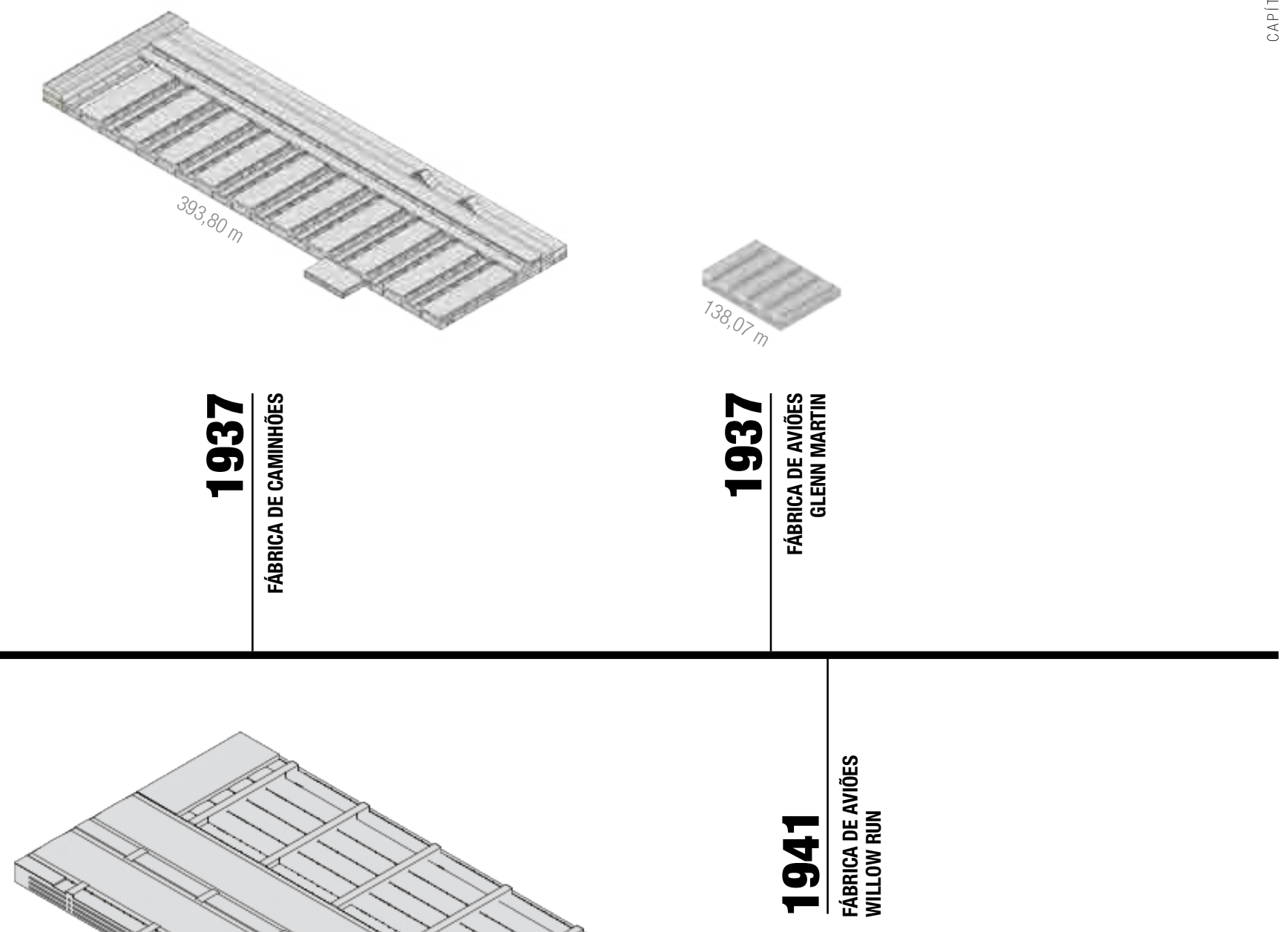

CAP. 4 FÁBRICA 
A instalação da indústria automobilística no Brasil dos anos 1920 alterou de forma significativa os cenários político, econômico, social e cultural do país. Mais do que simplesmente a incorporação tecnológica do fordismo por ela propiciada, o que se consolidou de fato no Brasil foi todo um projeto de modernidade, hegemônico no pós-Guerra e de inspiração norte-americana, que tinha no automóvel seu elemento central.

A entrada das montadoras americanas no Brasil, particularmente a Ford Motor Company, coincidiu com o nascimento do movimento modernista. A Semana de Arte de 1922, ocorrida em São Paulo, e a ideia de um Brasil unificado por um sistema amplo de rodovias oferecia a possibilidade de transformar o país não apenas de maneira econômica e espacial, mas também no âmbito cultural. Além do mais, trouxe à indústria métodos de produção e consumo que prometiam o progresso e o desenvolvimento dos brasileiros. Neste contexto, em 1921, a construção de uma nova fábrica de montagem da Ford Motor Company no Bairro Bom Retiro, em São Paulo, dotada de uma arquitetura inovadora em relação aos edifícios industriais até então existentes no país, marcou um ponto de virada fundamental no relacionamento do Brasil com o automóvel e com a própria modernidade arquitetônica.

Contudo, antes de se abordar a fábrica da Ford Motor Company inaugurada no Brasil, é essencial tratar dos fatores que a antecederam, até por que estes se relacionam não somente com questões econômicas e políticas, mas se espalham pela história da indústria brasileira, com reflexos na arquitetura nacional. 


\subsection{ANTECEDENTES}

Para iniciar a história sobre a instalação da fábrica da Ford Motor Company no Brasil, é preciso retomar a extensão da presença norte-americana na economia brasileira. As transformações causadas pela Primeira Guerra Mundial (1914-1918) beneficiaram, sem sombra de dúvida, os Estados Unidos. No período entreguerras, uma luta global pela supremacia dominou as relações entre ingleses e americanos ${ }^{166}$, ao passo que a amplitude do desafio dos Estados Unidos à influência britânica teve repercussões em várias regiões do mundo, gerando reflexos na América Latina e, consequentemente, no Brasil.

A América Latina apresentava-se como campo aberto para a penetração econômica estrangeira, interessada nos mercados e recursos naturais dos países em desenvolvimento. Por sua vez, o Brasil, com uma população de 30 milhões de habitantes e um dos maiores PIBs do continente, despontava no contexto latinoamericano como um mercado altamente promissor, transformando-se em um alvo natural de oportunidades de negócios. ${ }^{167}$

166 Sobre o assunto, ver MCKERCHER, B. J. C. Wealth, power, and the new international order: Britain and the American Challenge in the 1920s”. In: Diplomatic History, v. 12, n. 4, Wilmington, p. 411-441, 1988 e GARCIA, E. V. Estados Unidos e Grã-Bretanha no Brasil: transição de poder no entreguerras. Contexto int. [online], v. 24, n.1, p.41-71, 2002.

167 O modelo agroexportador era a base de sustentação econômica da República Velhae, nos anos 1920, a despeito das mudanças no cenário mundial e da aceleraçãodo processo de industrialização em diversos países, a economia brasileira continuava essencialmente agrícola. Ver VILLELA, A. e SUZIGAN, W. Política do Governo e Crescimento da Economia Brasileira, 1889-1945. Rio de Janeiro: IPEA/INPES, 1975, p. 141-142. 
Em tal contexto, o avanço dos Estados Unidos na economia brasileira, visível desde os anos da guerra, possibilitou novos contornos à rivalidade econômica entre as grandes potências. A queda no comércio durante a guerra e a concorrência norteamericana haviam deixado claro às potências europeias que o Brasil não era mais um mercado tranquilamente ocupado e repartido entre interesses estabelecidos. Mesmo antes da guerra, algumas companhias norte-americanas já se encontravam instaladas no Brasil, mas foi durante aquele conflito que o ritmo de abertura de novos empreendimentos ganhou impulso. ${ }^{168} \mathrm{~A}$ descrição do cenário da época, feita por João Normano, merece destaque:

\begin{abstract}
"A guerra foi um verdadeiro terremoto econômico para este continente, o qual não tinha o mínimo grau de preparo para enfrentar a paralisação repentina e simultânea do seu comércio marítimo, investimento, comércio e imigração, e financiamento de crédito. A rotina de vida foi alterada. Os investidores de capitais e os clientes de seus produtos haviam desaparecido. Os representantes das firmas alemãs deixaram de obter novas encomendas; os artigos de luxo franceses, tão procurados, não existiam mais no mercado; os estoques das casas inglesas estavam exaustos; a América do Sul tinha sido abandonada pelos seus velhos amigos. [...] Diante desta confusão, os Estados Unidos fizeram sua investida. Foi sua entrada triunfal." ${ }^{169}$
\end{abstract}

No pós-guerra, a tendência passou a ser de uma aceleração ainda maior no volume de novas empresas e investimentos norte-americanos no Brasil. Em fevereiro de 1919, foi fundada a Câmara Americana de Comércio de São Paulo, presidida por William T. Wright, um membro ilustre da comunidade norte-americana. Um dos primeiros boletins publicados pela nova entidade, que pretendia impulsionar as relações comerciais entre os dois países, informava que o Brasil estava importando mais da metade dos seus artigos de necessidade e de luxo dos Estados Unidos. Em 1920, a Câmara já havia cadastrado 320 empresas norte-americanas estabelecidas somente na cidade de São Paulo. ${ }^{170}$

168 Um caso típico foi o da indústria de carnes congeladas, a qual, por meio do estabelecimento ou compra de frigoríficos no Brasil realizadas por companhias como Continental, Wilson, Armour e Swift, objetivava processar aqui a matéria-prima para exportação. Ver: GARCIA, E. V. Estados Unidos e Grã-Bretanha no Brasil: transição de poder no entreguerras. Contexto int. [online], v. 24, n.1, 2002, p. 44.

169 NORMANO, J. F. A luta pela América do Sul. Rio de Janeiro: Atlas, 1944, p. 23-24.

170 FREITAS JUNIOR, N. O Capital Norte-Americano e Investimento no Brasil: características e perspectivas de um relacionamento econômico (1950-1990). Rio de Janeiro: Record, 1994, p.146-147. 
Os investimentos dos Estados Unidos na América Latina, em geral, e no Brasil, em particular, experimentaram notável crescimento ao longo de toda a década de 1920. Antes da guerra, 80\% dos investimentos dos Estados Unidos na América Latina estavam concentrados apenas no México e em Cuba. No início de 1929, aumentou para 40\% os investimentos alocados apenas na América do Sul, onde os maiores receptores foram a Argentina e o Brasil. ${ }^{171}$

O dinamismo econômico experimentado pelos Estados Unidos durante a Primeira Guerra Mundial foi bastante exitoso no Brasil. A partir de meados da década de 1910, os Estados Unidos ocupariam, pela primeira vez, o lugar de maior fornecedor das importações brasileiras, uma posição historicamente preenchida até então pela Grã-Bretanha. ${ }^{172} \mathrm{O}$ maior país da América do Norte vinha fazendo progressos econômicos durante a década de 1910, sendo que a guerra funcionou como fator catalisador de uma tendência que já estava em curso, conforme bem observado por Eugênio Vargas Garcia:

"As vendas norte-americanas passaram a estar alicerçadas em estratégias empresariais mais sólidas e abrangentes, ao contrário do que ocorria antes da guerra, quando o mais comum era a exportação pura e simples do excedente da produção norte-americana. Em 1913, os Estados Unidos exportavam US\$ 146 milhões para a América do Sul e importavam US\$198 milhões. Em 1920, ano particularmente favorável, pois ainda não era sentida a recuperação comercial europeia, os Estados Unidos haviam passado a exportar US\$ 623 milhões e importar US\$760 milhões. O intercâmbio comercial Brasil - Estados Unidos evoluiu na mesma proporção." ${ }^{173}$

Os setores que registraram os maiores avanços foram aqueles ligados a automóveis, petróleo, máquinas e implementos, bens de consumo duráveis, produtos farmacêuticos, companhias de seguros e outros que serviam indiretamente para reproduzir o American way of life, tais como empresas de comunicações, jornais,

171 Por ocasião da visita do presidente eleito Herbert Hoover a países latino-americanos, ocorrida no final de 1928, o jornal The New York Times divulgou que os Estados Unidos tinham US\$ 5 investidos na América Latina e Caribe para cada US\$ 4 investidos na Europa. Ver: GARCIA, E. V. Estados Unidos e Grã-Bretanha no Brasil: transição de poder no entreguerras. Contexto int. [online], v. 24, n.1, 2002, p. 45.

172 VALLA, V. A penetração norte-americana na economia brasileira (1898-1928): sempre de acordo ou nobre emulação? Rio de Janeiro: Ao Livro Técnico, 1978.p. 145.

173 GARCIA, E. V. Estados Unidos e Grã-Bretanha no Brasil: transição de poder no entreguerras. Contexto int. [online], v. 24, n.1, 2002, p. $50-51$. 
cinema e a indústria de entretenimento. ${ }^{174} \mathrm{~A}$ internacionalização das companhias norte-americanas nesse período refletiu o novo padrão no relacionamento econômico dos Estados Unidos com os países latino-americanos, em especial aqueles localizados mais ao sul do continente.

O caso da indústria automobilística talvez seja o exemplo que melhor ilustra o avanço dos Estados Unidos na economia brasileira nesse período. Em 1913, os automóveis existentes no Brasil eram sobretudo franceses, alemães e britânicos, e representavam cerca de $75 \%$ das importações de carros no país. Com a queda do comércio com a Europa, provocada pela guerra, o Brasil passou a importar quase que exclusivamente, e de forma crescente, automóveis norte-americanos. ${ }^{175} \mathrm{Com}$ o aumento da importação de veículos, cresceu a demanda por bens e serviços correlatos, incluindo peças, acessórios, pneus e combustíveis.

A receptividade dos carros americanos pelos consumidores brasileiros estimulou as companhias norte-americanas a realizarem investimentos diretos no país. A Ford Motor Company tomou a iniciativa e propôs planos para a instalação de uma fábrica no Brasil, que produziria carros com peças e componentes vindos dos Estados Unidos. Em 1921, a Ford inaugurava a sua primeira linha de montagem, localizada no bairro Bom Retiro, em São Paulo. Na mesma época, a General Motors também se interessou pelo mercado brasileiro. A empresa iniciou, em 1925, a montagem de automóveis em instalações no bairro Ipiranga, em São Paulo. Em 1928, a General Motors inaugurou sua nova fábrica em São Caetano do Sul, com vistas à produção em larga escala. ${ }^{176}$

Nos anos 1920, ocorreu um boom na aquisição de carros e caminhões no Brasil, em grande parte estimulado pela forte presença da Ford e da GM. Somente no Estado de São Paulo, o número de veículos cresceria de 2.661, em 1917, para 59.213, em $1928 .{ }^{177}$ Criou-se o mito de que os carros norte-americanos eram mais adaptados às condições das estradas brasileiras, especialmente no interior, onde os fazendeiros eram vistos como compradores em potencial.

174 Em 1926, 95\% de todos os filmes exibidos no Brasil eram norte-americanos. No caso do telégrafo, depois de romper, em 1917, com o monopólio britânico exercido no Brasil pela Western TelegraphCompany, os Estados Unidos ampliaram rapidamente sua participação no total de cabos submarinos instalados em águas brasileiras. Em 1920, a Central and South American TelegraphCompany, pertencente à AllAmericaCables Inc., instalou-se no Brasil. Agências de notícias norteamericanas, como a United Press International (1918) e a Associated Press (1919), também passaram a fornecer seus serviços para jornais brasileiros. Ver: ROSENBERG, E. World War I and the growth of United States preponderance in Latin America. Tese (Ph.D in Philosophy). New York: State University of New York at Stony Brook, 1973, p. 146-148; e TULCHIN, J. S. The Aftermath of War World War I and U.S. Policy toward Latin America. New York: New York University Press, 1971 p. 208-233.

175 GARCIA, E. V. Estados Unidos e Grã-Bretanha no Brasil: transição de poder no entreguerras. Contexto int. [online], v. 24, n.1, 2002, p. 47.

176 Ver as páginas na Internet da Ford do Brasil <http://www.ford.com.br> e General Motors do Brasil <http://www.gmb. com.br>.

177 DOWNES, R. The seeds of influence: Brazil's 'Essentially Agricultural' Old Republic and the United States, 19101930. Tese (Ph.D. Dissertation). University of Texas, 1986, p. 429 e 447-448. 
Esse aumento do investimento comercial dos Estados Unidos no Brasil tinha, como ponto de especial inflexão e estímulo, a indústria automobilística. Foi justamente tirando partido do dinamismo desse setor que outras empresas norteamericanas se instalaram no Brasil, operando nas áreas de autopeças, pneumáticos, óleos combustíveis e mecânica. ${ }^{178}$ Os interesses de tais companhias resultaram na formação de um poderoso lobby a favor do automobilismo, que, para sua continuidade e expansão, necessitava cada vez mais de estradas por onde os carros pudessem trafegar. Essa era a proposta defendida pelo programa pan-americano Good Roads, do Departamento de Comércio dos Estados Unidos, voltado para a promoção do mercado de automóveis na América Latina através da construção de rodovias e incremento da malha rodoviária, com a assistência de técnicos e engenheiros norte-americanos. ${ }^{179}$

Entidades organizadas por brasileiros, entre as quais o Automóvel Club e a Associação de Estradas de Rodagem, divulgavam a mesma mensagem, considerando o automóvel não só como um bem de consumo, mas como uma condição de status. Sintomaticamente, o presidente Washington Luís, um entusiasta do automobilismo, havia cunhado o lema "governar é abrir estradas", demonstrando o espírito da época e a receptividade do governo brasileiro à nova realidade econômica trazida pelos veículos automotores. No início de maio de 1928, foi inaugurada, com grande publicidade e estardalhaço midiático, a rodovia São Paulo-Rio de Janeiro, considerada desde esta época uma obra-símbolo. No mesmo governo, seria também inaugurada a rodovia Rio-Petrópolis. ${ }^{180} \mathrm{~A}$ partir de então, o sistema rodoviário impôs-se no Brasil como modelo dominante no campo dos transportes.

O advento do automóvel produzido em série significou o triunfo definitivo do rodoviarismo sobre as ferrovias. Em 1920, o sistema ferroviário brasileiro, organizado para atender aos interesses da economia agroexportadora, ainda não havia atingido um nível de desenvolvimento que correspondesse às necessidades de integração nacional. Esse sistema caracterizava-se pelo predomínio das estradas de ferro que ligavam regiões produtoras aos portos de exportação. Com a concorrência

178 Subsidiárias de companhias petrolíferas norte-americanas capitalizariam essa demanda e, em 1929, a Atlantic Refining Company of Brazil, a Standard Oil Company of Brazil e a Texas Company of South America eram algumas das empresas que obtiveram grandes lucros e diversificavam seus empreendimentos no país. Ver: GARCIA, E. V. Estados Unidos e GrãBretanha no Brasil: transição de poder no entreguerras. Contexto int. [online], v. 24, n.1, 2002, p. 48-49.

179 SEIDEL, R. N. Progressive Pan Americanism: Development and United States Policy toward South America, 19061931. Tese (PhD. in Latin American Studies). Latin American Studies Program. New York: Cornell University, 1973, p. 266-268.

180 Matéria a respeito da inauguração da rodovia, com fotos da época, publicada em: <https://acervo.oglobo.globo.com/riode-historias/washington-luis-inaugura-primeira-rodovia-asfaltada-do-pais-rio-petropolis-8849272> Acesso: 25 nov. 2018 
enfrentada pelo sistema rodoviário, a construção de novas ferrovias começou a estagnar e, como resultado, o país nem chegaria a completar uma rede ferroviária satisfatória, especialmente em termos nacionais. ${ }^{181}$

A ascensão do rodoviarismo na década de 1920 não poderia simbolizar melhor as mudanças de longo prazo na infraestrutura brasileira e a transição de poder que se estava desenvolvendo no plano global, com o eixo de domínio econômico saindo da Grã-Bretanha e passando para a América do Norte. O modelo agroexportador, ligado ao capital britânico, entraria em crise após a depressão econômica mundial de 1929. Assim, diminuiu a demanda brasileira por exportações britânicas de têxteis, carvão e material ferroviário, as quais compunham os três pilares de seu comércio desde o século XIX.

Em detrimento dos interesses econômicos ou da capacidade produtiva da Grã-Bretanha, o processo de industrialização no Brasil começava a se acelerar, abrangendo tanto a substituição de importações em setores tradicionais, como o vestuário, quanto investimentos diretos de capital estrangeiro em setores não tradicionais, entre os quais os carros. ${ }^{182}$ Os Estados Unidos, portanto, estavam melhor aparelhados para fornecer os bens e serviços de que o Brasil necessitava para ingressar na economia industrial do século XX: máquinas, derivados do petróleo e automóveis.

Diante de tais antecedentes, os quais forneceram um breve contexto econômico, político e social para a instalação da indústria automobilística no Brasil, e conforme foi dito antes, a Ford Motor Company resolveu expandir os negócios para a porção sul do continente americano. No entanto, sua instalação na América Latina ocorreu de forma gradual e progressiva, o que também ajuda a entender a própria condição em que o edifício industrial do Brasil seria, enfim, construído.

181 Para uma análise detalhada do tema automóveis versus ferrovias, ver: DOWNES, R. Autos over Rails: How US business supplanted the British in Brazil, 1910-28. In: Journal of Latin American Studies, v. 24, n. 3, p. 551-83, 1992.

182 ROSENBERG, E. S. Anglo-American economic rivalry in Brazil during World War I. In: Diplomatic History, v. 2, n. 2, 1978, p. 151. 


\subsection{OS PRIMEIROS PASSOS}

Contudo, a Ford Motor Company não decidiu se instalar inicialmente no Brasil. O país escolhido para inaugurar suas expansões no mercado latino-americano acabou sendo a Argentina, com a abertura de uma filial em 1914. Não resta dúvida de que a América Latina não era considerada um mercado fácil. A instabilidade política e econômica, além da falta de estradas para automóveis, tornavam os negócios mais complexos do que à primeira vista. Contudo, mesmo diante desse cenário, muitas encomendas eram originadas especialmente da Argentina e do Brasil, pois havia uma elite emergente pronta para comprar o custoso produto, apesar da falta de infraestrutura local.

Com a eclosão da Primeira Guerra Mundial, cessou a maioria das exportações automotivas da Europa para a América Latina e a Ford aproveitou para ampliar rapidamente a sua organização de funcionários e revendedores, passando a preencher a lacuna. A Argentina havia anunciado a neutralidade de seu país na guerra e, desse modo, foi um dos países que mais atraiu grandes investidores estrangeiros ${ }^{183}$. A primeira filial argentina, a qual contava com oficina e

183 Algumas empresas estrangeiras já haviam se instalado no país: a Smithfield, a Argentine Meat Co., a Armor, a United Shoe Machinery, a West India Oil. Ver: WILKINS, M. e HILL, F. E. American Business Abroad: Ford on Six Continents. New York: Cambridge University Press, 2011, p. 92. 
salão de vendas, era responsável pela venda diretamente aos clientes, bem como aos revendedores espalhados pelo país. Naquele ano, apesar das condições econômicas adversas e da concorrência dos carros europeus, a Ford teve um bom resultado, vendendo quase 800 automóveis. ${ }^{184}$

O rápido crescimento dos negócios da Ford Motor Company no sul do continente justificava o estabelecimento de uma fábrica de montagem argentina, garantindo, assim, taxas de importação e vendas mais baratas. A nova operação fabril da Ford foi instalada em uma antiga fábrica de cigarros na Calle Peru, em Buenos Aires. No entanto, a primeira fábrica de automóveis da Ford em toda a América Latina - essa antiga fábrica de cigarros - rapidamente se mostrou inadequada, e uma fábrica de montagem de carrocerias foi instalada em um prédio alugado a seis quarteirões de distância. Quando a operação conjunta dos dois edifícios se tornou pouco eficiente, a empresa decidiu, então, construir uma nova fábrica.

Um terreno relativamente grande foi comprado na região portuária de Buenos Aires, próximo ao Rio da Prata. É uma lenda em Buenos Aires que, antes do terreno ser comprado, um pedido de autorização foi enviado a Detroit, o qual obteve a seguinte resposta: "Land too expansive. Try other side of the river."185 Como aponta Mira Wilkins e Frank Hill, essa resposta demonstra claramente a ignorância da matriz da Ford, em Detroit, em relação às condições locais. Uma olhada de relance em qualquer mapa teria mostrado que o Rio da Prata tem, nesse ponto, cinquenta quilômetros de largura e, do outro lado do rio, está o Uruguai.

Em 1917, a Ford aprovou a quantia de US\$ 240 mil para a construção da nova fábrica. No entanto, com o envolvimento americano na Primeira Guerra Mundial, a construção do edifício foi adiada; a demanda latino-americana, contudo, permaneceu estável. Assim, em 1919, a pressão pela construção da fábrica voltou mais forte do que nunca. Claro também estava que, se a Ford quisesse aproveitar o boom da expansão do pós-guerra, precisaria estabelecer filiais de vendas e montagem em outras partes da América do Sul. ${ }^{186}$ Nesse momento, a concorrência europeia havia desaparecido e o Modelo $\mathrm{T}$ percorreria um caminho vitorioso na disputa com os carros americanos de outras marcas.

A fábrica de concreto armado, projeto do escritório de Albert Kahn, estava localizada na Calle Wenceslao Villafañe, no bairro La Boca. Com o projeto de

184 Em 1915, a empresa vendeu, apenas na Argentina, 1.455 automóveis. Ver: WILKINS, M. e HILL, F. E. American Business Abroad: Ford on Six Continents. New York: Cambridge University Press, 2011, p.91.

185 Tradução da autora: “Terreno muito caro. Tente o outro lado do rio.” Ver: WILKINS, M. e HILL, F. E. American Business Abroad: Ford on Six Continents. New York: Cambridge University Press, 2011, p. 94.

186 A demanda por carros Ford nunca havia sido tão grande nos países sul-americanos. O Uruguai fez um pedido para 400 unidades em 1916-17, enquanto que, em Valparaíso, no Chile, 500 carros foram comprados. Contudo, a maior demanda pelo Modelo T veio da Argentina, onde, somente no mês de dezembro de 1917, a filial vendeu 1.280 unidades. As vendas naquele país no ano totalizaram 6.957 unidades, mais que o dobro das vendas da Ford França, por exemplo. Ver: WILKINS, M. e HILL, F. E. American Business Abroad: Ford on Six Continents. New York: Cambridge University Press, 2011 , p. 92. 
Kahn em mãos, a construção foi iniciada em 1919 pelo engenheiro B. R. Brown, que supervisionara a construção da fábrica Ford Highland Park, em Detroit (1909), assim como da fábrica Ford em Cork, na Irlanda (1917) e da fábrica Ford em Nova York (1918). Logo depois, ele seria enviado para a América do Sul para supervisionar a construção das fábricas na Argentina e, posteriormente, no Brasil. A respeito da escolha dos terrenos para as fábricas e sobre os projetos, Brown comenta em seu depoimento:

"This is the way those things generally worked out: The local manager would bring material on several available sites to Detroit. Through conferences there, the best site, both as to price and location, would be selected. We would have a survey made and then develop the plans here. When I would leave here, I would have all the plans and specifications with me so that I wouldn't have to depend on foreign architects." ${ }^{187}$

Além de demonstrar um certo preconceito em relação aos arquitetos estrangeiros, o engenheiro Brown e a própria Ford Motor Company não confiavam na qualidade dos materiais locais, quando disponíveis. A cobrança em relação ao cumprimento dos prazos era rigorosa por parte da matriz, em Detroit, e os atrasos após os materiais de construção chegarem ao porto deixavam o engenheiro Brown desesperado:

"The steel... which arrived here on the 'Helenas," he wrote Detroit in a
typical letter, "was not passed through customs and delivered to us until
four weeks after its arrival, so... you will see what I am up against in
making the desired progress on this building." An entire steel structure
was shipped from Youngstown, Ohio, to Buenos Aires, while more steel
for re-enforcement was sent from Chicago. Knudsen rated Argentina
too high in assuming that it could supply wood; Brown could not get

187 Tradução da autora: "Essa é a maneira como as coisas geralmente funcionavam: o gerente local levava material de vários terrenos disponíveis para Detroit. Através de conferências, o melhor terreno, tanto em relação ao preço quanto à localização, era selecionado.Uma pesquisa então era feita e, depois, desenvolvíamos o projeto aqui [Detroit].Quando eu saía daqui, tinha todos os planos e especificações para que não precisasse depender de arquitetos estrangeiros”. O depoimento do engenheiro Brown faz parte de um programa de história oral dirigido por Owen Bombard referente à comemoração do quinquagésimo aniversário da Ford Motor Company. Ver: The Reminiscences of Mr. B. R. Brown, p. 21. Disponível em: <http://cdm15889. contentdm.oclc.org/cdm/compoundobject/collection/p15889coll2/id/3253/rec/11> Acesso: 25 nov. 2018. 

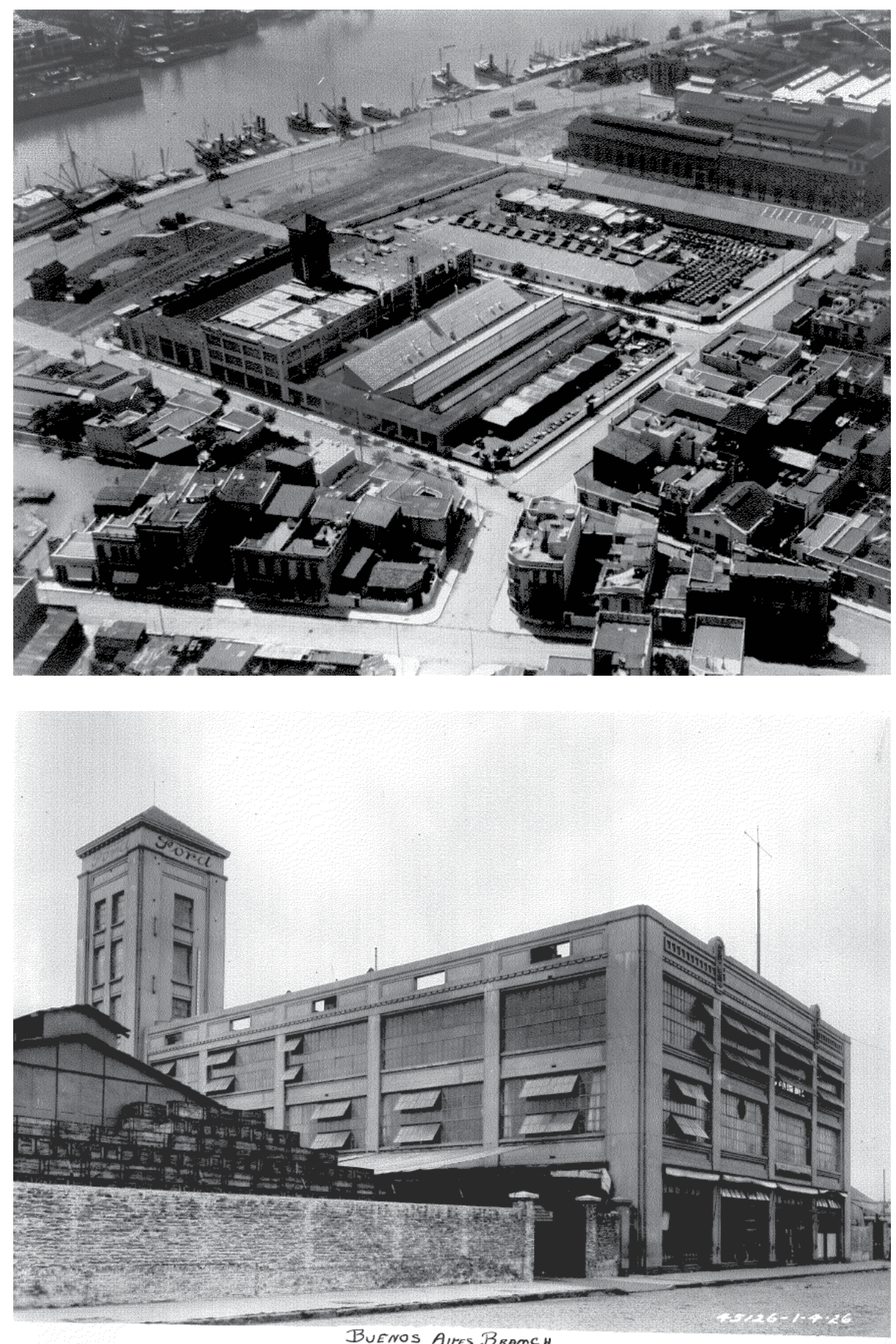

Fig. 124 Vista aérea da Fábrica da Ford de Buenos Aires, Argentina (1921). Fonte: Benson Ford Research Center.

Fig. 125 Exterior da Fábrica da Ford de Buenos Aires, Argentina (1921) Fonte: Benson Ford Research Center. 

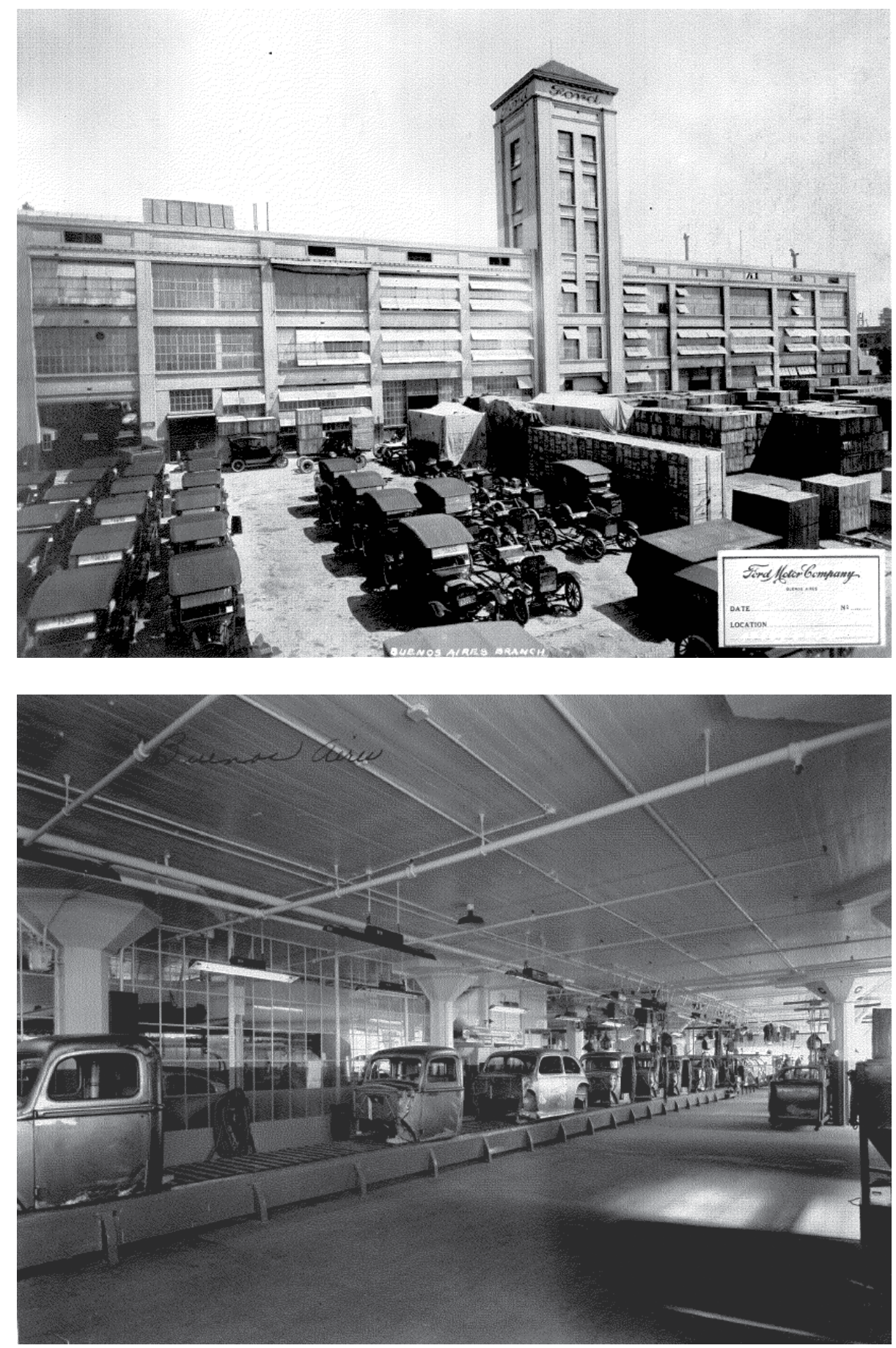

Fig. 126 Exterior da Fábrica da Ford de Buenos Aires, Argentina (1921). Fonte: Benson Ford Research Center.

Fig. 127 Interior da Fábrica da Ford de Buenos Aires, Argentina (1921)

Fonte: Benson Ford Research Center. 


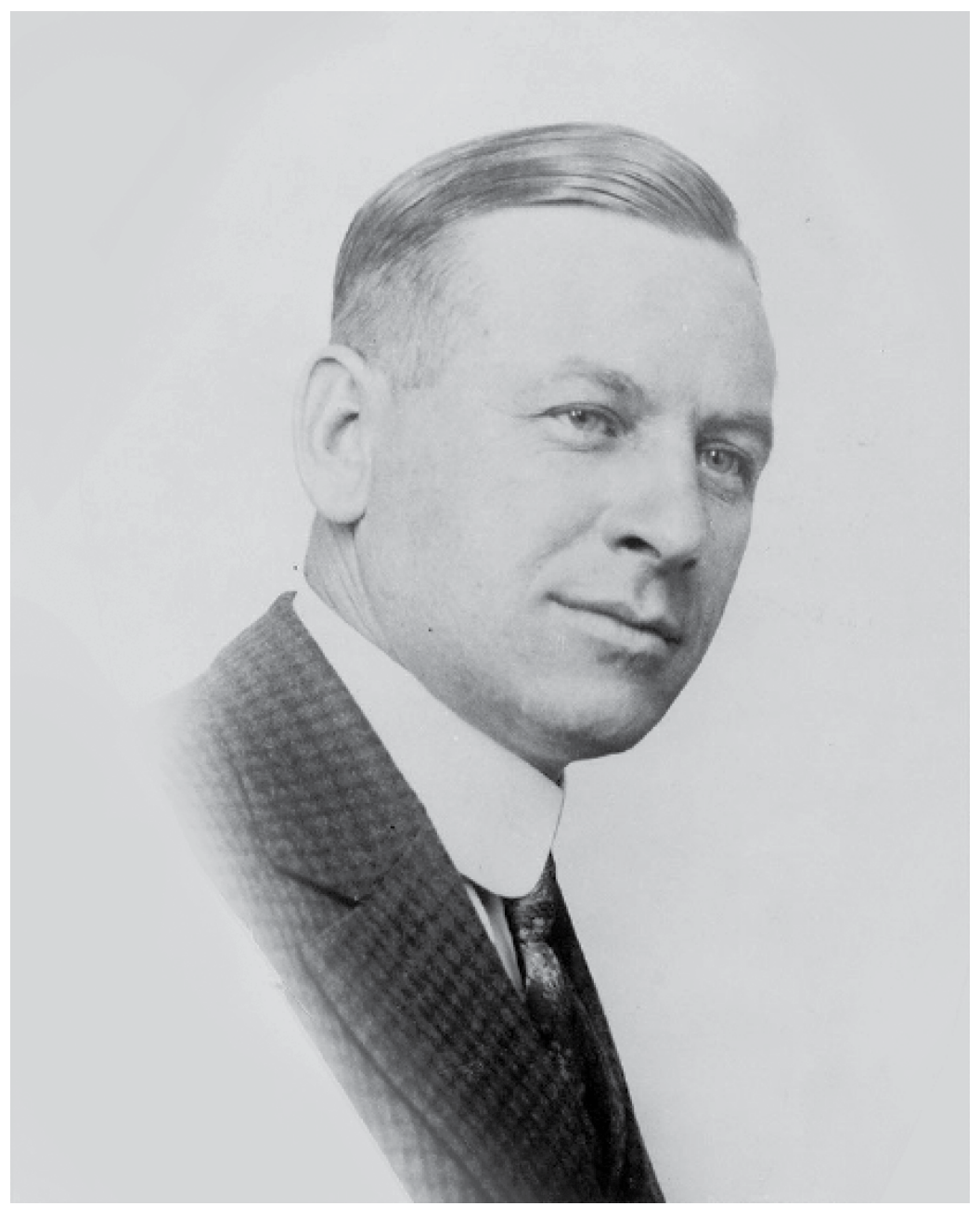

Fig. 128 Engenheiro B. R. Brown.

Fonte:<http://cdm15889.contentdm.oclc.org/cdm/compoundobject/collection/p15889coll2/id/3253/rec/11> Acesso: 25 nov 18 . 
enough, or the quality he wanted, and was even receiving shipments of lumber from the States!" ${ }^{188}$

A fábrica foi inaugurada em 1921, com a produção do famoso carro Modelo T, o qual vinha dos Estados Unidos semi-montado (CKD). Logo que o negócio na Argentina encontrava-se solidamente organizado, uma fábrica de montagem foi construída em São Paulo e, ainda durante a construção da fábrica brasileira, decidiu-se estabelecer uma filial em Montevidéu, no Uruguai. Devido à estabilidade e à crescente prosperidade econômica do Uruguai, muitas empresas estrangeiras acabaram se estabelecendo na capital uruguaia e, em 1926, uma nova fábrica de montagem foi finalmente construída em Montevidéu, também com projeto realizado por Albert Kahn.

Como a América Latina não possuía indústria automotiva própria, a Ford Motor Company não encontrou concorrência local ou políticas governamentais discriminatórias que favorecessem a produção nacional. Tais condições, de acordo com Mira Wilkins e Frank Hill, diferiam da europeia, onde havia tradicionalmente orgulho em produtos e processos nacionais. Nesse cenário, os carros americanos, fabricados nos seus respectivos países, eram vistos com entusiasmo pelos compradores latino-americanos.

A popularização do carro e a construção das fábricas foram convertidas em um poderoso emblema de progresso durante a primeira metade do século XX, ajudando a explicar a expansão do nome Ford e do fordismo não só na Argentina como nos demais países da América Latina. O mito do automóvel como símbolo da modernidade em uma época em que a indústria pesada ainda era percebida como sinônimo de progresso é um elemento indispensável na compreensão da instalação da fábrica em São Paulo. Nesta linha de pensamento, o desejo do Brasil de atingir a modernidade encontrou perfeita consonância no edifício industrial construído em São Paulo para abrigar a fábrica, refletindo-se em outras partes da vida nacional, em especial na cultura.

188 Tradução da autora: “O aço... que chegou aqui no 'Helenas", escreveu ele em uma carta típica para Detroit, "não passou pela alfândega e foi entregue a nós quatro semanas depois de sua chegada, então... você verá o que estou enfrentando para fazer o progresso desejado neste edifício." Uma estrutura de aço inteira foi enviada de Youngstown, Ohio, para Buenos Aires, enquanto mais aço para reforço foi enviado de Chicago. Knudsen avaliou a Argentina muito alto em assumir que poderia fornecer madeira; Brown não conseguia o suficiente, nem a qualidade que queria, e recebia até remessas de madeira dos Estados Unidos! Ver: WILKINS, M. e HILL, F. E. American Business Abroad: Ford on Six Continents. New York: Cambridge University Press, 2011, p. 94. William Knudsen, americano nascido na Dinamarca, trabalhou na Ford Motor Co. como supervisor do estabelecimento de fábricas de montagem nos Estados Unidos e no exterior. 


\subsection{O DESEJO DE SER MODERNO}

As comemorações do centenário da Independência em 1922 fizeram aflorar, para a sociedade brasileira, a necessidade de não apenas repensar os rumos da República, mas também de traçar caminhos inéditos a serem trilhados. Por todo o país, a intelectualidade comprometida com a construção de um Brasil moderno buscava sintonizar a realidade nacional com o ritmo veloz do mundo urbano e industrial daquele início do século XX.

Para autores como Mário de Andrade e Oswald de Andrade, a busca de uma nova nação passava necessariamente pela "oposição ao passadismo, a busca da atualização e modernização cultural"189, além da adesão aos ritmos cada vez mais intensos da vida urbana. A cidade de São Paulo, com seu dinamismo, suas fábricas, seu progresso, sua realidade urbano-industrial e a incorporação das novas tecnologias da sociedade de massas, representava a base "para superação do atraso e garantia da entrada do país na modernidade" ${ }^{190}$.

Oswald de Andrade, através da visualização de uma estrutura dinâmica,

189 PINTO, M. I. Urbes industrializada: o modernismo e a pauliceia como ícone da brasilidade. In: Revista Brasileira de História, São Paulo, v. 21, n. 42, 2001, p. 436.

190 Ibidem. 
capta o movimento frenético e contraditório da urbanização de São Paulo, com traços provincianos que não deixam esconder a sua avidez pelo progresso:

"Locomotivas e bichos nacionais

(...)

Arranha-céus

Fordes

Viadutos

Um cheiro de café.”

(Oswald de Andrade, Pau-brasil, 1925) ${ }^{191}$

No que diz respeito ao campo cultural, a Semana de Arte Moderna, realizada na capital paulista em fevereiro de 1922, trazia explicitamente a mensagem de que era preciso garantir para São Paulo o lugar de principal polo industrial do país, de centro das decisões político-nacionais e de eixo da produção cultural brasileira moderna. Na avaliação de Mário de Andrade, São Paulo encontravase mais preparada para assumir o protagonismo do que a então capital do país, o Rio de Janeiro:

"Ora São Paulo estava muito mais "ao par" que o Rio de Janeiro. E, socialmente falando, o modernismo só podia ser importado por São Paulo e arrebentar aqui. Havia uma diferença profunda, já agora pouco sensível, entre Rio e São Paulo. [...] São Paulo era muito mais "moderna" porém, fruto necessário da economia do café e do industrialismo consequente. [...] São Paulo ao mesmo tempo estava, pela sua atualidade comercial e sua industrialização, em contato, se menos social, mais espiritual (não falo "cultural") e técnico com a atualidade do mundo. É mesmo de assombrar como o Rio mantém, dentro da sua malícia de cidade internacional, um ruralismo, um caráter tradicional muito maiores que São Paulo." ${ }^{192}$

191 AMARAL, A. Tarsila, sua obra e seu tempo. São Paulo: Edusp, 2010, p.21.

192 Semana de 22, por Mário de Andrade. Disponível em: < https://cultura.estadao.com.br/noticias/geral,semana-de-22por-mario-de-andrade,20020210p2229> Acesso: 05/01/19 
O papel de liderança econômica do país aos poucos foi assumido pela cidade de São Paulo. A capital paulista incorporava plenamente o papel de metrópole, foco do desenvolvimento e irradiadora dos novos hábitos e costumes. Graças ao seu processo de industrialização mais intenso, no início do século XX também assumiria, em grande medida, o protagonismo político em esfera nacional. Olhando em retrospecto, São Paulo parecia ser um local óbvio para a instalação das indústrias estrangeiras, mas, na época, não fazia tanto sentido, uma vez que o Rio de Janeiro era a capital nacional e possuía um importante porto. A cidade de São Paulo, por outro lado, não tinha saída para o mar, fazendo com que a carga marítima fosse descarregada em Santos e levada de trem até a capital paulista.

É nesse contexto que o primeiro automóvel chega ao Brasil, trazido por Alberto Santos Dumont, um dos precursores da aviação. Desde muito jovem, Santos Dumont interessava-se pelas fascinantes máquinas modernas, o que levou seu pai a enviá-lo à Europa para que aprendesse mais sobre esses avanços tecnológicos do novo mundo. Em 1891, Santos Dumont desembarcou no Porto de Santos com seu Peugeot. Como observa Victor Andrade de Melo, "logo transferido para a cidade de São Paulo, pode-se imaginar a surpresa da população ao ver aquela máquina barulhenta deslocando-se pelas ruas sem a necessidade de cavalos para a tração" ${ }^{193}$. Não demorou muito para a novidade atrair a atenção de alguns membros da elite brasileira, tornando-se objeto de desejo e símbolo de status, para não dizer de pujança econômica.

Os automóveis contribuíram para a reestruturação da forma de viver, em parte por facilitarem o cotidiano das pessoas - ainda que inicialmente tenham sido um privilégio dos membros das elites -, mas também por explicitarem símbolos que expressavam a construção de um novo ideário. ${ }^{194}$ A este respeito, Giucci comenta que o automóvel é "o símbolo por excelência do moderno no início do século. É a máquina bufante, o novo sáurio mecânico, o carro de fogo, envolto numa nuvem de pó." 195

O avanço tecnológico não influenciava somente em termos laborais, mas também afetava o tempo da diversão. Os automóveis eram úteis para o trabalho, realizando o transporte de pessoas ou de cargas; no aspecto da diversão, ampliavam

193 MELO, V. A. O Automóvel, o Automobilismo e a Modernidade no Brasil (1891-1908). In: Revista Brasileira de Ciências do Esporte, Campinas, v. 30, n. 1, setembro 2008, p. 193.

194 Uma discussão sobre esse assunto pode ser obtida nos estudos de SEVCENKO, Nicolau. Introdução. O prelúdio republicano, astúcias da ordem e ilusões do progresso. In: SEVCENKO, N. Introdução. O prelúdio republicano, astúcias da ordem e ilusões do progresso. In: ___ (org). História da vida privada no Brasil. República: da Belle Epoque à era do rádio. São Paulo: Companhia das Letras, 1998, p.7-48, e CHARNEY, L.; SCHWARTZ, V. O cinema e a invenção da vida moderna. São Paulo: Cosac\&Naify, 2001

195 GIUCCI, G. Máquinas e estética. In: Lugar Comum, Rio de Janeiro, NEPCOM/UFRJ, n. 8, maio/agosto 1999, p.66. 
as possibilidades de viagens e passeios. Serviam tanto para potencializar a busca da natureza, algo valorizado no início do século XX em função do rápido crescimento das cidades, quanto também ajudavam a celebrar, com as corridas de carro, a grande excitabilidade urbana.

É também no início do século XX que podemos observar em São Paulo uma melhor estruturação de um mercado de diversões, que incluía espetáculos musicais e teatrais, os primeiros momentos do cinema nacional e o crescimento da organização, presença e diversificação das práticas esportivas. Os esportes passaram a ser entendidos como um estilo de vida, adequado aos que se pretendiam modernos, constituindo a expressão dos novos tempos, a criação de hábitos saudáveis, e expressavam uma nova relação com o corpo, com a higiene e com a saúde. ${ }^{196}$ Articulava-se, assim, tecnologia, progresso, ciência e diversão:

"O fonógrafo, o cinema (uma grande novidade, muitas vezes chamada de “a invenção do século"), as exposições universais (aliando a demonstração de avanços tecnológicos com situações festivas), as exibições musicais e de dança, a melhoria das condições para a manutenção dos cafés abertos à noite e para a realização de funções teatrais noturnas (possíveis graças à "milagrosa luz elétrica”), a nova configuração dos espetáculos esportivos (com os recordes e resultados sendo aferidos com precisão pelo uso de cronômetros) são alguns dos exemplos de como a tecnologia esteve presente não só na esfera do trabalho, mas também na da diversão, envolvendo todos e tudo em novas e cada vez mais crescentes estratégias comerciais, marcas de uma indústria cultural que dava seus primeiros passos, já configurada a partir da articulação das ideias de consumo e espetáculo.” ${ }^{197}$

Em São Paulo, crescia o desejo de ser moderno, de se ajustar e de se inserir na grande onda mundial do início do século XX. Industrialização, reformas urbanas, preocupações com a higiene e com a saúde, surgimento de novos hábitos, importação de produtos, entre outras, são propostas que se encontram nos discursos

196 MELO, V. A. O Automóvel, o Automobilismo e a Modernidade no Brasil (1891-1908). In: Revista Brasileira de Ciências do Esporte, Campinas, v. 30, n. 1, setembro 2008, p. 191.

197 Ibid, p. 189-190. 
e nas práticas daqueles que detinham o poder de designar os rumos da sociedade brasileira. Uma clara expressão são as ações do primeiro prefeito de São Paulo, Antônio da Silva Prado, que tomou posse em 1899 e permaneceu no cargo por 12 anos. De família tradicional, ligada à economia cafeeira, Antônio Prado procurou modernizar a cidade através da construção de pontes, aterramento de várzeas e implantação do sistema de energia elétrica, para citar algumas realizações. A crônica de João do Rio retrata esse cenário onde o automóvel não só passou a ser bastante valorizado como inclusive se transformou em símbolo da época:

"E, subitamente, é a era do Automóvel. O monstro transformador
irrompeu, bufando, por entre os descombros da cidade velha, e como
nas mágicas e na natureza, aspérrima educadora, tudo transformou com
aparências novas e novas aspirações." ${ }^{198}$

Os primórdios da indústria automobilística em São Paulo são parte desse contexto histórico, dialogando com os aspectos sociais, econômicos, políticos e culturais de um país ansioso por um salto de modernidade. O perfil dos primeiros proprietários brasileiros de automóveis era semelhante: membros da elite, muitas vezes originários de famílias tradicionais, e que buscavam - nos carros - a ideia de modernização do país. $\mathrm{Na}$ época, o uso do veículo estava especialmente relacionado à busca de elementos de status e distinção, uma forma de vinculação ao civilizado mundo moderno e suas maravilhas tecnológicas.

Um dos expoentes mais significativos de tal ponto de vista era, sem dúvida, o próprio Henry Ford. Através de seus inúmeros escritos, Ford defendia a modernidade baseada nos carros, destacando o Brasil como um país preparado para as mudanças. ${ }^{199}$ As ideias de Ford eram bem conhecidas no Brasil, uma vez que seus livros, assim como aconteceu em outros países, foram rapidamente traduzidos para o português tão logo publicados no mercado americano. Em seu trabalho mais relevante, "Today and Tomorrow", Ford defendeu de forma explícita e categórica a transformação do Brasil: "The automobile will make a great nation out of Brazil”. ${ }^{200}$

Muitos brasileiros viam Henry Ford como um homem que usava a inovação industrial para promover a modernidade e, neste aspecto, seria uma espécie de

198 JOÃO do Rio. In: GOMES, R. C. (Org.). Nossos clássicos. Rio de Janeiro: Agir, 2005, p. 57-60 199 WOLFE, J. Autos and progress: the Brazilian search for modernity. New York: Oxford University Press, 2010, p. 67-68. 200 Tradução da autora: "O automóvel fará do Brasil uma grande nação". Em: FORD, Henry. Today and tomorrow. New York: Doubleday, 1926, p. 262-263. 
guru dos tempos modernos, um arauto da prosperidade trazida pela nova era de evolução tecnológica. Até mesmo a tentativa fracassada de industrializar a produção de borracha na Amazônia foi vista como um experimento ousado. ${ }^{201}$ Vários proeminentes intelectuais brasileiros ajudaram a divulgar as ideias de Ford, mas ninguém superou - em entusiasmo e verve - o escritor Monteiro Lobato. Ele traduziu os livros de Ford e escreveu o prefácio para a edição brasileira do livro "Minha vida e minha obra":

\footnotetext{
"E quem no mundo moderno, mais que Henry Ford, está fecundando o progresso humano com o pólen que fará o nosso amanhã melhor que o nosso hoje e o nosso ontem? [...] Para o Brasil não há leitura nem estudo mais fecundo que o livro de Henry Ford. Tudo está por fazer - e que lucro imenso se começarmos a fazer com base na lição do portador da nova Boa Nova!"202
}

Assim, não surpreende que a Ford Motor Company tenha sido a primeira fábrica de automóveis a se instalar no país, e que São Paulo acabou se tornando a cidade escolhida como local ideal para a construção da fábrica. $\mathrm{Na}$ condição de um polo nacional que ambicionava a industrialização e a modernidade, a capital paulista era um lugar que não só representava o desejo de desenvolvimento como ainda estava imersa em uma situação social e cultural ávida por recepcionar as novidades e, não bastando, difundi-las para o país inteiro. São Paulo tinha o mesmo ideário de Henry Ford; era uma cidade com uma visão empreendedora e voltada para a modernização constante e inexorável, uma cidade que respirava progresso.

Não resta dúvida de que o contexto social e cultural serviram de substrato psíquico para a escolha da cidade como porta de entrada da Ford Motor Company no Brasil. Não só o país ansiava por um salto de modernização (representado pelo desenvolvimento intenso de São Paulo) como os automóveis fabricados por Henry Ford eram a parte mais visível deste desejo. O país estava pronto para as inovações fordistas, e a construção da primeira fábrica da Ford Motor Company em solo brasileiro constituiu na materialização dessa vontade de sair de um país ainda majoritariamente rural e passar para uma nova fase de industrialização e progresso. 


\subsection{FORD MOTOR COMPANY DO BRASIL}

Antes da decisão de construir uma fábrica de montagem no Brasil, a Ford estabeleceu uma filial em São Paulo em 1919. Através da transferência de um capital de 25 mil dólares, o qual estava originalmente destinado à filial argentina, a Ford Motor Company do Brasil deu seus primeiros passos em um pequeno depósito de dois andares alugado na Rua Florêncio de Abreu, na capital paulista, onde iniciou a montagem dos automóveis Modelo T. ${ }^{203} \mathrm{~A}$ empresa tornou-se, assim, a primeira fabricante de automóveis a se estabelecer em território nacional. A visita à fábrica de montagem da Ford acabou por se tornar um dos programas favoritos dos paulistanos nos finais de semana:

"O brasileiro que quiser e tiver dinheiro suficiente para ter um automóvel não precisa mais comprá-lo no exterior. Basta aguardar que um modelo Ford Bigode - apelido que o popular Ford-T ganhou no Brasil - saia quentinho da linha de montagem da empresa americana, que obteve a permissão de Epitácio Pessoa para funcionar no país, na Florêncio de

203 Antes disso, os veículos da Ford chegavam ao Brasil importados por William T. Wright. Ver: WILKINS, M. e HILL, F. E. American Business Abroad: Ford on Six Continents. New York: Cambridge University Press, 2011, p. 93. 
Abreu, em São Paulo. A fábrica, na verdade, é apenas uma montadora de carros, já que as peças são todas importadas. Para colocar cada uma em seu devido lugar, a Ford precisa usar apenas a mão-de-obra de 12 funcionários. Os paulistanos, que adoram uma novidade e sobretudo os automóveis, transformaram a montadora num ponto turístico da cidade. Nos fins de semana, não é raro ver centenas de pessoas tentando entender como um monte de peças se transforma em um carro." ${ }^{204}$

A Ford permaneceu pouco tempo nesse endereço e, em 1920, alugou um edifício maior na Praça da República, também no centro da cidade de São Paulo. $\mathrm{O}$ antigo Cine Teatro República, mais conhecido por Skating Palace por abrigar uma grande pista de patinação, foi convertido na fábrica de montagem da Ford após o seu abandono. ${ }^{205}$ Contudo, o espaço disponível não tardou a se mostrar inadequado:

\begin{abstract}
"The only place available for assembly operations was an old movie theater on Praca da Republica in the center of the city. There the assembly line together with storage of heavy materials were installed on the ground floor, and on the various balconies all the operations, such as body assembly, upholstery, etc. were placed. An oven for enameling fenders, hoods, and other materials was also installed on one of the balconies. It was an old-fashioned box oven heated with crude oil and it proved to be a very dangerous piece of equipment. Explosive gases would form inside the tightly closed oven and any impurity that might happen to get in could easily ignite and cause an explosion. This happened one day when the oven blew up with a tremendous bang that shook the whole building. Material and equipment fell from the balcony down below where the cars were being assembled and considerable damage was done, but fortunately nobody was seriously hurt." 206
\end{abstract}

Nesta época, aumentou a demanda dos brasileiros pelo carro Modelo T e pelo caminhão Modelo TT, o que levou a empresa americana a propor a construção de sua primeira grande fábrica de montagem no país. $\mathrm{O}$ terreno escolhido para

204 Publicado no Jornal do Brasil, na edição de 12 de maio de 1920. Disponível em: <http://archive. li/1luev\#selection-363.3-363.814> Acesso em: 15 jan. 2019.

205 Para se adaptar ao processo fabril, algumas modificações foram feitas no antigo edifício, como fechamento parcial do segundo pavimento e instalação de um forno na seção de pintura. Para saber mais informações sobre o edifício, acessar o site: <http://www.arquiamigos.org.br/info/info30/i-estudos2.htm> . Acesso: 24 nov. 2018

206 Tradução da autora: “O único lugar disponível para operações de montagem era um antigo cinema na Praça da República, no centro da cidade. Neste local, a linha de montagem, juntamente com o armazenamento de materiais pesados, foi instalada 

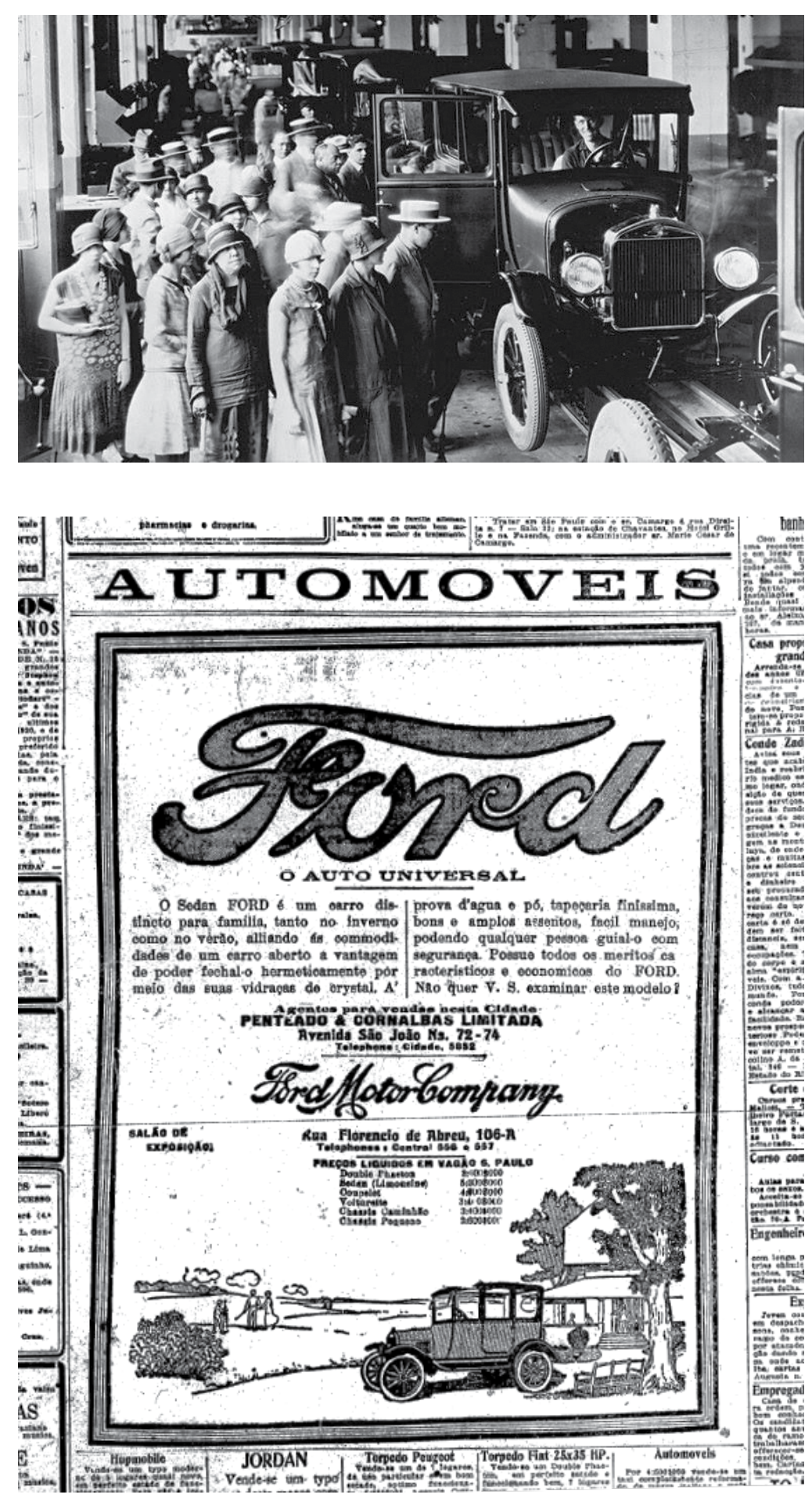

Fig. 129 Fábrica da Ford Motor Company do Brasil, na Rua Florencio de Abreu, São Paulo (1919). Fonte: <http://www.saopauloinfoco.com.br/ford-sao-paulo/>Acesso: 15 jan 19 .

Fig. 130 Anúncio da Ford no jornal Estado de São Paulo, em 1920. 


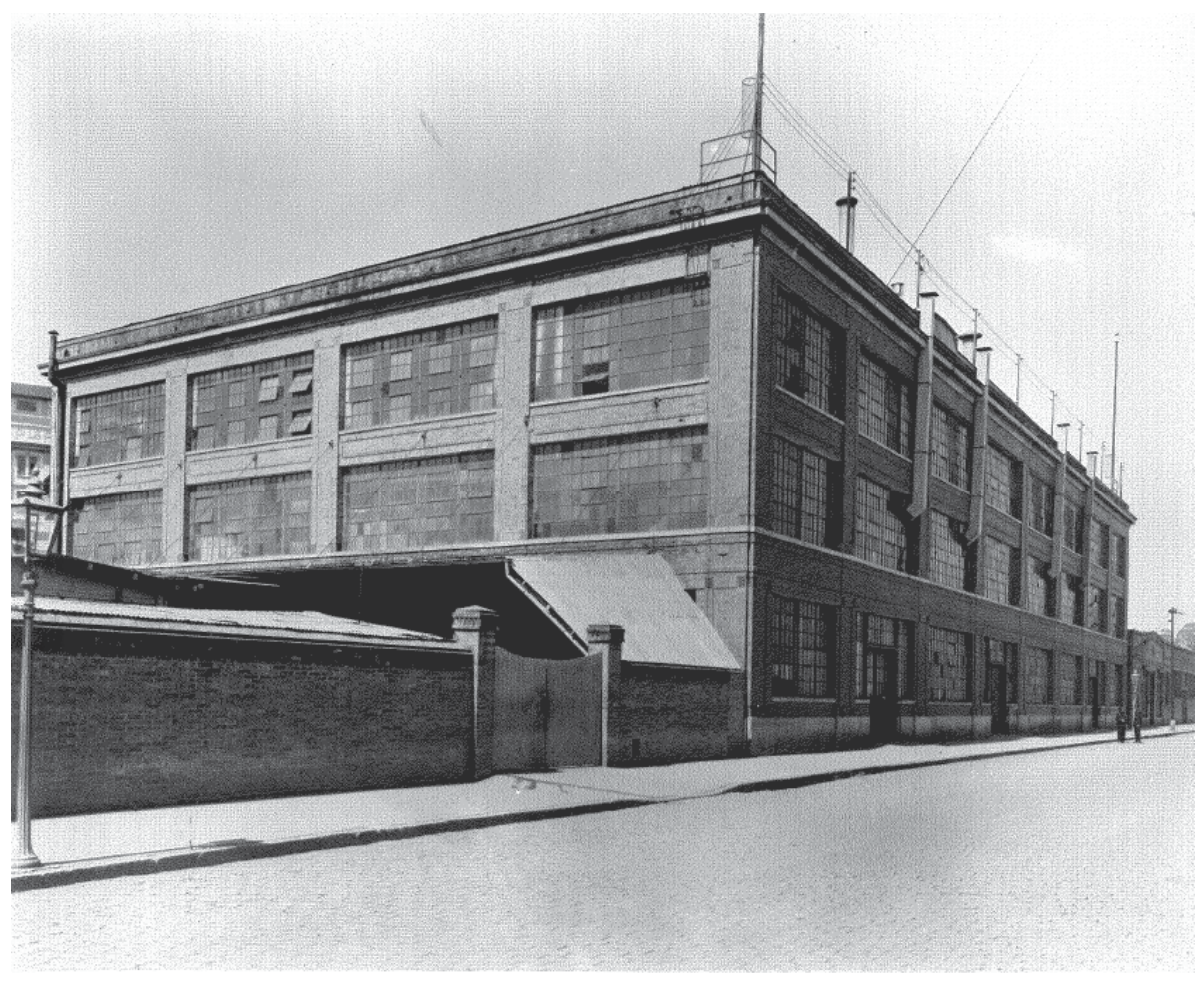

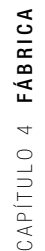

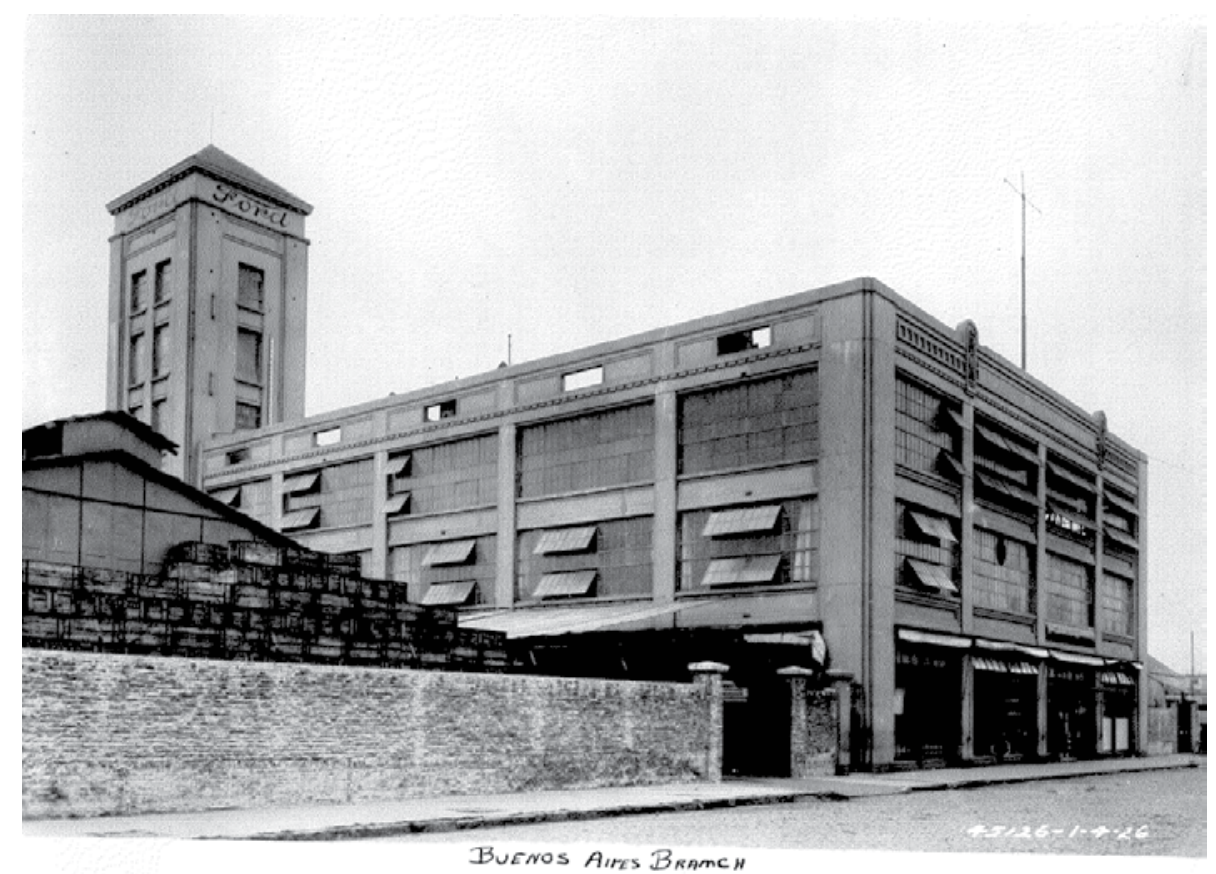

Fig. 131 Exterior da Fábrica da Ford de São Paulo, Brasil (1921). Fonte: Benson Ford Research Center.

Fig. 132 Exterior da Fábrica da Ford de Buenos Aires, Argentina (1921)

Fonte: Benson Ford Research Center. 
a nova fábrica brasileira mantinha a tradição de se localizar no centro da cidade, desta vez na Rua Solon, bairro Bom Retiro. Esta região, por se encontrar margeada por uma linha férrea, era considerada uma importante área industrial da capital paulista.

Logo que o projeto foi aprovado, o engenheiro Brown ficou responsável pela construção das duas fábricas - argentina e brasileira -, indo e voltando pelos quase dois mil quilômetros que separam os dois projetos com o intuito de supervisioná-los. Era uma das poucas fábricas da Ford sem contato com a orla, uma vez que o porto de Santos estava localizado a setenta quilômetros de distância. Mira Wilkins e Frank Hill comentam que as duas fábricas eram muito semelhantes entre si, parecendo miniaturas da Ford Highland Park, construída em Detroit em 1909. ${ }^{207}$ Tanto a fábrica argentina quanto a brasileira eram de concreto armado e tinham três pavimentos de altura, os quais, no final, ganharam o acréscimo de um quarto pavimento.

A respeito da construção, o engenheiro Brown também se queixava do Brasil, especialmente em relação à oferta de materiais locais e da dificuldade de cumprir os prazos devido à burocracia para o material ser liberado no Porto de Santos - algo muito semelhante ao que acontecera em Buenos Aires:

\footnotetext{
"The Buenos Aires job wasn't an easy one but it wasn't too hard either. I had more trouble in Sao Paulo, Brazil, building that plant. In that case I hired the contractor on a fee basis instead of a lump sum contract because I had to buy the material and furnish it to him. As a matter of fact, the cement for Sao Paulo came from Canada. There was no cement available in Brazil. The lumber came from New Orleans; that was the form lumber for the concrete structure. The structural steel came from Europe. Those were the main items that went into the buildings; lumber, steel, and concrete. ${ }^{208}$
}

no piso térreo e, nas diversas varandas, todas as operações, como montagem de carroceria, estofamento, etc., foram colocadas. Um forno para esmaltar pára-lamas, carrocerias e outros materiais foi instalado em uma das varandas. Era um forno antiquado, aquecido com óleo, e provou ser um equipamento muito perigoso. Gases explosivos se formariam dentro do forno hermeticamente fechado e qualquer impureza que pudesse acontecer poderia inflamar facilmente e causar uma explosão. Infelizmente, isso acabou acontecendo um dia. $\mathrm{O}$ forno explodiu, abalando todo o edifício. Materiais e equipamentos caíram das varandas em cima dos carros que estavam sendo montados, causando danos consideráveis. Felizmente, ninguém ficou ferido com seriedade.” Ver: The Reminiscences of Mr. Kristian Orberg, p. 9. Disponível em: <http://cdm15889.contentdm. oclc.org/cdm/compoundobject/collection/p15889coll2/id/12875/rec/1> Acesso: 25 nov. 2018.

207 WILKINS, M. e HILL, F. E. American Business Abroad: Ford on Six Continents. New York: Cambridge University Press, 2011, p. 94-95.

208 Tradução da autora: O trabalho de Buenos Aires não foi fácil, mas também não foi difícil. Eu tive mais problemas em São Paulo, Brasil, construindo aquela fábrica. Nesse caso, contratei o empreiteiro com base em honorários, ao invés de um contrato de preço fixo, porque tive de comprar o material e fornecer a ele. De fato, o cimento para São Paulo veio do Canadá. Não havia cimento disponível no Brasil. A madeira veio de Nova Orleans; essa era a fôrma da madeira para a estrutura de concreto. $\mathrm{O}$ aço estrutural veio da Europa. Esses eram os principais itens que os edifícios eram feitos; madeira, aço e concreto. Ver: The Reminiscences of Mr. B. R. Brown, p. 22. Disponível em: <http://cdm15889.contentdm.oclc.org/cdm/ compoundobject/collection/p15889coll2/id/3253/rec/11> Acesso: 25 nov. 2018. 
Assumindo o cargo de gerente geral, o dinamarquês Kristian Orberg mudou-se para São Paulo em 1921. Apesar do otimismo dos brasileiros em relação ao progresso econômico, social e cultural do país naquele momento, Orberg compartilhava uma visão parecida com a de Brown a respeito do Brasil:

“To choose and train new dealers at that time, that is, in the early 1920's when we really started organizing the Ford business in Brazil, was not a easy as it might sound. Roads where extremely bad or nonexisting and the railroads, most of which were constructed during the last half of the nineteenth century, could not possibly cover the vast area which constitutes the Brazilian Republic or take care of the increasing transportation problems of all kinds that were pressing on. Under these conditions, communications in the interior were extremely slow and difficult."209

Em menos de um ano, a fábrica foi inaugurada, o que aconteceu em 1921, permitindo que a empresa expandisse as suas operações em território brasileiro e iniciasse um período de prosperidade. A fábrica foi projetada para uma produção diária de cerca de trinta unidades de automóveis, algo que, na época, era considerada como uma produção bem simples. ${ }^{210}$ No entanto, o Brasil estava entrando em um período muito próspero, e os negócios e atividades industriais, em geral, estavam passando por um rápido crescimento.

Um número recorde de pessoas foram vistas no pavilhão da Ford Motor Company, na Primeira Exposição de Automobilismo, realizada no Rio de Janeiro, em 1925, onde a Ford possuía uma linha de produção na qual montava carros durante o evento. ${ }^{211}$ Mário de Andrade, no artigo "Manuel Bandeira", publicado na Revista do Brasil, refere-se explicitamente ao impacto que a linha de montagem lhe causou ao visitar a fábrica em São Paulo, comparando a montagem de um automóvel à escrita da poesia:

209 Tradução da autora: "Escolher e treinar novos revendedores na época, isto é, no início dos anos 1920, quando realmente começamos a organizar os negócios da Ford no Brasil, não era fácil, por mais que isso soasse simples. Estradas extremamente ruins ou inexistentes e as ferrovias, que foram construídas durante a última metade do século XIX, não poderiam cobrir a vasta área que constitui a República brasileira ou atender aos crescentes problemas de transporte de todos os tipos que estavam pressionando. Sob tais condições, as comunicações no interior eram extremamente lentas e difíceis." Ver: The Reminiscences of Mr. Kristian Orberg, p. 13. Disponivel em: <http://cdm15889.contentdm.oclc.org/cdm/compoundobject/ collection/p15889coll2/id/12875/rec/1> Acesso: 25 nov. 2018.

210 The Reminiscences of Mr. Kristian Orberg, p. 10. Disponível em: <http://cdm15889.contentdm.oclc.org/cdm/ compoundobject/collection/p15889coll2/id/12875/rec/1> Acesso: 25 nov. 2018.

211 Informações sobre o Salão de 1925 em: <https://oglobo.globo.com/economia/carros/o-salao-de-1925-uma-exposicaode-automoveis-no-pais-que-nao-tinha-estradas-16327979> Acesso em: 25 jan. 2019. 

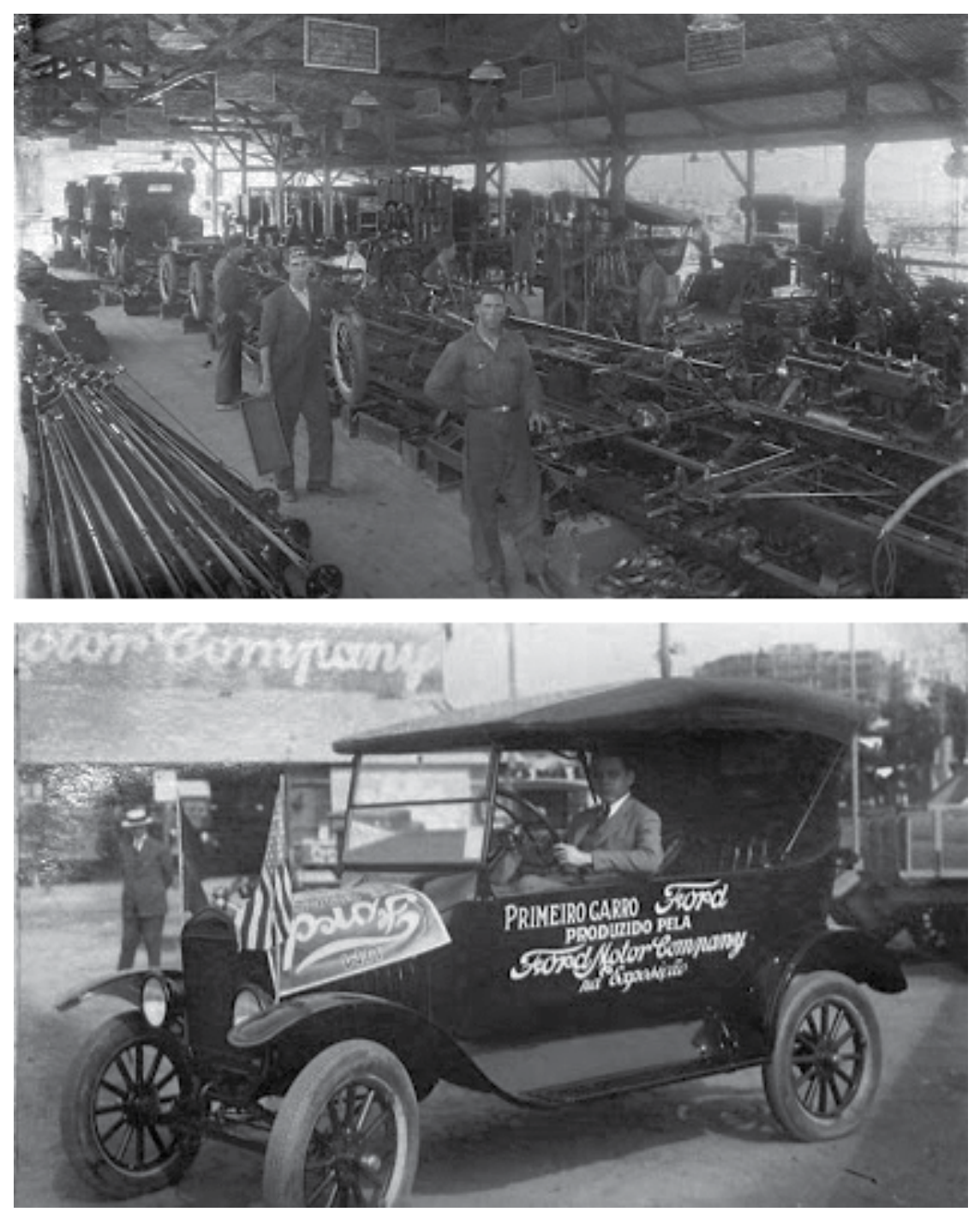

Fig. 133 Linha de montagem da Ford na Exposição de automóveis no Rio de Janeiro, em 1925.

Fonte: <http://antigosverdeamarelo.blogspot.com/2011/05/primeira-exposicao-de-automobilismo-no.html>Acesso: 15 jan 2019. 


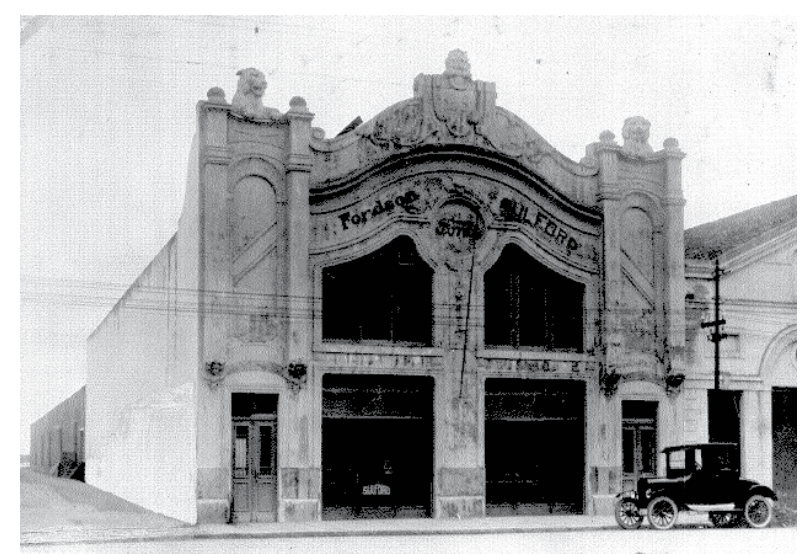

Porto Alegre
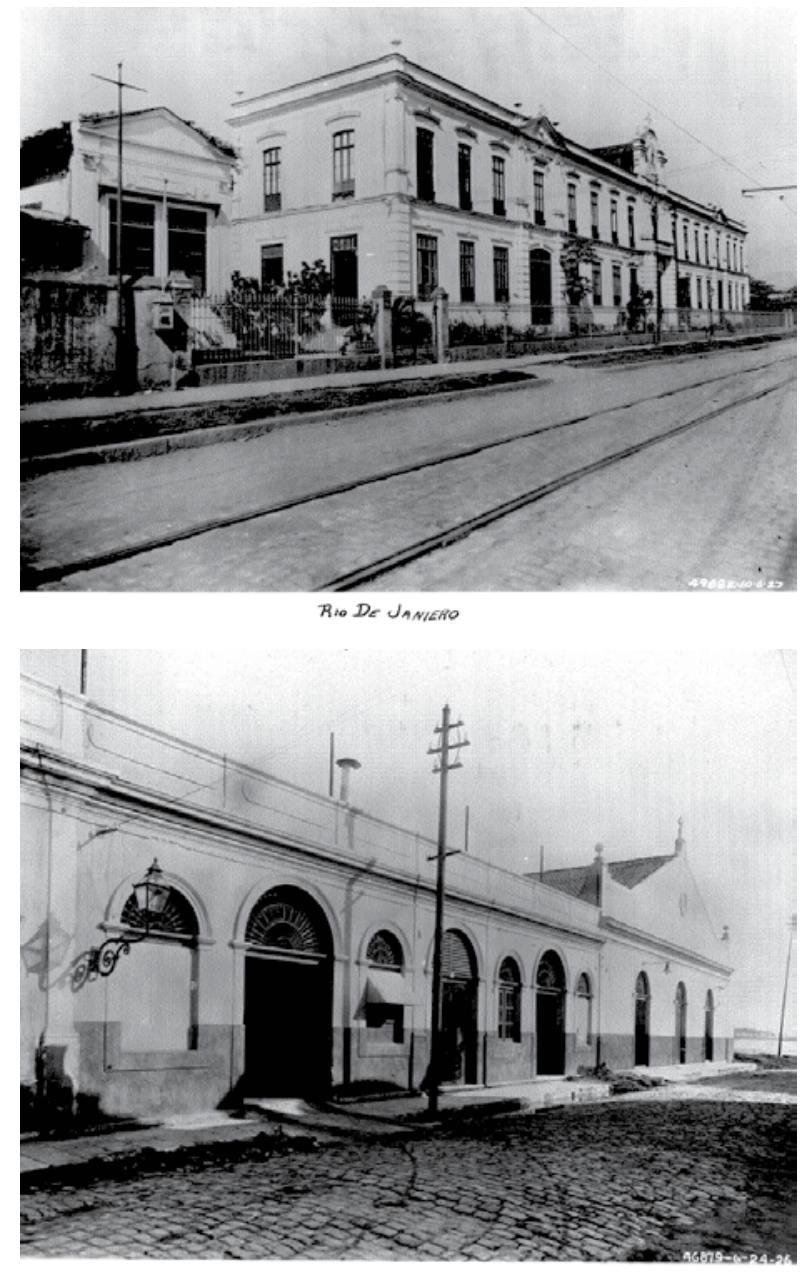

PEANAMBUCO

Fig. 134 Filial da Ford Motor Company do Brasil, em Porto Alegre. Fonte: Benson Ford Research Center.

Fig. 135 Filial da Ford Motor Company do Brasil, no Rio de Janeiro. Fonte: Benson Ford Research Center.

Fig. 136 Filial da Ford Motor Company do Brasil, em Pernambuco. Fonte: Benson Ford Research Center. 


\begin{abstract}
"Os poetas geralmente nascem como um Ford. Cada livro, outro poeta passado que lêem é um operário que lhes ajeita uma roda, carburador, molas. Afinal, mais um irmão bota a gasolina. Então o poeta sai andando, fom-fom! E escreve poemas seus." ${ }^{212}$
\end{abstract}

As vendas registraram tanto sucesso que, em 1925, a Ford abriu filiais menores de sua fábrica paulista em Porto Alegre (1925), no Rio de Janeiro (1927) e até em Recife (1926). Em 1928, a Ford possuía uma rede de setecentas agências e mais de duas mil mecânicas autorizadas por todo o Brasil. No caso dos veículos pesados, ainda em 1925, o Brasil tornou-se o terceiro maior importador de caminhões dos Estados Unidos, depois da Austrália e da Itália. ${ }^{213}$

Em muitos aspectos, as filiais latino-americanas eram tratadas como qualquer outra filial da Ford Motor Company. Henry Ford descreveu as experiências da fábrica no Brasil como tendo tanto sucesso quanto as filiais americanas ou europeias, exceto pelo fato dos trabalhadores brasileiros serem menos qualificados. No capítulo "The Wealth of Nations", do livro Today and Tomorrow, Ford fala do impacto que a fábrica da Ford causava na vida dos trabalhadores:

"Our branch is hardly more than a year old, but already the high wages
$[\ldots]$ are beginning to have an effect. The workers have not yet made
much change in their housing conditions but they are buying more
clothing, they are buying a few furnishings, and they are saving money.
$[\ldots]$ Soon they will begin to develop more needs, and the process of
material civilization will start. [...] The natives, though totally unused to
machinery of any kind or to discipline of any kind, fell very quickly into
the work of assembly and repair." 14

No entanto, como as distâncias envolvidas eram enormes e como as comunicações eram extremamente irregulares, a Ford Motor Company de Detroit não conseguia acompanhar as atividades das filiais latino-americanas com muita atenção. Henry Ford nunca veio para a América do Sul, e nem mesmo seu filho

212 ANDRADE, M. Manuel Bandeira. In: Revista do Brasil 9, n. 107, novembro 1924, p. 217, apud KIMORI, L. Os mestres do passado: Mário de Andrade lê os parnasianos brasileiros. Dissertação (Mestrado em Letras). Faculdade de Filosofia, Letras e Ciências Humanas. São Paulo: USP, 2014, p.78.

213 GARCIA, E. V. Estados Unidos e Grã-Bretanha no Brasil: transição de poder no entreguerras. Contexto int. [online], v. 24, n.1, 2002, p. 48.

214 Tradução da autora: "Nossa filial tem pouco mais de um ano, mas os altos salários [...] estão começando a surtir efeito. Os trabalhadores ainda não fizeram muita mudança em suas moradias, mas estão comprando mais roupas, comprando alguns móveis e economizando dinheiro. [...] Logo eles começarão a desenvolver mais necessidades, e o processo de civilização começará. [...] Os nativos, embora pouco acostumados com qualquer tipo de máquina ou em qualquer tipo de disciplina, aprenderam rapidamente o trabalho de montagem e conserto." Ver: FORD, Henry. Today and tomorrow. New York: Doubleday, 1926, p. 262-263. 

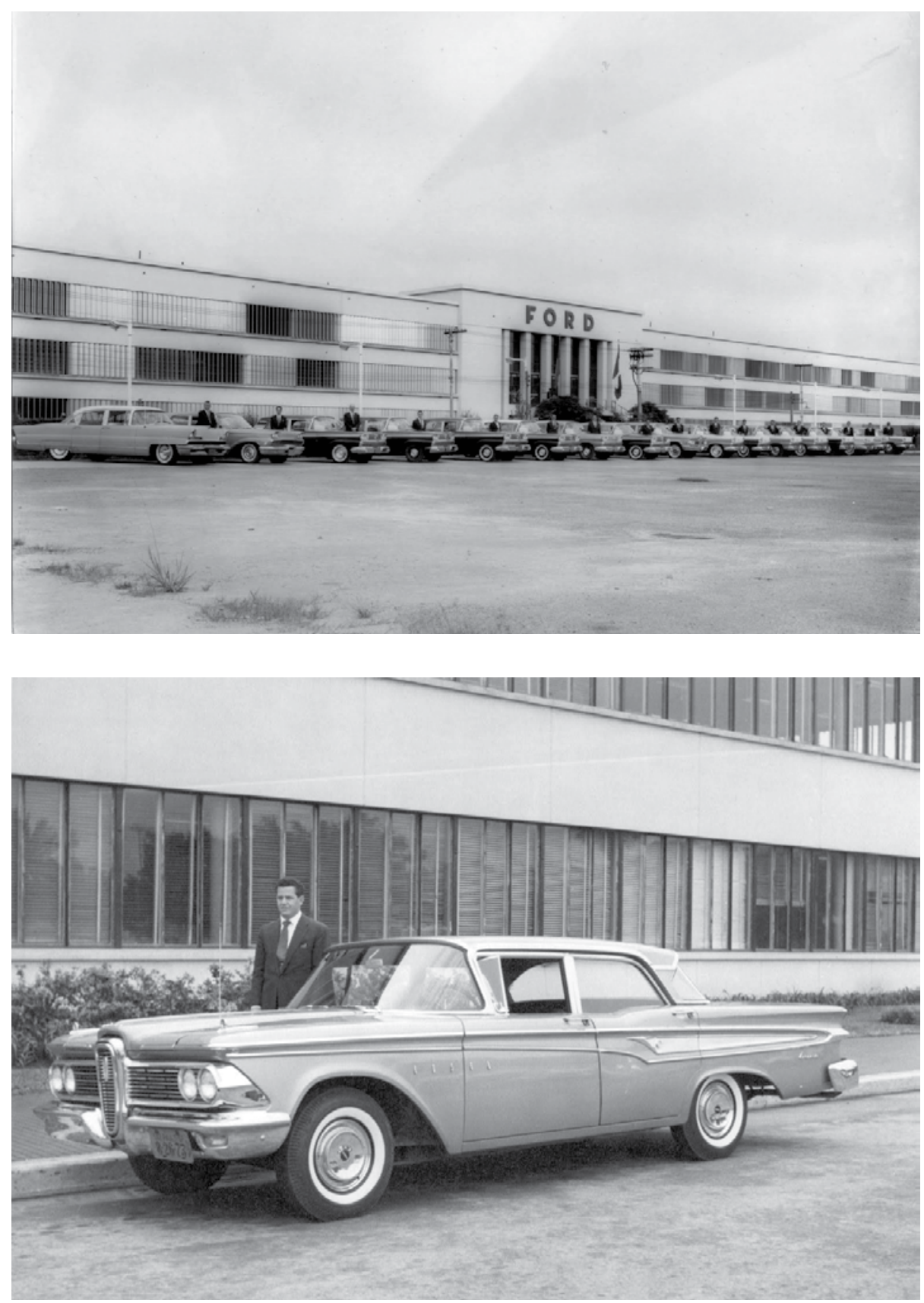

Fig. 137 Exterior da Fábrica da Ford Motor Company do Brasil, na Vila Prudente, em São Paulo (1953). Fonte: <http://antigosverdeamarelo.blogspot.com/2011/05/primeira-exposicao-de-automobilismo-no.html>Acesso: 15 jan 2019.

Fig. 138 Henry Ford II na frente da Fábrica da Ford Motor Company do Brasil, na Vila Prudente, São Paulo. Fonte: <http://antigosverdeamarelo.blogspot.com/2011/05/primeira-exposicao-de-automobilismo-no.html>Acesso: 15 jan 2019. 
Edsel Ford, embora o escritório americano enviasse auditores a cada dois anos. ${ }^{215}$

Depois de alguns anos da fábrica construída, a empresa decidiu comprar um novo terreno para ampliação do parque industrial da Ford em São Paulo. Assim, no ano de 1927, a empresa adquiriu um terreno na Vila Prudente para uma nova fábrica, a qual incluiria a fabricação de peças. Entretanto, por conta da grave crise nos Estados Unidos no início dos anos trinta, das dificuldades surgidas no Brasil e, finalmente, do início da Segunda Guerra Mundial, a nova fábrica somente foi inaugurada em 1953. ${ }^{216}$ A partir deste momento, a unidade do Bom Retiro começou a ter suas atividades reduzidas de maneira gradativa, até ser totalmente desativada.

Ao contrário da unidade do Ipiranga, desativada em 2001 e demolida alguns anos atrás para a construção do Mooca Plaza Shopping ${ }^{217}$, a unidade do bairro do Bom Retiro sobrevive, mesmo inativa, até os dias de hoje. A velha unidade da Ford chama atenção não somente pelo aspecto histórico, mas igualmente pela sua excepcional qualidade arquitetônica, um excelente exemplar da modernidade industrial que está prestes a completar 100 anos de existência.

215 WILKINS, M. e HILL, F. E. American Business Abroad: Ford on Six Continents. New York: Cambridge University Press, 2011, p. 95.

216 The Reminiscences of Mr. Kristian Orberg, p. 33. Disponível em: <http://cdm15889.contentdm.oclc.org/cdm/ compoundobject/collection/p15889coll2/id/12875/rec/1> Acesso: 25 nov. 2018.

217 Disponível em: <https://sao-paulo.estadao.com.br/noticias/geral,shopping-vai-revitalizar-area-na-mooca-imp-,597149> Acesso: $15 \operatorname{dez} 2018$ 


\subsection{ANTEPROJETO E CONSTRUÇÃO}

Localizada na Rua Solon, n. 1143, desde a esquina da Rua Visconde de Taunay até o Viaduto Eng. Orlando Murgel, no bairro Bom Retiro, a fábrica montadora de veículos teve a sua execução a cargo da Construtora Scott \& Urner Engenharia e Construções Ltda., com supervisão do engenheiro Brown. Essa fábrica era destinada à montagem dos carros Modelo $\mathrm{T}$ e dos caminhões Modelo TT para a Ford do Brasil. Ocupando um terreno de quase 7 mil metros quadrados, a fábrica consistia, inicialmente, em um grande edifício de três pavimentos destinado à linha de produção.

No seu formato básico, a fábrica brasileira da Ford era semelhante à Ford Highland Park, construída em Detroit, conservando, assim, as proporções das fábricas tradicionais, ou seja, edifícios alongados e de múltiplos pavimentos. Além da arquitetura, o maquinário automático e a disposição dos operários no espaço físico da fábrica eram concebidos de forma a atuar sinergicamente com o sistema de produção da linha de montagem fordista acionada pela gravidade. Sobre o projeto das fábricas se adaptarem à linha de montagem fordista, o engenheiro Brown lembrou em seu depoimento: 


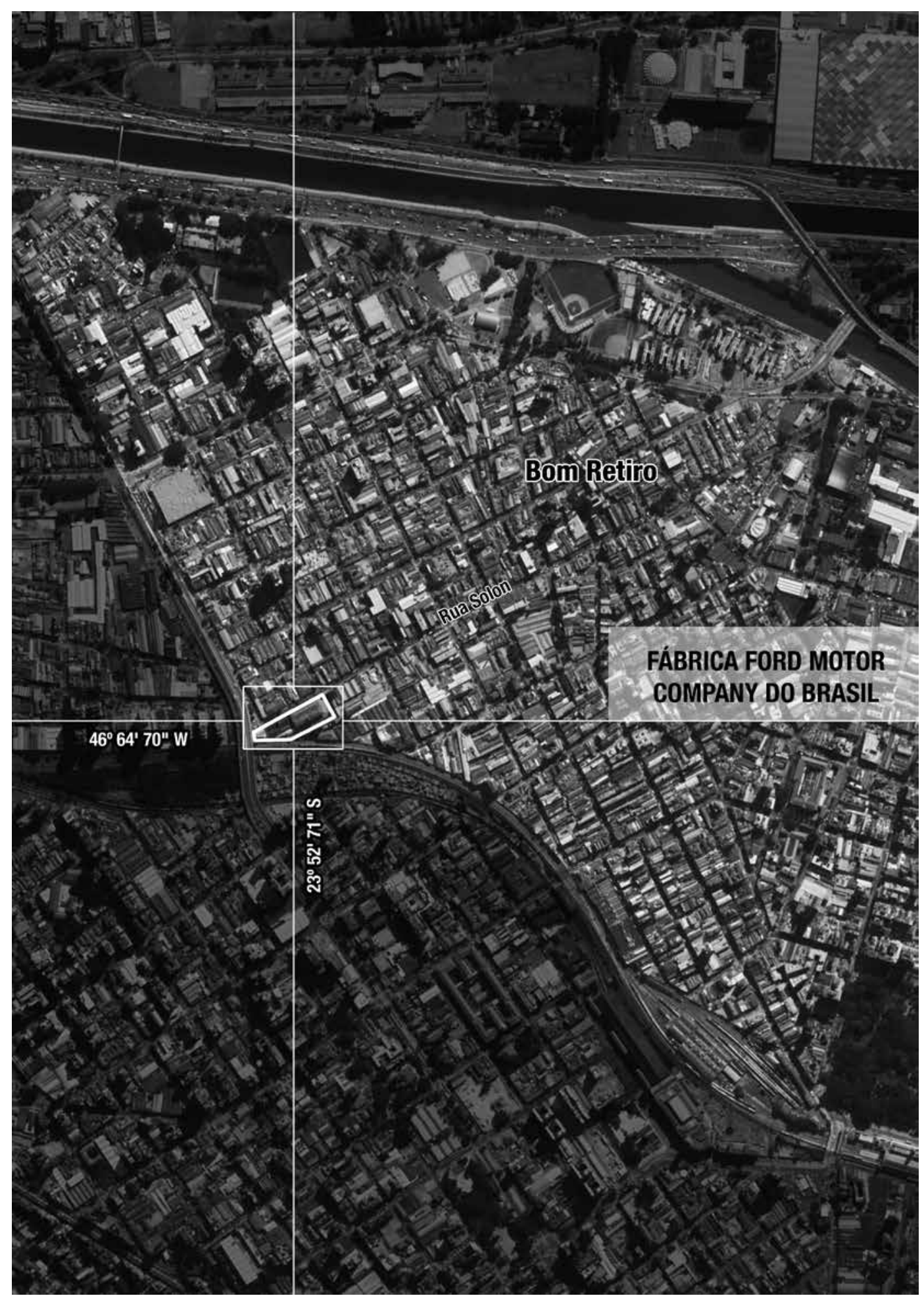

Fig. 139 Localização da Fábrica da Ford Motor Company do Brasil, em São Paulo. Fonte: Arquivo pessoal da autora , a partir da imagem de satélite do Google, 2019. 

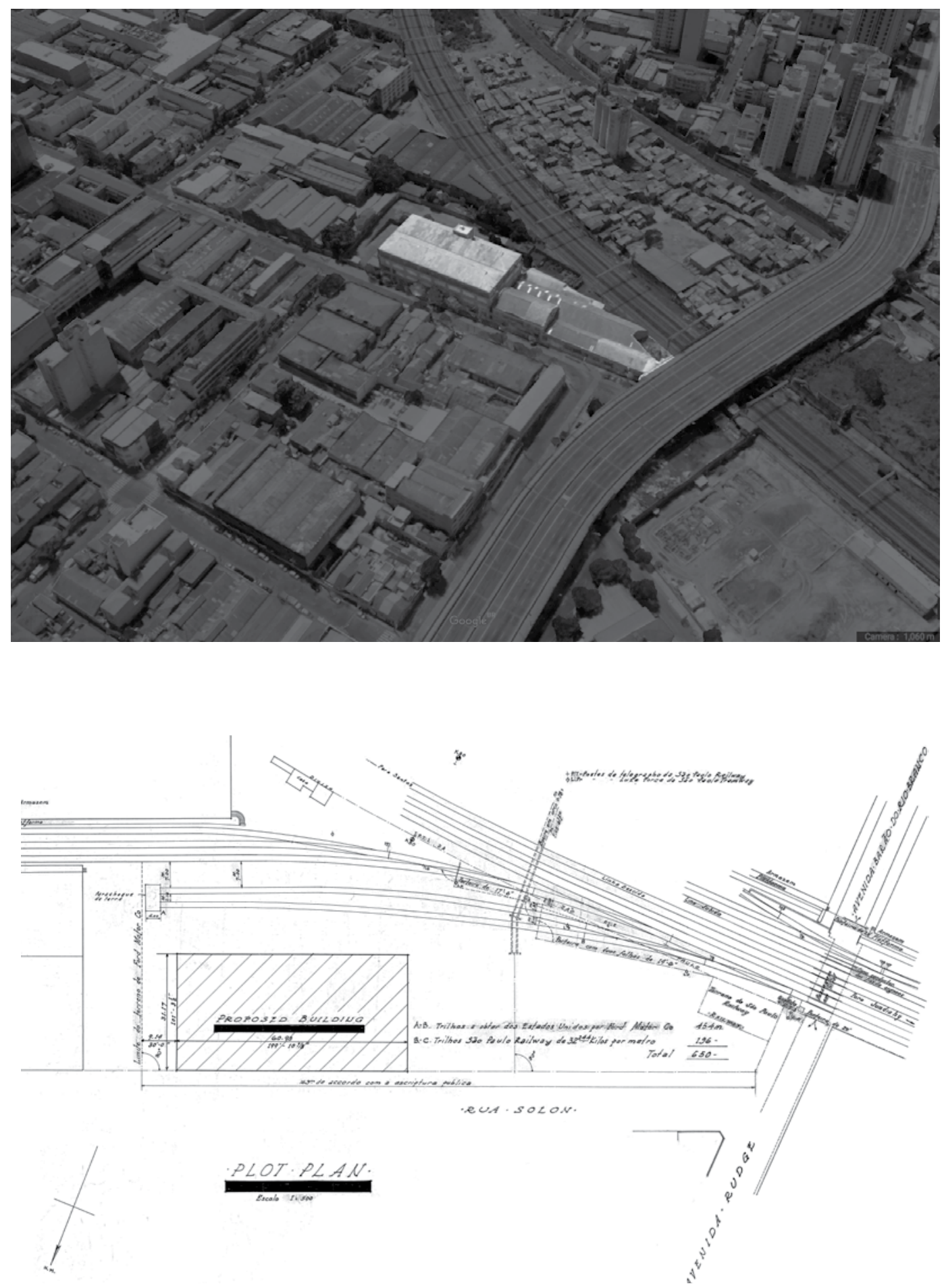

Fig. 140 Localização da Fábrica da Ford Motor Company do Brasil, em São Paulo. Fonte: Arquivo pessoal da autora , a partir da imagem de satélite do Google Earth, 2019.

Fig. 141 Implantação da Fábrica da Ford Motor Company do Brasil no Bairro Bom Retiro, em São Paulo. Fonte: Albert Kahn Associates Records, Bentley Library, University of Michigan. 
"I always conferred with them [the Manufacturing Department] before we began the plant plans. I insisted that the Layout Department give me a layout so the column spacings would be correct and so there would be no interference with the assembly lines, drying ovens and other installations. In other words, we built the buildings around their layouts rather building the buildings and then putting the equipment in. We did that because I remember in one plant we built before I had seen the layout, we had trouble fitting the paint ovens into the plant.” ${ }^{218}$

A solução adotada na fábrica brasileira privilegiou, portanto, o fluxo eficiente de materiais, o qual seguia um processo de montagem acionado pela gravidade. Os materiais chegavam na fábrica via trem, cuja circulação acontecia paralelamente à fachada sul. Os trilhos de trem da fábrica então se conectavam aos trilhos da São Paulo Railway, a primeira ferrovia do Estado de São Paulo, responsável por fazer a conexão com o Porto de Santos. Acima dos trilhos, havia uma ponte rolante permitindo que a descarga de materiais acontecesse de forma mecânica, uma vez que os carros vinham semi-montados da fábrica de Detroit.

Dentro da fábrica, um núcleo de elevadores de carga transportava partes da carroceria sem pintura da ponte rolante até o terceiro andar para pintura e montagem parcial. Guindastes e transportadores poderiam então mover as peças para os locais de armazenamento apropriados dentro do edifício e ao longo dos processos de montagem. Finalmente, todos os subconjuntos e partes remanescentes convergiam para a linha de montagem final, localizada no pavimento térreo. A partir daí, os carros podiam ser expostos no showroom ou levados para estocagem fora da fábrica.

No edifício, foram estabelecidos dois eixos verticais de circulação: o de pessoas, através de escadas, e o de máquinas, por meio de elevadores de cargas. Havia um núcleo de circulação vertical, localizado no centro da fachada sul, que era composto de uma escada e dois elevadores de carga. Junto ao núcleo de circulação vertical, encontrava-se um conjunto de vestiários e banheiros para os operários, dispostos em cada um dos três andares. A outra forma de conexão vertical entre os

218 Tradução da autora: Eu sempre conferi com eles [o Departamento de Fabricação] antes de começarmos os projetos da fábrica. Insisti para que o Departamento de Projeto me desse um layout em que os espaçamentos dos pilares estivessem corretos e, portanto, não houvesse interferência nas linhas de montagem, fornos de secagem e outras instalações. Em outras palavras, construíamos os edifícios em função dos seus layouts, em vez de construir os edifícios e depois colocar o equipamento. Fizemos isso porque eu me lembro que, em uma fábrica que construímos antes de verificar o layout, tivemos problemas para instalar os fornos de pintura na fábrica. Ver: The Reminiscences of Mr. B. R. Brown, p. 27. Disponível em: <http://cdm15889.contentdm.oclc.org/cdm/compoundobject/collection/p15889coll2/id/3253/rec/11> Acesso: 25 nov. 2018. 
pavimentos acontecia através de uma escada, localizada na extremidade do edifício, entre as fachadas norte e leste.

Embora a maior parte do interior da fábrica Ford fosse um espaço livre, existiam várias áreas fechadas e subdivididas nos pavimentos. De acordo com o projeto, no terceiro andar localizava-se uma área para pintura; no segundo andar, ficava o setor de verniz e retoques; por fim, no pavimento térreo, estavam localizados o setor de montagem e estoque, o showroom e a administração. A área administrativa estava localizada no canto sudoeste e incluía escritório geral, salas individuais para gerentes e banheiro. A área do showroom ocupava três módulos estruturais, estando localizada ao longo da fachada principal, na Rua Solon, próxima à área administrativa. A localização da administração era estratégica, pois permitia a visualização tanto da área de montagem quanto do showroom.

Assim como na Ford Highland Park, o pé-direito do térreo, medindo 4,86 metros, era um pouco mais alto que os demais, os quais possuíam 4,07 metros, pois era o pavimento de onde o carro sairia totalmente montado. A caldeira ficava localizada no subsolo, com acesso pela fachada sul. $\mathrm{O}$ acréscimo de um quarto pavimento foi feito posteriormente, mas faltam informações a respeito do uso a que se destinava esse pavimento.

Apesar da atenção ao fluxo de materiais ter sido uma das condições imprescindíveis para a estratégia da concepção do edifício, o seu sistema estrutural era bastante significativo e pode também ser considerado como norteador do projeto. O desenvolvimento da instalação obedece a uma disposição regular da estrutura, tendo recebido um desenho próprio para desempenhar a sua função. $\mathrm{O}$ edifício, de acordo com o projeto, era um volume prismático de três andares e possuía 60,93 metros de comprimento no sentido leste-oeste, 31,17 metros de largura no sentido norte-sul e 15,35 metros de altura. Os pilares, espaçados em intervalos regulares de 7,75 metros, tinham capitéis de reforço para apoiar a laje plana, também em concreto, garantindo, assim, maior resistência estrutural. Esse mesmo formato de pilar já fora usado pelo arquiteto na ampliação da Ford Highland Park, em 1914.

A estrutura foi calculada para suportar o peso da maquinaria e das peças nos andares superiores, ao mesmo tempo em que a modulação regular de 7,75 x 7,75 


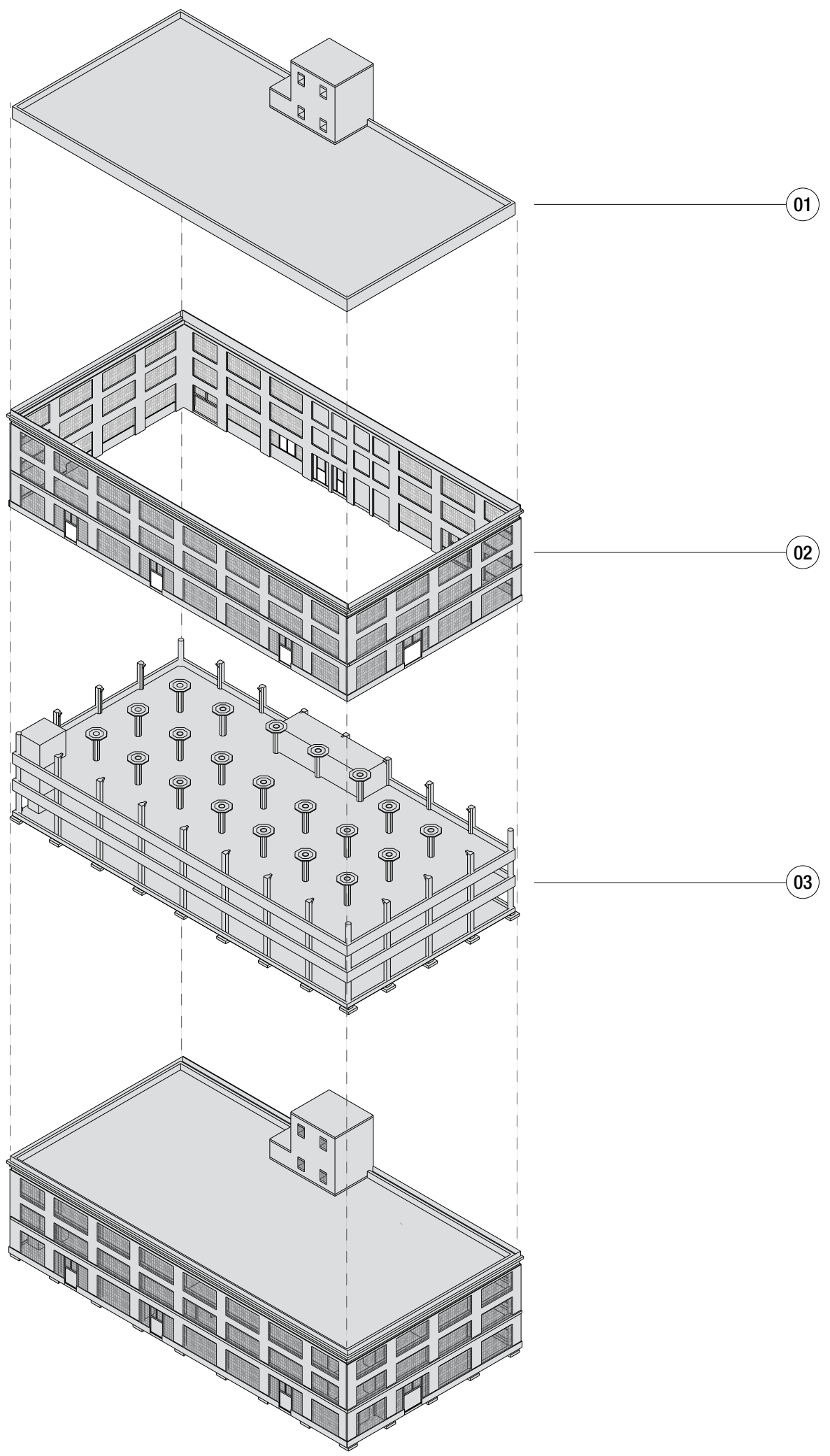

Fig. 142 Diagrama da Fábrica da Ford Motor Company do Brasil no Bairro Bom Retiro, em São Paulo. Fonte: Arquivo pessoal da autora, 2019. 

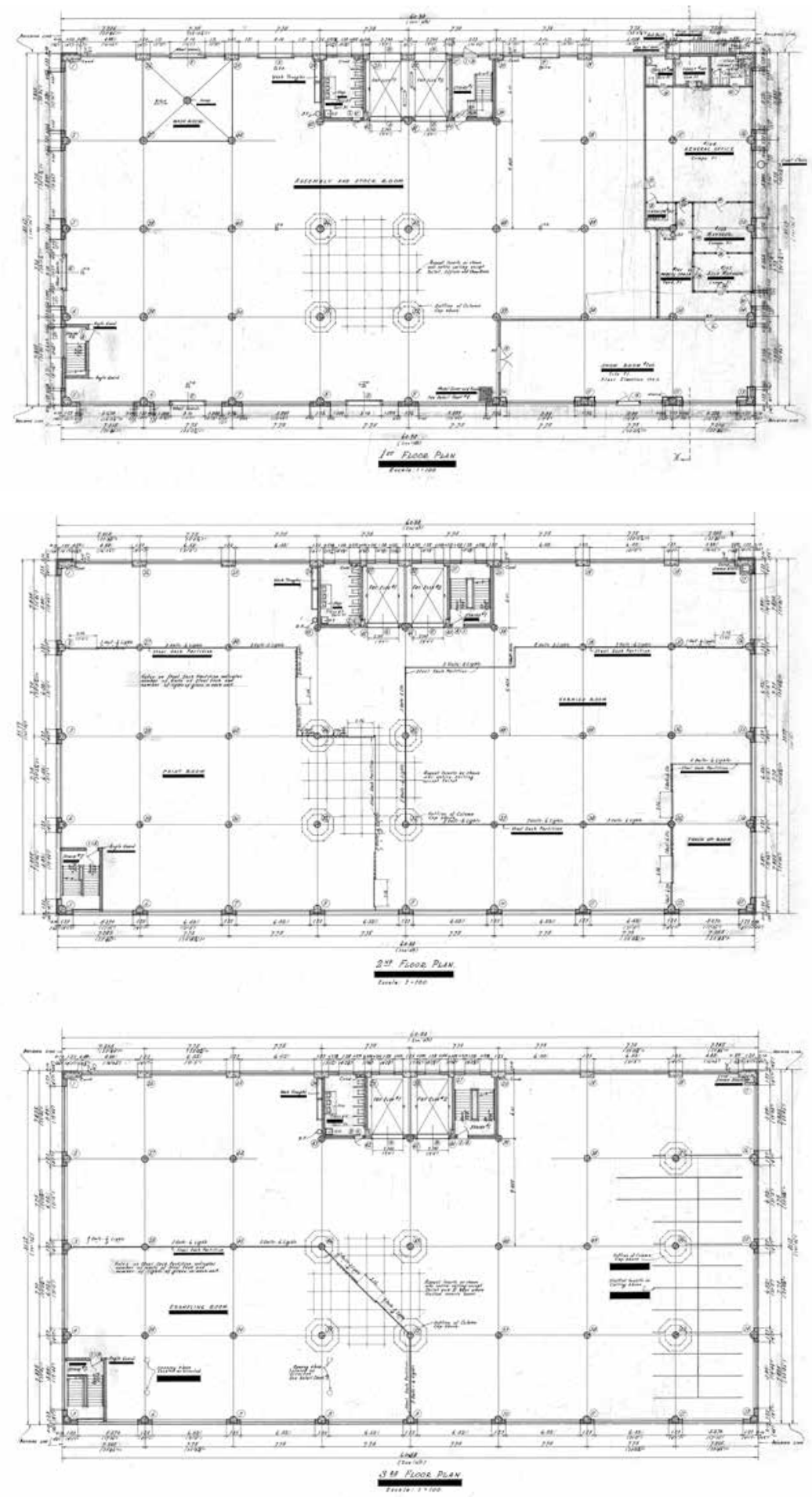

Fig. 143 Planta baixa do primeiro pavimento da Fábrica da Ford Motor Company do Brasil no Bairro Bom Retiro, em São Paulo. Fonte: Albert Kahn Associates Records, Bentley Library, University of Michigan.

Fig. 144 Planta baixa do segundo pavimento da Fábrica da Ford Motor Company do Brasil no Bairro Bom Retiro, em São Paulo. Fonte: Albert Kahn Associates Records, Bentley Library, University of Michigan.

Fig. 145 Planta baixa do terceiro pavimento da Fábrica da Ford Motor Company do Brasil no Bairro Bom Retiro, em São Paulo. Fonte: Albert Kahn Associates Records, Bentley Library, University of Michigan. 

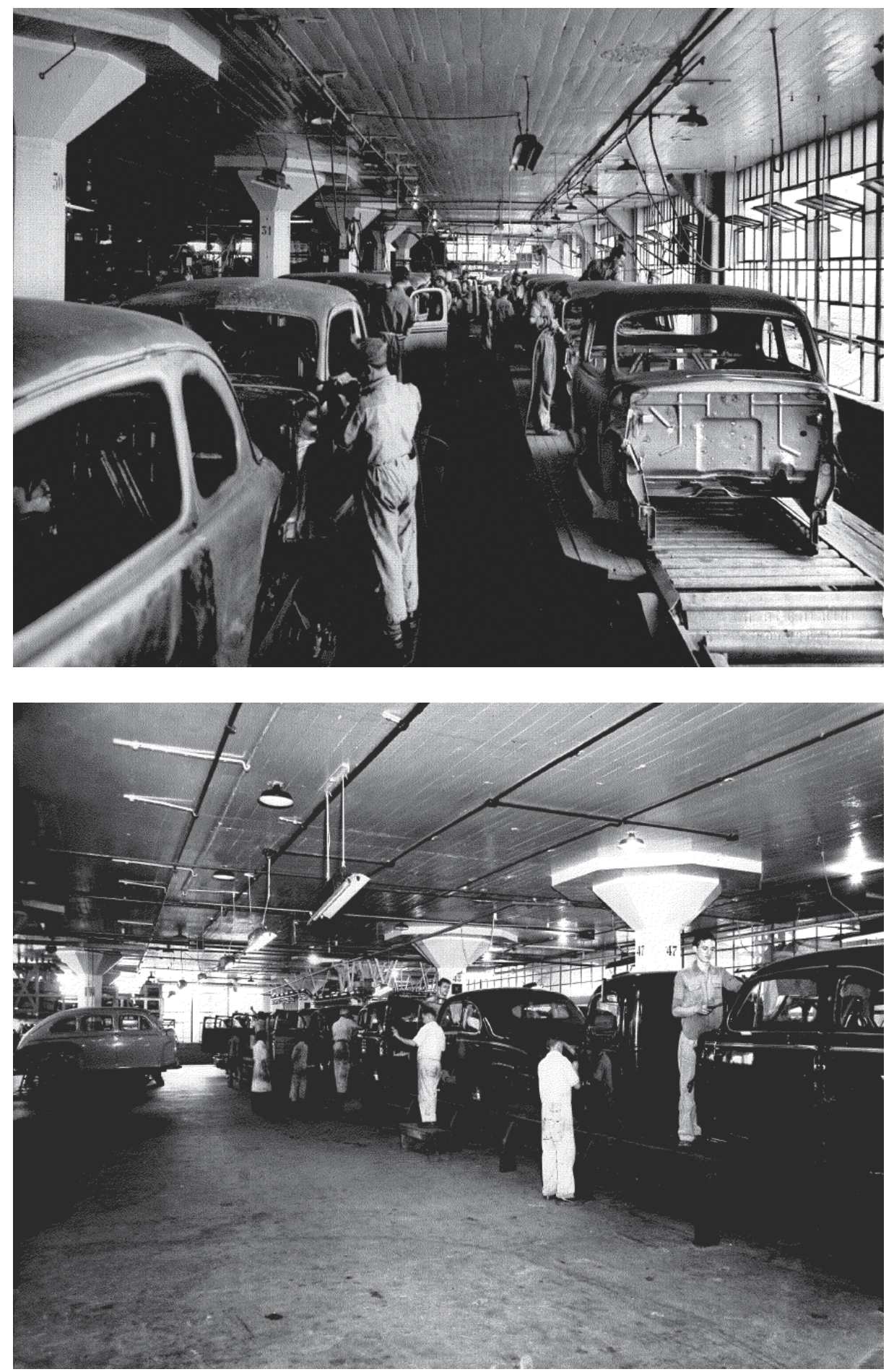

Fig. 146 Interior da Fábrica da Ford Motor Company do Brasil no Bairro Bom Retiro, em São Paulo. Fonte: Benson Ford Research Center.

Fig. 147 Interior da Fábrica da Ford Motor Company do Brasil no Bairro Bom Retiro, em São Paulo. Fonte: Benson Ford Research Center. 

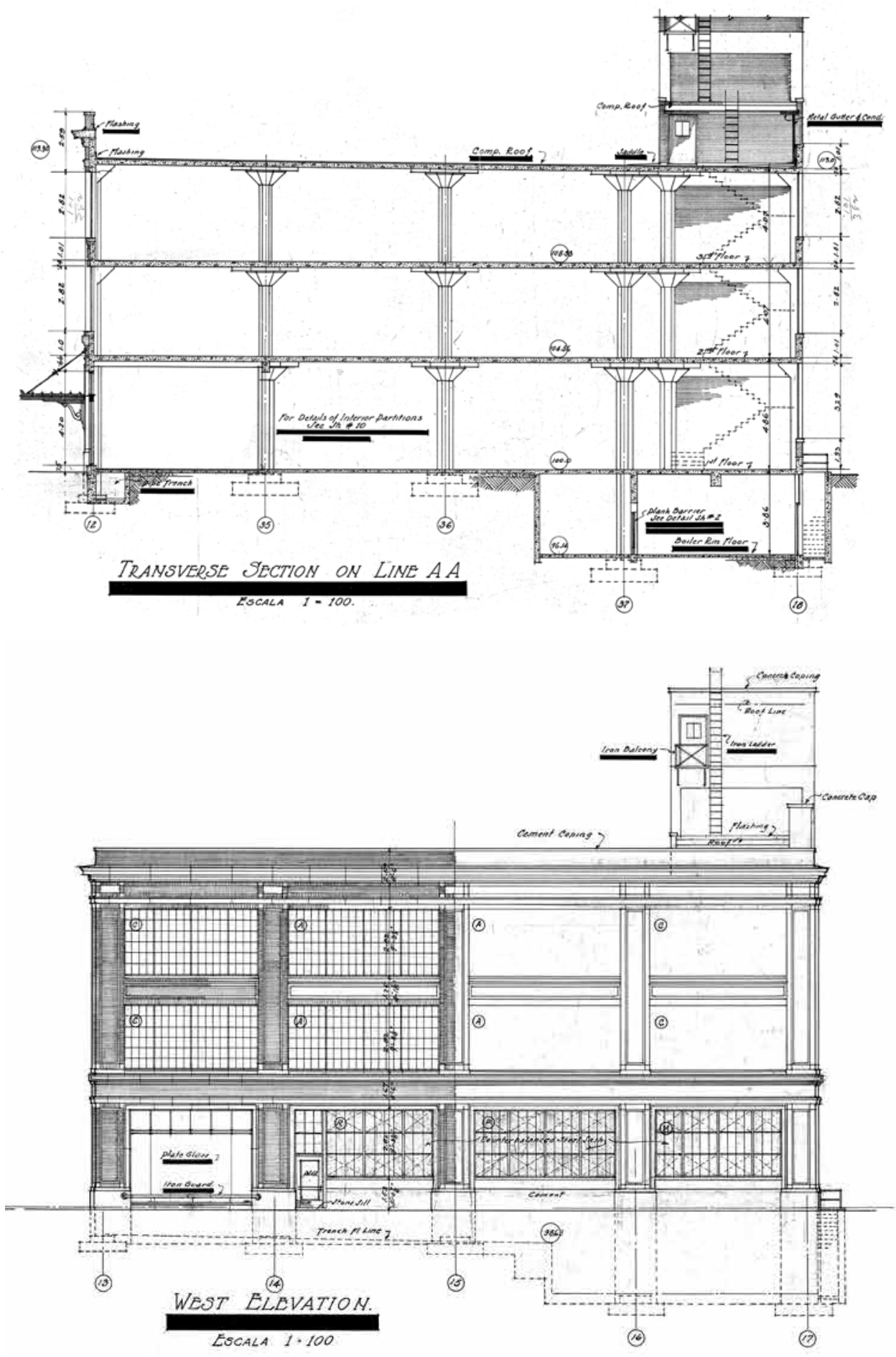

Fig. 148 Corte transversal da Fábrica da Ford Motor Company do Brasil no Bairro Bom Retiro, em São Paulo. Fonte: Albert Kahn Associates Records, Bentley Library, University of Michigan.

Fig. 149 Fachada oeste da Fábrica da Ford Motor Company do Brasil no Bairro Bom Retiro, em São Paulo. Fonte: Albert Kahn Associates Records, Bentley Library, University of Michigan. 


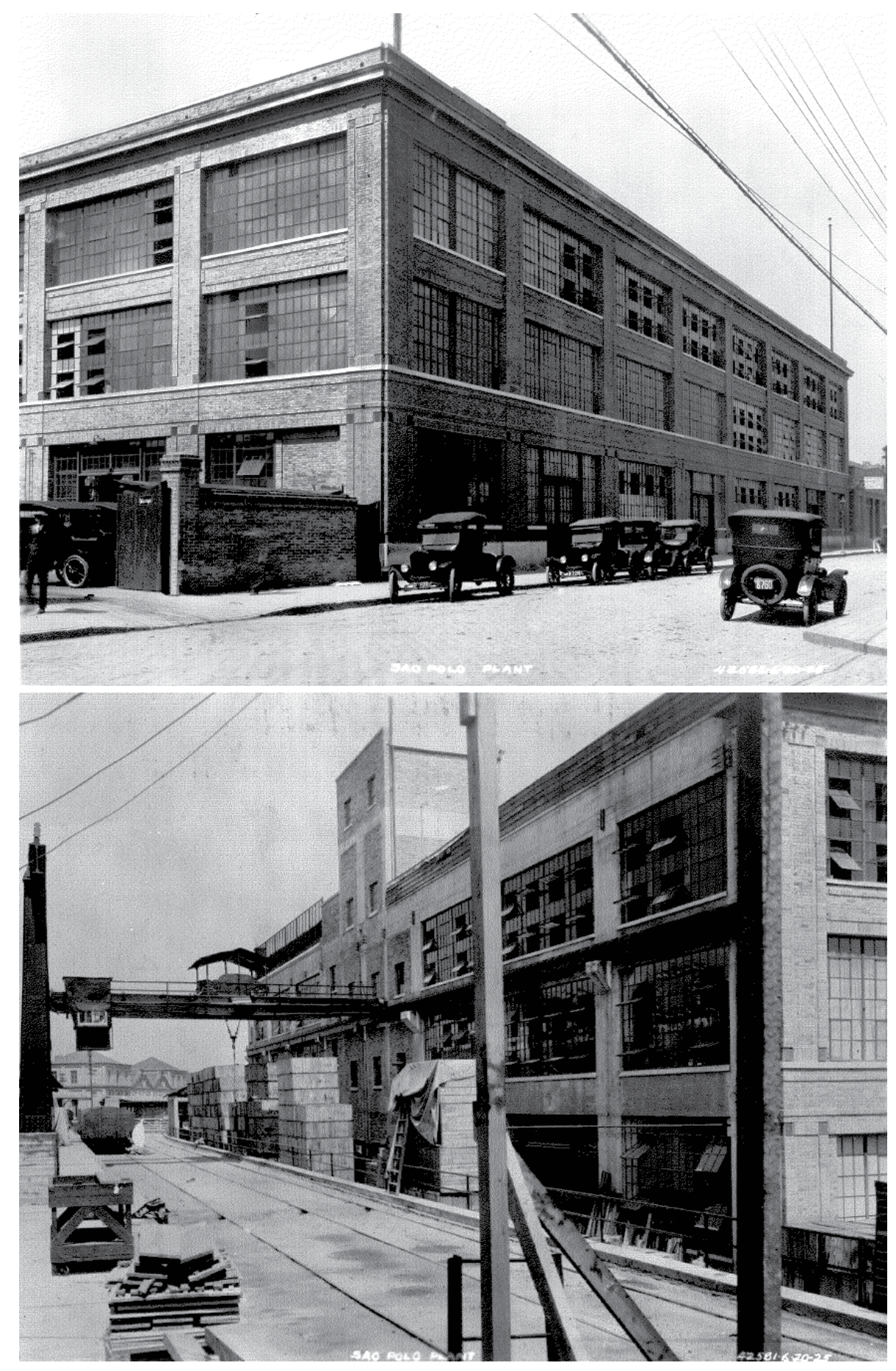

Fig. 150 Exterior da Fábrica da Ford Motor Company do Brasil no Bairro Bom Retiro, em São Paulo. Fonte: Benson Ford Research Center.

Fig. 151 Vista da fachada sul da Fábrica da Ford Motor Company do Brasil no Bairro Bom Retiro, em São Paulo. Fonte: Benson Ford Research Center.. 

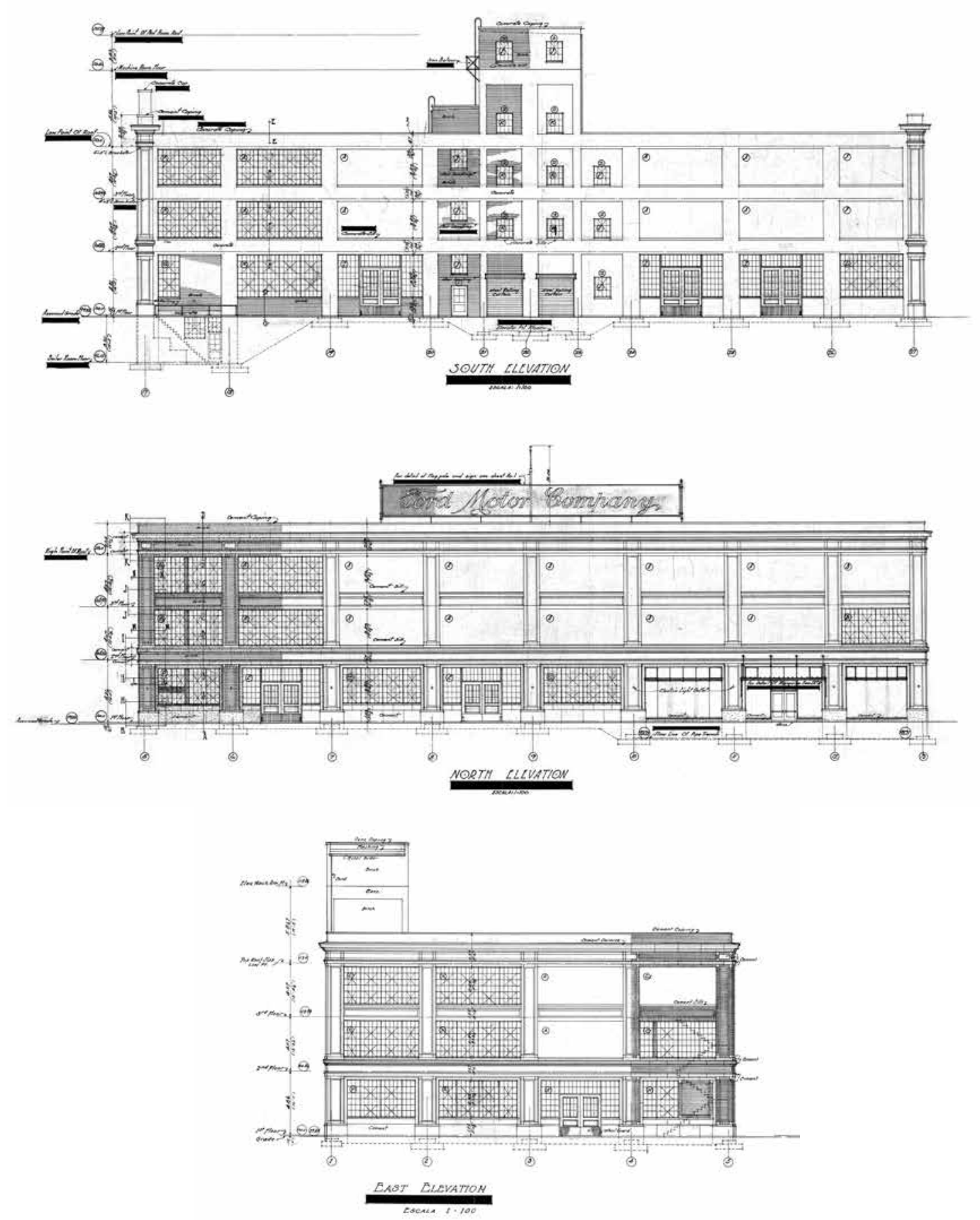

Fig. 152 Fachada sul da Fábrica da Ford Motor Company do Brasil no Bairro Bom Retiro, em São Paulo. Fonte: Albert Kahn Associates Records, Bentley Library, University of Michigan.

Fig. 153 Fachada norte da Fábrica da Ford Motor Company do Brasil no Bairro Bom Retiro, em São Paulo. Fonte: Albert Kahn Associates Records, Bentley Library, University of Michigan.

Fig. 154 Fachada leste da Fábrica da Ford Motor Company do Brasil no Bairro Bom Retiro, em São Paulo. Fonte: Albert Kahn Associates Records, Bentley Library, University of Michigan. 


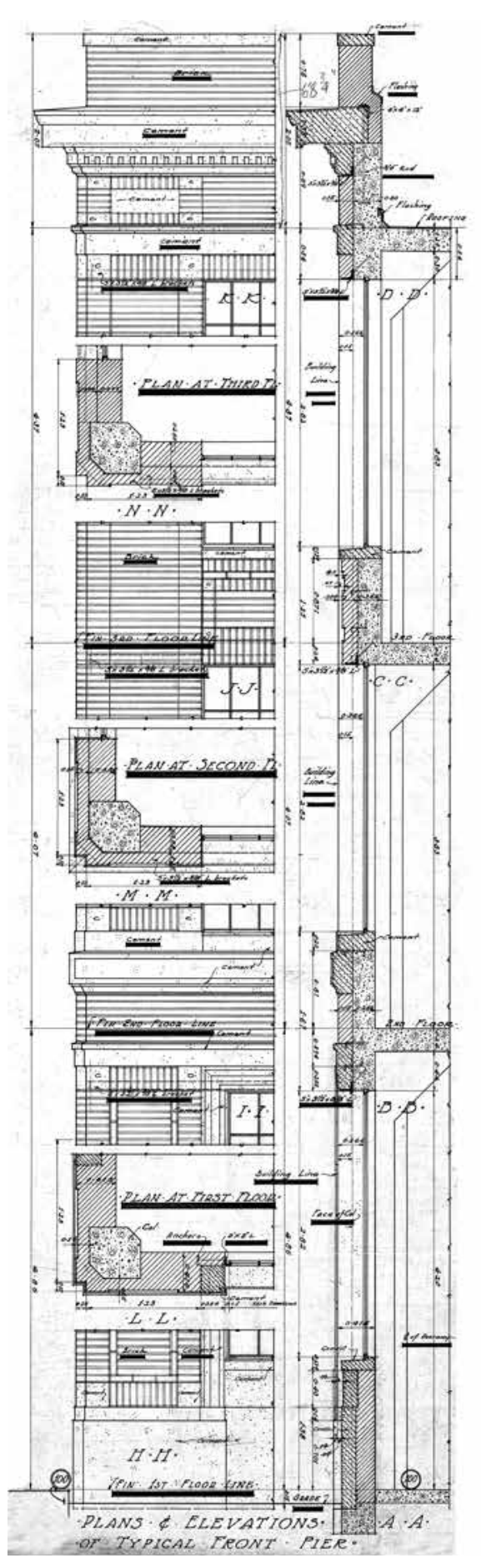

Fig. 155 Corte de pele da Fábrica da Ford Motor Company do Brasil no Bairro Bom Retiro, em São Paulo. Fonte: Albert Kahn Associates Records, Bentley Library, University of Michigan. 

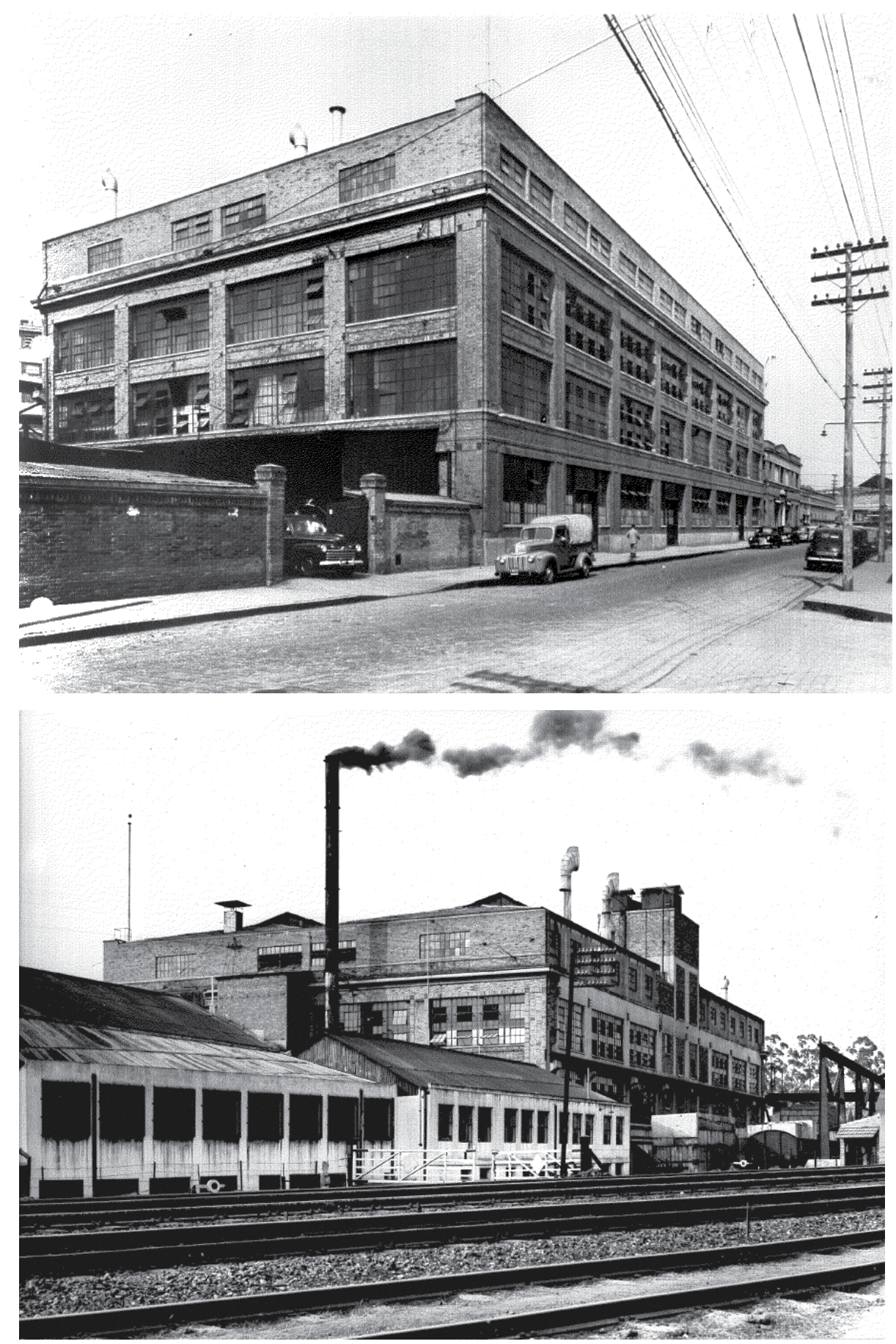

Fig. 156 Exterior da Fábrica da Ford Motor Company do Brasil no Bairro Bom Retiro, em São Paulo, com o acréscimo do quarto pavimento

Fonte: Benson Ford Research Center

Fig. 157 Vista a partir dos trilhos de trem da Fábrica da Ford Motor Company do Brasil no Bairro Bom Retiro, em São Paulo, com o acréscimo do quarto pavimento. Fonte: Benson Ford Research Center. 
metros racionalizava a construção e permitia que as fôrmas do concreto fossem reutilizadas, uma vez que a estrutura foi moldada in loco. Nas bordas, os vãos eram levemente diferentes, compensando a espessura das paredes da fachada. Nesses casos, o pilar possuía uma seção retangular e vigas de borda foram utilizadas no plano das fachadas.

A cobertura da fábrica, no projeto original, era uma laje plana de concreto, semelhante às lajes dos demais pavimentos. Era possível que, desde o início, já existisse a previsão de acréscimo do quarto - e último - pavimento, uma vez que, quando foi acrescentado esse pavimento, a iluminação natural passou a acontecer através da cobertura, com sheds voltados para sul, a qual permanece até hoje, modificando assim o projeto inicial De qualquer forma, a fonte de luz natural também era garantida através do uso de grandes aberturas nas fachadas.

A lógica de um sistema estrutural independente do seu invólucro foi utilizada no edifício. Por meio de uma estrutura interna independente, a superfície de vedação que envolvia o grande edifício prismático tinha sua leveza acentuada pela translucidez. Essa superfície de vedação obedecia também a um esquema de modulação que se articulava à estrutura principal, tratada com grande clareza na fachada. A dimensão dos elementos estruturais verticais (pilares) e horizontais (vigas) era semelhante, medindo em torno de 1 metro, e todos foram revestidos com tijolos. Apesar do revestimento da estrutura, o exterior possuía um caráter industrial, com ornamentação limitada e modesta. Coroado por uma platibanda opaca e contínua, com cerca de dois metros de altura, o projeto previa alguns ornamentos na superfície externa e na marquise do acesso principal. No entanto, de acordo com as fotografias da época, ambos acabaram não sendo executados.

Com exceção da fachada dos fundos, a mais funcional, Kahn foi capaz de usar grandes extensões de vidros para melhorar a iluminação e ventilação naturais. As esquadrias com caixilhos metálicos preenchiam totalmente os vãos da fachada, ao passo que as esquadrias possuíam a possibilidade de abertura através de janelas basculantes.

Adições posteriores, como ampliação da área de showroom, escritórios e área de montagem, fizeram com que a fábrica ocupasse toda a largura do terreno. Em 
meados da década de 1920, um grande anexo de um pavimento foi acrescentado, ocupando toda a extensão do terreno voltada para a Rua Solon. Esse anexo, colado ao edifício principal, era formalmente dividido em duas partes: a primeira destinada a uma ampliação do showroom e a outra, pelo que sugerem as fotografias, à montagem dos caminhões Modelo TT. Na década seguinte, no ano de 1934, um projeto com duas opções foi feito pelo escritório de Albert Kahn para propor um segundo pavimento em uma parte do anexo, acima da área do showroom, o qual seria destinado à ampliação do setor administrativo.

As ampliações também utilizaram tijolos como revestimento externo, mantendo uma relação de altura com o térreo do edifício principal de três pavimentos. Nesse caso, a permeabilidade da fachada foi revista e os planos envidraçados tornaram-se proporcionalmente menores. A exceção ao caráter industrial encontrava-se no modesto frontão de tijolos, posicionado acima do acesso ao showroom, eis que se tratava de um local aberto ao público.

Mesmo desativada há muitos anos, a fábrica encontra-se em bom estado de conservação externamente. Apesar de estar um pouco vandalizada por pichações em parte da fachada, toda a arquitetura original ainda está preservada, mantendo-se bastante fiel ao prédio inaugurado em 1921. Embora muitos acreditem que o velho prédio da Ford esteja abandonado, o imóvel está em plena atividade. Contudo, não se conseguiu obter a informação se o edifício da antiga fábrica ainda pertence à Ford Motor Company do Brasil ou se já foi vendido e alugado a terceiros. A certeza que se tem é que este imóvel é um grande patrimônio de São Paulo, parte viva e preservada da história arquitetônica e automobilística do Brasil.

A fábrica brasileira da Ford é um exemplo interessante na evolução da arquitetura industrial em São Paulo. O uso de novos elementos estruturais, como o concreto armado e grandes planos de vidro, assim como a concepção dos interiores como superfícies contínuas e flexíveis, era algo bastante inovador para a época.

Apesar do sistema construtivo do concreto armado ter sido introduzido no Brasil no início do século XX, ele era aplicado, inicialmente, somente em obras de engenharia, tais como pontes e viadutos. A partir da instalação das primeiras fábricas de cimento ${ }^{219}$, inicia-se o processo de difusão da tecnologia do concreto 

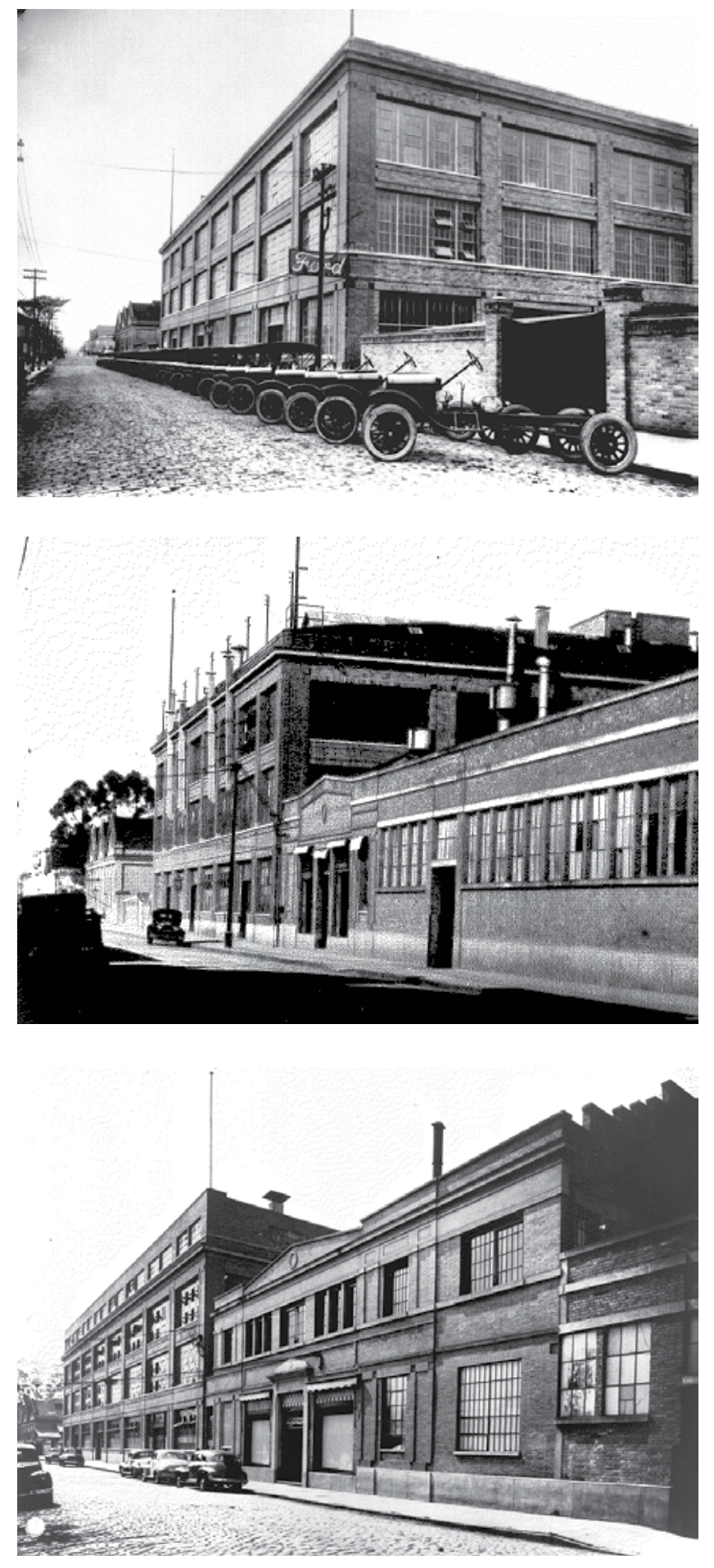

Fig. 158 Exterior da Fábrica da Ford Motor Company do Brasil no Bairro Bom Retiro, em São Paulo, no início da década de 1920. Fonte: Benson Ford Research Center.

Fig. 159 Primeira ampliação da Fábrica da Ford Motor Company do Brasil no Bairro Bom Retiro, em São Paulo. Fonte: Benson Ford Research Center.

Fig. 160 Segunda ampliação da Fábrica da Ford Motor Company do Brasil no Bairro Bom Retiro, em São Paulo. Fonte: Benson Ford Research Center. 


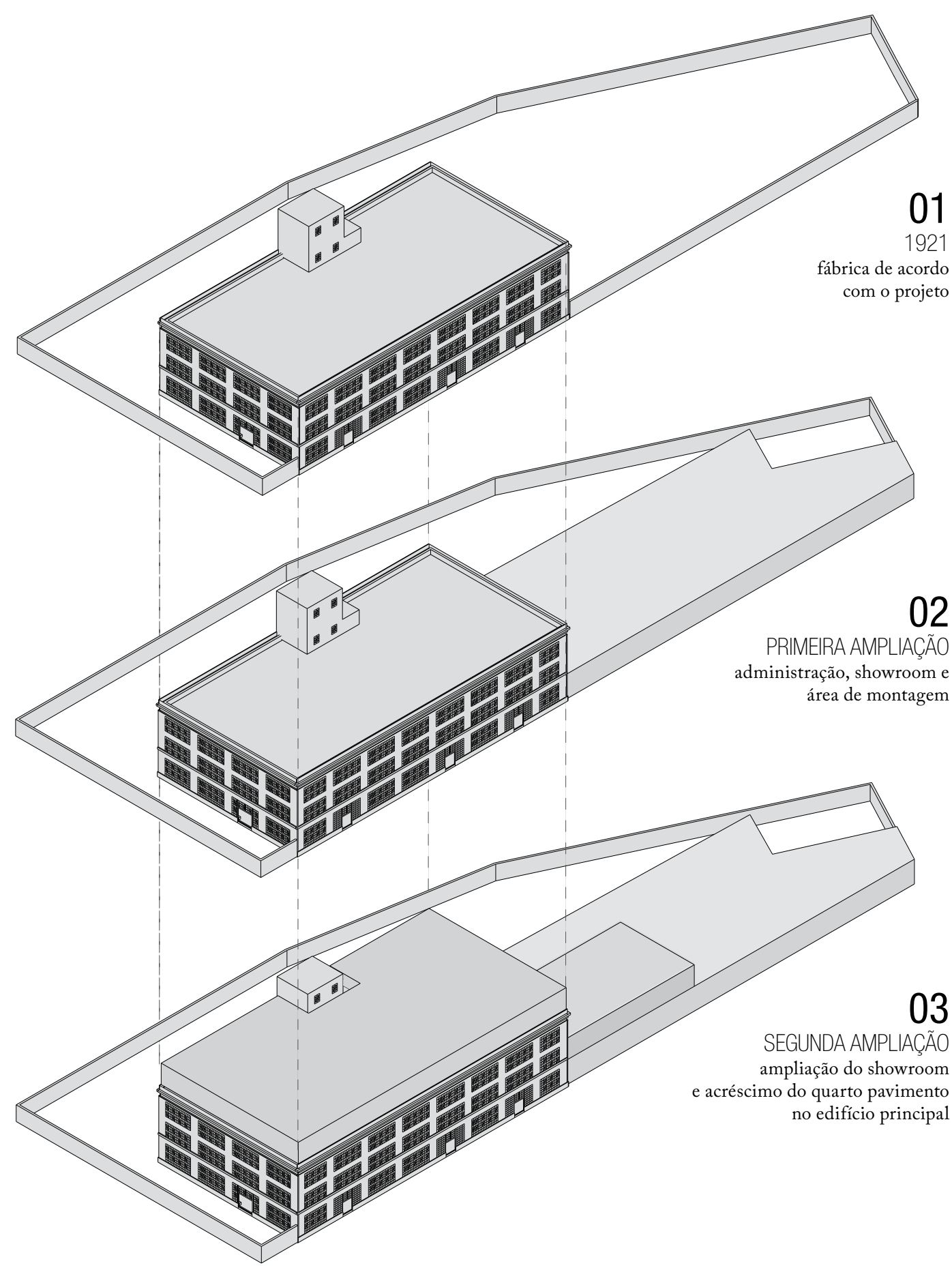

Fig. 161 Diagrama mostrando a sucessão das ampliações da Fábrica da Ford Motor Company do Brasil. Fonte: Arquivo pessoal da autora, 2019. 
e, a partir dos anos 1930, cresceu o seu uso no setor de edificações da construção civil. ${ }^{220}$ Ainda hoje, o concreto armado é considerado o material mais conveniente para a construção civil brasileira, levando-se em conta a sua segurança, o fato de ser relativamente barato e de demandar pouca exigência quanto à mão de obra. ${ }^{221}$

Segundo Augusto Carlos de Vasconcelos ${ }^{222}$, o primeiro edifício de cimento armado em São Paulo (como o concreto armado era chamado até 1920) foi de autoria do italiano Francisco Notaroberto, tendo sido construído em 1908, localizado na Rua São Bento, esquina com a atual Praça do Patriarca. No mesmo ano, a Revista Polytechnica descreveu a estação ferroviária da cidade Mairinque, em São Paulo, projeto do arquiteto Victor Dubugras, ressaltando o pioneirismo da obra:

“A bela composição do Sr. Dubugras tem [...] [o] grande mérito [...]
de convencer da possibilidade de fazer bela uma obra de cimento
armado os descrentes da estética do novo sistema de construção, os que
acreditam que o único meio de tornar atraente uma obra executada com
esse material é esconder a natural rigidez geométrica das formas que
decorrem da construção da mesma, fazendo-a desaparecer sob sucessivas
camadas de emboço e reboco." 223

Em 1913, foi construído o que muitos consideram como o primeiro "arranha-céu” da cidade de São Paulo: o Edifício Guinle. Projetado pelo engenheiro Hyppolito Pujol Júnior, o prédio em estilo art nouveau de uso misto - residencial e base comercial - possui sete andares e 36 metros de altura, o que, para a época de sua construção, constituiu um marco na arquitetura de São Paulo, tornando-se o prédio mais alto já construído com concreto armado. $\mathrm{O}$ edifício, tombado pelo Conpresp (Conselho Municipal de Preservação do Patrimônio Histórico, Cultural e Ambiental de São Paulo), resiste até hoje com as mesmas características, na rua Direita, no centro da capital paulista. ${ }^{224}$

220 SANTOS, R. A armação do concreto no Brasil: história da difusão do sistema construtivo concreto armado e da construção de su a hegemonia. Tese (Doutorado em Educação). Faculdade de Educação. Belo Horizonte: UFMG, 2008, p.13.

221 BRUNA, P. J. V. Arquitetura, industrialização e desenvolvimento. São Paulo: Perspectiva, 2002, p. 139-144.

222 Embora seja escassa a documentação brasileira sobre as primeiras obras de concreto armado, adotaremos a retrospectiva histórica do engenheiro Augusto Carlos de Vasconcelos. Ver: VASCONCELOS, A. C. O concreto no Brasil: recordes, realizações, história. São Paulo: Copiare, 1985.

223 Artigo assinado por P.J. (hipoteticamente Hyppolito Pujol Júnior) publicado na Revista Polytechnica $n^{\circ} 22$, 1908. Ver: SEGAWA, H. Arquiteturas no Brasil: 1900-1990. São Paulo: Edusp, 2014, p. 34.

224 O Edifício Guinle foi a primeira construção no país a ter sua obra acompanhada de perto por técnicos do Laboratório de Ensaios da Escola Politécnica. Ver: VASCONCELLOS, J. C. Concreto Armado, Arquitetura Moderna, Escola Carioca: levantamentos e notas. Dissertação (Mestrado em Arquitetura). Porto Alegre: UFRGS, 2004, p.62. e BERGAMIN JUNIOR, G.. Erguido há 97 anos, edifício Guinle esbanja saúde de concreto. Folha de São Paulo, 09 out 2010. Disponível em: <https://www1.folha.uol.com.br/saopaulo/794048-erguido-ha-97-anos-edificio-guinle-esbanja-saude-de-concreto. shtml> Acesso: 18 jan. 2019. 
A partir da década de 1920, em pleno processo de incremento de seu parque industrial, com o crescimento acelerado da cidade e os investimentos do mercado imobiliário, a produção arquitetônica passou a ser mais acentuada, ainda que não necessariamente seguisse os preceitos da Arquitetura Modernista. Contudo, com certeza existiu uma produção ainda não estudada e suficientemente registrada, produção esta que possui características arquitetônicas modernas, como é o caso da fábrica da Ford.

Muitos historiadores apresentam como a primeira manifestação Modernista na arquitetura a obra residencial do arquiteto Gregori Warchavchik, construída na vila Mariana em São Paulo, em 1928. Contudo, a contribuição efetiva para a Arquitetura Modernista Brasileira, inclusive por dispor de aval governamental, foi o prédio do Ministério da Educação e Saúde no Rio de Janeiro. Este projeto, realizado por uma equipe de profissionais ligados ao movimento Modernista e dirigido por Lúcio Costa, ocorreu no ano de 1936, contando inclusive com a colaboração de Le Corbusier, convidado para vir ao Brasil e ser consultor desta obra.

Contudo, merece destaque o fato de que Carlos Lemos, tratando acerca do tombamento da estação de Mairinque, atesta o ineditismo desta obra, salientando a coerência entre as relações das características de linguagem e as características técnico-construtivas, com enfoque para o pioneirismo no uso do concreto armado em nosso país, elevando-a, portanto, à categoria de primeira obra Moderna realizada no Brasil. Isto posto, Lemos irá discorrer sobre a referida obra desta forma:

"A prática da arquitetura moderna começa, então, pelo uso de uma nova tecnologia atendendo a um novo programa e, aos poucos, os demais condicionantes vão sendo atendidos com outros recursos ou enfoques. Assim não será muito fácil a gente determinar com exata precisão quais foram as primeiras obras arquitetônicas modernas brasileiras, ou pelo menos tendentes à modernidade mercê do uso racional da nova tecnologia. Cremos que a primeira manifestação moderna de arquitetura tenha ocorrido entre nós através de algumas obras, ou projetos, do arquiteto franco-argentino Victor Dubugras (1868 - 1933). Dentro de 
seu ecletismo pelas conveniências do momento, em certas ocasiões, tinha lampejos personalistas de extremo bom senso como se percebe na sua estação da Estrada de Ferro Sorocabana em Mairinque, de 1907, trabalho que podemos considerar pioneiro na arquitetura moderna brasileira, quando vemos pela primeira vez o concreto armado empregado dentro de sua potencialidade plástica nas marquises atirantadas, nos torrões, nos vãos, nos espaços abrigados, segundo cálculos estruturais corretos e atendendo a um programa ferroviário que, se não era novo, era ligado a uma recente vida na região até praticamente aqueles dias vinculada ao mundo de transporte pelas tropas e ao comércio de muares na célebre feira de Sorocaba ali próxima” ${ }^{225}$

O projeto da fábrica da Ford trata-se também de um dos primeiros edifícios no Brasil a ser construído com uma linguagem plástica moderna, em concreto armado. $\mathrm{O}$ aspecto pioneiro da fábrica, enquanto inovação arquitetônica, é ainda maior porque nos faz recuar quase uma década do início "oficial" da Arquitetura Moderna Brasileira, cujo marco de referência tem sido considerado, consoante o anteriormente dito, a residência de Warchavchik. A relevância do projeto de Albert Kahn é estabelecida graças ao uso de materiais modernos e de novos métodos de construção, que se traduziram em espaços transparentes, espaçosos e luminosos. Dessa forma, reunia uma série de ideais técnicos e arquitetônicos que vinham tomando forma tanto nos Estados Unidos quanto na Europa, e que definiriam o Movimento Moderno.

Contudo, apesar da modernidade que a fábrica da Ford Motor Company em São Paulo representou para o contexto brasileiro nos âmbitos político, econômico, cultural, social e arquitetônico, ela não pode ser considerada como um protótipo dos trabalhos mais significativos de Albert Kahn. $\mathrm{Na}$ época da construção dessa fábrica, as prioridades de Henry Ford - as quais se refletiam de forma decisiva no trabalho de Kahn - já tinham se alterado. Em busca da melhoria da produção, o industrial americano percebeu que as fábricas de vários pavimentos eram ineficientes por causa dos enormes custos necessários para mover verticalmente as peças pelo edifício.

225 Carlos Lemos em “Arquitetura Contemporânea”, apud CORRÊA, P. R.; PISANI, M. A. J. A Estação de Mayrink do arquiteto Victor Dubugras: Resgate de um patrimônio arquitetônico. Arquitextos, São Paulo, ano 10, n. 109.01, Vitruvius, junho 2009. Disponível em <http://www.vitruvius.com.br/revistas/read/arquitextos/10.109/44>. Acesso em 08 out 2018. 


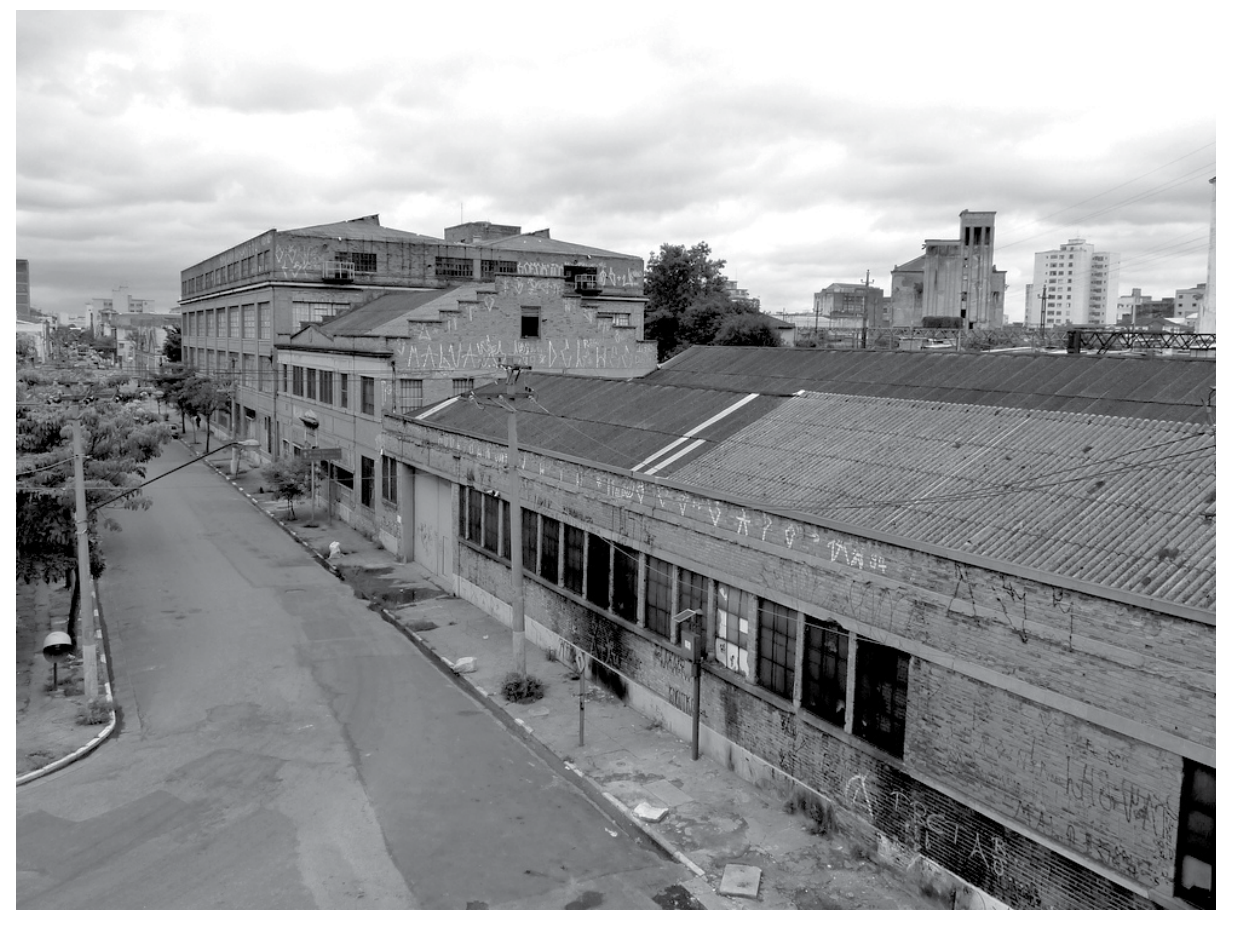

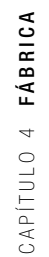

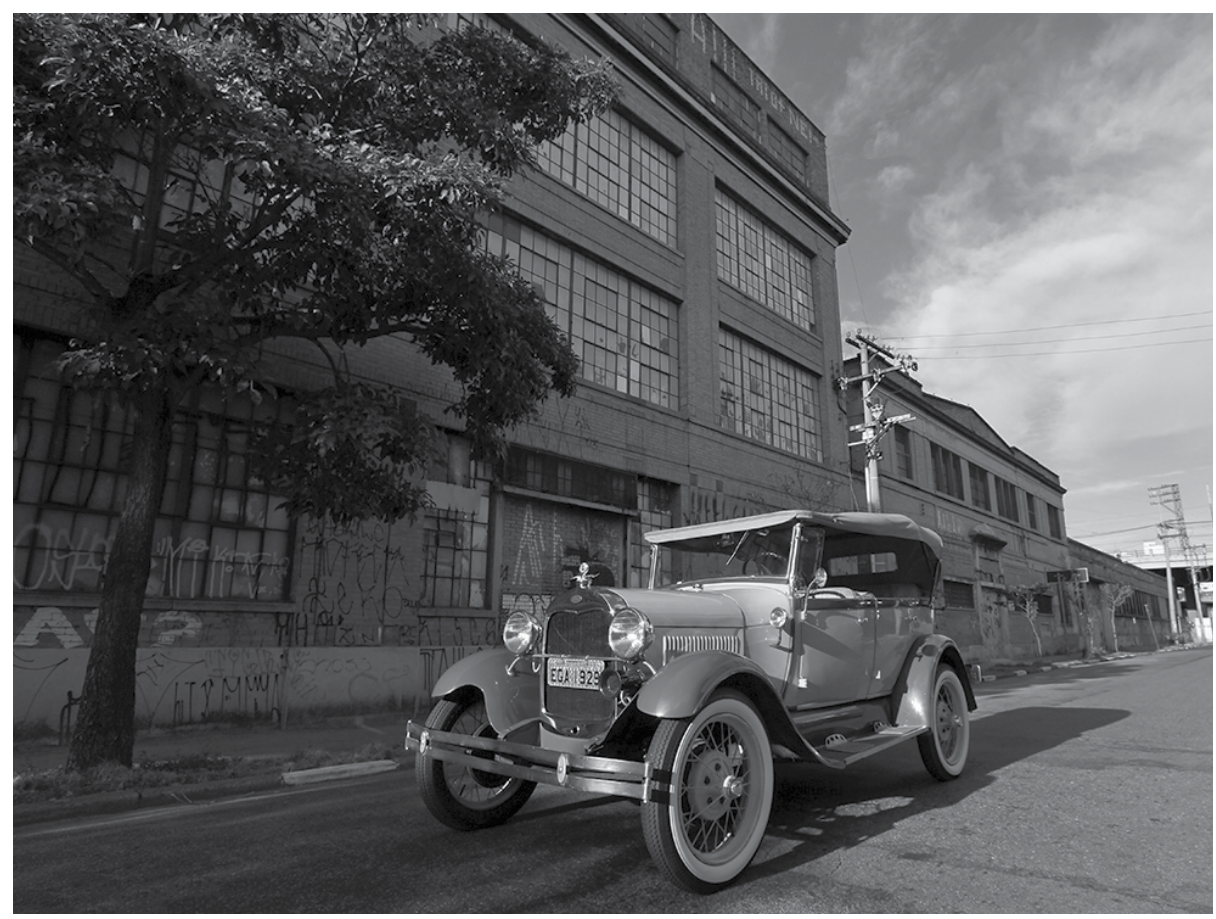

Fig. 162 Situação atual da Fábrica da Ford Motor Company do Brasil. Fonte: <http://www.saopauloinfoco.com.br/ford-sao-paulo/> Acesso 15 jan 2019.

Fig. 163 Situação atual da Fábrica da Ford Motor Company do Brasil. Fonte: < http://www.saopauloantiga.com.br/ford/> Acesso 15 jan 2019. 
Portanto, a partir do complexo da Ford River Rouge, em 1917, Kahn começou a adotar um novo projeto arquitetônico de fábrica - o edifício com pé-direito alto, pavimento único, grandes vãos e estrutura metálica.

O trabalho de Kahn, especialmente aquele visto nas fábricas inovadoras projetadas para Henry Ford, foi um componente essencial para a evolução da arquitetura industrial do início do século XX. De espírito altamente pragmático, Albert Kahn interessava-se em resolver a nova tipologia fabril através da combinação entre programa, estrutura e economia. Em um movimento de redução de suas formas ao estritamente necessário, o edifício industrial passou, assim, a servir de referência para a Arquitetura Moderna.

Ao refletir acerca de algumas preocupações técnicas características dessa época, como, por exemplo, as relativas aos problemas da salubridade e do conforto, ou as relacionadas com os sistemas estruturais e com os meios de produção em massa, a arquitetura industrial tornou-se o campo por excelência da experimentação das formas modernas, dada a importância simbólica do espaço de produção na sociedade. Pensando em termos do que foi transmitido dessas preocupações para a própria área da arquitetura, é imperativo tecer algumas palavras sobre o legado que a obra de Albert Kahn deixou, assim como é importante refletir sobre o quanto a construção da fábrica de automóveis da Ford Motor Company no Brasil, por vias indiretas, acabou se tornando relevante na Arquitetura Moderna Brasileira que estava em vias de iniciar. 

CAP.5 LEGADO 
Em conjunto com o nascimento da arquitetura moderna, a adoção do paradigma mecânico passou a ser generalizado a partir do início do século $\mathrm{XX}$. Isso significou a adoção não somente da ciência, mas também da técnica, ambas atuando como novas protagonistas das aspirações da atividade arquitetônica. Nesse cenário, a figura de Albert Kahn é de extrema importância como uma das principais influências na disciplina arquitetônica. Mesmo assim, possivelmente por se tratar de arquitetura industrial, o impacto global da arquitetura de Kahn foi minimizado, negligenciado ou simplesmente desconhecido pela maioria dos críticos da história da arquitetura.

Essa é uma injustiça que vem sendo reparada a passos lentos. Conforme visto, o trabalho de Kahn viajou para vários locais em todo o mundo, e não foi somente através da construção de encomendas de projetos. Pelo menos três outras atividades de exportação do escritório de Kahn merecem consideração, além do projeto de arquitetura: a circulação de imagens fotográficas dos projetos; a produção e a disseminação dos componentes de edifícios e, por fim, a formação de arquitetos e engenheiros pelo escritório do arquiteto. Tais elementos, quando acrescidos dos próprios edifícios construídos por Kahn, demonstram o quanto o território americano se expandiu através destes instrumentos de projeto. A influência interdisciplinar realizada por Albert Kahn e seus reflexos na arquitetura podem ser divididas, assim, em três subcategorias: simbólica, técnica e formativa. 


\subsection{INFLUÊNCIA SIMBÓLICA}

A influência simbólica baseia-se no conhecimento e divulgação das imagens do trabalho de Albert Kahn que apareceram nas publicações fundacionais do Movimento Moderno. Uma característica muito peculiar dessas publicações era a representação fotográfica de objetos técnicos, exemplificando a perfeição mecânica e a total adequação entre forma e função desejada pelos arquitetos europeus. Entre tais objetos, destacavam-se, além de navios, aviões, carros, guindastes e máquinas em geral, o aparecimento de uma nova categoria de obras arquitetônicas que incluía silos, fábricas e galpões industriais, as quais também foram assimiladas à ideia de objeto técnico. ${ }^{226}$ Essa foi a primeira maneira através da qual o trabalho de Kahn viajou para fora do seu país de origem. Baseou-se, em um primeiro momento, no conhecimento e apreciação das imagens das fábricas, uma vez que não foram publicadas informações técnicas ou condicionantes acerca dos projetos.

A arquitetura industrial, divulgada através das fotografias, teve um impacto considerável no desenvolvimento das ideias modernistas europeias ${ }^{227}$

226 A importância da engenharia e da técnica para o Movimento Moderno já é detectada em publicações como BEHRENDT, W. C. Modern building: It's nature, problems and forms. Nova York: Harcourt, Brace and Company, 1937, e HITCHCOCK, H. R. e JOHNSON, P. The international style. Nova York: W.W. Norton \& Company, 1931.

227 Sobre esse assunto, um estudo bastante abrangente foi feito por Reyner Banham no livro A Concrete Atlantis, que detalha a descoberta europeia da "atlântida de concreto" americana, examinando quais aspectos do Estilo Internacional foram antecipados por edifícios industriais construídos nos Estados Unidos. Ver: BANHAM, R. A Concrete Atlantis: U.S. industrial building and European modern architecture 1900-1925. Cambridge: MIT Press, 1986. 

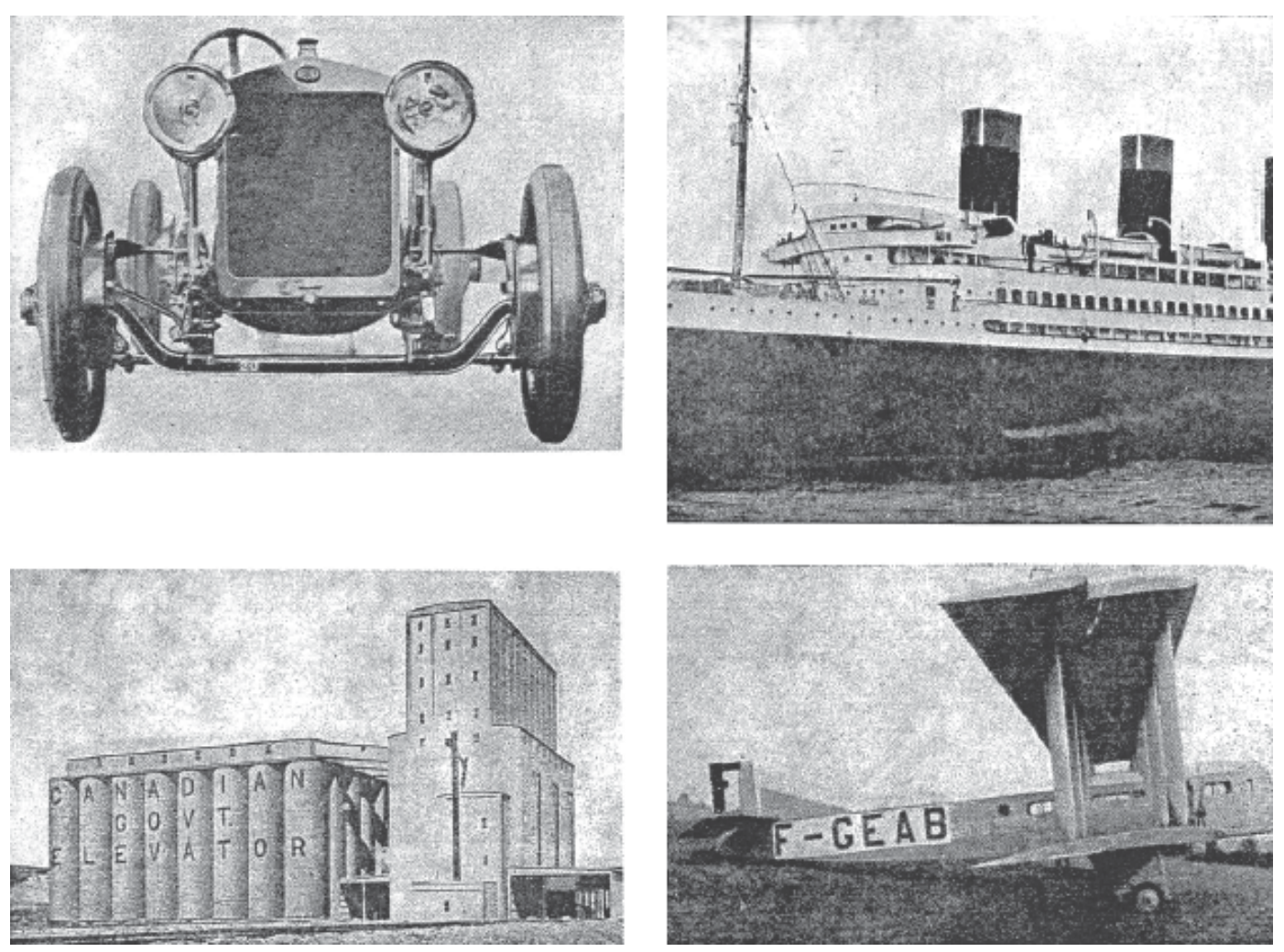

Fig. 164 Objetos técnicos representados no livro Por Uma Arquitetura, de Le Corbusier. Fonte: Pancorbo (2014) 
e nas vanguardas artísticas, entre as quais o Futurismo, o Expressionismo e o Construtivismo Russo. Os edifícios eram obras pioneiras da produção industrial americana, e se tornaram um ideal daquilo que era desejável para a arquitetura devido à sua adequação técnica e econômica, além da natureza compositiva, clareza estrutural e a utilização de novos materiais. "Escutemos os conselhos dos engenheiros americanos. Porém, temamos os arquitetos americanos!"228, declarou Le Corbusier, que, como outros arquitetos europeus de sua época, acreditava que o trabalho dos construtores industriais americanos deveria ser um modelo de desenvolvimento para a arquitetura.

Albert Kahn não era um inovador tecnológico ao estilo do seu irmão Julius - que desenvolveu um sistema de reforço de concreto armado -, mas conseguiu combinar a inovação da linha de montagem automotiva e a tecnologia de estruturas de aço e concreto para criar um novo tipo de arquitetura altamente padronizada. De acordo com Carl Condit, a união dos seus métodos de trabalho como produto arquitetônico constituiu uma "subrevolution in architecture which has influenced designing practice throughout the world."229 Em suma, o que Kahn alcançou foi uma ciência do projeto arquitetônico apropriada à tecnologia científica da indústria moderna.

Conforme Reyner Banham observou, as fotografias das fábricas construídas por Albert Kahn para os fabricantes de automóveis de Detroit, nas primeiras décadas do século XX, apareciam com frequência no cenário europeu deste período. ${ }^{230}$ Em 1913, com referências ao antigo Egito e mostrando fotografias de silos e fábricas americanas (incluindo uma da Ford Highland Park), o arquiteto Walter Gropius publicou o artigo "Die Entwicklungmoderner Industriebaukunst”, no anuário alemão "Jarhbuchdes Deutschen Werkbund". Ao mesmo tempo que seu texto glorificava os edifícios industriais americanos, o arquiteto aproveitou para abordar as elaborações teóricas feitas pela vanguarda arquitetônica europeia. ${ }^{231}$

As fábricas não foram visitadas pessoalmente por Gropius, uma vez que ele somente cruzaria o Atlântico após deixar a Bauhaus, o que ocorreu em 1928. Banham acredita que as fotos das indústrias publicadas no anuário teriam chegado ao conhecimento de Gropius através do contato com seus clientes da fábrica alemã

228 LE CORBUSIER. Por uma arquitetura. São Paulo: Perspectiva, 2011, p.24.

229 Tradução da autora: "subrevolução na arquitetura que influenciou a prática de projetono mundo". Ver: CONDIT, C. W. Review of Design for Industry: The Architecture of Albert Kahn, by Grant Hildebrand. Technology and Culture, v. 16, n. 2, pp. 313-315, 1975.

230 BANHAM, R. A Concrete Atlantis: U.S. industrial building and European modern architecture 1900-1925. Cambridge: MIT Press, 1986, p.15-17.

231 BUCCI, F. Albert Kahn: Architect of Ford. New York: Princeton Architectural Press, 1993, p.166. 

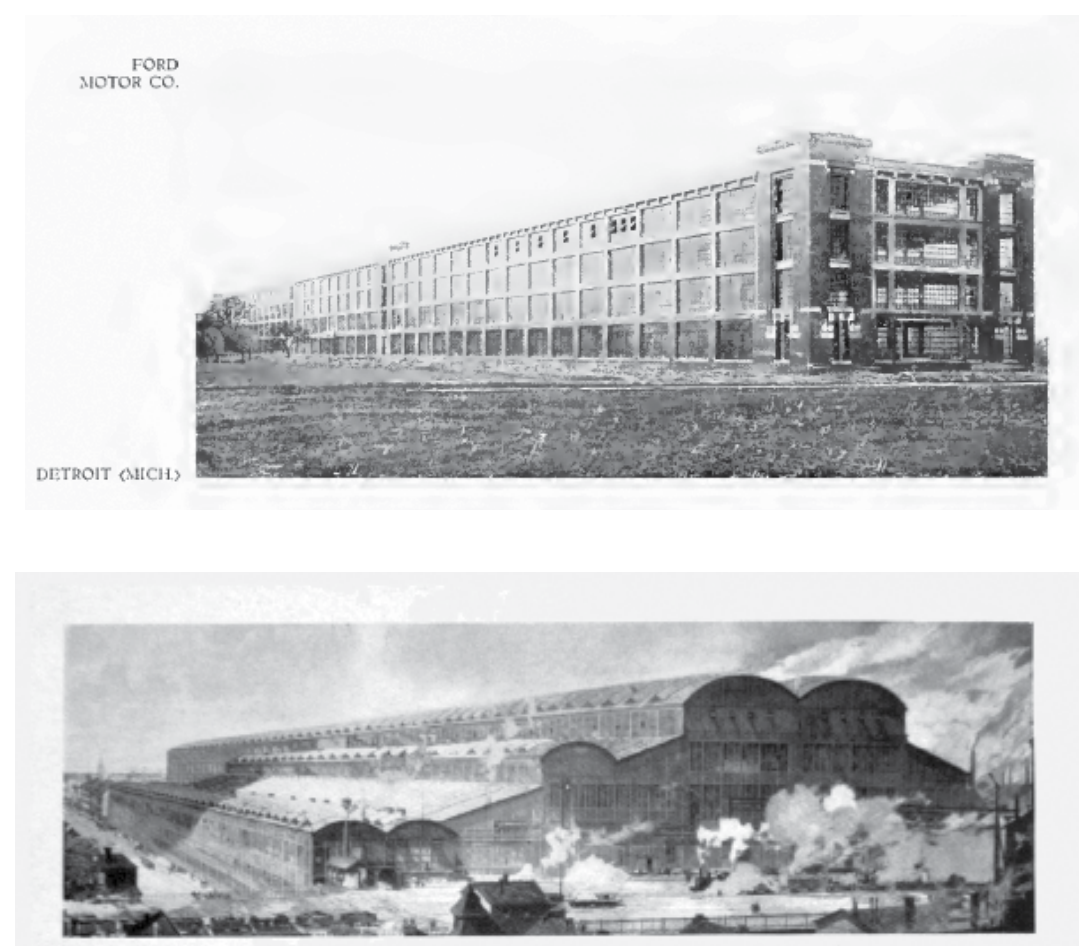

Abb. 115. Maschinenharas IX der Fried. Krupp A. C.. Essen

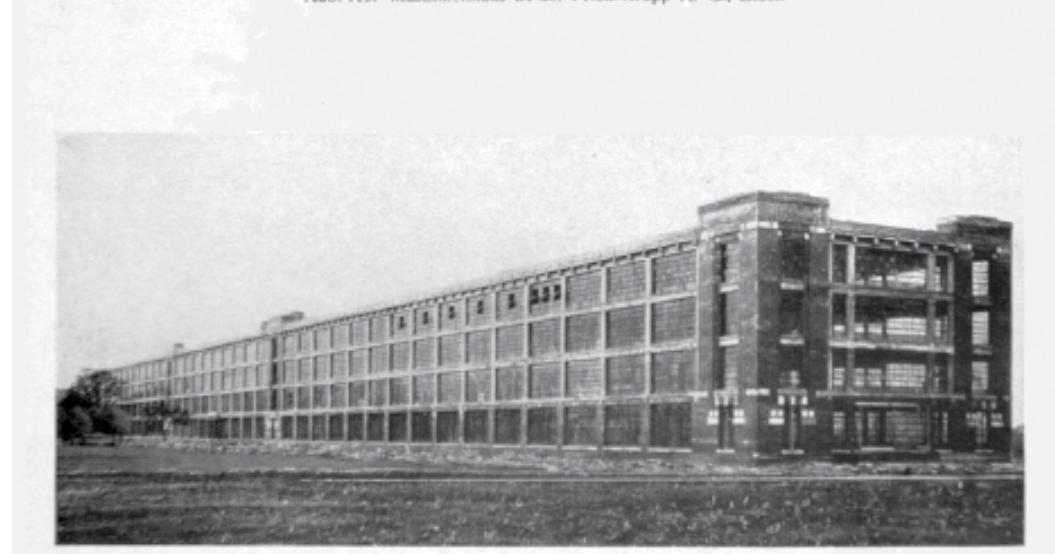

Abb. 116. Fabrik in Nordamerika

Fig. 165 Página do Deutschen Werkbund mostrando a fábrica Ford Highland Park. Fonte: Deutschen Werkbund (1913)

Fig. 166 Página do Die Ingenieurbauten in ihre guten Gestaltung (1923), de Werner Lindner, mostrando a fábrica Ford Highland Park. Fonte: Zimmerman (2014) 


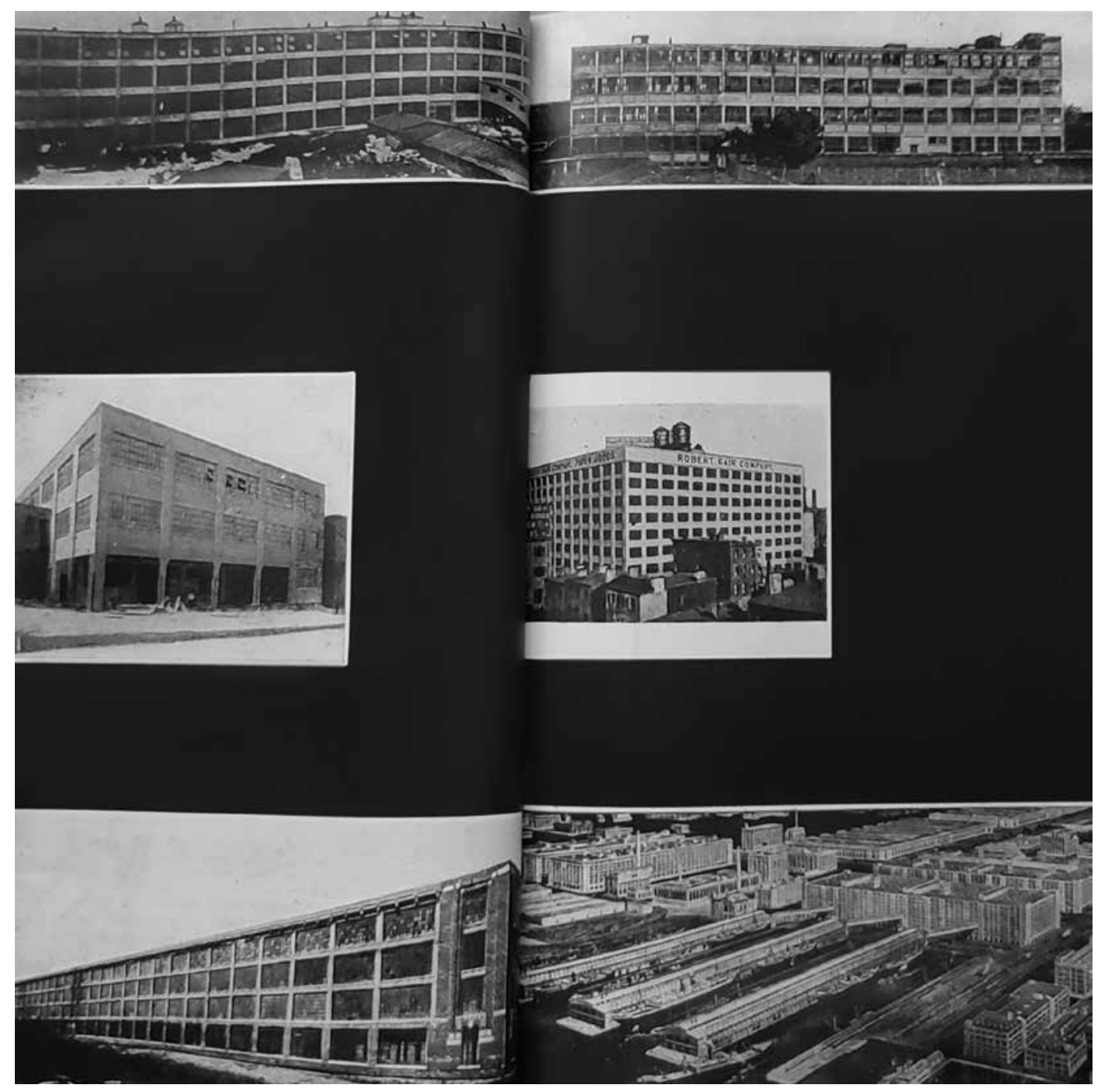

Fig. 167 Página do livro Por Uma Arquitetura, mostrando a fábrica Ford Highland Park. Fonte: Le Corbusier (2011) 
Fagus, os quais visitaram os Estados Unidos em 1910.232 Este artigo teve uma forte influência sobre outros arquitetos modernistas europeus, incluindo Le Corbusier e Erich Mendelsohn, tanto que eles reimprimiram as fotografias do artigo de Gropius. ${ }^{233}$

Em 1919, Le Corbusier escreveu a Gropius pedindo as imagens para serem publicadas na revista "L'Esprit Nouveau", que foram posteriormente utilizadas também no seu livro "Vers une Architecture" (1923). Le Corbusier, que só visitaria os Estados Unidos em 1935²34, usou a mesma fotografia da Ford Highland Park, sem atribuir autoria. Depois de se familiarizar com conceitos da produção industrial ${ }^{235}$, reunindo experiência em projetos de concreto e organizando suas teorias, Le Corbusier, nas páginas de "Quandles catedrais étaient blanches” (1937), não mediu elogios entusiasmados à fábrica da Ford:

"I come out of the Ford factories at Detroit. As an architect, I am plunged into a kind of stupor[...] In the Ford factory, everything is collaboration, unity of views, unity of purpose, a perfect convergence of the totality of gestures and ideas. ${ }^{236}$

Em algum momento, os pioneiros do Movimento Moderno europeu definiram-se como fordistas ou, pelo menos, citaram Henry Ford em seus escritos. A adoção mundial do fordismo, inicialmente circunscrita à organização da produção industrial, mais tarde acabaria por se estender a todas as áreas da atividade humana, tornando-se fundamental no caso da Arquitetura Moderna ${ }^{237}$. O livro de Ford, "My life and work", publicado nos Estados Unidos em 1923 e traduzido em vários países no mesmo ano, vendeu muito rapidamente. A obra incluía material autobiográfico,

232 BANHAM, R. A Concrete Atlantis: U.S. industrial building and European modern architecture 1900-1925. Cambridge: MIT Press, 1986, p.21.

233 BROWN, W. J. American Colossus: The Grain Elevator, 1843 to 1943. New York: Colossal Books, 2009, p.185.

234 Em 1935, Le Corbusier foi convidado pelo MoMA para ministrar uma série de palestras em diversas instituições culturais e universidades norte-americanas. SEGRE, R. O sonho americano de Oscar Niemeyer: Niemeyer, Le Corbusier e as Américas. In: Revista aU, v. 165, dezembro 2007. Disponível em: < http://au17.pini.com.br/arquitetura-urbanismo/165/ artigo67576-1.aspx> Ver também: BANHAM, R. A Concrete Atlantis: U.S. industrial building and European modern architecture 1900-1925. Cambridge: MIT Press, 1986, p.21.

235 Sobre a posição de Le Corbusier em relação ao tema da produção industrial, ver: MCLEOD, M. Architecture or Revolution: Taylorism, Technocracy, and Social Change. In: ArtJournal, v. 43, n. 2, Revising Modernist History: The Architecture of the 1920s and 1930s, p. 132-147, 1983.

236 Tradução da autora: "Eu saio das fábricas da Ford em Detroit. Como arquiteto, estou mergulhado em uma espécie de estupor [...] Na fábrica da Ford, tudo é colaboração, unidade de pontos de vista, unidade de propósito, uma perfeita convergência da totalidade de gestos e ideias". Em: LE CORBUSIER. When the cathedrals were white. New York: McGraw-Hill Book Company, 1964, p. 167-168

237 Essa relação entre o fordismo e a arquitetura foi detalhada em numerosas publicações, com a consequente formação do conceito de funcionalismo e a adoção do objeto técnico como modelo para o projeto da Arquitetura Moderna. Entre os mais destacados estudos sobre este assunto, podemos citar: GARTMAN, D. From Autos to Architecture: Fordism and Architectural Aesthetics in the Twentieth Century. New York: Princeton Architectural Press, 2009; GUILLÉN, M. F. The Taylorized Beauty of the Mechanical: scientific management and the rise of modernist architecture. Princeton: Princeton University Press, 2006; HILPERT, T. La ciudad funcional: Le Corbusier y su visión de la ciudad. Madrid: Instituto de Estudios de Administración Local, 1983. 
bem como maneiras de desenvolver a industrialização, a racionalização e a padronização da produção de automóveis. Tais temas tornaram-se particularmente interessantes para os arquitetos, que tentaram aplicar estes ensinamentos na arquitetura com o intuito de otimizar os processos de projeto e construção dos edifícios. ${ }^{238}$

$\mathrm{O}$ arquiteto alemão Erich Mendelsohn visitou os Estados Unidos pela primeira vez em 1924, acompanhado do cineasta Fritz Lang. ${ }^{239}$ O impacto da visita para ambos foi esmagador. Enquanto Fritz Lang teve a inspiração para fazer o clássico filme de ficção científica "Metropolis" (1927), Mendelsohn relatou as suas experiências no livro "Amerika: Bilderbucheines Architekten”, publicado em 1926, que, juntamente com a publicação do livro seguinte, "Russland, Europa, Amerika”, em 1929240, acabou se tornando uma importante fonte do imaginário do Movimento Moderno.

Os arquitetos Adolf Behne, Bruno Taut e Richard Neutra estavam mais interessados nas inovações técnicas apresentadas pelos edifícios industriais americanos. Em “Der Moderne Zweckbau”, publicado em 1926, Adolf Behne citou algumas declarações de Henry Ford relativas à arquitetura industrial, publicando duas fotografias das fábricas de Albert Khan. ${ }^{241}$ Bruno Taut, no capítulo "IndustrieBauten" de "Die Neue Baukunst in Europa und Amerika" (1929), incluiu, ao lado dos trabalhos de Adolf Meyer, em Frankfurt, e da Fábrica Van Nelle, de Brinkman e Van der Vlugt, quatro fotos de fábricas da Ford, identificando Albert Kahn como o autor do projeto. ${ }^{242}$ Richard Neutra, em seu livro "Wie Baut Amerika?" (1927) ${ }^{243}$, descreveu o novo tipo de dispositivos de fechamento para edifícios industriais introduzido por Albert Kahn. Mais fotografias apareceram em "Die Ingenieurbauten em ihreguten Gestaltung” (1923), publicado por Werner Lindner, assim como em outras publicações alemãs sobre a evolução americana em arquitetura. ${ }^{244}$

Um exemplo posterior desse tipo de influência ocorreu com a emigração do arquiteto alemão Mies van der Rohe para os Estados Unidos. Após sua chegada a Chicago em 1937, Mies encontrou, na arquitetura industrial de Albert Kahn, a qual

238 POERSCHKE, U. Architectural theory of modernism: relating functions and forms. New York: Routledge, 2016, p.133.

239 BANHAM, R. Review: Amerika, Bilderbuch Eines Architekten by Erich Mendelsohn. In: Journal of the Society of Architectural Historians, v. 38, n. 3, p. 300-301, Outubro 1979.

240 MENDELSOHN, E. Amerika: Bilderbucheines Architekten. Berlim: Rudolf Mosse Buchverlag, 1926, e MENDELSOHN, E. Russland, Europa, Amerika. Berlim: Rudolf Mosse Buchverlag, 1929.

241 BEHNE, A. The modern functional building. Los Angeles: Getty Research Institute, 1996, p.41.

242 TAUT, B. Die neue Baukunst in Europa und Amerika. Stuttgart: Julius Hoffmann, 1929, p. 94,96 e 99.

243 NEUTRA, R. Wie Baut Amerika? Stuttgart: Julius Hoffmann, 1927.

244 BUCCI, F. Albert Kahn: Architect of Ford. New York: Princeton Architectural Press, 1993, p.167. 

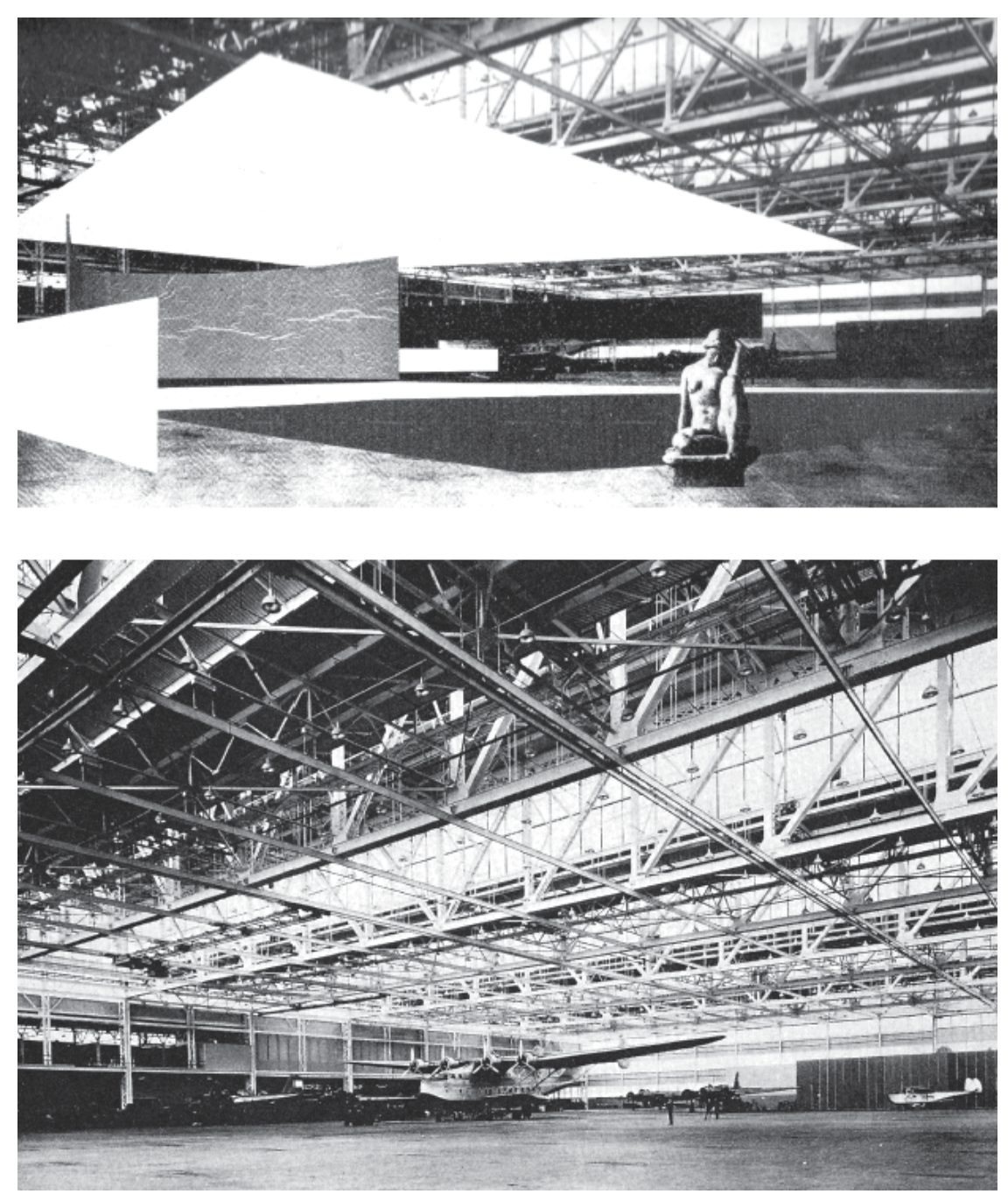

Fig. 168 Superior: Fotomontagem de Mies van der Rohe, Concert Hall, 1942. Inferior: Interior da fábrica de aviões da Glenn Martin, de Albert Kahn, 1937.

$$
\text { Fonte: Pancorbo (2014) }
$$


conheceria pela monografia publicada em 1939 por George Nelson ${ }^{245}$, uma enorme coincidência com os postulados teóricos trazidos por ele da Europa. Tal fato gerou uma forte influência sobre a obra americana de Mies, baseada na valorização da técnica como principal configuradora da arquitetura. $\mathrm{O}$ profundo conhecimento do trabalho de Kahn por Mies é documentado não apenas pela utilização de fotos das fábricas de Kahn, em suas fotomontagens de 1942 ou por depoimentos de seus alunos do Illinois Institute of Technology, em Chicago ${ }^{246}$, mas igualmente por uma série de características de seu trabalho que se relacionam com o arquiteto de Detroit. ${ }^{247}$

Os projetos de Albert Kahn foram exemplificados, sobretudo, com as fábricas da Ford Motor Company dos anos 1910 e 1920. Em tais fábricas, era possível observar a evolução da produção industrial de Kahn, que começou na arquitetura considerada como um objeto técnico até constituir um edifício como uma máquina total. Muitas vezes atribuídas a Henry Ford sem mencionar o nome do arquiteto, tais imagens concretizaram a abstração fordista. Segundo Banham, a força dessas fotografias residia na representação de uma verdade tão objetiva e moderna quanto as estruturas funcionais que ilustravam. ${ }^{248}$

Divulgada nas principais publicações modernas, a fábrica Ford Highland Park, especialmente a Old Shop, foi eleita como monumento ao espírito moderno. "Kahn influenciou fortemente o movimento modernista", constatou o arquiteto Alan Cobb, presidente da Albert Kahn Associates desde 2013, acrescentando que "Gropius e Mies van der Rohe se inspiraram em Kahn para as suas filosofias. Basicamente, enquanto eles estavam desenvolvendo uma filosofia para a arquitetura moderna, Kahn silenciosamente já a estava construindo." ${ }^{249}$

A Ford Highland Park ofereceu uma contribuição genuína ao mundo da arquitetura e da construção em geral, através da tipologia proposta, da sua economia e simplicidade construtivas e também da sua enorme flexibilidade organizacional, que eram aspectos desejáveis nos projetos da nova Arquitetura Moderna. O valor iconográfico da Ford Highland Park acabou por ser demonstrado, enquanto imagem e linguagem arquitetônica, justo no momento em que se tornou um edifício ultrapassado pela tecnologia e pela gestão industrial nos Estados Unidos.

245 NELSON, G. Industrial architecture of Albert Kahn, Inc. New York: Architectural Book Pub., 1939.

246 Um dos alunos de Mies no IIT, Myron Goldsmith, lembra-se de Mies, em 1940, debruçado sobre a recente publicação de George Nelson. O trabalho de Mies mudou significativamente a partir daquele momento. HILDEBRAND, Grant. Beautiful factories. In: Albert Kahn: inspiration for the modern. Ann Arbor: University of Michigan Museum of Art, 2001, p. 26.

247 PANCORBO, L. e ROBLES, I. M. El espacio como membrana. Mies van der Rohe y Albert Kahn. In: RA - Revista de Arquitectura, Universidad de Pamplona, n. 16, p 49-58.

248 BANHAM, R. A Concrete Atlantis. Cambridge: MIT Press, 1986, p. 27.

249 DORMAN, J. L. Legado do 'arquiteto de Detroit' cativa o turista na cidade do carro. Folha de São Paulo, São Paulo, 12 abr. 2018. Disponível em: <https://www1.folha.uol.com.br/turismo/2018/04/passeio-revela-legado-de-albert-kahnconhecido-como-o-arquiteto-de-detroit.shtml>. Acesso em: 28 mai 2018. 
Isto aconteceu não só ao nível das suas capacidades de abrigar novas atividades, mas inclusive como modelo tipológico de edifício fabril. No entanto, ao passo que a Old Shop possuía um marcante significado imagético para os mestres da Arquitetura Moderna europeia, a New Shop apresentou um enorme valor referencial na qualidade de modelo produtivo e arquitetônico. 


\subsection{INFLUÊNCIA TÉCNICA}

Este tipo de influência se baseou na produção e na disseminação dos componentes de construção dos edifícios, influenciados pelo sistema monolítico de concreto armado patenteado pelo irmão de Kahn, Julius. Em uma segunda etapa, a influência técnica se consolidou através das réplicas europeias das fábricas de Albert Kahn, projetadas e construídas por arquitetos europeus.

O sistema de concreto armado, ou "Kahn-crete"250, patenteado em 1903 por Julius Kahn, foi exportado para todo o mundo através da empresa Truscon Trussed Concrete Steel Company. Fundada por Julius com o apoio financeiro de Albert, a Truscon desenvolveu os produtos de construção que foram utilizados em estruturas de todos os tipos e em várias partes do mundo. Além de possuir filiais nas principais cidades dos Estados Unidos, a empresa também supervisionava filiais na Inglaterra e no Japão. ${ }^{251}$

O catálogo de produtos da Truscon logo passou a oferecer uma ampla variedade de componentes de construção comercializados como produtos prontos para uso, que foram amplamente utilizados em projetos do início do século $\mathrm{XX}$.

250 O sistema de concreto estrutural "Kahncrete" encontra-se detalhado em um Catálogo da empresa de Albert, Julius e Moritz Kahn, a Trussed Concrete Steel Company: Kahn System of Reinforced Concrete. General catalogue D, publicado em 1904. Disponível em: < https://archive.org/details/kahnsystemofrein00trus/page/n10>. Acesso em: 12 jun 2018.

251 Sedlar explora as primeiras atividades desta empresa, identificando os produtos comercializados pela empresa e documentando seu uso em uma ampla gama de edifícios Kahn e outros projetos em todo o mundo. Ver: SEDLAR, F. Engineering Industrial Architecture: The Trussed Concrete Steel Company and Albert Kahn. Visual Culture and Archives, Bentley Historical Library. Disponível em < https://deepblue.lib.umich.edu/bitstream/handle/2027.42/98436/Sedlar_ Engineering_Industrial_Architecture.pdf?sequence=1> Acesso: 7 abr. 2018 
No. 736,602 .

J. ХAHN.

PATENTED AUG. 18, 1903.

GONCRETE AND METAL OONSTRUCTION.

SO YODEL. $\quad$ APPLIOATION FILED DEO, 11, 1003.
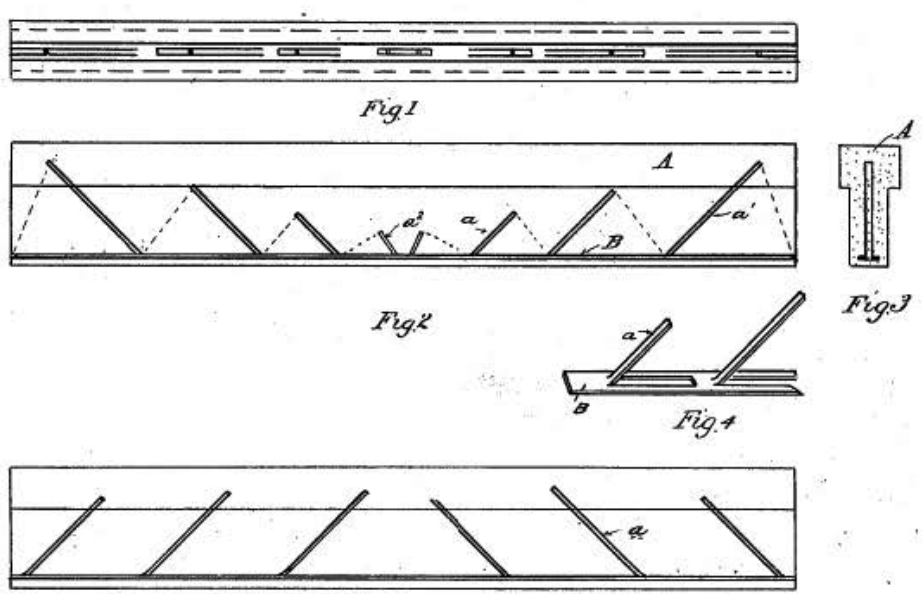

Fig.s
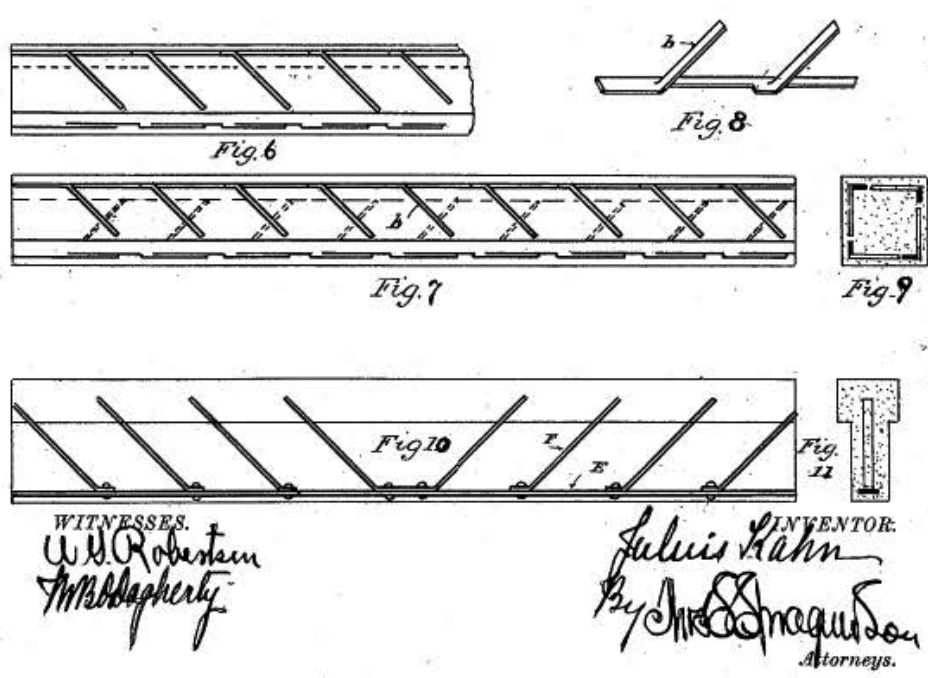

Fig. 169 Patente de concreto armado de Julius Kahn. Fonte: Pancorbo (2016) 

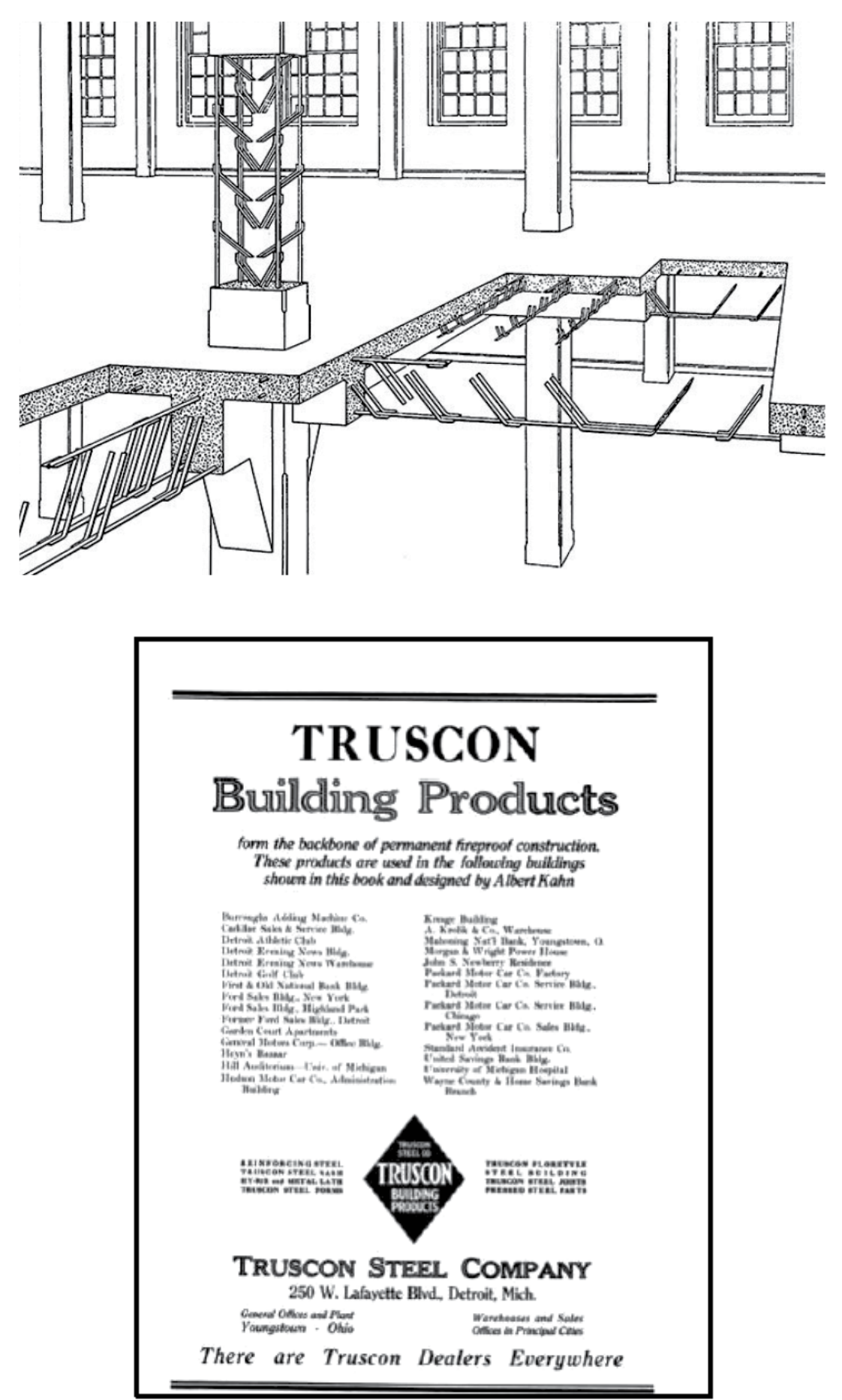

Fig. 170 Esquema tridimensional da patente de concreto armado de Julius Kahn. Fonte: Pancorbo (2016)

Fig. 171 Anúncio dos produtos da Truscon, empresa de Julius Kahn. Fonte: Pancorbo (2016) 
A exportação quase invisível, mas extensa, dos produtos Truscon, sua influência na indústria da construção e os edifícios possíveis de serem construídos através de suas técnicas são pouco conhecidos nos tempos atuais. ${ }^{252}$ No entanto, os produtos Truscon foram usados em estruturas notáveis, como o Hotel Imperial de Frank Lloyd Wright em Tóquio, na reconstrução da Torre de Londres, na Fábrica Boots na Inglaterra e na casa da família de Albert Kahn em Detroit, para citar alguns projetos específicos. ${ }^{253}$

Claramente, a resistência ao fogo e a facilidade de instalação tornaram o sistema Kahn tão atraente para os arquitetos internacionais quanto para os americanos, seja na arquitetura industrial ou não. Apoiando as inovações de seu irmão Julius e demonstrando ser um grande consumidor dos produtos Truscon, Albert Kahn era apenas um dos muitos arquitetos e construtores atendidos pela empresa nos Estados Unidos e no exterior.

Uma segunda etapa da influência técnica encarrega-se de analisar como o conhecimento do trabalho industrial de Kahn - especialmente as fábricas Ford Highland Park e o complexo River Rouge - interferiu na maneira com que os industriais e arquitetos europeus passaram a projetar e construir as fábricas europeias.

Abraçando a tecnologia e o racionalismo, a Fábrica Fagus representou a renovação da arquitetura europeia nas primeiras décadas do século XX. O arquiteto Walter Gropius, que havia colaborado com o arquiteto Peter Berhens na concepção da Fábrica de Turbinas da AEG (1909), foi encarregado em 1911 da melhoria da imagem da fábrica de sapatos Fagus, então em construção, em Alfeld-an-der-Leine, Alemanha. Dois anos mais tarde, Gropius projetaria uma expansão da fábrica através da construção de um novo edifício para acomodar escritórios e armazéns.

Segundo Kenneth Frampton, Gropius adotou a linguagem da Fábrica de Turbinas da AEG, com uma estética arquitetônica mais aberta. ${ }^{254}$ Gropius manteve a ideia de separação entre a pele de vidro e a estrutura, a qual foi revestida de tijolos. O plano transparente que envolve o edifício era interrompido apenas por placas metálicas, que escondiam as lajes dos pisos interiores, sem, contudo, perder a sua continuidade. A grande inovação estava nas arestas, que passaram a ser de vidro,

252 Em 1907, o sistema havia sido usado em mais de 1.500 edifícios nos Estados Unidos e 90 edifícios no Reino Unido. Ver: CODY, J. Exporting American Architecture 1870-2000. New York: Routledge, 2005 (Planning, History, and the Environment Series), p. 38.

253 SIRY, J. The Architecture of Earthquake Resistance: Julius Kahn's Truscon Company and Frank Lloyd Wright's Imperial Hotel. In: Journal of the Society of Architectural Historians, v. 67, n. 1, Mar. 2008, p. 78-105 Ver também MEISTER, C. Albert Kahn's Partners in Industrial Architecture. In: Journal of the Society of Architectural Historians, v. 72, n. 1, p. 78-95, 2013.

254 FRAMPTON, K. História Crítica da Arquitetura Moderna. São Paulo: Martins Fontes, 2003, p.135. 

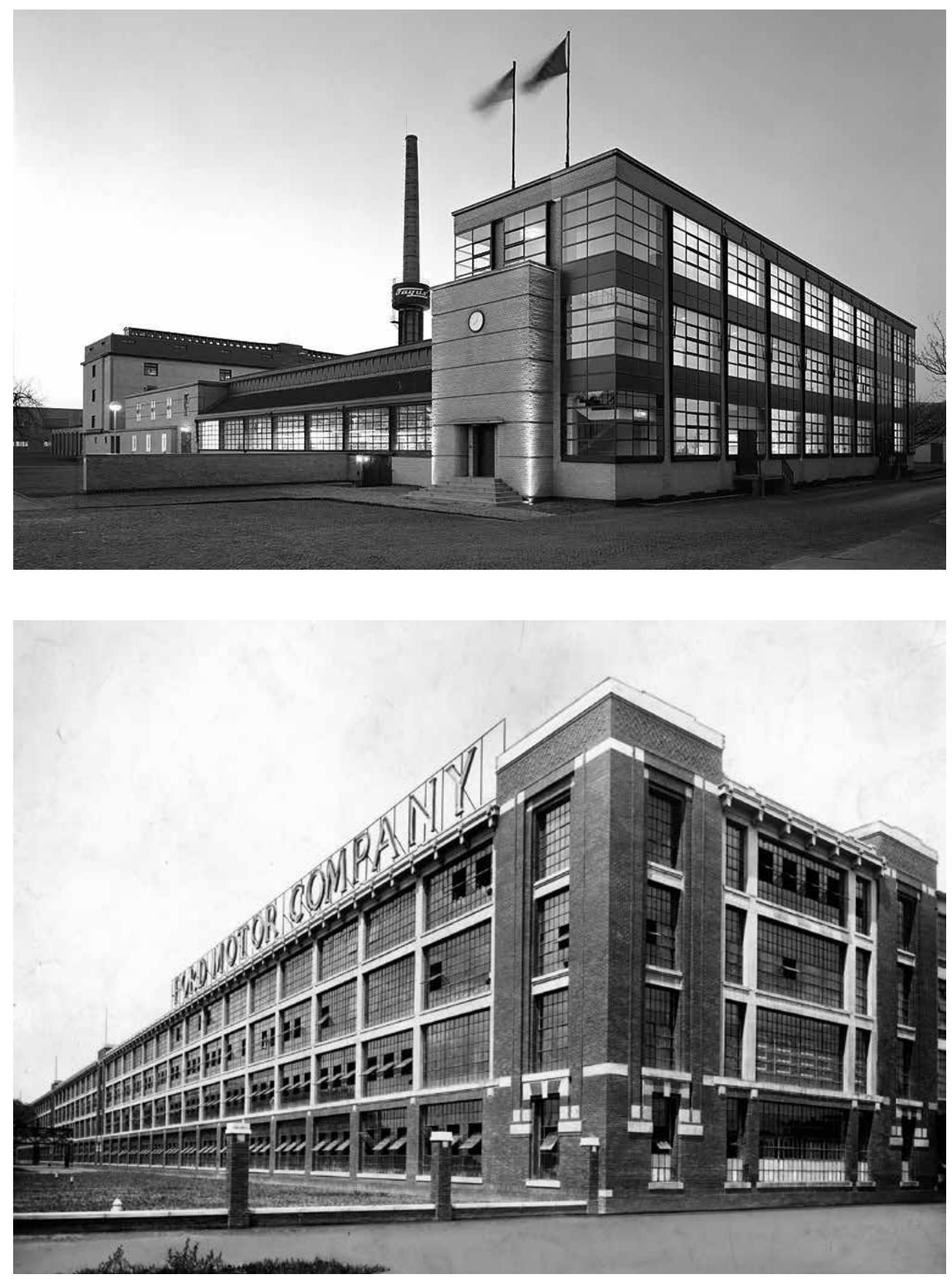

Fig. 172 Fábrica Fagus (1911), em Alfeld, Alemanha. Projeto de Walter Gropius e Adolf Meyer Fonte: <www.archdaily.com/612249/ad-classics-fagus-factory-walter-gropius-adolf-meyer> Acesso: 15 jan 2019.

Fig. 173 Edifício de montagem da fábrica Ford Highland Park Old Shop.

Fonte: Albert Kahn Associates Records, Bentley Library, University of Michigan. 
provocando uma sensação de desmaterialização da estrutura. Diferentemente da Fábrica de Turbinas da AEG, a cobertura da fábrica Fagus era plana, o que servia para ajudar a leitura do edifício como um prisma geométrico puro. A novidade da cobertura plana foi, possivelmente, um reflexo da influência dos edifícios industriais americanos, entre eles a recém construída fábrica da Ford Highland Park, da qual Gropius era um admirador. Com a Fábrica Fagus, o arquiteto buscou criar um edifício que expressasse o espírito industrial moderno, através do uso de novos materiais de construção e manifestando preocupação com respeito ao bem estar dos trabalhadores, o que se refletia por meio da iluminação adequada e de uma maior ventilação. Estas preocupações estão expressas em um texto de 1935, The New Architecture and the Bauhaus, onde Gropius escreve:

\footnotetext{
"Durante mi colaboración activa en los importantes proyectos que le encargaron y las frecuentes discusiones que sostuve com él [Peter Berhens] y otros miembros destacados del Deutscher Werkbund, empezaron a cristalizar mis próprias ideas sobre lo que tenía que ser la verdadeira naturaleza de un edificio. Estaba obsesionado por la convicción de que la técnica constructiva moderna debía expresarse en la arquitectura y, al expresarse, exigiría formas nuevas, vírgenes." ${ }^{255}$
}

Uma década depois, um audacioso projeto foi introduzido na Itália pela Fiat, na cidade de Turim. Projetada pelo engenheiro Giacomo Matté-Trucco, a fábrica Fiat Lingotto foi considerada pioneira na Europa nos aspectos de racionalizar a produção e usar a linha de montagem. Com a sua pista de teste localizada na cobertura, a fábrica se tornaria o ícone da marca Fiat, estabelecendo-a como um fabricante de automóveis de renome internacional. Foi igualmente considerada como um triunfo do progresso e da modernidade, representando o melhor exemplo de supremacia da estética do engenheiro sobre a arquitetura europeia.

O edifício era uma manifestação física de seu conceito de fabricação. Em oposição direta à fábrica Ford Highland Park, que utilizava a gravidade para a produção dos carros fluir dos níveis mais altos para o térreo, a fábrica da Fiat

255 Tradução da autora: "Durante a minha colaboração ativa nos importantes projetos de que estava encarregado e nas frequentes discussões que tive com ele [Peter Berhens] e com outros membros da DeutscherWerkbund, comecei a cristalizar as minhas próprias ideias sobre o que deveria ser a verdadeira natureza de um edifício. Estava obcecado pela convicção de que a técnica construtiva moderna devia expressar-se na arquitetura e, nessa expressão, exigiria formas novas." STRIKE, J. De la construcción a los proyetos: la influencia de las nuevas técnicas en el diseño arquitectónico, 1700-2000. Barcelona: Editorial Reverté, 2004, p. 103. 

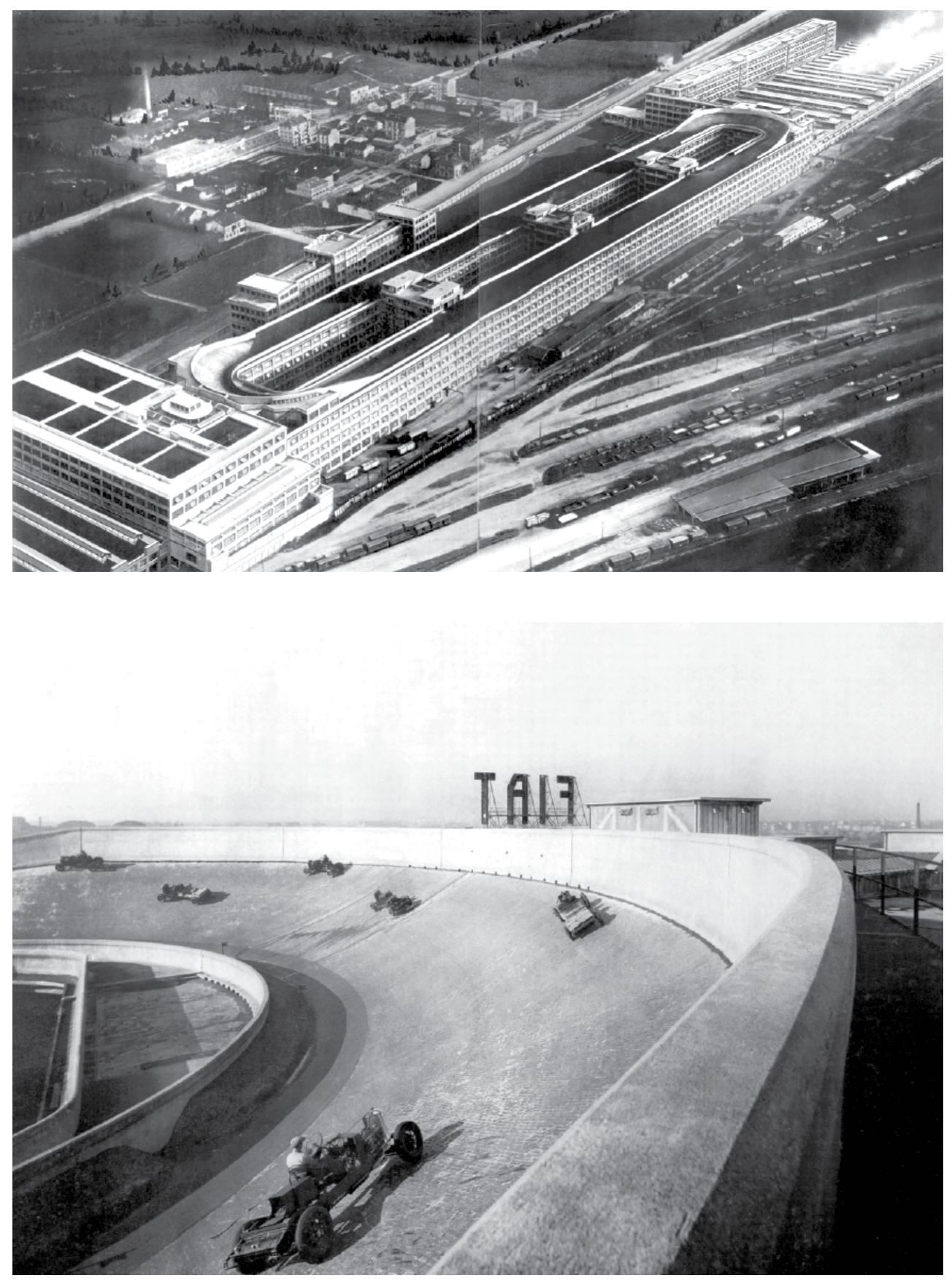

Fig. 174 Fábrica de automóveis da Fiat Lingotto (1923).

Fonte: <https://www.flickr.com/photos/flakacars/1754912774> Acesso 12 jun 2018.

Fig. 175 Pista de teste da Fábrica de automóveis da Fiat Lingotto (1923)

Fonte: <www.pathofkahn.com> Acesso 12 jun 2018. 

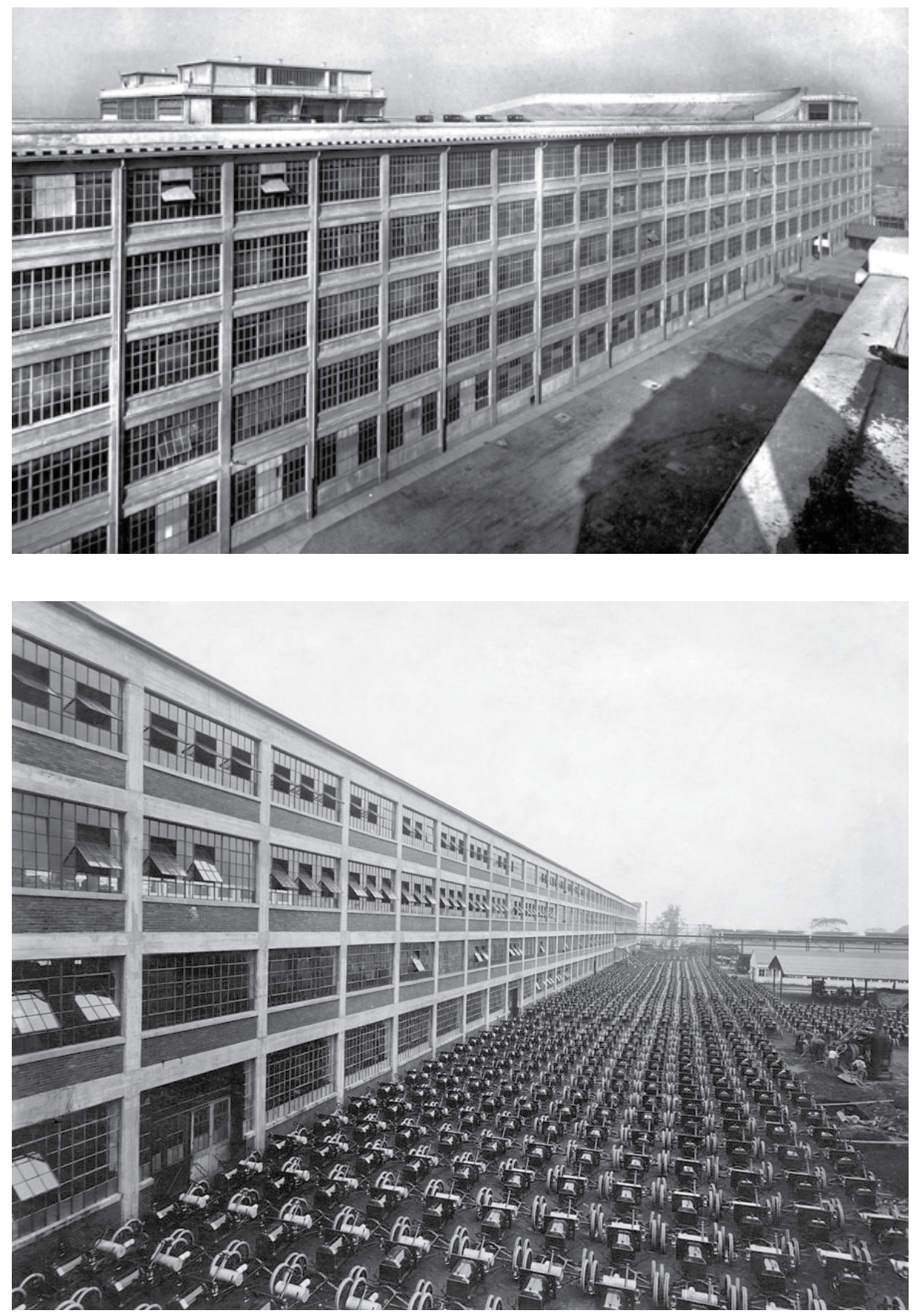

Fig. 176 Exterior da Fábrica de automóveis da Fiat Lingotto (1923). Fonte: Pancorbo (2014)

Fig. 177 Exterior da Fábrica Ford Highland Park.

Fonte: <https://fineartamerica.com/featured/ford-motor-company-ca-1920s-everett.html> Acesso em 12 jun 2018 

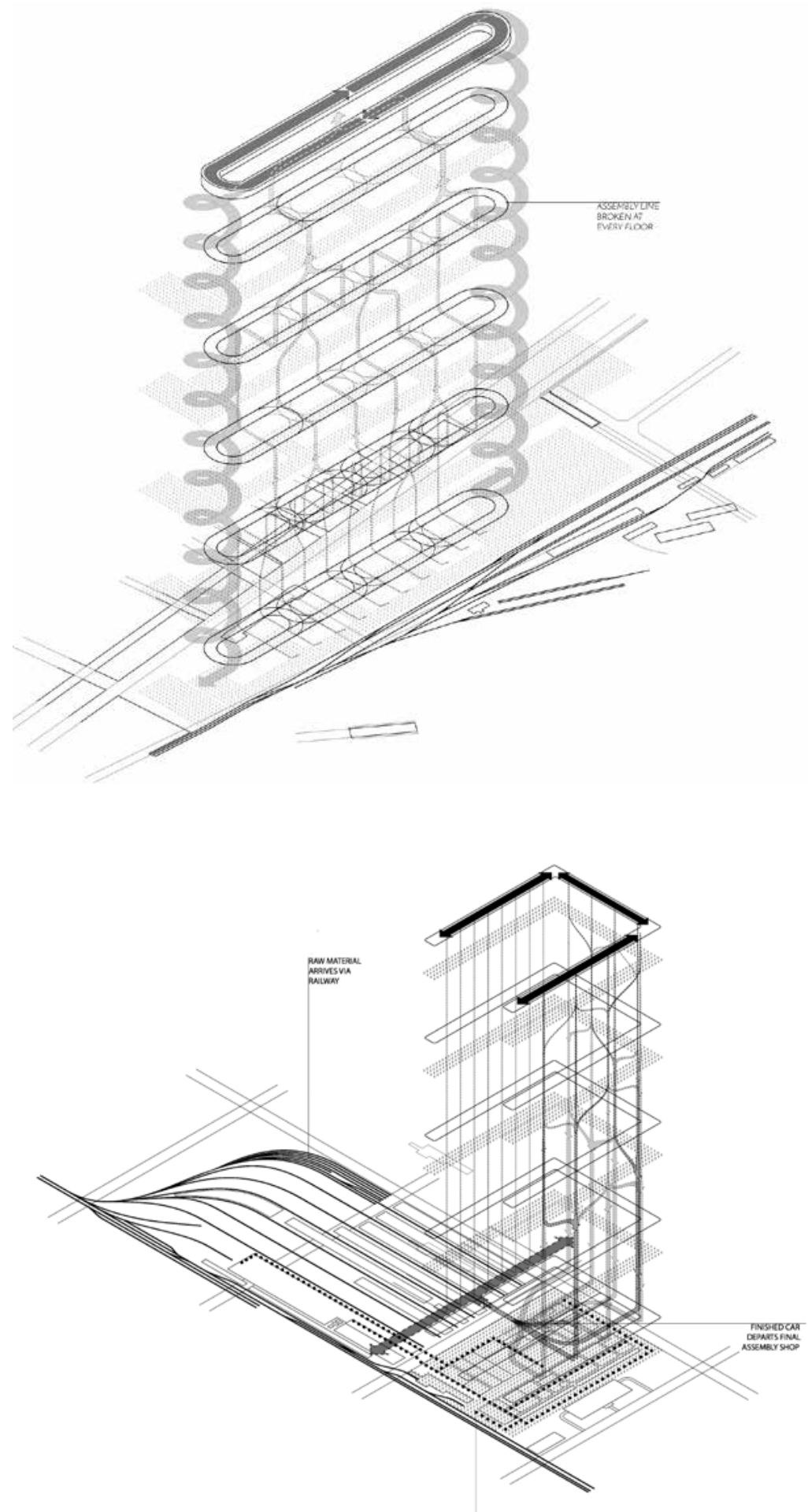

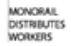

Fig. 178 Diagrama do fluxo produtivo da Fábrica de automóveis da Fiat Lingotto. Fonte: <www.pathofkahn.com> Acesso 12 jun 2018.

Fig. 179 Diagrama do fluxo produtivo da Fábrica Ford Highland Park.

Fonte: <www.pathofkahn.com> Acesso 12 jun 2018. 

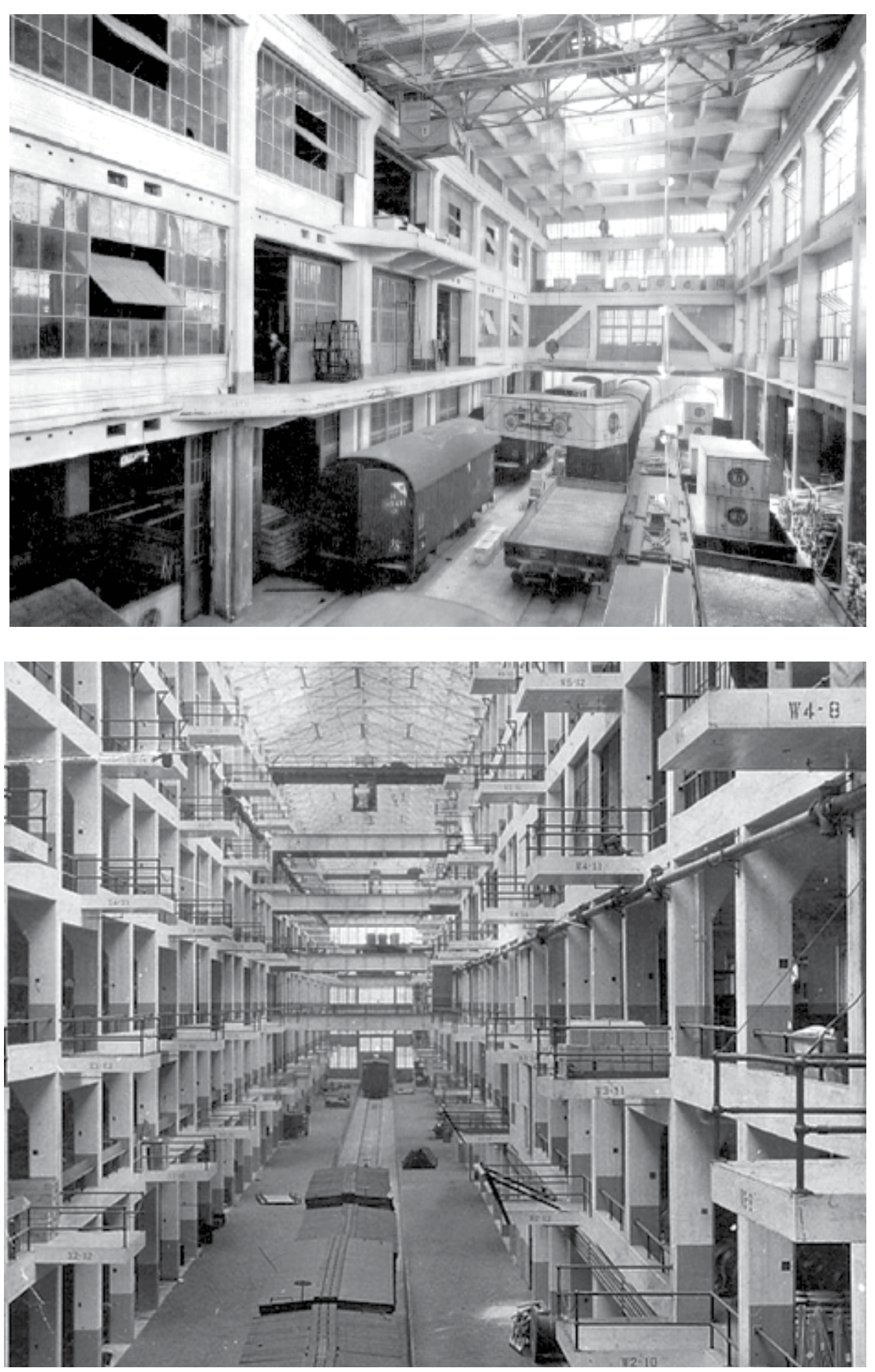

Fig. 180 Exterior da Fábrica de automóveis da Fiat Lingotto.

Fonte: <www.pathofkahn.com> Acesso 12 jun 2018

Fig. 181 Vista do pátio da fábrica Ford Highland Park New Shop.

Fonte: Pancorbo (2014) 

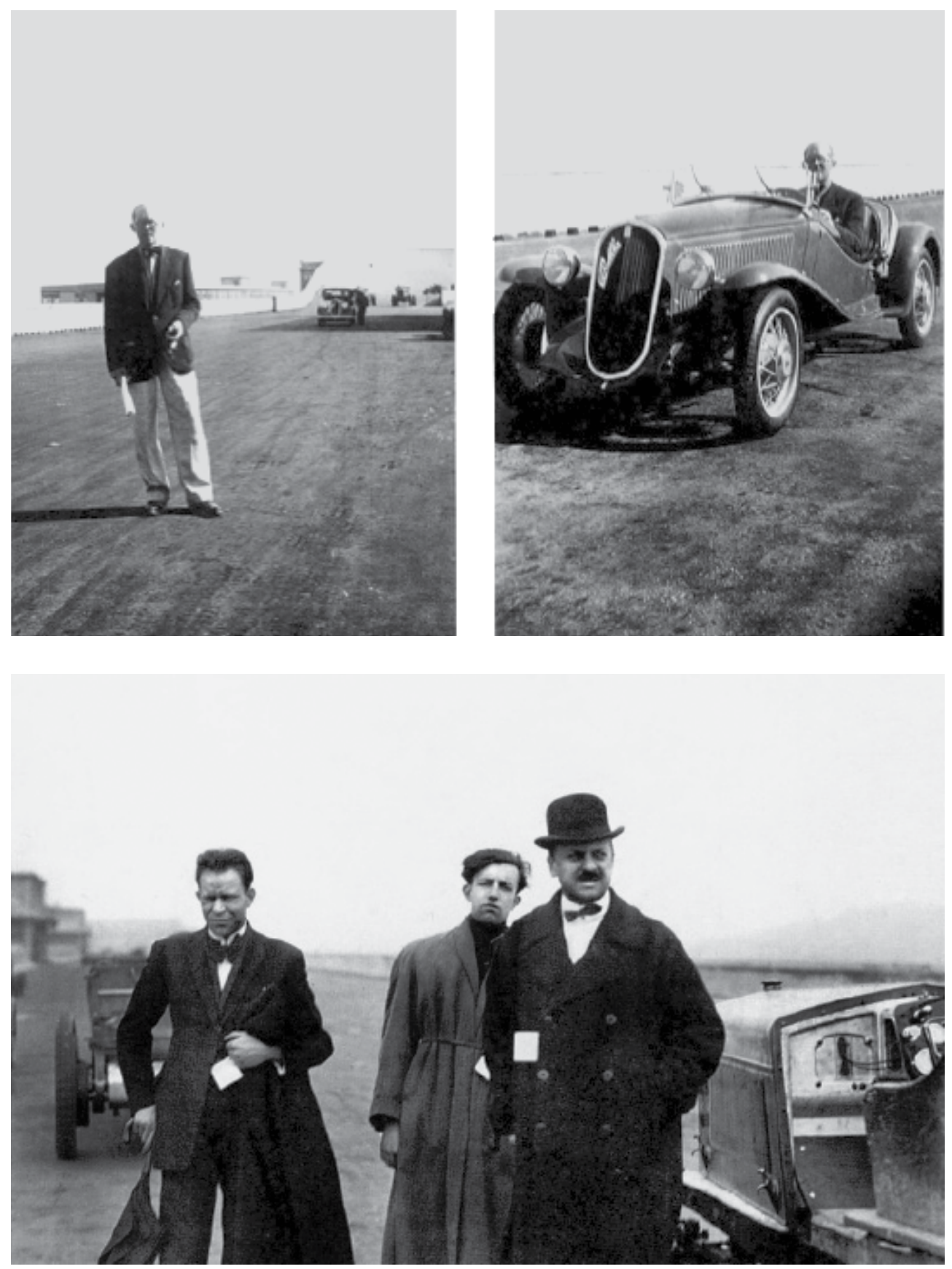

Fig. 182 Le Corbusier visitando a Fábrica Fiat Lingotto em 1925. Fonte: <www.pathofkahn.com> Acesso 12 jun 2018.

Fig. 183 Marinetti visitando a Fábrica Fiat Lingotto em 1924. Fonte: <www.pathofkahn.com> Acesso 12 jun 2018. 
começava a produção no piso térreo, movendo-se continuamente pelos cinco andares do edifício até o carro ser testado em uma pista de corridas na cobertura. É significativo o fato de Giovanni Agnelli, um dos membros fundadores da Fiat, ter visitado a Ford Highland Park. Além de obter a influência que se traduziria diretamente na fábrica de Turim, Agnelli recrutou engenheiros com experiência nas fábricas americanas para auxiliar na sua linha de produção. 256

A pista de corridas - que nunca foi inteiramente funcional - constituíase em um elemento simbólico e monumental. Na época de sua inauguração, era algo radicalmente novo e atraiu muita atenção: em 1924, foi saudada por Filippo Tommaso Marinetti, fundador do movimento futurista, como a "first Futurist constructive invention" 257 e, no ano seguinte, Le Corbusier, que esteve na fábrica pela primeira vez, descreveu o edifício como "one of the most impressive sights in industry”258. Dessa forma, a fábrica foi inserida no cânone do Movimento Moderno, transformando-se em um símbolo internacional da nova arquitetura.

Além dos conceitos como produção verticalizada e linha de montagem, a fábrica da Fiat incorporou também o uso cuidadoso do espaço interno e a consideração do bem-estar psicológico e físico dos trabalhadores - elementos com inspiração direta no modelo fordista. Para isso, Mattè-Trucco empregou uma estrutura de concreto armado quase idêntica ao método de $\mathrm{Kahn}^{259}$, resultando em um projeto que se assemelhava - tanto no aspecto formal quanto no técnico - à fábrica Ford Highland Park.

Fato curioso é que, na época da construção da Fiat Lingotto, a Ford Highland Park já estava desatualizada. Em 1924, ano em que a Fiat Lingotto se tornou totalmente funcional, Albert Kahn estava construindo a fábrica de River Rouge para a Ford Motor Company, adotando uma nova concepção de produção em massa. Portanto, quando a Fiat Lingotto ficou pronta para uso, tinha como referência um modelo já obsoleto.

Mesmo após o seu abandono, ocorrido na década de 1970, a fábrica Fiat Lingotto continuou tendo relevância no discurso arquitetônico. Reyner Banham revisitou-a no seu livro “A Concrete Atlantis”, publicado em 1986, referindo-se à

256 Conforme descrito em <http://www.imprese.san.beniculturali.it/web/imprese/protagonisti/schedaprotagonista?p_p_id=56_INSTANCE_6uZ0\&groupId=18701\&articleId=20933\&p_p_lifecycle=1\&p_p_ state $=$ normal\&viewMode $=$ normal\&articleIdPadre=20933> Acesso: 29/12/18.

257 Tradução da autora: "a principal invenção da construção futurista”. Em: BANHAM, R. A Concrete Atlantis: U.S. industrial building and European modern architecture 1900-1925. Cambridge: MIT Press, 1986, p.246.

258 Tradução da autora: "uma das paisagens mais impressionantes da indústria". Ver: COOK, J. Lingotto: Myths, Mechanisation and Automobiles, p. 5. Disponível em: <https://www.academia.edu/14362388/Lingotto_Myths_ Mechanisation_and_Automobiles?auto=download>Acesso em 19 set 2018

259 O projeto contou com a colaboração de muitas pessoas, especialmente do engenheiro estrutural Vittorio Bonade Bottino, que tinha trabalhado no escritório de Albert Kahn, em Detroit, e conhecia as técnicas de construção em concreto que Kahn havia utilizado na Ford Highand Park. Ver: COHEN, J. L.; DAMISCH, H. Scenes of the world to come: European architecture and the American challenge, 1893-1960. Paris: Flammarion, 1995, p. 80. 
fábrica como um locus classicus do modernismo, destacando o "triunfo" da estrutura como um símbolo da modernização da Itália. ${ }^{260}$

Após o fechamento da fábrica em 1982, houve muito debate acerca do futuro do edifício da Fiat Lingotto, uma vez que se trata de uma estrutura icônica, com grande significado para a cidade de Turim e para a Arquitetura Moderna. Em 1985, realizou-se uma competição de arquitetura com o objetivo de receber propostas de futuros possíveis para o edifício, consagrando-se vencedor o escritório de arquitetura de Renzo Piano. A proposta do arquiteto transformou a antiga fábrica em um centro de uso misto com amplas instalações, incluindo salas de concerto, um teatro, um centro de convenções, shopping center, três hotéis e a sede da Faculdade de Engenharia Automotiva da Universidade Politécnica de Turim. ${ }^{261}$

A fábrica de tabaco, café e chá Van Nelle, construída em 1925 em Roterdam, foi outro exemplo da concretização das premissas técnicas e estéticas modernas. De autoria dos arquitetos J. A. Brinkman e Van der Vlugt, em colaboração com Mart Stam e J. G. Wiebenga, a fábrica retirou a sua expressão do dinamismo do processo de produção que abrigava. Van Nelle incorporava a ideia de um novo tipo de fábrica, totalmente funcional, e veio a se tornar uma obra-prima da arquitetura industrial moderna.

Kees van der Leeuw, proprietário da fábrica Van Nelle, interessado em incluir o tabaco americano na produção, viajou para os Estados Unidos em duas ocasiões - 1911 e 1926 -, onde visitou fábricas americanas, dentre as quais a Ford Motor Company. Van der Leeuw ficou fascinado com as ideias da gestão científica do trabalho e particularmente interessado nas teorias de Henry Ford. ${ }^{262}$

Com muitas características semelhantes aos projetos da Ford Motor Company, a Fábrica Van Nelle constituía em uma excelente forma de ilustrar a organização racional dos fluxos produtivos. O processamento do tabaco, chá e café ocorriam por gravidade - como encontrado na Ford Highland Park - e em edifícios separados entre si. Para resolver o problema de transporte de matérias-primas entre os edifícios, algumas passarelas foram adicionadas, solução semelhante àquela adotada no complexo da Ford River Rouge.

Van Nelle reunia uma série de ideais técnicos e arquitetônicos

260 BANHAM, R. A Concrete Atlantis: U.S. industrial building and European modern architecture 1900-1925. Cambridge: MIT Press, 1986, p.221.

261 Mais informações sobre o projeto encontram-se disponíveis no site do arquiteto Renzo Piano: <http://www.rpbw.com/ project/lingotto-factory-conversion> Acesso: 20 jul. 2018.

262 JONGE, W.. The technology of change: the Van Nelle factories in transition. In: Back from Utopia. Rotterdam: Henket and Heijnen, 2002, p. 48. 

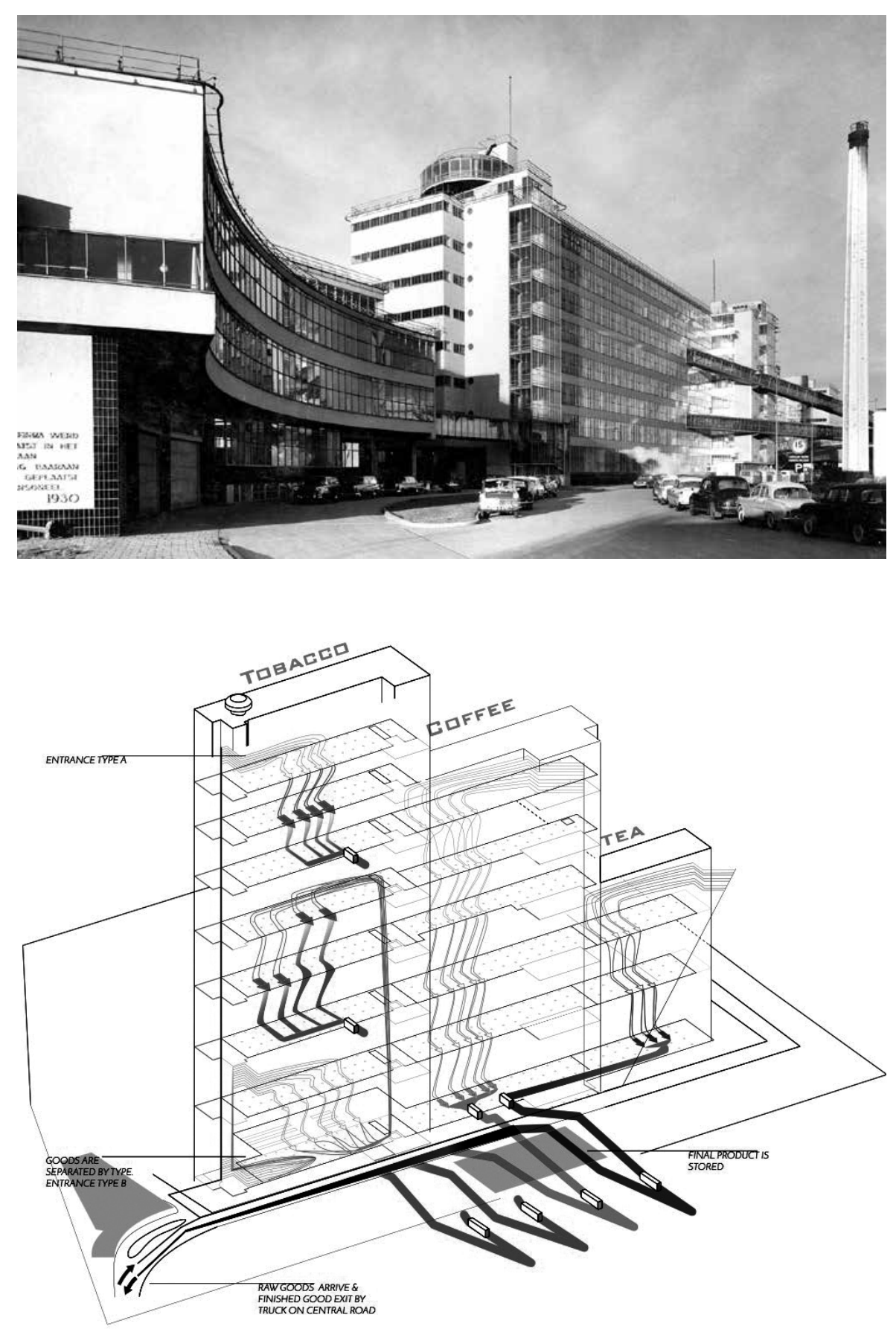

Fig. 184 Fábrica Van Nelle, em Roterdam, Holanda. (1925). Fonte: <www.pinterest.com> Acesso em 17 jun 2018.

Fig. 185 Diagrama do fluxo produtivo da Fábrica Van Nelle. Fonte: <www.pathofkahn.com> Acesso 12 jun 2018. 

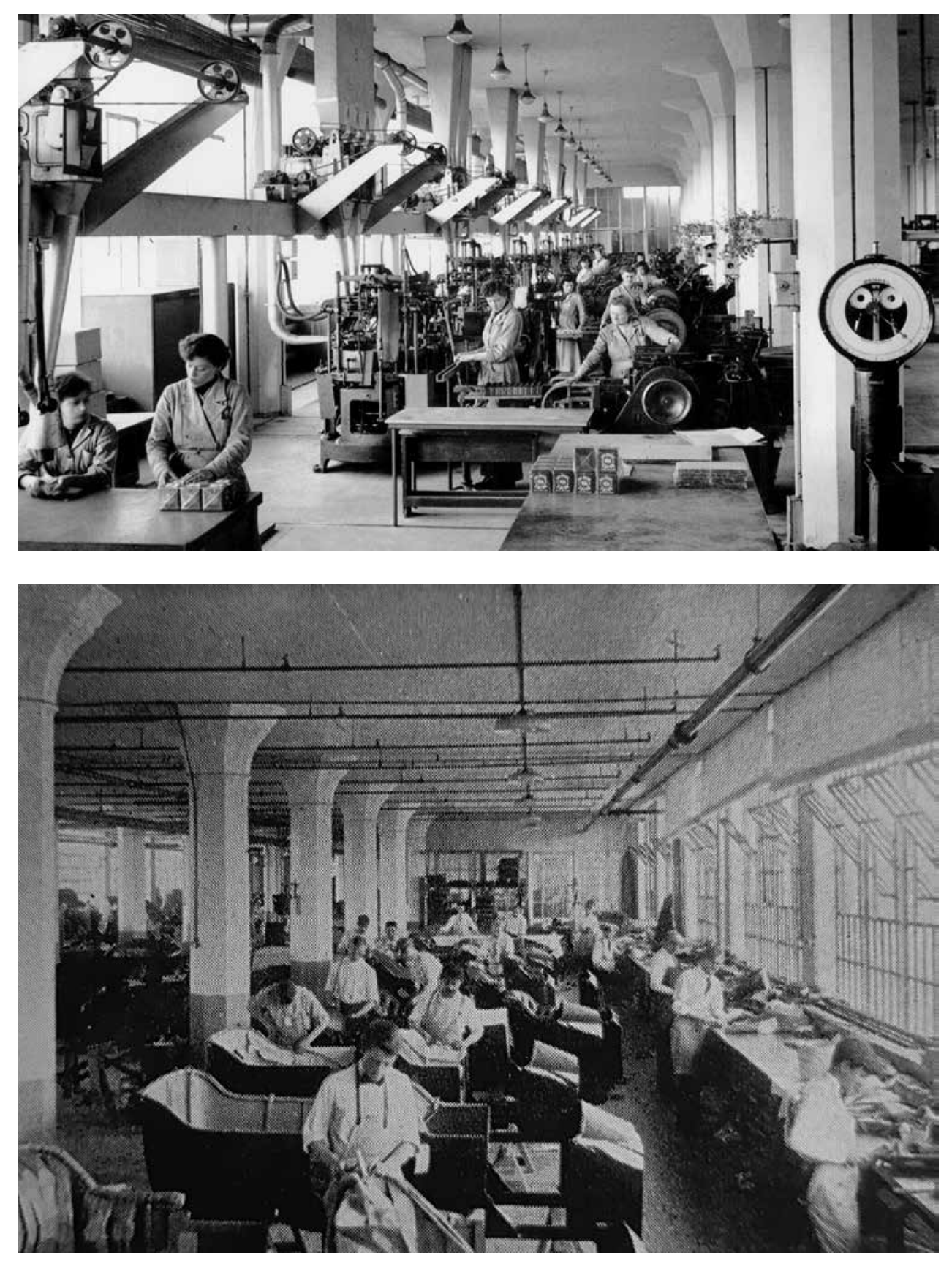

Fig. 186 Interior da Fábrica Van Nelle, em Roterdam, Holanda.

Fonte: <http://atlasofplaces.com/filter/Architecture/Van-Nellefabriek-Brinkman-Van-der-Vlugt> Acesso 17 jun 2018.

Fig. 187 Interior da Fábrica Ford Highland Park New Shop.

Fonte: Nelson (1939) 

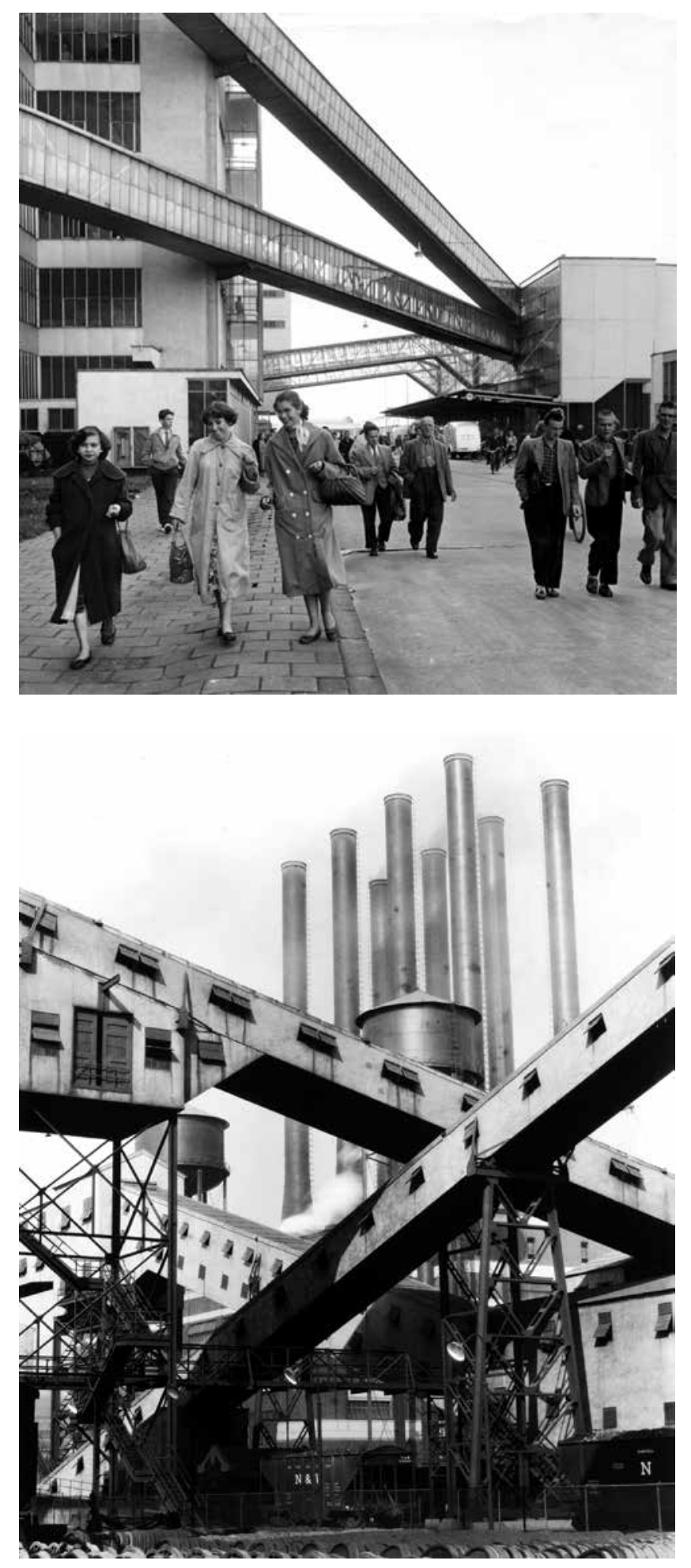

Fig. 188 Passarelas da Fábrica Van Nelle, em Roterdam, Holanda.

Fonte: <http://atlasofplaces.com/filter/Architecture/Van-Nellefabriek-Brinkman-Van-der-Vlugt> Acesso 17 jun 2018.

Fig. 189 Passarelas da Fábrica Ford River Rouge. Pintura de Charles Sheeler (1927).

Fonte: <https://www.moma.org/collection/works/49016> Acesso 17 jun 2018. 
que vinham ganhando espaço tanto nos Estados Unidos quanto na Europa, as quais definiriam o próprio Movimento Moderno. $\mathrm{O}$ uso de materiais modernos e de métodos inovadores de construção se traduziram em espaços transparentes, espaçosos e luminosos. O efeito de transparência era reforçado pelas fachadas, que apresentavam a primeira parede-cortina pré-fabricada industrial do mundo. ${ }^{263}$

A incidência de luz natural nos espaços de trabalho internos visava proporcionar condições de trabalho agradáveis. Vidro, aço e concreto eram os materiais usados, e deles emergia uma composição onde a estrutura detinha um papel expressivo fundamental: uma parede-cortina em vidro envolvia uma estrutura em concreto armado constituída por laje plana e pilares com capitéis de reforço em forma de cogumelo ${ }^{264}$. Dessa forma, permitia uma grande entrada da luz diurna nos espaços internos, expressando clareza, fluidez e abertura da fábrica para o mundo exterior.

A fábrica atraiu a atenção internacional tão logo foi concluída em 1931, rapidamente tornando-se um dos melhores exemplos da arquitetura moderna na Holanda. Quando o arquiteto Le Corbusier visitou o edifício em 1932, ele o descreveu como "the most beautiful sight of the modern age" e "sparkling evidence of the life that is yet to come, of clean, absolute purity". ${ }^{265} \mathrm{Na}$ época da construção, a apresentação elegante e futurista do edifício era considerada um prenúncio do futuro.

Van Nelle operou até 1995, quando a empresa foi reorganizada e a produção acabou sendo interrompida. Atualmente, os edifícios abrigam uma variedade de novas empresas de mídia e design, com espaço para reuniões, conferências e eventos. Essa conversão foi planejada em 1997 por Eric Gude, especialista holandês em conversão de edifícios industriais, e pelo arquiteto Wessel De Jonge, responsável pela renovação, que começou no ano $2000 .{ }^{266}$ Com isso, o interior da fábrica foi exposto como nunca, e a estética da máquina realmente se destacou por meio das passarelas que transportavam as mercadorias.

O elegante edifício D10 da empresa farmacêutica Boots, devido à sua construção inovadora em concreto, aço e vidro, é considerado um ícone da

263 JONGE, W.. The technology of change: the Van Nelle factories in transition. In: Back from Utopia. Rotterdam: Henket and Heijnen, 2002 , p. 47.

264 FRAMPTON, K. História Crítica da Arquitetura Moderna. São Paulo: Martins Fontes, 2003, p.162.

265 Tradução da autora: "a mais bela visão da era moderna" e "evidência cintilante da vida que ainda está por vir, de pureza absoluta e limpa”. Em: MOLENAAR, J.; KAUFFMANN, F.; BACKER. A. M. Van Nelle: monument in progress. Roterdam: De Hef Publishers, 2005, p.124.

266 Informações sobre o estado atual da fábrica se encontram no site: <www.vannellemuseum.com> 

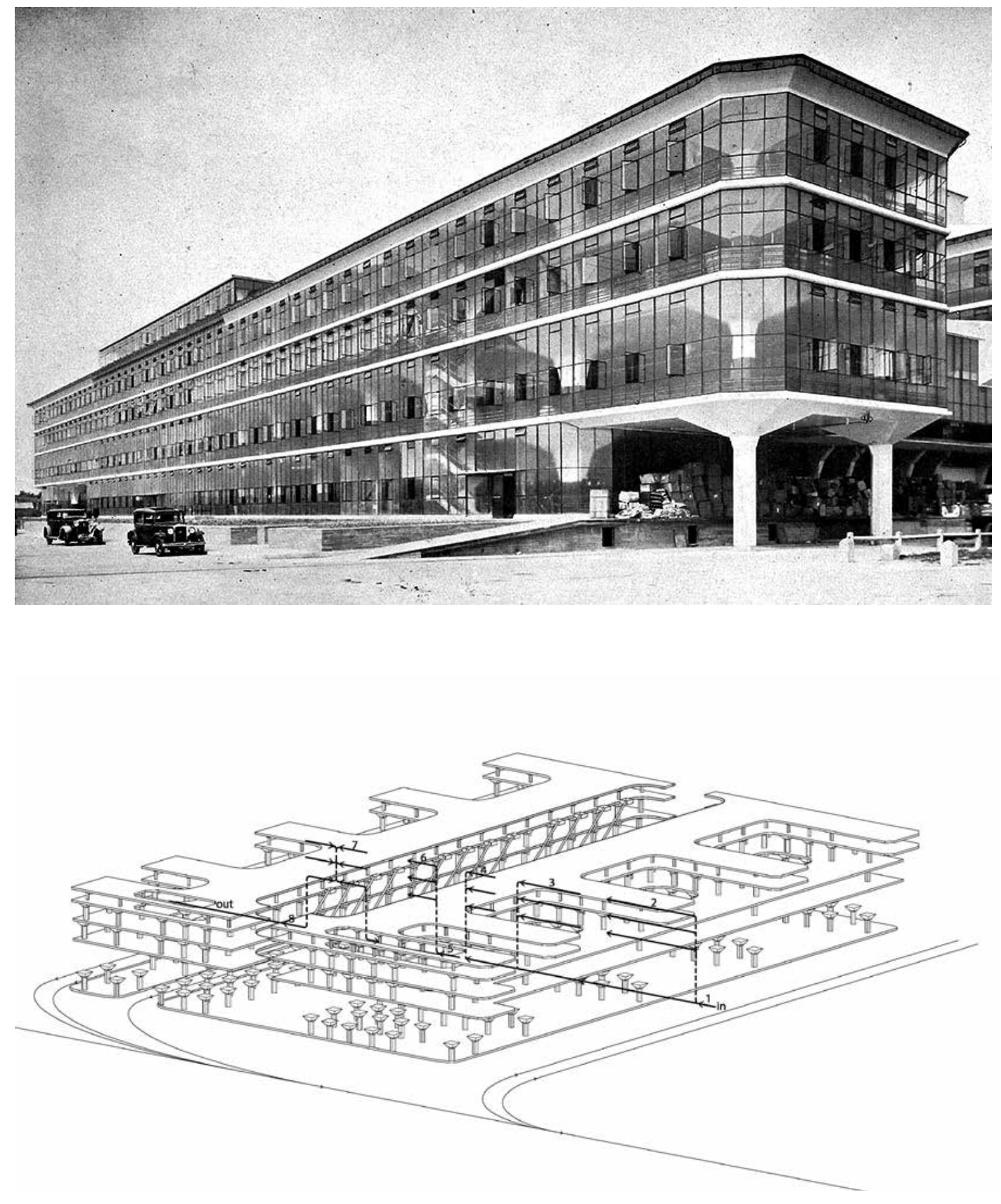

Fig. 190 Edifício D10, Fábrica Boots, em Beeston, Inglaterra (1932)

Fonte: <https://www.architecturalrecord.com/articles/11533-when-modernism-was-young> Acesso 20 jun 2018.

Fig. 191 Diagrama do fluxo produtivo do Edifício D10, Fábrica Boots.

Fonte: <www.pathofkahn.com> Acesso 12 jun 2018. 

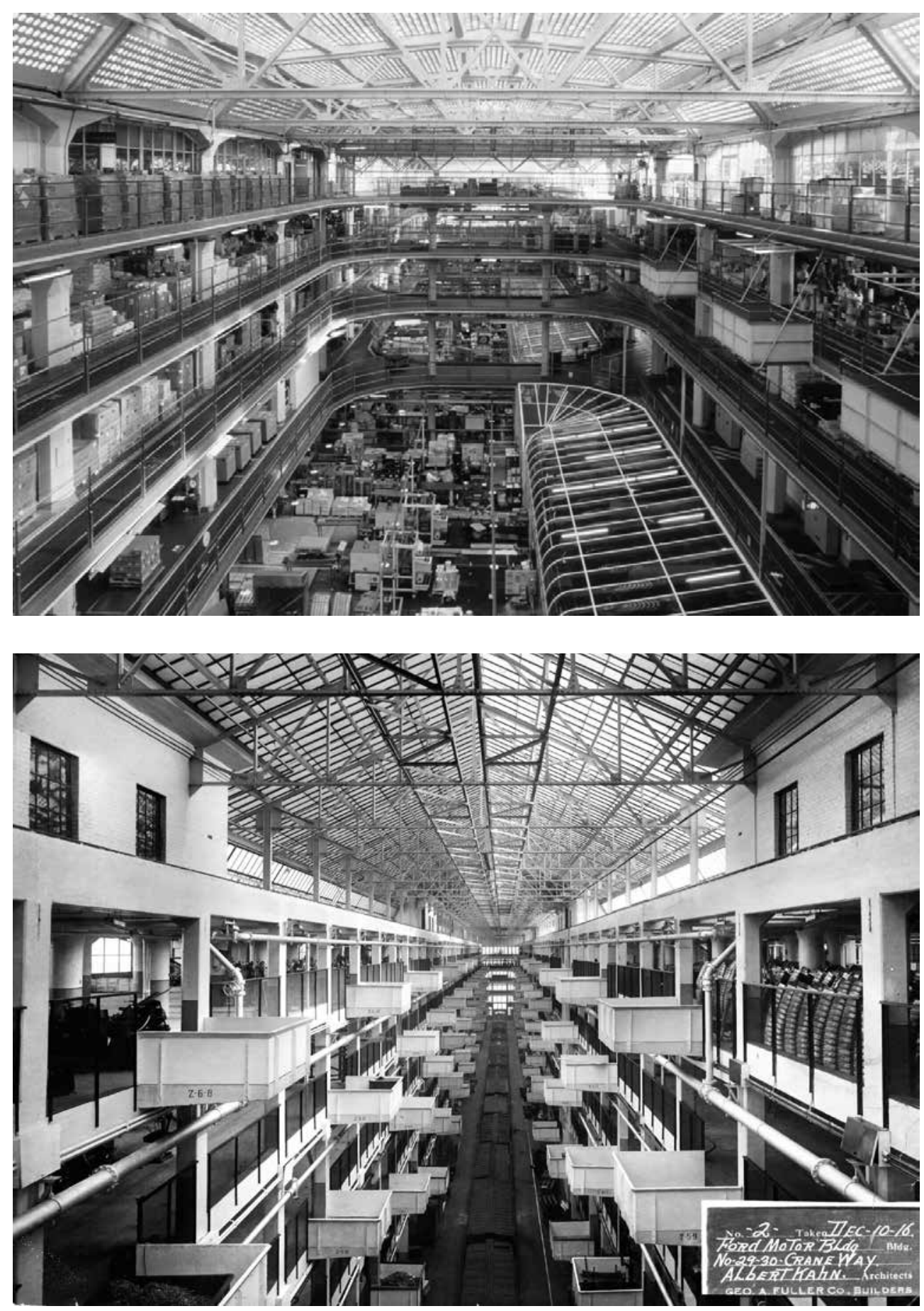

Fig. 192 Pátio interno do Edifício D10, Fábrica Boots. Fonte: Darley (2013)

Fig. 193 Pátio interno da Ford Highland Park New Shop. Fonte: Albert Kahn Associates Records, Bentley Library, University of Michigan. 
Arquitetura Moderna inglesa. O projeto do engenheiro britânico Evan Owen Williams foi construído em 1930 e está localizado em Beeston, uma cidade próxima de Nottingham. O caso do engenheiro Owen Williams é paradigmático, uma vez que, de 1912 a 1916, ele trabalhou na filial inglesa da Truscon, empresa de Julius Kahn. ${ }^{267}$ Este fato influenciou de forma notável a sua obra posterior.

A participação na Truscon colocou Owen Williams diretamente em contato com os projetos que Albert Kahn estava realizando em Michigan. O engenheiro dizia que uma fábrica era "a place protected from wind and weather where things, most unnecessary, are made most efficiently." 268 Ele acreditava que o edifício fabril deveria ser feito com o menor custo possível, permitindo a sua total flexibilidade caso futuras alterações fossem necessárias. Owen Williams teve um importante papel na disseminação da influência americana na Inglaterra.

A semelhança do edifício D10 da Fábrica Boots com a Ford Highland Park, especialmente a New Shop, ocorria em vários aspectos formais e funcionais, tais como a produção organizada através da gravidade, a estrutura de concreto e o pátio interno coberto. $\mathrm{O}$ engenheiro baseou-se nos novos modelos industriais americanos que visavam a criar um ambiente espaçoso, luminoso e saudável para os trabalhadores, tudo isto sem perder de vista a gestão científica da produção.

Além disso, outra influência americana na obra de Owen Williams ocorreu através de um artigo para o Technical Journal of London, em 1917, escrito pelo outro irmão de Albert Kahn, Moritz. Nesse texto, Moritz delineou os princípios teóricos fundamentais do trabalho do escritório de Albert Kahn. As explicações de Moritz, baseadas quase que exclusivamente em princípios funcionais e econômicos, foram fundamentais para a educação de Owen Williams a respeito de como uma fábrica deveria ser organizada. ${ }^{269}$

A racionalização estrutural com certeza foi uma força motriz. O esquema modular utilizava as mais recentes técnicas e materiais estruturais, como o uso de concreto armado, através dos produtos da Truscon, e grandes planos envidraçados na fachada. A estrutura de quatro pavimentos era composta por lajes planas e pilares com capitéis de reforço em formato de cogumelo, sendo este um formato de pilar

267 STRATTON, M. e TRINDER, B. S. Twentieth Century Industrial Archaeology. New York: Taylor \& Francis, 2000, p. 207. 268 Tradução da autora: "um lugar protegido do vento e do clima, onde as coisas, na maioria das vezes desnecessárias, são feitas de forma eficiente”. Em: DARLEY, G. Factory. Londres: Reaktion Books, 2003, p. 122.

269 BUCCI, F. Albert Kahn: Architect of Ford. New York: Princeton Architectural Press, 1993, p. 49. 
também encontrado na Ford Highland Park e na Fábrica Van Nelle.

No interior, o elemento mais significativo da fábrica era o grande pátio em formato oval, destinado ao espaço de produção. Acima desse espaço , o pátio de quatro pavimentos de altura era coberto com vidro. Mais uma similaridade com a fábrica da Ford era o processo produtivo acionado pela gravidade.

O edifício D10 foi construído em uma escala que ainda não havia sido vista na Inglaterra. Resultado da influência americana, a experiência de Owen Williams como engenheiro permitiu que ele compreendesse e respondesse mais adequadamente aos requisitos operacionais dos processos de produção da fábrica. Logo após a conclusão do edifício D10, em 1932, algumas adições foram feitas à fábrica, em diversas datas, para atender aos novos padrões de produção e de trabalho. Desde 1990, o edifício encontra-se incluído na Lista do Patrimônio Nacional da Inglaterra ${ }^{270}$, em virtude de sua importância arquitetônica, sendo considerado um exemplo da arquitetura modernista europeia.

A extensão, a profundidade e a relevância da influência dos projetos de Albert Kahn, seja nos componentes de construção exportados pela Truscon ou nos quatro exemplos paradigmáticos da arquitetura industrial europeia, permitem-nos, mais uma vez, situá-lo como um dos personagens de grande importância dentro da Arquitetura Moderna no século XX.

270 Informações disponíveis em: <https://historicengland.org.uk/listing/the-list/list-entry/1247927> Acesso em 20 jun. 2018. 


\subsection{INFLUÊNCIA FORMATIVA}

O terceiro modo de influência de Kahn na arquitetura moderna ocorreu por meio da formação de arquitetos e engenheiros pelo escritório de Albert Kahn. Este processo de transmissão de conhecimento e de formação ocorreu, em especial, com a presença de Albert Kahn na União Soviética, período em que foi formada uma geração completa de arquitetos soviéticos. ${ }^{271}$

Durante o Primeiro Plano Quinquenal (1929-1932), a necessidade de uma industrialização maciça da União Soviética conduziu ao planejamento e à construção de uma grande quantidade de conjuntos industriais. A maior parte do investimento foi para a indústria pesada, destinada a consolidar a força da União Soviética. Novos setores industriais, incluindo o químico, automobilístico, agrícola, de máquinas e aviação, foram criados praticamente do zero. Mais de mil e quinhentas novas fábricas e complexos industriais gigantescos acabaram sendo construídos.

As instalações de Kahn, graças à sua grande inovação técnica, construção racional e econômica, eficiência funcional e aspecto expressivo, acabaram por cativar os soviéticos. ${ }^{272} \mathrm{O}$ complexo da Ford River Rouge teve especial impacto na União Soviética. A parceria entre Albert Kahn, a Ford Motor Company e os soviéticos

\footnotetext{
271 Sobre o trabalho de Albert Kahn na União Soviética, ver: SENKEVICH, A. J.. Albert Kahn’s Great Soviet Venture as Architect of the First Five-Year Plan, 1929-1932. In: Dimensions 10, 1996, p. 34-49. Disponível em: https://issuu.com/ taubmancollege/docs/dimensions10 Acesso em: 05 mar 2018. Ver também: MELNIKOVA-RAICH, S. The Soviet Problem with Two 'Unknowns': How an American Architect and a Soviet Negotiator Jump-Started the Industrialization of Russia, Part I: Albert Kahn. In: IA - The Journal of the Society for Industrial Archeology, v. 36, n. 2, 2010, p. 62-64. 272 HUGHES, T. P. American Genesis: A century of invention and technological enthusiasm, 1870-1970. New York: Viking, 1989, p. 269-271.
} 
ocorreu por intermédio da assinatura de dois contratos com o governo soviético, um para desenhar a fábrica de tratores de Stalingrado e outro que convertia a empresa americana e o arquiteto em consultores para todas as construções industriais da União Soviética realizadas durante o Primeiro Plano Quinquenal.

A possibilidade de contratar o escritório de Albert Kahn como consultor para o Primeiro Plano Quinquenal surgiu em 1926, quando a Amtorg Trading Corporation, representante comercial da União Soviética nos Estados Unidos, estabeleceu contato com a Ford Motor Company para obter sua ajuda na criação de uma indústria de tratores. Entre os anos de 1920 a 1926, a União Soviética havia comprado mais de 24 mil tratores Fordson para a produção agrícola. Então, no início de 1926, as autoridades soviéticas tentaram persuadir Henry Ford a construir uma fábrica de tratores na União Soviética. ${ }^{273}$

No início, Ford estava receoso com a ideia, mas acabou concordando. Em maio de 1929, a Ford Motor Company assinou um contrato com a Amtorg para implementar uma parte do Primeiro Plano Quinquenal de Stalin. Henry Ford concordou em fornecer desenhos detalhados e especificações para uma fábrica completa, da qual Albert Kahn seria o arquiteto. Além disso, Ford também cedeu aos soviéticos todos os direitos para fabricar e usar as máquinas, invenções e avanços técnicos da Ford Motor Company. Para tanto, os engenheiros russos deveriam adquirir treinamento prático nas fábricas americanas da Ford, bem como no escritório de Albert Kahn. A Ford Motor Company, por sua vez, enviaria seus próprios engenheiros e encarregados para a União Soviética com o intuito de ajudar no planejamento e na operação da nova fábrica. ${ }^{274}$

Em 1929, um grupo de engenheiros da União Soviética, acompanhados por representantes da Amtorg, chegou ao escritório de Albert Kahn, em Detroit, com o pedido da grande fábrica de tratores a ser construída na cidade de Stalingrado. Além da fábrica, os soviéticos possuíam um programa para ser implementado posteriormente, que previa a construção de mais dois bilhões de dólares em edifícios industriais. A fábrica de tratores de Stalingrado seria a primeira do gênero e, na época, a maior a ser construída na União Soviética.

O projeto começou em março de 1929, sob a direção de Albert Kahn em colaboração com os engenheiros soviéticos. O escritório de Kahn ficou responsável

273 SENKEVICH, A. J.. Albert Kahn's Great Soviet Venture as Architect of the First Five-Year Plan, 1929-1932. In: Dimensions 10, 1996, p. 38. Disponível em: https://issuu.com/taubmancollege/docs/dimensions10 Acesso em: 05 mar 2018. 274 NEVINS, A.; HILL, F. E. Ford: Expansion and Challenge: 1915-1933. New York: Charles Scribner's Sons, 1957, p. 673-684. 
pelo projeto e pela construção da fábrica. Além disso, o complexo incluía uma usina de energia e moradias para os trabalhadores. A fábrica de tratores foi a primeira na União Soviética a empregar uma construção racional, com fechamento de vidro e claraboias em formato de dente de serra. Pela restrição de oferta de materiais de construção, alguns deles tiveram que ser importados. $\mathrm{O}$ trabalho de construção foi concluído em cerca de seis meses, mais rápido do que se costumava construir nos Estados Unidos. ${ }^{275}$

Se alguma dúvida existia em relação ao trabalho e à competência de Albert Kahn, ela foi sanada após a construção da fábrica em Stalingrado. A fábrica obteve grande sucesso para Kahn, fazendo com que ele se tornasse, de maneira efetiva, o arquiteto consultor da União Soviética. Kahn assinou um contrato sem precedentes com a Amtorg, com o objetivo de auxiliar o país a mobilizar sua capacidade industrial, conforme estabelecido no Plano Quinquenal. Porém, aceitar a oferta da Amtorg para ajudar o governo soviético com sua grande expansão industrial não era uma questão simples, dada a desconfiança geral dos Estados Unidos em relação à União Soviética. Kahn lembrou o processo agonizante em uma conversa com o colunista de Detroit, Malcom Bingay:

"I was somewhat hesitant about accepting such a task. First, I knew little or nothing about the Russian government, and the people behind it. Second, the United States had refused to recognize that government. Third, there was bitter feeling against Communists among the people with whom I had to do business. Fourth, the enemies of my people echoed what the Nazis were saying and accused the Jews of fostering Communism. I wondered what would be said if I took the job. And yet the challenge fascinated me. Deep down in my heart I believed that the Russian people - regardless of their form of government - were entitled to help after all their generations of suffering under the czars. The more I thought about it the more I became convinced it was the right thing to do. I said yes." ${ }^{276}$

O fato de Kahn ser escolhido pelo governo soviético para a construção de inúmeras fábricas demonstra que o arquiteto era considerado bom o suficiente na

275 Sobre a fábrica de Stalingrado, ver: DODGE, N.e DALRYMPLE, D. The Stalingrad tractor plant in early soviet planning. Soviet Studies, v. 18, n. 2, p. 164-168, 1966.

276 Tradução da autora: "Eu estava um pouco hesitante em aceitar tal tarefa. Primeiro, sabia pouco ou nada sobre o governo russo e sobre as pessoas por trás dele. Em segundo lugar, os Estados Unidos se recusavam a reconhecer esse governo. Terceiro, havia um amargo sentimento contra os comunistas entre as pessoas com as quais eu tinha que fazer negócios. Quarto, os inimigos do meu povo ecoaram o que os nazistas estavam dizendo e acusaram os judeus de fomentar o comunismo. Eu me perguntava o que seria dito se aceitasse o trabalho. E, no entanto, o desafio me fascinou. No fundo do meu coração, acreditava que o povo russo - independentemente da sua forma de governo - tinha o direito de receber ajuda depois de todas as suas gerações de sofrimento sob os czares. Quanto mais eu pensava nisso, mais me convencia de que era a coisa certa a fazer. Eu disse sim." Em: BINGAY, M. W. Detroit is my own home town. New York: Bobbs-Merrill Co., 1946, p.308. 
tarefa de conceber e construir projetos de tal magnitude. $\mathrm{O}$ acordo formal entre o escritório de Albert Kahn e a Amtorg Trading Corporation, acordo este que o designou como arquiteto consultor para a União Soviética, foi concluído em fevereiro de 1930. O contrato foi negociado por Moritz Kahn, vice-presidente do escritório, tendo sido assinado por Albert Kahn e Saul G. Bron, presidente da Amtorg. Em 11 de janeiro de 1930, uma edição do New York Times descreveu desta forma os detalhes do acordo:

\begin{abstract}
"The Soviet government proposes to construct four large motor-car, motortruck, and motor-cycle factories, and nine plants to produce tractors and farm implements... According to the present arrangement, Moritz Kahn will go to Russia shortly with a staff of twenty-five special assistants to organize a designing bureau which will comprise about 4.500 architectural and engineering designers, selected principally from Russia. This bureau will be directed by B. E. Barsky, who will be practically the dictator of building construction in Russia, according to Mr. Kahn.”277
\end{abstract}

No início, o trabalho foi feito no escritório de Detroit, mas logo Moritz Kahn partiu para Moscou com uma equipe de 25 arquitetos e engenheiros da empresa com o objetivo de organizar o escritório soviético, que seria o responsável pelo projeto das inúmeras fábricas planejadas para o Primeiro Plano Quinquenal. Em maio de 1931, Moritz Kahn descreveu a extensão do escritório de Moscou após seu primeiro ano de operação:

\footnotetext{
"The Gosproyektstroy (State Design Construction Trust) is only a year old. Formerly our office in Detroit, employing 400 to 500 architects, engineers, and draftsmen in normal times, ranked as the largest in the world. Gosproyektstroy has just under 600 in its Moscow office, with another 150 to arrive soon, and about 60 students in addition. Its Leningrad office has 300 employeesand its Kharkov branch 100.”278
}

277 Tradução da autora: “O governo soviético propôs a construção de quatro grandes fábricas de automóveis, caminhões
e motocicletas, e nove fábricas para produzir tratores e implementos agrí́colas... De acordo com o presente acordo, Moritz
Kahn irá para a Rússia em breve com uma equipe de vinte e cinco assistentes especiais para organizar um escritório de
arquitetura que compreenderá cerca de 4.500 projetistas de arquitetura e engenharia, selecionados principalmente da Rússia.
Este escritório será dirigido por B. E. Barsky, que será praticamente o ditador da construção civil na Rússia, segundo o Sr.
Kahn.” Artigo publicado no Jornal The New York Times, em 11 de janeiro de 1930. Em: BUCCI, F. Albert Kahn: Architect
of Ford. New York: Princeton Architectural Press, 1993, p. 91 .
278 Tradução da autora: “OGosproyektstroy tem apenas um ano de idade. Anteriormente, o nosso escritório em Detroit,
empregando 400 a 500 arquitetos, engenheiros e desenhistas em tempos normais, foi classificado como o maior do mundo.
Gosproyektstroy tem pouco menos de 600 em seu escritório em Moscou, com outros 150 para chegar em breve, e, além
disso, conta com cerca de 60 estudantes. O escritório em Leningrado tem 300 funcionários e a sua filial em Kharkov, 100”.
Em: SENKEVICH, A. J.. Albert Kahn's Great Soviet Venture as Architect of the First Five-Year Plan, 1929-1932. In:
Dimensions 10, 1996, p. 46. Disponível em: https://issuu.com/taubmancollege/docs/dimensions10 Acesso em: 05 mar 2018. 

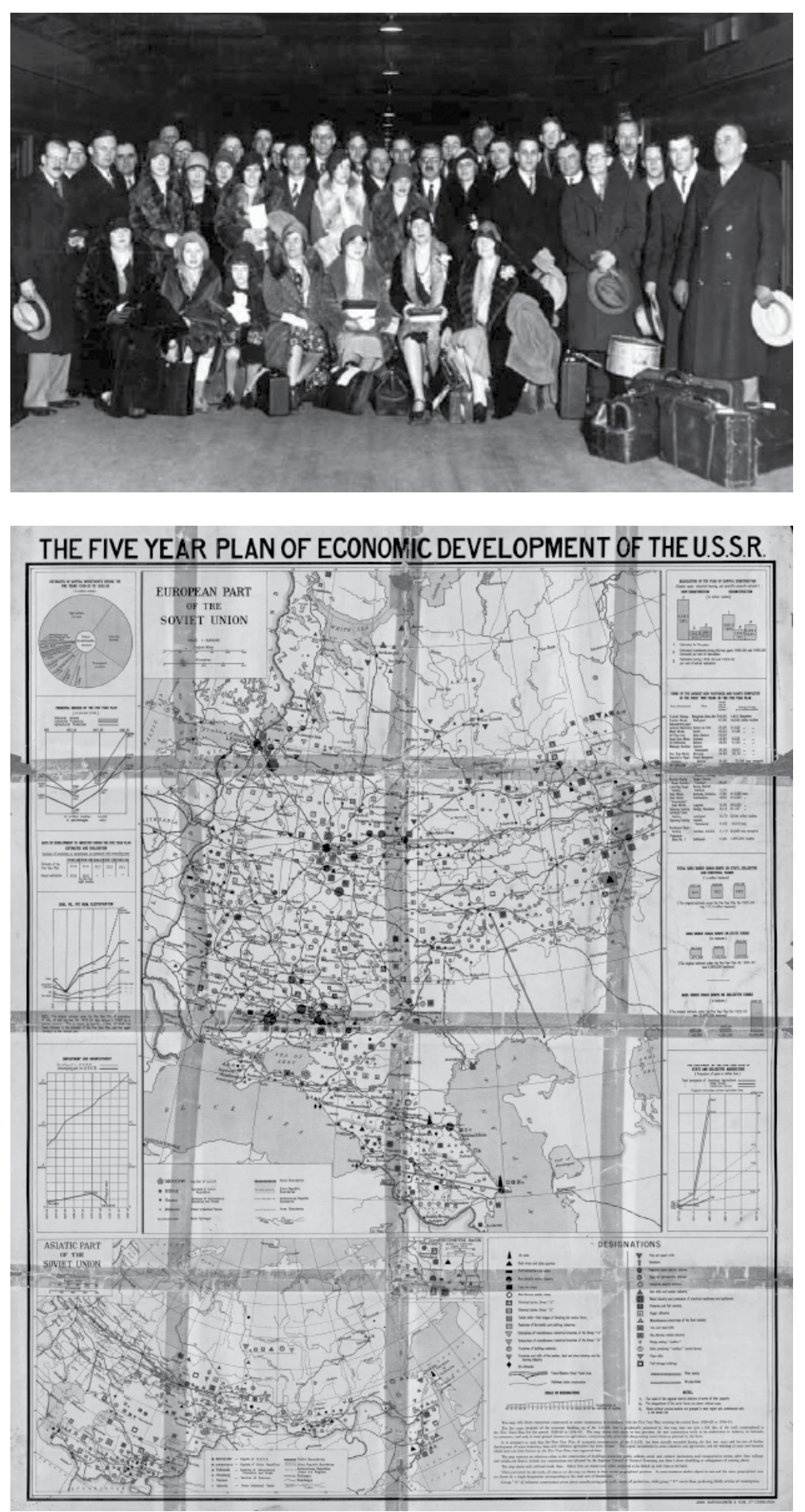

Fig. 194 Moritz Kahn e seus funcionários na Grand Central Station, de Nova York, a caminho de Moscou, em março de 1930 Fonte: Melnikova-Raich (2010)

Fig. 195 “The Five Year Plan of Economic Development of the U.S.S.R.” por John Bartholomew \& Son, Edinburgh, 1929. Fonte: Zimmerman (2014) 
Posteriormente, mais especialistas foram enviados a Moscou para assumir trabalhos adicionais. $\mathrm{O}$ papel atribuído a este escritório era controlar, ensinar e projetar todas as indústrias da União Soviética. ${ }^{279}$ A Gosproyektstroy, formada pelos americanos e por centenas de arquitetos, engenheiros e desenhistas soviéticos, tornou-se a maior organização mundial dedicada à arquitetura, superando o próprio escritório de Albert Kahn, em Detroit.

Em parte, a instalação do escritório em Moscou representou um meio conveniente de realizar um volume muito grande de trabalho. Além disso, também se adequava aos propósitos do regime soviético, pois o seu objetivo era fazer com que o escritório de Kahn projetasse apenas uma parcela das fábricas. Os conhecimentos de projeto e as técnicas deveriam ser passados para os arquitetos e engenheiros russos, os quais assumiriam sozinhos os projetos no futuro. Atividades com esses profissionais ocorriam sem intervalos: no período diurno, existia um programa de treinamento prático no projeto das fábricas e, à noite, eram ministradas aulas pela equipe de Albert Kahn.

É provável que nenhum escritório de arquitetura jamais tenha passado por um teste tão severo de sua flexibilidade, competência e eficiência. As fábricas não apenas deviam ser projetadas com rapidez, mas as máquinas precisavam ser selecionadas e encomendadas, ao mesmo tempo em que os materiais necessários para construir os edifícios eram comprados nos Estados Unidos e enviados para a União Soviética. Muitos materiais padronizados nos Estados Unidos inclusive não eram encontrados na União Soviética, circunstância que exigiu muito estudo para se adaptar às condições existentes. ${ }^{280}$ Naturalmente, os americanos encontraram inúmeras dificuldades: a língua, o clima, os costumes e, acima de tudo, a escassez de materiais e de mão de obra qualificada.

Entre os inúmeros projetos do escritório de Kahn, estavam os das fábricas de aço e fundições de Kharkov, Upper Tagil, Kuzniztsk, Kamenskoi, Kolomna, Lubertsk, Sormovo, Nigi Tagil; a fábrica de automóveis em Moscou; as fábricas de aviões em Kramatorsk e Tomsk; a fábrica de produtos químicos em Kalinin e as três fábricas de tratores, localizadas em Stalingrado, Cheliabinsk e Magnitogorsk. As fábricas de Cheliabinsk e Stalingrado produziam automóveis e tratores, enquanto que a fábrica de Magnitogorsk estava encarregada da produção de aço. ${ }^{281}$ Muitas das fábricas projetadas e iniciadas em 1929 e 1932 eram realmente gigantescas em termos de tamanho.

279 MELNIKOVA-RAICH, S. The Soviet Problem with Two 'Unknowns': How an American Architect and a Soviet Negotiator Jump-Started the Industrialization of Russia, Part I: Albert Kahn. In: IA - The Journal of the Society for Industrial Archeology, v. 36, n. 2, 2010, p. 62-64.

280 SENKEVICH, A. J.. Albert Kahn's Great Soviet Venture as Architect of the First Five-Year Plan, 1929-1932. In: Dimensions 10, 1996, p. 47. Disponível em: https://issuu.com/taubmancollege/docs/dimensions10 Acesso em: 05 mar 2018. 281 BUCCI, F. Albert Kahn: Architect of Ford. New York: Princeton Architectural Press, 1993, p. 92. 
Em março de 1932, o contrato de Kahn expirou sem ser renovado, apesar das negociações realizadas em Moscou, nas quais Albert Kahn participou pessoalmente. $\mathrm{Na}$ época, a razão alegada para o fracasso em renovar o contrato de Kahn se devia à nova política soviética de cessar os pagamentos em dólares, ou moeda estrangeira, e fazer pagamentos em rublos, que não eram negociáveis fora da União Soviética. Essa era uma condição que nem Kahn e nem a maioria dos ocidentais poderiam aceitar. ${ }^{282}$ Embora possa ser válida esta explicação, não se pode ignorar o fato do regime soviético estar ansioso em se libertar da enorme transferência de tecnologia, materiais e conhecimento americano.

A importância e a extensão da influência de Kahn na arquitetura soviética não podem ser subestimadas. O legado da curta, mas produtiva, fase soviética da prática de Kahn é inegável. Quando os arquitetos e engenheiros do escritório de Albert Kahn deixaram Moscou, em 1932, tinham projetado e construído (ou ainda estavam em construção) mais de 500 fábricas em 21 cidades. Cerca de quatro mil arquitetos, engenheiros e desenhistas soviéticos haviam recebido treinamento nos escritórios de Kahn, em Moscou. Eles deixaram para trás arquitetos soviéticos treinados e capazes de desenvolver instalações semelhantes em todo o país. ${ }^{283}$

O legado pedagógico de Kahn continuou nas atividades subsequentes realizadas pelos seus ex-colaboradores. Estima-se que centenas de estruturas industriais foram construídas com a utilização dos projetos de Kahn. ${ }^{284} \mathrm{O}$ impacto subsequente do método do arquiteto americano é perceptível em uma série de outros projetos industriais posteriores construídos na União Soviética.

Pouco valorizada também é a participação soviética de Albert Kahn na historiografia moderna. Em geral, aparecem apenas arquitetos que trabalharam na União Soviética e que estiveram comprometidos com a causa socialista, como é o caso de Eric Mendelsohn, Ernst May, Mart Stam ou André Lurçat. ${ }^{285}$ Considerando a brevidade da associação, o trabalho de Albert Kahn deixou uma marca decisiva na cultura tecnológica e profissional da União Soviética. Victor A. Vesnin, Presidente da Academia de Arquitetura da União Soviética, confirmou a enorme contribuição do arquiteto de Detroit à arquitetura soviética e ao desenho industrial em um telegrama enviado à Sra. Kahn na época da morte do arquiteto em 1942:

282 Artigo publicado no Jornal The New York Times, em 26 de março de 1932. Em: SENKEVICH, A. J.. Albert Kahn's Great Soviet Venture as Architect of the First Five-Year Plan, 1929-1932. In: Dimensions 10, 1996, p. 48. Disponível em: https://issuu.com/taubmancollege/docs/dimensions10 Acesso em: 05 mar 2018.

283 MELNIKOVA-RAICH, S. The Soviet Problem with Two 'Unknowns': How an American Architect and a Soviet Negotiator Jump-Started the Industrialization of Russia, Part I: Albert Kahn. In: IA - The Journal of the Society for Industrial Archeology, v. 36, n. 2, 2010, p. 75.

284 SENKEVICH, A. J.. Albert Kahn's Great Soviet Venture as Architect of the First Five-Year Plan, 1929-1932. In: Dimensions 10,1996, p. 49. Disponível em: https://issuu.com/taubmancollege/docs/dimensions10 Acesso em: 05 mar 2018. 285 PANCORBO, L. Arquitectura industrial de Albert Kahn Inc. 1900-42. La arquitectura como objeto técnico. Tese (Doutorado em Proyectos Arquitectónicos). Escuela Técnica Superior de Arquitectura - Universidad Politécnica de Madrid. Madrid: ETS - Arquitectura, 2016, p. 253. 
"Soviet engineers builders architects send you their sincere sympathy in connection with the death of your husband Mr. Albert Kahn, who rendered us great service in designing a number of large plants and helped us to assimilate the American experience in the sphere of building industry."286

A experiência soviética de Kahn serviu para ampliar e enriquecer a concepção da arquitetura industrial realizada por seu escritório, estimulando os debates sobre o significado cívico, cultural e ideológico das instalações industriais. Embora outros projetos internacionais do escritório tenham sido distribuídos de forma mais ou menos global, indo do Canadá até a Argentina ou de Cuba até Xangai, certamente esses edifícios soviéticos são o exemplo mais dramático do impacto que as exportações americanas de arquitetura tiveram sobre a economia global antes da Segunda Guerra Mundial.

Todos esses modos de influências são pouco conhecidos individualmente e, quando combinados, expandem nossa compreensão do impacto global representado pelo trabalho de Albert Kahn. A relação entre a arquitetura e o fordismo, adotado como a nova religião industrial em lugares tão diversos quanto a Europa Ocidental e a recém-criada União Soviética, foi responsável pela formação do conceito de funcionalismo e a adoção do objeto técnico como modelo para o projeto arquitetônico moderno.

Os diferentes modos de influência que o trabalho de Kahn produziu na arquitetura foram analisados, na tentativa de explicar as maneiras pelas quais a transferência de valores de engenharia ocorreram para os domínios da arquitetura, cujo principal protagonista é, certamente, Albert Kahn. O legado do trabalho de Kahn ilustra com perfeição a importância, geralmente subestimada, que o trabalho industrial do arquiteto - não apenas através da construção dos seus edifícios - teve para o desenvolvimento da arquitetura moderna.

286 Tradução da autora: "Os engenheiros soviéticos, construtores e arquitetos the enviam suas sinceras condolências em conexão com a morte de seu marido, o Sr. Albert Kahn, que prestou um grande serviço ao projetar uma série de grandes fábricas e nos ajudou a assimilar a experiência americana na esfera da indústria da construção civil.” Em BUCCI, F. Albert Kahn: Architect of Ford. New York: Princeton Architectural Press, 1993, p. 95. 

CONSIDERAÇÕES FINAIS 
No início do século XX, quando os industriais americanos criaram novos e diferentes sistemas de produção para fabricar os seus sofisticados produtos, não foram poucos os que procuraram a ajuda de Albert Kahn. O arquiteto ganhou uma progressiva fama graças à sua capacidade de projetar edifícios econômicos e que podiam ser construídos de forma rápida e precisa, algo essencial para a cada vez mais vibrante industrialização que atravessava os Estados Unidos. Um detalhe diferencial do trabalho de Kahn em meio ao cenário da arquitetura industrial da época era que, assim como as indústrias que abrigavam, os prédios projetados pelo seu escritório possuíam uma escala sem precedentes, sendo inovadores tanto do ponto de vista tecnológico quanto no aspecto arquitetônico.

Assim, em conjunto com o desenvolvimento da construção de concreto armado nos Estados Unidos, surgiu uma indústria totalmente nova - a automobilística. Liderada por Henry Ford, um jovem entusiasta e visionário, esta indústria apresentou um arrojado sistema de produção e de projeto de fábrica. Apesar do arranjo produtivo dos edifícios industriais trazer consigo uma série de desafiadores problemas para o projeto da fábrica, a maioria dos arquitetos não estavam interessados em projetá-los, entendendo ser mais um trabalho de engenharia do que de arquitetura. Contudo, Albert Kahn, com a colaboração do seu irmão engenheiro Julius, encarou a tarefa de projetar edifícios industriais que se adequassem de forma precisa à sua função, além de criar condições que acabariam se tornando revolucionárias para a prática profissional. Não suficiente, o arquiteto inovou em relação aos modelos estabelecidos da prática de arquitetura, reunindo, em um único escritório, todas as diferentes disciplinas envolvidas no projeto e construção de edifícios. Dessa forma, a prática no seu escritório era extremamente parecida com as formas de trabalho desenvolvidas pela nova indústria.

Kahn caracterizava seu trabalho como "90\% business and 10\% art". Tendo isto em mente, trabalhou com equipes multidisciplinares para elaborar propostas para edifícios industriais que contrastariam fortemente com as formas históricas e a linguagem clássica de outras arquiteturas do período, inclusive as projetadas por ele mesmo para os outros programas arquitetônicos. O projeto de Kahn demonstrou claramente o que acontecia quando a forma física seguia a função operacional. 
Com maior liberdade estrutural e beneficiando-se do desenvolvimento de novos materiais construtivos, Kahn projetou e construiu com velocidade e eficiência sem precedentes. Os edifícios facilitaram a fabricação das máquinas que transformariam radicalmente a vida das pessoas a partir do século XX, tais como os automóveis e os aviões.

Todavia, foi outra máquina que teve um impacto fundamental no trabalho de Kahn e seria fundamental para projetá-lo em todo o mundo: a máquina fotográfica. Ao mesmo tempo em que os primeiros edifícios industriais de Kahn estavam sendo construídos, eles também eram registrados através das fotografias. Essas imagens foram amplamente divulgadas e acabaram atraindo a atenção de arquitetos estrangeiros. Fotografias, em especial da fábrica Ford Highland Park e do complexo Ford River Rouge, foram veiculadas em várias publicações europeias de vanguarda, tendo sido estudadas com afinco por muitos arquitetos e artistas, admiração esta que se tornou uma das fontes de inspiração do Modernismo. No entanto, essas fábricas eram frequentemente apresentadas como construções anônimas, vernaculares, com seus projetos sendo atribuídos a construtores, engenheiros ou até mesmo ao próprio Henry Ford, e dificilmente ao arquiteto.

Não resta dúvida de que as fábricas projetadas por Albert Kahn para Henry Ford foram essenciais para o início de uma era industrial que transformou o mundo no século XX. Representantes desta abordagem inédita, que integrava o projeto de arquitetura, o entusiasmo pela tecnologia e a crença no potencial da produção, tais edifícios tornaram-se significativos na história da arquitetura moderna. No entanto, concebidos como uma consequência direta dos processos de fabricação que foram projetados para abrigar, eles eram considerados meros cenários para a produção industrial, o que tirava o seu valor como obra arquitetônica. Como resultado, permanecem obscuros na história da arquitetura, assim como o seu arquiteto continua quase anônimo. No entanto, não se pode esquecer que, através das imagens fotográficas, as contribuições de Albert Kahn ao Modernismo foram transformadas em ícones que se tornaram uma inspiração para a Arquitetura Moderna.

O legado deixado pela obra de Kahn não se limita apenas à arquitetura do Movimento Moderno europeu, mas também acabou chegando no Brasil. 
Afinal, ao projetar um dos primeiros edifícios que apresentavam uma linguagem plástica moderna, construído com o uso de uma tecnologia praticamente inédita no país, o arquiteto acabou influindo na história da arquitetura nacional. Mais do que simplesmente a incorporação tecnológica do fordismo por ela propiciada, a Fábrica da Ford Motor Company, construída em 1921 no bairro Bom Retiro, em São Paulo, consolidou todo um projeto de modernidade brasileiro, de inspiração norte-americana, e que tinha no automóvel o seu elemento central. Apesar de, como atestou o engenheiro americano responsável pela sua construção, os materiais de construção terem sido tão importados quanto o seu projeto arquitetônico, em um país onde a miscigenação cultural se faz tão presente, é inegável que a fábrica acabou marcando um ponto de virada fundamental no relacionamento do Brasil com a própria modernidade arquitetônica que estava em vias de iniciar.

Neste sentido, a hipótese levantada pela presente tese, de que a autoria da fábrica da Ford em São Paulo seria do arquiteto Albert Kahn, veio a ser comprovada através da consulta aos desenhos arquitetônicos do projeto, disponíveis apenas no acervo do escritório Albert Kahn Associates, doado à Universidade de Michigan em 2004. Com isto, a ligação de Kahn com a própria evolução da arquitetura industrial do país, ainda que não tacitamente admitida por nenhum arquiteto ou publicação, acabou se tornando demonstrável, em especial pelo impacto que as inovações trazidas pelo arquiteto americano representaram no Brasil, um país que, na época, estava em um estágio ainda incipiente de industrialização. Ainda que as semelhanças com a fábrica da Ford Highland Park fossem evidentes, a ausência de materiais gráficos e publicações a respeito nos impediam de fazer tal afirmação, para que pudéssemos, enfim, demonstrar o elo de Albert Kahn com a arquitetura industrial brasileira.

A coleta, análise e divulgação desse material inédito é certamente uma contribuição para a história da arquitetura brasileira, algo que poderá ser fundamental para a mudança de paradigmas a respeito da arquitetura industrial e sua importância como parte indissociável da arquitetura moderna. Lançando as sementes para pesquisas e reflexões posteriores, espera-se, com isso, contribuir para o surgimento de novos estudos que apresentem, discutam e qualifiquem as fábricas 
como produção arquitetônica, dando-lhes a devida importância como programas tanto técnicos quanto formalmente inovadores.

Contudo, para atingir os objetivos inicialmente traçados na tese, enfrentouse algumas limitações e, se elas são agora destacadas, é justamente para iluminar os caminhos de estudos posteriores. A primeira delas foi decorrente da falta de recursos financeiros, uma vez que não se teve sucesso nas tentativas de conseguir auxílio para a pesquisa no exterior. Portanto, a pesquisa nos arquivos da Biblioteca Histórica Bentley, da Universidade de Michigan e no Centro de Pesquisas Benson Ford, localizado dentro do Museu Henry Ford, na cidade de Dearborn, acabou durando apenas duas semanas, tendo ocorrido somente 3 meses antes do depósito da tese, o que foi um período de tempo mais exíguo do que aquele realmente necessário, ainda mais se considerarmos a vastidão e a complexidade dos arquivos.

O acervo do escritório Albert Kahn Associates, disponível na Biblioteca Histórica Bentley, é composto de materiais produzidos pelo arquiteto Albert Kahn, bem como materiais produzidos por seu escritório, Albert Kahn Associates, Inc., incluindo correspondências, arquivos da empresa, fotografias, materiais publicados e desenhos arquitetônicos. Para se ter uma ideia da dimensão do acervo, a coleção com o título "Albert Kahn Associates records: 1825-2014" possui 90 pastas com fotografias e mais de 12 mil desenhos arquitetônicos, todos brilhantemente catalogados. Diante da quantidade e qualidade do material contido nesses arquivos citados, percebeu-se que o tempo disponível para a pesquisa era extremamente escasso. Apesar do êxito de visitar parte dos edifícios projetados pelo arquiteto nas cidades de Detroit, Dearborn e Ann Arbor - todas no estado americano de Michigan - algumas obras analisadas nessa pesquisa, assim como outros locais que abrigam materiais sobre o arquiteto e a Ford Motor Company, não puderam ser colocados na lista pelo mesmo motivo de falta de tempo. Em razão da coleta dos dados ter ocorrido tão tardiamente, parte da pesquisa poderia ter atingido resultados melhores se houvesse um pouco mais de tempo disponível para acessar tais arquivos.

No Brasil, as dificuldades ocorreram pelo fato do Arquivo Histórico de São Paulo possuir pouquíssimo material sobre a fábrica e, além disso, o escasso material 
obtido não ser relevante para a pesquisa. Não foram encontrados, por exemplo, desenhos que comprovam quando e como foram feitos os acréscimos na fábrica, no momento em que houve a expansão da fábrica pelo terreno. Outro agravante foi o fato dos atuais locatários não permitirem o acesso ao edifício, dificultando a tarefa de visualização das qualidades espaciais internas da fábrica, assim como impossibilitando verificar as possíveis alterações feitas ao longo do tempo - fato que certamente auxiliaria a realização de uma crítica mais aprofundada sobre a fábrica.

A falta de publicações nacionais a respeito de Albert Kahn e a ausência de publicações a respeito da primeira fábrica da Ford no Brasil, ao mesmo tempo em que foram grandes limitadores da pesquisa, permitem que um novo capítulo seja escrito na historiografia da arquitetura brasileira. As poucas publicações consagradas ao arquiteto e comentadas na revisão bibliográfica certamente são uma excelente porta de entrada para compreensão da obra desse pragmático arquiteto. Nos tempos atuais, a pesquisadora Claire Zimmerman, professora da Faculdade de Arquitetura da Universidade de Michigan, possui a vantagem de ser uma das responsáveis pelo acervo de Albert Kahn doado à biblioteca da universidade, realizando uma relevante tarefa na divulgação do trabalho do arquiteto.

Em decorrência do fato de não terem sido encontrados estudos no Brasil a respeito dos assuntos tratados nessa pesquisa, a tese optou por um caráter biográfico e histórico devido ao ineditismo do tema, ciente de que análises mais aprofundadas são possíveis de serem realizadas a partir de agora. É óbvio que ainda restaram muitas dúvidas sobre a encomenda, construção e, principalmente, sobre a influência da fábrica para a arquitetura brasileira. A dúvida se os arquitetos e engenheiros brasileiros conheciam esse projeto é muito intrigante, em especial se levarmos em conta que a instalação da indústria automobilística no Brasil dos anos 1920 foi responsável por alterar de forma significativa os cenários econômico e cultural do país. Outro ponto que precisa ser melhor esclarecido é a relação entre os projetos das fábricas da Ford na Argentina e no Brasil, uma vez que foram projetadas praticamente juntas e construídas, de forma concomitante, pelo mesmo engenheiro. 
Durante o desenvolvimento da tese, abordou-se rapidamente a segunda fábrica da Ford Motor Company do Brasil, inaugurada em 1953, também na cidade de São Paulo. Não foi possível confirmar a autoria do projeto, uma vez que o arquiteto morreu em 1942 e nada foi encontrado nos arquivos doados à biblioteca de Michigan. Existe inclusive a possibilidade do projeto ter sido feito antes da morte de Albert Kahn e somente ter sido construído posteriormente, já que possui características formais muito parecidas com os projetos realizados pelo escritório de arquitetura de Detroit. No entanto, essa é uma pesquisa que ainda precisa ser feita. Portanto, quando se iniciou essa tese, estava-se ciente que a abordagem deveria ser feita no intuito de apresentar os fatos e colocá-los ao alcance de todos, para que futuras pesquisas possam vir a complementar com maiores informações e críticas a respeito do assunto que recém foi iniciado.

Por fim, reiteramos que uma abordagem mais ampla sobre a história da arquitetura brasileira - em especial sobre a industrial, geralmente tão negligenciada - torna-se cada vez mais imprescindível, expandindo e lançando novas luzes na compreensão da gênese da arquitetura moderna do Brasil. Além disso, documentar e interpretar uma história, uma parte que consideramos importante de um passado arquitetônico, representa um importante instrumento para o seu melhor conhecimento e valorização cultural, bem como significa um apoio à necessária reflexão e tomada de decisões acerca do papel que estas instalações industriais, comumente consideradas como algo provisório e vinculado aos interesses econômicos, podem desempenhar no futuro. 

REFERÊNCIAS 
ABREU, M. P. A dívida pública externa do Brasil, 1824-1931. In: Estudos Econômicos, São Paulo, v. 15, n. 2, IPE/USP, p. 167-189, 1985.

. Anglo-Brazilian economic relations and the consolidation of american preeminence in Brazil, 1930-1945. In: ABEL, C.; LEWIS, C. M. (eds.). Latin America, Economic Imperialism and the State. London: Athlone Press, 1985.

Brazil and the World Economy, 1930-1945: aspects of foreign economic policies and international economic relations under Vargas. Tese (Doutorado em Economia). University of Cambridge, 1977.

The Niemeyer Mission: an episode of British financial imperialism in Brazil. In: Working Paper, no 10, Centre of Latin American Studies/University of Cambridge, 1973.

ADDIS, C. Cooperação e desenvolvimento no setor de autopeças. In: ARBIX, G. e ZILBOVICIUS, M. (orgs.). De JK a FHC: A reinvenção dos carros. São Paulo: Scritta, 1997.

ALBERT Kahn Associates. Continuing the legacy. Milan: l'Arca Edizioni, 2000.

_ The AIA 2003 Gold Medal Submission: Albert Kahn, FAIA, 19691942.

ALBERT Kahn Collection. Bentley Historical Library, University of Michigan (arquivos).

ALMEIDA, A. C. Industria e Arquitectura. Prova Final de Licenciatura em Arquitetura. Coimbra: Parq/FCTUC, 2009

ALMEIDA, J. A evolução da capacidade de produção da indústria automobilística brasileira no período de 1957-1969. Pesquisa e Planejamento Econômico, v. 2, n.1, p. 5580, Junho 1972.

Implantação da indústria automobilística no Brasil. Rio de Janeiro: FGV, 1972.

ALMEIDA, C. et. al. Indústria automobilística brasileira: conjuntura recente e estratégias de desenvolvimento. Indicadores Econômicos FEE, v. 34, n. 1, 2006.

AMARAL, A. Tarsila, sua obra e seu tempo. São Paulo: Edusp, 2010. 
ANASTAKIS, D. From independence to integration: the corporate evolution of the Ford Motor Company of Canada, 1904-2004. The Business History Review, v. 78, n. 2, p. 213-253, 2004.

ARAVANIS, E. Os primórdios da indústria automobilística no Brasil: O caso da "General Motors" (1924 a 1935). In: IX Encontro Estadual de História ANPUH-RS, 2008. Disponível em: < http://eeh2008.anpuhrs.org.br/resources/content/ anais/1211770922_ARQUIVO_EvangeliaAravanis. pdf >. Acesso em 16 nov. 2018.

ARNOLD, H. L.; FAUROTE, F. L. Ford methods and the Ford shops. Nova York: Arno Press,1972.

ASSOCIAÇÃO Nacional de Fabricantes de Veículos Automotores. (ANFAVEA). 50 anos da indústria automobilística. São Paulo: ANFAVEA, 2006.

Anuário Estatístico. São Paulo: ANFAVEA, 2009. Disponível em: $<$ http//:www.anfavea.com.br> Acesso em 25.12.2018.

Indústria automobilística brasileira - uma história de desafios. São Paulo: ANFAVEA, 1994.

BACHA, E.; GREENHILL, R. Marcellino Martins e E.Johnston Exportadores: 150 anos de café. $2^{\text {a }}$ ed. São Paulo: Salamandra Editorial, 1992.

BALDWIN, G. C. The offices of Albert Kahn, Architect, Detroit, Michigan. In: The Architectural Forum, v. 29, n. 5, p.125-130, Novembro 1918.

BANHAM, R. A Concrete Atlantis: U.S. industrial building and European modern architecture 1900-1925. Cambridge: MIT Press, 1986.

. Review: Amerika, Bilderbuch Eines Architekten by Erich Mendelsohn.

In: Journal of the Society of Architectural Historians, v. 38, n. 3, p. 300-301, Outubro 1979.

— Teoria e projeto na primeira era da máquina. São Paulo: Perspectiva, 2006.

BARANSON, J. Automotive industries in developing countries. Washington: Washington International Bank for Reconstruction and Development, 1969.

BAUMGARTEN, A. L. Demanda de automóveis no Brasil. Revista Brasileira de Economia, v. 26, n. 2, 1972. 
BEHRENDT, W. C. Modern building: It's nature, problems and forms. Nova York: Harcourt, Brace and Company, 1937.

BEHNE, A. The modern functional building. Los Angeles: Getty Research Institute, 1996.

BELTING, H. An anthropology of images: picture, medium, body. Princeton: Princeton University Press, 2011.

BENTEL, P. Modernism and professionalism in American Architecture, 1919-1933. Tese (Ph.D in Architecture, Art and Environmental Studies). Massachusetts Institute of Technology: Cambridge, 1993.

BERGAMIN JUNIOR, G.. Erguido há 97 anos, edifício Guinle esbanja saúde de concreto. Folha de São Paulo, 09 out 2010. Disponível em: <https://www1.folha.uol. com.br/saopaulo/794048-erguido-ha-97-anos-edificio-guinle-esbanja-saude-de-concreto. shtml> Acesso: 18 jan. 2019

BERNARD, D. From Taylorism to Fordism, a Rational Madness. London: Free Association Books, 1988.

BETHELL, L. Britain and Latin America in historical perspective. In: BulmerThomas, V. (ed.). Britain and Latin America: a changing relationship. Cambridge: Cambridge University Press, 1989.

BIGGS, L. B. Industry's master machine: factory planning and design in the age of mass production, 1900 to 1930. Tese (Ph.D in Urban Studies and Planning). Massachusetts Institute of Technology: Cambridge, 1987.

. The rational factory. Baltimore: The John Hopkins University Press, 1996.

BINGAY, M. W. Detroit is my own home town. New York: Bobbs-Merrill Co., 1946.

BOASE, A. J. Brasilian Concrete Building Design Compared with United States Practice. In: Engineering News Record, p. 80-88, 28 jun. 1945.

BOURDIEU, P. Como é possível ser esportivo? In: BOURDIEU, P. Questões de sociologia. Rio de Janeiro: Marco Zero, 1983. p. 136-163.

BOCCIONI, U. Estética y arte futuristas. Barcelona: Quaderns Crema, 2004. 
BRADLEY, B. Industrial Modernism: architecture and ideology. In: Journal of the Society of Architectural Historians, v. 54, n. 4, pp. 508-510, 1995.

The Works: the industrial architecture of the United States. New York: Oxford University Press, 1999.

BROWN, W. J. American Colossus: The Grain Elevator, 1843 to 1943. New York: Colossal Books, 2009.

BRUNA, P. J. V. Arquitetura, industrialização e desenvolvimento. São Paulo: Perspectiva, 2002.

BRUNO, E. História e tradições da cidade de São Paulo. São Paulo: Hucitec, 1991.

BUCCI, F. Albert Kahn: Architect of Ford. New York: Princeton Architectural Press, 1993.

CAIN, P.; HOPKINS, A. British Imperialism: Crisis and Deconstruction, 19141990. London: Longman, 1993.

CAMARGO, O. As mudanças na organização e localização da indústria automobilística brasileira (1996-2001). Tese (Doutorado em Economia). Centro de Desenvolvimento e Planejamento Regional. Belo Horizonte: UFMG, 2006.

CARTER, B. (ed.) Albert Kahn: inspiration for the modern. Ann Arbor, Michigan: The University of Michigan Museum of Art, 2001.

CASAL, A. El automóvil en America Del Sur: orígenes - Argentina, Brasil, Paraguay, Uruguay. Montevideo: Ediciones de la Banda Oriental, 1996.

CASSIE, W. F. Early reinforced concrete in Newcastle upon-Tyne. In: Structural Engineer, v. 33, Abril de 1955.

CASTRO, A. C. As empresas estrangeiras no Brasil (1860-1913). Rio de Janeiro: Zahar, 1979.

CATAFESTA, M. Habitar a indústria. Dissertação (Mestrado em Arquitetura e Urbanismo). Faculdade de Arquitetura e Urbanismo. Porto Alegre: UFRGS, 2012.

CAVALCANTI, L. e LAGO, A. C. Ainda moderno? Arquitetura brasileira contemporânea. In: Arquitextos, São Paulo, ano 06, n. 066.00, Vitruvius, nov. 2005. Disponível em <http://www.vitruvius.com.br/revistas/read/arquitextos/06.066/404>. Acesso em 09 nov 2018 
CHANDLER, A. The visible hand. Cambridge, MA: Harvard University Press, 1977.

CHARNEY, L.; SCHWARTZ, V. O cinema e a invenção da vida moderna. São Paulo: Cosac\&Naify, 2001.

CHRISTENSEN, L. K. Between Denmark and Detroit: unionized labour at Ford Motor Company, Copenhagen, 1919-1939. Labor History, v. 55, n. 3, 2014.

CODY, J. Exporting American Architecture 1870-2000. New York: Routledge, 2005 (Planning, History, and the Environment Series).

COHEN, J. L. America: a soviet ideal. In: AA Files, n. 5, pp. 32-40, 1984. . Architecture in uniform. New Haven: Yale University Press, 2011, p. 81-140.

COHEN, J. L.; DAMISCH, H. Scenes of the world to come: European architecture and the American challenge, 1893-1960. Paris: Flammarion, 1995.

COHEN, Y.The Soviet Fordson. Between the politics of Stalin and the philosophy of Ford, 1924-1932. In: Ford, 1903-2003, the European History. BONIN, H. et al (ed). Paris: Plage, 2003.

CONDIT, C.W. Review of Design for Industry: The Architecture of Albert Kahn, by Grant Hildebrand. Technology and Culture, v. 16, n. 2, pp. 313-315, 1975.

.The first reinforced-concrete skyscraper: the Ingalls Building in Cincinnati and its place in structural history. In: Technology and Culture, v. 9, n. 1, p. 1-33, Janeiro 1968.

CONSONI, F.L.; CARVALHO, R.Q. Desenvolvimento de produtos na indústria automobilística brasileira: perspectivas e obstáculos para a capacitação local. Revista de Administração Contemporânea, v.6, n.1, p. 39-61, 2002.

COOK, J. Lingotto: Myths, Mechanisation and Automobiles, p. 5. Disponível em: <https://www.academia.edu/14362388/Lingotto_Myths_Mechanisation_and_ Automobiles?auto=download $>$ Acesso em 19 set 2018

CORBIN, A. (org). História dos tempos livres. Lisboa: Teorema, 2001.

CORRÊA, P. R.; PISANI, M. A. J. A Estação de Mayrink do arquiteto Victor Dubugras: Resgate de um patrimônio arquitetônico. Arquitextos, São Paulo, ano 10, n. 109.01, Vitruvius, junho 2009 Disponível em <http://www.vitruvius.com.br/revistas/read/ arquitextos/10.109/44>. Acesso em 08 out 2018. 
CORREIA, J. C.. Impactos da indústria automobilística nas cidades do estado de São Paulo e sua transformação em função do processo industrial. Tese (Doutorado em Arquitetura e Urbanismo). Faculdade de Arquitetura e Urbanismo. São Paulo: USP, 2008.

COSTA, J. Mudança tecnológica na indústria brasileira de automóveis e comerciais leves: uma comparação entre as décadas de oitenta e noventa. Dissertação (Mestrado em Política Científica e Tecnológica). Campinas: UNICAMP, 1998.

COSTA, M. C. C. A reestruturação produtiva do setor automobilístico e seus impactos na qualificação dos trabalhadores. Dissertação (Mestrado). Rio de Janeiro: UFRJ, 1999.

CRAWFORD, C. Soviet planning praxis: from tractors to territory. In: Centerpiece, v. 29, Primavera 2015. Disponível em: < https://wcfia.harvard.edu/ publications/centerpiece/spring2015/feature-crawford> Acesso em 09 out 2018

DATHEIN, R. Inovação e revoluções industriais: uma apresentação das mudanças tecnológicas determinantes nos séculos XVIII e XIX. Publicações DECON Textos Didáticos 02/2003. Porto Alegre: DECON/UFRGS, 2003. Disponível em < http://www. ufrgs.br/decon/ > Acesso em 17 mar 2018

DARLEY, G. Factory. Londres: Reaktion Books, 2003.

DODGE, N.; DALRYMPLE, D. The Stalingrad tractor plant in early soviet planning. Soviet Studies, v. 18, n. 2, p. 164-168, 1966.

DORMAN, J. L. Legado do 'arquiteto de Detroit' cativa o turista na cidade do carro. Folha de São Paulo, São Paulo, 12 abr. 2018. Disponível em: <https://www1. folha.uol.com.br/turismo/2018/04/passeio-revela-legado-de-albert-kahn-conhecidocomo-o-arquiteto-de-detroit.shtml>. Acesso em: 28 mai 2018.

DOWNES, R. Autos over Rails: How US business supplanted the British in Brazil, 1910-28. In: Journal of Latin American Studies, v. 24, n. 3, p. 551-83, 1992.

The seeds of influence: Brazil's 'Essentially Agricultural' Old Republic and the United States, 1910-1930. Tese (Ph.D. Dissertation). University of Texas, 1986.

ENGLISH, E. Iconic Ford plant to become protected structure. Irish Examiner, Dublin, 22 jun. 2009. Disponível em: < https://www.irishexaminer.com/ireland/iconicford-plant-to-become-protected-structure-94633.html>. Acesso em: 9 jul. 2018. 
ESCH, E. D. Ford goes to the world; the world comes to Ford. In:

The Color Line and the Assembly Line: Managing Race in the Ford Empire. Oakland, California: University of California Press, p. 23-49, 2018.

FEATHERSTONE, M. Automobilities: an introduction. Theory, Culture \& Society, v. 21, n. 4-5, p. 1-24, 2004.

FERRY, H. Legacy of Albert Kahn. Detroit: The Detroit Institute of Arts, 1970. . The buildings of Detroit. Detroit: Wayne State University Press, 1968.

FLUSSER, V. Filosofía del diseño: la forma de las cosas. Madrid: Editorial Síntesis, 2002.

FONSECA, P. D. Vargas: Capitalismo em construção. São Paulo: Brasiliense, 1988.

FORD, H. Minha Philosophia da Industria. São Paulo: Companhia Editora Nacional, 1929.

. My life and work. New York: Doubleday, Page \& Company, 1922.

. Today and tomorrow. New York: Doubleday, 1926.

FOREST, M. Automóveis de São Paulo. São Paulo: Editora Oficial, 2002.

FRAINER, D. M. A estrutura e a dinâmica da indústria automobilística no

Brasil. Tese (Doutorado Institucional em Economia). Porto Alegre: UFRGS, 2010.

FRAMPTON, K. História e crítica da arquitetura moderna. São Paulo: Martins Fontes, 2000.

Studies in tectonic architecture. The Poetics of construction in nineteenth and twentieth century architecture. Cambridge, Massachusetts: M.I.T. Press, 1995.

FREEMAN, J. B. Behemoth: A History of the Factory and the making of the Modern World. New York: W. W. Norton, 2018.

. Giant factories. In: Labour/Le Travail, v. 72, p. 177-203. Outono 2013.

FREITAS JUNIOR, N. O Capital Norte-Americano e Investimento no Brasil: características e perspectivas de um relacionamento econômico (1950-1990). Rio de Janeiro: Record, 1994.

FREYSSENET, M. et.al. One best way? Trajectories and industrial models of the world's automobile producers. Oxford: Oxford University, 1998. 
FRITSCH, W. External Constraints on Economic Policy in Brazil, 1889-1930. Pittsburgh: University of Pittsburgh Press, 1988.

GARCIA, E. V. Estados Unidos e Grã-Bretanha no Brasil: transição de poder no entreguerras. Contexto int. [online], v. 24, n.1, p.41-71, 2002.

GARTMAN, D. From Autos to Architecture: Fordism and Architectural Aesthetics in the Twentieth Century. New York: Princeton Architectural Press, 2009.

.Three ages of the automobile: the cultural logics of the car. Theory, Culture \& Society, v. 21, n. 4-5, p. 169-195, 2004.GATTÁS, R. A indústria automobilística e a segunda Revolução Industrial no Brasil. São Paulo: Prelo, 1981.

GIEDION, S. Mechanization Takes Command: A Contribution to Anonymous History. New York: Oxford University Press, 1970.

GIUCCI, G. Máquinas e estética. In: Lugar Comum, Rio de Janeiro, NEPCOM/ UFRJ, n. 8, p. 63-87, maio/agosto 1999.

. The cultural life of the automobile: roads to modernity. Texas: University of Texas Press, 2012.

GLANCEY, J. Architecture and the car. In: The Architectural Review, n. 217, p. 48-49, 2005.

GOMES, R. Nossos clássicos -João do Rio. Rio de Janeiro: Agir, 2005.

GONÇALVES, V. C. Automóveis no Brasil - 1893-1966. São Paulo: Editora do Automóvel, 1966.

A primeira corrida na América do Sul. São Paulo: Empresa das Artes, 1988.

GRAHAM, R. Britain and the Onset of Modernisation in Brazil, 1850-1914. Cambridge: Cambridge University Press, 1968.

GREENHILL, R. The Brazilian Coffee Trade. In D. C. M. Platt (ed.), Business Imperialism, 1840-1930: An Inquiry Based on British Experience in Latin America. Oxford: Clarendon Press, 1977.

GREENOUGH, H. Form and function. Remarks on art, design and architecture. California: University of California Press, 1947.

GUILLÉN, M. F. The Taylorized Beauty of the Mechanical: scientific management and the rise of modernist architecture. Princeton: Princeton University Press, 2006. 
GUIMARÃES, E. Acumulação e crescimento da firma: um estudo de organização industrial. Rio de Janeiro: Guanabara, 1987.

GUERRA, A. (org.). Textos fundamentais sobre história da arquitetura moderna brasileira. São Paulo: Romano Guerra Editora, 2010. 2 partes.

HAAG, C. Fé na modernidade e pé na tábua: A polêmica relação que o Brasil criou com o automóvel. In: Pesquisa (Fapesp), São Paulo, edição 179, jan. 2011. Disponível em: http://revistapesquisa.fapesp.br/2011/01/31/f\%C3\%A9-na-modernidade-e-p\%C3\%A9na-t\%C3\%A1bua/ Acesso em 09 set 2018

HALSEY, D. The "D": Detroit in the new millennium. Dissertação de mestrado. Bozeman, Montana: Montana State University, 2007.

HILDEBRAND, G. Albert Kahn: the second industrial revolution. In: Perspecta, v. 15 , p. $31-40,1975$.

Beautiful factories. In: Albert Kahn: inspiration for the modern. Ann Arbor: University of Michigan Museum of Art, p. 16-27, 2001.

Designing for industry: the architecture of Albert Kahn. Cambridge, Massachusetts: MIT Press, 1974.

. New Factory for the Geo. N. Pierce Company, Buffalo, New York - 1906.

In: Journal of the Society of Architectural Historians, v. 29, n. 1, p. 51-55, 1970.

HILL, E. e GALLAGHER, J. AIA Detroit: The AIA Guide to Detroit Architecture. Detroit: Wayne State University Press, 2003.

HILPERT, T. La ciudad funcional: Le Corbusier y su visión de la ciudad. Madrid: Instituto de Estudios de Administración Local, 1983.

HILTON, S. O Brasil e as grandes potências: os aspectos políticos da rivalidade comercial (1930-1939). Rio de Janeiro: Civilização Brasileira, 1977.

HITCHCOOK, H. R.. Architecture: nineteenth and twentieth centuries. Harmondsworth: Penguin Books, 1987.

. The architecture of bureaucracy and the architecture of genius. In:

Architectural Review, n. 101, p. 3-6, Jan. 1947

HITCHCOCK, H. R. e JOHNSON, P. The international style. Nova York: W.W. Norton \& Company, 1931.

HOBSBAWM, E. A era dos impérios. São Paulo: Paz e Terra, 1988. 
HOFFMAN, D. Detroit, capital of the 20th Century. In: Praxis - Journal of Writing Building, n. 5, p. 113-119, 2003.

HORMAIN, D. O relacionamento Brasil-EUA e a arquitetura moderna: Experiências compartilhadas, 1939 - 1959. Tese (Doutorado em Arquitetura e Urbanismo). Faculdade de Arquitetura e Urbanismo. São Paulo: USP, 2012.

HUGHES, T. P. American Genesis: A century of invention and technological enthusiasm, 1870-1970. New York: Viking, 1989.

HUNTER, G. Despite Order, City works on Packard Plant. In: The Detroit News, Detroit, 16 mar 1999, p. D6.

. Ownership Battle Brews at Packard: Bloomfield Hills Company, Detroit, Tenants Square Off. In: The Detroit News, Detroit, 7 mai 1999, p. C6. . Packard Tenants Must Move Out: Renters Plan Petitions. City Plans for Demolition. In: The Detroit News, Detroit, $23 \operatorname{dez} 1998$, p. B1. . Police Still Guard Packard Plant. In: The Detroit News, Detroit, 29 jan 1999, p. B1. . Tax Payment Ends Dispute in Detroit: Former Packard Plant was Scene of Standoff Between Owner, City. In: The Detroit News, Detroit, 9 out 2000, p. 6.

HYDE, C. K. Detroit: An industrial history guide. Society for Industrial Architecture Conference. Wayne State University, Maio 1980.

. Assembly-Line Architecture: Albert Kahn and the evolution of the U.S. Auto Factory, 1905-1940. In: IA - The Journal of the Society for Industrial Archeology, v. 22, n. 2, p. 5-24, 1996.

. Detroit the Dynamic: the industrial history of Detroit from cigars to cars. In: Michigan Historical Review, v. 27, n. 1, p. 57-73, 2001.

JOÃO do Rio. In: GOMES, R. C. (Org.). Nossos clássicos. Rio de Janeiro: Agir, 2005, p. 57-60.

JONGE, W.. The technology of change: the Van Nelle factories in transition. In: Back from Utopia. Rotterdam: Henket and Heijnen, p. 44-59, 2002.

JIMENEZ, E. El pilar en Mies Van der Rohe: El lèxic de l'acer. Tese (Doutorado em Projects Arquitectònics). Universitat Politècnica de Catalunya. Barcelona: UPC, 2012. 
KAHN, A. Weekly Bulletin of the Michigan Society of Architects. In: Industrial Architecture, v. 12, n. 52, 1938.

KEITH SCOTT, N. Toward a new architecture for industry. Dissertação. (Me.D in Urban Studies and Planning). Massachusetts Institute of Technology: Cambridge, 1955 .

KENNA, M. The Rouge. Santa Monica: Michael Kenna and Ram Publications, 1995.

KIDDER, W. Willow Run: Colossus of American History. Lansing, MI: KFT Publishing, 1995.

KIM, C. e MAUBORGNE, R. A estratégia do oceano azul: como criar novos mercados e tornar a concorrência irrelevante. Rio de Janeiro: Campus-Elsevier, 2005.

KIMORI, L. Os mestres do passado: Mário de Andrade lê os parnasianos brasileiros. Dissertação (Mestrado em Letras). Faculdade de Filosofia, Letras e Ciências Humanas. São Paulo: USP, 2014.

KING, S. Creative-Responsive-Pragmatic; 75 Years of professional practice, Albert Kahn Associates, architects-engineers. New York: Newcomen Society in North America, 1970.

KOPP, A. Arquitectura y urbanismo soviéticos de los años veinte. Barcelona: Editorial Lumen, 1974.

KOSELLECK, R. Future's Past: On the Semantics of Historical Time. New York: Columbia University Press, 2004.

KREGER, J. Albert Kahn and the Design of Angell Hall. LSA Magazine, primavera 1998, p. 5.

KRENN, M. U.S. Policy toward Economic Nationalism in Latin America, 1917-1929. Wilmington: SR Books, 1990.

KUBO, M. The anxiety of anonymity: bureaucracy and genius in late modern architecture industry. In: 101st ACSA Annual Meeting Proceedings, New Constellations, New Ecologies, p. 810-817, 2013.

. The concept of the architectural corporation. In: Office US Agenda, n.1, p. 37-45, 2014.

LAPLANE, M.F. e SARTI, F. The brazilian automobile industry in the nineties. In: Fourth International Colloquium of GERPISA, Paris, 1996. 
LAUDER, A. e RODNEY, L. Albert Kahn's five-year plant and the birth of "Uncertain Space". In: Future Anterior: Journal of Historic Preservation, History, Theory, and Criticism, v. 12, n. 2, p. 39-61, 2015.

LE CORBUSIER. Por uma arquitetura. São Paulo: Perspectiva, 2011. When the cathedrals were white. New York: McGraw-Hill Book Company, 1964.

LEITE, R. P. Painel de automóveis populares: o design do cluster de direção sob o aspecto da ergonomia informacional. Rio de Janeiro: PUC-Rio, Departamento de Artes e Design, 2006.

LEUCHARS, C. Brazilian foreign policy and the great powers, 1912-1930. Tese de Doutorado. University of Oxford, 1983.

LEVINE, N. The significance of facts: Mies's collages up close and personal. In: Assemblage, n. 37, p. 71-101, 1998.

LEWIS, D. The public image of Henry Ford. Detroit: Wayne State University Press, 1976.

LEWIS, D. L. Ford and Kahn. In: Michigan History, n. 64, set/out, 1980.

LINDNER, W. Die Ingenieurbauten in ihrerguten Gestaltung. Berlim: Wasmuth, 1923.

LOPES, H. Aarão Reis: pensamento econômico, social e político de inspiração positivista. In: Revista Eletrônica de Economia, v. 1, n. 1, mar. 2003. Disponível em: <http://www.viannajr.edu.br/revista/eco/doc/artigo_00003.pdf>. Acesso em: 14 mar. 2018.

LOWRY, R. “The People's Tycoon”: Driven. New York Times, New York, 4 set. 2005. Disponível em: < https://www.nytimes.com/2005/09/04/books/review/the-peoplestycoon-driven.html >. Acesso em: 27 jun. 2018.

LUEDEMANN, M. Transformações na indústria automobilística mundial: o caso do complexo automotivo no Brasil - 1990-2002. Tese (Doutorado em Geografia Humana). Programa de Pós- Graduação em Geografia Humana da Faculdade de Filosofia, Letras e Ciências Humanas. São Paulo: USP, 2003.

MAGAZINER, H.J. Working for a Genius: my time with Albert Kahn. In: APT Bulletin, v. 32, n. 2/3, p. 59-64, 2001. 
MAIER, C. Consigning the Twentieth Century to History: Alternative Narratives for the Modern Era. In: The American Historical Review, v. 105, n. 3, p. 807- 831, jun 2000.

MANCHESTER, A. British preeminence in Brazil: its rise and decline. New York: Octagon Books, 1972.

MARICHAL, C. Historia de la Deuda Externa de América Latina. Madrid: Alianza Editorial, 1988.

MARIN, L. Frontiers of utopia: past and present. In: Critical Inquiry 19, no. 3, p. 397-420, Primavera 1993.

MCDONALD, M. Preserving the History of Motown's automotive Glory: City Leaders May See the Once Grand Packard Plant as a \$3.5 Million Square-foot Eyesore. In: The Detroit News, Detroit, 22 nov 2000.

MCKERCHER, B. Anglo-American relations in the 1920s: The struggle for supremacy. Basingstoke: Macmillan, 1991.

. Transition of power: Britain's loss of global preeminence to the United States, 1930-1945. Cambridge: Cambridge University Press, 1999.

.Wealth, power, and the new international order: Britain and the American Challenge in the 1920s”. In: Diplomatic History, v. 12, n. 4, Wilmington, p. 411-441, 1988.

MCLEOD, M. Architecture or Revolution: Taylorism, Technocracy, and Social Change. In: ArtJournal, v. 43, n. 2, Revising Modernist History: The Architecture of the 1920s and 1930s, p. 132-147, 1983.

MCMORDIE, M.John B. Parking Associates and Albert Kahn Inc.: an industrial view of architecture. In: JSSAC / JSEAC, v. 24, n. 1, p. 16-23, 1999.

MEEKS, C. The railroad station. An architectural history. New York: Dover Publications, 1995.

MEISTER, C. Albert Kahn's Partners in Industrial Architecture. In: Journal of the Society of Architectural Historians, v. 72, n. 1, p. 78-95, 2013.

MELNIKOVA-RAICH, S. The Soviet Problem with Two 'Unknowns': How an American Architect and a Soviet Negotiator Jump-Started the Industrialization of Russia, Part I: Albert Kahn. In: IA - The Journal of the Society for Industrial Archeology, v. 36, n. 2, p. 57-80, 2010. 
MELO, V. A. O Automóvel, o Automobilismo e a Modernidade no Brasil (18911908). In: Revista Brasileira de Ciências do Esporte, Campinas, v. 30, n. 1, p. 187-203, setembro 2008.

. Cidade sportiva: primórdios do esporte no Rio de Janeiro. Rio de Janeiro: RelumeDumará/Faperj, 2001.

MENDELSOHN, E. Amerika: Bilderbucheines Architekten. Berlim: Rudolf Mosse Buchverlag, 1926.

Russland, Europa, Amerika. Berlim: Rudolf Mosse Buchverlag, 1929.

MEYER, R.. São Paulo Metrópole. São Paulo: Edusp, 2003.

MILLER, R. Britain and Latin America in the Nineteenth and Twentieth Centuries. London: Longman, 1993. British Trade with Latin America (1870-1950). In: MATHIAS, P. e DAVIS, J. (eds.). International Trade and British Economic Growth. Oxford: Blackwell, 1996.

MILLER, R. Doing business in newly privatized markets: global opportunities and challenges. Greenwood: Publishing Group, 2000.

MILONE, P. Estudo de bens duráveis de consumo: estudo da demanda de automóveis. Dissertação (Mestrado em Economia). Faculdade de Economia, Administração e Contabilidade da Universidade de São Paulo. São Paulo: USP, 1973.

MIRANDA, C. R. T. Na trilha da Macunaíma: ensaio para uma política pública de lazer. Dissertação (Mestrado em História). Faculdade de História. Campinas: UNICAMP, 2004.

MOLENAAR, J.; KAUFFMANN, F.; BACKER. A. M. Van Nelle: monument in progress. Roterdam: De Hef Publishers, 2005.

MONIZ BANDEIRA, L. A.. Presença dos Estados Unidos no Brasil. Rio de Janeiro: Civilização Brasileira, 1973.

MORTON, T. Something, Something, Something Detroit: Lazy Journalists Love Pictures of Abandoned Stuff. In: Vice, agosto 2009.

MUELLER, W. Reinforced concrete construction. In: Cement Age 3, p. 313-332, outubro de 1906.

NASCIMENTO, Benedito. Formação da indústria automobilística brasileira. São Paulo: Universidade de São Paulo, 1976. 
NEEDELL, J. D. Belle Époque tropical. São Paulo: Companhia das Letras, 1993.

NEGRO, A. Automóveis 100\% Nacionais para Argentina e Brasil. Parceria Desenvolvimentista no Além-Mar. In: FORTES, A. et. al. Na luta por direitos. Estudos recentes em História Social do Trabalho. Campinas: Editora da Unicamp, 1999.

NELSON, G. Industrial architecture of Albert Kahn, Inc. New York: Architectural Book Pub., 1939.

NEUTRA, R. Wie Baut Amerika? Stuttgart: Julius Hoffmann, 1927.

NEVINS, A.; HILL, F. E. Ford: Expansion and Challenge: 1915-1933. New York: Charles Scribner's Sons, 1957.

NORMANO, J. A luta pela América do Sul. Rio de Janeiro: Atlas, 1944.

OLMO, C. M. Il Lingotto, 1915-1939: l'architettura, l'immagine, il lavoro. Turim: Umberto Allemandi, 1994.

PANCORBO, L. Arquitectura industrial de Albert Kahn Inc. 1900-42. La arquitectura como objeto técnico. Tese (Doutorado em Proyectos Arquitectónicos). Escuela Técnica Superior de Arquitectura - Universidad Politécnica de Madrid. Madrid: ETS Arquitectura, 2016.

PANCORBO, L. e MARTÍN ROBLES, I. Anestética de la desaparición. La sección como definidora del proyecto en la arquitectura de Albert Kahn. In: ZARCH n. 2. Rethinking/Remaking. Journal of interdisciplinary studies in Architecture and Urbanism, p. 118-131.

. Architecture as technical object. Industrial architecture of Albert Kahn. VLC arquitectura. In: Research Journal UPV, n. 2., p 1-31, outubro 2014.

El espacio como membrana. Mies van der Rohe y Albert Kahn. In: RA Revista de Arquitectura, Universidad de Pamplona, n. 16, p 49-58.

. Funcionalism in Detroit. The Ford factories designed by Albert Kahn.

RITA - Revista indexada de textos acadêmicos,_n. 02, p 132-139, outubro 2014. Poetics of assembly. Albert Kahn and D.W. Griffith and the beggining of the Machine Age. In: Cuadernos de Proyectos Arquitectonicos. DIÁLOGOS CRUZADOS/ANTAGONISMOS. Departamento de Proyectos Arquitectonicos. Escuela Tecnica Superior de Arquitectura de Madrid. UPM, n. 6, 2016, p. 40-49. 
. Rail lineages. Use of railway typologies in Albert Kahn. In: Cuaderno de Notas. Departamento de Composición Arquitectónica. ETSAM UPM, Patrimonio Industrial, n. 17, p 78-103, jul 2016.

PEVSNER, N. Pioneers of modern design: from William Morris to Walter Gropius. New Haven: Yale University Press, 2005.

PIMENTA, L. A crise na rede de concessionárias de automóveis no Brasil. Dissertação (Mestrado em Análise Regional). Departamento de Ciências Sociais Aplicadas. Salvador: Universidade Salvador, 2002.

PINTO, M. I. Urbes industrializada: o modernismo e a pauliceia como ícone da brasilidade. In: Revista Brasileira de História, São Paulo, v. 21, n. 42, p. 435-455, 2001.

PLATT, D. Latin America and British Trade, 1806-1914. London: Adam \& Charles Black, 1972.

POERSCHKE, U. Architectural theory of modernism: relating functions and forms. New York: Routledge, 2016.

POSTHUMA, A.C. Industrial renewal and inter-firm relations in the supply chain of the brazilian automotive industry. In: Ninth International Colloquium of GERPISA. Paris, 2001.

RAGO, M. A invenção do cotidiano na Metrópole: sociabilidade e lazer em São Paulo, 1900-1950. In: PORTA, P. (org). História da cidade de São Paulo. São Paulo: Paz e Terra, 2004. p. 387-436.

RANCIERE, J. Introduction. In: . The Future of the Image. Londres: Verso, 2007.

RANSOME. E. e SAURBREY, A. Reinforced concrete buildings. New York: McGraw-Hill Book, 1912.

RAPPAPORT, N. Vertical urban factory. New York: Actar Publishers, 2015.

RASNER, D. Albert Kahn: Evolution of the factory. 2003. Disponível em: <https://issuu.com/a1579/docs/albert_kahn_factory> Acesso em 07 mai 18.

RAVARA, P. B. A consolidação de uma prática: do edifício fabril em betão armado nos EUA aos modelos europeus de modernidade. Tese (Doutorado em Arquitetura). Faculdade de Arquitectura da Universidade Técnica de Lisboa. Lisboa: UTL, 2008. 
REA, C. C. Rethinking the industrial landscape: the future of the Ford Rouge Complex. Dissertação (Master in Architecture). Massachusetts Institute of Technology: Cambridge, 1991.

RIPPY, J. British Investments in Latin America, 1822-1949: a case study in the operations of private enterprise in retarded regions. Minneapolis: University of Minnesota Press, 1959.

ROMERO, S. Em plena Amazônia, Fordlândia: o sonho falido de Henry Ford. Estadão, São Paulo, 10 mar. 2017. Disponível em: <https://sustentabilidade.estadao. com.br/noticias/geral,em-plena-amazonia-fordlandia-o-sonho-falido-de-henryford,70001693319>. Acesso em: 26 mai. 2018.

ROSENBERG, E. S. Anglo-American economic rivalry in Brazil during World War I. In: Diplomatic History, v. 2, n. 2, p. 131-152, 1978.

. World War I and the growth of United States preponderance in Latin

America. Tese (Ph.D in Philosophy). New York: State University of New York at Stony Brook, 1973.

ROWE, C. Manierismo y arquitectura moderna y otros ensayos. Barcelona: Gustavo Gili, 1976.

ROTH, L. American Architecture - A History. Boulder, CO: Westview Press, 2001.

RYAN, B. e CAMPO, D. A utopia's End: The Decline and Fall of Detroit's Automotive Manufacturing Landscape. In: Journal of Planning History, v. 12, n. 2, p. 95-132, maio 12013.

SALERNO, M. S. et. al. Mudanças e persistências no padrão de relações entre as montadoras e autopeças no Brasil. In: Revista de Administração, v. 33, n. 3, 1998, p. 1628.

SANDLER, P. C. e SIMONE, R. SIMCA - A história desde as origens. São Paulo: Alaúde, 2002.

SANT'ANNA, D. Corpos de passagem: ensaios sobre a subjetividade contemporânea. São Paulo: Estação Liberdade, 2001.

SANTOS, A. e BURITY, P. O complexo automotivo. In: BNDES, 50 ANOS: Histórias Setoriais. Brasília: BNDES, 2002. 
SANTOS, R. A armação do concreto no Brasil: história da difusão do sistema construtivo concreto armado e da construção de sua hegemonia. Tese (Doutorado em Educação). Faculdade de Educação. Belo Horizonte: UFMG, 2008.

SASSEN, S. Territory, Authority, Rights: from Medieval to Global Assemblages. Princeton: Princeton University Press, 2006.

SCALI, P. Circuitos de rua - 1908-1958. Porto Alegre: Imagens da Terra, 2004.

SCHEU, J. Design for the workplace: a new factory. Dissertação (Master of Architecture). Massachusetts Institute of Technology: Cambridge, 1979.

SEDLAR, F. Engineering Industrial Architecture: The Trussed Concrete Steel Company and Albert Kahn. Visual Culture and Archives, Bentley Historical Library. Disponível em <https://deepblue.lib.umich.edu/bitstream/handle/2027.42/98436/Sedlar_ Engineering_Industrial_Architecture.pdf?sequence=1> Acesso: 7 abr. 2018

SEGAWA, H. Arquiteturas no Brasil: 1900-1990. São Paulo: Edusp, 2014.

SEGRE, R. O sonho americano de Oscar Niemeyer: Niemeyer, Le Corbusier e as Américas. In: Revista aU, v. 165, dezembro 2007.

SEIDEL, R. N. Progressive Pan Americanism: Development and United States Policy toward South America, 1906-1931. Tese (PhD. in Latin American Studies). Latin American Studies Program. New York: Cornell University, 1973.

SENKEVICH, A. J.. Albert Kahn's Great Soviet Venture as Architect of the First Five-Year Plan, 1929-1932. In: Dimensions 10, 1996, p. 34-49. Disponível em: https:// issuu.com/taubmancollege/docs/dimensions10 Acesso em: 05 mar 2018.

SENNETT, R. O artífice. Rio de Janeiro: Record, 2009.

SEVCENKO, N. Introdução. O prelúdio republicano, astúcias da ordem e ilusões do progresso. In: (org). História da vida privada no Brasil. República: da Belle Epoque à era do rádio. São Paulo: Companhia das Letras, 1998, p.7-48.

. A capital irradiante: técnica, ritmos e ritos do Rio. In: (org).

História da vida privada no Brasil: da Belle Époque à era do rádio. São Paulo: Companhia das Letras, 1998. p. 513-620.

SHAPIRO, H. A primeira migração das montadoras: 1956-1968. In: ARBIX, G.; ZILBOVICIUS, M. (org). De JK a FHC: a reinvenção dos carros. São Paulo: Schitta, 1997. 
SINGER, P. O Brasil no Contexto do Capitalismo Internacional (1889-1930). In: FAUSTO, B. (org). História Geral da Civilização Brasileira. São Paulo: Difel, 1975, p. 347-390. Volume 8.

SIMONDON, G. E1 modo de existencia de los objetos técnicos. Buenos Aires: Prometeo, 2008.

SIRY, J. The Architecture of Earthquake Resistance: Julius Kahn's Truscon Company and Frank Lloyd Wright's Imperial Hotel. In: Journal of the Society of Architectural Historians, v. 67, n. 1, Mar. 2008, p. 78-105

SMITH, M. G. Designing Detroit: Wirt Rowland and the rise of Modern American Architecture. Detroit: Wayne State University Press, 2017.

SMITH, T. Making the modern. Industry, art and design in America. Chicago: The University of Chicago Press, 1993.

SORENSEN, C. E. My Forty Years with Ford. W. W. New York: Norton \& Company, 1956.

SPAETH, D. Mies van der Rohe. Barcelona: Gustavo Gili, 1986.

STALLINGS, B. Banker to the Third World: U.S. Portfolio Investment in Latin America, 1900-1986. Berkeley: University of California Press, 1987.

STIEL, W. História do transporte urbano no Brasil. São Paulo: Pini/EBTU, 1984.

STRATTON, M. Construction History. In: Construction History, v. 3, 1987, p. 138-140. Disponível em: www.jstor.org/stable/41613643 Acesso em 04 set 2018.

STRATTON, M. e TRINDER, B. S. Twentieth Century Industrial Archaeology. New York: Taylor \& Francis, 2000.

STRIKE, J. De la construcción a los proyetos: la influencia de las nuevas técnicas en el diseño arquitectónico, 1700-2000. Barcelona: Editorial Reverté, 2004.

SWARTHOUT, G. Willow Run. New York: Crowell, 1943.

SUHR, J. Past Imperfect Detroit, History Buffs Square Off Over Decaying Packard Plant. In: Chicago Tribune. Chicago, 13 mai 1999, p. 1.

TAUT, B. Die neue Baukunst in Europa und Amerika. Stuttgart: Julius Hoffmann, 1929.

THE BUILDINGS of Detroit. Detroit: Detroit Wayne State University Press, 1968. 
TOWNDROW, F. Architecture in the Balance: an approach to the art of scientific humanism. New York: Frederick A. Stokes, 1934.

TRUSSED CONCRETE Steel Company. Kahn System Standards: a Hand Book of Practical Calculation And Application of Reinforced Concrete. London: Trussed Concrete Steel Company, 1907.

TULCHIN, J. S. The Aftermath of War World War I and U.S. Policy toward Latin America. New York: New York University Press, 1971.

TYLER, I. R. Highland Park Ford Plant: Documentation and Redevelopment. In: APT Bulletin, v. 46, n. 2/3, p. 36-43, 2015.

TYRRELL, H. Engineering of shops and factories. New York: McGraw-Hill, 1912.

VALLA, V. A penetração norte-americana na economia brasileira (1898-1928): sempre de acordo ou nobre emulação? Rio de Janeiro: Ao Livro Técnico, 1978.

VAN DEVENTER, J. Links in a Complete Industrial Chain. In: Industrial Management, n. 64, setembro 1922.

VASCONCELlOS, J. C. Concreto Armado, Arquitetura Moderna, Escola Carioca: levantamentos e notas. Dissertação (Mestrado em Arquitetura). Porto Alegre: UFRGS, 2004.

VASCONCELOS, A. C.. O concreto no Brasil: recordes, realizações, história. São Paulo: Copiare, 1985.

VIANNA, R. L. O comportamento da demanda de automóveis: um estudo econométrico. Dissertação (Mestrado em Economia). Rio de Janeiro: PUC - RJ, 1988.

VILLELA, A. e SUZIGAN, W. Política do Governo e Crescimento da Economia Brasileira, 1889-1945. Rio de Janeiro: IPEA/INPES, 1975.

WATTS, S. The People's Tycoon: Henry Ford and the American Century. Nova York: Vintage Books, 2006.

WERTH, A. Stalingrado: 1942, o início do fim da Alemanha nazista. São Paulo: Editora Contexto, 2015.

WILKINS, M. e HILL, F. E. American Business Abroad: Ford on Six Continents. New York: Cambridge University Press, 2011. 
WILSON, M. The story of Willow Run. Ann Arbor: University of Michigan Press, 1956.

WINKLER, M. Investments of United States Capital in Latin America. Boston: World Peace Foundation, 1929.

WOLFE, J. Autos and progress: the Brazilian search for modernity. New York: Oxford University Press, 2010.

WOMACK, J. P. et. al. A máquina que mudou o mundo. Rio de Janeiro: Campus, 1992.

WRIGHT, A.. Desafio americano à preponderância britânica no Brasil: 18081850. Rio de Janeiro: Imprensa Nacional, 1972.

YACOB, S. Ford's Investment in Colonial Malaya, 1926-1957. In: The Business History Review, v. 83, n. 4, p. 789-812, 2009.

ZILBOVICIUS, M. (org). De JK a FHC: a reinvenção dos carros. São Paulo: Schitta, 1997.

ZIMMERMAN, C. Albert Kahn in the Second Industrial Revolution. In: AA Files, n. 75, p. 28-44, 2017.

Albert Kahn's Territories. In: Office US Agenda. Zurich: Lars Müller Publishers and PRAXIS, p. 117-127, 2014.

Photographic Architecture in the Twentieth Century. Minneapolis: University of Minnesota Press, 2014.

- The Labor of Albert Kahn. Aggregate Architectural History

Collaborative. Disponível em: http://www.weaggregate.org/piece/the-labor-of-albertkahn Acesso em 10 mai 2018.

\section{REFERÊNCIAS ELETRÔNICAS}

Albert Kahn Associates records: 1825-2014 (bulk 1900-1945). In: BENTLEY HISTORICAL LIBRARY. University of Michigan. Disponível em: < https://quod.lib. umich.edu/b/bhlead/umich-bhl-0420?byte=202857978; focusrgn=bioghist;subview=stand ard;view=reslist $>$. Acesso em: 07 mai 2018. 
Building D10 at Boots Factory Site. In.: HISTORIC ENGLAND, 1971 [última atualização: 26 abr 2013]. Disponível em: <https://historicengland.org.uk/listing/the-list/ list-entry/1247927>. Acesso em: 20 jun 2018.

CABRAL, D. C. Qual foi o primeiro carro à combustão? In: MUNDO ESTRANHO. Disponível em: <https://super.abril.com.br/mundo-estranho/qual-foi-oprimeiro-carro-a-combustao/>. Acesso em: 18 jul 2018.

David Dunbar Buick. In: HEMMINGS. Disponível em <www.hemmings.com/ magazine/hcc/2015/06/David-Dunbar-Buick/>. Acesso em: 07 mai 2018.

Detroit, Toledo and Ironton Railroad: we have the connections. In.: AMERICANRAILS. Disponível em: <https://www.american-rails.com/detroit-toledo-and-irontonrailroad.html>. Acesso em: 27 jun 2018.

FORD | SITE OFICIAL DA FORD BRASIL. Disponível em: <http://www. ford.com.br>

Ford Bigode faz sucesso em São Paulo. In: JORNAL DO BRASIL, 12 maio 1920. Suplemento Jornal do Século. [última atualização: 26 abr 2002]. Disponível em: <http:// archive.li/1luev\#selection-363.3-363.814>. Acesso em: 15 jan 2019.

Ford in Europe: the first hundred years. In: SERIOUS WHEELS. Published by John Filiss. Disponível em: <http://www.seriouswheels.com/art-Ford-Europe.htm.. Acesso em: 18 jul 2018.

FORD MOTOR CAR COMPANY HISTORY. Disponível em: <www. fordmotorhistory.com>. Acesso em: 16 jan 2018.

Ford River Rouge B Building. In.: FORD RIVER ROUGE PLANT. Disponível em: <http://www.fordmotorhistory.com/factories/river_rouge/building_b.php>. Acesso em: 26 mai 2018.

FORD'S SYSTEM OF BRANCH ASSEMBLY PARTS. Disponível em: <http://fordmotorhistory.com/factories/branch_system.php>. Acesso em: 09 jul 2018.

General Motors Building / Cadillac Place. In.: ENCYCLOPEDIA OF DETROIT. Detroit Historical Society. Disponível em: <https://detroithistorical.org/ learn/encyclopedia-of-detroit/general-motors-buildingcadillac-place>. Acesso em: 09 jan 2019. 
HENRY FORD - FOUNDER, FORD MOTOR COMPANY. Disponível em: $<$ https://www.thehenryford.org/explore/stories-of-innovation/visionaries/henry-ford/>. Acesso em: 05 dez 2018.

Henry Ford por Monteiro Lobato. In.: CULTOR, fev 2016. Disponível em: <http://www.cultor.com.br/2016/02/henry-ford-por-monteiro-lobato.html> Acesso em: 20 jan 2019.

Indústria e a produção do vidro. In.: UNIVERSIDADE DE SÃO PAULO. Disponível em: <http://www2.fau.usp.br/deptecnologia/docs/bancovidros/prodvidro. htm>. Acesso em: 15 dez 2018.

KOEPER, H. F. Louis Sullivan. In: ENCYCLOPAEDIA BRITANNICA. Disponível em: https://www.britannica.com/biography/Louis-Sullivan>. Acesso em: 08 fev 2019.

LINGOTTO FACTORY CONVERSION, 1983-2003, TORINO, ITALY. Disponível em: <http://www.rpbw.com/project/lingotto-factory-conversion>. Acesso em: 20 jul 2018.

M-1 - Michigan Highway. In.: WIKIPEDIA, 2018 [última atualização]. Disponível em: <https://en.wikipedia.org/wiki/M-1_(Michigan_highway)>. Acesso em: 25 jun 2018.

Modelando o República: um cine-teatro da década de 1920. Informativo do Arquivo Histórico de São Paulo, ano 7, n. 30, julho/setembro 2011. Disponível em <http://www.arquiamigos.org.br/info/info30/i-estudos2.htm>. Acesso em: 24 nov 2018.

ROMERO, S. Em plena Amazônia, Fordlândia: o sonho falido de Henry Ford. ESTADÃO, 10 mar 2017. Disponível em: < https://sustentabilidade.estadao. com.br/noticias/geral,em-plena-amazonia-fordlandia-o-sonho-falido-de-henryford,70001693319> Acesso em: 26 mai 2018.

Semana de 22, por Mario de Andrade. ESTADÃO, Suplemento Cultura, $10 \mathrm{fev}$ 2002. Disponível em: <https://cultura.estadao.com.br/noticias/geral,semana-de-22-pormario-de-andrade,20020210p2229>. Acesso em: 05 jan 2019.

SITE OFICIAL DA CHEVROLET BRASIL | FIND NEW ROADS. Disponível em: <http://www.gmb.com.br> 
The reminiscences of Mr. B. R. Brown Sr. In: BENSON FORD RESEARCH CENTER. Arquivo 1, 1955. Disponível em: < http://cdm15889.contentdm.oclc.org/cdm/ compoundobject/collection/p15889coll2/id/3253/rec/11>. Acesso em: 25 nov 2018.

The reminiscences of Mr. Kristian Orberg. In: BENSON FORD RESEARCH CENTER. Arquivo 1, 1956. Disponível em: <http://cdm15889.contentdm.oclc.org/cdm/ compoundobject/collection/p15889coll2/id/12875/rec/1> Acesso em: 25 nov 2018.

VAN NELLE MUSEUM, STICHTING WERELDERFGOED VAN NELLEFABRIEK. Disponível em: <www.vannellemuseum.com>.

VOGEL, J. O Salão de 1925: uma exposição de automóveis no país que não tinha estradas. O GLOBO, Rio de Janeiro, 02 jun 2015. Disponível em: < https://oglobo.globo. com/economia/carros/o-salao-de-1925-uma-exposicao-de-automoveis-no-pais-que-naotinha-estradas-16327979>. Acesso em: 25 jan 2019.

Washington Luis inaugura a primeira rodovia asfaltada do Brasil, a Rio-Petrópolis. In.: ACERVO O GLOBO, Rio de Janeiro, 28 jun 2013. Disponível em <https://acervo. oglobo.globo.com/rio-de-historias/washington-luis-inaugura-primeira-rodovia-asfaltadado-pais-rio-petropolis-8849272>. Acesso em: 25 nov 2018.

ZANCHETTA, D. Shopping vai revitalizar área na Mooca. O Estado de São Paulo, São Paulo, 19 ago 2010. Disponível em: <https://sao-paulo.estadao.com.br/noticias/ geral,shopping-vai-revitalizar-area-na-mooca-imp-,597149> Acesso em: 15 dez 2018. 
REVISÃO

Gustavo Czeskster

DIAGRAMAS

Studio Trim

(www.studiotrim.com.br)

DIAGRAMAÇÃO

Juliano Medina

(www.julianomedina.com) 